



36543 parats 


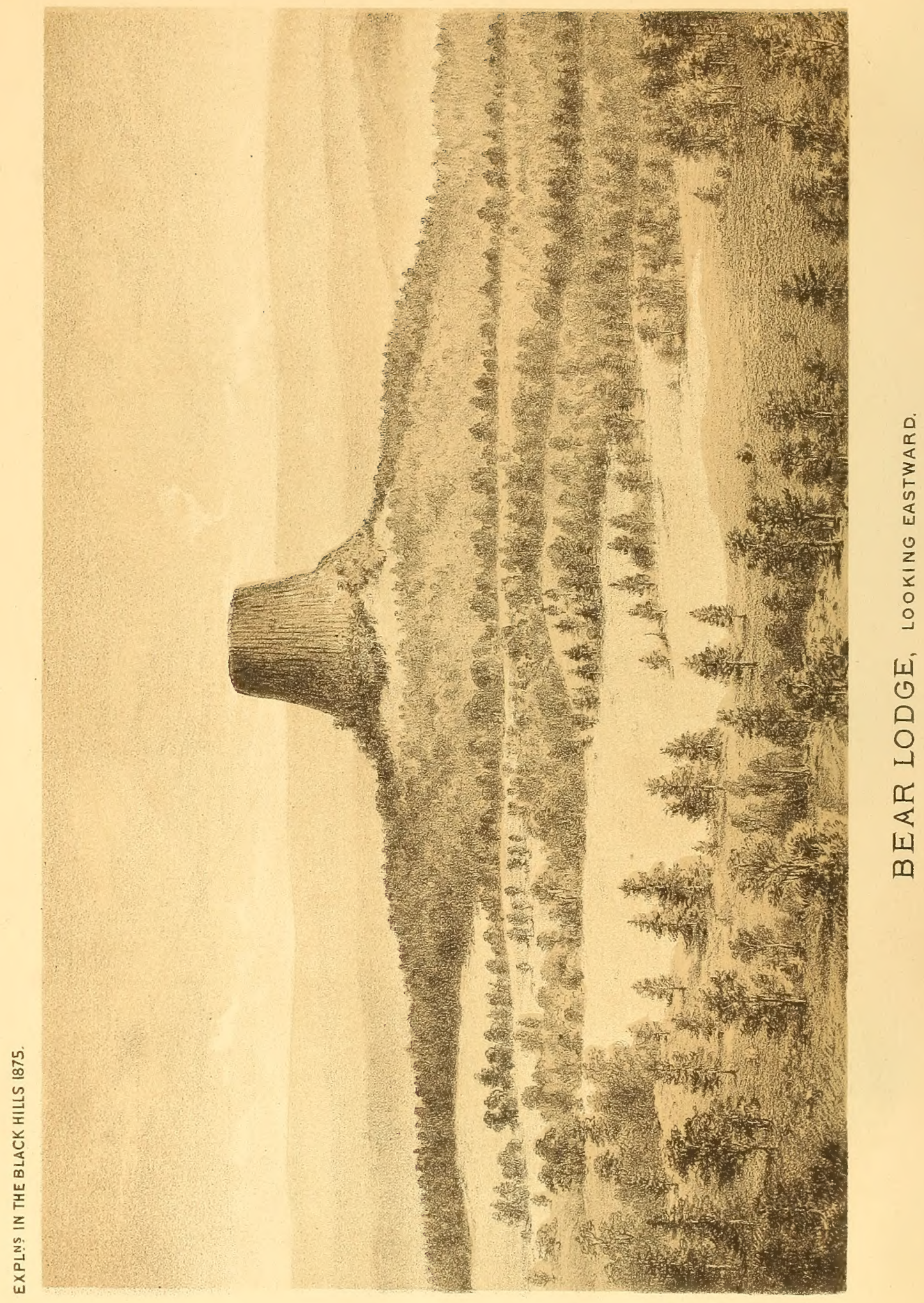


$(200) 1$
P3e v. 3 c/2.1

DEPARTMENT OF THE INTERIOR

U. S. GEOGRAPHICAL AND GEOLOGICAL SURVEY OF THE ROCKY MOUNTAIN REGION

J. W. POWELl in Charge

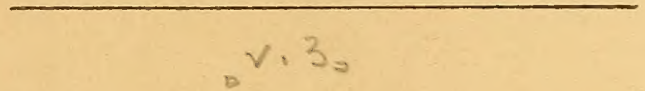

\section{R E P O R T}

ON THE

\section{GEOLOGY AND RESOURCES}

OF THE

\section{BLACK HILLS OF DAROTA}

WITH ATLAS 10974

BY HENRY NEWTON, E. M., AND WALTER P. JENNEY, E. M.

WASHINGTON

GOVERNMENT PRINTING OFFIOE 1880 

Washington, D. C., March 1, 1880.

Sir: I have the honor to transmit herewith the manuscript of the Report on the Geology and Resources of the Black Hills of Dakota, placed in my hands for revision.

I am, with respect, your obedient servant,

G. K. GILBERT.

Maj. J. W. Powell,

In charge U.S. G. and G. Survey, R. M. R., Washington, D. C. 



\section{PREFACE BY THE EDITOR.}

At the time of Mr. Newton's death his manuscript was incomplete. It was chiefly in the form of a first draft, with much erasure and interlineation, but by no means perfected. Two important sections were unwritten, and he was engaged in making a re-examination of some parts of his field, for the purpose of settling certain geological questions that had arisen in his mind while he was at work upon his report. He regarded no part of his manuscript as a finished composition, but intended to revise the whole and recast some portions on his return. The editor has therefore felt called upon to put himself, in a certain sense, in the place of the author, and make such emendation of form as seemed necessary to harmonize the whole. But while he has freely modified the language in such ways as he conceived the author might have modified it had he been able to revise it, he has, with a single exception, carefully preserved the substance.

At the time of Newton's first examination of the Black Hills, gold had been discovered only in the modern gravels and in a few Archæan quartz ledges. It was natural to assume that all the placer gold originated in the Archæan ledges, and Mr. Newton and Mr. Jenney made that assumption. The logic of events has shown their error, and Newton was aware of it before his death, although he had no opportunity to record his later understanding. In this single case the editor has modified the substance of the manuscript so far as was necessary to eliminate the error.

In Newton's scheme of the third chapter, there were two sections indicated by title but unwritten; the first on "The Quatenary," the second on the "Structure and Age of the Black Hills." It was impossible to supply data 
for the first, and it was omitted. The second was largely foreshadowed by scattered allusions in the preceding sections, and as it must consist in any event chiefly of simple deductions from the facts set forth in the descriptions of the formations, its composition was undertaken by the editor. The thoroughness and fidelity of the record of observations and its freedom from bias made the task an easy and pleasant one. All the data are Newton's, and so are all the principal deductions except those derived from the drainage system, but he should not be held responsible for the manner of presentation.

The majority of the wood-cuts illustrating his text were made under his own direction with the friendly assistance of Mr. J. L. Fitch, and others were afterwards prepared for the engraver by Mr. Thomas Moran. The topographic map and the base of the geological map were drawn by Dr. V. P. McGillycuddy, the topographer of the expedition. The colors of the geological map, unfortunately, have not the author's full authority. He traced the outlines of the formations rudely upon a small and imperfect map prepared for the preliminary report, but the final map was printed too late to be used by him. The editor transferred the colors from the small map to the large, and filled in the details, so far as he was able, to correspond with the descriptions given in the manuscript, but it is to be supposed that he fell into many errors which the author would have been able to avoid. The bird's-eye view, although projected by Newton and drawn under his supervision, was not engraved until after his death.

The editor's responsibility does not extend to the chapters which succeed Mr. Newton's. Mr. Jenney's chapters have already been published in a preliminary report, and are here copied verbatim from that text. In its separate publication his chapter on the Mineral Resources was introduced by a general account of the geological structure, which is here omitted because it is superseded by Mr. Newton's chapters. Mr. Jenney has substituted for it a brief classification of the auriferous formations.

At the time of this writing, the editor is called away from Washington, and confides the general supervision of all the text beyond Chapter III to Mr. J.C. Pilling, of the Bureau of Ethnology. The proofs of Chapters VI, VII, VIII, and IX will be submitted to their authors. 
Besides the papers on Petrography, Paleontology, Botany, and Astronomy, it was Mr. Newton's purpose to include several chapters on the Dakota Indians, and an account of the topographic work of the survey. The former were prepared for his use, but have been reserved for a more appropriate place in the publications of the Bureau of Ethnology. The latter does not appear among the papers.

The topographic work was performed by the reconnaissance method. The topographer traversed the district by numerous and intersecting routes, sketching and observing the country as he went. His courses were estimated by noting his traveling time. Their bearings and the bearings of the features of the topography were observed with a prismatic compass. Sextant observations for latitude were made by the astronomer each night and at the midday camp. The whole was checked by a triangulation including the principal peaks. There was no measured base line, but scale was derived from the astronomical latitudes. The azimuth of the triangulation was determined astronomically. Longitude was at first derived from chronometers carried with the party, but a telegraphic determination, made afterward, was adopted in the final map.

Yielding to none in my appreciation of Newton's noble qualities and brilliant promise, and sharing as geologist and friend in the regret and grief at his untimely loss, I yet yield the place of biographer to his early instructor and life-long friend, Dr. Newberry.

Washington, D. C., May, 1880. 



\section{B I OGR A P H IC NOTICE.}

NEW YoRK, February 26, 1880.

Mr. G. K Gilbert:

Dear SIR: I take pleasure in complying with your request to furnish you a brief sketch of the personal character of the late Prof. Henry Newton and of the work accomplished in his short but busy life. My relations with him were most intimate for many years, and there is perhaps no one living who more fully shared his confidence, is more familiar with what he accomplished, or better capable of judging of the promise of the life upon which he had but just entered when it was brought to a close.

I fear, however, that I shall hardly find words to do justice to the rare qualities he possessed, or to express my own affection for him.

Mr. Newton was born in the year 1845 in the city of New York. He early showed a strong taste for scientific studies, and an unusual mathematical faculty, which he inherited from his father-the late Isaac Newton, well known from his connection with the growth of the great system of steam navigation on the Hudson-and shared with his brother Isaac, the distinguished naval engineer. His academical education was obtained at the College of the City of New York, from which he graduated in 1866, and came to us at the School of Mines in the autumn of the same year. During all his course of study he exhibited the traits which marked his after career. He was noted for his punctuality, thoroughness, and accuracy of thought, and success in all the studies pursued, and no less so for his modest, reserved, and at the same time agreeable manners. No student has left the school with a better record, and when he graduated, in 1869, he had won the sincere respect and esteem of all his teachers and associates. The follow- 
ing summer he was appointed an assistant on the Geological Survey of Ohio, with which he was intimately connected for some years, rendering important aid in several departments, to which I shall have occasion to refer again. In 1870 he went to Europe with his intimate friend and classmate, Prof. W. B. Potter, and spent some months in visiting the principal centers of iron and steel industry in the British islands and on the Continent.

In $1871 \mathrm{Mr}$. Newton became assistant in netallurgy at the School of Mines; in 1872 he was appointed assistant in geology, a position which he held for two years. During this time we were brought into daily and hourly communication, and I came to entertain for him not only a sincere and warm friendship, but an almost paternal affection. Through the summers of these and succeeding years we were working together on the Geological Survey of Ohio; in all our intercourse not an unkind word was ever spoken, and I cannot too highly praise the prompt, punctilious, and thorough manner in which his every duty was performed. He was always at his post, courteous and obliging in his manners, doing a great variety of work, and doing it so well that I ultimately came to feel that whatever task was committed to him would be done with accuracy and dispatch.

In field geology he was a close observer, and an exact and rapid worker, and I early learned that ground that he had gone over need not be revisited unless for a different purpose. Ile wielded a facile pen, and his notes and reports were at the same time concise and comprehensive.

The subject which lay nearest his heart, however, and that in which his acquisitions and labors were most important, was the metallurgy of iron and steel. This he pursued for some years with a devotion which absorbed all the time he was able to give to it, and with a success that made him at his death second to no one in this country in his mastery of principles and practical familiarity with details.

While connected with the Geological Survey of Ohio he made a thorough and exhaustive study of all the resources of the State as regards ores and furnace fuels, and of the conditions and possibilities of the future development of the iron industrp there. This report has not yet been published, but I have no hesitation in pronouncing it the most complete monograph of its kind that has yet been prepared in this country. 
Of his published reports on iron and steel, the most important are "A Sketch of the Present State of the Steel Industry" (Ohio, Creol. Surv., Report of Progress for 1870, p. 529) and "The Ores of Iron, their Geographical Distribution and Relation to the Great Centers of the World's Iron Industries" (Trans. Inst. Min. Eng'rs, Vol. III, p. 360).

In 1875 the Secretary of the Interior applied to Professor Henry, the head of the Smithsonian Institution, requesting him to suggest a geologist to take charge of an exploration of the Black Hills, Dakota, for the purpose of ascertaining the extent and value of the gold deposits discovered there. This request was, by Professor Henry, reterred to me, and in accordance with my nominations Mr. W. P. Jenney was appointed geologist and Mr. H. Newton his assistant The purely geological work of the expedition was for the most part performed by Mr. Newton, and the report now committed to you for publication is the result. Although limited to a single season, the amount of work accomplished by the expedition was surprisingly large and of excellent quality. The topography and geological structure of the Black Hills were accurately determined and mapped, and the collection of fossils made by Mr. Newton and described by Mr. Whitfield contributed a larger amount of new material than that gathered by any single expedition to the West. Mr. Newton took great pains with his report, as he had done in the accumulation of facts, and in its preparation expended about eighteen hundred dollars from his own pocket, when it was quite uncertain whether this sum would be repaid him by the government When presented to Congress its publication would have been immediately authorized except for a selfish and heartless opposition it encountered springing from the fear that it would betray the inaccuracy of previously published descriptions of the geology of this region. This opposition cost Mr. Newton his life, for when Congress deferred action on his report till another session he determined to employ a part of the interval in revisiting the Black Hills, repeating some of his obserrations and recording the results of the rapidly-developing mining industry. While engaged in this work he was attacked by typhoid fever, and died at Deadwood, August 5, 1877.

Previous to his second journey to the West, Mr. Newton had received the appointment of professor of mining and metallurgy in the State Uni- 
versity at Columbus, Ohio, a recently organized but already vigorous institution, and one that promises to be among the strongest of western colleges. Had he lived this would probably have been the field of his labors for many years, and we can hardly imagine one better adapted to his tastes and talents. Columbus is situated but a few miles distant from the Hocking Valley coal and iron region, which has proved to be one of the richest in the country, where furnaces are multiplying at a rapid rate, and where increasing thousands are deriving subsistence, and many wealth, from the iron and steel industries. Here he would have found immediate application for the knowledge gained in years of study and observation, and by bringing to the aid of the Ohio iron masters the last results of progress elsewhere, and a keen and suggestive intellect for the solution of all new problems, he would have been to them a most efficient helper, and would doubtless have gained for himself fame and fortune. It is, of course, useless to speculate upon what would have been the career of Mr. Newton if he had been permitted to enter upon the life thus opened to him; but when we consider the keen and logical quality of his mind, his already great acquirement, his indefatigable industry, and his gentleness and equanimity, which secured the affection as well as the respect of all who knew him, we cannot but conclude that it would have been eminently successful.

To his family, by whom he was idolized, and to his friends, who all loved as well as admired him, his loss is, of course, irreparable. We may also say that, from his peculiar qualifications to take a leading part in the development of the great industries which are to be among the most important elements in our national prosperity, his early death must also be regarded as a great public calamity.

Yours, very truly,

J. S. NEWBERRY. 


\section{CONTENTS.}

GEOLOGY OF THE BLACK HILLS, BY HENRY NEWTON.

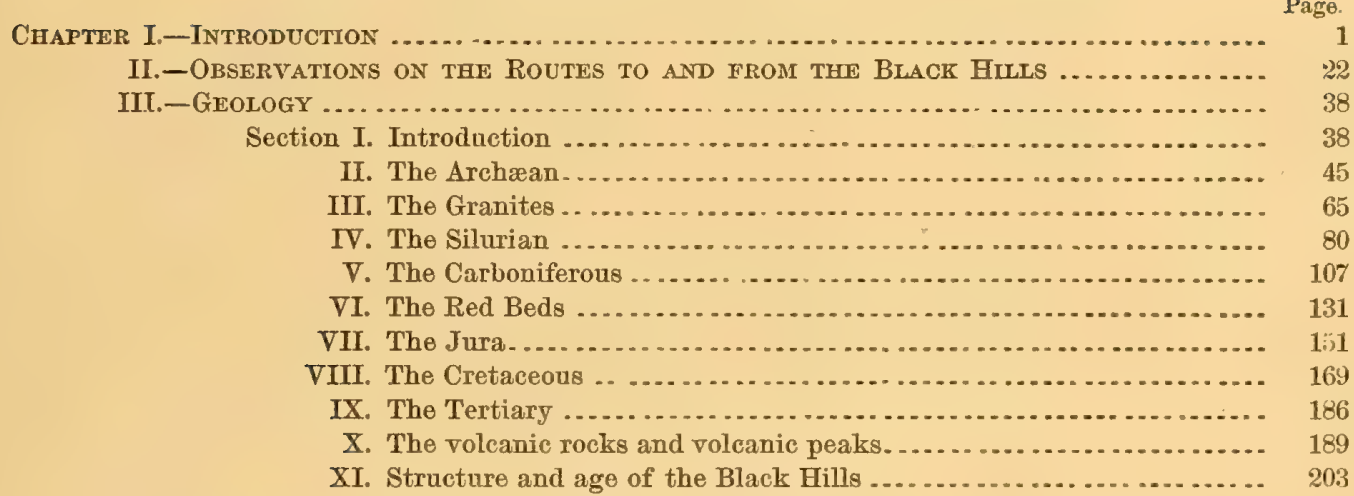

MINERAL RESOURCES OF THE BLACK HILLS, BY WALTER P. JENNEY.

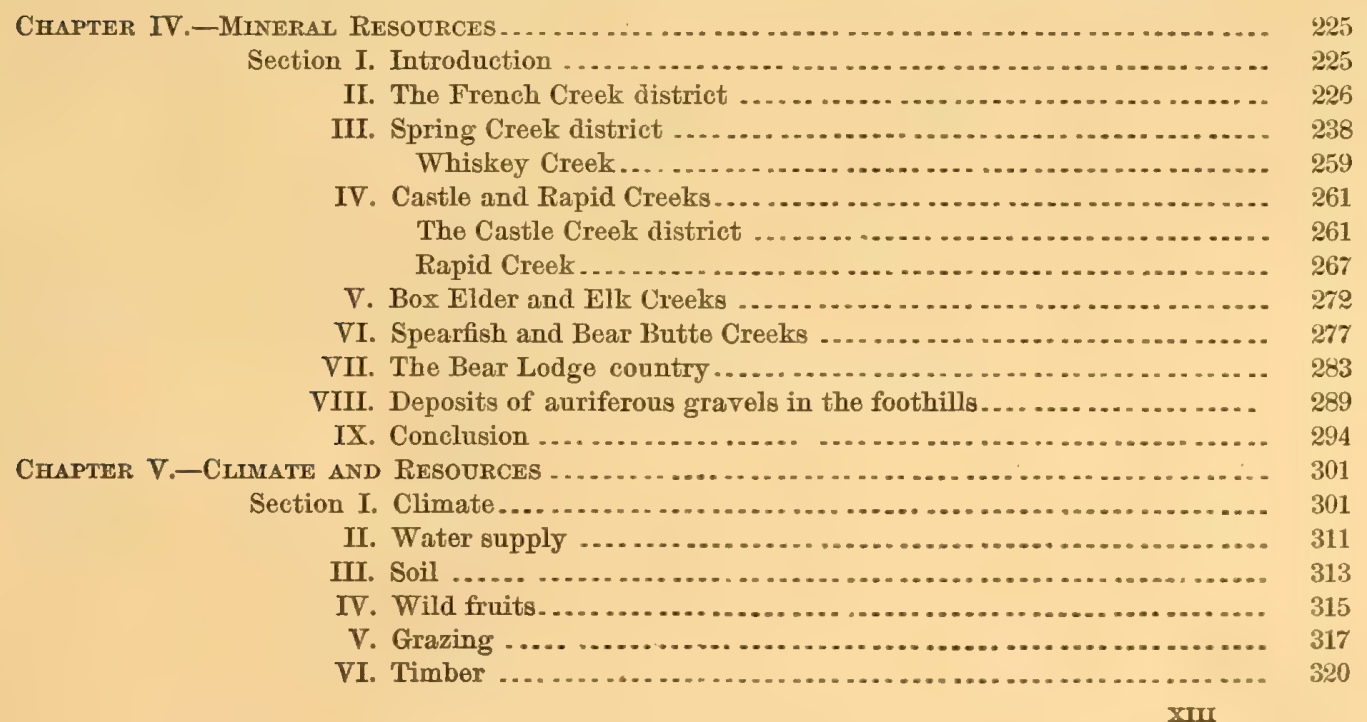


PALEONTOLOGY OF THE BLACK HILLS, BY R. P. WHITFIELD.

Chapter Vi.-Paleontological Report on the Fossils Collected...................

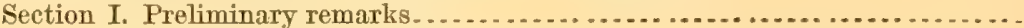

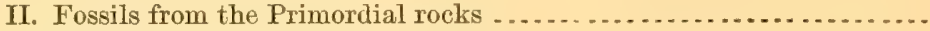

III. Fossils from the Jurassic rocks ...............................

IV. Fossils from the Cretaceons rocks ..........................

$\nabla$. Synopsis of species from the Black Hills, noticed in other works, not described in this report ..............................

VI. List of fossils described in this report .......................

MICROSCOPIC PETROGRAPHY OF THE BLACK HILLS, BY JOHN H. CASWLLL.

Chapter ViI.-Microscopic Petrography . . . . . . . . . . .

Section 1. Quartzites.......................................... 471

II. Mica schists and slates ................................. 476

III. Rhyolite, trachyte, and phonolite...................... 483

BOTANY OF THE BLACK HILLS, BY ASA GRAY.

Chapter VIII.-Botany

ASTRONOMY AND BAROMETRIC HYPSOMETRY OF THE BLACK HILLS, BY HORACE P. TUTTLE.

Chapter IX.-ASTroNomy AND BAROMETRIC HyPSOMETRY . . . . . . . . . . . . . . . . . . . . . 54:3

Section I. The astronomical work ............................. 543

II. Magnetic variation .................................... 547

III. Barometric work .................................. 547

Table of positions and altitudes of camps and other points...... 551

IV. Supplement ...................................... 554 


\section{LIST OF ILLUSTRATIONS.}

FrontisPIECE.--Bear Lodge, looking eastward.

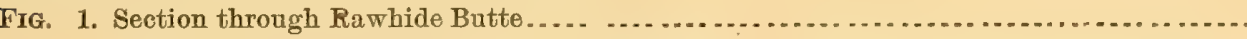

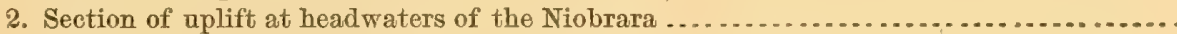

3. Section through outer foothills at Camp Jenney, east fork of Beaver ..................

4. Head of Golden Valley, illustrating park scenery . . . . . . . . . . . . . . . . . . . . . . . . . .

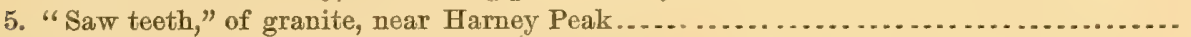

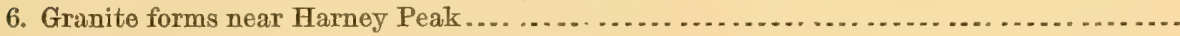

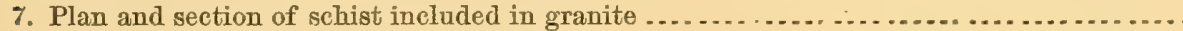

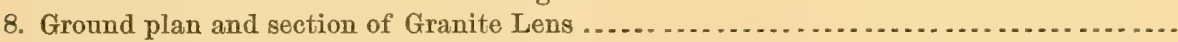

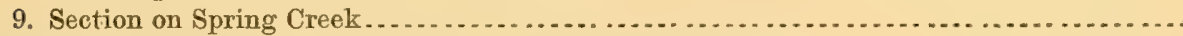

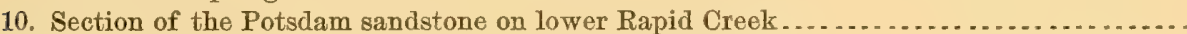

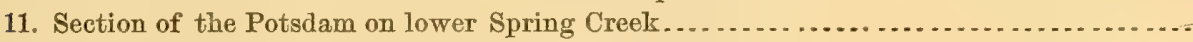

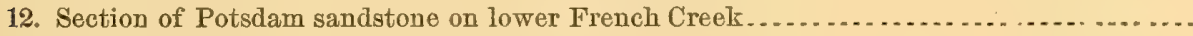

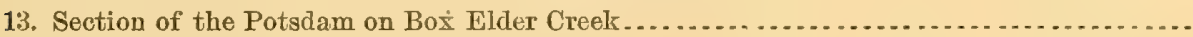

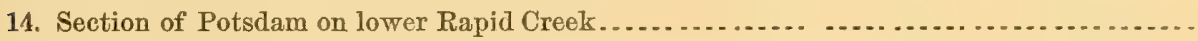

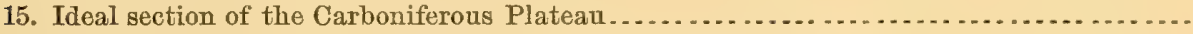

16. Ideal section across the Carboniferous Plateau at Camp Jenney . . . . . . . . . . . . . . .....

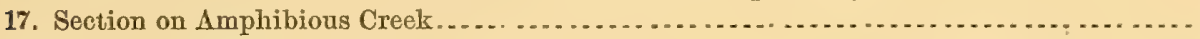

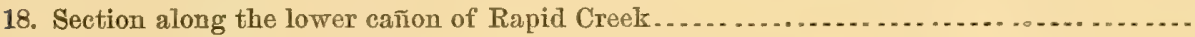

19. Ideal section across the Red Valley at Camp Jenney ...............................

20. Ideal section across the Red $\nabla$ alley on Amphibious Creek ........................... .

21. Ideal section across the Red Valley on Rapid Creek .................................

22. Ideal section across the Red Valley near Spearfish Creek..........................

23. Ideal section across the Red Valley through Sun Dance Hills ........................

24. Section across the valley of the Belle Fourche near Bear Lodge......................

25. Ideal cross-section of the Black Hills

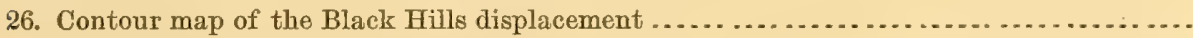

27. Diagram to exhibit the relation of the drainage system of the Black Hills to the zones

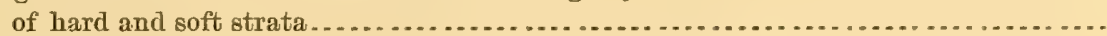

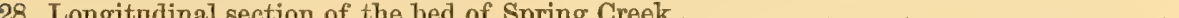

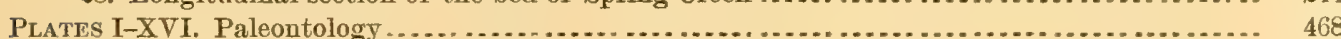

I-II. Microscopic Petrography ........................................ 528 

U. S. GEOGRAPHICAL AND GEULOGIC.IL SITRVEY (iF THE ROCKY IOUNTAIN REGION.

J. W. POWELL, iN Charge.

\section{GEOLOGY}

OF THE

\section{BLACK HILLS OF DAKOTA.}

Br HENRY NEITTON, E. M. 



\title{
GEOLOGY OF THE BLACK HILLS.
}

\author{
By HenRy NeTton.
}

\section{CHAPTER I.}

INTRODUCTION.

\begin{abstract}
Situation and relations of the Black Hills,-Historical Sketch of Explorations in the Upper Missouri Region.-Discoveries of Gold ly the Black Hills,-Origin aNd organization of the Expedityox to the BLack Hills.
\end{abstract}

The Black Hills were explored during the summer of 1875 , in accordance with the instructions of the Secretary of the Interior. Some little confusion has arisen in regard to their identity, for the reason that the mountains adjoining Laramie Peak, in the southeastern part of the Territory of Wyoming, have been called by the same name. The latter, however, in the recent surveys of that region, have been more properly designated the Laramie Mountains; and as a further guard against confusion, the mountains which form the subject of this report are usually called the Black Hills of Dakota.

The name Black ${ }^{-}$Hills is said to have been applied to these, the only mountains of Dakota; from the fact that, as they are approached from the barren, desert wastes of the Plains, they loom up in the distance as a dark range, black from the heavy growth of timber they support. They lis between the $43 \mathrm{~d}$ and 45 th parallels of north latitude, and between the $103 \mathrm{~d}$ and 105th meridians of longitude west from Greenwich, occupying an irregularly shaped area, about 120 miles in length, from north-northwest to south-southeast, and having a width of from 40 to 50 miles.

The meridian of $27^{\circ}$ west from Washington (approximately $104^{\circ}$ west from Greenwich) forms the boundary line between the Territories of Dakota $1 \mathrm{~B} \mathrm{H}$ 
and Wyoming, and it will be seen by referring to the map accompanying this report, that by far the greater area of the Hills is in Dakota, and that but a comparatively small portion of the northern and middle parts is in Wyoming. The entire Bear Lodge range is in Wyoming.

The area of the Hills proper is about 5,000 square miles-not far from that of the State of Connecticut.

The whole area of the main section of the Hills determined to be gold bearing-the French Creek, Spring Creek, Rapid Creek, Deadwood Creek, Terry Peak, \&c., districts-is in Dakota, while the small and unimportant gold district of the Bear Lodge range lies in Wyoming.

The Black Hills are embraced between the two forks of the Cheyenne River, the Belle Fourche and South Fork, which, rising near Pumpkin Buttes, in eastern Wyoming, spread out, the former northeasterly and the latter southeasterly, to enfold the Black Hills, and then approaching each other join about 60 miles east of the Hills in latitude $44^{\circ} 25^{\prime}$, forming the Big Cheyenne, which then flows northeast and empties into the Missouri River some 15 miles above New Fort Sully. Surrounded on all sides by the comparatively unbroken sea of the Great Plains, they are entirely separated from the main chain of the Rocky Mountains on the west, to which system, however, in character and structure they belong, and rise an island of rough and rugged mountains complete within themselves.

The elevation of the Hills above the surrounding country-an average of 2,000 to 3,000 feet-and their heavy growth of timber cause them to act as condensers upon the water-bearing clouds, and the precipitation of moisture upon them is much greater than upon the neighboring region of the Plains. Though they give rise in themselves to no great river or important system of drainage, the enfolding branches of the Cheyenne become augmented to fully double their previous volume by the few running streams that drain from their heights and valleys. While the region of the Hills proper is well watered, containing innumerable springs and brooks of clear and cold water, all the important streams, save about five, sink and disappear in their beds before they reach the regions of the Plains, and though they occasionally rise and sink again, they carry no running water to the Cheyenne. 
There are many parts of the interior area that recall the mountain scenery of northern New York and New England, and the general character of the region is exceedingly broken and rugged.

Having passed the barrier of foot-hills surrounding the Black Hills, and having traversed the broad, red valley that encircles them as a moat, one gradually ascends the outer slope of the Hills and soon enters, at an altitude of 4,500 or 5,100 feet, the wooded portion of the region. This outer slope varies greatly in width, and is underlaid by the older sedimentary rocks, cut in almost every direction by narrow and deep cañons. Usually from the broken interior edge of this slope or plateau of sedimentary rocks one descends a bluff or escarpment and enters the central area of slates and granites, which is tossed into high ridges and sharp peaks, cut up by narrow and deep valleys and ravines, and generally thickly timbered with the common pine of the Rocky Mountains (Pinus ponderosa).

In the structure of the Hills there are many points that make them a miniature representative, compact and wonderfully complete within themselves, of the topography and geology of the great Rocky Mountain system. In their interior area of sharp ridges of schist and slate and serrated peaks of granite are represented the character and structure of a large portion of the nucleal regions of the Rocky Mountains; and in the surrounding sedimentary strata we have, exhibited in a beautifully clear manner, some of the most interesting features. of the composition and structure of the sedimentary formations of the Far West.

To the geologist the detailed study of their rocky structure presents many points of exceeding interest, and, unlike the volume in the East which is so generally concealed with heavy covers of drift or soil, he has here the pages of the geological record plainly spread before him, with no concealing surface accumulations, and with the intimate structure plainly revealed by bluffs and numerous cross-cutting cañons.

The results of the geological observations, which were as carefully made as the limited time and rapid work of the exploration would permit, will be given in a somewhat detailed manner in Chapter III. Our small collections of fossils were made from formations so wonderfully rich that Professor Whitfield has been enabled to prepare a most important mono- 
graph on the paleontology of the region, with illustrations of many new and characteristic forms.

The mineral resources of the country, for the examination of which the expedition was primarily organized, are not greatly varied in character. The deposits of auriferous gravels, found in many parts of the Hills, produced "prospects" sufficient to attract a large influx of miners; and it is probable that many of the districts will pay a fair remuneration for labor and outlay. Reports on the discoveries made during the summer were transmitted from time to time to the department, and fuller accounts, with analyses since made, will be found in the chapter on Economic Geology. This chapter, from its immediate importance, was published by resolution of the Senate, April 18, 1876, in advance of the rest of the report, being accompanied by a description of the climate and general resources of the Hills and by a small preliminary map.*

The portion of the Black Hills east of the meridian of $101^{\circ}$ lies within the permanent reservation set aside for the different tribes of the Dakota or Sioux Indians by the provisions of the treaty of 1858. According to the terms of this treaty the reservation is bounded "on the south by the north line of Nebraska, latitude $43^{\circ}$; on the west by the boundary between $\mathrm{Wy}$ oming and Dakota, longitude $104^{\circ}$ west; on the north by the parallel of latitude $46^{\circ}$ north, and on the east by low water on the Missouri River," altogether embracing an area of about 40,570 square miles. Beside this area, by the same treaty, all the country north of the North Platte and east of the summits of the Bighorn Mountains, is held as unceded Indian territory, practically granted to them as a hunting reservation. By special agreement, however, made in 1875 , the right of the Indians to hunt in Nebraska, south of the Niobrara and west of the 100th meridian, was relinquished for the sum of $\$ 25,000$.

This large reservation, excepting the Black Hills, their immediate vicinity, and the narrow valleys of some of the more important streams, is a most inhospitable region, desolate and barren, and includes a large area of the well-known sterile and clayey tracts of "bad lands." Once abound-

* Forty-fourth Congress, first session, Senate Ex. Doc. No. 51. The Mineral Wealth, Climate and Rainfall, and Natural Resonrces of the Black Hills of Dakota, by Walter P. Jenney, E. M., Geolrgist in charge. Washington, 1876. 
ing in buffaloes and smaller game, which afforded an abundant maintenince for the hunting Indians, it is now deserted, save by a few antelopes and deer. The buffaloes have been destroyed or driven to the Upper Missouri, and this large population of 50,000 Indians is held in a tract of country whose natural resources are utterly inadequate to maintain even a tithe of the number.

The agricultural possibilities of the Sioux Reservation may practically be considered as nothing. The soil and climate will admit of farming only at a few places in the narrow valleys of some of the larger streams, and even in the most favored spots cultivation is possible only by a systematic work of irrigation. It is a high estimate to say that one-half of one per cent of this great country can possibly be irrigated.

Many parts of the reservation afford excellent grazing during the summer, though water is very deficient, but the rigors of a Dakota winter forbid any attempt at a systematic engagement in the grazing of stock, especially by the improvident Indians. It may be said with truth that the Black Hills include all the desirable land in the reservation and all the useful timber, and by those who view the treatment and future of the Indians in this region in a purely humanitarian spirit the presence of gold in the Black Hills has been regarded as unfortunate, for if it were not for its discovery, this beautifully timbered and grassed region would afford them an excellent retreat during their initiation into the simpler labors of civilization.

By many of the more intelligent of the Dakotas the Black Hills have been long thought of as the final refuge of their tribe from the encroachments of the whites. They are by far the most powerful Indian nation within our territories, including, as they $d o$, a population of $50,044^{*}$; and by the absence of game in their country, coupled with its agricultural barrenness, they are of necessity thrown upon the bounty of the government, which has taken all the desirable land they possessed in Minnesota and elsewhere, leaving them a desolate waste.

Exploration in the region between the Missouri River and the Rocky Mountains has not been so thorough and complete as in the corresponding

* Report of Commissioner of Indian Affairs, 1875. 
region south of the Pacific Railway, partly because of the hostile Indians, the expense of transporting supplies, and the barrenness of the country, but especially because the more rapid settlement of the south has demanded the prior exploration and opening up of that part of the Plains. To illustrate the progress of exploration in the Upper Missouri Region, and particularly to show the course of exploration in the area of our last summer's work, the different expeditions that have passed over and examined this northwest territory will be briefly reviewed. Many of the facts relating to the earlier expeditions are derived from Dr. Hayden's paper in the report of General W. F̌. Raynolds" "Exploration of the Yellowstone and Missouri Rivers" (1859-1860).

The first authorized expedition made by our government, and the first intelligent exploration of the Upper Missouri region was conducted in 1804, '05, and '06, by Captains Lewis and Clarke of the United States Army, who were commissioned in 1803 by President Jefferson. They started in the spring of 1804, following up the Missouri River to its source, and then pushed across the Rocky Mountains to the Columbia River and the Pacific. Returning, they descended the Yellowstone to the Missouri and the Missouri to Saint Louis. Their journal, published in 1814,* contains the first reliable account of this great northwest territory, and though of exceeding interest, especially in relation to the Indian tribes they encountered, it contains little or no information as to the geological structure of the country. They collected a few fossils, however, and from their study Dr. Mortont was able to establish the presence of the Cretaceous formation on the Upper Missouri.

A long period intervened before the next expedition of note, which was made in 1832, by Prince Maximilian of Neuwied, who ascended to the headwaters of the Missouri. The results of his travels were published in a most elegant manner, profusely illustrated from sketches made in the field, which possess much artistic value, beside being truthful pictures of the country and natives. Maximilian noted more carefully than his predeces-

* History of the expedition under the command of Captains Lewis and Clarke to the sources of the Missouri, thence across the Roclsy Mountains and down the river Columbia, \&c., during the years 1804, '05 '06, by order of the United States Government. 2 vols, 8vo. Philadelphia, Bradford and Inskeep, 1314.

t Synopsis of the Organic Remains of the Cretaceous Groups of the United States, etc. By S. G. Morton. Philadelphia, 1834. 
sors the geological features of his route, and mentions the occurrence of well known Cretaceous fossils from the headwaters of the Missouri to the mouth of the Big Sioux; and the great geologist Von Bach, from his observations, was led to state, "that this great river flows uninterruptedly from the font of the Rocky Mountains, through strata of chalk, at least as far as the mouth of the Sioux River. This is the result of the accounts and collections of Prince Neuwied and of the report of the celebrated astronomer Nicollet." *

In 1839, the geographer J. N. Nicollet, under the auspices of the War Department, ascended the Missouri River as far as Fort Pierre, and though his travels did not extend so far as his predecessors', from his accurate observation we obtained the first definite and reliable information of the geology of that region. Devoting considerable time to the study of this part of the Missouri Valley, he collected a large series of fossils from the Cretaceous formation, and, on his return to Philadelphia, they were described by Conrad and Morton, and published in the Proceedings of the Academy of Natural Sciences. The results of his explorations were published by authority of the government.

Mr. Audubon, in his expedition to the mouth of the Yellowstone in 1843, was accompanied by Mr. Edward Harris, who had been instructed by the Philadelphia Academy of Natural Sciences to make observations on the geology of the region. The committee apointed by the Academy to report on the notes and collections of Mr. Harris, consisting of Professors Rogers, Morton, and Johnson, gave the first intimation of the proofs of the freshwater origin of certain deposits of the Upper Missouri. Previous explorers, though recording the presence of lignites, \&c. on the Missouri River above Fort Clarke, never recognized the different character of the deposits above and below this point; and in the collection of Mr. Harris the first proofs are presented of the great lignitic and fresh-water Tertiary beds, which occupy such large areas on the Upper Missouri. Mr. Harris obtained at one point "a brown, ferruginous, argillaceous rock, containing three or four specimens of freshwater, univalve shells, Limnca, Planorbis, ete. One of the specimens of Planorbis, it is conjectured, may be a form extinct, but the 
mutilated condition of the specimens prohibits a positive opinion." * In these collections we have also the first specimens of that great fossil flora of the Upper Missouri, which has since yielded such rich and valuable stores of deciduous plants to our paleo-botanists, Newberry, Lesquereux, etc.

It will be noticed that the expeditions mentioned confined their explorations in Dakota and Wyoming almost entirely to the immediate valley of the Missouri and its branches, and did not penetrate into the great unknown land beyond the banks of the river. The territory was sterile and disheartening to look upon, and was inhabited then by warlike aborigines. Those hardy and adventurous pioneers of our earlier civilization, the fur-traders and voyageurs, had, however, scoured the country far and near, seeking their peltry and trading with the native tribes in their distant dwelling places. The employés of the old United States and American Fur Companies and their powerful rivals in trade the Hudson Bay Company, were familiar with all points of the great Northwest, but their observations were of little value from a scientific point of view. Good descriptions of the general features of the country, of the Indians, and of life in the West, are given in many of the old books of travels, prominent among which are Irving's "Astoria" and "Bonneville." Specimens, however, brought in from time to time by these traders gave evidence of interesting deposits, and from this source was obtained the first information regarding the great bone beds of the "bad land" Tertiary deposits-the "Mauvaises Terres" of the White River. An account of these specimens was first made public in the American Journal of Science, by Dr. H. A. Prout, in 1847.

In 1849, Dr. D. Dale Owen, who had been intrusted to make a geological survey of the Chippewa land district, directed his assistant, Dr. John Evans, to make a trip into the Mauvaises Terres of White River. Dr. Evans obtained a very excellent collection of Cretaceous shells and vertebrate remains, and the former were described and published in Dr. Owen's final report in 1852, while the latter were described by Dr. Leidy, of Philadelphia. $\dagger$

In this report of Dr. Owen the first description is given by Dr. Evans $\ddagger$ of these now celebrated "bad lands."

\footnotetext{
* Proc. Phil. Acad. Sci., May 1845, vol, ii, p. 240.

†Proc. Phil. Acad. Sci., vol, vi, 1852-'53, p. 392.

$\ddagger$ D. D. Owen's Final Report, 4to, 638 pp., 27 plates, 16 maps, p. 194, ct seq.
} 
In 1850 the Upper Missouri country was visited by Mr. T. A. Culbertson under the direction of the Smithsonian Institution. He collected some vertebrate fossils from the White River bad lands and ascended the Missouri above Fort Union, and though he notes the character of the country, his report shows that he made no collections and no valuable observations on the geology of these very interesting formations.

Dr. Evans again, in 1853, passed through this region en route to Oregon Territory, where he was ordered by the government to make a geological survey. He made here another valuable collection of vertebrate fossils from the Bad Lands and of Cretaceous fossils from the now wellknown Sage Creek region. Dr. Leidy made a study of the vertebrate remains, publishing the results in the Journal of the Pliladelphia Academy of Natural Sciences, while Drs. Evans and Shumard described the molluscan fossils in the Proceedings of the Saint Louis Academy of Sciences.

In the same year, 1853 , the region was visited for the first time by Mr. Meek and Dr. Hayden, to whom so much is due for their study of the geology of the Northwest, and they have continued to the present time* among the most voluminous contributors to the geology and paleontology of the far West. These gentlemen visited the country under the auspices of Prof. James Hall, of Albany, the veteran American paleontologist, for the purpose of making a collection of the Cretaceous and Tertiary fossils of the Bad Land region. The vertebrate remains collected were examined by Dr. Leidy, and the invertebrate forms of the Cretaceous, studied by Professor Hall and Mr. Meek, furnished the subject of a memoir published by the Boston Academy of Science. $\dagger$ In this memoir was a section prepared by Mr. Meek, showing for the first time the order of succession of the different beds of the Cretaceous in the Upper Missouri Region. The interesting observations of Meek and Hayden on the geology of the country from Fort Pierre to Council Bluffs were presented also by Professor Hall in a paper read before the American Association for the Advancement of Science, at Providence in 1865.

In 1854 Dr. Hayden, for the most part alone and unaided, again

* Mr. Newton's MS. was prepared before the lamented death of Mr. Meek, which occurred December 22, 1876.-ED.

† Proceedings, 1854. 
visited the Upper Missouri region, in which he spent two years, traversing it in different directions, often on foot. During this time he passed up the Missouri River to Fort Benton, and up the Yellowstone to the north of the Bighorn River, and traversed large portions of the bad lands of the White River region.

In 1855 an expedition was made into the Dakota country, called the "Sioux Expedition," under the command of General W. S. Harney. This was unaccompanied by any scientific observer, and was undertaken primarily to determine upon routes to the far west and between the frontier military posts. A report of the exploration was made in a small document, "Exploration in the Dakota Country," published by order of the United States Senate. In 1856 these explorations were continued under the immediate command of Lieut. (now Major of Engineers and Bvt. Maj. Gen.) G. K. Warren, of the United States Topographical Engineers, and he was accompanied by Dr. F. V. Hayden as geologist and naturalist. Starting from Saint Louis, Lieutenant Warren made a careful survey of the Missouri to Fort Pierre, at which place the expedition was organized. From this point the Missouri was ascended in the American Fur Company's boat to some 60 miles above the mouth of the Yellowstone River, careful examinations being made en route. With wagons the Yellowstone was ascended for 100 miles above its mouth, and with pack mules to the mouth of the Powder River, some 30 miles farther. The expedition returned to Fort Pierre by boats, mapping the Yellowstone River, verifying the map of the Missouri, and examining all interesting points. Lieutenant Warren was ordered in 1857 to continue these explorations, and to determine the best route between the Big Sioux and Fort Laramie and South Pass, and then to examine the Black Hills as far as possible. This expedition is of particular interest here, because it obtained the first reliable information regarding the Black Hills of Dakota, and a more detailed notice of it will not be out of place.

Leaving Sioux City with wagons, Lieutenant Warren ascended the Loup Fork to its source, and crossing to the Niobrara ascended it, and thence reached Fort Laramie. Here his party divided, and one part, under Lieutenant McMillan, with the wagons, descended the Niobrara, where it awaited the main party. Lieutenant Warren, accompanied by Dr. Hayden 
as naturalist, with only a pack train, proceeded northward from Fort Laramie to the Black Hills. His route passed by Rawhide Butte and down Old Woman's Fork to the South Cheyenne, and thence to Beaver Creek, by the east branch of which he entered the Hills. This is much the same route as that taken by the expedition of 1875 , and Lieutenant Warren's camp of September 12 is almost the same as our first camp in the Hills, known as Camp Jenney. From here Lieutenant Warren proceeded northward to Inyan Kara, where he was met.by a large force of the Sioux, who were engaged in herding immense numbers of buffaloes in the Red Water Valley. His party being small and the Indians opposing their progress they retraced their steps, and passing around the southern end of the Hills struck northward on the east side of Bear Butte. Leaving this on Oetober 1st, they traveled down Warren Creek, and thence southeast to the South Cheyenne, near Sage Creek, and, ascending the Cheyenne to near French Creek, crossed over to the White River, meeting Lieutenant McMillan and the rest of the party on the Niobrara. Fort Randall was reached on the 1st of November. The preliminary report of Lieutenant Warren, accompanied by a catalogue of the collections made by Dr. Hayden, was published by the War Department in 1858.*

Owing to the breaking out of the civil war no final report of Lieutenant Warren's exploration was ever published, and it is very much to be regretted that the valuable material collected by this and other surveys undertaken in the far west about the same time have never been made public. $\dagger$

The results of Dr. Hayden's observations were combined with those subsequently made, and published in papers and places hereafter mentioned.

This reconnaissance of the outskirts of the Black Hills was made in a most rapid manner and with a small amount of instrumental aid, but it has

* Preliminary Report of Explorations in Nebraska and Dakota in the years 1855, '56, '57. 8 vo., pp. 125, with map. Engineer Department, 1858. Republished in 1875.

tA portion of the material to which Mr. Newton refers has recently been published. The War Department has brought out the report of Capt. J. H. Simpsen on "Explorations across the Great Basin of the Territory of Utah," with many scientific appendices, and the report of Capt. J. N. Macomb's "Exploring Expedition from Santa Fe to the Junction of the Grand and Green Rivers," with a most valuable geological report by Dr. J. S. Newberry; while an important paper on the "Tribes of Western Washington and Northwestern Oregon," by the Iate George Gibbs, has appeared in the publications of this survey, "Contributions to North American Ethnology, vol. i."-ED. 
been proved by our more detailed survey to exhibit unusual accuracy, and it remains a most gratifying testimony to the care and precision of the mapping of Lieutenant Warren. All the subsequent maps of the region, up to the present time, have been based on his work.

In the year 1859 an expedition under the command of Captain (now Colonel) W. F. Raynolds, United States Engineers, was organized "for the exploration of the region of country through which flow the principal tributaries of the Yellowstone River, and of the mountains in which they and the Gallatin and Madison forks of the Missouri have their sources." This expedition was accompanied by Dr. Hayden as geologist, and started from Fort Pierre, on the Missouri, en route for Fort Sarpy, on the Yellowstone. Passing by Bear Butte it followed the Red Water Valley westward, and then striking northwest erossed the Belle Fourche branch of the Cheyenne near its great northern bend. A passing examination was made of that portion only of the Black Hills through which their route lay, and a successful scout was made by Mr. J. D. Hutton, topographer, to the curious peak of the Bear Lodge. The rest of the season was spent in explorations of the Bighorn and Powder River region, winter quarters being made on the North Platte near Deer Creek. The following year was occupied by different parties of the expedition in the exploration of the Wind River, Upper Yellowstone, and Upper Missouri regions, and meeting at Fort Union, at the mouth of the Yellowstone, the main party followed the Missouri to Fort Randall and Omaha on land, while a division under Lieutenant Maynadier descended the river in boats The preparation of the reports of the expedition was delayed by the war of the rebellion, but a report by General Raynolds was issued in 1868,* while the-report of Dr. Hayden on the geology of the region visited was published in the following year. $\dagger$

In the interval between the making of this survey and the publication of the final official reports there appeared numerous valuable publications on the geology and natural history of the region. In 1857 Dr. Hayden presented the first map of the geology of the region, in a paper read before the

* Report on theE xploration of the Yellowstone River, by Bvt. Brig. Gen. W. F. Raynolds. 8vo, pp. 174, with map. Washington, 1868.

t Geological Report of the Exploration of the Yellowstone and Missouri rivers, by Dr. F. V. Hajden. 8vo., pp. 144, with geological map. Washington, 1869. 
Philadelphia Acadeny of Natural Sciences,* and in the following year another map was published by him in the Proceedings of the Philadelphia Academy, together with the results of his expedition with Lieutenant Warren to the Black Hills. The most important publication, however, including all his observations to date, was read as a memoir by Dr. Hayden before the American Philosophical Society of Philadelphia in $1861, \dagger$ being accompanied by a map. The descriptions by Dr. Leidy of the vertebrate remains collected in these various expeditions appeared at different times in the Proceedings of the Philadelphia Academy of Natural Sciences, and form a most important contribution to our knowledge of these very interesting fossils. Much of the same material, with the addition of that since collected in other parts of the Far West, appears in a more accessible form in a quarto publication of the Geological Survey of the Territories. $f$ The molluscan collections of the formations of the Upper Missouri have been described and published through the Philadelphia Academy of Natural Sciences by Messrs. Meek and Hayden and form the subject of one of the memoirs issued by the Smithsonian Institution. \$

In 1859 Captain (now Colonel) J. H. Simpson, United States Engineers, made a survey for a wagon road across the Great Basin of Utah, and the records of the route from Fort Leavenworth to Fort Laramie and South Pass contain many valuable facts regarding the geology of the southern part of the Upper Missouri region. The geologist was Mr. Henry Engelmann.\|

In 1866 Dr. Hayden again visited the Bad Land region of the Niobrara and White Rivers, and in the following year the "Geological Survey of the Territories," in his charge, was begun under the auspices of the Commissioner of the General Land Office. The work was commenced in Nebraska, and in the following year was extended into Wyoming, but it embraced only the southern portion of that Territory and the northern

\footnotetext{
* Notes explanatory of a map and section illustrating the geographical structure of the country bordering the Missouri. May, 1857.

t On the Geology and Natural History of the Upper Missouri, with map. Trans. Am. Phil. Soc. Philadelphia, July 19, 1861.

$\ddagger$ Contribution to the Extinct Vertebrate Fauna of the Western Territories, by Joseph Leidy. 4to, pp. 358, pl. 37. Washington, 1873.

(5) Paleontology of the Upper Missouri. Part 1. F. B. Meek and F. V. Hayden. Washington, 1865.

i| Exploration across the Great Basin of Utah, 1859, by Capt. J. A. Simpson. (Geology by H. Englemann.) 5to. Engineer Department, 1876.
} 
part of Colorado-from Cheyenne and Fort Laramie westward to Fort Bridger and the South Pass. The results of these two years' work were made public in two annual reports issued by the General Land Office.*

The more complete report of the exploration in Nebraska and the parts of the Territories immediately adjoining, prepared in 1868, was published by the Commissioner of the General Land Office in 1872. $\dagger$

In the following year, 1869, the appropriation for the surveys under Dr. Hayden's care was increased, and the work was placed under the immediate direction of the Secretary of the Interior. The field of operations was transferred to the Territories of Colorado and New Mexico, and the results of the year's work were published in a report to the Secretary of the Interior. $f$ In 1870, 1871, and 1872, the field of survey was once more north of the railroad, but it included no portion either of eastern Wyoming or of Dakota. The results were published in annual reports to the Secretary of the Interior. \$ Since 1872 the field of survey has again been transferred to the Territories lying south of the railroad.

In 1873 Captain W. A. Jones, United States Engineers, proceeded from Fort Bridger to northwestern Wyoming, and made a reconnaissance of the country within that Territory about the headwaters of the Snake, Bighorn, Grey Bull, Clark's Fork, and Yellowstone Rivers. This expedition was accompanied by Prof. 'T. B. Comstock as geologist, and though much of the territory examined had already been passed over by Hayden and other explorers, the report of Professor Comstock affords many valuable additions to our knowledge of the geological structure of the Wind River Mountains and the adjoining region, including the headwaters of the Yellowstone and the Yellowstone National Park.\|

* First Annual Report of United States Geological Survey of the Territories, embracing Nebraska. 8vo., pp. 64, 1867, and Second Annual Report, \&c., embracing Wyoming. 8vo., pp. 36, 1868.

†Final Report of the United States Geological Survey of Nebraska and portions of adjacent Territories. 8vo., pp. 269, plates xi, and Geological Map.

¥ Third Annual Report of United States Geological Survey of Territories, embracing Colorado and New Mexico. 8vo, pp. 25. Washington, 1870.

$\oint$ United States Geological Survey Wyoming and contiguous Territories. 8vo., pp.511. Washington, 1871. United States Geological Survey Montana and adjoining Territories. 8vo., pp.538. Washington, 1872. United States Geological Survey Montana, Wyoming, \&c. 8vo., pp.844. Washington, 1873 .

\| Northwestem Wyoming, including Yellowstone National Park, Geology, by Prof. T. B. Comstock. 8 vo., pp. 331, maps 51. Washington, 1875. 
Lieut. Col. G. A. Custer, in the summer of 1874, was directed by General Sheridau, of the Department of the Missouri, to organize an expedition at "Fort Abraham Lincoln, Dakota Territory, for the purpose of reconnoitering a route from that post to Bear Butte in the Black Hills, and exploring the country south, southeast, and southwest of that point," and to "return within sixty days from the time of his departure from it" General Custer left Fort Abraham Lincoln, and striking southwestward to the valley of the Little Missouri, crossed the Belle Fourche about 10 miles east of the great northern bend; thence, through the Red Water Valley and past Sun Dance Hills, he entered the Hills proper near Inyan Kara, and passing along Floral Valley and Castle Creek encamped on French Creek near its lower cañon. From this point two scouts were made, one southwestward to the Cheyenne River, via Red Cañon Creek, and another down French Creek to the Red Valley. An ascent of Harney Peak was also made. Returning northward the expedition passed over the old trail to Castle Creek, and then out of the Hills by the valley of the Box Elder. Passing near Bear Butte, and crossing the Belle Fourche, they returned to Fort Abraham Lincoln by the valley of the Little Missouri and the headwaters of Cannon Ball and Heart Rivers, being absent just sixty days. This was the first expedition that had ever penetrated the fastnesses of the Black Hills. In his rapid march General Custer was accompanied by Capt. Wm. Ludlow, United States Engineers, under whose direction the route was mapped, by Prof. N. H. Winchell as geologist, and by Mr. G. B. Grinnell as naturalist. The report of General Custer was published in 1875 in compliance with a Senate resolution,* while the reports of Captain Ludlow, Professor Winchell, and Mr. Grinnell form a volume published by the Engineer Department in the same year. $f$

General Custer was accompanied by several miners and prospectors, who were engaged on all possible occasions during their rapid march through the Hills in examining the region for the existence of mineral de-

* Report of the Expedition to the Black Hills of Dakota, under command of Bvt. Maj. Gen. G. A. Custer. Ex. Doc. No. 32, U. S. Senate. 187\%.

† Report of a Reconnaissance of the Black Hills of Dakota, made in the Summer of 18r4, by Capt. William Ludlow, United States Engineers. 4to, pp. 121, maps 3 and plate. 
posits but more especially in prospecting for gold. In regard to the discoveries made, the words of General Custer may be quoted from his preliminary report to the Department of Dakota:

It will be understood that within the limits of the Black Hills we were almost constantly marehing, never halting at any one point for a longer period than one day, except once, and that was near Harney's Peak, where we remained five days, most of the command, however, being employed in operations during the halt. * * * Enough, however, was determined to establish the fact that gold is distributed thronghout the extensive area within the Black Hills. Gold was obtained in numerous localities in what are termed gulches. No discoveries, so far as I am aware, were made of gold deposits in quartz, althongh there is every reason to believe that a more thorough and extended search would have discovered it. No large nuggets were found; the examination, however, showed that a very even, if not a very rich, distribution of gold is to be found throughont entire valleys. In other words, the "prospecting" showed that, while the miner may not in one panful of earth find nuggets of large size or deposits of astonishing richness, to be followed by days and weeks of unrewarded labor, he may reasonably expeet, in certain localities, to realize from every panful of earth a handsome return for his labor.

While I feel satisfied that gold in satisfactory quantities can be obtained in the Black Hills, yet the hasty examination we were foreed to make did not enable us to determine in any satisfactory degree the richness or extent of the gold deposits in that region. Seeking for gold was not one of the objects of this expedition, consequently we were but illy prepared to institute or successfully prosecute a search for it even after we became aware of its existence in the country.

These reports of General Custer, correct in thernselves, were magnified and exaggerated by others until the sensitive imagination of western prospectors and frontiersmen constructed for itself a region of riches and wealth untold, awaiting only the reaping of the harvest. On the other hand, it must be recorded that the presence of gold in the Hills, at least in any quantity, was strongly denied by high scientific authority on the ground of their supposed general structure, and also by members of the expedition itself, who would be supposed to have had the opportunity of practically testing the question. It is proper to mention, too, that the existence of gold in this region was undoubtedly known long before to the Indians and some of the old pioneers. The statement of Father de Smet has often been quoted, and considerable reliance has been placed upon what he said, but more imagined from what he left unsaid. Father de Smet was born in Belgium in 1801, and early in life emigrated to this country, entered the Order of the Society of Jesus, and became a missionary to the 
native tribes of the far west. His account may best be given in the words of a letter written in March, 1875, to General Sherman by General Sheridan, who was personally acquainted with the holy father and learned from his own lips the following story:

That while living with the Sionx Indians he was shown by them nuggets of gold, which they informed him had been obtained at different points in the Black Hills, supposed to be from the beds of the Bighorn, Rosebud, and Powder Rivers, and from branches of the Tongue River; and on his representation that such cellow metal was of the greatest value, they told him they knew where there was a mountain of it. Subsequent investigation, however, proved that the Indian mountain of gold was nothing more than a formation of yellow mica, such as may be found in the above-described country.

The reports of General Custer brought this story of Father de Smet again prominently to light. In the winter of 1874-'75 several of the prospectors who had accompanied General Custer in his expedition returned from Sioux City with others to French Creek. Arriving there about Christmas time, twenty-five in number, with the wife and child of one of the party, they immediately proceeded to erect a stockade and cabins to protect themselves from possible Indian attacks and from the sererity of the climate They prospected the valley of the creek in their immediate vicinity, and although the snow and coldness of the winter prevented a thorough examination they were satisfied and encouraged. Two parties from the camp returning in February to Cheyenne, fired anew the dormant spirits, ready for excitement of any kind.

The presence of this party in the Hills and the certainty that others would follow their footsteps compelled the government to take some notice of these unauthorized operations within the Indian Reservation, which they were bound by the terms of the treaty of 1858 to protect from the incursions of the whites A company of cavalry under Captain Mix was therefore dispatched from Fort Laramie early in March, and the remainder of the stockade party were brought back to Fort Laramie. Measures were also taken at the various military posts to prevent the starting of others to the Black Hills.

The reports that had been brought in by the stockade party, in their

* The recent discovery of nuggets weighing several ounces, in the northern parts of the Hills, renders the knowledge of rich deposits there quite possible.

$2 \mathrm{~B} \mathrm{H}$ 
true and in their more exaggerated forms, with the addition of others more or less fictitious, were now spread far and wide over the West, and great excitement prevailed in the frontier settlements bordering on the reservation, and extended even into the thickly-settled region of the East. The great floating population of the frontier, miners and others, suffering from a dearth for several years of the excitement peculiar to mining discoveries were now ready to rush into this new El Dorado of the West, and the different towns of the immediate frontier rivaled each other in the statements of their superiority as outfitting posts for the Black Hills, while the mere fact that there was a desire on the part of the government to sustain its part of the treaty and keep intruders out of the reservation only added new zest to the enterprise.

It soon became evident that there was a large body of miners ready to enter the new field, many of whom expressed no wish to transgress the word of the government given in the treaty, and there was a very general desire that the right to prospect and mine should be acquired for them by the government either by purchasing the Black Hills or by obtaining a concession from the Indians, as was endeavored in a subsequent council.

As many of the reports circulated were undoubtedly greatly exaggerated, and many persons well informed in regard to this region of the Northwest, and of high authority, were strong in their denials of the presence of gold there, at least in remunerative quantities, it became of general - importance to obtain accurate and reliable information on the subject. It was determined, therefore, that trusty persons should be sent immediately to examine the region and report to the Secretary of the Interior, so that the true facts regarding the nature and value of the mineral deposits should be authoritatively known, and might furnish a basis for any subsequent negotiations with the Indians for the territory.

As this expedition, both in the territory to be examined and in the purpose of the examination, was one relating specially to the rights and interests of the Sioux Indians, the organization and control were given to the Bureau of Indian Affairs, under which the work was begun and completed. Under authority of the Secretary of the Interior, Mr. Walter P. Jenney was therefore appointed by the Commissioner of Indian Affairs, 
March 26, 1875, to undertake the work of the examination, and Mr. Henry Newton was commissioned to act as his assistant.

At first it was proposed that with his assistant, and with the help of a small force of miners and laborers, $\mathrm{Mr}$. Jenney should immediately proceed to the field, make in a few weeks a hasty examination, return, and make his report. But as much of the value of the labor would be lost without a reliable map of the region-that of Lieutenant Warren and General Raynolds expressing only the outer rim of the Hills-it was finally arranged to add to the party a topographer and an astronomer. Dr. V. T. MeGillycuddy, late of the Lake and Northern Boundary Surveys, and Capt. H. P. Tuttle, late of the Cambridge Observatury, were therefore commissioned to accompany the expedition, respectively as topographer and astronomer. The personnel of the expedition, as finally organized, consisted of Walter P. Jenney, E. M., geologist in charge; Henry Newton, E. M., assistant geologist; V. T. McGillycuddy, M. D., topographer; Captain Horace P. Tuttle, A. M., astronomer ; C. G. Newberry, M. D., assistant astronomer and naturalist; * W. F. Patrick, E. M., and the following corps of miners and laborers: John Brown, jr.; William H. Root, head mining assistant; William O. Baldwin, A. J. Bottsford, A. P. Sanders, T. H. Mallory, Thomas Morey, James Conklin, Robert M. Jones, A. E. Guerin, and George Bowlin, cook.

With all possible haste the plans were matured and the necessary instruments and tools purchased, and on April 25 the whole party assembled at Cheyenne, Wyo. Here an unexpected delay was unfortunately forced upon us, as the orders for the necessary means of transportation, wagons, horses, \&c., had not been issued by the War Department, as had been supposed. The time, however, was spent in fitting out the numerous little details of the expedition, and finally, on the 17th of May, all transportation, \&c. being fully provided for, Cheyenne was left behind. Arriving at Fort Laramie on May 20 all arrangements were consummated; and crossing the Platte on the afternoon of the 24th of May we joined the military escort furnished by the War Department, consisting of Lieut. Col. R. I. Dodge, Twenty-third Infantry, commanding; Lieut. M. F. F'oot, Ninth Infantry,

* From ill health Dr. Newberry was unfortunately compelled to resign at Fort Laramie on the eve of departure. 
adjutant; Lieut. J. F. Trout, Twenty-third Infantry, quartermaster; Lieut. J. G. Burke, Third Cavalry, topographer, and Surgeons Jaquette and Lane; with two companies of the Ninth Infantry, under Captains Burt and Munson and Lieutenant De Lany; two companies of the Second Cavalry, under Captain Spaulding and Lieutenants Hall, Coale, and Kingsbury; four companies of the Third Cavalry, under Captains Hawley, Russell, and Wessells and Lieutenants King, Whitman, Lawson, Foster, and Morton, with a train of 75 wagons.

This large command, numbering fully 400 men, would seem at first unnecessarily strong for the mere purpose of protecting from Indians those who were pursuing the investigation in the Hills, but the attitude of the Indians on the penetration of this, the most cherished spot of their reservation, could not be foretold, and it was known that they had been not a little agitated by the incursion of General Custer in the previous year and by the subsequent visits and operations of miners. Though no bands of Indians were met during the work, our safety and freedom from their visits were probably due to the well known magnitude and strength of the expedition.

A great measure of the success of the exploration is due to the hearty co-operation of the various officers of the command, but particularly to the commander, Colonel Dodge, whose unwavering interest and determination to make the work successful, and whose constant assistance and courtesy were especially valuable and grateful during the entire course of the work.

'To Lieutenants Morton and Foster, who were detailed for topographical work, Dr. McGillycuddy is indebted for assistance in the prosecution of his mapping.

Reaching the Black Hills on the east fork of the Beaver on the $3 \mathrm{~d}$ of June, the work of the survey was soon begun, and a permanent camp was established on French Creek near the stockade erected by the miners during the previous winter. In order to pursue the work more rapidly and thoroughly, a division of the party was made as follows: Mr Jenney, with a corps of assistants, assumed more particularly the investigations of the mineral resources of the country, prospecting the gold deposits, \&c.; while the remainder of the party, Mr. Newton, Dr. MeGillycuddy, and Captain Tuttle, continued the topographical and more complete geological study 
of the Hills. As the work of the survey progressed northward, the main body of the escort of troops was transferred from one base of supplies to another so as to keep up with the course of the explorations. In this manner, with scarcely a day's remission from work, the survey continued until the entire area of the Black Hills between the forks of the Cheyenne had been mapped and its geology and mineral resources determined as fully as the rapid progress would permit. Having passed over the entire country and accomplished the object of the expedition, the various parties assembled on the Cheyenne at the mouth of Rapid Creek, and began the march homeward, reaching Fort Laramie, via White River and the agencies of Spotted Tail and Red Cloud, on the 14th of October, after an absence of four months and twenty days.

Having disbanded the expedition at Cheyenne the officers of the Survey returned east and assembled in Washington early in November to complete their report.

While in the field, the various discoveries of the presence of gold in the different districts were announced to the Commissioner of Indian Affairs at Washington; and a preliminary report by Mr. Jenney on the mineral resources of the Hills, accompanied by a small preliminary map by Dr. McGillycuddy, was published in the Annual Report of the Commissioner of Indian Affairs for 18i5. The completed observations on the mineral resources, climate, \&c. (Chapters IV and V of this volume), possessing immediate and particular interest, were, by resolution of the Senate, called for in advance of the final report, and with a preliminary map were published in the spring of 1876 *

* The Mineral Wealth, Climate and Rainfall, and Natural Resources of the Black Hills of Dakota. by W. P. Jenney with map. Washington, 18\%6. 8vo., 71 pp. 


\section{CH A P T E R II.}

\section{OBSERVATIONS ON THE ROUTES TO AND FROM THE BLACK HILLS.}

Cheyenne to Fort Laramie.-Fort Larame to the Black Hills.-Rawhide Butte and monoClinal RIDGES ON ROAD TO CHEYENNE River.-TERTIARY ANd CRETACeOUs ON OLd Woman's Fork.-Fort Union Group on Cheyenne River.-Hog-Backs or Monoclinal Ridges of Cretaceous on west side of the Hills.-Route through the Hills.-Notes on Geology of eastern side of Hills,-Tertiary or White River Group.-Bad lands, \&c.

The country between Cheyenne, at which place our party was organized, and Fort Laramie, 96 miles farther north, where the military escort was added to it, has been so frequently examined and reported upon by geologists and others, that little need be said concerning its features and geological structure. Dr. Hayden has repeatedly passed over the route, and his observations may be found recorded in the annual report of the Geological Survey of the Territories for 1870 .

The government road between these two points runs in a northerly direction, crossing the valleys of Lodge Pole, Bear, and Horse Creeks to the Chugwater Valley, which it follows for some 15 miles, and then strikes northwest to the valley of the Platte and Fort Laramie. It runs its entire distance along the eastern base of the Laramie Mountains (Black Hills of Wyoming), whose rugged and snow-capped summits lie some 15 to 18 miles to the west, while to the east spreads the broken, desolate, and treeless region of the Plains. This great country of the Plains, which on the Missouri River at Omaha has an elevation above the sea of 1,060 feet, rises westward, until at Cheyenne, 516 miles distant, it has imperceptibly reached an elevation of 6,075 feet.

From Cheyenne to Fort Laramie the country is gently rolling, being cut by the main drainage valleys from the mountains at the west into 
rounded hills and isolated ridges-with numerous dry ravines and arroyos, the result of surface denudation The general elevation of the surface appears to vary only a little, but there is a quick descent to the valley of the North Platte, and at Fort Laramie the altitude is only 4,500 feet, while the summit point of the mountains, Laramie Peak, 45 miles to the west, attains an altitude of 10,000 feet above the sea

Of the creeks that we pass on our route, Crow Creek, on which Cheyenne is situated, and Lodge Pole Creek, bend southward and join the South Platte, while Horse and Bear Creeks empty into the North Platte, and the Chugwater joins the Laramie River. With the exception of Crow Creek and the Chugwater, which are of considerable size, these small, feeble streams are barely worthy of the name. Their valleys, which are from 4 to 6 miles in width, are almost destitute of trees, but a fair soil, especially on Horse Creek, supports an excellent growth of grass well adapted for grazing purposes. The Chugwater, for the distance traversed by the road, is quite a fertile valley, excavated in the light-colored sandstones and sandy clays of the Tertiary, which in sharp cliffs line its margins, giving them a drear and castellated appearance. Many ranches have been established in these valleys for grazing stock, and considerable hay is cut from their bottoms, finding a ready market at the neighboring military posts. The valley of the Chugwater, from its sheltered character, is a favorite place for wintering stock, which finds abundant pasturage in its deep and protected bottoms.

In this region, wherever irrigation can be directed, the common hardy vegetables and some of the cereals can be cultivated with a good measure of success. The military post at Fort Russell, near Cheyenne, has succeeded by a system of irrigation in raising several kinds of vegetables whose verdant and luxuriant growth presents a most pleasing contrast to the sere and bare plains around. At the military post of Sidney, 100 miles east of Cheyenne, and at Phillips's Ranch on the Chugwater, gardens have also been maintained by irrigation. At Fort Laramie, where are present all the facilities for an abundant irrigation, all attempts hitherto made have been entirely futile, by reason of the poverty of the soil and the vicissitudes of the climate. Proper irrigation requires very considerable 
labor and care, and while, perhaps, it has not been persistently followed, it is the opinion of many of those best capable of judging that though with great pains hardy vegetables may be cultivated, the usual cold nights of this high and dry altitude are serious drawbacks. 'Besides, it may be said that grazing requires so much less labor and produces so much greater returns, that agriculture offers few charms to the settler.

From Cheyenne to Fort Laramie, and in fact northward to the South Fork of the Cheyenne River, the country is underlaid by the beds of the White River Miocene Tertiary, consisting of gray and yellowish sandstones and sandy clays and marls. These are the deposits from the ancient Tertiary fresh-water lake which overspread so large an area of the Great Plains, and they are found to cover unconformably the truncated strata of the Cretaceous, Trias, Jura, and Carboniferous. These older rocks were nowhere seen on our road to Fort Laramie, as their outcrops are along the immediate base of the mountains, fifteen miles to the westward, but their character and occurrence have been repeatedly examined. (See Hayden's report for 1870.) Frequent exposures of the composing beds of the Tertiary are presented in the different valleys, and especially in the cuttings of the Chugwater, while isolated ridges and buttes on the Plains indicate their composition, and bear witness to the enormous thickness of material that has been removed by denudation. The lowest observed rock of the Tertiary is a heavy sandstone, sometimes locally calcareous, with occasional bands of impure limestone, but more frequently arenaceous and loosely aggregated, crumbling and weathering rapidly. This is best exhibited in the Chugwater Valley and on the road between the Chugwater and Fort Laramie. On the Chugwater it has a thickness of 150 to 250 feet, and borders the creek valley on both sides like a wall, though often cut up and weathered into castellated forms like those of the Bad Lands.

Above this soft rock occurs a coarse conglomerate. This is noticeable on Crow Creek south of Cheyenne, and on Lodge Pole and Horse Creeks, and on the Chugwater it becomes a very prominent feature in the geology. Capping the underlying soft rocks, it has protected them from rapid weathering, and where it is wanting, the whole character of the landscape changes, rounded and rolling hills taking the place of abrupt cliffs and escarpments. 
The thickness of the conglomerate varies from 25 feet to nothing. In places it graduates from the maximum thickness to a feather edge; elsewhere it merges imperceptibly into the underlying rocks. In the weathering of the borders of the Chugwater there are often found buttes or pinnacles, detached from the face of the cliff and capped by conglomerate. The conglomerate contains large quantities of the chalcedonic quartz, which is so constant an associate of the Tertiary in the West. The agate formations are often of great beauty and commonly contain the black dendritic disseminations to which the name "moss" has been applied. In certain places on the Chugwater the accumulations are large, and many hundreds of pounds have been collected for ornamental purposes.

On the surface of the Plains along the road south of the Chugwater there is found a very extensive accumulation of gravel, pebbles, and small bowlders, that have been carried down from the mountains at the west and from the beds outcropping at their base. On Horse Creek this formation attains a thickness of 10 to 20 feet and is composed largely of granitic fragments, while from Lodge Pole to Bear Creek it is peculiar in containing a large quantity of labradorite fragments. Frequently it is cemented by a calcareous cement. Wherever found, the deposit is largely made up of pieces of the older sedimentary rocks which underlie the Tertiary and outerop along the base of the mountains at the west. Fragments of Carboniferous limestone with its characteristic fossils are numerous. No bowlders nor fragments were noticed with a greater diameter than two feet, and few are more than six inches in diameter.

So far as our rapid and superficial examination extended, this bowlder deposit is more strongly developed at or near the margins of the valleys draining from the Laramie Mountains, as though it was the result of the denuding and carrying power of streams once larger and filling those channels, rather than of a more wide-spread and general agent of denundation and distribution.

Where the road crosses the divide between the valley of the Chugwater and that of the Laramie, there are cliffs showing from 100 to 200 feet of the soft, light-colored beds of the White River Tertiary, overlying the conglomerate of the Chugwater Valley. 
The time spent in the final preparations for a start was occupied by Captain Tuttle in making observations for the latitude and longitude of Fort Laramie and in rating the chronometers. By his observations the flagstaff on the parade ground at the post was found to be in longitude $104^{\circ}$ $32^{\prime} 01^{\prime \prime}$ and latitude $42^{\circ} 12^{\prime} 30^{\prime \prime}$.

All preparations having been concluded the expedition started from Fort Laramie on the morning of May 25 and thence striking northeast to Rawhide Creek followed up that creek to the east side of Rawhide Butte, where it turned northward past the headwaters of the Niobrara to Old Woman Fork and the Cheyenne River. It followed down the valley of the Cheyenne for some miles, and then took a northeasterly course to the west fork of the Beaver, and entered the Hills by the east fork.

The geology of the region between Fort Laramie and the headwaters of Old Woman Fork is, with the exception of Rawhide Butte and a few less prominent ridges, very similar in character to that between Cheyenne and Fort Laramie. In fact it is but a continuation northward of the soft and somewhat calcareous sandstones of the great Tertiary deposit that follows along the eastern slope of the Rocky Mountains.

On the Platte and the Rawhide and their numerous dry branches there are sections showing from 200 to 300 feet of these beds, and to this is to be added the thickness exposed in the numerous buttes and cliffs, making the entire thickness of visible Tertiary rocks about 500 feet. They consist of a soft, more or less incoherent sandstone, light brown, yellow, or drab in color, and generally more or less calcareous, with occasional streaks and concretions of impure limestone. The latter occurrence was specially noticed on the Rawhide. In some of the limestone nodules fragments of bone were observed, but no well-preserved fossils were procured from them. In the bluffs, however, immediately adjoining Rawhide Butte, a complete jaw of Oreodon was found by Captain Burt, besides numerous fragments of the bones of the same animal. So far as observed, the strata occupy a nearly horizontal position, and abut against, or unconformably overlie, the ridges of elevation of which Rawhide Butte is the most conspicuous.

Rawhide Butte is situated at the head of Rawhide Creek, twenty-five miles north of Fort Laramie. It is a monoclinal ridge or upheaval, chiefly 
of granitoid rocks, and its granite is similar in character to that of the Laramie Range fifty miles southwest, and to that of the Harney Peak series of the Black Hills, one hundred miles northeast. The ridge is about three miles long, and has three principal peaks, the highest of which has an elevation above the sea of 6,300 feet, or about 1,200 feet above the base. It is, however, but the southeastern termination of a long range of upheaval on the headwaters of the Niobrara and Old Woman Fork mentioned in a subsequent place.

In detailed structure the Rawhide Butte consists of a series of black micaceous schists or gneisses, with alternating strata of a coarse, very feldspathic granite. The latter range from 2 to 20 or more feet in thickness, and the whole dip $70^{\circ}$ to sw. $75^{\circ}$ toward the east, with a strike north $40^{\circ}$ west. The summit is covered with common pine of

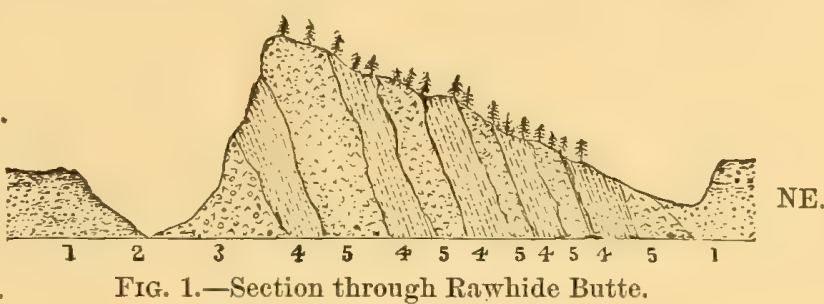

1. Tertiary sands and clays.

2. Valley of Rawhide Creek

3. Graphic granite.

1. Schists.

5. Feldspathic granite. good size, and while the slope on the east side is gentle the descent on the west is very abrupt. The structure is fairly illustrated by the annexed illustration.

On the extreme southeastern corner, occupying a position beneath all the other strata of the butte, is exposed a bed of graphic granite (3), whose junction with the overlying strata is curved irregularly. It is very similar in character to the graphic granite met with in many places in the Harney Peak region of the Black Hills. In it were found graphite, rose-quartz, and tourmaline, and in the gneissic portions of the peak, black mica, red or pink feldspar, and grains of magnetic iron. Seams or intercalated veins of quartz are very numerous in the gneissic strata, running always with the stratification of the rock.

Around the western portion of the butte numerous fragments of the Carboniferous limestone were found, but nowhere was it seen in place.

The Tertiary strata which surround the ridge on all sides lie perfectly. horizontal, and in places are seen to lap ligh up on the ridge itself, while 
several of the cliffs of Tertiary rock near the ridge are curiously capped with a small thickness of conglomerate of granitic pebbles derived from the ridge. By these facts it is shown that the elevation of the butte was prior to the deposition of the Tertiary strata.

The elevation appears to be a monoclinal ridge, such as would have been formed along a line of faulting where one side of the dislocated series was elevated considerably above the other, or such as is called by Major Powell, in his classification of mountain structure, a "monoclinal ridge of displacement."*

At the springs or headwaters of the Niobrara, twelve miles north or northeast from Rawhide Butte, there is an elevation exhibiting the older schists, the Potsdam, and the Carboniferous, as shown in the annexed figure.

The dip of the strata is $20^{\circ}$ eastward, and the strike about the same

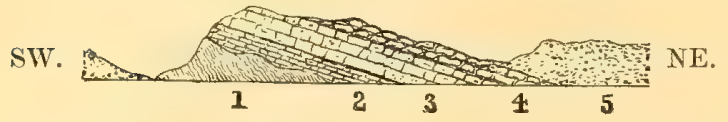

FIG. 2.-Section of Uplift at Headwaters of the Niobrara.

1. Micaceous schist.

2. Coarse, somewhat metamorphosed saudstones (Silurian?); 10 feet.

3. Redrish and whitish sandstones (Silurian?) ; 125 feet.

4. White or grasish limestone (Carboniferous?).

5. Tertiary sauds and clays. as that at Rawhide Butte. The lowest member seen is a micaceous gneiss or schist (1), containing large quantities of quartz and feldspar and seams of feldspathic quartz. The dip of the gneissic strata, though exceedingly variable, is high, the strike having an easterly course.

Above the gneiss lies a coarse, somewhat metamorphic sandstone 10 feet in thickness, then 2 feet of a highly ferruginous sandstone, and then 50 feet of a whitish and reddish quartzite containing much chalcedonic and agatiferous quartz. This is capped by 75 feet of reddish sandstone, which from its character and position is referred to the Silurian, though no fossils were found in it.

Resting conformably upon the sandstone series is a small thickness of white limestone, doubtless of Carboniferous age, while surrounding the elevation are the nearly horizontal beds of the Tertiary, which probably once covered it as a cloak but have been worn through by erosion exposing the upturned strata.

Again, from the summit of the divide near the headwaters of Old

* The Geology of the Uinta Mountains, by J. W. Powell; Washington, 1876; pp. 16 and 22. 
Woman Fork, from which point was gained our first view of the Black Hills, there were seen, low down in the northeast horizon, several low elevations of the older rocks, all trending in the same northwest direction and dipping towards the east, like the monoclinal ridges just mentioned. Though these ridges were noticed on several occasions along the route, and seen to extend far to the northwest, the character of our march was such as to prevent any close or detailed examination of them. At the head of Old Woman Fork, however, a ridge was examined and found to be composed of the following strata, beginning at the top: 2. Gray or whitish limestone, in places showing an interstratification of reddish brown calcareous clays. Thickness 60 to 75 feet; dip $25^{\circ}$ southeast. The limestone contains in places much flint, chalcedony, and agate, and many fossils of well-known Carboniferous types-Athyris subtilita, Spirifera camerata, Productus, \&c. 1. Reddish and whitish sandstone, similar in character to that observed previously, and probably of Silurian age.

Surrounding and overlapping the monoclinal uplift were seen the soft beds of the Tertiary.

The unconforming relation which the surrounding horizontal Tertiary bears to these old lines of uplift shows that the latter were upheaved, and were carved by denuding agencies before the Tertiary beds were deposited, and that these were spread over them like a sheet, concealing their irregularities. They have again been brought to light by the erosion of the Tertiary.

Southwest of Rawhide Butte, between it and the Laramie Mountains, and $a$ short distance northwest from Fort Laramie, several points of upheaval have been noticed by other observers, exposing granitoid rocks with overlying Carboniferous and Cretaceous strata, and, as indicated by the descriptions, they have a similar structure to those already noticed. These uplifts, with Rawhide Butte and the associated ridges, have been considered to form a line of connection between the upheaval of the Laramie Mountains and that of the Black Hills. Though less continuous they have much of the character of the hog-backs; or ridges of sedimentary rocks, which are so marked a feature of the flanks of the Rocky Mountains. But unlike the hog-backs, which are the remnants of anticlinal folds of the 
strata, now removed from the mountains by denudation, the ridges of which Rawhide Butte is a type appear to be ridges of displacement following lines of faulting-monoclinal ridges of displacement. Their trend, so far as observed, is southeast and northwest, or nearly parallel with the axis of the Black Hills, but the Laramie Mountains, running from Long's Peak, Colorado, in a northerly direction to Laramie Peak, there make a great bend toward the west, and in nearly an east and west direction extend to South Pass, where they join the Wind River Mountains.

Though the ridges undoubtedly belong to the period of elevation during which occurred the main uplifting of the neighboring portion of the Rocky Mountains and of the Black Hills, they are separate in themselves, and, except as products of the same forces, form no connection between the Black Hills and the Rocky Mountains proper.

The valley of Old Woman Fork, along which our route was pursued, is excavated from the beds of the middle and lower portions of the White River Tertiary to within twelve or fifteen miles of its mouth, at which place the underlying Cretaceous beds make their appearance. The Tertiary beds consist of the same light gray or drab, argillaceous or calcareous sands, and the banks of the valley are picturesquely sculptured into castellated bluffs and buttes.

Near Old Woman Butte the upper members of the Cretaceous appear, well developed and containing an abundance of characteristic and beautifully preserved fossil forms. The basal portions of the Tertiary are also well shown, with the characteristic Titanotherium bed, full of vertebrate remains. A somewhat imperfect section, showing the relation between these formations near Old Woman Butte, is given below in descending order:

Feet.

7. White sandstone, coarse and incoherent, with quartz pebbles, and at base

6. A bed of coarse greenish sand, containing large quantities of the bones and teeth of Titanotherium, Rhinoceros, \&c................... 10-15

5. Yellowish and grayish clay, capping two prominent buttes in the valley.... 5-8

4. Brick red clay....................................... $5-8$

3. Yellowish elay ......................................... 10-15

2. Coarse sand and conglomerate, quite ferruginous, with some limestone.

Amount exposed above creek ............................ 20 20 30 

west is:

Zhis is probably the base of the Tertiary. Within a short distance to the

1. Dark gray Cretaceous clays (No. 4 of Meek and Hajden), with many nodules filled with most beautifully preserved forms-Baculites ovatus, B. compressus, Inoceramus, Ammonites placenta, \&c................. 40-50

Cretaceous No. 5 was not recognized in the immediate vicinity. The only observed evidence of unconformity between the two systems is the nature of the coarse stratum (2). The Cretaceous in this vicinity is very fossiliferous, yielding to our hasty examination many beautiful and some new forms, and it will undoubtedly afford an abundant harvest to a thorough and systematic collector. From this point on the creek the Cretaceous occupies the valley, but at several places there are evidences of a line or lines of elevation similar to those already mentioned. Thus, at one place on the northeast side of the creek a few miles below Old Woman Butte, appears a cliff, 200 feet in height, of coarse yellowish and reddish sandstone, having all the characteristics of the Dakota or lower Cretaceous sandstone. Again, between this point and the Cheyenne several other lines of uplift were passed, exposing a soft reddish sandstone, dipping $15^{\circ}$ to $30^{\circ}$ east. Other points of upheaval in the vicinity of Old Woman Fork have been noticed by Dr. Hayden, and in one place he records an exposure of the entire series of the Cretaceous.

The entire region seems to be crossed in a northwesterly direction by upheavals which have involved the Cretaceous rocks. These ridges once formed islands or reefs in the great Tertiary lake, which has deposited its sediments around and over them, concealing now nearly all their irregularities and only exposing them occasionally where the cloak of Tertiary rocks has been removed by denudation.

The valley of the Cheyenne, where it was crossed below the mouth of Old Woman Fork, is cut to a depth of 250 to 300 feet in soft sandstone, bearing a few thin seams of lignite.

On the immediate north bank of the river the following section was exhibited in descending order:

13. Red quartz conglomerate............................. (feet).. 5

12. Soft jellowish sandstone........................... . feet) .. $35-40$

11. Soft red sandstone................................. (feet).. 4 
10. Soft incoherent white sandstone, with bands of harder red sandstone and small ferruginous concretions ......................... (feet)..

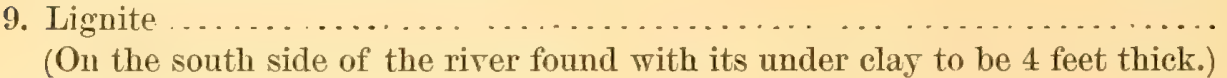

8. Yellowish and reddish sandstone ....................... (feet)..

7. Band of iron-ore nodules ............................ (inches) . . 3-10

6. Soft jellowish sandstone, with iron nodules ................ feet).. 22

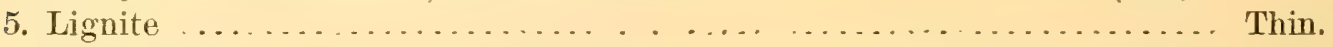

4. Brown sandy elay, with much carboniferous matter and iron nodules; with fragments of plant impressions........................ (feet).. $\quad 10$

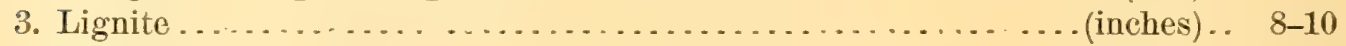

2. Dark fire-clay................................... (feet). 5

1. Soft whitish sandstone to bed of the Cheyenne River........... feet) . . 15 Total height of section............................. (feet) . 250

These beds are considered to belong to the Fort Union group or Great Lignitic Tertiary, which contains such large beds of lignite in the Upper Missouri region. In this locality the beds have a very slight dip toward the west, about $4^{\circ}$ or $5^{\circ}$, which is the same as the angle observed in the beds of No. 5 Cretaceous exposed a few miles farther east. In other portions of the northwest the series of Tertiary beds is found resting conformably upon the upper Cretaceous and underlying the deposits of the White River Tertiaries.

From this point on the Cheyenne River northwestward to the Black Hills one rises gradually to their elevation over a succession of monoclinal ridges or hog-backs of Cretaceous rocks, which with more or less regularity are found in parallel and continuous lines surrounding the Hills. The strata composing them dip from the Hills at varying but low angles$5^{\circ}$ to $10^{\circ}$ or $25^{\circ}$. They are monoclinal ridges of denudation, the remnants of strata which formerly were continuous across the area now occupied by the Hills; and across their escarped edges, facing the Hills, one passes from the highest to the lowest strata of the Cretaceous. Definition has been given to the ridges by the interposition among softer beds of certain more resistant strata. The most prominent and persistent of these occasions the range of rampart-like foothills that surrounds the immediate base of the mountains, forming the outer margin of the remarkable Red Valley, which as a moat encircles the Hills. This inner and last of the series of ridges 
or hog-backs is formed of the sandstone of the lower Cretaceous, directly overlying the softer Jurassic beds.

From the Cheyenne River northwestward to Camp Jenney on the east fork of the Beaver; several sections were obtained across the hog-backs. Thus, on the Cheyenne, two or three miles below the place where the section last given was obtained, the following section of the upper Cretaceous was observed:

5. Red ferruginous sandstone, sometimes conglomeratic, capping the bluff and dipping $5^{\circ}$ westward . ................................ 10

4. Sandy shales........ ... .......................... 40

3. Red sandstone, full of beantifully preserved shells................ 5

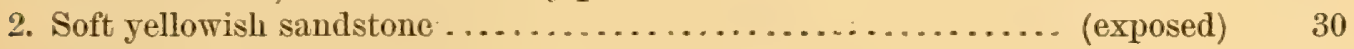

1. Concealed to base of cliff.................................... 100-150

These beds are shown by their fossils to belong to the Fox Hills group, or No. 5 Cretaceous. Eastward from these outcrops the surface of the country for a considerable distance is undulating, exhibiting but few sharp exposures-such a contour as would naturally arise from the soft character of the underlying dark clays of the Fort Pierre group, No. 4 of the Cretaceous. In the valley of Beaver Creek, near the junction of its east and west forks, are exposed excellent sections, capped by the highly fossiliferous, calcareous strata of the Niobrara group-No. 3 of the Cretaceous seriesfull of fragments of Ostrea congesta and Inoceramus.

11. Shaly limestone, filled with fragments of Ostrea and Inoceramus, dipping $20^{\circ}$ west and eapping the bluff . . . . . . . . . . . . . . . . . . . . . . .

Feet.

10. Gray shale or marl, with small limestone coneretions, calcite crystals, and gypsum in thin layers or seams; becomes reddish and yellow, changing to

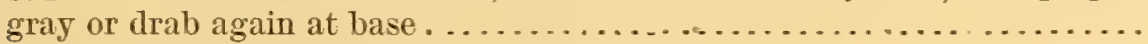

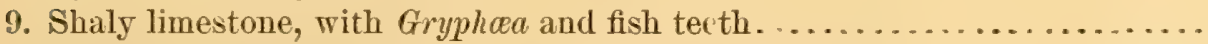

8. Bluish or drab clay shale or marl, becoming nearly black below, with much alkaline matter and several bands of carbonate of iron, 10 or 12 inches thick

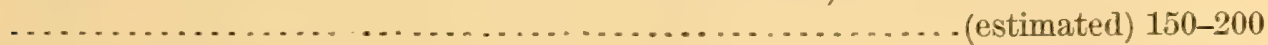

7. Shaly sandstone.......................................... 5

6. Sandy and argillaceous shales, with calcite.................... 30

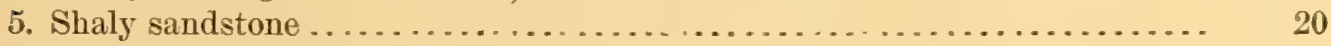

4. Drab clay shales with cone-in-cone concretions . ................. 20

3. Gray or drab, clay or marl. ............................... 20

2. Shaly limestone, with Inoceramus fragments. ...................... 8

1. Black alkaline shale, with some shaly sandstone, some iron-ore, limestone nodules, calcite, and gypsum, ................... to Beaver Creek 3 B H 
The greater portion of this would seem to belong to the Niobrara group, but the lower 200 feet are perhaps referable to the Fort Benton or No. 2.

Beaver Creek at its forks is a stream of small dimensions, but draining a large area of these alkaline strata of the Cretaceous it is highly impregnated with salts, which are exceedingly unpalatable and are medicinal in their effects. It may be remarked here that the streams which rise in or flow for a long distance through the Cretaceous strata are almost invariably undrinkable by reason of the large amounts of salts dissolved from these beds; but the streams that flow hrough long stretches of the Tertiary or bad land country, generally contain a large amount of suspended clayey matter with less of soluble salts, and are more endurable.

A section of the rampart foothills, as exposed on the east fork of the Beaver, is given in annexed figure.

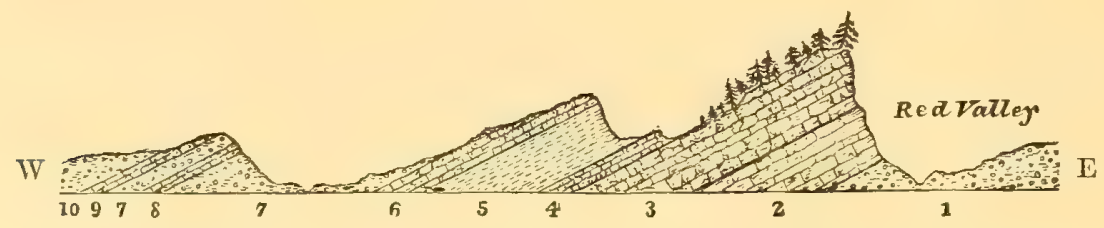

FiG. 3.-Section through outer Foothills at Camp Jenney, East Fork of Beaver.

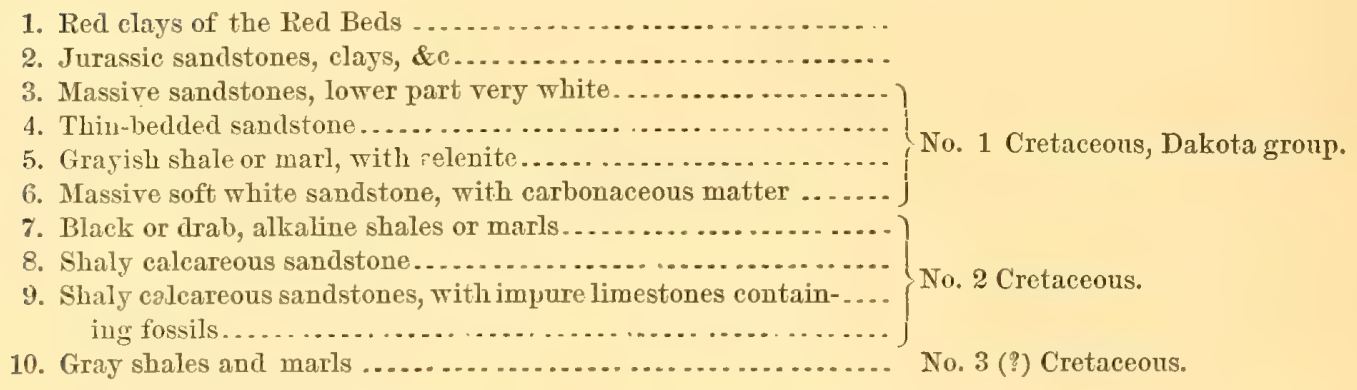

From Camp Jenney, after a delay of two or three days, the entire expedition moved into the Hills proper, establishing the first base of operations at the stockade on French Creek. Here in order to expedite the work the corps was divided into two parties: (1) Mr. Jenney, with the miners, assumed the work of examining the mineral deposits and prospecting the various districts for gold, and (2) Mr. Newton, Dr. McGillyeuddy, and Captain Tuttle were directed to undertake the more detailed and 
thorough topographical and geological study of the country. When the region of the southern part of the Hills had been worked up as completely as was practicable the entire expedition moved northward and established a second camp on Rapid Creek below the forks, from which the region on each side was in a similar manner explored; a third camp was made on Bear Butte Creek near Terry Peak, and a fourth on Inyan Kara Creek about ten miles southeast of Inyan Kara. From this last point the Bear Lodge range was examined by Mr. Jenney's party while the other party descended the Belle Fourche to the mouth of Bear Butte Creek, where all portions of the expedition again met. The main body of the escort then skirted the Hills on the east side to Rapid Creek, while Mr. Jenney's party crossed southeastward outside of the foothills to the mouth of Rapid Creek, and the topographical party descended the Belle Fourche and ascended the South Fork of the Cheyenne to the mouth of Rapid Creek, where all parts of the expedition met September 22, preparatory to the homeward march.

The details of the methods pursued in the work of exploring the Hills can be of no interest in this place. The results of the geological studies, of the examination of the mineral products, and of the astronomical work are given with considerable detail in the several chapters referring to those subjects and in the accompanying maps.

The country on the east side of the Hills has much the same character as that on the west. Near the Hills is a succession of ridges of the upturned and eroded Cretaceous rocks, which decrease in inclination and size as their distance from the Hills increases, till near the borders of the Cheyenne the country has a flat mesa-like appearance, cut up, however, by numerous dry ravines.

South of Rapid Creek, two or three miles from its mouth, and occupying the divides between Rapid, Spring, and French Creeks, are irregular areas of the lower members of the White River Tertiary, attaining a maximum thickness of about 200 feet. They possess all the lithological characteristics of the White River group, but no organic remains were found, even after very careful examinations. No perceptible unconformity of dip could be detected between the underlying Cretaceous and these Tertiary strata, but in the 
presence of a very persistent stratum of quartz conglomerate several feet in thickness, occupying the base of the Tertiary, we have a strong evidence of a change of circumstance in the deposition of the sediments.

These detached areas of Tertiary approach the immediate western banks of the Cheyenne near French Creek, and on the opposite side of the river portions of the White River deposits approach equally near, being separated only by the deeply excavated valley of the river. There can be no doubt that the two areas were once continuous, and are now separated only as a result of erosion. The valley of the Cheyenne in the region of Rapid Creek has a breadth of from one to two miles, and is cut from 150 to 200 feet in the shales and clays of the upper Cretaceous, which in this vicinity and in the numerous creeks that here join it-Bull Creek, Bear Creek, Sage Creek, etc.-contain abundant and beautifully preserved fossils, especially of group No.4. From this region our collections were enriched with some of the most beautiful forms obtained on the expedition. The river itself is shallow and narrow; the water contains much saline matter, and is milky with fine suspended clay.

Near Rapid Creek the summit of the eastern bank of the Cheyenne extends eastward in a broad plateau for six or seven miles, when the edge is suddenly reached, and spread out below in a seeming basin lie the wondrous bad lands of the White River Tertiary. They are carved into the most fantastic shapes; castles and pinnacles, domes and minarets, cover the surface, all hewn in drab and flesh colored clays, and it seems almost as if they were a ruined city of the dead, rich in the fantasies of a forgotten architecture. The valleys of the several streams that rise in this bad-land country and flow into the Cheyenne-Sage Creek, Bull Creek, etc.-have a peculiar funnel-like shape, with their broader parts in the Tertiary and their narrow portions cut through the Cretaceous to the river.

From the mouth of the Rapid the surveying party ascended the Cheyenne River to near the mouth of Burntwood Creek, and then, crossing eastward to the White River, joined the main body of the military escort, which had crossed through the Bad Lands from near Spring Creek. Thence following up the White River, via the Indian agencies of Spotted 
Tail and Red Cloud, the expedition retumed by the agency road to Fort Laramie.

The geological features of our return route from the White River to Fort Laramie are very uniform, the underlying rocks belonging entirely to the White River Tertiary. The typical bad-land arenaceous clays, destitute of vegetation, already mentioned as lying between the White and Cheyenne Rivers, are the very lowest members of the White River group, while the strata found on the immediate banks of the White River, and especially in the upper portion of its valley, are more recent and belong to the upper part of the series. Their equivalents probably form the underlying rocks on the line of our outward march. Though the whole country bordering the White River is commonly known as the Bad Lands, the term is more properly applied solely to the lower clays, which weather in the fantastic shapes already mentioned, and which contain such abundant remains of vertebrate animals.

Our march on White River took us across the scene of the distinguished paleontological discoveries of Dr. Hayden and Professor Marsh, a district which their labors and those of Dr. Leidy have rendered as famous as the Sivalik Hills of India; but it was not our privilege to linger.

Between the White River and the Platte the Tertiary is very little denuded, and presents all the aspects of the geology of our outward route. 


\title{
CHAPTER III.
}

\author{
GE O L O G . \\ SECTION I.
}

I NTRODUCTION.

It has been remarked by Dr. Hayden that-

The Black Hills of Dakota will form one of most interesting studies on this continent. There is so much regularity in the upheaval that all obscurity is removed and all the formations known in the West are revealed in zones or belts around the granite nucleus in their fullest derelopment. A careful detailed topographical and geological survey of this range would be a most valuable contribution to science. In all the western country I have never seen the cretaceous, Jurassic, triassic, or red-beds, the carboniferous and Potsdam rocks, so well exposed for study as around the Black Hills.*

His statement, founded upon a rapid reconnaissance of the foothills and extremities of the region during the exploration of Lieutenant Warren in 1857, has been fully corroborated by the more thorough and complete survey which our party was enabled to make during the past summer. Elevated as they are like an island above the surrounding sea of the Plains, and separated by more than one hundred miles from the nearest spur or subrange of the Rocky Mountains, the Black Hills are a complete study in themselves. Exhibiting in the strata exposed and in the general character of the elevation most of the principal features of the geology of the Rocky Mountains, they are a geological epitome of the neighboring portions of that great range. The geologist therefore finds in this region a monographic study of universal interest; and by the regularity of the uplift, by the absence of great faults in the strata, and by the splendid exposures of the

* United States Geological Survey of Wyoming and Contiguous Territory, 1870. p.98. 38 
sedimentary rocks, he is given a piece of mountain geology of great beauty, simplicity, and ease of elucidation.

Usually in explorations in the West or elsewhere the field of work of the geologist at any one time or season is but a part, and commonly a very small part, of a great system that extends over vast areas of country. Thus, in explorations in the Rocky Mountains, the most assiduous labor of the geologist can cover thoroughly in one season but a small part of the great range, and his discussion of results cannot be complete in itself, but must depend largely upon work in the adjoining regions. Rarely, then, does the geologist find his work so admirably circumseribed by nature as did those to whom the exploration of the Black Hills was committed.

The area of the Hills, to a discussion of whose geological features the present chapter is devoted, includes only that country between the forks of the Cheyenne, limited on the north and west by the Belle Fourche, on the south and west by Beaver Creek and the South Fork, and on the east by the South Fork. A somewhat detailed account has already been given in Chapter II of the principal geological features observed in going to and returning from the Hills-a narration which could not be introduced in this place without in a measure marring the unity of the plan.

Generally and simply the geological structure of the Black Hills is as follows: Around a nucleal area of metamorphic slates and schists, containing masses of granite, the various members of the sedimentary series of rocks, the Potsdam, Carboniferous, Trias or Red Beds, Jura, Cretaceous, and Tertiary, lie in rudely concentric belts or zones of varying width, dipping on all sides away from the elevatory axis or region of the Hills. From the Hills outward the inclination of the beds gradually diminishes until all evidence of the elevation is lost in the usual rolling configuration of the Plains. At numerous points, also, within the area of the Hills are centers of volcanic eruption of an age probably coincident with that of the elevation of the mountains themselves.

The succession of the different formations as found in the Hills, together with their character and approximate thickness, is exhibited in the following synopsis : 
Synopsis of the Rocks of the Black Hills.

\begin{tabular}{|c|c|c|c|}
\hline & Ages. & Feet. & Strata. \\
\hline 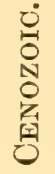 & Miocene. & 200 & $\begin{array}{l}\text { White clay, with chalcedony: at base a conglomer- } \\
\text { ate. }\end{array}$ \\
\hline \multirow{4}{*}{ 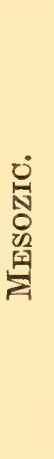 } & \multirow{2}{*}{ Cretaceous. } & 600 & $\begin{array}{l}\text { Clays and shales; gray, yellow, and black; with } \\
\text { some sandstone. }\end{array}$ \\
\hline & & 300 & Coarse yellow sandstone, with sandy shale. \\
\hline & Jura. & 200 & $\begin{array}{l}\text { Gray, white and red, clays and marls, with some im- } \\
\text { pure limestone. }\end{array}$ \\
\hline & Red Beds. & 340 & $\begin{array}{l}\text { Red clay, sometimes arenaceous, interrupted by a } \\
\text { single bed of limestone. }\end{array}$ \\
\hline \multirow{6}{*}{ 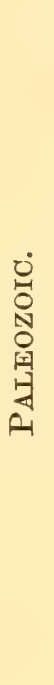 } & \multirow{5}{*}{ Carboniferous. } & 125 & $\begin{array}{l}\text { Sandstone, red and variegated, somewhat calcareous } \\
\text { and argillaceous. }\end{array}$ \\
\hline & & 175 & Alternating sandstone and magnesian limestone. \\
\hline & & 175 & Silicious limestone; silica in nodules and geodes. \\
\hline & & 175 & Gray limestone, massive, pure. \\
\hline & & 40 & Shaly limestone, pinkish; in part arenaceous. \\
\hline & $\begin{array}{l}\text { Silurian. } \\
\text { (Potsdam.) }\end{array}$ & 250 & $\begin{array}{l}\text { Silicious sandstones, in part quartzitic. Conglomerate } \\
\text { usual at base. Calcareous cement and intermin- } \\
\text { gled glauconite in upper part. Colors, dark brown } \\
\text { and red, rarely white. }\end{array}$ \\
\hline \multirow{2}{*}{ 案 } & \multirow{2}{*}{ ? } & ? & Slates. \\
\hline & & ? & Schists, with lenses of intrusive granite. \\
\hline
\end{tabular}


The thickness of the highly inclined and distorted schists of the Archæan is practically impossible to estimate with any degree of accuracy. In their present greatly denuded and metamorphosed condition one cannot determine whether they are the remnants of several great anticlinal folds among themselves, or whether they are the broken strata of one vast fold, though the latter, judged from a study of the nature of the rocks, seems the more probable structure. In that case the total thickness of the Archæan strata must be more than one hundred thousand feet.

The study of these rocks has shown them to be readily divisible into two groups-1st, a series of coarsely crystalline micaceous schists, and, $2 \mathrm{~d}$, a series of very fine micaceous clay slates-the latter of which in structure and associated minerals bears a close resemblance to the Huronian in the typical localities of its development around the Great Lakes. The lithological structure of the metamorphic rocks has been examined critically, both in hand specimens and by a microscopic study of thin sections, by Mr. Caswell, the results of whose labors will be found in the chapter on Petrography.

Associated with the schists in the southern portions of the Hills are immense masses and peaks of highly feldspathic granite, culminating in the region of Harney Peak; and on the outskirts of the same district are many smaller masses of the same material. So far as their structure was made out, each of the bodies has a lenticular shape, and is intercalated among the strata of the schist. All the observed phenomena of the occurrence of the granitic masses have been weighed and studied with care, and the conclusion that they are of intrusive origin is discussed at length in the section devoted to them.

In the series of the Paleozoic rocks on the opposite page the facts that will first attract the attention of a student of the geology of the eastern portion of our continent are, 1 st, that the great Silurian system is represented only by a sandrock about 250 feet in thickness, referable to the Potsdam period, and $2 \mathrm{~d}$, that the entire Devonian system is absent. The study of the Potsdam was not surpassed in interest by that of any other formation of the country. It was in this region that the Silurian in the Far West was first recognized, and the collections made the last summer have, by the study 
of Professor Whitfield, added several new species to the fauna of the period. Of the remaining portions of the Silurian system, which in the eastern United States reach a maximum thickness of over 20,000 feet, we have no deposits in the Black Hills, though in other portions of the Rocky Mountain region equivalent strata have been found.

The Devonian system, as has been said, has no representatives in the rocky strata of the Hills. Though the exposures are excellent and examinations were carefully made at the proper horizon, no trace of it could be found. The general thinning of the formation from east to west-from 14,000 or 15,000 feet in the Appalachian region to 1,000 feet in Ohio and 150 feet in Iowa-culminates in the Black Hills in complete disappearance.

The Carboniferous system is the most prominent and frequently the sole representative of the Paleozoic age in the Far West; and while in the East it is divisible into two periods Sub-Carboniferous and Coal Measures, the latter bearing the great deposits of coal, in the Far West it contains no coal and is largely composed of calcareous deposits, in which the two periods have not usually been distinguished from each other. In the Black Hills we were not enabled to determine to what period or periods of the Carboniferous age the strata were properly to be referred. Though they were found highly fossiliferous, sufficiently characteristic forms were not obtained to decide the question, and it was not possible to give to the study the necessary careful attention.

Above the beds of undoubted Carboniferous age were found a series of pink, red, and white sandstones and limestones, with no well-marked separation from the Carboniferous below, and these pass upward into a very impure, concretionary or distortedly weathered, reddish sandstone, above which is the red clay of the Red Beds. In the absence of good fossils, it was difficult to determine to which system these beds should be referred, whether to the Carboniferous below or to the Red Beds above, but preference was finally given on lithological grounds to the former.

The Trias (?), or Red Beds, the as yet blank leaf in the geology of the Rocky Mountains, is finely exposed aronnd the Hills, forming in the Red Valley, or "Race Course," one of the most prominent features of the topography. It consists of three parts-a red clay at base, separated by an 
impure argillaceous limestone from a similar red clay 200 to 300 feet thick, containing large quantities of pure white gypsum. Assiduous search, especially in the limestone, revealed not the slightest trace of organic life in the series, and there is nothing new to present that will aid in settling the question of the true age of the formation.

In connection with the occurrence of the Jurassic formation, the Black Hills have again a historical interest, for it was first recognized in the geological series of the West from fossils collected here by Dr. Hayden. Its separation from the underlying Red Bed series is tolerably well defined by lithological change, but is especially marked by the occurrence of Jurassic fossils close to the line of division. From the Dakota sandstone of the Cretaceous, whose harder strata everywhere form the overlying and protecting cover to the softer Jurassic beds, the separation of the Jura is less plainly denoted; for the upper portion of the Jura contains much sandstone and is usually unfossiliferous. Fortunately we were enabled to make a large collection of Jurassic fossils, among which are many of the species described by Professor Meek, upon which he based his determination of the age of the rocks, besides many new forms.

The Cretaceous rocks were not studied with the care that was given to the older series, mainly because the opportunities were not so favorable. The lower member, or Dakota sandstone, is a prominent feature in the topography, forming, as it does, the chief stratum of the rampart foothills, but the separation of the other groups, as established by Meek and Hayden, was not so clearly made out, though they are exposed on all sides of the Hills. The general similarity in the nature of the deposits and the scarcity of good exposures were hinderances to their accurate examination. With some modifications of thickness, the divisions established by Professor Meek, and described by Dr. Hayden in various parts of the Upper Missouri region, are equally applicable in the Black Hills, and to their description there is little to be added or changed as a result of our examinations. Some recompense for the insufficiency of our study of the formation is found in the fine collection of invertebrate fossils which it was our fortune to obtain from it. The perfection, number, and beauty of the specimens can scarcely have been excelled by any other collection from this region. 
Tertiary strata of the White River group are abundantly exposed on our routes to and from the Hills, as well as on lower Rapid Creek. Many excellent sections, especially of the lower members, were obtained, though little of importance was learned in addition to the published results of observers who have been able to examine the region more thoroughly. Few fragments of vertebrated fossils, and those of little interest, were obtained.

The Quaternary deposits have had little interest geologically, as they consist merely of certain local deposits of gravel along a portion of the foothills, and the alluvial deposits of bowlders, gravel, sand, and clay, forming the bottoms or floors of the valleys of the creeks. The latter, however, are of very considerable moment by reason of the contained gold, and in certain regions have yielded large returns to the miners. The deposits all belong to very recent geological time, and are the result of the wearing and abrading action of existing streams. Of the true glacial drift we could find no evidence.

The peaks and ejections of volcanic rock which are found at numerous points in the northern end of the Hills are probably all of similar age, and consist chiefly of sanidin-trachytes and rhyolites. The effect of the extrusion of the volcanic masses on the surrounding strata has been exceedingly local, and if the elevation of the Hills took place synchronously with their ejection the topography was probably little affected by the accompanying seismic throes. It is possible, however, that the elevation of the Hills was entirely subsequent to the volcanic extrusions; for we have no evidence that will define the time of the elevation closer than that it belongs to a date subsequent to Cretaceous and prior to middle Tertiary time, while of the age of the volcanic outbursts we can only say that they were subsequent to the deposition of the Cretaceous.

In this brief résumé an endeavor has been made to give the most comprehensive view of the formations which constitute the Hills. The remainder of the chapter will be devoted to a more detailed description of the same formations, together with a discussion of all peculiar or interesting features and of the general history and origin of the Hills.

Notwithstanding the smallness of our corps, only two members of which 
were engaged in the actual study of the geology of the country, almost every portion of our large area (over 6,000 square miles) was more or less carefully examined and the main features of the geology attentively studied; and if, as is well-nigh inevitable, later study shall convict our work of errors of omission or of incompleteness, it is hoped that the gravity of our sentence may be somewhat mitigated by giving consideration to the rapidity with which the work was necessarily performed. Indeed, it could scarcely be expected that such a corps in four brief months of field work could unravel without error the geology of a country larger than the State of Connecticut.

\section{SECTION II.}

\section{THEARCHA $\mathrm{A}$.}

The Archæan system as founded by Professor Dana includes the oldest known rocks-those which lie below all our fossiliferous strata, and which constitute the "only universal formation." It is for the most part composed of crystalline and metamorphic rocks-granite, syenite, gneiss, and micaceous, talcose, hornblendic, and chloritic rocks, with ores of iron, graphite, etc. It has been divided into two ages, an Azoic, or lifeless age, and an Eozoic, or age of the dawn of life. Of the former, the Azoic, we are not as yet accurately informed, either as to its distinctive characters or as to its limits. It has, however, been established as distinct from the other members of the Archæan; first on the philosophical ground that there must be a series of rocks in the earth's formation that existed before the beginning of life on its surface; and, second, to separate the Archæan rocks containing evidence of life (the Eozoic) from those in which no evidences of organic existence have been found (the Azoic.)

The Eozoic has been separated by the Canadian geologists into two periods, the Laurentian and Huronian, which are well distinguished in Canada, where they attain a thickness of nearly 50,000 feet, and have been recognized or separated in various parts of the eastern United States and in Europe. Where the rocks of both groups are observed in Canada 
they are found to sustain an unconforming relation to one another, but elsewhere, where the Eozoic has been divided into these periods, or supposed to be so divisible, the separation rests almost exclusively upon the slender ground of lithological characters. It is true that to a certain extent particular rocks or constituent minerals are found to be characteristic of a particular formation; but such evidence alone cannot be taken as conclusive in co-ordinating series of rocks, especially where the points of observation are separated by any considerable distance. At the best, a similarity of lithological structure is only presumptive evidence as to similarity of age.

In rocks of the Laurentian the Canadian geologists discovered a peculiar structure concerning the character and relations of which there has been no little discussion. It is considered by Carpenter, Dawson, and others to be a fossil, a gigantic foraminifer, and has been described by its first student, Dr. Dawson, as Eozoon Canadense. A similar structure has since been recognized from the Eozoic of Bohemia and Scandinavia. This is the oldest remnant of organic life yet discovered, and it is the main foundation for the primary division of the Archæan into Azoic and Eozoic. The presence, however, of large beds of limestone, graphite, apatite, and iron ore in the Eozoic rocks is strong evidence of the existence of organic life, for life appears in all observed modern processes to be necessary to the separation or accumulation of such deposits.

The Laurentian, where best known, is composed chiefly of granitoid rocks, gneiss, quartzite and crystalline limestone. It is frequently characterized by hornblendic rocks, but is seldom very micaceous; and the presence of graphite and large beds of magnetic and titaniferous iron ore in many regions prominently characterizes the series. The system was first studied by Sir William Logan in a field where it is largely developed-the Canadian highlands bordering the Saint Lawrence and the Great Lakes and extending far northwestward. The Archæan rocks of the Adirondacks, at least a portion of those in the Alleghanies, those of the Ozarks in Missouri, and a portion if not the larger part of the iron-bearing rocks of the Lake Superior region, are considered to be of Laurentian age, and in all these regions the system is characterized by immense beds of iron ore.

In Scotland the "fundamental gneiss" has been regarded by Murchison 
as Laurentian, in Bohemia large areas have been so recognized by Barrande, and in Norway and Sweden the crystalline rocks bearing the iron ores have also been referred to the same age.

In Canada the Laurentian is subdivided into Lower and Upper, and the two groups are supposed by Sir William Logan to be separated by unconformity and by a long interval of time. The upper and less important group is especially characterized by the abundance of the opalescent labradorite feldspar, and is particularly well developed in Labrador. It has been called by Dr. Hunt the Norian or Labradorian series, and it has been recognized by him in the Adirondack region and elsewhere in the eastern United States, though it is not yet known to be a persistent member of the Eozoic of the Appalachian Mountains.

The Huronian system was first studied on the Canadian border of Lake Huron, where its rocks are typically developed and are found to overlie unconformably rocks of well known Laurentian age. They are as a rule here more silicious in their character than the Laurentian, and consist chiefly of silicious slates and conglomerates, quartzite, jasper, diorite, and chloritic and epidotic rocks, with ores of iron. The Huronian is less widely recognizable and distinguishable than the Laurentian, and where its occurrence is maintained beyond the region of its typical development, the opinion rests solely upon lithological characters.

The iron-bearing region on the south shore of Lake Superior is in part regaded as of Laurentian age, but the iron-bearing strata of the Marquette region are very generally considered to be Huronian. On our eastern coast the existence of the Huronian is announced as probable. Credner refers to this age a series of rocks in the Appalachian Mountains from the Saint Lawrence to Georgia, which includes most of the auriferous rocks of that region. Hunt also, who has devoted much time and study to the examination of the Eozoic rocks of Canada and the northern part of the Appalachian Mountains, regards a portion at least of the Green Mountain series of Vermont as of Huronian age, and believes that they may be traced southwestward through Pennsylvania to Virginia. In the Green Mountain series the rocks are gneisses (more micaceous than the Laurentian), diorites, 
epidotic and chloritic rocks, steatites, serpentines, and talcose (or more probably hydrous mica) schists.

Hunt further distinguishes the White Mountain or Montalban series of rocks, which he regards as newer than the Huronian but Pre-Silurian and Pre-Cambrian, and he traces them, in a series of deposits parallel to the Green Mountain rocks, far southward into Pennsylvania. The rocks of this series in the White Mountains are characterized by mica-schists passing on one hand into micaceous gneisses and on the other into argillite. They include beds of micaceous quartzite and concretionary granitic veins with beryl and tourmaline.

West of the Missouri the Archran is exposed over large areas in the axial lines of the Rocky Mountains and its various subordinate ranges, and includes most of the rocks already enumerated, though the granites, syenites, and highly feldspathic rocks are more largely developed in many regions, to the exclusion often of the schists and slates. Un til lately wo attempt has been made to draw any line among these Archæan rocks and establish the divisions recognized in the East. Such a separation would be based exclusively upon the lithological structure of the rocks and the presence or absence of particular mineral species, for no fossil has been found; and by the majority of geologists such evidence is not admitted in the identification of geological formations when, as here, the points of observation and comparison are widely separated. Mr. King, of the 40th Parallel Survey, has, however, noticed differences in the rocks of certain of the ranges, which lead him to regard a separation into Laurentian and Huronian as possible.

The Archæan rocks of the Black Hills, as may be seen on the geological map, occupy the axial or nucleal area, and their exposure is somewhat to the east of the center of the uplift. The extent of country occupied by them is about sixty miles long north and south, and twenty-five miles in its greatest width east and west, with an area of about $8 j 0$ square miles.

Rugged and broken as is the entire region of the Hills, the interior area underlaid by the Archæan schists and slates is particularly mountainous and rough. Cut up into peaks, ridges, and valleys, and watered by numerous brooklets, it has the aspect of many of the picturesque 
regions of the Adirondack and Green Mountains, and covered usually with a heavy growth of timber, but opening out occasionally into grassy parklike valleys, it often vies in wildness and beauty with those better-known mountain regions of the East. Viewed from a height, as from Harney Peak, the area has a billowy appearance-a succession of ridges and peaks, with now and then a stretch or spot of open park-and at first it reveals no system of structure, save that it is cut from west to east by the draining streams which have eroded deep and usually narrow valleys or cañons. Though the strike of the rocks is toward the north or northwest, there at first appears no feature in the topography due to this fact, but a closer and more detailed study reveals the presence of a continuous ridge or series of ridges extending on the east side of the area from southeast to northwest; and in the more minute inspection of the geology along the streams these ridges are seen to have been defined by the presence of particularly hard strata, quartzites, etc., through which the several draining streams have cut their way in intricate and deep cañons. On the western side of the area a similar belt of prominent and resistant rocks is observed, through which many of the streams have cut narrow gorges. Between these ridges the country, excepting in the region of the Harney Peak granites, is less rugged, and not unfrequently the banks of the streams widen out into valleys broad and gently sloping.

Toward the southern end of the Archæan region is a tract of feldspathic granite the most rugged and mountainous in the Hills. It is characterized by numerous peaks and ridges, of which Harney Peak and Dodge Peak are the most prominent. South of it and quite in the southern end of the Archæan are many of the park-like expanses already alluded to, well grassed and devoid of trees, and among them are the largest that are found in the Hills. Several of the most important have received special names, as Custer Park, on the headwaters of French Creek, in which is located Custer City; Dodge Park, farther southwest, on the headwaters of Red Cañon Creek; and Elkhorn Prairie, on the headwaters of Spring Creek and the south branch of the Rapid.

The margin of the Archæan area is bordered continuously by an escarpment more or less abrupt, and usually several hundred feet high, 4 B H 
formed of the Potsdam sandstone and the Carboniferous limestones. This escarpment faces inward or toward the Archæan area, and in the cañons which eut into it the slates and schists are seen beneath the sandstone of the Potsdam which rests unconformably upon them. With the exception of Harney and a few of the neighboring peaks, the average elevation of the schist and slate area is considerably below that of the encompassing sedimentary rocks. Its relative depression is plainly due to the more rapid decay and degradation of the schists and slates, while the hard limestones, being less destructible, remain prominent.

Besides this main area of the metamorphic rocks, there are a number of minor exposures to the north and northwest of Custer and Terry Peaks. The country is there underlaid by the Carboniferous limestone, and this, together with the underlying Potsdam, has been cut through in deep and narrow cañons with innumerable branches, making the country a perfect labyrinth of eañons many of which are 400 to 600 feet in depth. The main cañons have been eroded also many feet deep into the underlying Archæan, and in some places the gold concentrated from its slates and schists has been collected in very considerable quantities.

The metamorphic rocks of the Black Hills are separable into two distinct groups, whose lithological characters are marked and persistent. Their stratigraphy was carefully studied in the hope that it would be possible to definitely determine the historical relation between them, but the result was not satisfactory. The great differences, however, in the characters of the rocks are sufficient to warrant their separation into a western series or group of schists and an eastern series or group of slates. The line of separation between them can be only imperfectly indicated. Its trend, so far as could be ascertained, is a little west of north. Starting just east of the granitic range of Harney Peak, it curves westward about the north end of that range, and then turns toward the north-northwest, passing near the forks of Spring Creek or the present site of Hill City, crossing Castle Creek in the west cañon, and disappearing beneath the Paleozoic rocks in the vicinity of Custer Peak. To the north of the peak it reappears with a northerly course. 
A distinct discordance of dip between rocks representing the characters of these two groups was seen by Mr. Jenney in the west cañon of Castle Creek, but in the absence of corroborative observations, the fact of the unconformity of the two series cannot be insisted upon.

The western series consists of quartzose schist and garnetiferous, quartzose, and ferruginous, mica schists, together with some gneiss, chloritic and talcose (or hydrous mica) schists, hornblendic schist, and quartzite. The whole series is coarse in texture and highly crystalline, and it contains many seams or veins of quartz traversing the schists conformably with the stratification and having usually a swelling or lenticular structure. These veins are interlaminated veins and are not often of any great width; they contain finely disseminated gold, and have probably afforded by their disintegration the larger portion of the gold found in the valleys and gulches. The granite masses are found wholly within the area of the schistose rocks. The eastern series is composed of metamorphic rocks distinguished from the western mainly by their exceedingly fine and compact texture, though, as shown by Mr. Caswell, their ultimate mineral composition is quite similar. The rocks are mainly micaceous clay slate, clay slate, silicious slate, and quartzite. The last forms persistent strata from 50 to 200 and sometimes 500 feet in thickness, which may often be traced for long distances with little variation. The quartzite frequently contains seams or veins of interlaminated or ribbon quartz, and with them are associated large deposits of hematite or specular iron ore, also interlaminated with quartz. Frequently the quartz seams are highly ferruginous and in places they have been found to contain undecomposed pyrites. Unquestionably they are often auriferous.

Micaceous schist is the prevailing and most characteristic rock of the western series, but its variation in character is very considerable. More commonly it is a gray, tolerably fine, highly crystalline, uniform, micaceous, silicious schist, which, from its large proportion of mica, weathers readily and uniformly. Very frequently, especially in the western part of the area, it is so highly charged with garnets that it acquires a dark reddish color. The garnets are well crystallized but of small size, rarely exceeding a quarter of an inch in diameter. In the weathering down of the garnet- 
iferous mica schists, the fine material removed and deposited in the creekbeds consists largely of garnets and mica, the latter showing so brightly on the creek bottoms beneath the water as often to be mistaken for flakes of gold. In panning the gravel of upper French Creek and Castle Creek, when the pan of dirt has been nearly washed, the residue is found to be composed almost entirely of garnet crystals more or less rounded, beneath which the particles of gold are collected in the heavier iron sand, while the light mica is completely washed off. Farther down the streams the mica is found still finer, while by the abrasive action of the current the garnets have been worn round and smooth.

The mica schist changes sometimes almost imperceptibly, becoming finer and containing less and less mica, and passes into a talcose or hydrousmica schist, frequently highly garnetiferous, presenting the usual soapy feeling and general character of talcose schist. The talcose schist being more coherent than the very micaceous rocks is more prominent in the topography, and forms harder and rougher ridges.

By a similar gradation the mica schists pass into silicious schists containing but little mica, and then by a more abrupt change into ledges or strata of hard, dense, and tough quartzite. The quartzites, which are less developed in the western than in the eastern series, are among the most durable rocks and in the Hilis generally stand in abrupt, dike-like ridges, running with the stratification of the rocks. They vary from almost white to a light or dark gray color, and are bright and glassy on the fracture, which is usually conchoidal. They commonly contain mica in small quantities and sometimes are like very silicious mica schists in which the mica is subordinate and the quartz tough and glassy. They never in their structure or relations indicate an intrusive origin, but are true metamorphic strata, differing in character from the associated schists because of an aboriginal difference in their composition-the latter having been originally mixed deposits, while the former were more or less purely silicious. They are similar in character to the quartzites of the eastern series. Sometimes the mica schist passes by almost imperceptible gradations into true chloritic schist, in which the mica seems to have been replaced by chlorite. This chloritic schist is usually soft and easily decomposable, of a 
green color, and with no mica readily visible to the eye. Crystals of ripidolite may often be picked out from it with a knife, and it frequently. contains garnets in abundance. In small pieces the rock is flexible, but it has little or no elasticity.

Associated with the above-mentioned rocks, but of less frequent occurrence, is true gneiss-silicious mica schist with feldspar. It was seen on French Creek near the stockade, in Custer Park, and at several points in the Harney Peak region. While the occurrence of feldspar in the schist is probably more common in the vicinity of the great granitic region, there is nowhere any evidence of a gradation of the gneissic rock into the granite, but the separation between them wherever observed is sharp and distinct. Gneiss, however, is not an abundant rock, and though its occurrence is mentioned as being more pronounced near the granitic areas, it is not by any means a constant and immediate associate of the granite masses themselves, but shares the field with the silicious, micaceous, chloritic, and hydrous mica schists.

Special descriptions of the veins of quartz found in the schistose rocks are given in Mr. Jenney's chapter on Mineral Resources, and little need be said here further than to mention their general composition and mode of occurrence. They are very abundant, are always parallel with the stratification of the schists, and are what may be termed veins of intercalation. On Castle Creek, on the headwaters of Spring Creek, and generally in the western part of the schistose area, they are very numerous, and have nearly always a lenticular shape, swelling out and narrowing down as veins so commonly do. They are not usually traceable for great distances, and are generally narrow, rarely exceeding a few inches in width; a few have a thickness of several feet. The quartz composing them is usually bright, vitreous, and translucent, of a pure white, milky, or brown color, and sometimes very ferruginous. Frequently bunches or lenses of quartz are found in the schists, but these are not of great extent. Some of them are evidently true segregations, while others appear to be silicious depositions coincident in origin with the associated strata.

Where the veins are highly ferruginous they become converted superficially into tolerably pure oxide of iron by the weathering and removal of 
the quartz. In many instances the quartz veins are undoubtedly auriferous and the larger portion of the gold found in the gravels of the Hills has originated from them, but by reason of its sparse dissemination in the vein matter, specimens containing visible particles are not often found. Such specimens, showing thin flakes of gold have, however, been obtained from some of the ferruginous quartz veins of Custer Park. The very fine state in which the gold is found in the gravels of the southern end of the Hills is also an evidence of the fine state of division in which it occurs in the veins.

The gold which since our exploration has been found in the ancient gravels of the Potsdam formation must be referred, together with that our party obtained from gravels of the most recent formation, to the quartzes of the Archæan as its source. The fact that the concentration was begun by the shore action of the Potsdam sea renders it probable that some at least of the gold of the recent gravels is derived immediately from the Potsdam gravels, just as are the associated quartz pebbles.

Hornblendic schist or homblende rock was found in a few localities. Near the stockade and on the headwaters of Amphibious Creek a very silicious schist occurs containing a large proportion of hornblende, and on French Creek near the point where it leaves the Hills hornblendic masses were found at more than one place in the bluff of the cañon. The latter is a very compact and close-textured hornblende rock, containing considerable silicious matter. The general scarcity of hornblende among the schists and its entire absence from the slate rocks, except as a microscopic element in their structure, are facts deserving of remark.

The minerals found in the schists and pertaining to them particularly are few in number, and with the exception of garnets and mica are not abundant. Staurotide, well crystallized, was found in one locality in the schists east of Harney Peak, and a single specimen of crystallized epidote was brought in for examination. Highly crystalline feldspar and mica are found in thin veins in the gneissic rocks in some places. Scales of graphite were found in small quantities in certain of the schists near Harney Peak.

The granites are found only in the schists and gneiss of the western series, and careful observations nowhere discovered them among the argillaceous slates of the eastern series. They occupy a large area entirely in 
the southern portion of the Archæan district. Their principal mass is in the Harney Peak region, and has an area twelve miles in diameter north and south and about seven east and west. Besides this central mass others of less magnitude are found, diminishing in size as the distance from the peak increases. The smaller bodies occur at the west and east, but particularly at the south. All of the granite masses whose relations could be closely examined were found to be parallel with the stratification of the schistose rocks, and when their structure was readily discernible were seen to be lenticular in shape.

The strike or trend of the schists is in general north and south, but it varies from northeast and southwest to northwest and southeast, and south of Harney Peak in the region of French Creek and in the park country immediately south of that stream even this range of variation is exceeded. Here the strata are found to sweep around from a strike on the headwaters of Castle Creek of north $30^{\circ}$ west to an east and west course on French Creek in the vicinity of the stockade, returning again on the east side of the Harney Peak range to their usual north and south direction. In the vicinity of the stockade the varying strike is marked by bold ridges of granite, which bend around and change their strike as indicated.

The dip of the schists is usually very high and often vertical, though occasionally by local variation it becomes quite low. In several places a difference of dip was noticed between the schistose rocks on the west and the slates on the northeast side of Harney Peak, the former being toward the west and the latter toward the east, but the number of observed points of variation was not sufficient to warrant the statement that this difference is a persistent feature of the relation of the two series of rocks. On Castle Creek and on the other heads of Rapid Creek the dip is from $55^{\circ}$ to $85^{\circ}$ west, but in going southward and eastward there is found a change corresponding to the change in strike already noticed on French Creek, and the dip becomes slightly southward from the vertical. On the headwaters of Red Cañon Creek it is $70^{\circ}$ to $80^{\circ}$ south; on lower French Creek $45^{\circ}$ south.

The vertical position of the schists and their highly micaceous nature cause them to decompose readily and uniformly, giving a peculiarly smooth and unbroken surface to the topography and producing those beau- 
tiful expanses of treeless and well-grassed parks that are found in the southwestern and western part of the schist area. The parks occupy irregular and discontinuous tracts along the western margin of the Archæan region, and extend from Box Elder Creek to the headwaters of French, Red Cañon, and Amphibious Creeks. One of the smaller of them with a granite ridge in the distance is shown by the view in Golden Valley, Figure 4.

Where the mica of the schists becomes less prominent and quartz takes its place, or where strata of quartzite or beds of granite predominate among the schists, the surface of the country becomes more rugged and peaks or ridges of harder rocks stand out above the surface as rough and soilless reefs. In the area where granite is the prevailing rock an excessive roughness and ruggedness is given to the surface, which then becomes a mere succession of sharp ridges and towering peaks.

Characteristic samples of the schistose rocks will be found described in Mr. Caswell's report under the numbers 1, 13, 24, 27.

The eastern or slate series occupies probably a larger portion of the Archæan area than do the schists of the western series. Its predominant rocks are distinguished by their fine and uniform texture, and though they nowhere have the true slaty cleavage making an angle with the bedding, they are finely laminated and commonly split on their stratification into tolerably thin pieces. They are quite distinct in their structure from the coarsely crystalline schists of the western series, and are fairly distinguished as slates, although the term does not apply in its more restricted sense. They do not exhibit the variety of character observed in the rocks of the western group, but consist mainly of fine silicious slate, clay slate (argillaceous mica slate), argillite, talcose slate and quartzite. With these are interpolated many seams of quartz and specular iron ore. Characteristic specimens of the slate have been submitted to $\mathrm{Mr}$. Caswell, and though their structure and composition are not readily discernible by an inspection with the naked eye, under the microscope they are in general found to have a true crystalline constitution and to be distinguished from the rocks of the western series rather by the fineness and minuteness of their structure than by a difference of composition. A large portion of the rocks of the eastern 


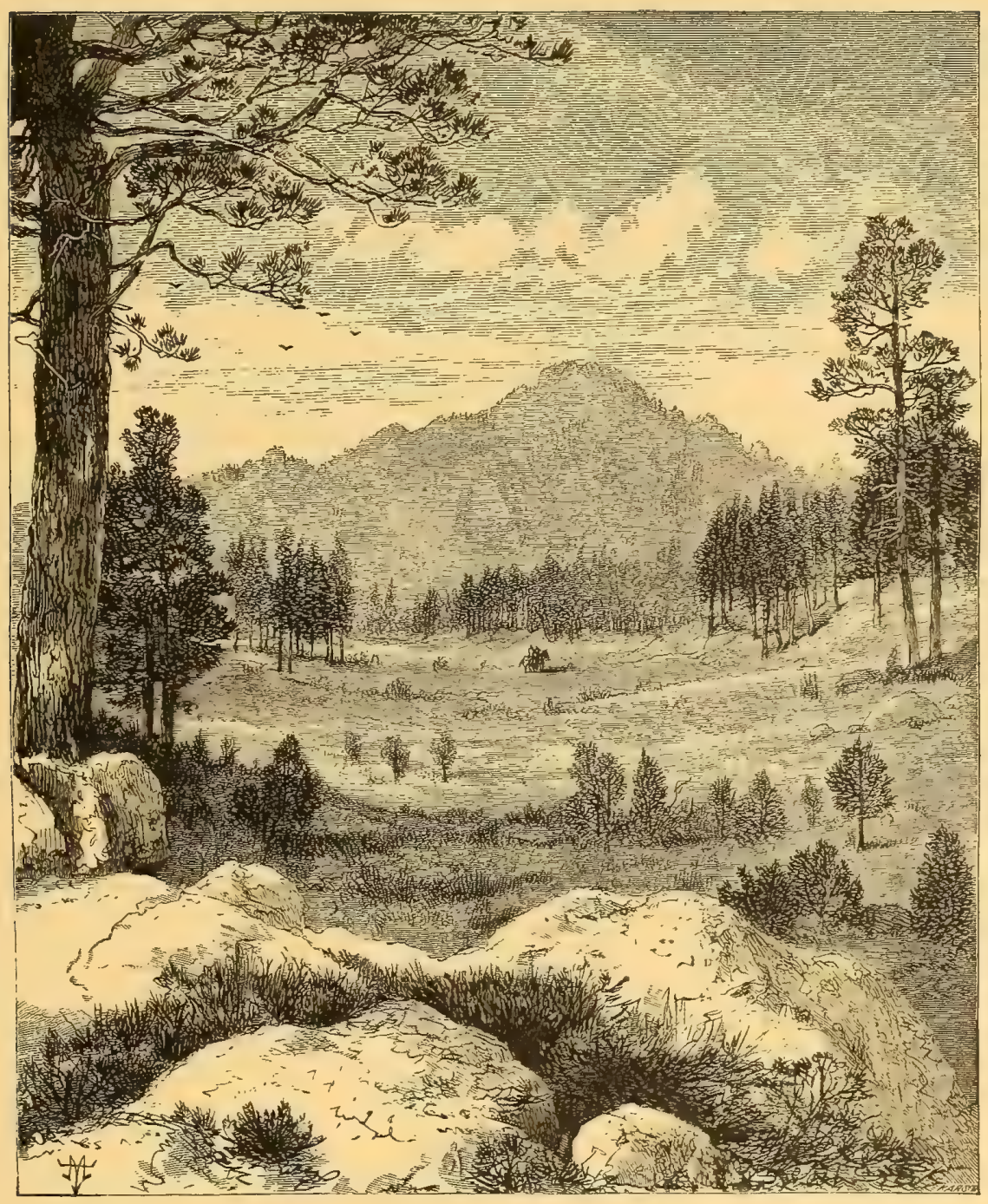

FIG. 4.-Head of Golden Valley, illustrating Park Scenery. 

series would be classed by Dana as mica slates, but by Von Cotta and Zirkel as argillaceous mica shists. Rocks of this character are described by Mr. Caswell from Rapid Creek under numbers 64, 65, 67, and 71.

The argillaceous slates (argillaceous mica schists, Caswell) are among the most prominent of the slaty rocks, and in color they are usually dark brown or gray. By reason of their compact and uniform structure they are less easily decomposed by atmospheric influences than the micaceous schists of the western group. They are so fine in texture that it is difficult to detect with the eye the elements of their composition. They appear generally to contain fine particles or grains of mica, quartz, and argillaceous mineral, and they always give an argillaceous odor when moistened with the breath. Their most argillaceous varieties split readily into thin sheets, resembling in texture and appearance roofing or school slates, or become soft and are readily cut like slate pencils. In many places, as on upper and lower Spring Creek and lower Rapid Creek, the clay slates are exceedingly dense and fine, and owing to peculiar cleavage planes break up into slabs or splints, which may be seen in many places piled up like cord-wood. These pieces are cut with difficulty by a knife and give a strong metallic ring when struck.

Light gray or drab, fine, soft, talcose, argillaceous slates, containing minute particles of mica, have been found in some localities, as on middle Rapid and Box Elder Creeks.

From the distinctive clay slate there is frequently a passage into a very silicious slate, close-grained and banded with thin laminæ of different colors; and this silicious slate sometimes passes into true quartzite, hard, uniform, and compact. Silicious slates associated with quartzites are well exhibited in the cañons of Box Elder, Rapid, and Spring Creeks.

In several localities the silicious slates contain interlaminated with them immense quantities of iron, almost always specular oxide. On Box Elder Creek, a ridge some 400 feet in height is composed of a vast deposit of silicious hematite, which was estimated to be from 800 to 1,000 feet in thickness across the upturned strata. Occasional bands of almost pure specular hematite several inches in thickness are found in the mass with frequent layers of highly crystallized micaceous hematite. The body of 
the ferriferous strata, however, is highly siliciferous and entirely useless as an iron ore, consisting of thin strata an inch or less in thickness of specular hematite alternating with silicious slate or with pure white quartz in seams or irregular masses, the whole presenting a remarkable resemblance to the silicious banded hematite of the Huronian of the Lake Superior region. In other localities on the same creek hematites were also found in the silicious slates, but nowhere of any practical value because of their highly silicious character. The slates associated with these iron deposits are commonly highly argillaceous as well as silicious, as is indicated by their color, texture, and strong clayey odor. Similar ferrugineous slates occur also on the headwaters of Rapid Creek a short distance north of the Elkhorn Prairie.

The quartzites vary in thickness from seams only a few inches wide to masses 400 or 500 feet in width, though the more moderate thickness of 75 to 100 feet is more common. Several of these ledges have been traced long distances, maintaining their regular relations with the adjoining strata and holding to their own dimensions and character, running across the country like dikes, bristling suddenly in peaks, or outcropping in the cañons of the creeks in sharp, well-defined walls. A prominent quartzite ledge on Spring Creek, known as the "Mammoth Lode," has been traced continously five or six miles in each direction, and others are distinguishable still greater distances. They seem to be limited in their extent, in thickness as well as in length, only by changes in the composition of the original deposits from which they have been formed by metamorphism.

The color of the quartzites is varied, being sometimes an almost pure white but more often a light or dark gray or an impure blue or pink or, when much iron is contained, a dark reddish brown. In texture they are very compact and homogeneous, and on a fresh fracture, which is conchoidal or fragmental, they have a vitreous or glassy luster. They are almost pure quartz.

Though they are found throughout the entire series of the slates, they are of greater thickness and more numerous in certain parts of the district. As has already been mentioned, there extends on the eastern border of the Archæan area a long ridge or succession of prominent peaks and bluffs, 
which cuts across all of the creeks north of Harney Peak, occasioning in each one an intricate, precipitous and exceedingly rough cañon. This ridge and these cañons are due to a series of quartzite strata, which by their hardness and durability preserve the interbedded slates from rapid erosion, and not only retain their own supremacy in the topography but restrain the creeks from opening broad valleys.

West of this prominent geological edge there is a stretch of country which is rolling in character and nowhere very rough. In passing it the creek bottoms often spread out into valleys of considerable extent, and the divides between them are neither rough nor steep. Its smooth character marks it as the outcrop of the soft slates rarely interrupted by harder strata.

On the west of this strip the headwaters of the various branches of Spring and Rapid Creeks are secluded in cañons precisely similar to those on their lower courses and due to a similar cause. A series of quartzite strata resists the wear of the elements and conserves a belt of peaks and ridges.

Quartz seams of a thickness varying from less than an inch to many feet are numerous in the more silicious slates. Usually they run parallel with the stratification but do not have the lenticular, wedging character noticed in the small quartz veins of the micaceous schists. In many places the quartz is interlaminated with the slate in thin, alternating seams. Some of the quartz seams appear to be true veins, formed by the collection of the quartz along lines of separation of the strata, and such can be traced long distances. Commonly they run parallel with the bedding, but in a few instances they have been found cutting across the strata at a right angle, following cleavage or jointing planes. They are frequently highly ferruginous, so that on their decomposed edges they are made by the weathering out of the quartz to appear like ledges of brown hematite ore. The quartz of the seams is highly crystalline, is usually translucent or opaque, and when unstained by iron is milk-white in color.

A prominent deposit, segregation, or accumulation of quartz is found two or three miles east of Custer Peak, to which the name of Jasper Hill was given. It is irregular in shape, about 200 feet in height, and without any 
clearly defined structure. The silicious materials composing it display great variety in color and character. Among them are a deep red jasper, a grayish quartzite and a pure white milky or translucent quartz which in places has a bright red erystalline iron oxide running through it like the dendrites in moss-agate.

On Box Elder Creek, south of this deposit and on the summit of a high elevation, there is found running parallel with the stratification a ledge of pure milky quartz which from its position attracts the attention of the passer by. It is some feet in thickness and is traceable for nearly a mile. Samples were taken from it and tested for gold, but yielded no trace by fire assay. The quartzites also frequently carry seams of quartz which in many cases seem to be true yeins produced after their formation and consolidation. The banded structure already noticed is found also in the seams in the quartzites. Bands of iron ore, ferruginous strata of the inclosing rock, and seams of ferruginous quartz are found in the quartzites, and though the separation between the ordinary quartzite and the ferruginous portions is generally ill-defined, the latter are sometimes so well marked as to run like true veins within the body of the quartzite itself. There is, however, no slickensiding nor other direct evidence of the existence of fissure veins In many instances the ferruginous quartzite ledges are probably due to the original dissemination in the quartzite of iron oxides, which in the process of weathering are oxidized and hydrated to brown hematite. Sometimes, however, the ferruginous portions arise from the decomposition of iron pyrites which existed in seams or irregular masses of later date than the quartzite. The Mammoth Lode, for example, which is highly ferruginous, owes its iron largely to the decomposition of pyrites, some pieces of which, unchanged and slightly auriferous, were found in place beneath the level of the creek.

A fuller exposition of the occurrence and character of the veins is given by Mr. Jenney in his chapter on the Mineral Resources.

The dip of the strata of the eastern series is always high, $70^{\circ}$ to $90^{\circ}$, and though it varies in amount and direction, it is usually toward the west. The general strike is about north $30^{\circ}$ west, but it swings now in one direc- 
tion, now in another, ranging freely between the limits of northeast and northwest.

In the study of the Archæan slates and schists the absence of the numerous minerals so abundantly found in the metamorphic slates and schists of the East is peculiarly worthy of remark. With the exception of garnet, crystallized mica, and hornblende, and in the micaceous schists of the western series the rare staurotide, epidote, and graphite, none of the common silicated minerals were met with. Excepting the brown hematite of the oxidized silicious veins or strata and the specular hematite of the slates, the metallic minerals were rarely obtained from indigenous rocks. Galena is said to have been found at one place on Castle Creek, but that it is not a common mineral is proven by the entire absence of any particles in the drift or gravel. Pyrites, as a portion of vein matter, was found in several localities, and though at present not largely found it probably was once widely distributed in the veins and seams, the oxidation of which has converted it superficially to the brown oxide of iron. Mispickel has also been found in the same association.

Gold, originating undoubtedly in the quartz seams, is now found in the gravel and drift of the valleys and in the basal portions of the Potsdam, and though there are doubtless many of the seams that carry the gold in a free state, it is so fine and so sparsely disseminated that gold-bearing rock with visible particles is rarely met with. The wearing down of the rocks and the concentrating action of waves and currents have nevertheless so sifted out and accumulated the precious metal, that in many places it is now found in tolerable abundance in the ancient and modern gravels. Quartz seams are so abundant that if they were all, or the larger part of them, auriferous, the quantity of gold in the gravels would be much larger than it is actually found.

No fossils were found in the Archæan rocks; and marble and serpentine, the metamorphic rocks most likely to yield them, were not seen.

Our examination brought to light no evidence of the duplication of any parts of the Archæan rock system. If the slates or the schists were folded upon themselves and afterwards worn away so as to leave two or more parallel outcrops of the same beds, the folding must have been confined to the 
homogeneous soft beds; and the presumption is that no such folding took place within the area exposed in the Hills. The whole system of vertical beds, with a width of about twenty-five miles, is believed to retain its original relation of parts. It has not, of course, its original position, for the same great process of change which has produced its metamorphic structure has turned it bodily on edge and either broken away or eroded away its upward continuation; but it is probable that the system presents the clays and shales and sandstones from which it was produced by metamorphism in the same order in which they were originally deposited.

The division of the system into two series, a series of schists and a series of slates, is based on lithological differences purely, and is fully warranted, whatever may be the structural and historical relation of the two. The fact that Mr. Jenney discovered an apparent unconformity between them at one point, although it stands alone, and although the two series generally conform in strike, is not to be ignored; and coupled with the great lithological difference gives strong support to the view that the slate period and the schist period were separated by an interval of time and not merely distinguished by a change of sediments. Indeed it is questionable if the original sediments were materially different. Mr. Caswell's examinations show that the same minerals constitute the typical rocks of both series, only in the schists they are more coarsely crystallized, so that the lithological contrast seems to depend more on the degree or character of their metamorphism than on any difference in chemical constitution. This fact gives additional support to the view that there was an intervening lapse of time; for if we assume that the schists are older than the slates, it is but natural that they should have been subjected to an antecedent and more powerful metamorphism from which the slates were exempt.

My idea of the history, not by any means as proved, but as most probable in the imperfect light of the facts now known, is as follows: The sediments of the western series were first deposited and were altered to the condition of schists. They were then raised above the ocean, were somewhat eroded, and sank again. The eastern series were deposited on them with slight unconformity, and the whole were again subjected to metamorphic action, which ceased when the eastern rocks had reached their present 
microcrystalline condition. Then came a great dynamic revolution, followed by a great erosion, and the result at the site of the Black Hills was the exposure at the surface of a broad section of vertical schists and slates. Of the base of the schists and of the summit of the slates we have no evidence.

Can we correlate them with the Archæan rocks of the East?

Primarily the historical order of rocks is shown by the order in which they overlie each other, and since every change in the character of successive strata represents a historical change, the geologist always classifies his section by means of these changes. But when remote sections, the connection between which cannot be traced by the eye, are to be compared, and their historical relations are to be made out, or, in other words, when correlation is attempted, the all but universal verdict of geologists is that evidence from fossils is alone of value and that lithological evidence is not to be trusted. Nevertheless there are some lithological correspondences so general that they cannot be accidental, and they must be counted to give a certain weight to lithological evidence in the absence of paleontological. Triassic rocks are characterized by a red color the world over. Permian limestones are always magnesian. The great limestones of all great rock systems are Paleozoic. In innumerable localities in all lands the Paleozoie system begins with a conglomerate and the rocks beneath it are metamorphic. These agreements cannot be due to mere coincidences, and if they are not, then lithological resemblances are not always without meaning, and they may be taken to afford the basis for a presumption so long as the better evidence from organic forms is not available. I shall, therefore, give consideration to the lithological affinities of the Black Hills Archæan as the best available means of judging of their relations.

The rocks of the eastern division of the Archæan-the argillaceous and silicious slates-have a very similar character to the Huronian rocks of the south shore of Lake Superior and Canada. They agree in their partly argillaceous character, in the presence of silicious slates, in the great abundance of quartzite, and in the occurrence of silicious hematite, banded quartz, and jaspery formations. We find, however, in the Black Hills no diorites, conglomerate quartzites, nor limestones, and the iron deposits, 
though of considerable magnitude, are not frequently recurring. The collection of the typical rocks of the slate series brought in from the Black Hills have a peculiar resemblance in their general facies to the typical Huronian rocks, and this fact was inımediately noticed by several geologists to whom the Huronian types are familiar.

In the western series of schists we cannot trace so close a resemblance to either member of the Archæan of the East. The characters which distinguish them from the adjacent slate series serve equally to distinguish them from the typical Huronian. Their rocks are all found in some abundance in the Laurentian, but they are not the characteristic rocks of the Laurentian. If there is one Laurentian rock more prevalent than another it is gneiss, but gneiss is almost unknown in the Black Hills; while calcareous rocks and magnetic iron ores, the constant associates of the Laurentian schists, do not occur in the Archæan of the Hills.

The lithological evidence fails, therefore, to give even its feeble support to the theory that the two Archæan groups of the Black Hills are the representatives of the two Archæan groups of Canada. The fact that there are two great groups in each case is a resemblance. A second resemblance is found when the younger group of the two pairs are compared with each other. But when the older groups are compared a decided disparity is brought to light. With evidence of this character nothing short of a full coincidence could serve to establish even a presumptive correlation, and the question can only await further light. I have, therefore, abstained from any provisional assignment of names to the slates and the schists further than to call the former Newer Archean and the latter Older Archean.

The Archæan rocks of the Black Hills, like Archæan rocks elsewhere, were fully metamorphosed before the dawn of Potsdam time. This is proved by the Potsdam resting upon their upturned edges unconformably, and carrying in the conglomerate at its base fragments of slates, schists, quartzites, etc., of a character precisely similar to that of the underlying rocks.

A portion at least of the Archæan area was above the sea in early Potsdam time, for the Potsdam conglomerate could only have been formed by the action of waves on a shore line. The erosion of the Archæan, which 
ceased with the deposition of the Potsdam, was not renewed until after the Tertiary disturbances which produced the Black Hills uplift.

\section{SECTION III.}

\section{THE GRA N I T S .}

The granites occur only within the area of the Archæan; but the discussion of their character and origin and the question of their age present so many points of interest that it has been thought better to consider them separately instead of treating them in connection with the slates and schists.

As has been mentioned already, they are wholly confined to the southern end of the Hills; none whatever are found north of Spring Creek. Their greatest development appears in the accumulation of ridges and summits about Harney Peak. North of Harney little granite is found and that merely the ending off of the main range. West, south, and east it becomes gradually less and less predominant and the schists are more and more exposed, until at the limit of the Archæan exposure it is rarely met with. West of Harney there are many masses of no little magnitude but they are more abundant toward the south and southeast. In several of the cañons of the creeks draining the southeastern corner of the Hills granites appear among the quartzites and schists, while the tops of the cañon walls are capped by the fossiliferous rocks. Harney thus seems to be an eccentric point in the development, the northern focus of an ellipse whose longer axis is directed to the southeast and whose area incloses all the outcrops.*

The maximum expansion of the granites around Harney seems to be at or near the separating line between the two series of metamorphic rocks, the schists of the western and the slates of the eastern series, and our careful examination found them to be confined entirely to the area of the schists, none whatever being found in the slates.

It would be a task of no little magnitude to give an adequate idea of the

* Tote BY the Editor. - The reader who compares the distribution of the granite, as described in the text, with its distribution as given by the geologieal map, will find discrepancies. The anthor drew a few granite areas on a small preliminary map, but attempted no thorough representation, because the topographical material was not then fully compiled. The editur has transferred these areas to the final map, but las not attempted to supply the outerops deseribed in general terms in the text, because be could not do so without inventing details.

$5 \mathrm{~B} \mathrm{H}$ 
surface features of the rugged and craggy region of the granites, probably the most difficult of passage of any district in the Hills. A few words, however, will be devoted to some of the most conspicuous characters of its topography. Viewed at a distance from the Plains at the west or east, the Hills appear as a long, low ridge, above which the peaks and ridges of the interior area raise their sharp and broken summits, and the highest elevation is readily recognized in Harney Peak. Beginning near the extreme southern end of the Hills, in the high points south of French Creek, there is seen to be a succession of elevated peaks and ridges, increasing in height and ruggedness until they culminate in Harney and its retinue of smaller peaks. These latter are defined, sharp and craggy, against the background of sky, and even at a great distance Harney Peak with its peculiar cathedral-like summit is easily recognized. By a freak of weathering the highest point is carved into a seemingly square tower, and joined to this on the south is a lower ridge forming the body of the edifice. The granite range is cut off sharply just north of Harney, which stands with its bold front looking northward over a broad array of lower rolling hills. It rises two thousand feet above the valleys near its base and several hundred feet above the other peaks in the Hills, but it is rivaled in height by a point of the limestone plateau called Crook's Tower. The latter, however, is an inconspicuous butte, rising but little above the general level of the plateau, while Harney, springing abruptly from lower surroundings, is far the most conspicuous of the high points.

Approaching Harney from the west, from near the base of the limestone plateau, we pass over the upturned edge of the schists, and though the country is occasionally rough no granite is seen until within about ten miles of the peak. At first we cross a few ridges of granite running parallel with the stratification of the schists, and ranging in height from a few feet to several hundred feet. They are extremely rugged, their surfaces being shattered by weathering and thickly grown with trees, and as we approach the main range they increase in frequency, size, and roughness. The schists become at the same time less and less visible, and the little parks and grassy valleys are less prominent, until at a distance of about five miles from the peak the schists are no longer seen, and we have reached the unending 
granite. Beyond us, in a succession of peaks and ridges, or shooting up vertically in slim pinnacles and points, rounded, grooved, and scarred by the action of the weather, the summits of the granite masses tower in an almost endless repetition. Many little drainage valleys, with sides and bottoms thickly tangled with aspen and pine, wander through the maze of peaks.

The sides of the peaks are generally covered by a dense growth of small pine trees, and this extends up to the vertical eliffs. In many places, however, large areas of the mountain flanks have been burned off, leaving the blackened trunks; and in others a tornado has covered the slopes with fallen timber.

Starting from French Creek near the stockade, winding among the granite ridges, which here run east and west, and going northward through a series of grassy valleys which follow the outcrops of the schists and head toward the high peaks of the Harney range, the headwaters of Battle Creek are soon reached. Dammed by the beaver, the creek is spread out in swampy valleys overgrown with a dense brake of aspen and willow. Breaking through this undergrowth one is soon compelled to dismount and arduously force his way along, leading his horse as best he may, while the presence of his comrades is only known by the plunging and crashing they make in their slow progress. With rugged granite heights before and on both sides, singling out a prominent peak that promises most to be Harney, we thither direct our course, and soon find the tangled valley narrowing, while before us rises the face of a granite ridge. Mounting its side, rough with broken fragments of rock and perhaps still further encumbered with a growth of small pines or with fallen timber, we reach the summit, and exhausted with the exertion of climbing and pulling up the horses we look eagerly around over the waste of granite, piled in endless confusion, weathered in fantastic shapes, and cleft with deep and narrow valleys, to see if Harney is recognizable. Across a steep-sided valley we think we see it raising its summit in the distance, and descending several hundred feet over the broken mountain slope, and crossing the narrow valley, thickly grown with trees and piled with bowlders, we painfully ascend its farther side, which to our discourage- 
ment is seen to overlook a similar valley, beyond which is Harney. Thus ascending rugged mountain slopes and erossing intricate valleys our guiding peak, after almost endless labor, is finally reached and joyously ascended, only to crown our disappointment with the sight of Harney still in the far distance, standing high above the surrounding peaks, to reach which still other and many high ridges and deep valleys must be scaled and crossed. Such was the experience of several of the officers of our escort, who thrice attempted the ascent of Harney from the south and southeast, and each time were foiled by the difficulties of the rugged mountain region. The triangulation party, however, was more successful, for approaching the granite range from the west it encountered less difficulty. Following first one of the grassy valleys of French Creek, and thence crossing a high ridge from which Harney was visible, a small valley was reached, which afterward was found to meander to the very base of the peak itself. Here encamping, the peak was considered but a slight climb for the following morning. On the morrow, leaving here the horses, the ridge bordering the valley was easily mounted, and among the multitude of peaks in view one was singled out as Harney. This proved to be an error, but from its summit the true Harney was seen. Following then a high ridge, along which for a long distance we had to cut a passage through the undergrowth of pine and aspen and pick our way over fallen timber and rough crags, the peak was finally reached. At the base of the tower were found cartridges and other evidence of the presence of General Custer's party in 1874, but the tower itself, the summit of the peak, seemed never to have been ascended. After some struggling and climbing the highest point was surmounted, from which the whole character of the country could be studied. A mercurial barometer observed on the top of the tower gave for its altitude 7,403 feet.

The general character of the view from this point has already been mentioned in describing the topography of the slate area. Northward the granite range ends somewhat abruptly, and descends at a high angle for nearly two thousand feet, while beyond are seen the rounded hills and scattered valleys of the slate area, with Custer and Terry Peaks in the distance, and far to the northeast the conical top of Bear Butte. On all 
sides are the cliffs of the sedimentary rocks, which bound the area of the crystalline rocks, while near the horizon at the east and west are seen the bare wastes of the Plains. Immediately around the peak on the east and south and west rise a myriad of serrated peaks only less than Harney in height-all weathered and scored and gradually crumbling under the hand of time. Toward the west and southwest the peaks become less numerous and prominent as they recede from the granite range, and the country is seen to open up in little parks and grassy glades; and in the far southwest it spreads out into Custer Park. East and south the rough and mountainous character is maintained, though a few openings may be seen on the headwaters of Battle and French Creeks. In the southeast, however, the rugged character of the country is most eontinuous and marked.

The rock of all the granite masses of the hills varies little in character. Its texture is so extremely coarse that it would scarcely be recognized as granite by one accustomed to the fine-grained varieties of New England or the Rocky Mountains. It is granite on a large scale, with all the elements of that rock-feldspar, quartz, and mica-present, but instead of their being mixed with tolerable uniformity throughout the mass each constituent is very highly crystalline and aggregated by itself. Feldspar is the most abundant constituent and forms 70 or 75 per cent of the whole. It is always highly crystalline and sometimes exhibits large crystal faces but no perfect crystal was discovered. It is generally of a pearly white or grayish white color, having on fresh fractures a bright luster, but it is occasionally flesh-colored and it often receives a reddish or pinkish stain from the decomposition of associated ferriferous minerals. This discoloration is more observable in the southern part of the granite area and in places where the feldspathic mass is especially weathered and rotten. To the preponderance of the feldspar is mainly due the rapidity of the decomposition of the granite, the pinnacled, sharp, and rugged mode of its weathering, and the superficially shattered character of its masses. So readily does it decompose and crumble that it is in many places difficult to get even a hand specimen of firm and unchanged rock. 
The quartz of the granite is commonly glassy and clear, but its variation in texture and color is great. It is usually crystalline, but no crystals are found. It is frequently found opaque and white, and sometimes lightly tinted with pink, while many large masses are of a delicate rose color. From the decomposition of associated minerals it is often stained by oxide of iron to a dull red or brown color. It composes approximately about 20 per cent of the granite, but is distributed with great irregularity. In many cases the quartz penetrates the feldspar mass in irregular seams or fragments, which on certain fracture planes produce the figures so suggestive of oriental inscriptions, and which have given to the variety its name of graphic granite. Sometimes it occurs in large compact bodies, sometimes in the form of huge veins, and sometimes it forms a more equable mixture with the feldspar and mica, making a normal and tolerably uniform but coarse granite.

The mica ranges from silvery white to dark brown in color. It is always highly crystallized, and well defined hexagonal crystals two inches in diameter are very common; mica plates six or more inches across have been found. The mineral forms only about 5 per cent of the granite, and though sometimes distributed generally through the mass it is more often found in bunches or segregations. It was observed that it rarely accompanies the feldspar alone, but is almost always associated with quartz.

Besides the three minerals essential to the formation of granite the only ones found in abundance are rose quartz and tourmaline. The latter is quite common and sometimes composes 3 or 4 per cent of the granite. It is usually but not exclusively associated with the quartz. It is black in color, and is generally highly crystallized, though sometimes massive. At Harney Peak and elsewhere massive pieces of tourmaline were found weighing several pounds and covered with small well defined crystals. More generally it occurs in trigonal pyramids, well defined, and sometimes with beautifully terminated ends. These crystals are often found from three to eight inches in diameter and nearly a foot in length; but perfect specimens could not be obtained from the weathered surfaces accessible to us. Though very abundant in the granite it is strictly confined to that rock and was never seen in either the schists or the slates. 


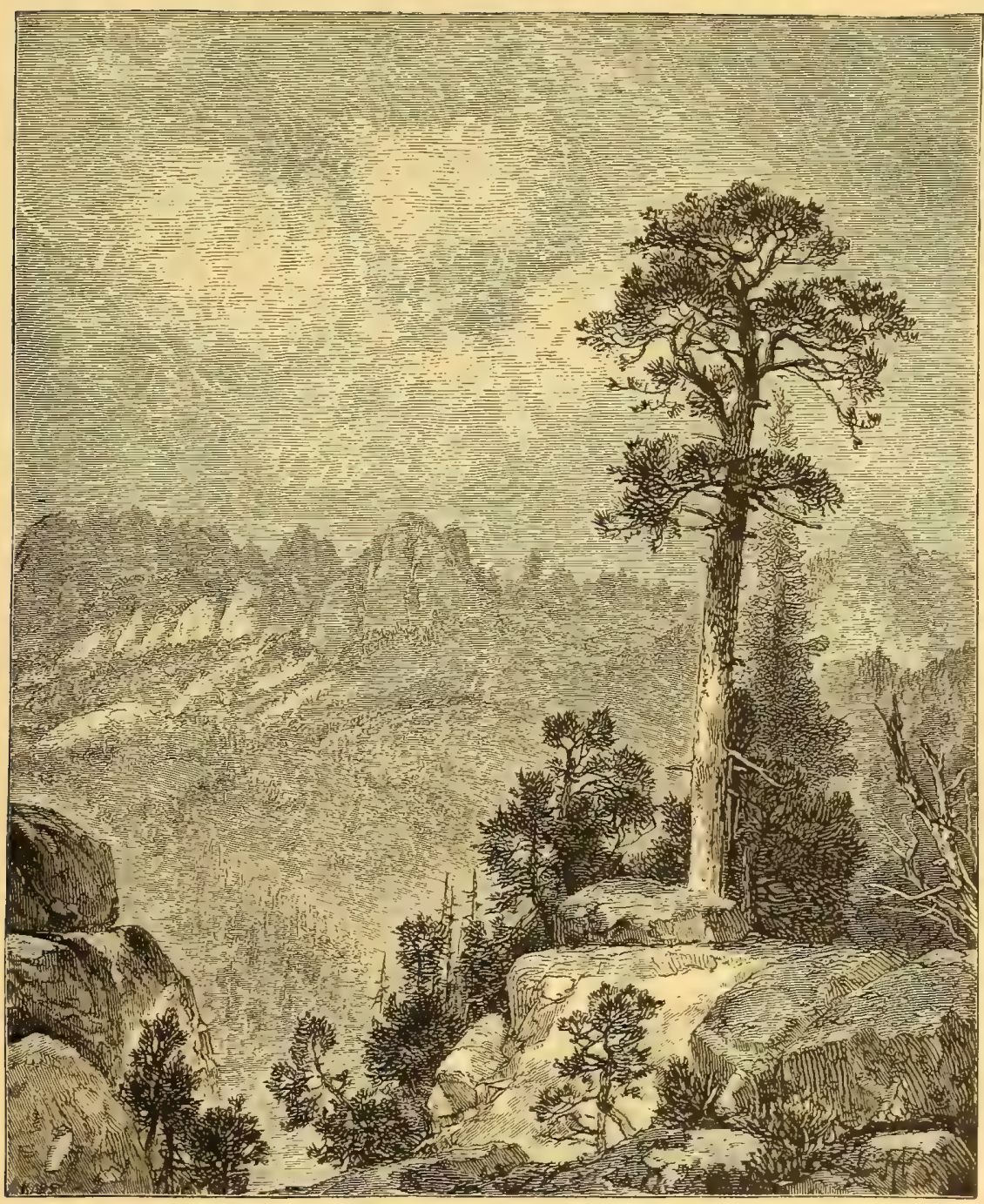

FIG. 5. -"Saw 'Teetl" of Granite, near Harney Peak. 

From this brief notice of the components of the granite it is seen to be exceedingly coarse, feldspathic, and crystalline, and it would probably be classed by Nauman and Von Cotta as approaching the variety Pcgmatite. In the southern end of the Hills, however, on French Creek and the headwaters of Amphibious, a fine-grained variety was found which has more nearly the typical character of granite. In places it has much the appearance of Scotch granite, though considerably coarser in texture, and in nearly every hand specimen that may be selected crystals of tourmaline can be found, but these are neither so large nor so finely crystallized as those in the coarser rock.

In one of the smaller granite deposits in Custer Park a particular arrangement of the minerals was observed, which, though interesting, is quite exceptional. The tourmaline, mica, and quartz have a roughly concentric disposition within the general matrix of feldspar. On the exterior of each aggregation the tourmaline preponderates, with a sprinkling of quartz. In an intermediate layer the tourmaline is less abundant, and associated with quartz are quantities of mica in crystal tablets, while a large mass of clear, highly crystalline quartz constitutes the nucleus.

In the great peaks and masses of the central nucleus there seems to be an arrangement in a north and south direction, $i . e$., their greater diameters have that trend. There are many cross ridges, it is true, but they appear to be due rather to an accidental arrangement of the deep eroded valleys that wander through the granite area than to any primary arrangement of the granite itself. No distinct marks of stratification were observed even in a large way. The main peaks are of massive granite, fissured and cracked, weathered and worn in every direction, but they are longer in a northeast and southwest direction and comparatively narrow crosswise, forming in many instances crests or ridges. South and southwest of Harney are some excellent examples of what might be termed weathering planes, in which granite pinnacles or slabs are weathered out and stand 100 or 200 feet above the mass of the range. These planes have the same general northwest or north-northwest trend observed in the whole structure of the granite area. They divide some of the crests into serried pin- 
nacles, which near by resemble organ pipes and in the distance saw teeth, and which contribute greatly to the picturesqueness of the scenery. They undoubtedly owe their formation to a more readily decomposed material which has been removed from between their surfaces, but they can hardly be due to a true stratification in the granite itself. The peculiar pinnacled topography to which they give rise is confined to a limited area extending about three miles southwest from Harney Peak and is not generally observable. The saw teeth and the weathering planes are illustrated by Figures 5 and 6 , which represent scenery photographed near Harney Peak.

In the summit of Harney Peak a small mass of mica schist was observed cemented in the feldspathic rock, with its stratification nearly

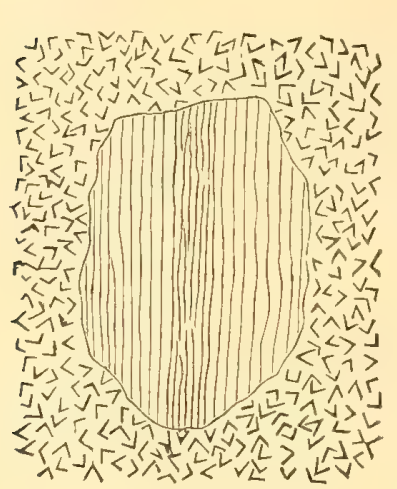
horizontal. It appears to be an entrapped piece of schist enfolded by the granite when the latter was in a plastic state. Mr. Jenney observed near Harney Peak a huge fragment of schistose rock similarly entrapped in a mass of granite. This is represented in the annexed cut. The mass is about 100 by 75 feet in size and lies with its stratification vertical. Between the strata of schist is a seam of the ferruginous quartz so common in that association, and by weathering the rocks have been cut

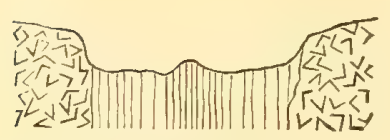

Fig. 7.-Plan aud section of away in the manner shown in the cross-section.

To study with facility the relation of the granite to the schitose rocks, we must leave the main granite area and observe those outliers or ridges which run among the schists and have no immediate connection with the central mass. In them the character of the granite is similar in all respects to that of Harney Peak, and we may safely assume that the main range bears the same relation to the great schist area that we find them to bear to the schists about them. That relation is in every case the same; they all run parallel with the stratification, and are perfectly distinct and separate from the schistose rocks. There is always an absolute and positive line of demarkation between the two ; the transition is sudden, and in no case was there observed any gradation of one rock into the other, though such facts 


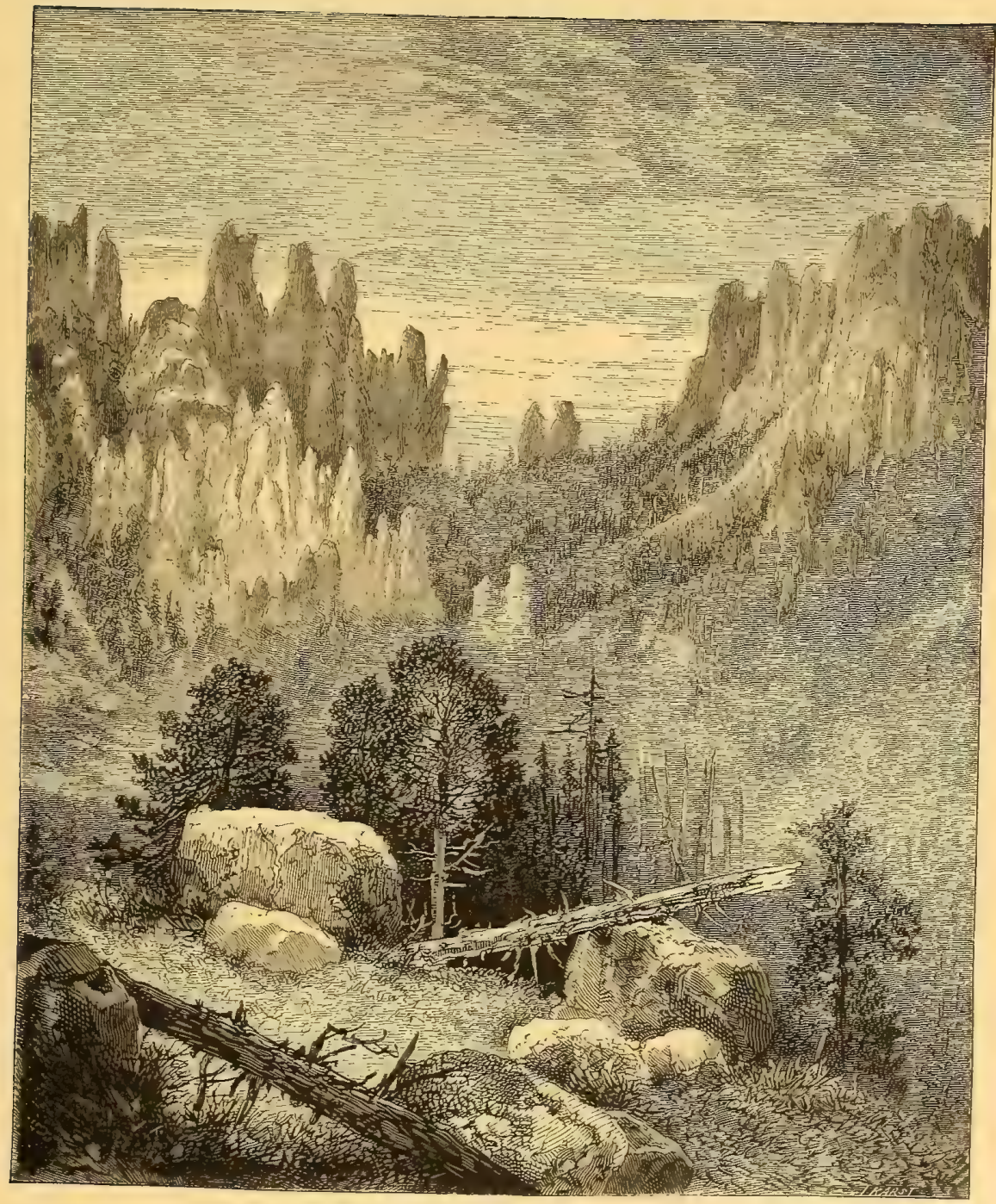

FIG. 6.-Granite Forms near Harney Peake. 

were carefully looked for. Hand fragments may be found anywhere along the separating line, showing the micaceous schist on one side and the granite on the other, separated by a line that can be traced with a needle point.

In several instances the contact surface of the granite was found beantifully polished or slickensided, and many others doubtless escaped notice because of the easy disentegration of the granite. One particular case is worthy of specification. It was seen near French Creek, as we approached it from the headwaters of Spring Creek. An exposed surface of one of the granite masses stands there four or five feet above the incasing schist, and in fragments extends a distance of twenty feet. 'This surface is as beautifully smoothed and polished as any glacial planing I have ever seen, and the resemblance is so striking that it was taken at first to be a glaciated surface. These smoothed surfaces are produced by the movements of the rocks against each other, and as the granite is harder than the schist, it became polished just as a tool of hardened steel is polished on a grindstone. West of Harney the strike of the rocks is from north and south to northwest and southeast, and we find the inclosed granite masses running in the same manner. Southward, on French Creek at and above the stockade, the strike of the schists is changed, and with them the inclosed granite ridges run nearly east and west. Southwest of the stockade, in Custer Park, the schists and granite run north and south, and this strike is exchanged in the eastern part of the Park region for an east and west, which bends around on the east side of Harney, becoming the customary trend toward the north and northwest. These features in the strike of the rocks have already been noticed in the description of the general features of the schist area, and need here no further comment. In all the region where the granites are included in the schists they rise abruptly above the general level; for though they are somewhat easily disintegrated, they are surpassed in destructibility by the schists and the latter have been much more rapidly removed, leaving the granite prominent.

The masses vary greatly in size. Sometimes they are merely veins an inch or two in thickness and of very limited extent. More commonly, however, they are 25 or 50 or more feet in width, and several hundred feet or several hundred yards in length. The larger peaks or ridges are often 
500 feet in height and several miles in extent. Whatever their size, they have always a lenticular horizontal section, that is, they are thickest near the middle and taper off toward each end; but whether this same form would appear in a vertical section we have no means of ascertaining. Their form is illustrated in the annexed cut.

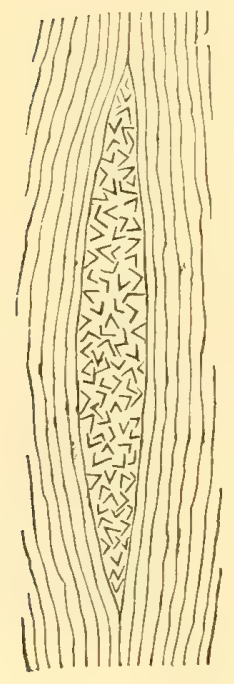

Frequently, standing on one of these lenses of granite and looking along the strike, the geologist can trace a series of others trending in the same direction and on the same line. They appear like masses of granite that have filled seams or separations in the schists, pinching in and swelling out like fissure veins.

In the cañon of French Creek a cliff was observed wherein a stratum of granite is inclosed between two of quartzite, the granite mass itself inclosing some gneiss and having distinctly marked in its short exposure the swelling or lenticular form.

The peculiar granite of the Black Hills resembles but few of the described granites of the Rocky Mountains proper. The rock of Rawhide Butte, mentioned in Chapter II, is very similar in its highly feldspathic and coarse character and in the abundance of tourmaline and rose quartz.

Laramie Peak, too, presents many of the features of the granites of the Hills. Dr. Hayden* finds the granite Fig. S.-Grouud Plan and Section bodies thinner and less abundant at a distance from the main of Granite Lens. peak and the interstratified schistose rocks more prominent, while the peak itself is composed almost entirely of granite. This he describes as an "aggregation of large crystals of reddish feldspar, with quartz and mica; the feldspar so predominating that it gives the character to the rock. The mica usually occurs in small masses and in limited quantities."

Dr. Hayden states that the granite of the Wind River Mountains is very uniform and gray, $\dagger$ and Prof. Theo. R. Comstock remarks a gradual change from the schists to gneiss, gneissoid granite, and compact fine-

*Geological Survey of the Territories, 1870, p. 18.

†Id. , p. 3\%. 
grained granite, and otherwise does not describe them as similar to those of the Black Hills.*

In the survey by Mr. Clarence King of the 40th Parallel no granites were found of the highly feldspathic and coarse character observed in the Black Hills.

In Colorado the granites and metamorphic rocks of the Middle Park region have been studied with care by Mr. A. R. Marvine $\dagger \mathrm{He}$ finds them to range from "quartzite through silicious and mica schists to very simple varieties of gneisses and granites, in which the mica is wholly subordinate, and the feldspar mostly a tabular and twinned orthoclase, *** while the syenitic element and the more basic rocks generally were almost entirely wanting." Excepting some minor granitic areas of uncertain eruptive character, Mr. Marvine regards the granites of this region as metamorphosed shale, which over large areas "has reached that last term of metamorphism, viz, structureless granite."

The intercalation of granite and gneissic strata with a gradual increase of the granite ratio in the direction of the main granitic mass is also mentioned by Mr. Marvine-an arrangement noticed in the Black Hills. Frequent mention is made of the gradual passage from the schists to the granites, of their mutual conformity, and of evidences that seem to prove their metamorphic origin in situ. These granites do not closely resemble those of the Black Hills in composition, and they differ moreover by containing many metaliferous fissure veins. Dr. J. J. Stevenson, $\ddagger$ who has examined the granites of the southern part of Colorado, finds nowhere the very coarse, feldspathic granite described in the Hills, and from their study is firmly convinced that they are metamorphosed strata.

Notwithstanding the study that has been given to the subject, the origin of granite is still an unsettled problem. There was a time when it was universally regarded as an igneous or plutonic rock, being at every locality either a part of the original crust of the earth formed

* Northwest Wyoming, including Yellowstone National Park. Jones, United States Engineers. 1873. Geology by T. B. Comstock. p. 103.

† United States Geological and Geographical Survey of Colorado. Hayden, 1873. p. 139.

$\ddagger$ Uniter States Geographical Surveys west of the 100th Meridian. Vol. iii, p. 345, et seq. 
when the surface of the molten globe first cooled, and so indigenous, or else the result of an extrusion of the still molten interior magma, and so exotic. Later investigations showed that in some places granite passes by insensible gradations into gneiss, a rock that is universally recognized as metamorphic, and left no doubt that some granites are the products of the metamorphism of sedimentary rocks. A school of geologists at once arose who maintained that all exotic as well as indigenous granites were the result of the fusion or partial fusion of ancient sediments, and that the original crust of the earth and the uncongealed substance of the interior are not illustrated by the rocks accessible to the geologist. Professor Ramsey, an advocate of this view, says:

That in one sense it [granite] is an igneous rock; that is to say, that it has been completely fused. But in another sense it is a metamorphic rock, partly because it is impossible in many cases to draw any definite line between gneiss and granite, for they pass into each other by insensible gradations; and granite occupies the space that onght to be filled with gneiss, were it not that the gneiss has been entirely fused. I believe, therefore, that granite and its allies are simply the effect of the extreme of metamorphism, brought about by great heat with presence of water. In other words, when the metamorphism has been so great that all traces of the semi-crystalline laminated structure has disappeared, a more perfect crystallization has taken place.*

At the present time it is admitted on all hands that there are certain granites which are merely highly crystalline gneisses, but there are those who doubt the metamorphic origin of the exotic or intrusive granites.

It has already been intimated that the granite of the Black Hills is intrusive, and many of the facts by which its relation is proved have been narrated in describing its distribution; but the latter will be recapitulated here, in connection with all others that seem pertinent, for the sake of giving completeness to the demonstration.

First. The feldspar, amounting to 75 per cent of the granite, could not have been supplied by a simple metamorphism of the schists, which are not very generally gneissoid, but more commonly micaceous, and in general may be said to contain 75 per cent of mica. The maximum ratio of alkalies in the slates and schists is only about 8 per cent, while in the granite it is fully 15 per cent.

It may be said, by the way, that the granite is chemically very similar

* Physical Geology and Geography of Great Britain. A. E. Ramsey. p. 38,2 ed. 
to the volcanic rock in the northern part of the Hills, and may perhaps be closely related in origin. Only a difference in the conditions of cooling would be needed to produce from the same magma a granite on the one case and a feldspathic volcanic rock on the other.

Second. The occurrence of pieces of schist rock inclosed in the mass of the granite is evidence of a plastic condition of the granite coincident with a non-plastic condition of the schist.

Third. Each granite mass has a long lenticular shape, and several of them could sometimes be traced in a series along the same line of bedding. This is the character which veins following the strata of a pliant rock like mica schist are most apt to assume.

Fourth. The cuarseness of the erystallization, the thoroughness of the separation of the several minerals, and the occasional concentric arrangement of the minerals on a large scale, all indicate a condition of the mass in which there was great freedom of movement among the particles-a condition of plasticity if not of perfect fluidity.

Fifth. The transition from the schist to the granite is always sudden; no graded passage of one rock to the other was anywhere observed.

The problem of the age of the granite occupied our attention from the time of our first examination, and for a while the weight of evidence led to a conclusion that is now demonstrably erroneous. The history of the problem is instructive as an illustration of the danger inherent in negative evidence.

The granite was intruded between strata of the Archæan; therefore it is younger than those strata. Its fragments were found as pebbles of the conglomerate at the base of the White River Tertiary; therefore it is older than that formation. There was no considerable disturbance during the deposition of the strata from the Potsdam to the Cretaceous, inclusive; therefore the intrusion did not take place in Paleozoic or Mesozoic time. The granite is coarsely and completely crystalline; therefore it was cooled slowly and under pressure, and it could not have been intruded after the Archæan strata were uplifted and eroded and before they were covered by the Potsdam. There remain two possible dates or epochs, the first in 
Archæan time before the processes of displacement and erosion had brought the inclosing schists near to the surface, the second in Tertiary time before the deposition of the White River beds.

This much could be deduced from the positive data of observation taken in connection with generally accepted principles; but the next step was taken on the authority of negative evidence. No granite whatever was found in the conglomerate at the base of the Potsdam sandstone, and this although definite search was made at every opportunity. The Potsdam was found to contain a great quantity of quartzitic pebbles easily referable to the Archæan quartzites and occasional specimens of Archæan schists, but no granite. This conspicuous absence, coupled with the presence of granite in the Miocene conglomerate and Quaternary gravels seemed to say that the granite was not a member of the subjacent rock system when the Potsdam was laid down and pointed to Post-Cretaceous time as the date of its introduction.

The conclusion thus reached was opposed by the analogy of other regions, but it was the logical sequent of the premises if weight was to be given to the negative element, and it was provisionally entertained. Its hold was soon weakened, however, when attention was directed to certain other facts of observation, the importance of which was not at first appreciated. As already described, a locality had been seen where a continuous sheet of the Potsdam passes from a surface of eroded schists to a surface of granite. There was found no intrusion of the granite along the parting between the Potsdam and the schists, and there was found no metamorphism of the Potsdam at the surface of contact with the granite. In these particulars the relations of the granite are strongly contrasted with those of the trachyte of the Hills. Wherever the trachyte appears beneath the Potsdam the latter is uplifted as though by the insertion of the trachyte between it and the Archæan, and its lowest beds are at the same time metamorphized as though by the heat of the molten intrusion. The fact that the granite did not at this locality affect the form and constitution of the Potsdam strata in a manner similar to the trachyte does not well accord with the idea that it was introduced under similar conditions and during the same geological period.

To the same intent are the mineralogical and textural relations of the 
two igneous rocks. Their mineralogical difference is not great and their chemical difference is small, but in texture they are widely contrasted. The granite is coarse-grained to a degree that is exceptional even for granite. The trachyte has a fine and uniform texture, and its crystals are embedded in a paste. All the analogies of modern petrography lead to the assumption that the conditions under which the two rocks cooled were very different. The trachyte must have solidified with some degree of rapidity, else its paste would not have remained. The granite, in order to have separated its minerals so completely and in masses of such size, must have congealed with infinite slowness. But if the granite was injected beneath the Potsdam in the early part of the Tertiary period just as the trachyte was injected beneath the Potsdam near the beginning of Tertiary time, the conditions under which the two were consolidated could not have been vastly different.

The first conclusion having been unsettled by these considerations, the question was asked whether it was not possible that peculiar atmospheric conditions in Potsdam time made granite a more perishable rock than it was during the Tertiary and Quaternary, and thus prevented the preservation of its bowlders. An examination was made of the descriptions of the basal beds of the Potsdam in the Northern States and Canada and in the Rocky Mountain region, and it was found that while silicious pebbles were everywhere observed as predominant and foliated rocks were occasionally noted, there was but a single record of granitic pebbles. It was seen that the absence of feldspathic pebbles, from whatever cause it arose, was not peculiar to the Black Hills locality, and the conclusion based upon this absence was relinquished.

When, therefore, in a subsequent year a feldspathic pebble was obtained from the Potsdam its discovery occasioned no surprise, for it merely established by positive proof a conclusion already entertained as the result of indirect but cumulative evidence.

The discovery of granitic débris in the conglomerate at the base of the fossiliferous rock system fixed the age of the granite as nearly as it is likely ever to be determined. It not only antedates the Primordial sediments, but it antedates a great division of Archæan time. We must count as Archæan 
not merely the time in which the slates and schists and quartzites were deposited as clay and sand, but also the time in which they were subjected to the vast displacement and degradation whereby their truncated edges were finally prepared to receive the later sediments. The intrusion of the granite took place before those changes were greatly advanced, and possibly before they were begun, for it occurred in the presence of a heat and a pressure that could not have existed close to the surface of the earth.

S E C I ON I V.

THE S L U R I A N

THE POTSDAM SANDSTONE.

The members of the great Silurian system, which form such voluminous chapters in the geological history of the territory east of the Mississippi River, attaining along the Appalachian Mountains a thickness of no less than 38,000 feet, thin out westward. In the Rocky Mountain region but few of the groups have been recognized, and those occupy but a very subordinate position when compared with the other members of the Rocky Mountain rock series. Of the lower Silurian formations, the Primordial, Canadian, and Trenton, there is found in the Black Hills only the Primordial, and of the Primordial no group but the Potsdam, while the different formations of the Upper Silurian-the Niagara, Salina, Helderberg, and Oriskany - are entirely absent. In other portions of the Rocky Mountains beds have been recognized by different geologists as belonging to the Canadian, Trenton, and Niagara formations, but they are always inferior in thickness and extent to the more recent formations.

In a few localities in New Brunswick, Nova Scota, and the Eastern States a series of fossiliferous beds, known as the Acadian or St. John's group, have been found underlying the Potsdam, but the latter is the first in order of time of the widespread, unchanged, fossiliferous strata of the American geological column. In the great area it is known to underlie, in its great persistency, and in the uniformity of its character, the Potsdam 
formation is one of the most remarkable features of American geology. It consists generally of a coarse sandstone, usually reddish in color, and often containing beds of conglomerate. In certain regions it is shaly, in a few places it embraces beds of limestone, and in the Far West it often contains beds of quartzite. Where the underlying Acadian formation is absent, the Potsdam rests unconformably on the upturned edges of the Archæan. Outcropping in immense beds in northern Wisconsin, it skirts the Archæan area on the south, and flanking the Canadian and Adirondack Mountains,- it is found in great thickness along the entire line of the Appalachians. Though it is exposed nowhere in the great continental basin between the Alleghanies and the Rocky Mountains, it has been recognized by its lithological characters in the deep borings at Columbus, Ohio, and Saint Louis, Mo, and in central Texas it has been investigated by Dr. Shumard.

The extension of the Potsdam to the region of the Rocky Mountains was first recognized by Mr. Meek from the fossils collected and observations made by Dr. Hayden during Warren's reconnaissance of the Black Hills. The formation is there very fossiliferous, containing many of the characteristic genera of the Potsdam as found in the east-Lingula, Lingulepis, Obolella, and Hyolites, with trilobites, fucoids, etc., and from their study the existence of the Potsdam in the Far West was first announced by Meek and Hayden in the Proceedings of the Philadelphia Academy of Natural Sciences for March, 1858. Since the time of Warren's reconnaissance the upturned edges of the Potsdam have been found in many places along the flanks of the Rocky Mountains, and though for long distances apparently absent, it is probably in most cases merely concealed by overlapping strata of more recent date. In no place, however, in its western development has it been found so abundantly fossiliferous as in the area of the Black Hills. Commonly in the study of Rocky Mountain geology its presence is recognized only by its lithological character and its stratigraphical relations.

In the Black Hills the Potsdam is the lowest member of the fossiliferous series, and in its numerous and excellent exposures its character and relations were easily determined and studied. It everywhere rests unconformably upon the upturned edges of the underlying Archæan slates and 6 в $\mathrm{H}$ 
schists, filling up irregularities in their surfaces, and its basal member is generally formed of coarse materials derived from the erosion of the subjacent rocks

Consisting mainly of coarse and friable sandstones, with conglomerates easily eroded, it covers superficially very limited areas, and its exposures, if

1

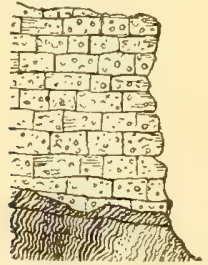
unexaggerated, would be represented on a geological map by a line rather than by a belt or zone. 'The cliffs or bluffs of greater or less prominence that have already been noticed as surrounding the Archæan area of the Hills on all sides like a wall, and which FIG. 9.-Section on spring are broken through here and there by the draining Creek, showing uncontormity of the Potsdam sand- streams as they escape through narrow cañons, are stones and underlying schists.

1. Coarse Potsdam sandstone and conglomerate. 2. Schistose rocks. a. Joint- lies the Potsdam sandstone. The Potsdam often out-
ing plane in the schists. crops in a bluff or in a series of steps of sandstone with intervening slopes, but generally the entire exposure is concealed under a talus composed of the débris of the Carboniferous limestone and of the Potsdam itself. In many places, however, clean and good sections are presented, especially in the walls of the cañons. Occasionally, near the cliff of fossiliferous rocks, isolated buttes or hills of Carboniferous limestone, with the underlying Potsdam, have been left by denudation in the midst of the Archæan; but on account of the friable and easily eroded character of the Potsdam, outliers of that formation alone are not frequent. In the northern part of the Hills, however, in the region north and northeast of Custer Peak, large areas of the Potsdam are exposed.

West, northwest, and north of Terry Peak, in the wilderness of deep and intricate cañons traversed by the headwaters of Spearfish, and Redwater Creeks and their branches, many of the cañons cut down through the Carboniferous into the Potsdam, and a few go still deeper, penetrating the schists beneath. The Potsdam has been examined in several of these cañons, and found to preserve its usual character and its usual relations to the associated rocks, but it was not thoroughly studied and no attempt has been made to map its sinuous outcrop. 
Wherever the formation is exposed around the margin of the Archæan area it is found to dip outward from the axial area of the Hills. On the western side the Potsdam underlying the broad plateau or table-land of Carboniferous limestone shows little dip along its outcrop, but along the western margin of the plateal the dip of the overlying and conforming limestone is away from the axis of the Hills or toward the west. In the southern, eastern, and western parts of the Hills the dip of the fossiliferous strata is always well marked, varying from $10^{\circ}$ to $25^{\circ}$ or $30^{\circ}$ from the horizontal. But while the dip of the Potsdam may vary from point to point, it sustains always the same relation to the underlying slates and schists and to the overlying Carboniferous series. It ever rests unconformably upon the former, and it is found always to be entirely and perfectly conformable with the latter.

The representatives of these two great systems, Silurian and Carboniferous, which in other parts of our country are separated by many thousands of feet of deposits, recording æons of time, are thus found in the Black Hills in direct and conformable contact.

Around Crow Peak, where the strata have been turned up at a high angle by the extrusion of the trachyte which composes the mass of the peak, the Potsdam stands nearly vertical against the mass of volcanic rock, and has been transformed by the latter into a hard white quartzite. The limestone of the Carboniferous rests conformably against it. In a similar relation the upturned edges of the Potsdam are found about the volcanic uplift six miles northeast of Inyan Kara.

Warren Peaks, the prominent points of the Bear Lodge range, consist of trachytic rocks, and the volcanic force by which they were ejected has tilted and exposed the various members of the fossiliferous series with the Potsdam sandstone at their base. The Potsdam is here in many instances highly metamorphosed, but bears the same stratigraphical relations to the accompanying rocks.

By a reference to the geological map accompanying this report the exposures of the Potsdam sandstone will be seen to form a very narrow band surrounding the Archæan area, and even this is somewhat exaggerated in width so that the formation may be distinctly represented. Near Terry 
Peak it forms the surface of a considerable territory, but in other portions of the Hills it is generally but an outcroping stratum in the face of a cliff or slope.

Though essentially a sandstone formation it has some variety of composition. Usually it carries a conglomerate at the base, but this is sometimes exchanged for a dense quartzite, and in many places there are interstratified beds of quartzite. In a few localities the formation is quite calcareous, and in a greater number it contains peculiar greensand deposits. Its thickness is quite uniform, ranging generally from 200 to 250 feet, but attaining to 300 feet on the north branch of Redwater Creek.

The basal conglomerate varies in character and thickness in different parts of the Hills and even within short distances, but is everywhere a wellrounded shore deposit. Even where it is replaced by quartzite the latter was determined to contain quartz pebbles. The pebbles and bowlders forming the conglomerate were examined with minute care, and were found in all cases to consist of the harder varieties of the rocks composing the metamorphic series-quartz, the hard blue and gray quartzites, and some of the harder slates and schists. The latter usually occur as flattened pebbles similar to those found in the present streams. The banded or jaspery quartz, ribbon quartz, ferruginous quartz, ete., of the characters mentioned in the previous sections, were also found, together with a ferw feldspathic pebbles from the granite. In the upper portions of the main conglomerate and in the occasional fine conglomerates occurring in the body of the formation the constituent pebbles are almost entirely of quartz.

The discovery of gold in the Potsdam was not made until after the completion of our field work, nor indeed until after the major part of this chapter was penned, and I am still unable to give the particulars of its occurrence. There is no need, however, to substantiate the announcement of that which is inherently so probable. The currents that spread the Potsdam sediments worked over the débris of the veins of the Archæan, sorting coarse from fine and heavy from light, and it might have been anticipated from the outset (if only the idea had suggested itself) that they would prove to have concentrated the gold which then as now was scattered through the ancient quartzes. 
Sometimes the bowlders or cobblestones forming the conglomerate are of considerable size, from one to four feet in diameter. One of the best exposures of this character was seen in the cañon of lower Rapid Creek, and is illustrated in the annexed illustration.

The large bowlders shown at the base of the section are perfectly waterrounded and form a broad talus extending to the bed of the creek. They

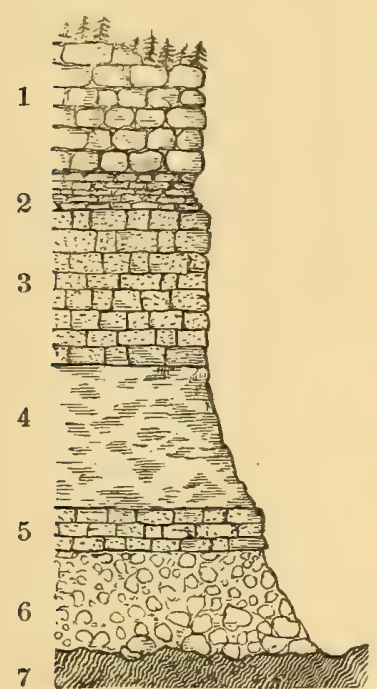

FIG. 10.-Section of the Potsdam sandstone on lower Rapid Creek, showing the bowlders at its base and its unconformity with the underlying schists. Tota] thickness, 300 feet.

1. Massive gray limestone (Carboniferous)

2. Thin bedded impure limestone (Carboniferous).

3. Reddish sandstone (Potsdam).

4. Concealed.

5. Coarse redilish sandstone (Potsdam).

6. Loose bowlders (Potsdam). \%. Schists (Archrean). appear to have had no cementing material, but lie as loosely as if they had been dumped from a cart. 'This is apparently but a local accumulation; at a short distance on either side no bowlders are visible, though the underlying slates are still exposed to view.

A similar heavy,conglomerate formation is found in many other parts of the Hills, as, for instance, on the headwaters of Box Elder Creek, where a bowlder or cobblestone conglomerate with fragments two feet or more in diameter, rests upon the upturned edges of the Archæan quartzites and slates.

In some places a conglomerate is found above the base of the formation, in which the pebbles seem to have been formed from previously existing portions of the sandstone. A good example may be seen near the eastern base of Terry Peak. Near Terry Peak also Potsdam conglomerate was found so thoroughly metamorphosed that a fracture could be made as easily across the quartz pebbles and bowlders as in any other direction, the silicious cement being changed into quartzite as hard as the quartz pebbles themselves.

The cementing material of the conglomerate is generally silex, and this is reinforced by the oxide of iron. Carbonate of lime also has been found in many localities, and in such cases the interstices are more perfectly filled and the conglomerate is more compact. The calcareous cement often contains the remains of fossils and grains of glauconite. As has been observed, 
the coarser conglomerates are sometimes scarcely cemented at all, but are loose aggregations of water-worn fragments.

A description of the character of the Potsdam sandstones of the Black Hills could be made in almost the same words that have been employed by various observers in describing the Potsdam in the eastern part of the United States and in the Rocky Mountains. Thus Professor Emmons describes the Potsdam of northern New York as of two varieties:

1st. An even bedded and somewhat porous rock, at many places a distinct white friable sandstone; in others it is a yellowish-brown sandstone, the particles of which are compacted together so as to form a firm even-grained mass. 2d. A close-grained, sharp-edged mass, *** so closely wedged together that it is with difficulty quarried. It is in fact a hard quartz rock [a quartzite] scarcely passing for a sandstone.*

And again, Professor Whitney, in the Report of the Geological Survey of Wisconsin, says:

As developed in the northwest and especially in the State of Wisconsin, where it occupies a large extent of surface, it is made up of an almost chemically pure silicious sand in minute grains hardly larger than a pin's head, which are held together by the minutest possible quantily of calcareous or ferruginous cement. Frequently even this small quantity of cementing material is wanting, so that the rock can be readily crumbled between the fingers like crystallized granular sugar. Where the ferruginous material, which is the peroxide of iron, becomes more abundant, so as to form two or three per cent. of the mass, the sandstone acquires a dark brown color * * *.t

Professor Comstock in the Wind River Mountains finds the Potsdam to be a "succession of beds of loosely granular almost friable sandstone, varying in color from red or brown below to white above; in texture, from a merely loose aggregation of the silicious particles to fairly compact sandstone." $\ddagger$ The wonderful uniformity of the Potsdam will be seen by comparing these descriptions with the following.

In the Black Hills the Potsdam formation is a coarse-grained, loosely granular, often saccharoidal sandstone, composed of small grains of quartz, more or less rounded, ranging up to the size of a pin-head or small grain of rice. Sometimes it contains also small seales of mica and grains of the

* Natural History of New York. Geologr. Emmons. p. 102.

† Geological Survey of Wisconsin, 1862. Vol. 1, p. 141.

$\ddagger$ Recounaissance of Northwest Wyoming, ete. W. A. Jones, United States Engineers. p. 10\%. 
harder metamorphic rocks, but it generally consists wholly of quartz grains In texture it varies from an almost incoherent mass of silicious grains, crumbling on exposure to the weather and easily crushed in the hand, to a tolerably dense and compact sandstone, which in weathering forms cliffs. Sometimes it passes almost into a quartzite, the silicious grains being bedded in a bright glassy silicious cement. The most friable varieties are

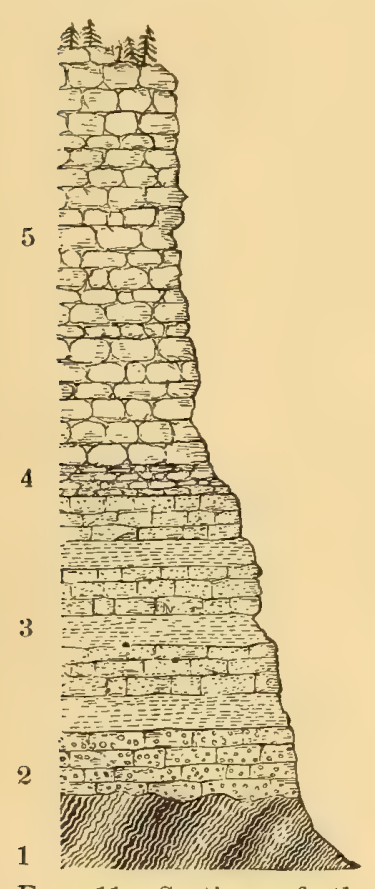

FIG. 11.-Section of the Potsdam on lower Spring Creek, with basal portions of the Carboniferous. in the perfection of the specimens the collections from better known and more thoroughly studied localities of the formation.

Complete sections of the group from base to summit are rarely met with, both because of its concealment by the broken fragments and talus of the Carboniferous above, and by reason of the soft and destructible character of its own beds. In the eastern cañon of Spring Creek, however, a most excellent section is exposed and was carefully measured by $\mathrm{Mr}$. Jenney. It is illustrated by Figure 11, in which the junction of the Potsdam with the Carboniferous and with the slates is also well exhibited. 
The strata exposed are as follows:

Archacan.

Feet.

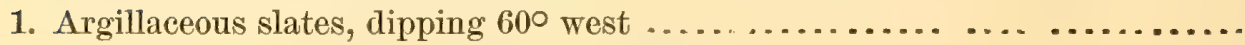

\section{Potsdam.}

2. Brownish yellow conglomerate, with quartz pebbles, resting unconformably on

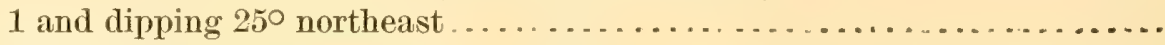

3. Reddish brown sandstone, thinly bedded at base, and alternating with soft shaly sandstones, containing large fucoids, Lingulepis, and fragments of trilobites. . . . . . . . . . . . . . . . . . . . . . . . . . . . . . . .

\section{Carboniferous.}

4. Reddish brown or pinkish, calcareous sandstone, thinly bedded, containing Spirifera camerata, cyathophylloid corals and crinoid columns ..........

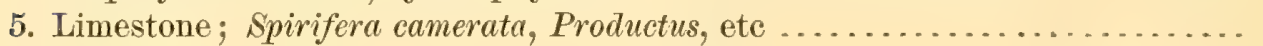

The sandstones are often riddled with small holes perpendicular to the bedding, one to three or more inches long and about one-eighth of an inch in diameter, often with rounded terminations. These are especially characteristic of the white sandstones and occur more frequently in the upper beds of the formation. Often they are so numerous that a section of the rocks resembles a piece of perforated card-board. They have been described by Professor Hall* under the name of Scolithus linearis, and were long thought to be the casts of a sea-weed. They are now generally considered the casts of worm borings, and though this explanation is more acceptable, there is still room to doubt its sufficiency. It has been suggested that they may be the peduncles of brachiopods (Lingula, etc.) or the borings of the same.

One of the most interesting points in the lithological structure of the Potsdam is the occurrence of beds of quartzite both at its base and interstratified with its sandstones. Near Warren Peaks, Crow Peak, and Terry Peak quartzites have been formed from sandstones by the direct metamorphic action of the volcanic outbursts, and in other portions of the Hills, particularly in the southern end of the Archæan area, there are quartzites at the base of the formation which may possibly be the result of metamorphism accompanying the uplift of the Hills. But in many 
places throughout the Hills beds of hard, compact quartzite are found interstratified with the ordinary soft sandstones. Some of these localities are far removed from any evident locus of igneous action, and indeed the change of particular strata into quartzite while the overlying and underlying beds of sandstone are unaffected is an occurrence which can scarcely be explained upon an igneous theory.

Near the headwaters of Red Cañon Creek in the southwestern corner of the Hills, the Potsdam with its usual soft sandstone character is underlaid by a bed of quartzite which rests upon the upturned mica schists. This is a hard, fine-grained, compact quartzite with a glassy fracture, and is seemingly composed of small grains of quartz sand, cemented by a glassy quartzose cement into a dense rock. It has a lamellar structure and breaks with some readiness parallel to the bedding. The color is a deep brownish or purplish red slightly tinted with green. The entire mass is filled with fossil remains of Lingula, Lingulepis, Obolella, etc., in a beautiful state of preservation, altogether yielding the finest collection of fossils obtained from the Potsdam in the Hills. A similar purplish quartzite was found on the headwaters of Amphibious Creek, and on the same creek near the beginning of the limestone cañon a heavy bed of grayish quartzite rests unconformably upon the schists and underlies strata of the usual coarse sandstone. On Burntwood Creek, on French Creek, and north of Battle Creek similar quartzites occupy a similar position. So hard and dense is this rock that it sometimes caps the schists over considerable spaces where the overlying more friable materials have been entirely removed. This is particularly well seen on lower Burntwood Creek. On some of the small streams north of Battle Creek it attains a thickness of about 50 feet. On Burntwood Creek it is not over 15 or 25 feet thick, and on Amphibious Creek, where it covers several adjoining hills with its hard and slippery fragments, it has a thickness of fully 50 feet. At these localities it closely simulates the quartzite of the schists and slates, but it is usually coarser in texture, betraying on close inspection the sand grains of which it is composed. Sometimes it is found to contain considerable portions of fine mica particles, but nowhere were any fossils seen in it. Its 
color is grayish or sometimes reddish. It is not a persistent stratum, but is devoloped only in the southern and southeastern parts of the Hills.

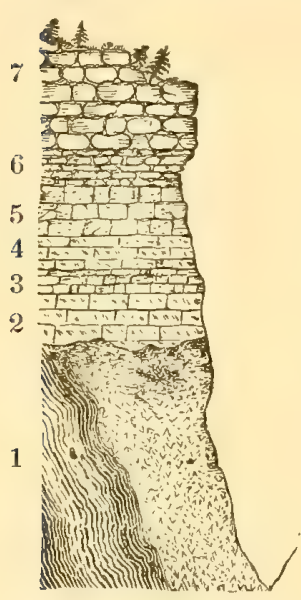

FIG. 12.-Section of Potsdam sandstone on lower French Creek, with underlying Archxan rocks.

The relation of the quartzite in the cañon of French Creek to the other members of the Potsdam and to the underlying rocks is shown in Figure 12, where the following strata are exposed.

\section{Carboniferous.}

7. White limestone.

6. Impure, pink, shaly and arenaceous limestone with crinoidal stems.

\section{Potsdam.}

5. Fine, shaly, calcareous, reddish sandstone, containing green glauconitic particles and some mica.

t. Yellowish or grayish quartzite, preserving somewhat the lines of stratification but with cracks or fractures perpendicular thereto.

3. Coarse yellowish and red sandstone with Potsdam fossils; slickensided in places.

2. Hard yellowish quartzite, with quartz pebbles. Has a vertical cleavage. Dip 30 to $5^{\circ}$ east.

\section{Archacan.}

1. Coarse, red, feldspathic granite, at top very much decomposed and changed into a soft clay, almost like a flucean; associated in other places near the creek with schists, hornblende rock, quartzites, etc., dipping to the southeast at a high angle.

At various places in the Rocky Mountains quartzites are found to occupy persistently a similar relation to the Archæan, and have been referred by various observers to the Potsdam formation. Thus on the mountain ranges of the Gallatin and Madison forks of the Missouri and elsewhere in the region of Yellowstone Lake, the Teton Range, and the Shoshone Mountains, quartzites lie unconformably on the metamorphic rocks, and are referred by Hayden, Peale, and Bradley to the Potsdam.*

They are found also in the Bighorn and in the Wind River Mountains, where Comstock describes a thick formation of compact red sandstone, and refers it to the Potsdam.t

The Wasatch Mountains exhibit a great thickness of quartzite-1,500

* Geological Survey of the Territories, 1872. pp. 25, 63, 163, etc.

t Northwest Wyoming and Yellowstone National Park. Jones, 1873, p. 107. 
feet-resting unconformably on the Archæan, and underlying Silurian and Carboniferons limestones; and this is considered by King, Hayden, and

6

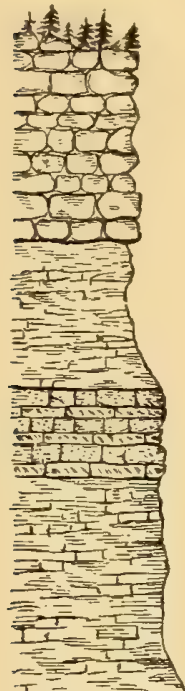

3

2

1

F1G. 13-Section of the Potsdam on Box Elder Creek.

1. Slates inclined at a high angle.

2. Coarse sandstone and gravel conglomerate.

3. Broad talus, no exposure.

4. Cliff of coarse red sandstone with interstratified layers of dense, hard, deep red or purplish quartzite.

5. Talus with fragments of the shaly impure limestone of the Carboniferous.

6. Carboniferous limestone.
Bradley to be Potsdam,* though no fossils are found in it. The Rocky Mountains of Colorado also contain in many places similar quartzites with the same relation to the older rocks. Peale has studied them in the Park range, and besides the basal quartzites here alluded to finds other beds intercalated with the sandstones he regards as Potsdam. In a continuation of the Organ Mountains, near El Paso, Tex., Jenney $\dagger$ found a quartzite 25 feet in thickness, resting upon the granite and overlaid by beds of Potsdam well characterized by fossils.

These citations suffice to show the wide-spread development in the Rocky Mountains of quartzites at the base of the Paleozoic system, and the unanimity with which they have been referred by the best authorities to the Potsdam sufficiently warrants the same reference of the basal quartzites in the southern part of the Hills.

The quartzites found in the body of the formation differ somewhat in their character from those just described. They were best observed and studied on Box Elder Creek in the section illustrated by Figure 13 .

On the same creek, some eight miles farther west, a cliff of red sandstone 30 feet in height at the top of the formation contains six or eight strata of hard, purplish, glassy quartzite from 6 inches to 1 foot in thickness.

Intercalated quartzites are also seen on French Creek where the color is yellowish brown, and the rock seems to be little more than a fine quartz

* Mining Industry, 40th Parallel Survey. King. Chap. vi. Geological Survey of the Territories,

1871. Hayden; p. 15; Ibid., 1872. Bradley. p. 194.

$\dagger$ American Journal of Seience. 3d series, vi, 1874, p. 25. 
sandstone in which the grains are bound together by a clear, glassy, quartzose cement. They occur also at other localities, but they were best studied on Box Elder Creek.

Their variations in color are the same as those of the normal sandstones of the formation. Their texture at a first glance seems very like the quartzites of the metamorphic rocks, but a closer examination reveals the same differences which distinguish the basal quartzites of the formation from the Archæan. The quartzites of the slates and schists have a very glassy and uniform fracture, and their texture is homogeneous, resembling that of quartz. The Potsdam quartzites on the other hand are found by close examination to consist of an aggregation of small quartz grains, compacted together by a glassy quartzose cement, which at the same time masks their minute structure. The grains of quartz are generally clear and transparent even in the darker colored varieties, rounded like water-worn sand, and often brilliantly lustrous like hyalite. In some instances the quartzite weathers into a coarse sandstone, readily crumbling, from which the silicious cement seems to have been removed by solution. The basal quartzites are usually more compact and durable, but even the quartzite formed at Crow Peak by the direct metamorphic influence of the heated volcanic ejection is found to decompose in a similar manner into a coarse sandstone.

An account of the minute structure of the quartzites will be found in Mr. Caswell's report. Specimens obtained from the Potsdam are indicated by the following numbers: $38,169,200,201,204,205,206,207,208,209$, z 10 , and 211.

Quartzites similarly interstratified in the Potsdam have been noticed in many places in the Rocky Mountains, but no theory has, I think, as yet been propounded for their formation. If only the basal member of the series assumed this character it would be easy to suppose that there was some metamorphic action proceeding from below-either an igneous action connected with the orographic movements by which usually the Potsdam is brought to light, or else a chemical interchange between the schists and the sandstones, whereby a silicious cement was supplied to the latter. But no such explanation will apply to the interstratified quartzites. If we suppose them to have been formed by igneous induration, even accompanied 
by heated waters, the unchanged condition of the intermediate and adjacent sandstones cannot be accounted for, and the uniformity of the quartzites in thickness and their marked separation from the associated common sandstone are equally difficult to understand. The quartzitic layers are sometimes separated by over one hundred feet of unchanged sandstone from the underlying schists, while even the basal conglomerate has not been metamorphosed in the least particular. In sections of the Potsdam, also, where the relations to the underlying schists are the same, and where there is no evidence of greater elevatory or igneous action in the one case than in the other, the sandstones of one exposure will contain numerous beds of quartzite and those of another none. Evidently some other explanation is required, and it appears to me that the true one must involve some peculiarity of the original deposition of the strata.

It is well known that many sandstones contain a considerable percentage of silica in soluble condition, which on exposure becomes insoluble and hardens them. Such sandstones when first taken from the quarry may be cut with ease but become harder on lengthened exposure and are then worked with much more difficulty. Again, scattered over the country from Maine to Georgia and westward to Nevada, are found numerous deposits of infusorial earth (composed largely of the silicious shields of diatoms) which contain from 2 to 75 per cent of silica in a form readily soluble in alkalies. The flint found so often in large beds in the Coal Measures and in masses in other formations often contains fossil diatoms composed of a soluble form of silica. Besides this, the numerous silicious deposits of springs on the Arkansas, the Yellowstone, etc., prove that silica in a soluble state is not an unfrequent ingredient in rocks, nor unusual as a present natural product. We know, too, that certain acids will throw down dissolved silica in a gelatinous state, that certain alkalies will precipitate it in the form of insoluble silicates, and that in the case of quarried sandstone soluble silica is rendered insoluble by simple exposure to the atmosphere. May not these quartzites, therefore, be the product of the cementation of sands by the simple action of waters holding silica in solution, by the admixture of the silicious portions of organisms, or in a manner similar 
to the formation of flint, at the time of their deposition as sandstone-the silica becoming afterwards insoluble?

In many places the Potsdam sandstone is found to contain calcareous

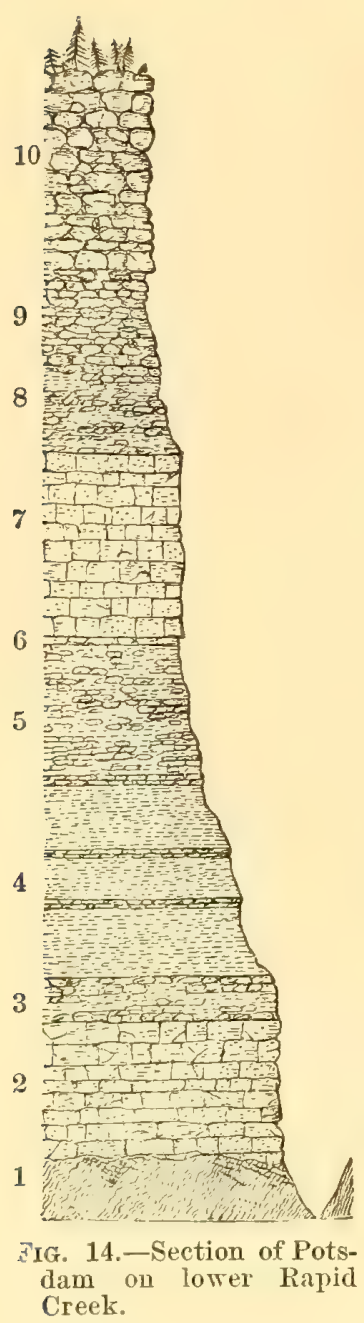
matter and also accumulations of glauconitic grains. The calcareous condition of the conglomerate at the base of the formation was frequently noticed and has already been mentioned. It is not peculiar to any horizon in the sandstones and does not persist for great distances, but seems to be a merely local variation or accident. It was observed to a slight extent on French Creek, but is more marked on lower Rapid Creek and on the headwaters of Box Elder Creek.

Figure 14 gives a section of the Potsdam in the cañon of lower Rapid Creek, where this calcareous nature is better exhibited than in any other place. It exhibits the following beds:

\section{Archwan.}

1. Argillaceous slates in the bed of the creek; strike, N.

Feot.

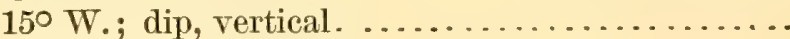

\section{Potsdam.}

2. Massive yellow and reddish sandstone, highly calcareous, dipping N. E. $20^{\circ}$...................

3. Impure shaly limestone with some clay shale, yellowish and reddish........................

4. Red and brown shale with some thin strata of limestone and large quantities of glauconite..........

5. Red and pink impure shaly limestone with green glauconite grains; sandy at bottom................

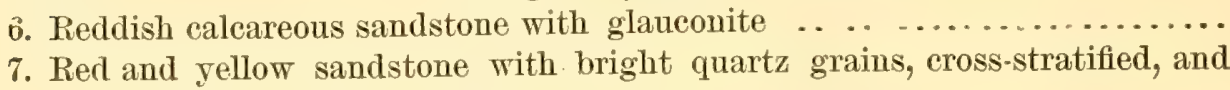
containing at base considerable calcareous matter ...............

\section{Carboniferous.}

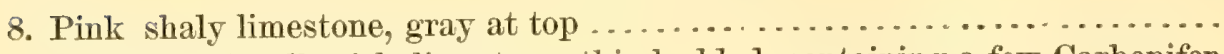

9. Pinkish and yellowish limestone, thin-bedded, containing a few Carbonifer-

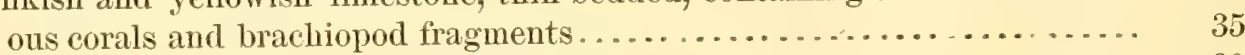

10. Gray limestone, stained at base with iron..................... 80 
The many peculiar features in the structure and variation of the Potsdam and its abundant fossils scarcely exceed in interest the discorery of its abundant greensand or glauconite grains. In almost every exposure of the sandstone where careful examinations were made the grains were found, and in some places they exist in such quantities as to give a green color to the rock. Though their presence is evidently a persistent feature of the formation, the reader who may wish to repeat our observations is referred especially to Castle Creek, to lower French Creek, and to the lower cañon of Rapid Creek. Usually the same portions of the sandstone are both glauconitic and calcareous, but the association is not invariable. Ordinarily the glauconitic sandstone is merely speckled with the green grains, but in some localities the glauconite composes the larger mass of the rock. The calcareous matter is often not evident until revealed by the touch of an acid. When the glauconitic sand-rock is treated with acids the lime matter is dissolved, and the rock readily crumbles into loose grains of sand and glauconite. The glauconitic grains are rarely over one-tenth of an inch in their larger diameters, and the majority are not more than half that size, and from this they range to almost microscopic sand. They are almost always flattened, and under a low-power magnifying glass appear as disks or flat flakes of irregular shape, round, oval, reniform, etc., but always smooth and nicely rounded as though water-worn. Their color is a dark olive green, sometimes nearly black, and when crushed the powder has a bright olive-green color. Their hardness is between 4 and 5 of the scale. Under a microscope of low power they appear perfectly regular in outline, their surfaces smooth but somewhat pitted, and their color dark olive green, but over the edges the green color is lighter. They are oqaque except on very thin edges, and there translucent or semi-translucent. They are only slightly acted upon by strong hydrochloric acid. Before the blow-pipe they fuse to a biack magnetic mass, and in salt of phosphoric lead dissolve with difficulty, learing skeletons of silica and giving in the bead the usual iron reaction. In these blow-pipe characters they resemble perfectly the greensand grains from the Cretaceous of New Jersey. The latter, however, are not so hard, and are less smooth and rounded, having botryoidal forms as though concretionary in character. 
Glauconite or greensand is a hydrous silicate of protoxide of iron and potash, with a variable amount of alumina, but "the material is mostly, if not always, a mixture, and consequently varies much in composition."**

The following analyses will indicate the composition of the mineral: 1 is from the Greensand of New Jersey; 2 from the Lower Silurian of the Island of Orleans, Canada; and 3 from the Potsdam of the Black Hills. The first two are by Dr. T. S. Hunt, the last by Dr. P. de P. Ricketts.

\begin{tabular}{|c|c|c|c|}
\hline & 1 & 2 & 3 \\
\hline Silica & 50.70 & 50.70 & 54.10 \\
\hline 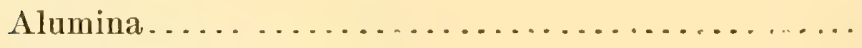 & 8.03 & 19.80 & 10.92 \\
\hline 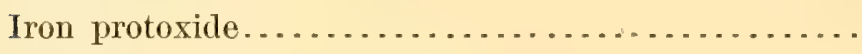 & 22.50 & 8.60 & 22.98 \\
\hline Potash ... . . . . . . & 5.80 & 8.20 & 6.75 \\
\hline 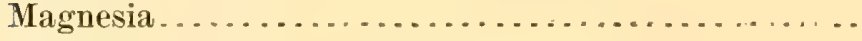 & 2.16 & 3.70 & 0.82 \\
\hline 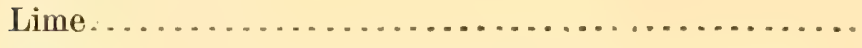 & 1.11 & - & 1.36 \\
\hline 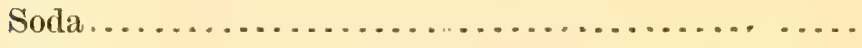 & 0.75 & 0.50 & 3.02 \\
\hline \multirow[t]{2}{*}{ 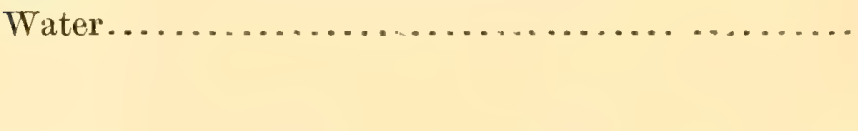 } & 8.95 & 8.50 & 0.04 \\
\hline & 100.00 & 100.00 & 99.99 \\
\hline
\end{tabular}

Greensand has been particularly observed in the Cretaceous, and certain beds of the formation sometimes contain 70 to 90 per cent. This feature of the Cretaceous is so persistent, that it has caused the application of the name "Greensand" to certain groups of strata. Such strata are widely recognized in Europe, and in the United States are well developed in New Jersey, Alabama, and Massachusetts (Gay Head). The mineral abounds also in the Tertiary rocks, is recognized in various members of the Silurian system in this country and Europe, and has been found by Bailey filling the recent shells of Polythalmia (foraminifera) from deep-sea soundings on the Atlantic coast. $\dagger$

In the Potsdam of the Rocky Mountains greensand has been found by Dr. A. C. Pealet in the middle cañon of the Madison River; and Dr. Hayden, $\S$ near the mouth of the Gallatin, finds in the Potsdam "layers of

\footnotetext{
* System of Mineralogy. Dana. p.462.

† American Journal of Science. 2, xxiv, p. 281.

$\ddagger$ Geological Survey of the Territories, 1872. p. 160 .

jIbid., p. 72.
} 
greenish sand and clay with shells and trilobites," but no particular notice is made of the occurrence.

Professor Hall* found in the Potsdam of Wisconsin, especially near the base of the formation, "extensive beds of a bright green-colored sand," and observes "that the most strongly colored portions contain few or no fossil remains." Professor Hall also recognized similar green material in collections from Texas.

In Canada the rocks of the Quebec group (Lower Silurian) are in some localities characterized by grains of a soft green mineral which closely resembles the more recent glauconites, and analyses and descriptions of glauconite from more recent formations in America are given at length by Dr. Hunt in the Report of the Canadian Geological Survey.

In the lower magnesian limestone (Canadian) of Minnesota, Dr. Owenf describes layers of a green mineral called by him a silicate of iron, an analysis of which shows its resemblance to recent greensand.

The material is so abundant in many of the geological formations that it is a matter of surprise that its source was for a long time unknown, and its mode of formation is still in doubt. To the great microscopist, Ehrenberg, belongs the credit of discovering that the grains of greensand are the casts of foraminifera. This he announced from an examination of the greensand matrix adhering to a bone of Zeuglodon from Alabama, and (in the Monatsbericht, Berlin, February, 1855) he states that "greensand, in all the numerous relations in which $I$ have as yet examined it, has been recognized as due to the filling up of organic cells." These observations were repeated by Professor Bailey, who examined also Cretaceous greensand from different parts of the United States, and he arrived at the same conclusions as Ehrenberg. Bailey also, in studying specimens of deep-sea soundings from the Atlantic coast in which "black sand, probably greensand," was found with globigerina ooze, states:§

That not only is greensand present at the above locality, but at many others, both in the Guif Stream and Gulf of Mexico, and that this greensand is often in the form

* Geological Survey of Wisconsin. James Hall. Vol. 1, p. 16.

† Geology of Camada, 186:3. P. 488.

$\ddagger$ Geologieal Survey of Wisconsin, Iowa, and Minnesota. D. D. Owen. 1.60.

$\$$ On the origin of greensand and its formation in the oceans of the present epoch. T. W. Bailey. American Joumal of Seience. $\%$, xxii, p. 280.

$7 \mathrm{BH}$ 
of well developer casts of Polythalmia, minute mollusks, and branching tubuli, and that the same variety of the petrifying material is found as in fossil casts, some being well defined greensand, others reddish, brownish, or almost white.

Bailey was the first to announce that other forms beside the Polythalmia produce greensand. Principal Dawson* calls attention to the fact that glauconite is akin to materials found filling the pores of Pre-Silurian fossils, such as the serpentine in the cells of the Eozoon of the Laurentian formation.

As to the origin of the greensand our knowledge is still deficient. Whether it is a compound secreted or formed by animal interposition, or whether it is a fossilizing mineral deposited by a purely chemical process we have no facts at present to determine.

To complete the observations on the formation, the line of its outcrop around the margin of the Archæan area will be rapidly passed over, beginning at Castle Creek where it was first seen and noting its appearance at the points where it was particularly studied. The Carboniferous limestone plateau which borders the slates on the west has been cut into by the numerous valleys of the creeks draining eastward, and each valley is a cañon with natural geological sections in its walls. The lower portions of the Carboniferous stand in cliffs and beneath them are imperfect exposures of the Potsdam and the schists. The last increase in prominence as we go eastward down the streams until beyond the serrated and broken edge of the plateau they alone are exposed.

The limestone always forms bold bluffs 100 or 200 feet in height, and sometimes stands in isolated buttes or peaks some distance in front of its main escarpment. From the base of the limestone cliff a broad and gentle slope descends toward the valleys, and the Potsdam, from its soft and friable nature, is generally concealed under a grassy slope or covered by limestone débris, so that cliffs or exposures of the sandstone are not common and a complete and good outcrop of the Potsdam is but seldom seen.

On Castle Creek the limestone lines both sides of the valley for eight miles or more in castellated bluffs, standing with their summits 500 or 600 feet above the stream. Though the valley in its lower part is deeply cut in 
the schists, but few and very imperfect exposures were seen of the Potsdain, which was usually found on the slopes only in fragments or in narrow and broken outcrops. Near the junction of Castle and Slate Creeks, however, the base of the formation was seen to be composed of 75 feet of coarse sandstone, its lower part being a coarse conglomerate of quartz pebbles, while above it for 200 feet fragments of coarse yellow or brown sandstone, sometimes calcareous and containing grains of glauconite, were seen scattered over the slope. These are succeeded by small outcrops of the shaly lower member of the Carboniferous, with crinoidal fragments, Productus, etc., and then comes the Carboniferous limestone, forming a cliff of 150 feet, the rampart of the valley. The metamorphic rocks, here cut to a depth of 150 feet by the creek, consist of micaceous, talcose, and chloritic schists, dipping $80^{\circ}$ to $85^{\circ}$ west, with a strike nearly northwest and southeast, while the sedimentary rocks above appear to be almost horizontal.

A few miles south of this point on Slate Creek the following section was observed by Mr. Jenney:

Carboniferous.

8. White, pinkish, and grayish silicious limestone, with Spirifera camerata, Pro-

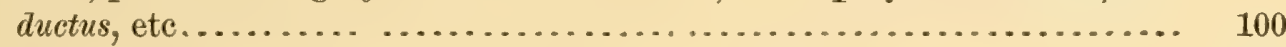

7. White compact limestone, containing the same fossils .............. 100

6. Unexposed slope..................................... 250

\section{Potsdam.}

5. Soft brown sandstone containing abundant fossils, Lingulepis, Obolella and trilo-

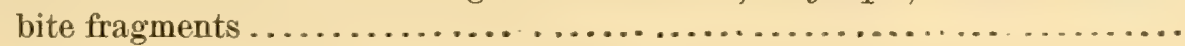

4. Coarse grained, brownish yellow sandstone, with small quartz pebbles, merg-

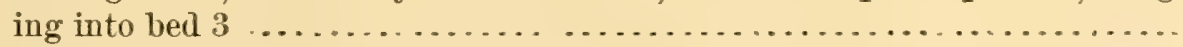

3. Conglomerate of quartz bowlders and pebbles, cemented by sand and oxide of

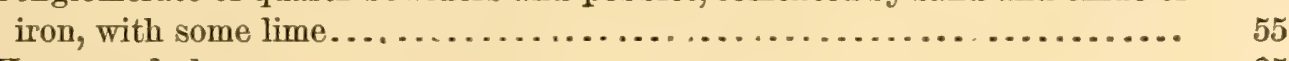

2. Unexposed slope ........................................ 35

\section{Archoean.}

1. Chloritic, talcose, and mica schists; dip, $55^{\circ}$ west; strike, north to northwest.

Some five miles southeast from this section a rounded peak, which is locally a prominent landmark, was found to contain a small but very fossil- 
iferous outcrop of the Potsdam, and to expose imperfectly the following strata:

(3) Shaly limestone, 15 feet in thickness, and full of fragments of crinoidal columns.

(2) Talus of 135 feet with imperfect outcrops of strata of red sandy conglomerate, and at base a reddish conglomerate with calcareous cement.

(1) An outcrop, 10 to 15 feet in thickness, of reddish and light colored sandstone, somewhat conglomeratic at base, containing Lingulepis, Obolella, and trilobite fragments.

From the summit of this butte the edge of the limestone plateau to the south and west can be seen for a long distance running out eastward in peninsulas and cut back westward by valleys, with occasional isolated buttes standing like sentinels along its serrated margin, while eastward is the rugged area of the slates, with now and then a grassy park, and in the distance the dark range of Harney.

Southward from these points of observation the Potsdam was not examined until it was reached between the headwaters of French and Red Cañon Creeks. The exposures are poor, being generally mere fragmentary outcrops on the slopes below the limestone cliffs. The cliff tops at the head of Red Cañon Creek are 600 feet lower than those on Castle Creek, showing a marked slope of the table toward the southwest. Levels taken at two places between approximate limits of the Potsdam gave a thickness at each of 220 feet. At the springs near the head of Red Cañon Creek a purplish quartzite was found at the base of the Potsdam resting on the schists, and from its abundant fossil remains an excellent collection of Lingulepis and Obolella was obtained.

Eastward from this point the formation was next examined in the broad prairie that lies on upper Amphibious Creek. Here the hills, capped with a cliff of 20 feet of limestone and a fragmentary outcrop of the underlying lower portions of the Carboniferous, contain along their base imperfect exposures of a brownish sandstone of the Potsdam with Lingulepis, etc. Some five or six miles down the creek, at the head of the Great Cañon, are heavy beds of the gray basal quartzite, and the slope above it is strewn 
with fragments of quartzite to within 150 feet of the capping Carboniferous limestone.

On Burntwood Creek the coarse sandstones of the Potsdam were not discovered, but the low hills near the creek are capped by a hard grayish quartzite lying unconformable upon the schists.

In the cañon of French Creek a most excellent exposure of the Potsdam is seen and the section there made has already been given. The basal quartzite is less prominent, but the formation contains an additional bed of quartzite separated from the basal by a soft coarse sandstone. The granite approaches the sedimentary rocks on Amphibious, Burntwood, French, and Battle Creeks more nearly than elsewhere in the Hills, and its proximity may bear some relation to the greater development of the basal quartzite of the Potsdam in those localities. On French Creek a granite mass abuts against the lower edge of the Potsdam quartzite for a considerable distance, and its upper two or three feet are decomposed into a soft, clayey material. With the rapid eastward dip at this place the Potsdam, from an elevation of 200 feet above the creek, sinks in three miles below its bed.

Between Battle and Whisky Creeks a peninsula of the Potsdam extends westward toward Harney Peak, consisting, so far as examined, of a hard quartzite estimated to be over 50 feet thick. With this peninsula ends the basal quartzite of the southeastern part of the Hills and on Spring Creek the Potsdam corresponds more nearly to its western development both in character and thickness. It may be well to note in this place that the best sections of the older sedimentary rocks are always exposed in the creek cañons on the east side of the Hills. The vertical cliffs of those cañons, 400 feet or more in height, are often clean walls of the composing formations.

The most interesting feature of the examination on Spring Creek was the discovery of strata covered with casts of a gigantic spreading fucoid, Palcophycus occidentalis. The rock is a shaly, argillaceous sandstone near the middle of the formation, and some of the specimens on its surface are five or six feet in length, the main stem being nearly an inch in diameter and dividing into numerous branches three-eighths of an inch in diameter. 
The stems usually divide into threes or bifurcate, and the smaller branches frequently terminate abruptly in rounded ends.

Excellent exposures of the Potsdam were found on Spring Creek, and a section of the strata there found has been given on a preceding page. On Rapid, the next creek north, the Potsdam presents some of the most interesting features observed in the Hills-the occurrence of large amounts of calcareous matter; the presence of great quantities of greensand or glauconite; and the rapid changes in character and thickness found within short distances in the cañon. A highly arenaceous series with a heavy bowlder conglomerate at the base changes in three miles to the highly calcareous series represented in Figure 14, and the section increases in thickness in the same distance fully 100 feet. The Potsdam was evidently deposited on an uneven bottom of slate, and a local sorting of its material seems to have been determined thereby. The calcite and glauconite, or the chemical and organic material, found there way into the depression, while the purely fragmental material remained in the shallower water. From the cañon of Box Elder Creek northward for ten miles the Potsdam is exposed at the base of the limestone cliffs which follow the creek. The creek valley then bends westward and the limestone cliffs run more directly northward to Bear Butte Creek. From the base of the cliffs there is usually a broad slope or talus, broken now and then by outcrops and small cliffs of the Potsdam sandstone, but rarely revealing any well-exposed section of the formation. Several outcrops of the sandstone exhibit intercalated strata of quartzite, and the thickness of the formation was found to vary from 200 to 275 feet.

The width of the Archæan area, which near Spring Creek separates the east and west outcrops of the Potsdam by more than twenty miles, has narrowed down, until near Custer Peak the outcrops on either side of the Hills are separated by only five or six miles, while some ten miles directly north from the same peak, near Black Butte, the eastern outcrop swings around and joins the exposures of the Potsdam on the western side of the Hills. In the area north and northeast of Custer Peak there are so many outlying tracts of Potsdam and even of Carboniferous strata that the imagination is but lightly taxed to restore them over the whole, and their former 
continuity cannot be doubted. The tract is so broken, cañoned, and intricate, that it was almost an impossibility to pass through it at all, except in the immediate valley of some stream, and its examination was therefore not so complete as could be desired; but the Potsdam, wherever seen, presents the same features that were observed in other parts of the Hills.

In some of the valleys in the northern end of the Hills, where such rich deposits of placer gold have been found since our exploration, the bed-rock of the stream is Potsdam sandstone. The auriferous gravels may in such cases have been derived directly from the wearing down of the schists and slates on the upper courses of the creeks, but it is more probable that they came indirectly from the same source through the medium of the Potsdam. The streams which drain the Archæan area are concentrating the gold by a method not very dissimilar from that of the Potsdam waves, and it is reasonable to suppose that dirt which has been first rocked by the waves and then sluiced by the creeks will hold its gold in a more concentrated condition than that which has had the benefit of but one process.

Near Terry Peak, where there have been great outbursts of volcanic matter, the Potsdam is changed in many places into a quartzite, and the conglomerate in some places is so metamorphosed that a fracture takes place as well through the quartz pebbles and bowlders composing it as in any other manner, the cementing matrix being changed to a rock as hard as the pebbles themselves.

The Potsdam is exhibited also in an imperfect outcrop around the base of Custer Peak, which seems to rest upon a foundation of that rock, and thence we may follow the outcrop southward to Castle Creek, where we took it up in the beginning of this narration.

In the northwest end of the Hills the Potsdam is brought to view by the volcanic uplifts at Warren and Crow Peaks. In each place its outcrop encircles the igneous mass and inclines against it at a high angle, exhibiting more or less metamorphism near the contact. About Warren Peaks its color is dark brown; in places it is a lamellar shale, and elsewhere it becomes massive and hard, while locally there were found conglomerates of brown sandstone pebbles resembling the Potsdam itself. About the middle of the formation there occurs a thick stratum of shaly, brown or 
gray, argillaceous sandstone full of fucoid impressions, and where the rock is more massive the holes of Scolithus are very abundant, fairly honeycombing it. These borings (?) are particularly numerous near the upper part of the sandstone. The base of the formation was concealed at the point of measurement, but the exposed section contains fully 350 feet. North of the peaks, at the head of the north branch of the Redwater, the Potsdam is full of the impressions of fucoids or sea-weeds, expecially near the base of the upper third of the formation. These fossil impressions are not found on merely isolated specimens, but over a large region almost every fragment of rock that may be picked up is found impressed, generally in relief, with the branching form of sea-weeds.

Even in the better studied and most fossiliferous localities of the formation fucoids occur but sparingly, and the great quantity found here and elsewhere in the Potsdam of the Black Hills indicates an abundance of vegetable life in the old Potsdam sea that has heretofore not been fully realized

Before leaving the subject of the Potsdam a few words will be devoted to the manner of its formation and the physical character of the region at the time, so far as they have been inferred from a study of the structure and relations of the rocks.

The whole character of the Potsdam rocks indicates them to be shore and shallow water deposits. The conglomerate, containing large bowlders of the Archæan rocks, could only have been produced by the immediate action of waves on a shore line, breaking against a reef or coast-wall, and rolling the fragments torn from it to and fro on the shore until they became smooth and rounded as we now find them. The sand of the sandstones is the result of the more complete trituration of the same materials by the shore waves, and being lighter and more easily moved by water currents it occupied a position some distance from the immediate shore line, but still at a nearness depending upon the size of the grains and their specific gravity, the coarser and heavier being deposited nearer and the smaller and lighter farther from the beach line. The heavy conglomerate is found only at the very base of the formation and in position nearest the axial line 
of the Archæan rocks, while the mass of the formation is uniformly a coarse sandstone, the product still of shore waves, but deposited farther from the shore. While in the base of the formation fragments may be found of nearly all of the harder rooks of the Archæan, its mass is composed of quartz grains without any admixture of other rocks.

We may thus, from a study of the Potsdam rocks and their relations, infer with a high degree of probability that at this early time the Black Hills were already marked out, and that they stood above the waves of the Potsdam shallow sea, probably as a long low reef or island. This reef was undoubtedly as long as we now find the exposure of the Archæan rocks, and may even have been of greater length, as we do not know the character of the unexposed Potsdam of the Hills.

Again, the Archæan rocks were in Potsdam time metamorphosed to nearly or quite the same extent as now; for the fragments composing the conglomerate are of the same character as the still unbroken strata of the metamorphic slates and schists. The slates were also tilted to their present high inclination, for upon their upturned surfaces the Potsdam rests unconformably, and if any tilting of the metamorphic rocks had taken place since the deposition of the Potsdam the evidence would be found in great breakings and fractures in the sedimentary rocks.

At the beginning of the Lower Silurian term we may hence imagine the Black Hills, and possibly a much more extended region, as an island ("an island" because the conglomerate is on both sides of the present axis) - a reef of schists, quartzites, slates, and granites, running northwest and southeast. Barren and desolate we may picture this island, for we know of no plants nor land animals that then had their existence. The only moving things that left their record were the waves that rolled over a broad and shallow sea and broke the silence by dashing against the primordial land. Slowly but surely they tore and undermined its cliffs and rolled away the fragments to form the conglomerates and sandstones of another age. The inequalities of the Archæan shore becanı gradually filled up, and as the sea rose higher upon the land all that was not worn away at last became entirely covered by the Potsdam sea and its sediments.

That the Potsdam stretched completely across the present area of the 
metamorphic rocks we have undoubted evidence. There is nowhere observed any thinning out of the formation as we approach the center of the Hills, but it everywhere maintains within narrow limits the same thickness.

In accounting for the origin of the sands forming the upper part of the formation, which once concealed the metamorphic rocks entirely, we start an old problem that has never yet been fully settled by geologists. What was the derivation of the mechanical deposits, covering now such wide extents of territory in the West, near which no original land surface has yet been revealed? The coarse silicious sand of the Potsdam could not have been derived from a distant shore, for it is not fine enough to be carried by ocean currents." There was undoubtedly at that time a great area of exposed land surface, much of which is now buried beneath the land or the sea, some primordial Archæa which having been worn away to form our present land surface has vanished from view. The great extent of Laurentian and Huronian rocks, stretching from Lake Superior to the Lake of the Woods and thence northwesterly to the Arctic Ocean, furnished in all probability much of the material; but for the sandstone of the Potsdam and later formation of the Rocky Mountains there must have been a land surface farther west, possibly in Pacific regions. The problem has occurred to Dr. Newberry, who says in his report to Lieutenant Ires*:

The outlines of the western part of the North American continent were approximately marked out from the earliest Paleozoic times; not simply by areas of shallower water in an almost boundless ocean, but by groups of islands and broad continental surfaces of dry land.

Since the erosion of rocks is always subaerial, or at least never takes place more than 40 feet below the ocean surface, it follows that to form the stratified rocks of only that portion of the great central plateau which borders the Colorado, an island three hunded miles in diameter and at least 6,000 feet high, or, what is more probable, a continent of six times that area and 1,000 feet high was worn down by the action of waves and rains, and in the form of sediments, sand, gravel, clay, or lime, deposited on the sea bottom.

When we reflect that, with the exception of narrow wedges of erupted material in the mountains, an area having, on the 36 th parallel, the breadth of the entire distance between the great bend of the Colorado and the Mississippi (twelve hundred miles), and a great though yet unmeasured extension north and south, is occupied by several thousand feet of Paleozoic and secondary strata, we must conclude that these sediments have not been derived from the erosion of emerged surfaces east of the Mis-

\footnotetext{
*Colorado Exploring Expedition, Lieut. J. C. Ives, 1×61, Geol. Rept., p. 47.
} 
sissippi, but were formed by the incessant action of the Pacific waves on shores that perhaps for hundreds of miles succumbed to their power, and by broad and rapid rivers which flowed trom the mountains and through the fertile valless of a primeral Atlantis.

In the sea of the Potsdam there was an abundance of life, though of a low order, huge sea-weeds and delicate brachiopod shells with trilobites of small size.

The following list gives the names of the genera and species which have been recognized or described by Professor Whitfield:

Palaochorda prima.

Palaophycus occidentalis.

Palcophycus —.

Scolithus

Lingulepis pinnaformis.

Lingulepis cuneolus.

Lingulepis perattenuatus.
Lingulepis Dakotensis

Obolus? pectenoides.

Obolella polita.

Obolella nana.

Crepicephalus centralis.

Crepicephalus planus.

SECTION $\nabla$.

THE CARBONIFEROUS.

East of the Plains the Carboniferous system is divided into two wellmarked series. The lower, known as the Sub-Carboniferous, is characterized by sandstones and limestones, the former predominating in the neighborhood of the Appalachians and the latter in the Mississippi Valley. The upper, known as the Coal Measures, is marked by alternations of sandstones and shales, with some limestone and some iron ore, and contains those stores of mineral fuel which have justly given name to the whole system. It was thought at one time that a third division had been recognized in the Mississippi Valley-a division overlying the Coal Measures and corresponding to the Permian of European chronology-but the line of separation from the Coal Measures proved so shadowy that the attempt to draw it was abandoned. The division is practically ignored at the present time, although it is not questioned that a fauna allied to the Permian fauna of Europe finds place at the top of the series and is gradually merged with the Coal Measure fauna below. 
In the Rocky Mountain region the Carboniferous is the most persistent and important of the Paleozoie formations. It is found in almost every great section and is everywhere identified by fossils. Its characteristic rocks are limestone and sandstone, and are so durable that in the progress of degradation they have been laid bare over large areas. Nevertheless the subdivisions known at the East have here received no general recognition. The prevailing fossils are of Coal Measure types, but with these are nearly always mingled Sub-Carboniferous forms, and it is but rarely that any distinctive Sub-Carboniferous strata have been recognized A Permian has been separated by King in the Uinta Mountains, by Peale in Colorado, and by other observers far at the south, but in many localities Coal Measure fossils seem to extend to the top of the system.

In the Black Hills we have established no subdivisions on paleontological grounds, and are unable to affirm or deny the presence either of Sub Carboniferous or of Permian. The rock series is definitely and continuously divided into several members, but the lowest and the highest of these members alike failed to afford us distinctive fossils. It is to be anticipated that future investigations will correlate them at least with the several members of the system as known in the neighboring portions of the Rocky Mountains, but for the present they can only be designated as Carboniferous.

The local subdivisions are four in number, and they are distinguished purely by lithological characters. Beginning with the lowest, they are as follows:

1. Shaly limestone.-Thinly bedded, impure, arenaceous limestone, pinkish in color, often filled with comminuted fragments of crinoidal columns; contains also Productus, cyathophylloid corals, ete .............. . .

2. Gray limestone.-Massive gray or whitish limestone, uniformly pure, containing Spirifera Rocky-montana, Productus, ete.................

3. Silicious limestone.-Weathering usually in a peculiar brecciated manner; somewhat cavernous and often stained with pinkish and reddish streaks; containing much flinty and silicious matter, often with a banded structure; with crystals of calcite lining the interior of weathered crevices or cavities. Fossils are found, but usually ill preserved and only exposed and obtainable when the rock is much weathered. There have been recognized Athyris subtilita, Spirifera Rocky-montana, Productus; corals, ete 
4. The Alternating Series.-A series of alternating beds of pink and light colored sandstones and limestones somewhat argillaceous; the limestones apparently somewhat magnesian and poor in fossils ..........

These pass upward into a variegated sandstone, irregularly stained reddish, yellowish, and white; somewhat argillaceous and calcareous and exhibiting little stratification; weathering in peculiar twisted, contorted (eurly) bands

Wherever the Potsdam sandstone and lower Carboniferous series are together visible they are absolutely conformable, and the distinction between the rocks of the two systems is often so perfectly marked that the blade of a penknife may be inserted at their line of separation. Passing upward from the coarse brown sandstones of the Potsdam, with Lingulepis, Obolella, etc., one first meets the thinly bedded pinkish limestones of the base of the Carboniferous with fossil forms characteristic of that formation, so that both lithologically and paleontologically the separation between the Potsdam and the Carboniferous is always distinct and easily traceable. This lowest member of the Carboniferous weathers easily and is not generally well exposed, though the separation between it and the heavy limestones above is very distinct where observable. It has a pinkish or grayish color, is never a pure limestone, and commonly has an argillaceous appearance. Its strata rarely exceed eight or ten inches in thickness, and it is often so thinly bedded as to resemble a calcareous shale. Though it is commonly very fossiliferous, specimens sufficiently well preserved for specific identification were not obtained. The genera Zaphrentis, Spirifera, and Productus were recognized.

The second member, the massive gray limestone, and the third, the silicious limestone, are the most persistent features of the formation in the Hills. They are well seen in nearly all parts of the country examined; in the western plateau, on the southern border, and on the eastern slope. Along the eastern edge of the plateau, however, there are considerable areas from which the silicious limestone and part of the gray have disappeared by denudation; and for this reason one who enters the Hills by crossing the plateau from the west obtains but a very inadequate idea of the true magnitude and thickness of the Carbonifeious formation. Complete and continuous sections of the Carboniferous are found only in the 
cañons cut by the various streams as they pass from the Hills to the Plains, where by the gradual dip of the strata one member after another is carried down and out of sight; and even in the cañons it was not always possible to study them closely in detail.

The gray limestone immediately overlies the thin-bedded pink limestones, and according to many measurements taken in different parts of the Hills has a thickness of 150 to 200 feet. It is a very uniform, pure limestone, and one of the most prominent members of the Carboniferous series. It is well exposed in every examined section of the Carboniferous rocks. Its fossils are numerous, but are not readily separable from the matrix except where the rock has been so greatly weathered as to destroy their surface markings. What few species were recognized appear to be equally characteristic of the overlying silicious limestone.

The silicious limestone is a hard, white or grayish, gritty rock, which, from the oxidation of its iron and perhaps also by percolation from the overlying rocks, is generally stained irregularly red or pinkish. It contains much silicious matter concentrated in spots, either as flint, or as crystalline quartz lining small cavities, or in concretionary or agate-like deposits. From its silicious and uneven composition it decomposes very irregularly, often having a brecciated appearance and weathering with cavities or crevices, and even with caverns of considerable extent. The cavities are usually lined with crystals of calcite.

The most abundant fossils in the two limestones are Spirifera Rockymontana, Athyris subtilita, Productus, Euomphalus, and Streptorhynchus.

While the lower members of the formation are well marked, easily traced, and readily distinguished from each other and from the underlying Potsdam, the study of the upper portions was attended with no little embarrassment. In the absence of any paleontological assistance of value, the upper limits of the formation had to be drawn from the lithological nature of the deposits. While the conclusion here reached is open to question and is liable to be set aside whenever fossils are brought to bear on the problem, I am strongly disposed to think that none of the beds here included in the Carboniferous will ever be relegated to the Trias.

Immediately overlying and conforming to the silicious limestone are 
the following beds: first, a series of thinly bedded sandstones and impure limestones, the latter somewhat magnesian, varying in color-pink, white, yellow, and gray; the limestones containing only traces of fossil remains. These have altogether a thickness of 150 to 200 feet, and pass gradually into (second) a sandstone somewhat argillaceous and calcareous, of a deep red color, but often streaked or variegated with yellow or pink Frequently on fracture the sandstone has a somewhat lighter color or is almost white; and while much of the predominating deep coloration is derived from the oxidation of iron in the rock itself, a considerable portion is also produced through staining by a downward infiltration from the red clay above. It generally shows little or no stratification and is massive, but it weathers in a brecciated or broken manner, with twisted or bent lines of decomposition parallel with the general stratification of the rocks. It has a thickness of 100 to 150 feet, making the entire thickness of the upper or fourth member of the Carboniferous 250 to 350 feet. Detailed and accurate sections of these rocks are given on another page.

Within the area of the plateau no good exposures of the upper beds were seen, but along its western edge they appear in a few cañons that drain westward, especially in those connecting with Beaver Creek. They are also excellently exhibited in Fanny Peak, which is composed of the serrated and broken edges of the red sandstones standing vertically.

In the southern end of the Hills in the cañons of Red Cañon and Amphibious Creeks the silicious limestone (3) is overlaid by over 200 feet (estimated) of red and pink sandstones, which are somewhat calcareous and contain occasional beds of limestone. Similar beds at the springs on Minne Katta Creek have a measured thickness of 300 feet. At the latter place a few fragments of crinoid stems were found in some of the limestones.

On the eastern side of the Hills, especially in the cañons of Rapid and Box Elder Creeks, where most excellent sections of the entire series are visible, these upper beds were studied with great care. They are there more calcareous than on Amphibious Creek and consist of an alternation of pink and red sandstones and limestones, an accurate measurement of which is given on a subsequent page. On Box Elder Creek a few fossils were found in the limestones about 115 feet above the base of the alternat- 
ing series, and above this fossiliferous stratum the same series continues for over 200 feet. The fossils, mere fragments, are indeterminable; but among them are minute gasteropods and small Spirifer-like shells.

Above the alternating series, and therefore, according to our classification, above the Carboniferous, there follow in ascending order, first, 75 to 100 feet of red arenaceous clay; second, 15 to 30 feet of purplish impure limestone; and, third, 200 to 250 feet of red clay with gypsum. The arenaceous tendency of the lower clay allies it to the sandstone at the top of the alternating series and makes it difficult to draw the line of separation even here; but, all things considered, the division is more easily made at this point than elsewhere. Limestone and sandstone are the characteristic rocks of the Carboniferous throughout the northwest region; and regarding only lithological evidence, it seems proper to make the separation where the sandstone and limestone cease and the clay begins. Nevertheless in Southern Colorado the Carboniferous is known to include in its upper part large deposits of gypsum and associated beds of a deep red color, and the same thing may possibly occur in the Black Hills.

In 1857 Dr. Hayden found a few fragments of fossils in the Hills which he recognized as identical with forms from western Kansas, which had been studied by Mr. Meek and himself and referred to the Permian. The rock in which they were found was a bowlder and the material was not seen in place, but the indication that the Permian is contained in the Black Hills section may furnish a cue by suggesting a comparison of the doubtful beds with the nearest rocks for which the title Permian has been claimed.

Dr. Peale has examined in Colorado, on the Grand River, etc., certain strata between the Coal Measures and Triassic which Professor Lesquereux decided from certain fossil plants found therein to be of Permian age. Dr. Peale describes the series in words that will apply almost as well to the lower part of the alternating series of the Black Hills, viz, "variegated strata, yellow, pink, and cream colored shales and limestones, subject to so much change that it was impossible to make any continuous section." Similar thin-bedded deposits are also described by him in his report for 1873, and he has regarded these also as of Permian age. 
Though the beds in Nebraska that were referred by Mr. Meek to the Permian are now considered by him as of upper Coal Measure age, it may be well to consider their character in this connection. The Sub-Carboniferous in all the Missouri region consists of massive limestone deposits, while the upper portions of the Carboniferous, the upper Coal Measures, are composed of more or less thin bedded, alternating deposits of shale, limestones, sandstones, bituminous shales, and, as far west as eastern Nebraska, thin coals. Such deposits are called "oscillatory," as indicating unsteady and repeated changes in the circumstances of their formation. The alternating series of the Hills differs conspicuously in the character of its component beds, but corresponds in the matter of oscillation.

With the very fragmentary and unsatisfactory evidence that is here brought to bear upon the question of the relation of these upper beds of the Carboniferous, we can arrive at no more definite conclusion than to say that they are with little doubt Carboniferous; that they are probably upper Carboniferous, and that they may possibly by future investigation be established as Permian.

In the position I have assigned to the upper limit of the Carboniferous I differ somewhat from Professor Winchell and Dr. Hayden. The former places it higher, including the purple limestone which interrupts the red clays, and the latter places it below the alternating series.

When Dr. Hayden visited the Hills in 1857, he labored under the disadvantage that always pertains to a rapid reconnaissance, and to this we must lay his low estimate of the dimensions of the Carboniferous. His error in this regard was very natural, as the portion of the formation traversed by him is greatly thinned by denudation. He divided the Carboniferous into two portions, as follows: "G. Hard, more or less gritty, yellowish and whiteish limestone, containing Productus, Spirifera, Euomphalus, etc., passing down into a light yellowish calcareous grit, altogether 50 feet;" and, passing downward, "H. Very hard, reddish-gray limestone, containing Syringopora, Productus, Terebratula, etc., * * * 50 feet."*

His " $G$ " is our No. 3; his " $H$ " is our No. 2; our smallest measurement gave them a total of 300 feet. The sandstones, etc., which we have

\footnotetext{
* Traus. Am. Phil. Soc, 186\%. Geology of the Upper Missouri, Hayden.
} $8 \mathrm{~B}$ H 
included as the upper member of the Carboniferous, together with the red arenaceous clay underlying the limestone of the Red Beds were placed by him in the Red Bed series, their thickness being given as 250 to 300 feet.

Professor Winchell, despite the rapidity of his passage through the Hills (he was in the region less than four weeks), was enabled to make some interesting observations on the geology. The route by which he entered them was not, however, a favorable one for geological purposes, and several of the records and observations made by him are now susceptible of a different interpretation. He includes in the Carboniferous two elements which are here placed in the Red Bed series: first the purple limestone, and second the lower red clay, which is not separated by him from the underlying variegated sandstone. - This sandstone, the upper part of our fourth member of the Carboniferous, is called by him the "Minne Lusa" sandstone, while the underlying sandstones and limestones, 150 to 200 feet in thickness, do not appear to have been separated by him. Excluding the beds that are here placed in the Red Beds, the Carboniferous, as estimated by Professor Winchell, has a thickness of about 300 feet, while the measurements we were enabled to make give the thickness as ranging from 570 to over 700 feet.*

The character and development of the Carboniferous have had a controlling influence in the production of some of the most prominent topographical features in the Hills. Though limestone is soluble to a certain extent by ordinary water, it is still one of the most durable of the sedimentary rocks The Carboniferous limestone is not only durable but thick, and its influence on the topography is heightened by the softness and incoherence of the overlying sandstones and clays. The latter have yielded to the action of the elements and disappeared from all the high places and by so doing have laid bare the limestone. The limestone stubbornly resists, and yields only as it is undermined by the disintegration of the shaly and arenaceous beds at its base. It survives over half of the flat-topped uplift which constitutes the Hills, forming a great plateau, and surrounds the other half in a continuous belt of cliffs.

* One of the most serious of Winchell's errors was the announcement of an unconformity between the purplo linestome and the gypsiferous c?ay. If that unconformity really existed his separation of

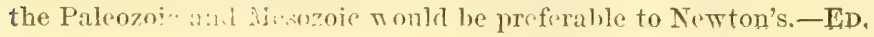


The form of the plateau can be seen by referring to either of the two maps of the Atlas. In the topographical map it appears as a topographical feature; in the geological it is marked as the great body of the Carboniferous exposure. It attains its high elevation by a gradual slope from the west, from the north, and from the south, while its eastern margin, overlooking the area of the slates, is a more or less bold escarpment or cliff, broken and serrated, however, by the penetration of valleys and streams. It has a width east and west of from fifteen to twenty miles, and a length north and south of sixty miles, covering altogether between nine hundred and one thousand square miles, or about one-sixth of the total area of the Hills. Its surface is generally smooth or gently undulating, but is sharply cut by the draining streams which traverse it in deep and steepsided cañons. Considered in its total mass it is the greatest elevation of the Hills, and it bears upon its broad back a crag which is second to but one other summit in height. Crook Tower has an altitude above the sea of 7,320 feet, and is only 80 feet lower than Harney Peak, while it overtops Terry Peak, the next in elevation, by fully 100 feet. It rises only about 200 feet above the level of the adjacent portions of the plateau.

Approaching from the west, at the headwaters of Beaver Creek, one ascends from the Red Bed Valley (5,300 feet) by a slope of the Red Beds, more or less gradual, to the general level of the plateau, here about 7,000 feet high. This general level, varied only by undulation, extends thence eastward to the margin of the plateau which overlooks the area of the slates.

From the base of Crook Tower (7,100 feet) the surface of the mesa spreads southward to the region west of Castle Creek and the headwaters of Spring Creek with a level varying little from 7,000 feet. From the headwaters of French Creek, however, there is a visible descent of the plateau toward the south and southwest. Near the head of Red Cañon Creek the elevation is about 6,000 feet, and at the southwest the mesa soon ends by the descent of the limestone.

Northward and northwestward from Crook Tower the Carboniferous rocks extend to the valley of the Redwater in much the same manner as they spread and disappear southward, except that the plateau character of 
the surface has been destroyed by the numerous forks and branches of Inyan Kara, Redwater, and Spearfish Creeks, which have cut cañons in all directions often to the depth of several hundred feet. Still a considerable share of the original surface survives, and it is easy to construct from the many tongues and spurs that remain a clear idea of the original form. If one views it from a station a little elevated above it, he sees clearly the plateau character, but may fail to comprehend how great a task lies before him should he attempt to force a passage across it.

The exposures of the Carboniferous on the eastern margin of the uplift are comparatively small in extent, and consist entirely of rocks dipping rapidly to the east. They constitute a monoclinal ridge curving about the edge of the Archæan. The creeks which drain the Archæan flow to the north, east, and south, and cut through this rim of Carboniferous rocks in cañons whose length depends on the rate of dip of the strata.

In the Bear Lodge range the Carboniferous has been tilted and raised to view, along with the other strata, by the elevation that accompanied the volcanic outbursts of Warren Peaks. The outcrop is not large and the strata composing it hardly differ from those in the main portion of the Hills save in a slight amount of metamorphism due to the volcanism Their dip is outward from the peaks in all directions, but most strongly towards the northwest.

The details of the geological structure of the Carboniferous mesa north of Crook Tower were not studied with much care for lack of the time necessary to penetrate its labyrinth of cañons. The dip of the rocks where they curve down from the table toward the Red Valley is more gradual than at the south and southwest of Castle Creek. Crossing it in a northwest direction we found the surface slope, cañons excepted, rarely greater than $6^{\circ}$ or $8^{\circ}$; and from well-marked Carboniferous rocks one passes almost imperceptibly to the Red Bed limestone, which continues the slope more steeply until it dips under the mass of red clays underlying the great Red Bed valley that sweeps around the northwestern end of the Hills. Because of the gentleness of this slope and the ready manner in which the upper Carboniferous arenaceous strata decompose and form a soil, but little is seen of them in passing over the slopes, though excellent exposures 
are to be found in the deeper of the cañons. On Inyan Kara Creek, and especially on Redwater Creek and Heron Creek, they are readily examined The accompanying ideal section, running from the Red Valley near Inyan Kara eastward across the plateau to Custer Peak, a distance of thirty miles, though only approximate in its details, will give a tolerably correct idea of the structure of the mesa at this point.

Nearly the whole of the northern part of the plateau bears at the surface either the silicious or the gray limestone (Nos. 2 and 3 of the general section), and of the two the gray limestone is more prominently exposed. Crook Tower consists probably of the gray limestone with a capping of the silicious, and fragments brought from its body are filled with Spirifera Rocky-montana. Considerable portions of the limestones have been removed by erosion from the surface of the plateau and a greater amount at the east than at the west. "The silicious limestone rarely appears in the cliff at the east, and never with its full thickness, and there are considerable areas covered by the gray limestone exclusively. Opportunities for the full measurement of either member are rare and are confined to the deep cañonsespecially to the cañons of streams running eastward. The upper valleys of Inyan Kara and Redwater Creeks, running from south to north, are not of very great depth, and the edges of the bordering rocks are

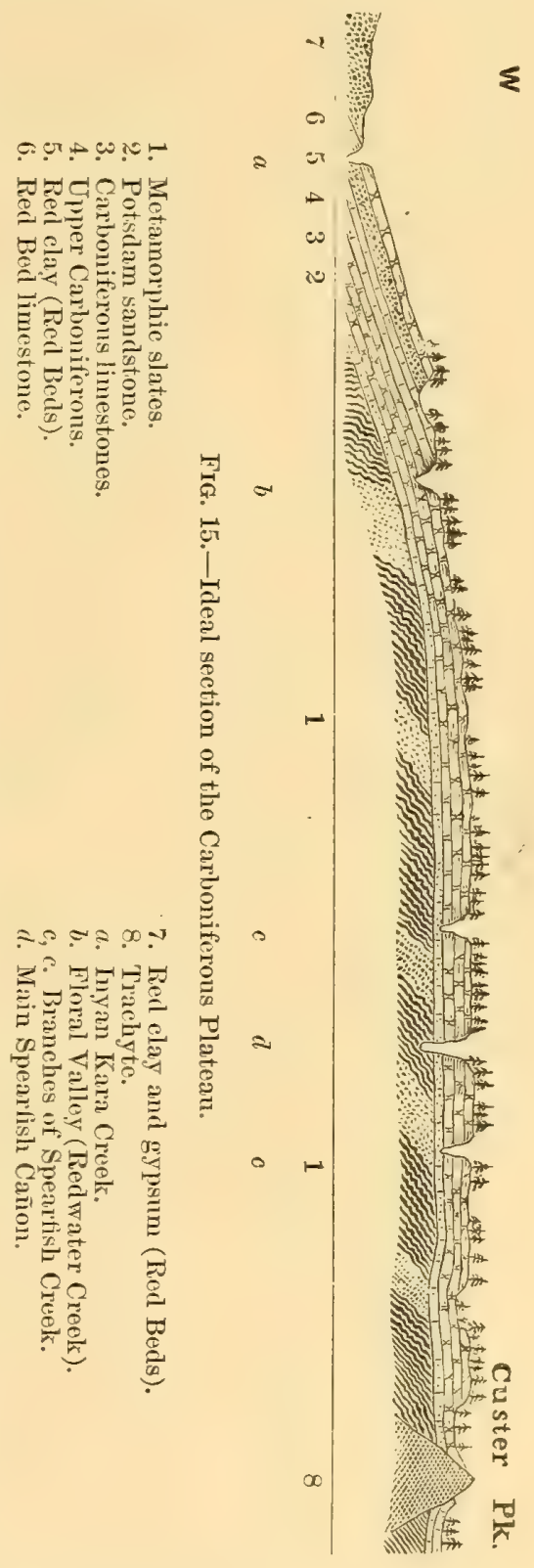
commonly in whole or part hidden in their sloping soil-covered sides. On the eastern side of the plateau, however, the northward flowing Spear- 
fish has cut a cañon from 300 to 600 feet deep, often penetrating into and below the underlying Potsdam. Frequent exposures of the variegated sandstones of the upper member of the Carboniferous are seen in the western valleys, where it is a prominent feature, but the intermediate series of alternating sandstones and limestones were not observed. It is not considered that they are here absent, but merely that their outcrop is locally concealed; for they are found farther north on lower Redwater Creek, farther south in some of the cañons running into Beaver Creek, and on the eastern hog-back wherever the Carboniferous was carefully examined.

The eastern margin of the plateau where it overlooks the country around Custer and Terry Peaks has much the same character as farther south, but it is flanked by more numerous outliers or mesas of Carboniferous and Potsdam. Northeast of Terry Peak, on the ridges between the creeks, a series of mesas extends across the slate area.

The plateau south of Crook Tower, so far as examined, is less cut by the cañons of draining streams. From an elevation near Castle Creek of 7,000 feet or a little more it dips off to the south and southwest, until at the head of Red Cañon Creek it is 1,000 feet lower, and thence its surface soon joins the Red Valley on the south. The extreme southern end was passed over by some members of the escort, who reported its surface as deeply scored by the cañons of streams draining into Beaver Creek and the Cheyenne, in which character it resembles the extreme northern end of the plateau. Along the eastern margin of the table near Castle Creek there is a small southward dip and it increases toward the southern end. There is also a general dip to the westward, and this, while barely discernible on the eastern side, increases rapidly toward the west and southwest, until at last the Carboniferous rocks dip steeply under the Red Valley.

At the western margin of the plateau near Camp Jenney, and for some distance along the east fork of the Beaver, there is a remarkable and exceptional dip, which is exceeded only in the rocks immediately surrounding some of the volcanic peaks at the north. It is illustrated in the accompanying section, running from the Red Valley at Camp Jenney eastward. across the mesa to the headwaters of French Creek. 
It is impossible on the scale of the section to illustrate accurately this sudden dip, but it is sufficiently well shown to indicate the main features of the uplift. The upturned edges of the variegated sandstone forming the peaks $(c)$ are broken and rugged, and with their brilliant red color are conspicuous features as seen from the west.

Another fact worthy of notice is illustrated by the section. It is observable almost everywhere on the slopes of the Hills, but more strikingly here, that in regions of elevation the inclining strata do not make their entire ascent in one continuous dip, but rise from their nearly horizontal position to their highest elevation by steps or waves, between which there may be considerable intervals with little or no inclination. This feature is not peculiar to the Hills, but has been observed in many regions the geology of which has been accurately studied. It is characteristic of the district of the Colorado plateaus, and is well exhibited in the Coal Measures in portions of the Alleghany Coal Field.

The basal member of the Carboniferous is shown at various places along the eastern margin of the southern portion of the plateau, and is distinguished by the great quantity of fragments of crinoidal columns it contains. The gray and silicious limestones, just as at the north, are the surface rocks of the top of the plateau. The alternating limestones and sand-

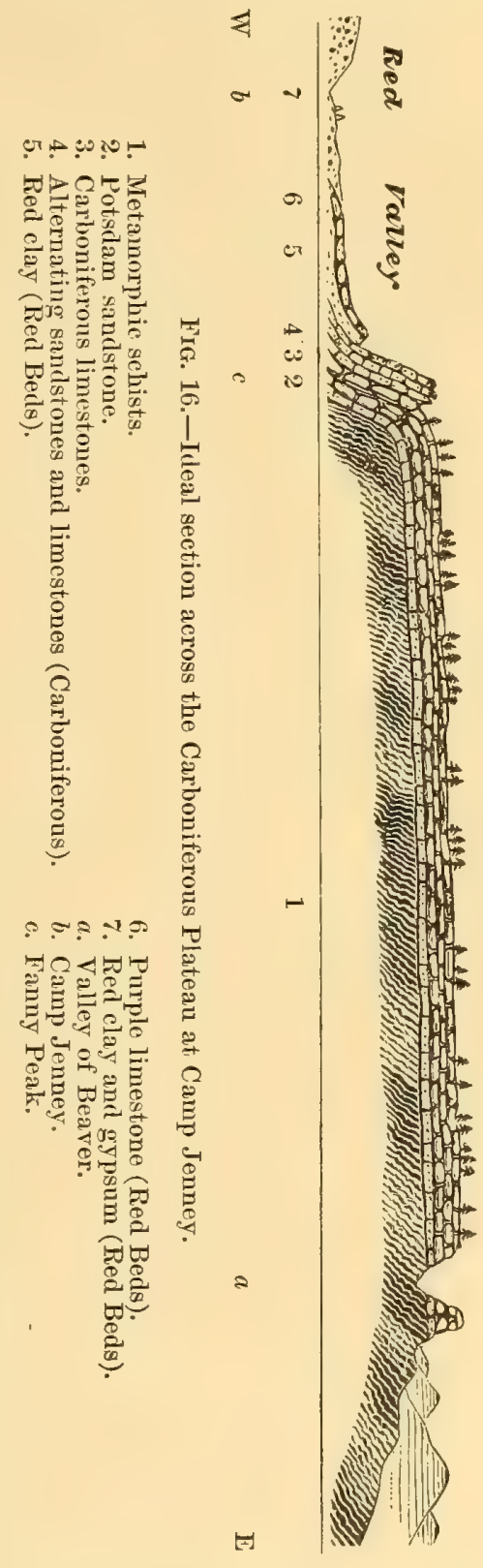
stones are well exposed in cañons across the western edge, and especially in the vicinity of Fanny Peak, where a number of dry branches of Beaver Creek score the slope of the plateau. 
On a small branch of Castle Creek a section of the eastern cliff was obtained, as follows:

6. Limestone; highly silicious, with no distinct stratification, but breaking irregularly; cavities with much calcedony; color white, with pink and red blotches . . . . . . . . . . . . . . . . . . . . . . . . . . . . . . . . . . . .

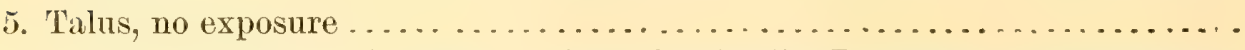

4. Limestone, white and compact, with a few fossils, Productus, a Bryozoan, ete.

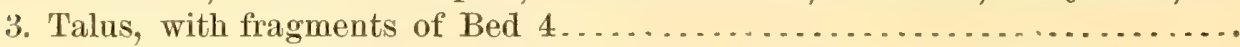

2. Limestone, white and compact like 4, with Chonetes, Zaphrentis, etc.......

1. Talus to creek, with the Potsdam indicated by a series of springs flowing

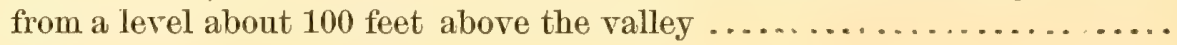

Several miles farther down Castle Creek, which is lined with an escarpment of limestone cliffs that render its name very appropriate, a measurement showed the silicious limestone to be 150 feet thick, standing in a steep bluff, with its top 750 feet above the bed of the creek. It is separated by a slight talus from a cliff of 100 feet of the white limestone, and from the base of this, evidently concealing a portion of the limestone, a slope extends down 400 feet to the schists, which occupy the lower 100 feet of the sides of the valley. About 75 feet of coarse Potsdam sandstone rest on the slates, and fragments of Potsdam were found on the slope for 200 feet higher, above which are numerous pieces of the purple shaly limestone (1) and rocks from the cliffs above.

From Castle Creek southward to Red Cañon Creek the Carboniferous beds 2 and 3 are continuously seen lining the western border of the schist area. Red Cañon Creek runs in a valley a mile or two in width, and for about four miles is bordered by cliffs with the limestones above and the Potsdam below. The increasing dip then brings the limestones in succession down to the stream level and after them the alternating beds, and through the latter the creek runs in a cañon to Red Valley. The creek makes its escape through the southeastern corner of the mesa, and is the most southerly of the fifteen streams that carry the drainage of the Archæan district across the encircling belt of Carboniferous.

At this point the plateau may be said to end and the monoclinal ridge to begin. The ridge runs at first eastward and dips to the sonth; it then turns toward the north and its dip becomes easterly; and finally to 
rejoin the plateau it curves to the northwest and its dip becomes northeasterly. Everywhere on the convex side of the curve it slopes down to Red Valley. Everywhere on the concave side it presents a cliff face toward the district of the slates and schists. In the following pages the local details of the ridge and of the cañons which intersect it will be described.

Minne Katta Creek issues from several large springs at the base of a cliff composed mainly of the upper series of the Carboniferous. A general section of the cliff by Mr. Patrick is given below, beginning with the capping Red Bed limestone:

\section{Red Beds.}

9. Purple limestone . . . . ........................... Feet.

8. Red clay; in places a soft, red saudstone ..................... 140

\section{Carboniferous.}

7. A series of colored sandstones, red, yellow, pink, etc., with calcareous layers and limestone......................................... 285

6. A layer of black, sandy, carbonaceous shale... . . . . . . . . . . . . Thin.

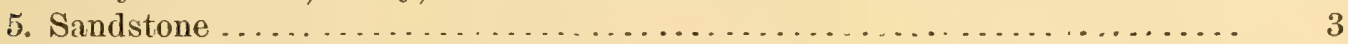

4. A layer of black, sandy, carbonaceous shale.................... 1

3. Sandstones, red and yellow ............................... 25

2. Silicious and argillaceous limestone, with nodules of flint ... . to bed of creek 20

1. Limestone, silicions, weathering irregularly, cavernous; outeropping just at the level of the creek; probably the silicious limestone, No. 3 of the Carbonif-

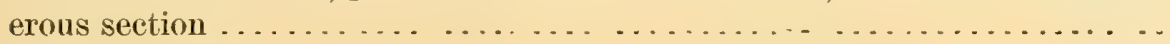

- The series 7 of the above section exhibits in a high degree the peculiar brecciated, wavy manner of weathering characteristic of the upper sandstone of the Carboniferous.

Near the head of Amphibious Creek the north-facing bluffs of the Carboniferous limestone were seen capping an escarpment from 250 to 350 feet in height, and preserving in thickness and character the features of the Carboniferous as observed near Red Cañon Creek. The accompanying section, Figure 17, was observed along the cañon of the creek from its entry into the sedimentary rocks to its exit in the Red Beds, a distance of about nine or ten miles, the larger portion of which is through the Carboniferous limestones and the red arenaceous beds of the upper Carboniferous. From the rapidity of our march and the rugged character of the cañon, it 
is necessarily incomplete and wanting in absolute accuracy, but it is believed to present the character and thickness of the Carboniferous strata with a

2

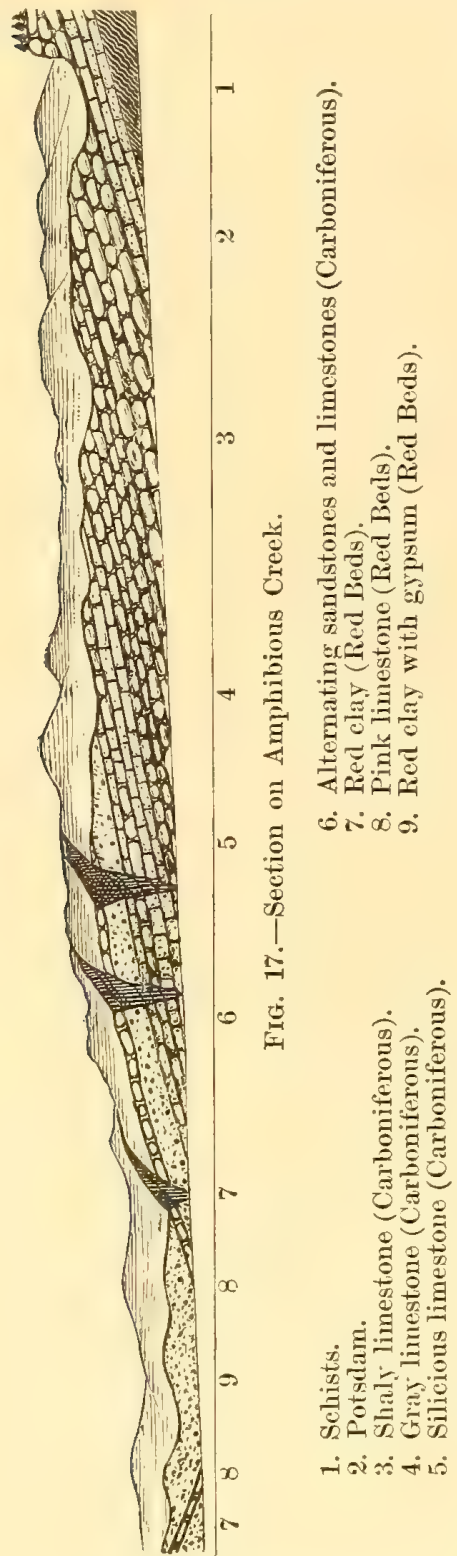

fair amount of exactness. The exposures of the Potsdam were not sufficiently perfect for measurement.

\section{Carboniferous.}

1. Limestone, pink, impure and silicious, containing fragments of crinoid stems (No. 1) .....................

2. Limestone, white or gras (No. 2) ......... 180

3. Limestone, silicious, containing much flint and colored silicious matter; has a brecciated appearance (No. 3) .............

Feet.

4. Alternating limestones and calcareous sandstones; yellow, reddish, white, and pink; near the base a marked stratum of deep red, calcareous sandstone 10 feet thick; the top beds a deep red sandstone, with much lime in nodules or concretions (lower part of No. 4).... . estimated..

5. Variegated sandstone, distinctly banded in strata of different colors, red, yellow, and white (upper part of No. 4)...........

Red Beds.

6. Red clay, with some soft, red sandstone... .

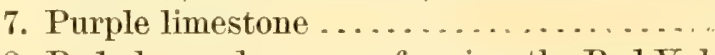

8. Red clay and gypsum forming the Red Valley

In obtaining the above section, series of partial measurements were made as follows: Having measured the first section the cañon was followed down until the capping bed of the section was seen to reach the creek, when another section was made, and so on through the cañon.

The limestones were not found at any place to be fossiliferous, but the different beds correspond elosely in their lithological characters with the Carboniferous as described in other parts of the Hills. No. 5 of the local 
section is, however, more silicious in character than the same division on the east side of the Hills, and its thickness also appears here considerably greater than elsewhere.

Between the cañons which divide the monoclinal ridge good points for studying the strata are not often met with, for they dip regularly from the axis of the Hills, and the surface forms an undulating slope on which the component strata are inseparable.

On Burntwood Creek, which has nowhere cut the older sedimentary rocks very abruptly, the Carboniferous is poorly exposed, but on French Creek, the next in order, although the belt of Carboniferous is narrowed, fair exposures are exhibited. A section showing the junction of the Potsdam and Carboniferous and a bluff of the white limestone has already been given on page 90. A short distance below the place of this section the dip increases, and the rocks are carried down to the bed of the stream near the point of its sinking. Within a short space the various members of the Carboniferous are exhibited in the walls of the cañon. They are all readily recognized and distinguished, but their exposures are not well placed for measurement. Above them in irregular order follow the members of the Red Bed series.

In the cañons of Battle and Whisky Creeks the Carboniferous limestones are well exposed, and in the cañon of Spring Creek a most excellent section is cut through the series for a considerable distance, as also on Rapid Creek. The limestone strata of the gray and silicious divisions are exposed on Spring Creek in a cliff 335 feet in height, and beneath them are 20 feet of pink calcareous sandstones, which rest conformable upon the Potsdam sandstones below. The pinkish, lamellar limestones, or calcareous sandstones contain the usual abundance of crinoidal fragments, with cyathophylloid corals, a Spirifera like S. Rocky-montana, and a Productus. The Carboniferous belt is here about four miles in width, and-a feature common to most of the creeks of the Hills-the water sinks at a point near where the massive limestones dip under the creek bed.

The peculiarity of the sinking of the creeks of the Hills is worthy of remark, for as a rule all the numerous creeks that rise in and flow from the Hills sink before reaching the Plains. There are but four exceptions- 
Minne Kaita, Rapid, Spearfish, and Redwater. Some of the streams rise again at intervals on the Plains, but none of them ever regain their original volume. Such at least was their character at the time of our visit, but

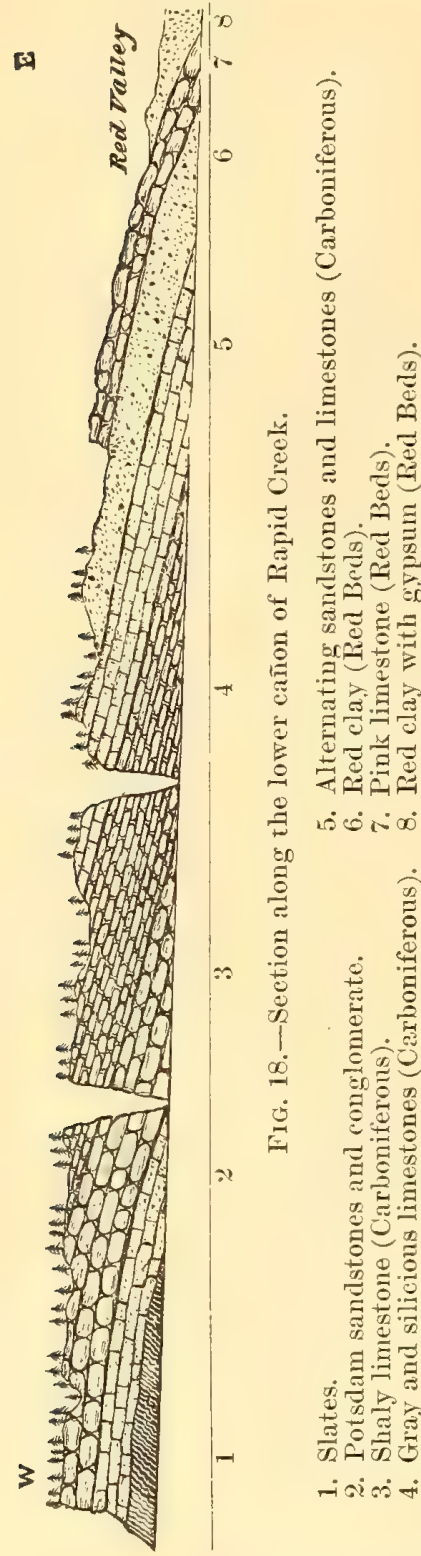

from numerous signs it would appear that in certain seasons or during great floods many or all of them carry water in great volume to the Cheyenne. This sinking of the water is no uncommon feature in the western country, and it is due in many cases to various circumstances of climate which need not be enumerated here. The sinking of the streams in the Hills takes place usually within a very small area, and I surmise that it is caused by a downward infiltration of the water into the limestones, through which it has dissolved subterranean channels, and from which it rises again at some distant place. Sometimes, however, it may find a passage under the visible bed of the stream among the bowlders filling the channel, and from them it may rise again in the Plains. Minne Katta, which in the matter of sinking is an exception, issues from a subterranean channel cut probably in the Carboniferous rocks; it rises in springs of great volume within a small area at the base of a cliff of the upper Carboniferous series.

Possibly after the work of active mining has been pursued in the valleys of the Hills for some time, sending down the creeks large quantities of fine sand and mud, some of them will become running streams out into the Plains, their old channels of subterranean escape being filled up by the débris carried down from the mining operations.

Returning to the review of the Carboniferous rocks on the eastern side of the Hills, on Rapid Creek is found one of the best exposures of the sedimentary rocks that was anywhere examined. The creek runs for some 
five or six miles through a cañon whose sides are almost vertical walls of the sedimentary series. The dip, though varying and increasing in the lower end of the cañon near the Red Beds, is not very great, being $15^{\circ}$ or $20^{\circ}$, and the rocks can therefore be studied with considerable ease. The accompanying section is derived from the walls of the cañon.

In ascending order the detailed section is as follows, adhering to the numbers of the beds as given in the above cross-section:

\section{Carboniferous.}

3. Limestone, pink, gray at top and weathering as though slightly argillaceous. $\quad 35$

Limestone, pink and yellowish, shaly; containiug some cyathophylloid corals. $\quad 40$

4. Limestone, gray or white, very massive; forming cliffs.............. $150+$

Silicious limestone, pinkish in color, brecciated; weathering in reddish streaks ............................................ $175+$

5. Silicious limestones and sandstones alternating in thin beds, pink and reddish in color .................................... $200+$

Impure, massive, white sandstone, stained red .................. 40

Massive; brecciated sandstone, stained red .................... 30

Red sandstone, stratified in well-marked strata................ 40

The section agrees in the main with the typical Carboniferous section, but the base of the Carboniferous is here thicker than elsewhere in the Hills, and is at the same time a more massive and pure limestone.

The interstratified sandstones and limestones of the upper Carboniferous are shown near the mouth of Rapid Creek in great detail, and because of the interest attaching to these beds a careful section was made of the exposure as follows, in descending order:

\section{Red Beds.}

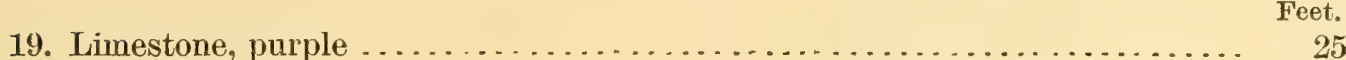

18. Clays, deep red ........................................ 100

Carboniferous.

17. Sandstone, white and stained red, distinetly stratified .............. 40

16. Sandstone, variegated, deep red; showing no stratification ............ 30

15. Sandstone, white and massive, stained red..................... 40

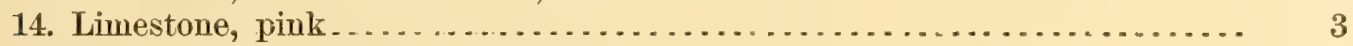

13. Sandstone, white and pinkish ................................. 3

12. Sandstone, argillaceous and calcareous, becoming a pink and white sand-

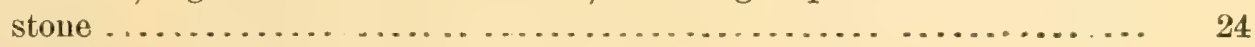

11. Limestone, purple, impure and argillaceous..................... 3 
10. Samlstont.

9. Limestone, pink ..................................... 5

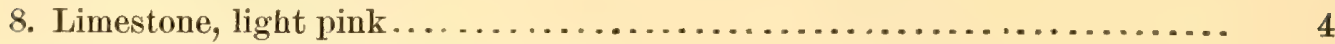

7. Sandstone, coarse, calcareous, pink ....................... 4

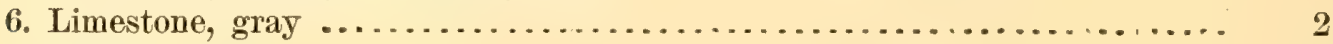

5. Talus. . . . . . . . . . . . . . . . . . . . . . . . . . . . . 40

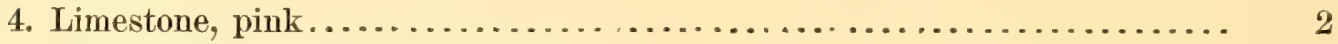

3. Limestone, argillaceous and silicious ..................... 5

2. Sandstone, white and pink ............................... 3

1. Limestone, gray and pink, in massive bands separated by bands of clay, and becoming sandy .................... to the bed of the creek

These beds are generally highly colored pink or red, and the majority of the limestones appear to be more or less magnesian and frequently silicious and flinty. Several of the limestone strata are somewhat fossilferous. The fossils are poorly preserved casts and are similar in character to those found in the same series of rocks on Box Elder Creek.

The Box Elder section is more complete, for the underlying silicious limestone and the purple limestone of the Red Beds both appear in the cliff. It was carefully measured and examined in detail.

Section of the upper Carboniferous series on Box Elder Creek, in descending order:

\section{Red Beds.}

45. Purple limestone $\begin{array}{r}\text { Feet. } \\ 25\end{array}$

44. Red clay ............................................. 100

Nos. 5 and 4 of the Carboniferous.

43. Variegated sandstone............................... 75

42. White and yellowish sandstone........................... 15

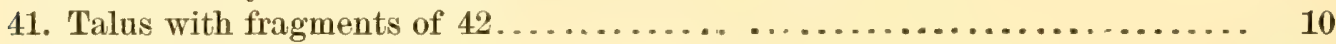

40. Sandstone, red, calcareous ........................... $5-6$

39. Sandstone with limestone fragments, talus . . . . . . . . . . . . . . . . 50

38. Sandstone, deep red, calcareous . . ........................ 5

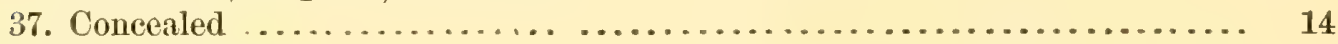

36. Limestone, pink.................................. 1

35. Concealed .......................................... 10

34. Limestone, purple...................................... 1

33. Sandstone, pink and white, soft and thin bedded............... 8

32. Limestone, pink and gray ............................. 6

31. Concealed ........................................ 5

30. Limestone, gray, stained red . . . . . . . . . . . . . . . . . . . . . . . 4

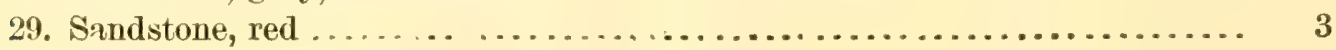




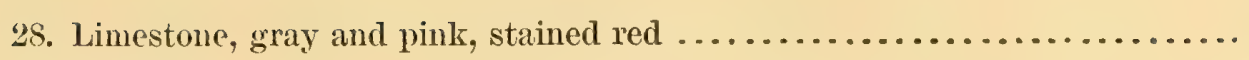

Feet.

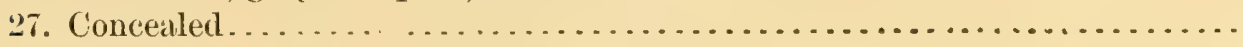

6

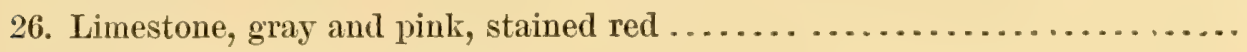

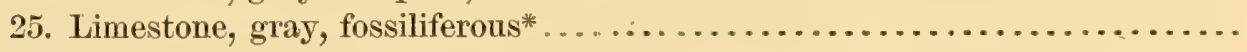

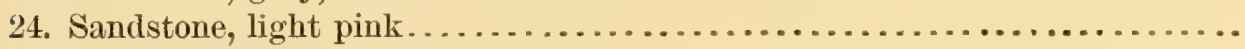

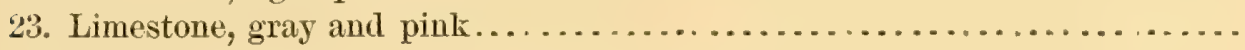

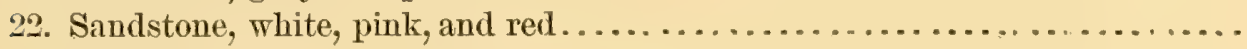

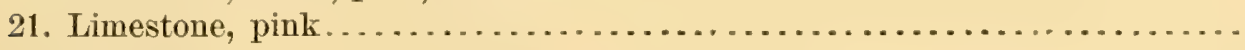

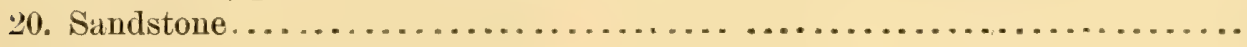

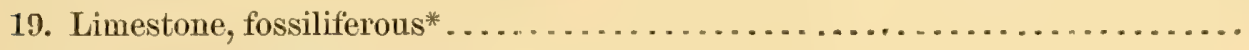

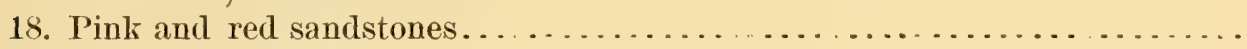

17. Limestone, gray and hard in strata, 2 feet thick .................. 12

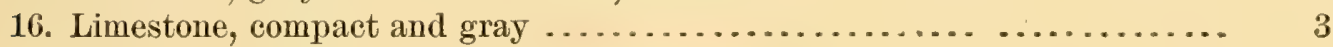

15. Limestone, gray and pink, hard and flinty................... 2

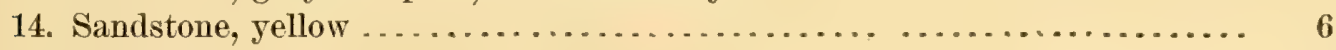

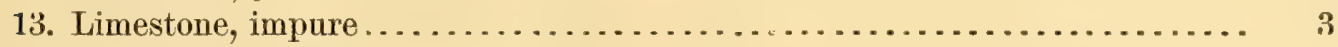

12. Sandstone, jellow, massive ................................. 4

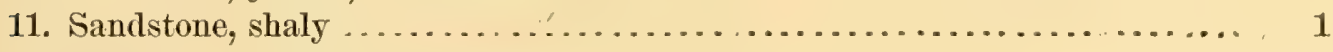

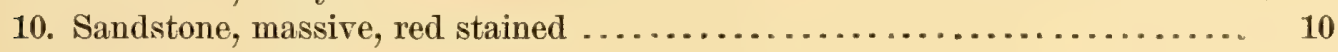

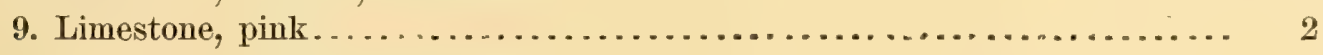

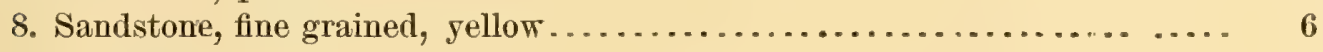

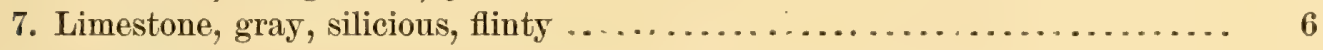

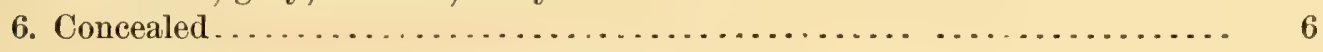

5. Limestone, gray, compact, fossiliferous*.................... 8

4. Limestone, flinty, pink.................................. 4

3. Sandstone, pink and yellow, fine grained, weathering red .......... 5 5

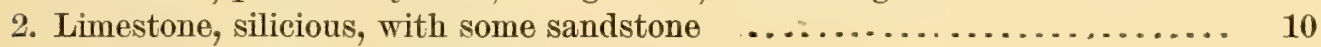

1. Limestone, silicious, brecciated .......................... 15

No. 3 of the Carboniferous.

The fossils found in the strata marked (*) are few in number and badly preserved. They are mainly ill-marked casts of very small brachiopods and gasteropods so poorly defined as to be indeterminable, and though close search was made, none were found that were of any value in determining the relationship of the inclosing rocks.

Before entering the cañon in which this section was observed Box Elder Creek flows for eight or ten miles in a southeasterly direction, and for the most of that distance it skirts the inner base of the monoclinal ridge. One who follows up the creek valley has at his right, beyond a short slope, a. vertical cliff 200 to 300 feet in height, formed by the lower Carboniferous rocks, which exhibit their usual character and thickness. In the neighbo:- 
hood of Elk Creek and beyond, where the slates carry numerous outlying patches of Potsdam and Carboniferous, the cliff loses its regularity, but there is still no difficulty in distinguishing the several beds.

In the cañon of Elk Creek, which for several miles cuts a vertical and tortuous channel 200 or 300 feet in depth through the Carboniferous and lower Red Beds, excellent sections are exposed of the Carboniferous rocks, and they were examined at several points as our trail descended into or wound its way out of the intricacies of the cañon. The cross-section already given of the development and pitch of the Carboniferous on Rapid Creek would answer almost equally well for a section on Elk Creek. The alternating bands of colored limestone and sandstone of the upper series are again well exposed, but the outcrops were not studied with any minute care.

The four creeks which cross the limestone ridge at the north end of its bow-shaped curve and flow to the Belle Fourche were not followed through their cañons. The next point examined on the margin of the uplift was the cañon of Spearfish Creek. The Carboniferous is well exposed, but owing to the presence of several volcanic peaks it is much tilted. Near the mouth of the cañon the intrusion of the volcanic rocks of Black Butte on the south side of the creek has raised and exposed the lower sedimentary rocks, and through them the creek flows in a profound cañon. The following section was taken at this place, beginning in the Red Valley.

Red Beds.

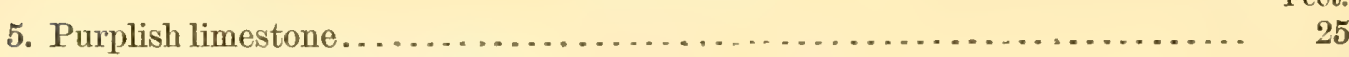

4. Crumbling, soft, red sandstone ........................... 100

Carboniferous.

3. White, yellow, orange, and dark red, massive, soft sandstone; irregular in

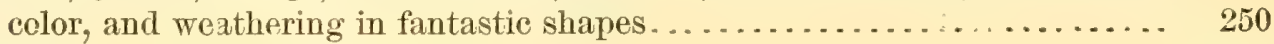

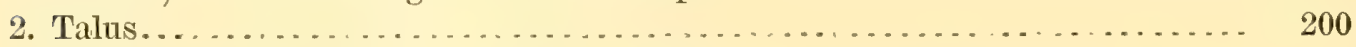

1. Silicious limestone to the bed of the creek . . . . . . . . . . . . . . . -

Near the butte, resting on the volcanic rock of the peak, fragments of the metamorphosed Potsdam were seen, and resting upon it in regular order are the strata of the above section.

Around Crow Peak the Potsdam, altered to a hard quartzite, stands nearly vertical resting against the trachyte. The Carboniferous also has 
been turned up, and its limestones, unchanged, are found resting upon the Potsdam, and standing in places in a nearly vertical position. The change from the normal horizontal position is sudden, and a few hundred feet away they lie so nearly flat as to give no evidence of their near proximity to a great cone of eruptive rock.

In a similar manner the Carboniferous is found encircling the volcanic peak or ridge northeast of Inyan Kara, but here the underlying Potsdam was not found exposed. The Carboniferous rocks are tilted at a high angle, and in their elevation are conformably accompanied by the Red Beds, which are represented most conspicuously by the purple limestone. This limestone wraps the lower part of the elevation, and rises in a gentle slope some distance upon its sides. Its arching uplift seems like an excrescence or large bubble upon the main slope, which descends from the Carboniferous plateau on the east to the valley of the Red Beds.

The only remaining outcrop of the Carboniferous is that which encircles the Warren Peaks, forming the foothills of the Bear Lodge range. It is the largest of the minor exposures, and like the other minor exposures it is associated in origin with large masses of volcanic rock.

Though geographically the peaks and elevations of the Bear Lodge range appear to form a distinct system of mountains, geologically they belong to the same system as the main range of the Hills. They pertain to the same epoch of elevation and igneous eruption in which were formed the numerous volcanic peaks of the northern end of the Hills, and they are closely identified with them in the character of their rocks and in their structure. They exhibit, however, a greater localization of the eruptive force, and the mass of igneous matter is much greater than in any of the other peaks. The Carboniferous is tilted up on every side just as it is around Crow Peak, but in several places its beds have become somewhat metamorphosed by proximity to the igneous rocks. In some localities the trachyte is found to penetrate between its strata. The strata are also severely dislocated, frequently in an intricate manner.

It is greatly to be regretted that the Carboniferous of the Black Hills is so loth to yield up its biological record. Consisting almost entirely of limestone, it is presumably constructed of the very ruins of the life of its 
age, and indeed half of the fragments that one picks up betray in some way an organic origin, but the preservation is so poor that it is only here and there that a form can be distinguished. Our collections add but four forms to the list of those gathered by Professor Winchell and Mr. Grinnell during the Custer expedition of 1874. The forms thus far obtained from the lower member (1) are-

Zaphrentis centralis? Spirifera.

Campophyllum (or Amplexus). Productus.

There have been brought from the middle members ( 2 and 3):

Zaphrentis.

Syringopora multattenuata.

Athyris subtilita.

Streptorhynchus.

Rhynchonella.
Terebratula.

Spirifera Rocky-montana.

Retzia.

Euomphalus.

On the eastern coast of the United States the Carboniferous period was followed by an epoch of great disturbance, in which the strata of the Carboniferous and the preceding periods were bent, twisted, and plicated in a grand manner, and the Alleghany Mountains were produced. During this disturbance there was also an extinction of old organic types and an ushering in of new ones. The Mesozoic strata deposited subsequently are, therefore, found resting upon or abutting against the older formations unconformably. In the Far West, too, in the region of the eastern flanks of the Rocky Mountains, observers have found a similar unconformity between the Paleozoic and Mesozoic.

In the Black Hills, however, we were able to detect no evidence of unconformity between the Carboniferous and the overlying Red Beds. There is even such a lithological gradation from Paleozoic to Mesozoic that in the absence of fossils the line between the two cannot be drawn with confidence. It is true, indeed, that the length of outcrop continuously exposed was not of sufficient extent to betray a slight discordance of dip, but from the comparative study of the strata at many different localities no evidence was obtained that would warrant us in assuming any want of conformity. For aught we know the area now included in the Black Hills was the scene of continuous deposition from the beginning of Paleozoic time to the end of Mesozoic time. 
SE CTION VI.

\section{THE RED BEDS.}

\section{(TRIASSIC ?)}

Resting conformably upon the Carboniferous rocks is a series three or four hundred feet in thickness of deep red, sandy, and gypsiferous clays, with an intercalated stratum of limestone. These beds yield no trace of organic remains, but they underlie conformably a series of lighter colored clays, marls, limestones and sandstones with abundant and characteristic Jurassic fossils. Beds of a similar brilliant red color are a conspicuous element in the structure of the entire Rocky Mountain region, and though they bear in some localities a few fossils, it is chiefly from their position between well determined strata of Carboniferous and Jurassic age that they are usually considered to be Triassic. On account of their prevailing red color they are also commonly known as the "Red Beds," and that name is here preferred, for the reason that it implies nothing in regard to their correlation with fossiliferous strata elsewhere. If the name Trias is occasionally used in these pages it is always with a reservation, for certainly in the Hills there is nothing to prove its applicability.

The difficulty of ascertaining the position of the base of the series has already been described in speaking of the Carboniferous. There is no such doubt about its separation from the Jura. At the top of the Red Beds there is an unequivocal change in the character of the sediments and immediately above it are Jurassic fossils in abundance. The Red Beds consist of the following members in descending order:

3. Deep red clay, sometimes becoming soft, shaly, argillaceous sandstone; containing large quantities of gypsum . . . . . . . . . . . . . . . . . 200-250

2. Pinkish or purple argillaceous limestone ................... $15-40$

1. Deep red clay, sometimes becoming a soft, argillaceous sandstone ; containing but little gypsum . . .......................... $75-100$

Dr. Hayden, in his general section of the geological formations of the Hills, includes in the lower portion of the Red Bed series all the strata between the purple limestone ( 2 of the above section) and the Carboniferous limestones-" brick-red material very similar to the bed D [3 of above 
section], and passing down into a very hard, compact, concretionary sandstone, 250 to 300 feet"-thus embracing both the red arenaceous clay (1 of the above section) and the colored sandstones and occasional limestones which form the upper member of our section of the Carboniferous.

On the other hand, Professor Winchell (Black Hills of Dakota, Ludlow, 1874, p. 65), while exaggerating very considerably the thickness of the purple limestone ( 2 of the above section), has included it, together with the underlying red clay and sandstones, whose thickness he greatly underestimates, in the Carboniferous system, indicating, however, their reference to that formation with some doubt.

The reasons for adopting the division here made between the Carboniferous and Red Beds have already been fully expressed in the section on the Carboniferous. There is one statement by Dr. Hayden which, if substantiated, would completely overthrow his own classification and at the same time establish Professor Winchell's. He speaks of finding in the purple limestone in the Hills Spirifera (like S. lineata), Pleurotomaria, Macrocheilus, and Bellerophon. Unfortunately in our most diligent search, examining and breaking the rock almost by the cart-load and in many localities, not the least trace of organic remains was found, and it is reluctantly inferred that there was some error in the reference of the fossils to this limestone.

The purple limestone is very conspicuous in the geological structure of the Black Hills and an important element in the topography. It forms the outer slope of the main portion of the Hills, and in a sloping belt from half a mile to three or four miles in width, dipping outward from $20^{\circ}$ to $30^{\circ}$, completely encircles them. It preserves the underlying red clay and sandstone from denudation and defines the inner margin of the great encircling Red Valley. Its inner edge marks with considerable accuracy the border of the timbered region of the Hills, though a few trees are in places scattered over its slope. It is so much harder than the overlying clay and lies at so steep an angle, that it is swept clean not only of the clay, but of all soil, and forms a bare and slippery pavement of rock, which, by its seams and peculiar weathering, has acquired a tesselated appearance. Were it not for the breaks caused by 
the cutting of the cañons of the outgoing drainage one could drive many wagons abreast entirely around the Hills on this encircling limestone pavement. At Warren Peaks, which exhibit in miniature all the main points of the geological structure of the Hills, the limestone forms also an encircling slope.

Underlaid by 75 to 100 feet and overlaid by over 200 feet of soft red clay, the limestone rests between two cushions, so that in the uplifting of the rocks at the time of the elevation of the mountains it was not shattered and dislocated so extensively as if it had been inclosed between more rigid strata. It is found bending and warping suddenly, especially about some of the volcanic peaks, and conforming to all the little irregularities of the outer slope of the Hills, without exhibiting any great fractures or dislecations. Though it is usually very fragmentary in its structure, filled with cracks and joints perpendicular to its bedding, they seem rather due to its composition and mode of weathering than to the bending of the strata.

The color of the limestone is grayish, pink, or purple; it is somewhat mottled and often deeply stained by the red filtration from the overlying clay. It is hard and gritty, and is rarely massive, but usually thinly bedded. A qualitative analysis was made by Dr. Ricketts, who reports that "it contains lime, carbonic acid, iron as protoxide, alumina and silica, in quantity; and traces of manganese, potash, soda, magnesia, and sulphuric acid. It consists essentially of carbonate of lime, with some silicate of alumina and iron (clay); has an odor when ground like Canada petroleum." The fetid odor noticed by Dr. Ricketts is plainly discernible whenever the rock is crushed or a fresh fracture is made. It is a common characteristic of limestones and is believed to be due to the presence of organic matter derived from the organisms-plants or animals-that inhabited the water at the time of their deposition. It is worthy of remark that with this strong evidence of the presence of life at the time of the formation of this deposit there should be such an absolute dearth of fossil remains.

The rock appears to be quite soluble in water, for many of the springs that flow from its base precipitate large quantities of calcareous tufa.

Above this limestone is a great development of brick-red clay, that in its ordinary exposures exhibits no lamination nor other evidence of sedi- 
mentary structure. It has, however, in places a sandy phase, and in that condition it is a plainly laminated shale or shaly sandstone. In the absence of observable bedding, the thickness had to be determined indirectly by measuring across the outerop and combining the result with observations on the dip and profile of the adjacent strata above and below. From a number of such estimates a general thickness of 200 or 250 feet was deduced.

The arenaceous phase of the clay was observed chiefly in the Belle Fourche region near Bear Lodge, in portions of the Redwater Valley, and on lower Red Cañon Creek.

A sample of the material in its typical condition of a fine plastic clay was submitted to Dr. Ricketts for a qualitative analysis and was found to contain "alumina, silica, lime, and iron (as protoxide and peroxide) in quantity, with traces of soda, potash, baryta, and carbonic acid. It is essentially a silicate of alumina (clay), with some silicate of iron, containing also some carbonate of lime and colored by sesquioxide of iron." It does not contain sufficient carbonate of lime to warrant the title of marl, but critically it may be considered a clay more or less silicious and colored by peroxide of iron.

Gypsum is found in intercalated beds in great abundance, but its exposures are not always easily traced The beds have. probably great variation in thickness, and their outcrops are apt to be covered by thin layers of clay. They were observed from 2 to 10 feet in thickness, and could probably be found considerably thicker if excavations were made. Our examinations did not suffice to determine whether they are more abundant in one portion of the clay than in another, nor to trace for any considerable distance a single stratum. They were found from within 75 feet of the purple limestone to the very summit of the well distinguished red clays, lying but a few feet below characteristic Jurassic fossils.

In many places in the vicinity of the gypsum strata the red clay is found penetrated by a net-work of thin seams of gypsum ranging in width from an inch to the thickness of a sheet of paper, cutting the clay in all directions and interlacing in the most intricate manner. These are unquestionably a secondary deposition formed by the infiltration in crevices and cracks in the clay of waters bearing in solution gypsum derived from the associated beds. The gypsum where exposed has been largely removed by 
solution, and long-standing outcrops are found to be rotten and crumbling. In some localities, especially in the Red Valley near Sun Dance Hills, where the red clay lies nearly horizontal, holes or sinks have been worn in the gypsum layers, into which the local drainage flows, gradually dissolving the gypsum and enlarging the sinks.

Its readiness of solution is also shown by its occurrence as an effloresence on surfaces of clay or rock, where it has been deposited by evaporating waters. The waters which flow through it or in contact with large surfaces are usually hard and medicinal.

It has a snowy white color, is massive and crystalline in structure with numerous little sparkling facets, and in outcrops unaffected by the weather is dense and firm. Occasionally small deposits of a pink, fibrous gypsum of great beauty are found, but it was never found in crystals. When long acted upon by the weather it becomes porous and soft and resembles chalk in texture.

Notwithstanding the enormous quantities in which it occurs, it will probably never, or at least for very many years, be of any commercial value. There is no market in which it can compete without great disadvantage in the matter of transportation.

The brilliant brick-red color of the Red Bed clay, intensified as it often is by a strong contrast with the snowy white of the included gypsum and the green of the scanty herbage, makes it one of the most conspicuous members of the rock system of the Hills. It is easily eroded and washed away by the action of rains and streams. Limited on each side by a hard rock, its broad outcrop has been hollowed into a valley between two ridges. On one side is the underlying. Carboniferous series faced by the purple limestone of the Red Beds, and on the other is the cliff capped by the lower sandstone of the Cretaceous. Between them is the valley, broad and open, completely encircling the Hills, and one of the most prominent features of the topography. Its prevailing red hue distinguishes it from all others, and it is appropriately entitled the Red Valley. From whatever side the Hills are approached the same, or nearly the same, topograpbical features are passed over in succession. By a gradual rise from the Plains, or sometimes by crossing a series of low cliffs, one reaches the 
summit of the foothills that encircle like a rampart the fastnesses of the Black Hills. Looking back from this elevation he commands a broad stretch of the Plains, a grassy sea, quietly undulating in the distance, but broken near his feet into rocky billows. Facing about, he finds that he is standing upon the verge of an escarpment 200 to 500 feet high, and beneath him is the undulating, treeless Red Valley stretching away to the right and left until by its curvature it is carried out of sight. Beyond it and two miles, or four miles, or six miles away, the main mass of the Hills rises darkly against the sky, timbered and rocky. Just at the base of the Hills, and parting them from the valley, runs the bare outcrop of the purple limestone, not an even band, but a serrated fringe, divided by every water-course that descends to the valley and pointing a sharp crag upward in every interval.

This structure of the Red Valley is indicated in the several cross-cuts in subsequent portions of this section, Figures 19,20 and 21 . Its course is shown on the geological map by the brown color which marks the outcrop of the Red Beds.

Though it is easily distinguishable and traceable around all parts of the Hills, preserving the same general features, it is subject to variations in width and in details of structure. Its width depends upon the width of the outcrop of the upper red clay and that depends on the local dip. It depends also, but to a less extent, on the thickness of the clay. Where the dip is slight, the outcrop and the valley are broad; where it is heavy they are narrow, but there is no place where the valley is less than a mile across.

The Indians, recognizing its continuity and the regularity of its surface, have followed it with their great trails or routes of travel, and it is known to them as the "Race-course."

It is generally well covered with the common short grass of the Plains, but it is entirely destitute of trees, save that an occasional hill may sustain a few pines. The immediate valleys of the streams and dry washes which drain across it from the interior of the Hills are narrow and frequently lined with small groves or scattered individual trees. Their principal tree is the cottonwood, but there are occasionally dwarfed and stunted oaks and thickets of willow and wild plum. As already remarked, the majority of 
the streams sink in the cañons of the Carboniferous, but many of them rise again in the Red Valley in unexpected places as springs or pools of water. They never, however, become again running streams.

Though the surface of the valley is generally undulating, with frequent wide level expanses, it is often deeply cut and scored by ravines and channels, and these are especially numerous near the main streams of the Hills, where the excavated and washed surfaces have an exceedingly bare and desolate appearance. As has been aptly described by Colonel Dodge, "sometimes it is really a smooth, beautiful valley; in other places it is a jumble of low, broken red hills, cut by innumerable ravines and looking like a Virginian 'old field' on a large scale."

Along the eastern border the valley is narrower than elsewhere, and all the principal lines of drainage run across it, issuing from the monoclinal ridge of Paleozoic rocks at the west, and immediately entering the Cretaceous rampart at the east. At the southern end the drainage crosses in the same manner, but the dip is gentler and the valley is broad. At the southwest it is again narrow, but it has a considerable drainage of its own. Following its course from Dodge Pass northward, one first ascends for six or eight miles a water-way that in some seasons must carry a large volume and then descends through a grassy prairie to the east fork of Beaver Creek, up which he travels for eight miles without leaving the Red Valley. Thence to Inyan Kara he finds the drainage longitudinal, though with no running water, and he crosses but a single divide between the two forks of the Cheyenne. Approaching Inyan Kara he finds the valley broader, and it is so broad beyond and so complicated by igneous uplifts that its typical character is lost. At the north beyond the Bear Lodge range it resumes its familiar form and for twenty miles it is the broad and open valley of Redwater Creek.

A small but interesting area of the red clay is exhibited on the Belle Fourche near Bear Lodge. Here, as also on lower Red Cañon Creek and in places on the Redwater, the elay has so large a proportion of sand that it becomes a shaly red sandstone, and instead of forming sloping and rounded surfaces it stands in sharp cliffs. 
The large percentage of peroxide of iron in the Red Beds, to which they owe their bright red color, bears an interesting relation to the absence of fossils. The material of which sediments are formed is derived by the various processes of denudation from the rocks of older land surfaces. Whatever iron they contain is dissolved from the land and transported in the condition of protoxide or some proto-salt, such as the carbonate, and the process is facilitated by the presence of carbonic acid in the water. Now iron occurs in these older rocks as protoxide and peroxide, the former of which is soluble and the latter insoluble in water. The peroxide, however, by the action of organic matter, such as is held in solution by boggy waters, may be deprived of a portion of its oxygen and converted into protoxide and thus rendered soluble. If the iron-bearing water is confined as in a shallow basin and exposed long to the action of the atmosphere the protoxide of iron absorbs oxygen, and is precipitated as the insoluble red peroxide of iron. If, however, plant or animal life be present in sufficient quantity this oxidation is prevented. . In case but little foreign material-clay or sandhas been brought by the waters, the deposit will be an iron ore; in the absence of organic matter the peroxide or brown hematite, or in its presence the proto-carbonate, such as the iron-ore beds of the Coal Measures. But in case large quantities of foreign material are deposited from the waters at the same time there will be produced in the absence of life a brown or red clay or sandstone, and in its presence a white or light-colored formation containing the iron as a protoxide. This question of the removal and deposition of iron has been ably elucidated by Dr. Newberry and others, and Dr. Hunt "can hardly conceive of an accumulation of iron, copper, lead, silver, or gold in the production of which animal or vegetable life has not either directly or indirectly been necessary." * The point to be established by this seeming digression is this; that reasoning from the condition in which the iron is found in the Red Beds we must conclude there could have been little or no life, animal or vegetable, in the water from which they were deposited. The conclusion is strengthened by the fact of the presence of large quantities of gypsum, which has been derived from the 
evaporation of saline waters The degree of saline concentration which the precipitation of gypsum indicates would be highly inimical to life

The presence of the gypsum helps to account for the absence of life, and the absence of life accounts for the brilliant color. The three prominent characteristics of the formation are therefore quite in harmony with each other.

In passing now to the details of the exposures of the formation there seems little need to linger. There is so great uniformity of relation and structure that one or two local sections will illustrate the whole, while nearly everything of importance has been anticipated by the description of the several members and of the general topography.

At the headwaters of the east fork of the Beaver the Red Valley is 1,000 feet higher than it is at Camp Jenney, fifteen miles farther south, and it has a total elevation above the sea of about 5,000 feet. The purple limestone is well exhibited all along the valley, rising to the eastward and lapping against the side of the plateau, and near the head of the creek it covers a considerable area. The main stream and several tributaries from the east cut through it to escape from the plateau to the Red Valley, and in their cañons excellent sections are exposed of the upper Carboniferous and the contiguous Red Beds. The valley is here three or four miles in width, and its western rampart-the Cretaceous and Jurassic foothills-is less prominent than usual. To the southward Beaver Creek cuts a channel of increasing depth into the red clay; the Red Valley becomes narrower, and the western escarpment becomes more pronounced, acquiring a height above the valley of two or three hundred feet. In the vicinity of Camp Jenney and Fanny Peak the purple limestone shows the double curvature represented in the section. It laps steeply against the foot of the plateau, sometimes rising a thousand feet or more above the valley. Then at the base it quickly curves to the horizontal and in a mile or less it bends down again, disappearing beneath the gypsiferous clay. Where it disappears its dip is $25^{\circ}$ to $\measuredangle 0^{\circ}$, and its eastern edge is upturned to $75^{\circ}$ to $85^{\circ}$. Its thickness is 40 feet.

Immediately east of Camp Jenney the lower red clay appears as a soft sandy clay 50 or 75 feet thick, separating the purple limestone from the 
underlying red sandstones which form Fanny Peak. The water of Beaver Creek issuing largely by springs from beneath the limestone is hard and limy, and many of the tributaries as they enter the Red Valley and become exposed to rapid evaporation deposit beds of travertine.

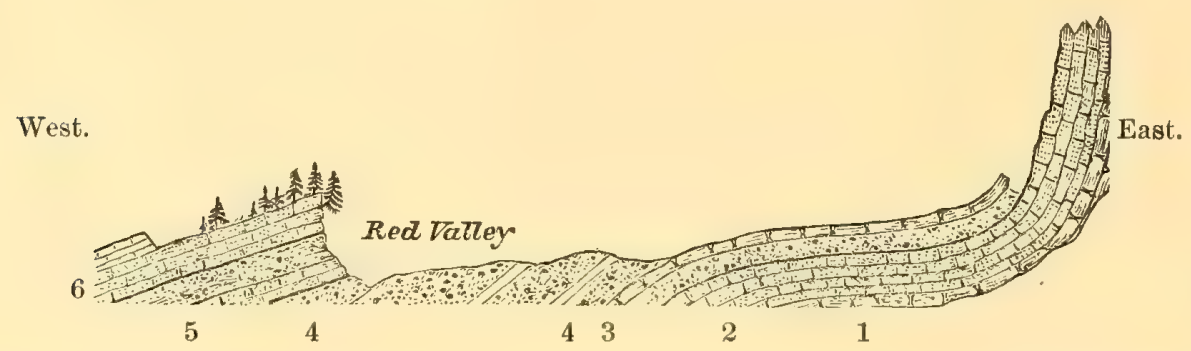

FIG. 19.-Ideal section across the Red Valley at Camp Jenney; showing the foothills at the left and Fanny Peak at the right.
1. Carboniferous limestone.
2. Red sandstone (Carboniferous).
4. Red clays with gypsum (Red Beds).
3. Purple limestone (Red Beds).
5. Jura.
6. Cretaceous.

Camp Jenney is at the point where Beaver Creek leaves the Red Valley and cuts through the Cretaceous rampart on its way to the Cheyenne. To the southward the valley rises gradually in a prairie-like expanse, destitute of water and but little broken by the dry channels that traverse it. Thence to Red Cañon Creek it was not examined geologically, but the account given by the topographical party shows that there are no peculiar features.

On Red Cañon Creek the Red Beds are finely exposed, and the width of the valley, including the slope of the purple limestone, is fully eight miles. Here again portions of the red clay are sandy, sometimes becoming a sandy shale, and in sereral places a tolerably massive but soft, argillaceous red sandstone. This character, as well as the relation of the red clays to the overlying Jura, is illustrated in the following section taken near the foothills on the west side of Red Cañon Creek.

Jura.

5. White ripple-marked sandstone, with a thin calcareous layer at its base full of Jurassic fossils: Rhynchonella myrina, Pseudomonotis curta, and Trape-

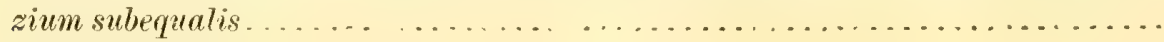

4. Gray shales or marls . . . . . . . . . . . . . . . . . . . . . . . . 15

3. White sandstone, soft, and at bottom shaly, weathering in pot holes...... 15 
Red Beds.

Feet.

2. Soft sandstone, blood red; appears somewhat argillaceous. . . . . . . . . . . 80

1. Shaly sandstone, deep red, changing into red sandy shales, and below into

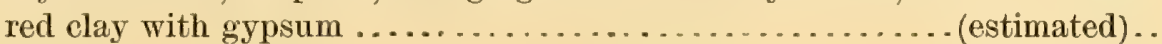

The transition from the red sandstones of the Red Beds to the soft white sandstone and gray marls above is perfectly distinct. Gypsum is seen in great abundance, and two seams have eacb a thickness of 8 or 10 feet. The locality affords a fine opportunity to study the infiltration veins of gypsum. The sandy clay in particular is highly suffused, and a labyrinth of dry gulches with vertical sides from 10 to 30 feet high expose fine natural sections.

Our next local examination was made on Amphibious Creek twenty miles east of Red Cañon Creek. The entire width of the valley, including the slope of the limestone, is between four and five miles, and the red clay, though well exposed, occupies but a narrow belt along the foothills.

The following ideal section is in direct continuation of the section already given in Figure 17 :

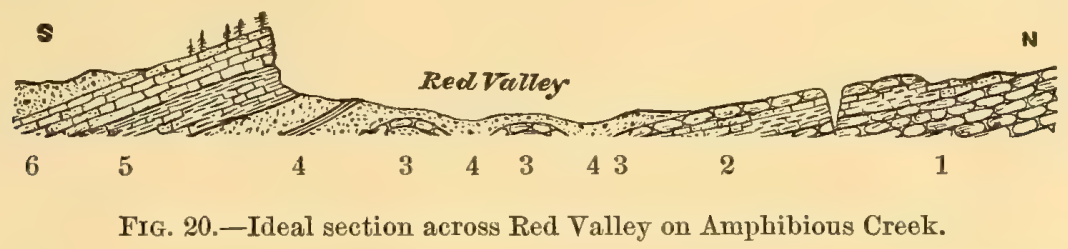

1. Carboniferous

2. Red sandstones and clay (Red Beds).

3. Purple limestone (Red Beds).

4. Red clay with gypsum (Red Beds).

5. Jura.

6. Cretaceous sandstone capping the foothills.

7. Clays of the lower Cretaceous.

As rudely indicated in the wood-cut the limestone after dipping down from the north side of the Red Valley warps up again in several places along the creek. Near the pass of the creek through the foothills there is exposed a stratum of gypsum 8 or 10 feet thick, lying 175 feet above the purple limestone; and elsewhere in the vicinity the same mineral shows numerous outerops. At the pass the following section was taken; it shows again the character of the junction between the Red Beds and Jura, though here there is no evidence from fossils: 
Jura.

Feet.

5. Sandstone, red or pink, soft at bottom and hard at top, with numerous ripple

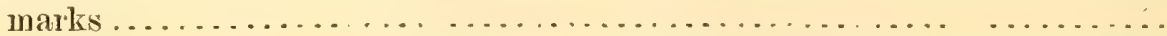

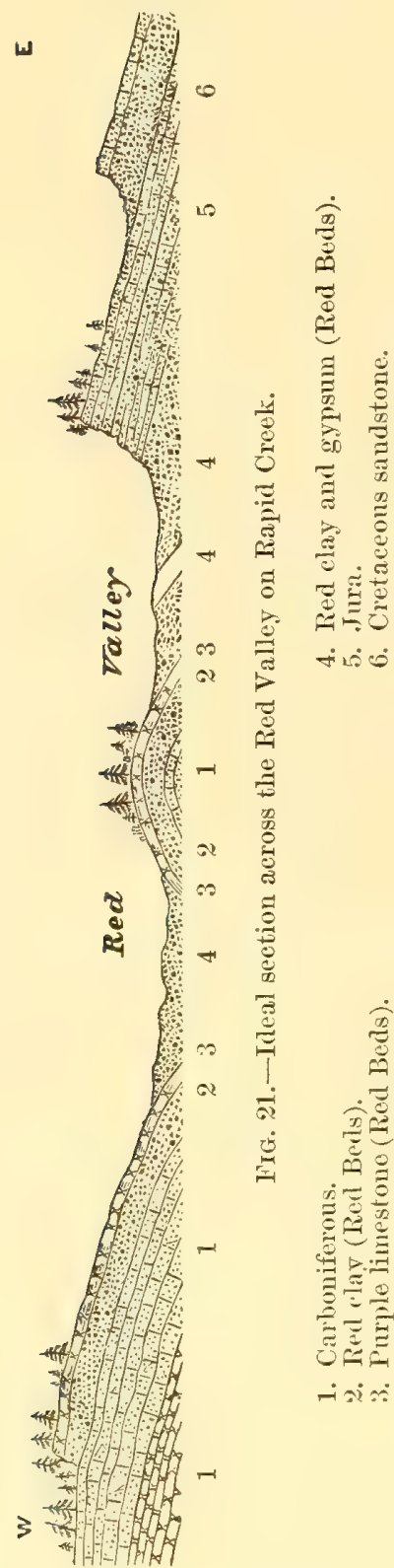

4. Sandstone, yellowish and greenish, with some tinge of red; containing some calcareous matter in thin bauds ........................ 10

3. White sandstone .................... 3

Red Beds.

2. Deep red clay ....................... 50

1. Gypsum................. to bed of ereek.. 8

From Amphibious Creek to Burntwood the Cretaceous rampart is very prominent, and near the pass of the latter, called "Buffalo Gap," it culminates in high hills. On French Creek, though the entire Red Bed series is exposed in places, its structure is not well developed, and the Red Valley is but poorly marked.

From Battle Creek northward past Rapid, Box Elder, and Elk Creeks, the Red Valley has again a fine development, extending to and joining the eastern extension of the great Redwater Valley on the north side of the Hills, and having a width, including the outer slope of the purple limestone, of from two to six miles. The profile and crosssection are nearly the same as on Amphibious Creek (Fig. 20). North of Rapid Creek the limestone warps up and creates a ridge in the center of the Red Valley, as shown in the accompanying figure (21). If the uplift be disregarded, an idea may be derived from the diagram of the general structure of the Red Valley on the eastern side of the Hills.

The purple limestone is very prominent on the eastern side of the Hills. Along the entire margin it forms a gentle slope, rising from the red 
clay of the Red Valley at an angle of $15^{\circ}$ or $20^{\circ}$, and marking closely with its inner margin the edge of the timbered area. It is frequently cut by little ravines or gulches that head back a short distance in the Hills, and from it arise many springs of deliciously cool water. One of these springs near Elk Creek is of such size that the stream to which it gives rise flows through and beyond the foothills. The surface of the limestone is cracked and weather-worn, and is bare of soil for long distances, forming a hard and somewhat slippery pavement.

Near Rapid Creek, immediately above this limestone, the following strata of the Red Bed series were observed:

6. Clay, red, with some gypsum ..........................

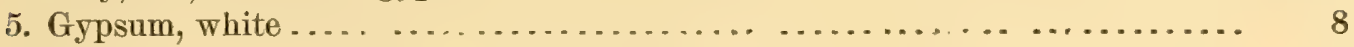

4. Clay, with several seams of gypsum near the base.................. 40

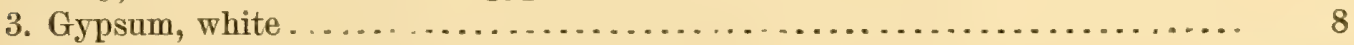

2. Clay, red, with some gypsum ............................. $75-100$

1. Limestone, purple ....................................... 25

In the region of Elk Creek and Warren Creek the purple limestone is tilted at a much higher angle than farther south, inclining $45^{\circ}$ to $60^{\circ}$ to the eastward, and the Red Bed valley is correspondingly pinched. At the same time it is more broken and scored by the minor drainage. Its greatest constriction is near Crook City, ${ }^{*}$ and bejond that point it opens out through the valley of Whitewood Creek into the broad valley of the Spearfish and Redwater, where the upper Red Beds find their greatest expanse. From the Spearfish the valley runs westward to Sun Dance Hills, with a width of five to eight miles, and then, bending around the northwestern end of the Hills, is confluent with the wide expanse near Inyan Kara.

Figure 22 gives a section from the Cretaceous rampart or foothills to Black Butte, the line running just east of Spearfish Creek.

The purple limestone all about the north end of the Hills has a low dip, averaging less than $10^{\circ}$, and the exposure of its upper surface is very broad, sometimes four or five miles. Its surface is frequently warped and bulged, but it is broken only by erosion. It is not only treeless, but for the most part soilless and grassless. Around the volcanic peaks-Crow, Sun Dance,

* On the geological map the outerop of the Red Beds is represented too broad at Crook City. The colors for Jura and Cretaceons should have been made to follow the contours on the west side of the creel. Wherever the text aul the mal' are at variance the former is to be preferred; the coloring of the map was completed after Mr. Newton's death.-ED. 
Warren, the cone northeast of Inyan Kara, and Inyan Kara-it has been bulged up at a high angle, and through it the igneons masses have been extravasated. It does not encircle Crow Peak, but it marks out by its flexure the limit in the Red Valley of the Crow Peak displacement. A

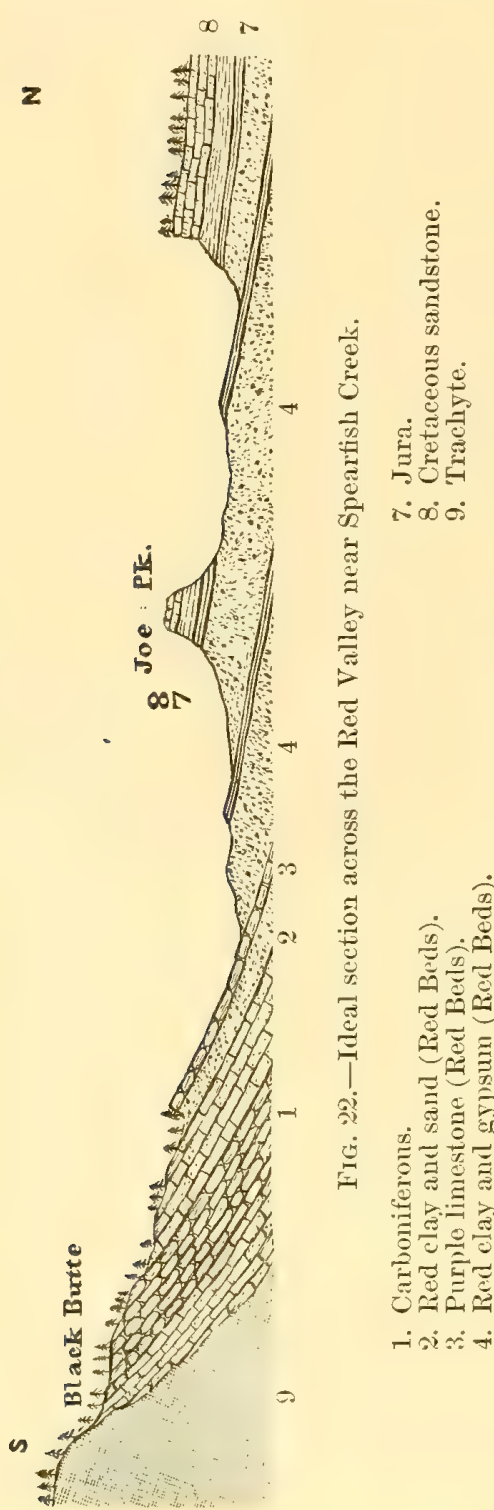
long, low, rounded ridge, sheathed entirely by the limestone, extends northward into the valley a distance of three or four miles. The thickness of the limestone is here from 15 to 25 feet.

On the northwestern exposure it is cut by the Redwater and its branches, some of which run for miles in a westerly direction, nearly coincident with the strike of the rocks. One of the western branches heads in the Red Beds southeast of Sun Dance Hills and enters the purple limestone from a higher horizon, while the main branch, rising in Floral Valley on the Carboniferous plateau, enters the purple limestone from a lower horizon. The lower red clay of the Red Beds is often in this vicinity so sandy as to acquire some degree of solidity. The upper red clay has a great development, and gives to this part of the Red Valley, as seen from an eminence, a striking appearance not readily forgotten. With a rounded, billowy surface, its bloodred mass deeply gullied in all directions, and with an occasional gash of white gypsum exposed on the red field, the valley stretches away to the dim line of the distant rampart.

Occasionally there is a small expanse of grassy surface, but the blades are scattered and there is scarcely any turf. The only trees are a few scattered groves that indicate the courses of the creeks. Notwith- 
standing the breadth of the exposure of the red clay-or rather perhaps because of the breadth-it is impossible to measure its thickness. The best estimate practicable seemed to indicate a thickness of between 250 and 300 feet. In many places the clay is quite sandy, especially in the eastern part of the valley where it sometimes becomes a soft argillaceous sandstone marked in the topography by hillocks and small buttes and mesas.

The junction of the Red Beds with the overlying Jura is well seen in many places along the foothills north of Redwater Creek. Several sections of the Jurassic rocks, including their relation to the Red Beds, were measured by Mr. Jenney and Mr. Patrick and will be found in the section on the Jura.

Southwest of Sun Dance and west and northwest of Inyan Kara there is a long range of low foothills cut by parallel valleys running north and south which carry in their bottoms red clay and on their sides the lower strata of the Jura. At one locality southwest of Sun Dance the following section was observed:

Jura.

Feet.

7. Slope of hill; no exposure ............................. 25

6. Sandstone, very soft, white and Jellowish; well exposed for 10 feet, in the remaining distance fragmentary outerops of soft white sandstones......

5. Shales, brown and yellow, sandy, containing Belemnites, Gryphoea calceola,

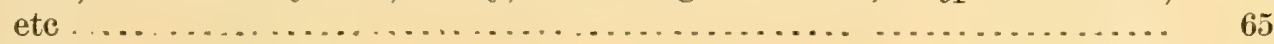

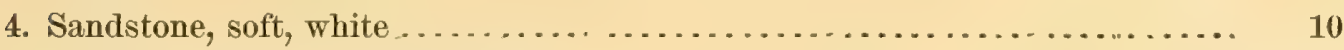

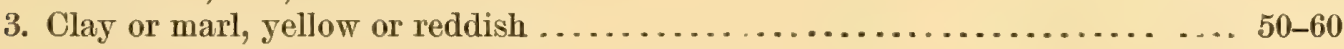

Red Beds.

2. Gypsum .............................................. 6-8

1. Clay, red ..........................................

In Figure 23 an attempt is made to illustrate the relation of the Red Valley and the Red Beds to the volcanic intrusions. The section runs from Warren Peaks in a southeast direction to the Carboniferous plateau, cutting on the way one of the Sun Dance Hills. It will be noticed that the Red Beds rest directly against the trachyte of the Sun Dance Hills, while at Warren Peaks the Carboniferous and Potsdam are interposed. If the Sun Dance Hills be omitted and the red clay (5) extended across the space, the sec$10 \mathrm{~B} \mathrm{H}$ 
tion will represent the typical synclinal character of the Red Valley at the northwest angle of the Hills:

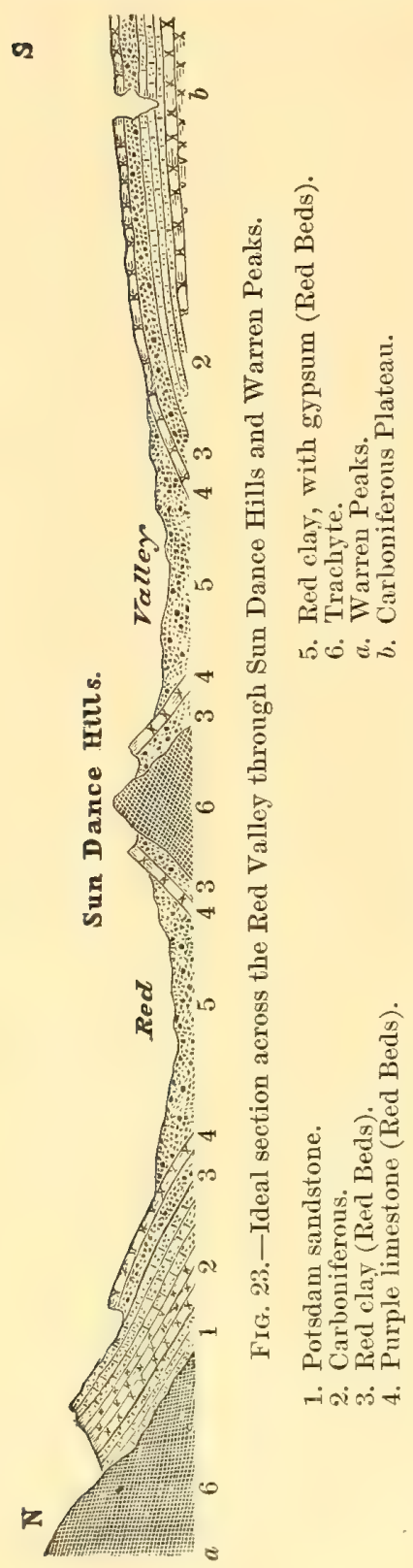

The Red Beds in the northern and northwestern part of the Hills contain large quantities of gypsum in strata of considerable thickness as well as in disseminated seams and veins of small size. The larger seams are usually 6 or 8 feet in thickness, and though frequent opportunities were taken to measure them they were not found to exceed 10 feet.

The causes which prevent close measurement of the red clay also preclude an accurate placing of the gypsum strata in their true position in the formation. There appear, however, to be several well-marked horizons occupied by thick beds. The first is about 75 or 100 feet above the purple limestone and the second 40 or 50 feet higher. A third is at the very summit of the red clay, and a fourth, less persistent, is a few feet lower. Over a large area between Redwater and Inyan Kara Creeks the red clays lie with little or no dip, and in them a continuous seam of gypsum is found which frequently has but a thin stratum of clay covering it. This thin covering is occasionally wanting, and then the gypsum is exposed. Under such circumstances it is never a firm rock, but its surface is decomposed and undermined by atmospheric action. As one rides over it the feet of his horse at every step break a thin crust and then sink a few inches through the pulverulent product of decomposition before striking the more solid bed below. The latter gives a hollow sound, caused probably by an undermining beneath.

There are numerous sink holes in the red clay, and these on close 
examination are traced to seams of gypsum lying generally only a few feet below the surface. The gypsum by percolation of water has been decomposed, dissolved, and washed away, forming vertical holes in the seam and channels of escape for the water to some lower level. These holes by the action of rain and the drainage from limited areas of the surrounding clays become enlarged, and some of them have attained a diameter of 50 feet. The majority are, however, only from 2 to 5 feet in diameter, and have all the characters of sinks in limestone countries.

East of Sun Dance these sinks are numerous, and between Sun Dance and Inyan Kara they are met every few hundred feet, dotting the surface of the red clay.

In the valley of the Belle Fourche, from the vicinity of Bear Lodge to a point twenty miles northeast, the stream has cut its valley through the upper Red Beds, here somewhat elevated by the fading extremity of the uplift which produced the Hills. Above them the Jurassic strata are exposed in a similar manner and to a greater extent. The cut through the Red Beds is nowhere more than 200 feet deep, and the width of their outcrop is not greater than two miles. In some of the side branches and dry cañons, however, the Red Bed exposure penetrates the bluffs for a distance of several miles.

The following cross-section will give a fair idea of the structure of the Belle Fourche Valley:

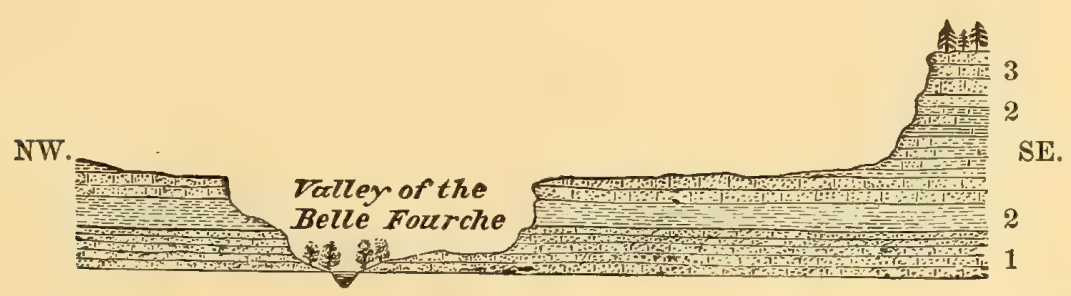

Fig. 24.-Section across the valley of the Belle Fourche near Bear Lodge.
1. Red Beds.
2. 2. Jurassic strata.
3. Dakota sandstone (Cretaceous).

The Red Beds are here so sandy as to form a tolerably coherent shaly sandstone, but in places they resume their usual clayey character. The following section, observed at the spot represented by the illustration, shows the strata from the summit of the lower plateau to the water of the river. 
Jura.

Feet.

4. Sandstone, yellowish, sometimes quite red; forming the floor of the lower plateau in Figure 24 ... . . . . . . . . . . . . . . . . . . . . . . . .

3. Clay or marl, gray or greenish, with a pink sireak near the middle; becoming in the lower 3 feet an impure shaly limestone, with many Jurassic fossils. Immediately above the latter layer there is considerable flinty matter....

Red Beds.

2. Sandstone, deep red, argillaceous and very shaly, containing a bed of gypsum

1. Sandstone, deep red, soft and shily, with several seams of gypsum in its upper 4 or 5 feet . . . . . . . . . . . . . . . . . . . . . . . to stream..

The red clays near the junction with the fossiliferous strata were observed to have a browner color than below. On the opposite side of the river the same fossiliferous strata were seen, and underneath them, below 60 feet of red clay, is a stratum 20 feet thick made up of seams of gypsum 1 foot thick separated by bands of clay, while below it are the red sandy clays of the section. Northward, down the river, the Red Beds retain the characters described. In some places they become so firm as to form the immediate banks of the river for considerable distances, rendering the crossing a matter of difficulty. Where they finally sink beneath the river they attain their depression by a gradual dip, and give place to the Jurassic strata, which in turn shortly dip under the river and are replaced by the lower Cretaceous series.

One other outlying outcrop of the Red Beds remains to be mentioned. It lies on the west base of Bear Butte, a few miles northeast of Crook City, and what little is known of its character is detailed in the description of Bear Butte in the section on the igneous rocks.

In conclusion, a brief notice may be given of the Red Beds or Trias in other portions of the Rocky Mountain region, for the sake of showing the more general relations of their development in the Black Hills.

A series of red beds, provisionally referred by most authorities to the Trias, is found on the eastern slope of the Rocky Mountains almost continuously from British America to Mexico, and in Indian Territory, Texas, and New Mexico it covers a large area of country. It occupies the same geological position as the series already described in the Black Hills, and is 
nearly always equally unfossiliferous. Its vivid color render's it a most conspicuous feature in the geological structure of the region, enforcing the attention of even the most casual observer. In thickness it ranges from scarcely 100 feet in some localities to 1,500 or 2,000 in others. Wherever exhibited it carries gypsum in greater or less quantity, and in the southwest it holds notable amounts of salt.

Near Abiquiu, N. Mex., and in Los Bronces, Sonora, the Red Beds are found to contain beds of coal, and associated with them a large number of fossil plants. These have been described by Dr. Newberry who pronounces them similar to the plants from the Triassic coal basin of Virginia and North Carolina and very like the Triassic plants of the Old World, with which many of the genera and some of the species appear to be identical. Fossil wood is also frequently found, and in Texas and New Mexico it is very abundant. It is often saturated with sulphide of copper, and in some regions this is found in such quantities as to have been worked in former times by the Spaniards as an ore of copper. At a locality in Southern Utah it is similarly saturated with silver ores. This fossil wood, however, is of little paleontological value, and, with the exception of the plant leaves just mentioned and a few molluscan forms announced within two or three years, the beds contain no proof of their age.

With this dearth of fossils the greater part of the evidence for considering them of Triassic age is derived from their occupying a position between unquestionable Carboniferous and Jurassic strata. In many cases, however, the Carboniferous is unrepresented where the Red Bed series occurs, and in a large part of its development in the Rocky Mountains the overlying Jura is either undistinguishable or wanting.

In Arizona near the Moqui villages Dr. Newberry found resting upon variegated marls of the Triassic series, and immediately underneath Cretaceous sandstones, a stratum of lignite containing fossil plants closely allied to Jurassic species of Europe.*

In eastern Colorado the series, according to Dr. Stevenson, underlies unconformably the Jura and Cretaceous, $\dagger$ and since along the eastern

- Ives Colorado Report, pp. 79-82.

t Survey West of the 100th Meridian, Vol. III, p. 379. 
range the Red Beds overlap greatly the Carboniferous rocks, they must be quite unconformable also to the Carboniferous.*

In central and northern Colorado the Red Beds have been carefully studied by the late Mr. Marvine, Dr. Peale, and others. They have there the normal red sandstone character, varying in thickness from 400 to 1,600 or 2,000 feet, and underlie Jurassic strata, but owing to a general absence or concealment of the Carboniferous they are found (almost as far north as the Union Pacific Railroad) to rest directly upon Archæan rocks. Mr. Marvine mentions that in the Middle Park region of Colorado the "development of the Carboniferous is far more marked, and consists principally of a second series of red beds of deeper purple hue than those referred to the Triassic," $†$ and that in their upper part Dr. Peale found leaves regarded by Professor Lesquereux as Permian. Northward the Red Beds are found on the flanks of the Laramie, Wind River, and Bighorn Mountains from Colorado to the British Possessions. North of the Platte they have not yet been critically examined, but it is known that a red arenaceous series underlies very fossiliferous Jurassic strata, and rests upon rocks of Carboniferous age.

In the Wasatch Mountains Mr. King, of the Fortieth Parallel Survey, finds the Trias to be composed of quartzites and silicious and dolomitic limestones capped by the typical red sandstones, and entirely unfossiliferous.

Mr. G. M. Dawson, of the British North American Boundary Survey, finds on the eastern flanks of the Rocky Mountains, on the 49th parallel, 300 feet of characteristically colored sandstones, which, by comparison with similar beds in the United States, he regards as of Triassic age.f

The interposition of the Red Beds between Jurassic and Carboniferous strata cannot be taken as positive proof of their Triassic age; but in the absence of evidence to the contrary it fully warrants their provisional assignment, and the case is strengthened by the fact that in certain parts of the Rocky Mountains an unconformity is found on the one hand between the

* Surveys West of the 100th Meridian, Vol. III, p. 499.

t United States Geological Survey of the Territories, 1873, p. 105.

$\ddagger$ Report on the Geology and Resources of the Region in the Vicinity of the Forty-ninth Parallel, B. N. A. B. Com., p. 71 . 
Carboniferous and the Red Beds, and on the other between the Red Beds and the Jura. In the Black Hills, however; no such unronformity is to be found.

\section{SECTION VII。}

THE J URA.

The Jurassic system, which is so largely developed in Europe, containing the remains of huge swimming and flying reptiles and holding immense deposits of iron ore that are the foundation of some of the largest iron industries in England and the Continent, is but sparingly represented in American geology, and none of the gigantic vertebrates have as yet been found here. For a long time the Trias of the Atlantic coast, especially in the coal basins of Richmond and North Carolina, was regarded by some of our most eminent geologists as in whole or part of Jurassic age, but that view is now abandoned, and the only developments of undoubted Jurassic rocks in our country lie west of the Mississippi.

The first determination of the formation in the Far West was made by Professor Meek from fossils collected in the Black Hills by Dr. Hayden in 1857, and the discovery was announced by Meek and Hayden in a paper published in the Proceedings of the Acadeny of Natural Science of Philadelphia in March, 1858.

The forms there made known are all molluscan, excepting one crinoid, Pentacrinus asteriscus, and are closely allied to species of the European Jura.

Since that announcement it has been found that the formation is very generally present in the Rocky Mountain system from the extreme north to New Mexico and from their eastern slope westward in the various ranges to the Wasatch. It is known, too, in the great interior basin and in the Sierra Nevada. For the most part, it has been identified by its fossil contents, but there are considerable districts where these guides are wanting and it has been traced merely by stratigraphical relations and lithological resemblances. In the mountain chains of the Northwest, the Laramie Mountains, the Wind River Mountains, the Bighorn Mountains, etc., it is often richly fossiliferous, but less so than in the Black Hills. In the Hills 
its strata from the base upward are well characterized by fossils, and, excepting on the eastern side, they occur in abundance.

The Jura of the Northwest has a very uniform character, consisting generailly of gray or ash-colored marls, marly or arenaceous limestones, and soft sandstones. The greatest thickness yet found is in the Wind River Mountains, where the formation is fully 1,000 feet thick, but elsewhere it ranges from 50 to 100 or 200 feet. In the southwest, however, in southern Nevada, Utah, Arizona, and New Mexico, though in places absent, it is found to range as high as 2,000 feet or even more. In the localities of its maximum development it is composed of highly colored marls, shales, and soft sandstone, with some limestone and considerable gypsum.

The Jura of the Black Hills consists primarily of gray or ash-colored clays or marls, with occasional bands of green and red. Interbedded with these are soft sandstones, more or less argillaceous, and a few restricted thin bands of impure limestone. The formation is so soft and weathers so easily that its outcrops are largely covered. by the talus of the overlying sandstone, and the exposures are generally imperfect. Its study was therefore not so satisfactory as that of the other formations; still, by combining the data gathered at many different points the general features were well made out.

The thickness of the formation in the main region of the Hills is about 200 feet, but it shows a remarkable increase toward the north and northwest, attaining in the Belle Fourche Valley a depth of nearly 600 feet. Its strata occupy the greater part of the inner slope of the foothills which form the outer rim of the Red Valley, and are overlaid by the heavy sandstone of the base of the Cretaceous, which everywhere forms the capping rock of the foothills. In the northwest, where the character and continuity of the foothills are somewhat interrupted by the Bear Lodge range, the Jurassic outcrop leaves the margin of the Red Valley and runs over to the Belle Fourche, where it encircles the outlying outcrop of the Red Beds.

On the north and west, and to a less degree on the south, the formation is well exposed and characterized by a greater or less abundance of fossils. On the southeast and east it is less plainly seen, being. usually 
covered by a broad talus, and so far as examined it was not found to be fossiliferous.

The relations of the Jura to the other formations of the Hills and the place it occupies in their physical structure are indicated in the figures that have besn given in the previous section to illustrate the structure of the Red Beds and the Red Valley.

Though it was examined in many places and with considerable care, it was found impossible to base any subdivision of the formation either on persistent lithological characters or on the distribution of fossil forms. There is no single bed that was recognized throughout the belt of exposure, and for the most part it was impracticable to correlate, bed by bed, any two sections.

But while the Jurassic strata vary indefinitely among themselves, they are always easily distinguished from the Red Beds. The change from the deep red clays below to the pale gray clays above is always abrupt, and the latter have a marly appearance never seen in the former. The heavy gypsum strata of the Red Beds are not found above, although the mineral is not entirely unrepresented. In a few places thin seams of a beautiful flesh-colored fibrous gypsum were found associated with thin limestone strata near the base of the formation.

The most marked single bed is a sandstone about 50 feet thick, usually of a yellow color, but sometimes quite red. On the Belle Fourche this is about 100 feet above the top of the red clays, and forms the floor of a rude platform or slope on the borders of the river, extending backward to the foot of the Dakota cliffs, which at base are formed of Jurassic strata and at top by the Cretaceous sandstone. Its area may be seen by referring to the geological map, for it underlies substantially all that part of the Belle Fourche Valley colored to represent the Jura. A similar stratum on the Redwater is probably equivalent to this; it is separated by 50 or 60 feet of yellowish shale from the red clays below. It is possible, also, that the same is represented by a thinner sandstone seen on the Beaver, 60 or 70 feet above the red clays; but in the remainder of the visited exposures it was not recognized.

It is usual to find this sandstone and others of the formation beauti- 
fully ripple-marked-an evidence of the shallowness of the water in which they were laid down.

The clays or marls do not appear to be more particularly confined to one part than another, though they perhaps are not so strongly developed in the extreme upper portion as in the lower two-thirds of the formation. Their colors are gray or drab and dull green, with an occasional streak of bright red or pink. They often contain seams of limestone more or less impure, and these are possibly more common in the lower portion of the formation. The limestones are frequently fossiliferous, but seem never to be more than a few inches in thickness, and do not constitute, so far as could be determined, continuous strata.

Everywhere a large proportion of the formation is composed of sandstones, which are usually light in color and even sometimes of a snowy whiteness. As a rule they are very soft or shaly, passing into sandy shales. Soft incoherent sands are met with at different points on the Redwater, which are probably the result either of the decomposition of soft fine sandstone or of the leeching of sandy clays.

Along the Redwater Valley, from Warren Peaks eastward to the Spearfish, there were found two horizons yielding fossils in abundance; one at 135 feet and the other at 350 feet above the Red Beds. The latter horizon is also well marked near Bear Lodge, but was not recognized elsewhere.

The meagerness and indefiniteness of this general description is due in part to the variability of the strata, and in part to the imperfection of the observations. The center of interest in the Hills was in the main body of the uplift, and what was learned of the periphery was acquired by radial excursions along the creek valleys. The Jura was crossed at a number of points, but it was not followed on its line of outcrop. Each observation is therefore isolated, and it will probably be best to put each one on record by itself. In the pages immediately following, the observed sections will be described in order, beginning with the point on Beaver Creek where the formation was first observed, and passing in succession to the south, east, and north sides of the Hills. 
The foothills on the west side of the east fork of the Beaver, for ten or fifteen miles north of Camp Jenney, reveal along their inner escarpment frequent exposures of the Jura, giving an excellent idea of the structure of the formation; and in various places abundant and characteristic fossils were found. The valley is at bottom an undulating and somewhat rugged surface of the brick-red clays of the Red Beds, and these in places form the base of the foothills. Between them and the Cretaceous sandstone at the top of the cliff the gray clays and sandstones of the Jura crop out at intervals. About ten miles north of Camp Jenney the following complete section was procured.

$$
\text { Cretaceous (No. 1). }
$$

Feet.

6. Sandstone, white and massive, forming the summit of the cliff...........

Jura.

5. Clays or marls, gray or greenish, with a streak of red clay near the middle;

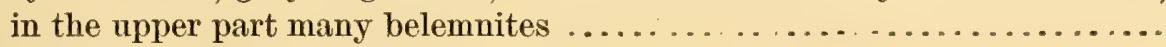

4. Sandstones, white and shaly, in places somewhat massive, ripple-marked; con-

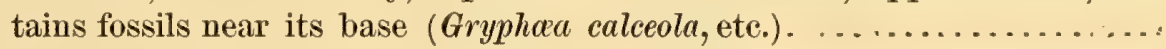

3. Clays or marls, brown or gray, with some gypsum; about 10 feet from base, in a thin and impure limestone, werefound a Gryphcea and ammonite fragments ... . . . . . . . . . . . . . . . . . . . . . . . . . . . . . . .

Red Beds.

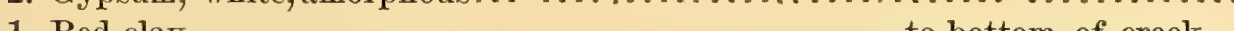
to bottom of creek. .

The following section was measured near Camp Jenney, on the northern side of the pass which Beaver Creek has opened through the foothills.

Cretaceous (No. 1).

6. Sandstone, yellow and white, somewhat lamellar, and containing ripple-marked surfaces . . . . . . . . . . . . . . . . . . . . . . . . .

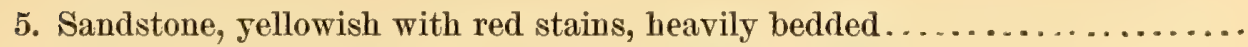

4. Sandstone, very white, fine-grained and massive, easily decomposing into fine white sand; forms a well-marked cliff, eaten into caverns and holes.....

Jura.

3. Covered by talus and not well exposed; at intervals outcrops of gray or greenish clays or marls, with occasional bands of limestone containing fossils;

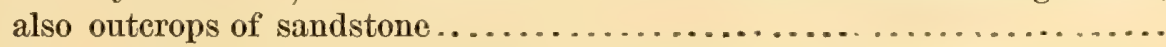

2. Marls or clays, gray and purple, with nodules of impure limestone; base

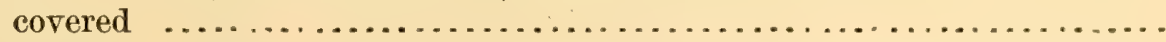

1. Marls or clays, gray and purple, with thin bands of impure limestone, containing fossils ............................. to base of cliff..
Feet. 50

100 
The base of the section is probably some little space above the base of the Jurassic series. On the opposite side of the creek the red clays with their inclosed gypsum occupy the bottom of the valley.

In several localities in the vicinity some thin seams of a purple fibrous gypsum were seen in the purple clays (2), but it exists in no great quantity and does not appear to be a persistent feature. The massive white sandstone (4) is extremely unlike the ordinary coarse and deeply colored sandstones of the Cretaceous. It is so very soft that it readily crumbles into a talus of exceedingly white and fine sand and it was not found at all coarse or conglomeratic, as is usual with the lower Cretaceous sandstones It is to such an extent intermediate in character between the Cretaceous rocks above and the Jurassic below, that its assignment to the upper formation is made with much hesitation.

In the Belle Fourche Valley a similar soft and white sandstone, about 50 feet in thickness, containing bands of pebbly conglomerate, was found separated from the overlying undoubted Cretaceous by 5 feet of an impure, dark calcareous shale.

At Camp Jenney two or three small hills stand in the Red Valley in front of the main range of the foothills. On the inner side of these hills are seen isolated exposures of the Jura, which are interesting by reason of the great abundance of Belemnites in the gray clays, and a recapitulation of the local section is therefore given.

\section{Crelaceous.}

3. Sandstone, capping the hill

\section{Jura.}

2. Clays or marls, greenish, grayish, and yellowish, with a streak of red; imperfectly exposed, and containing near the base great numbers of Belemnites

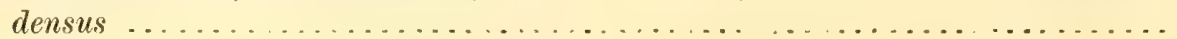

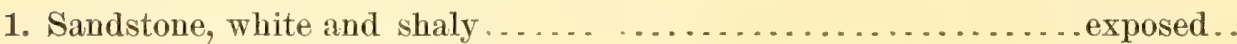

Then a grassed and undulating surface to the Red Beds and gypsum below, the base of the Jura being concealed.

The next examination was made on Red Cañon Creek, thirty-five miles south of Camp Jenney. The following section was observed in a small 
butte near the foothills and on the west side of the creek. It gives but a small part of the Jurassic series and that at the base.

Jura.

5. Sandstone, white, somwhat lamellar, and filled with ripple marks, containing at its base a very impure calcareous layer with abundant fossils . .......

4. Marl or clay shale, gray in color, with no fossils . . . . . . . . . . . . . .

3. Sandstone, white, soft, and somewhat lamellar at base..............

Feet.

Red Beds.

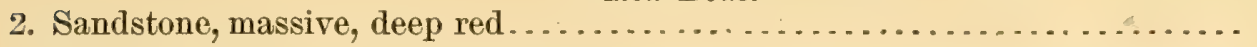

1. Red shaly sandstone changing into red shale and finally passing into red clay

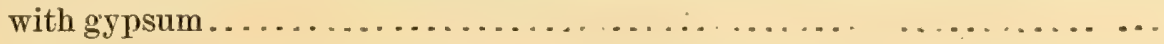

The red sandstone (2) belongs undoubtedly to the Red Bed series, which is in this part of the Hills very arenaceous, having many bands of sandstone interstratified with the clay and frequently becoming in considerable bodies a massive, though soft sandstone. The change is often sudden from a soft and plastic red clay to a soft and massive red sandstone.

To the northeast of the last section, and within two or three miles, complete exposures were obtained of all the strata of the Jura from base to summit. The following is the section:

Cretaceous (No. 1).

10. Sandstone, reddish and yellowish, massive; showing at base a small stratum

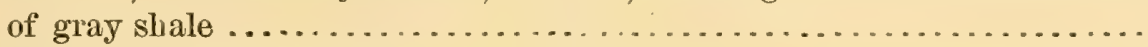

9. Sandstone, not well exposed. . . . . . . . . . . . . . . . . . . .

Feet.

Jura.

8. Red saudy clay or shaly sandstone, quite soft, with bands of more massive but soft sandstone. . . . . . . . . . . . . . . . . . . . . . . . .

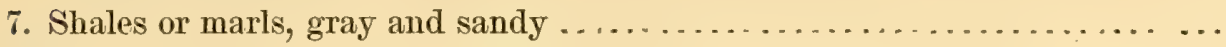

6. Sandstone, white, containing near its base a calcareous layer, with fossils similar to those in 5 of last section (with which stratum this is equiva-

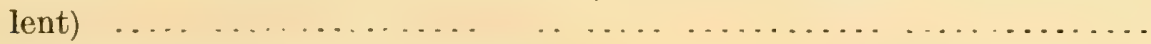

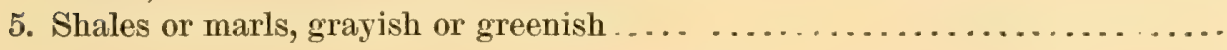
150

Red Beds.

4. Sandstones, soft and massive; upper 10 feet white and shaly, lower part

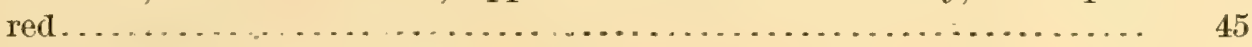

3. Red shales, changing to red clay ........................... 170

2. Gypsum, white and massive ................................ 10

1. Red clay, containing much gypsum, in thin ramifying seams; to valley of

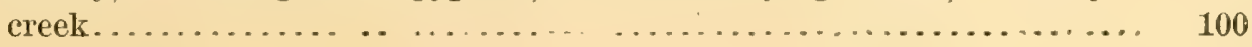


The next detailed examination of the formation was on Amphibious Creek, near the cañon by which it passes the Cretaceous ridge or "foothills." The following section was measured:

$$
\text { Cretaceous (395 feet exposed). }
$$

16. Sandstone, capping hill; massive, white, stained yellowish and reddish. 300

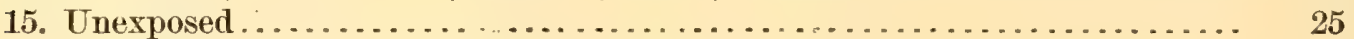

14. Sandstone, soft and massive; pinkish in color................... 70

\section{Jura $(234$ feet $)$.}

13. Mostly concealed, a talus overlying soft rocks which at base appear to be a

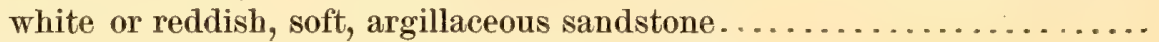

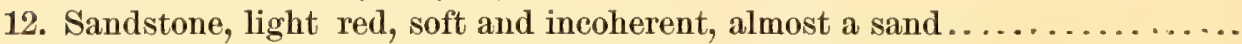

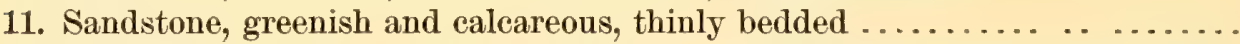

10. Sandstone, white or greenish, in thin layers (8-10 inches), with many ripple

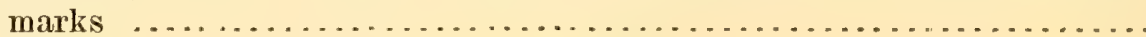

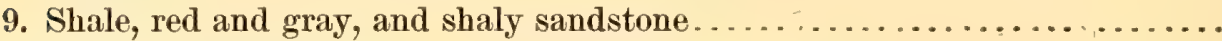

8. Shale, red and gray.................................... 5

7. Sandstone, red and pink; soft at bottom, hard above; with ripple marks... $\quad 8$

6. Sandstone, yellowish, greenish, reddish, a thin brecciated band......... 10

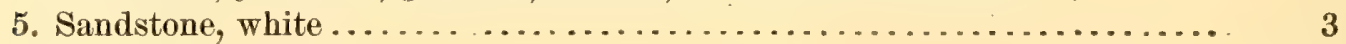

Red Beds (255 feet exposed).

4. Clay, deep red.......................................... 50

3. Gypsum ............................................... 10

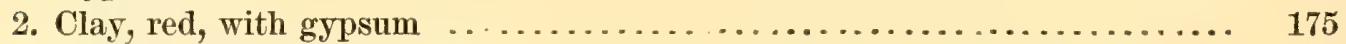

1. Limestone, pink or purple ................................ 20

The Jura was recognized in this section by certain of its beds, but in the absence of fossils it is hard to say where the separating lines should be drawn. Taking the demarkation here made the formation has a total of 234 feet, a much greater thickness than was found on Red Cañon Creek, twenty-five miles to the westward. It will also be noticed that the arenaceous materials are here more than usually predominant.

At Buffalo Gap, the pass by which Burntwood Creek breaks through the foothills, the exposures of the Jura are very imperfect. On lower French Creek and on lower Spring Creek observations were equally unsatisfactory. Occasional outcrops of the yellow and drab clays and soft sandstones were seen, but no continuous section was anywhere attainable, and the rocks appeared to be entirely barren of organic remains. Near Rapid and Box Elder Creeks and north of the latter, frequent exposures of the 
grayish marls were seen, and at one place in the valley of the Red Beds, where there had been a local uplift, the summit of the red clays, with a bed of gypsum 6 feet in thickness, was found to be overlaid conformably by 25 feet of greenish and reddish marls and shales and yellow sandstone-a relation similar to that already described on the western side of the Hills. At the pass of Rapid Creek through the foothills, the cliffs are capped by a heavy bed of the Dakota coarse sandstone, about 25 feet thick, stained deeply red and containing many ferruginous masses. Below this sandstone are about 200 feet of poorly exposed Jurassic beds resting upon the red gypsiferous clays of the Red Beds. The Jurassic beds consist in their upper part of shaly and soft sandstones, with clays or marls, and have below a greater thickness of greenish, drab and yellow marls or clays, with some streaks of deep red, and a snowy white stratum of very soft, argillaceous sandstone. This sandstone appears to be some 80 or 90 feet in thickness, and can be traced by its vivid whiteness several miles northward along the foothills. It weathers readily somewhat like a clay, and is probably a local variation of some of the argillo-arenaceous beds of the formation.

Near the pass of Box Elder Creek these same beds are seen in fragmentary exposures. At the pass of Elk Creek through the foothills, beneath the usual capping of coarse sandstone, here 300 feet in thickness, there are exposed about 175 feet of gray or greenish clays or marls containing considerable limestone in thin bands but no fossil remains. In the pass of the north branch of Bear Butte Creek there is a repetition of nearly the same facts: a capping of Dakota sandstone, here 15 feet in thickness, underlaid by 50 feet of dark gray and greenish marls or clays with a three-foot seam of argillaceous limestone, and then a grassy slope with no exposures to the red clays of the Red Valley below.

From this place around the northeast corner of the Hills to the valley of Spearfish Creek occasional outcrops of the drab clays are seen, but they present no good exposition of the structure of the formation and the notes on their exposures are scarcely worthy of quotation.

In the center of the Red Valley, two miles east of Spearfish Creek, rises a prominent butte, Joe Peak, capped by Cretaceous sandstone and 
based upon the Red Beds. The section is imperfect, but is added here to illustrate the thickness and character of the formation in this part of the Redwater Valley.

\section{Cretaceous.}

7. Sandstone, yellow, coarse and massive, fine grained; conglomerate at base..

Jura.

6. Talus, overlying (probably) beds of a soft nature . . . . . . . . . . . . . . 310

5. Sandstone, white and red. . . . . . . . . . . . . . . . . . . . . . . 15

4. Sandstone, yellow, soft; containing calcareous bands 2 or 3 feet thick..... 25

3. Clays or marls, greenish or gray ......................... 55

Red Beds.

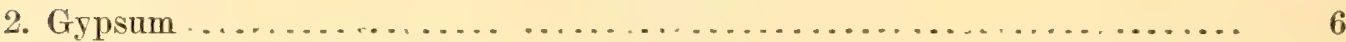

1. Clay, deep red, with gypsum ................... to level of creek...130

Assuming that the talus (6) is underlaid entirely by Jura, which seems to be the case, the section gives a thickness of 400 feet to the formation, and this, though greater than on the eastern side of the Hills, does not surpass the thickness found a few miles north on the Redwater. As may be seen by referring to the geological map the Redwater Valley widens out greatly west of Spearfish Creek, exhibiting the great development of the Red Beds so frequently mentioned in the discussion of that series. As the result of a study of the Jura in the foothills on the northern side of Redwater Creek a number of excellent sections were obtained by Mr. Jenney and Mr. Patrick which will relieve the monotony of the record of imperfect exposures on the eastern side of the Hills and illustrate the fine development of the formation on the northern. Here, too, the Jurassic is quite fossiliferous, especially in two horizons, as will appear by the sections. Referring again to the geological map it will be seen that the foothills approach the Spearfish from the east, and turning northward follow its east bank for some distance. Then crossing the Deepwater, they run nearly westward for twenty miles, keeping parallel to the course of the Redwater. The southern flanks of the foothills and frequently a considerable portion of their summits are composed of Jurassic strata, and these are overlaid by the Dakota sandstone which either caps the bluffs or appears at some little distance on the northward slopes. Fragments of the Jurassic rocks, with or without the cap of Cretaceous, are found in isolated buttes in 
the Red Talley, the sole representatives of the former wide-spread distribution of those formations. Of this character is the butte near Spearfish, a section of which has already been given.

On the east side of Spearfish Creek, some two or three miles north of the section last given, the following measurements were made by Mr. Jenney on the escarpment of the foothills.

\section{Cretaceous.}

9. Sandstone, massire, rellow; the Dakota sandstone................. Feet. 75

$$
\text { Jura }(340 \text { feet }) \text {. }
$$

8. Unexposed ....................................... 50

7. Sands and sandy shales, with a few fossils near the top............. 120

6. Sandstone, soft, crumbling and pinkish; weathering to a loose reddish sand. $\quad 60$

5. Sandstone, massire, yellow and pink; laminated with laýers of different shades of red; containing a few star-fish impressions............. 40

4. Sand, yellow .............................................. 70

Red Beds (exposed 245 feet).

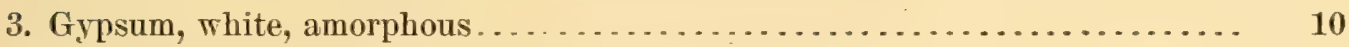

2. Sandstones and sandy clays, deep red; with gypsum.............. 220

1. Limestone, pink ........................................ 25

The "sands" mentioned in this and the following sections are fine and light colored, produced probably by the decomposition of a friable sandstone, but a little digging into the outcrop failed to discover a coherent rock.

Westward along the foothills on the north side of the Redwater the Jura is shown by frequent exposures to occupy the greater portion of the height of the cliffs, though the red clays encroach more or less upon their lower part, while the summits are usually capped by the Dakota sandstone. The dip of the strata is slight, commonly only $5^{\circ}$ or $10^{\circ}$, and in direction a little east of north. About ten miles west of the junction of Redwater and Spearfish Creeks (forming the Deepwater) the following: section was obtained by Mr. Jenney:

Jura.

7. Sandstones, soft, pink, decomposing to a reddish sand ...... Feet.

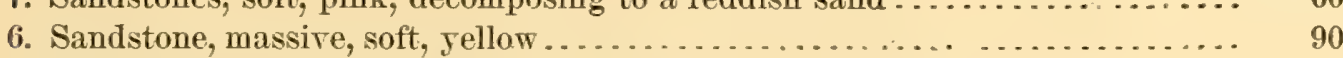

5. Shaly sandstones, Jellow in color, containing a few easts of mollusks ...... 20

4. Sandstone, lamellar, white and erumbling ..................... 10

3. Clays or marls, white and gray, full of Belemnites in the upper portion..... 70 $11 \mathrm{~B} \mathrm{H}$ 
Red Beds.

2. Gypsum, white and amorphous ............................. 3

1. Red clays, and red sandy clays .................... to base of hill.. 50

This section represents only the lower portion of the Jura. In the following section, observed by Mr. W. F. Patrick two miles farther west, the upper portion is better represented:

Jura (410 feet exposed).

10. Clas, white and purple; capping the bluff . .

9. Sandstone, lamellar and yellow; upper layers hard and brown......... 30

8. Sands, argillaceous, yellow and greenish, with layers of a calcareous sandstone full of fossil mollusks-Belemnites, Ammonites, ete ............ 35

7. Sandstone, white, massive and soft ......................... 20

6. Sands or sandy marls, white and caleareous, with Belemnites ............ 80

5. Sandstone, pinkish (the same as the summit of the last section) passes into Bed 4 . . . . . . . . . . . . . . . . . . . . . . . . . . . . . 60

4. Sandstone, yellow and massive ................................ 90

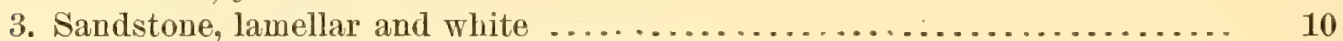

2. Clay, white and gray, with sandy clays....................... 50

Ren Beds.

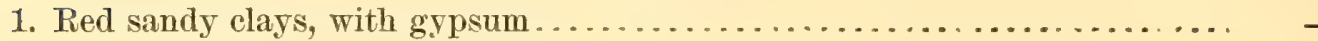

In this section the capping Dakota sandstone is wanting, but appears some distance down the northern slope of the foothills. The clay at the summit of the section is shown by a comparison with other sections to be very nearly the extreme upper portion of the Jura, so that the total of 410 feet represents very closely the full force of the formation at this point. The bed numbered 8, about 350 feet above the Red Beds, is a marked fossil-bearing horizon of the Jura in the Redwater and Belle Fourche Valleys; it has yielded a large collection, in which Professor Whitfield has described or identified-

Ostrea strigilecula.

Camptonectes bellistriatus.

Astarte fragilis.

Trapezium Bellefourchensis.

Tancredia inornata.

Tancredia corbuliformis.
Tancredia bulbosa.

Tancredia postica.

Dosinia Jurassica.

Saxicava Jurassica.

Ammonites cordiformis

Belemnites densus. 
One hundred and thirty-five feet above the same datum there is another horizon, distinguished in the northern part of the Hills by its numerous fossils, and in the following section, made by Mr. Patrick, one or two miles west of the last section and immediately north of the forks of the Redwater, its position in relation to the underlying strata is well shown:

Jura.

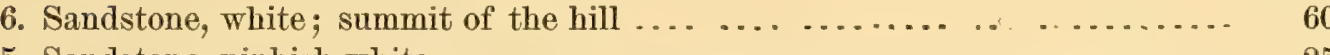

5. Sandstone, pinkish white.................................. 25

4. Sandstone, yellow and white, interstratified with sandy shales; a layer near the top $1 \frac{1}{2}$ inches thick ( 135 feet above the Red Beds) was found to be

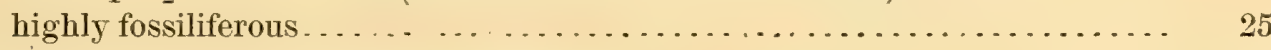

3. Sandstone, white, but reddish in places . ...................... 50

2. Clay, or clay shales, greenish ............................ 60

Red Beds.

1. Gypsum and red clays to valley

The same horizon (4) was found to carry many fossils in the exposures near Crow Peak.

The following section was observed by Mr. Jenney in a butte which stands in the Red Valley two or three miles south of the forks of the Redwater:

Jura.

Feet.

6. Sandstone, massive, of a yellowish brown color $\ldots \ldots \ldots \ldots \ldots \ldots \ldots \ldots . . . \ldots$

5. Shales or clays, argillaceous and silicious...................... 30

4. Conglomerate; pebbles cemented by lime; containing a few fragments of molluscan fossils........................................ 3

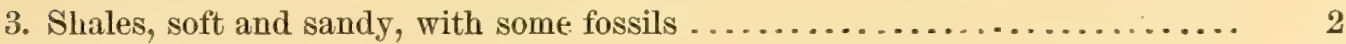

2. Clay, gray ............................................ 20

Red Beds.

1. Red clays

Southwest of Sun Dance Hills and west of Inyan Kara there is an inclining plateau cut into parallel ridges which run northwest and southeast, parallel with the course of Inyan Kara Creek. These were not examined critically, but many of them are capped with the Cretaceous sandstone, below which are the Jurassic strata, while others consist almost entirely of the Jurassic. They are a direct continuation of the foothills on the Beaver, but here, owing to the low angle of dip, they spread out and 
occupy a broader area. Southwest from Sun Dance Hills, and between them and the foothills, many fragmentary portions of the Jura are seen in the Red Valley.

Following the Jurassic outcrop westward and northwestward to the valley of the Belle Fourche one finds there the greatest vertical development of the formation in the Black Hills country. Around the main portion of the Hills its thickness, so far as ascertained, is 200 to 300 feet; along the Redwater Valley it is a little more than 400 feet, and on the Belle Fourche between 500 and 600 feet.

If the reader will refer to Figure 24 he will readily understand the structure of the Belle Fourche Valley in the vicinity of Bear Lodge. In the lowest part is the immediate valley or bottom of the river, carved from the Red Beds. On each side of this rises a bluff, showing Red Beds at base and Jura above. Above the bluff is a terrace on each side, floored by the local hard sandstone of the Jura. Back of this (on each side, though represented on one only) is a second bluff or cliff exhibiting Jurassic strata at base and Cretaceous at top. The strata are arched in a direction at right angles to the line of section, so that if one follows the river far enough in either direction he will find the Jurassic terrace to gradually descend until it finally dips entirely beneath the water level. Where this takes place the cliffs capped by the Cretaceous approach the stream so closely that they are separated only by the bottom land.

In the illustration the vertical scale is greater than the horizontal. In reality the face of the lower cliff is 300 feet high and the face of the upper about 500; the river bottom is one or two miles broad and the terrace three or four miles. It must not be understood that the terrace is regular and continuous. It is indented by numerous lateral valleys and on the divides between them salients of the upper cliff encroach more or less on its area.

On the east side of the Belle Fourche, about four miles southeast from Bear Lodge, the following section was made, beginning with the summit of the cliffs and their capping of Cretaceous sandstone, and showing the entire thickness of the Jura: 
13. Sandstone, yellow, with red stains, containing strata of coarse conglomerate.

12. Shales, dark gray, calcareous; with impure limestone ..............

11. Sandstone, very soft and white, near top pinkish; massive in places; contains

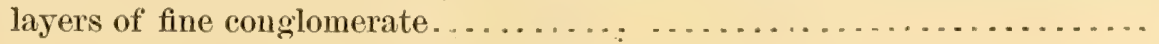

Jura (580 feet).

10. Clay or marls, yellow, greenish, and gray, sometimes sandy, with streak of

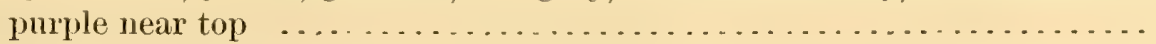

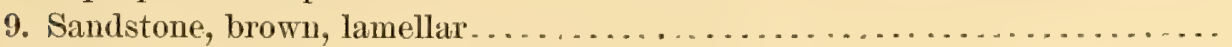

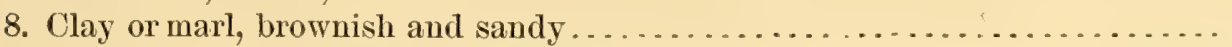

7. Limestone, thin stratum, very fossiliferous; from its equivalent in the vicin-

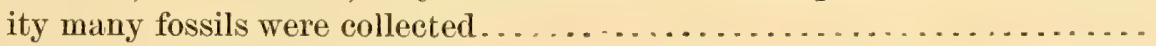

6. Clay or marl, yellow; with red sandy clay at base; exposures not complete.

5. Sandstone, jellow, in places quite red, shaly at the top butlower part massive. 50-75

4. Clay or marl, gray and greenish, with pink streak near the middle; calcareous at base, with much flint; in an impure limestone occur many fossils....

Red Beds.

3. Sandstone, red and soft, with much gypsum . . . . . . . . . . . . . .

2. Gypsum in layers of 12 inches, interstratified with red sandy clay for a space of. ............................................. 15-20

1. Sandstone, or sandy elay, soft, red ................ to bed of rirer.. 150

No. 11 in this section will be seen to correspond in position and character with a sandstone in the section on Beaver Creek, and it is included in the Cretaceous, although it has not the common character of the Dakota sandstone. The fossiliferous stratum (in 7) is probably the same as the upper fossiliferous stratum of the Redwater section. That stratum is 350 feet above the Red Bed; this, in a thicker series, is 50 feet higher. The Belle Fourche locality yielded-

Ostrea strigilecula.

Avicula mucronata.

Trapezium Bellefourchensis.

Pleuromya Newtoni.

Tancredia inornata.
Tancredia corbuliformis.

Tancredia bulbosa.

Tancredia postica.

Dosinia Jurassica.

Ammonites cordiformis.

At the base of the yellow calcareous clays (4) forming the bottom of the Jurassic series there is a calcareous layer containing many fossils. Among them are-

Ostrea strigilecula.

Camptonectes bellistriatus.

Pseudomonotis curta.

\section{Psammobia prematura}

Belemnites densus. 
It will be remembered that a similar fossiliferous layer was found on Red Cañon Creek, resting, as here, immediately upon the red clays of the gypsiferous Red Beds. The list of species at that locality is nearly the same.

From the southern end of the Hills, where the thickness of the formation is about 200 feet, there is a great thickening toward the north and northwest, reaching on the Belle Fourche a maximum of nearly 600 feet. There seems to be no reasonable cause for suspecting that this thickening is only apparent and is due to errors of observation. The possibility of errors of mensuration is negatived by the fact that independent measurements in the same neighborhood were always found to agree as closely as was to be anticipated. Nor is it credible that any appreciable error was made in tracing out and identifying the lines of demarkation by which the formation is separated from the Dakota sandstone above and the Red Beds beneath. Each of these lines represents a definite lithological change and could readily be recognized at every point. There was some hesitation in the selection of the point of separation between the Jura and the Cretaceous, but when it was once selected at one place there was no difficulty whatever in finding it at any other place.

The cause of this thickening toward the northwest is not fully understood, but it is probably a normal increase of depth in the direction of the source of the material which formed the sediments. East of the Black Hills the formation is not known. At the southeast end of the Hills area it is 200 feet thick; at the north end 410 feet; and thirty miles west of the north end 580 feet. Dr. Hayden found in the Bighorn Mountains (one hundred and twenty miles west of the Black Hills) a thickness of 800 to 1,000 feet, and Professor Comstock makes the same report of the Wind River Mountains.

North of the Uinta Mountains in the various ranges of the Rocky Mountain chain the Jura is well marked by abundant and characteristic fossils, from which considerable collections have already been made, and the same is true of the Black Hills. But to the southward very few fossil forms are known and their localities are rare. In like manner the rocks 
which compose the Jura in the northern Rocky Mountains are very similar to their representatives in the Hills, differing chiefly by carrying more carbonate of lime, while at the south a considerable portion of the formation assumes the habit of the Red Beds, abounding in vivid colors and carrying large quantities of gypsum.

The close of the Jurassic age witnessed great continental and orographic changes in what is now the western part of the continent. The Sierra Nevada was uplifted and so were the ranges of the great interior basin, and the continent was so elevated that the succeeding Cretaceous made no deposit between the east side of the Wasatch and the west side of the Sierra Nevada. In the Mississippi Valley, too, there must have been elevation and erosion either then or before, for Trias and Jura are absent and the Cretaceous rests on a worn surface of Carboniferous. But in the region of the Black Hills there was no emergence. The Dakota sandstone rests in perfect conformity on the Jura, and although the change in the character of the sediments is great, it is not abrupt. Probably in the magnitude of the change from soft calcareo-arenaceous clays below to coarse-grained sandstone above we have the only local evidence of the revolutions of the time.

The physical conditions which prevailed during the deposition of the Jura were a continuation of the shallow water of the Triassic age, with probably a somewhat deeper submergence. The marine type of the fossil forms indicates that there was a free communication with the ocean, and hence that the period was one of a shallow marine submergence over the Rocky Mountain area.

The fossil fauna of the European Mesozoic (Trias, Jura, and Cretaceous) includes so many species and individuals of huge aquatic reptiles and the reptilian type characterizes so largely the vertebrate remains, that the age is known as the Reptilian age. The saurians seem to have reached their maximum development during the Jura, though they are also found abundantly in the older Trias and the later Cretaceous. In the American Trias of the East have been found those great foot-tracks of the Connecticut Valley, now considered to have been made by huge batrachians; but in the Jura of the Far West no vertebrate remains have yet been discovered, 
excepting a single crocodilian bone found in the Uinta, Mountains. Among plants the European Jura has yielded an abundance of remains of ferns, conifers, and cycads, bearing a great similarity to the fauna of the Trias; but in America no undoubted Jurassic plants have yet been found. The plants from the Moqui region described by Dr. Newberry are regarded by him as not distinctive enough to decide whether they are Triassic or Jurassic, though they are of Mesozoic types and probably Jurassic.

The following list contains the invertebrate species that have been described from the Jura of the Rocky Mountain region up to and including the year 1876. Those marked (*) have been obtained from the Black Hills:

*Ammonites cordiformis.

*Ammonites Henryi.

Astarte arenosa.

* Astarte fragilis.

* Astarte inornata.

* Asterias dubium.

*Avicula mucronata.

*Belemnites densus.

* Camptonestes bellistriatus.

* Camptonectes extenuatus.

Camptonectes pertenuistriatus.

Camptonectes platessiformis.

Camptonectes stygius.

*Dosinia Jurassica.

* Gervillia recta.

* Grammatodon inornatus.

Gryphcea calceola.

Lima occidentalis.

* Lingula brevirostris.

*Lioplacodus veturnus.

Modiola subimbricata.

* Myacites Nebrascensis.

Myacites subcompressa.
Myophoria lineata.

*Mytilus Whitei.

Natica Lelia.

* Necara longirostris.

Neritina Powelli.

* Ostrea Engelmanni

Ostrea procumbens.

* Ostrea strigilecula.

*Pecten Newberryi.

*Pentacrinus asteriscus.

*Pholodomya humitis.

Pholadomya Kingii.

* Planorbis veturnus.

*Pleuromya Newtoni.

* Protocardium Shumardi.

* Psammobia prematura.

* Pseudomonotis curta.

* Pseudomonotis orbiculata.

Rhynchonella gnathophora.

*Rhynchonella myrina.

Septocardia carditoidea.

Septocardia typica.

* Saxicava Jurassica. 
*Tancredia aquilateralis.

* Tancredia bulbosa.

* Tancredia corbuliformis.

* Tancredia inornata.

* Tancredia postica.

* Tancredia Warrenana.

* Thracia arcuata.

* Thracia sublevis.

* Trapezium Bellefourchensis.

* Trapezium subequalis.
*Trigonia Conradi.

Trigonia Montanaensis.

Trigonia quadrangularis.

* Unio nucalis.

Unio Stewardi.

*Valvata scarbrida.

*Viviparus Gilli.

Volsella formosa.

Volsella isonema.

*Volsella pertenuis.

Trigonia Americana.

S F CTION VIII.

THE CRETA CEOUS.

The rocks of the Cretaceous system surround the Black Hills in an annular rim of irregular width; and this by means of a belt following the valley of the Cheyenne is connected with the great Cretaceous exposure of the upper Missouri. Beyond the border of Cretaceous on the south and southeast of the Hills stretch the White River Tertiary deposits which occupy a large area; while on the west and on the north lie the deposits of the Lignitic or Fort Union Tertiary, extending in one direction to the Wind River Mountains and in the other to our northern boundary and beyond.

The Cretaceous of the Far West underlies a vast area east of the mountains, reaching from beyond the Canadian line on the north into Mexico on the south; and though its deposits are found nowhere within the great interior basin, they extend from the southern part of the Plains westward into New Mexico and Arizona, and thence northward into Utah and Colorado, following around the southern end of the main spurs of the Rocky Mountains, as though in Cretaceous time the mountain chains had already received their definition and the Cretaceous sea laved only their outer slopes. A little north of the Black Hills the Cretaceous occupies a broad synclinal slope, with a width, from the Rocky Mountains to 
the western part of Minnesota, of over six hundred miles; but farther south the width diminishes. The greater portion of this slope, which underlies almost the entire area of the Great Plains, is covered and concealed by the more recent deposits of the Tertiary, but the continuity of these beds has been interrupted by erosion along some of the principal river valleys and by uplifts like that of the Black Hills.

The western margin of the Cretaceous area is revealed and readily studied where the edges of its composing strata are upturned against the foot-slopes of the Rocky Mountains, while the eastern margin, with a gentler dip, outcrops through eastern Dakota and western Minnesota, eastern Nebraska, and western Kansas. The two are joined in central Colorado.

There are few of the formations of the western rock system that have been so extensively and thoroughly studied as the Cretaceous, and none that can vie with it in the richness, abundance, and beauty of its fossil remains. Our knowledge of it begins with the explorations of Lewis and Clarke, and has been extended by subsequent expeditions, as related in the first chapter of this report. In 1853, Mr. Meek and Dr. Hayden were sent by Professor Hall, of Albany, to make collections of the Cretaceous and Tertiary fossils of the bad lands on the White River. They brought back a large collection of vertebrate rernains from the bad lands and Cretaceous fossils from the Cheyenne and Sage Creek region, as well as from various points on the Missouri below Fort Pierre. As a result of their exploration, the first attempt was made by Mr. Meek to group the different members and form a general section for the Cretaceous rocks of the West. This section appeared in a paper by Hall and Meek, entitled "Descriptions of new Cretaceous fossils from the Cretaceous of Nebraska," which was published in the Memoirs of the American Academy of Arts and Sciences in 1854. The thicknesses of the different divisions were given by estimate, and have been modified by later work, but the order of sequence is essentially the one now received, and because of its historical interest the section is given below. 
SECTION OF THE MEMBERS OF THE CRETACEOUS FORMATION, AS OBSERVED ON THE MISSOURI RIVER AND THENCE WEST'WARD TO THE MAUVAISES TERRES.

Tertiary formation.

Clays, sandstones, etc., containing remains of Mammalia. The entire thickness of this formation in the bad lands is firom 25 to 250 feet.

\section{Cretaceous Formation.}

Feet.

5. Arenaceous clay, passing ínto argillo-calcareous sandstones ............

4. Plastic clay, with calcareous concretions, containing numerous fossils. This is the principal fossiliferous bed of the Cretaceous formation upon the upper Missouri... .................................. 250-350

3. Calcareous marl, containing Ostrea congesta, scales of fishes, etc ... . . . . 100-150

2. Clay, containing a few fossils . ... . . . . . . . . . . . . . . . . . . . 80

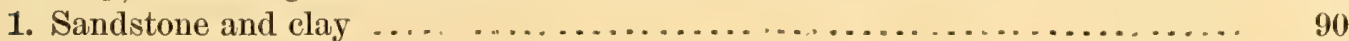

Subsequently the country was visited by Dr. Hayden alone and afterwards in connection with the reconnaissances of Lieutenant Warren and Captain Raynolds. From these various explorations the Cretaceous became better known, and much new material was published by Meek and Hayden at various times, including descriptions of new fossils and revisions of the above section, until in their joint paper of December, 1861 (Proc. Acad. Nat. Sci. Phila.) their final subdivision of the Cretaceous in the West was presented, with the geographical names which remain now the accepted nomenclature of the formation in the Northwest.

The following is their section of the Cretaceous of the upper Missouri country, as given in Professor Meek's Invertebrate Paleontology of the United States Geological Survey of the Territories, with the addition of a short synopsis of the character and estimated thickness of the different groups as they were found around the Black Hills; the divisions are given in descending order.

\section{No. 5.-Fox Hills group.}

Gray, ferruginous, and yellowish sandstone and arenaceous clays, containing Belemnitella bulbosa, Nautilus Dekayi, Placenticeras placenta, P. Tenticularis, Scaphites Conradi, S. Nicolleti, Baculites grandis, Pyropsis Bairdi, Piestochilus Culbertsoni, Pyrifusus Newberryi, Auchura Americana, Pseudobuccinum Nebrascense, Mactra Warrenana, Cardium subquadratum, and a great number of other molluscan fossils, together with the bones of Mosasaurus Missouriensis, ete.

Localities.-Fox Hills, near Moreau River; near Long Lake, above Fort Pierre; along the base of the Big Horn Mountains, and on North and South Platte Rivers.

Thickness, 500 feet. 
Black Hills.-Well exhibited on the western side of the Hills on the Cheyenne River near (east of) Old Woman Fork, where it is represented by ferruginous sandstones with Veniella humilis, Sphariola transversa, Idonearca Shumardi, ete. Not well distinguished on the eastern side; appears lithologically almost inseparable from No. 4.

On the Cheyenne in the vicinity of Rapid Creek, below the base of the Tertiary deposits, occurs a gray or brown clay with occasional variegated strata, pink, reddish, or ash-colored, containing large quantities of iron in irregular seams. This has a thickness of about 30 feet, and below it was found the gray clay with calcareous concretions filled with forms characteristic of No. 4, but with some also of those peculiar to No. 5 . Besides this deposit the highest well-marked strata of the Cretaceous observed on the eastern side of the Hills are the plastic clays of No. 4, which occupy by far the larger portion of the valleys of the Belle Fourche and South Fork of the Cheyenne. North of the Cheyenne No. 5 is reported to exhibit its usual characters.

Paleontologically No. 4 and No. 5 are not well distinguished on the eastern side of the Hills; the fauna appears to show a blending of the forms elsewhere found peculiar to each formation.

Thickness, roughly estimated, 100 feet.

$$
\text { No. 4.-Fort Pierre group. }
$$

(a) Dark-gray aud bluish plastic clays, containing, near the upper part, Nautilus Dekayi, Placenticeras placentu, Baculites ovatus, B. compressus, Scaphites nodosus, DentaTium gracile, Crassatella Evansi, Cuculloa Nebrascensis, Inoceramus Sagensis, I. Nebrascensis, I. Vunuxemi, bones of Mosasaurus Missouriensis, ete.

(b) Middle zone, nearly barren of fossils.

(c) Lower fossiliferous zone, contuining Ammonites complexus, Baculites ovains, $B$. compressus, Heteroceras Mortoni, H. tortum, H. umbilucatum, H. cochleatum, Ptychoceras Mortoni, Odontobasis vinculum, Anisomyon borealis, Amauropsis paludiniformis, Inoceramus sublavis, I. tenuilineatus, bones of Mosasaurus Missouriensis, etc.

(d) Dark bed of very fine unctuous clay, containing much carbonaceous unatter, with veins and seams of gypsum, masses of sulphuret of iron, and numerous small scales of fishes. Local; filling depressions in the bed below.

Localities.-(a) Sage Creek, Cheyenne River, and on White River above the Mauvaises Terres. (b) Fort P'ierre and ont to Bad Lands; also down the Missouri on the high country to Great Bend. (c) Great Bend of the Missouri below Fort Pierre. (d) Near Bijou Hill, on the Missouri.

Thickness of the whole group, 700 feet. 
The Fort Pierre is the most important of the divisions of the Cretaceous in the Northwest, alike in the extent of its development, in its influence on the character of the country, and in the great abundance and beauty of its fossils. In the number of its fossils it surpasses all the other Cretaceous groups collectively. Its clays lose by wetting their laminated structure and become adhesive and pasty, and then by drying become hard and crumbly, and split or crack from the surface to a depth of several inches. There is something in its physical or chemical constitution inimical to vegetation, and over large areas it wears a peculiar black and barren appearance, scarcely relieved by a shred of vegetable life. In other regions, however, the surface supports an excellent growth of grass.

Black Hills:-The group is well exposed on Old Woman Fork near the Cheyenne, and it exhibits there in its fossils a blending with No. 5. It is in general plainly recognizable entirely around the Hills. It constitutes the chief Cretaceous exposures on the Belle Fourche and South Cheyenne from their junction upward to the vicinity of the uplift, and appears again on the South Cheyenne near the mouth of Beaver Creek.

The upper fossiliferous zone is well exposed along the South Cheyenne from Rapid Creek downward, and near the mouth of that creek its characteristic fossils occur in great profusion. They are found in calcareous concretions or nodules, often of very large size. Sage Creek and Bear Creek, which enter the river nearly opposite the mouth of Rapid Creek, are rendered classic by the collections of Meek and Hayden.

Thickness, estimated, 150 to 250 feet.

\section{No. 3.-Niobrara group.}

Lead-gray calcareous marl, weathering to a yellowish or whitish chalky appearance above. Containing large scales and other remains of fishes, and many specimens of Ostrea congesta attached to fragments of Inoceramus; also several species of Textularia. Passing down into light, yellowish, and whitish limestone, containing great numbers of Inoceramus problematicus, I. pseudo-mytiloides, I. aviculoides, and Ostrea congesta, fish scales, ete.

Localities.-Bluft's along the Missouri below the Great Bend, to the vicinity of Big Sioux River; aiso below there on the tops of the hills.

Thickness, 200 feet.

From this formation Professor Marsh and Professor Cope have described nearly one hundred vertebrates, including birds, reptiles, and fishes. 
Black Hills.-Exposed around the Hills with its characteristic structure Well exposed on the west side of the Beaver Creek, where it contains great quantities of Inoceramus problematicus with adhering Ostrea congesta; on the Belle Fourche near the Great Bend; and near Bear Butte.

Thickness, roughly estimated, 100 to 200 feet.

\section{No. 2.-Fort Benton group.}

Dark-gray laminated clays, sometimes alteruating near the upper part with seams and layers of soft gray and light-colored limestones. Inoceramus problematicus, I. tenuicostatus, I. latus, I. fragilis, Ostrea congesta, Veniella Mortoni, Pholadomya papyracea, Ammonites Mullananus, Prionocyclus Woolgari, Mortoniceras Shoshonense, Scaphites Warrenanus, S. larvaformis, S. ventricosus, S. vermiformis, Nautilus elegans, etc.

Localities._Extensively developed near Fort Benton on the Upper Missouri; also along the latter, from ten miles above James River to Big Sioux River; and along the eastern slope of the Rocky Mountains, as well as at the Black Hills.

Thickness, 800 feet.

Four vertebrates are described by Professor Cope from the Fort Benton clays.

Black Hills.-This group, with its characteristic dark plastic clays, which usually contain large quantities of alkaline salts and selenite, is a very persistent feature in the geology of the outer rim of foothills. It is found resting upon the ferruginious sandstones of the Dakota group, and forms usually the outer slope to the series of foothills that border the encircling Red Valley. In its upper portion are frequently found thin bedded calcareous sandstones, containing numerous but fragmentary fossils, Inoceramus, Ostrea congesta, fish teeth, etc.

Thickness, 200 to 300 feet.

No. 1.-Dakota group.

Yellowish, reddish, and occasionally white sandstone, with at places alternations of various colored clays and beds and seams of impure lignite; also silicified wood, and great numbers of leaves of the higher types of dicotyledonons trees, with easts of Pharella? Dakotensis, Trigonarca Siouxensis, Cyrena arenarea, Margaritana Nebracensis, ete.

Localities.-Hills back of the town of Dakota; also extensively developed in the surrounding country in Dakota county below the mouth of Big Sioux River; and thence extending southward into Northeastern Kansas and bevond.

Thickness. 100 feet. 
Black Hills.-Prominently developed, forming the capping rock to the foothills that surround the Hills on all sides; appears with its characteristic composition-coarse yellow or red sandstones with discontinuous variegated clays. At places a considerable thickness of very soft and fine white sandstone appears at the base. Elsewhere considerable portions are of hard, dense quartzite. No animal fossils were found, but many remnants of plants-in no case more than mere coaly fragments.

Thickness, 250 to 400 feet.

The rim of Cretaceous strata which encircles the Hills dips outward on all sides or away from the axis of upheaval. The strata begin with the foothills that border the outer edge of the valley. The Dakota sandstone, resting conformably upon the Jura, forms the capping rock of the foothill ridge, and dips outward at various angles from $10^{\circ}$ to $40^{\circ}$. Just as the Cretaceous encircles the outcrop of the underlying Jura and Trias, so the different overlying groups of the Cretaceous-the Fort Benton, the Niobrara, the Fort Pierre, and the Fox Hills-succeed each other in regular order, forming a series of concentric ridges that decrease in altitude as the distance from the Hills increases.

One who journeys from the Hills without following a drainage line passes over a series of ridges of which each one is lower than the last, but is composed of strata higher in the geological scale. He finds, too, that the dip of each ridge-forming stratum is less than the dip of the last, until finally he reaches one that lies nearly or quite horizontal.

It has already been remarked that the concentration of attention on the main body of the Hills prevented a thorough study of the Jura. In a still greater degree it reduced our opportunities for the examination of the Cretaceous. Very few of our excursions penetrated more than the basal member, and the only examinations of the entire series were in our rapid approach to the Hills via Beaver Creek and on our return march. So far, however, as our observations extended, it was evident that the upper Missouri section of Meek and Hayden was applicable without essential modification.

Upon the geological map no attempt has been made to distinguish any individual member of the formation except the Dakota; all the upper divisions, from No. 2 to No. 5, inclusive, are represented by one shade. 
Taking up the groups, now, in order, the first to describe is the Dakota. Typically it is a coarse sandstone, generally conglomeratic, yellowish in color and stained red in places by the oxidation of the iron contained in its nodules. Sometimes the sandstone is white in color and uniform and fine in texture, and in several places large portions of the formation consist of intensely hard, glassy, and compact quartzite, white or brownish in color, and having the density, toughness, sharpness, and conchoidal fracture of typical flint. The quartzitic development was especially observed at the southern end of the Hills, where the Dakota expands into a plateau, and in the region north of Warren Peaks, but it is not confined to those localities.

The quartzitic sandstones are far removed from the possibility of any igneous action and are to be classed with the quartzites of the Potsdam already referred to. They consist, like them, of grains of sand cemented into a homogeneous mass by a silicious cement, but in many cases they are more flinty in their appearance and fracture. Just as with the Potsdam quartzites, there appear to be but two solutions to the problem of their formation. First, the silicious cement may be derived from the remains of infusoria, sponges, and other silicious organisms, as it is in the case of the Coal Measures and of the European Chalk; or, second, it may be derived from waters containing silica in a soluble condition, either at the time of the formation of the sandstone or after its deposition.

In severa] places on the northeastern side of the Hills the usual coarse yellow sandstone, with a thickness of 300 feet, is overlaid by 25 or 30 feet of red, yellow, and green variegated clays, 25 feet of white or gray clay, and 20 feet of yellowish sandstone. On one of the creeks running from the Hills near Bear Butte 200 feet of the usual coarse sandstones are separated by a series of light colored clays from another and thinner stratum of sandstone, above which come the dark clays of the Fort Benton group; and on Bear Butte Creek a similar section was seen. These variegated clays are not a constant feature, for in most sections on the flanks of the Hills they do not appear; neither are they, in the broad view, exceptional, for such clays are mentioned by Meek and Hayden in their general section.

Frequent allusion has already been made to the topographical prominence of the Dakota outcrop, and it was impossible in describing the Jura 
and the Red Valley to avoid anticipating a considerable share of that which belongs most properly here. A certain amount of repetition is therefore inevitable in presenting the relation of the group to the topography.

As a rule every monoclinal ridge contains a hard bed and a soft one. The hard bed forms one side of the ridge and its crest; the soft bed appears at the base of the other side and underlies the hard. In the case of the monoclinal that surrounds the Hills, and to which the title "foothills" has been applied, the capping hard bed is the Dakota sandstone, and the underlying soft bed is partly Jurassic and partly Triassic. But for the hardness of the sandstone there would be no ridge. 'But for the softness of the Red Beds and Jura, it would not be distinguished from the general arch of the Hills. It is the result, under the laws of erosion, of the contrast between the two.

Where the dip is great the base of the ridge is narrow and both sides are steep. Where it is small the base is broad and the side capped by the sandstone becomes a sloping plateau. On the east and west sides of the Hills the dip is so great that the ridge character is strongly marked. At the south end of the uplift the southward dip is very gentle, and the result is a plateau bounded on the north edge by a cliff. As the ridges approach the plateau they converge in direction and their lines of strike are continued as the limiting lines of the plateau until they meet. This gives to the plateau a triangular form. It is not, however, a plane triangle, but is arched from east to west. It pictures forth in a most striking manner the slow sinking of the axis of uplift beneath the quiet strata of the plain. Through this plateau the South Cheyenne has cut its way from west to east, formiing the defile known as the Big Cañon.

At the north end of the uplift-or rather at the northwest end, for the axis of uplift curves around until it has that direction-the structure is similar in its main points, but it lacks the simplicity exhibited at the south. The form of the uplift is less regular and it is complicated by volcanic disturbances. It is broader and it is carried a little higher. The Belle Fourche crosses it just as the South Cheyenne does at the south, but it has eroded a deep, broad valley instead of a narrow cañon, and the symmetry of the terminal sandstone plateau is thereby destroyed. Nevertheless the plateau $12 \mathrm{~B} \mathrm{H}$ 
character of the Dakota outerop is distinctly marked, and it is clearly seen to merge at the east and west into the south-trending "foothill" ridges.

If the reader will refer to the geological map and the bird's-eye view in connection with this description, he will obtain a clearer idea of the topography of the sandstone.

Excepting in the very extremities of the uplift the streams which cross the Dakota outcrop pass from the central region of the Hills outward toward the Plains. All of the streams, perennial or occasional, that flow from the limestone region into the Red Valley, escape from the valley by breaking through the foothill ridge-either singly or in combination-and the result is a series of cross-cutting eañons in which the composition of the Dakota group can readily be examined. A few of the succeeding pages will be devoted to the enumeration of some of the details thus ascertained.

At the Beaver Creek gap the summit of the cliff overlying the Jura is formed of-

1. Sandstone, at base very soft and white, but for the upper 50 feet yellowish

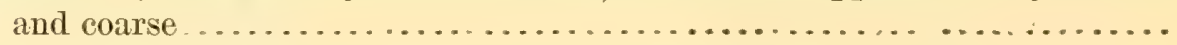

This sandstone dips restward $20^{\circ}$ to $25^{\circ}$, and near the foot of its slope is a second low ridge containing at its base, resting upon the above sandstone-

2. Sandstone, whitish and yellowish, thinly bedded, and with many ripple marks.

3. Sandy shales. . . . . . . . . . . . . . . . . . . . . . . . . . . .

4. Sandstone, gray and reddish; in places thinly bedded; with ripple marks...

5. Gray clay or marl, with nodules of impure limestone, strata of siderite, much

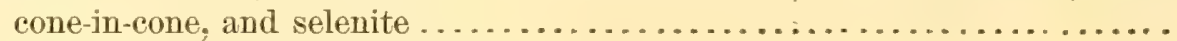

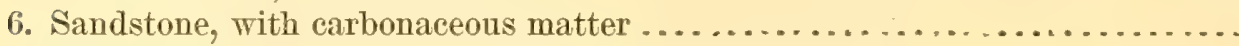

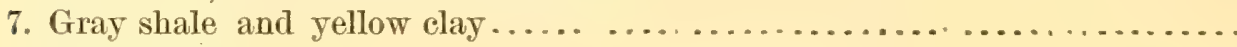

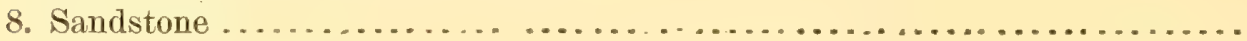

No fossils were found in these rocks, but they are all referred to the Dakota group because they are immediately underlaid by Jurassic strata, well characterized by fossils, and they immediately underlie the black plastic clays of the Fort Benton group.

The ridge character of the outcrop continues southward to the gap by which Red Cañon Creek issues from Red Valley, and there ceases. The southern plateau is included between Red Cañon and Minne Katta Creeks. The next points of examination were on and near the plateau. A section of the cliff at Red Cañon Creek, to be found in the Jurassic division of the 
chapter, gives the lower part of the Dakota group. Fuller sections, though still incomplete, were observed in the cañon of the Cheyenne, but the component beds were not measured in detail. The walls of the cañon are in places from 600 to 800 feet high, and they are composed in chief part of the sandstones of the Dakota They are perpendicular except at the base, and are there covered by débris, though a few glimpses are caught of soft rock, probably belonging to the Jura. The exposed portion of the Dakota is fully 500 feet in thickness and, allowing for waste above and concealment below, the group must be estimated to exceed that amount. It has its usual character in the main, but in the upper part there is a fine example of the quartzitic phase. In fact, a large portion of the higher part of the plateau is quartzitic, and the preservation of the table is largely due to this circumstance.

On the surface of the plateau near Red Cañon Creek there is much fine drift composed largely of quartz grains and garnets.

North of Minne Katta Creek the outcrop resumes its character of a monoclinal ridge, and so continues all about the east and northeast sides of the Hills. The dip finds here its maximum and ranges from $20^{\circ}$ to $40^{\circ}$ or $45^{\circ}$. The formation exhibits no peculiar features except the occurrence in the northeast of the variegated clays already referred to

At the north where the Dakota Cliff runs westward parallel to Redwater Creek the dip is only about five degrees and the exposure takes the form of a plateau. Farther west it diminishes still more, except in the immediate vicinity of the Bear Lodge range where the strata are upbent about the trachyte mass. From the summit of Warren Peaks the tabular character is plainly evident, and the plateau is seen to slope gently to the east and north and west. It has not, however, a continuous surface, but is deeply dissected by cañons in every direction. Topographically it is limited on the west by the valley of the Belle Fourche, but'a dissevered remnant is to be seen on the farther side, supporting on its surface the volcanic cones known as the Little Missouri Buttes.

Wherever examined in this northern portion of the Hills the group has its typical lithological character, but the thickness was nowhere seen to be greater than 200 feet. The following section shows so much of the forma- 
tion as caps the cliffs southeast of Bear Lodge. The top of the cliff is 950 feet above the Belle Fourche.

4. Sandstone, jellowish with red stains; containing layers of conglomerate.... 75

3. Dark graj calcareous shale and dark impure limestone . . . . . . . . . . . . 5

2. Sandstone, very soft and white, with layers of fine conglomerate........ 50

1. Clays and marls of the Jura. . . . . . . . . . . . . . . . . . . . . .

Twenty-two miles farther down the river the dip of the sandstone carries it down to the level of the stream, and it disappears beneath the overlying clays of the Fort Benton group. At this point the following section was observed:

4. Sandstone, reddish and yellowish ......................... 100

3. Shales or clays, gray, yellow, and red ... . . . . . . . . . . . . . . . 50

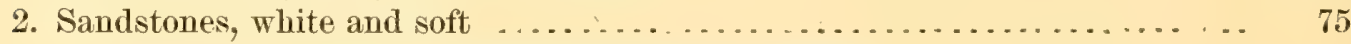

1. Jurassic clays or marls, sandy, gray, red, and yellow .................. -

Though the Dakota group contains occasional strata of clay or shale there is rarely any difficulty in separating it from the dark plastic clays of the overlying Fort Benton.

Of the Fort Benton and upper groups of the Cretaceous no general study was made, and the little that can be said is a very slight contribution to their history. They were seen only on a few lines of travel and for the most part under unfavorable circumstances.

Between Bear Butte and the foothills the undulating country appears to be underlaid entirely by the black clays of the Fort Benton group (No. 2), but we found no fossils. East of the butte No. 3 appears, and on the banks of the Belle Fourche near the mouth of Bear Butte Creek are the dark gray clays and shales of the Fort Pierre, No. 4, with a few characteristic shells, Baculites, Ammonites placenta, etc.

Southward along the base of the foothills the Fort Benton is easily traced by the fineness and darkness of its clays. They are remarkable for their large proportion of soluble salts, which contaminate all the streams that pass through or rise in them, rendering their waters bitter and medicinal. In their vicinity it is usual to see a white deposit or crust lining the banks of the streams, and occasionally alum springs are met with. The 
same bitter salts are found also in the higher beds but in smaller quantity. Selenite, in well defined and clear crystals, is very abundant and dots the exposures of the formation with bright spots that glisten like jewels in the sunlight.

On Rapid Creek the Fort Benton clays have a thickness of 150 or 200 feet, and dip eastward at about $20^{\circ}$. They rest upon the Dakota sandstone, and are covered in turn by a bed of sandstone 10 or 15 feet thick, which forms a ridge in the topography. Beyond this ridge a furrowed and rolling surface extends eastward to the Cheyenne, where No. 4 forms the bank of the stream. On the east side of the river Nos. 4 and 5 are overlaid by outliers of the White River Tertiary.

At the pass of the foothills on French Creek the Dakota sandstone, dipping eastward at an angle of $8^{\circ}$ or $10^{\circ}$, is overlaid by the following series :

1. Clays of the Fort Benton, dark brown or black ... Feet.

2. Sandstone, white, coarse; somewhat conglomeratic at base ............ 40

3. Clays, yellow and somewhat arenaceous; with thin shaly limestone near the top; containing Inoceramus ........................... 50

Nos. 2 and 3 of this section probably belong to the Niobrara group, the total thickness of which we could not readily estimate. Professor Winchell, who enjoyed better opportunities than we at this locality, places it at 150 feet. In the same vicinity he assigns to the Fort Pierre group a thickness of 250 feet.

The cascade on Minne Katta Creek, which is a little over two miles from the Cheyenne, is in the gap through which the creek passes the ridge of Dakota sandstone. The sandstone has a dip to the south and east of about $30^{\circ}$. Above it are the Fort Benton clays about 150 feet in thickness, which thence form the banks of the creek to the Cheyenne. In this short space the dip changes so rapidly that at the river the strata lie very nearly horizontal. Conspicuous hills near the mouth of the creek consist of shales with some sandstones, and probably exhibit a portion of the Niobrara group. 
At the pass of Red Cañon Creek the rocks which immediately overlie the Dakota sandstone are:

1. Black cay with ming Feet.

1. Black clay with much selenite ................................ 60

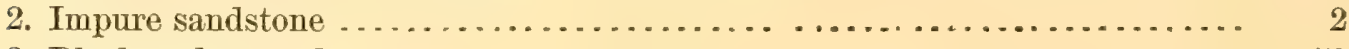

3. Black and gray clays .................................... 50

At the pass of the east fork of Beaver Creek, the outer slope of the Dakota, dipping westward at an angle of $35^{\circ}$, is overlaid by the black alkaline clays of the Fort Benton 150 or 200 feet thick. From these have been excavated the small valley of the "Bitter Fork," the waters of which are highly charged with dissolved salts. A small ridge immediately west of the valley exposes the following section, resting directly upon the Dakota sandstone:

7. Gray clay sholes

6. Sandstone, calcareous, lamellar, brown, with a very fossiliferous layer, containing imperfect specimens of Ammonites, teeth of Lamna, Otodus, ete... 5

5. Dark gray clay ........................................ 15

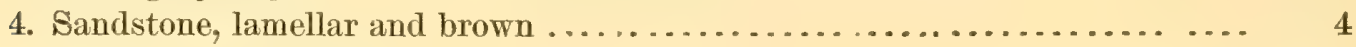

3. Dark gray elay shales ................................... 20

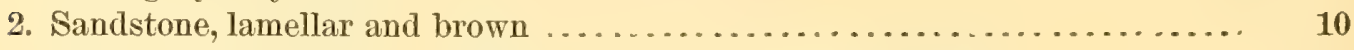

1. Dark gray or black clay shales with selenite and alkaline salts ......... $\quad 75$

Westward from this point to the west fork of the Beaver are fragmentary exposures of the gray or yellowish clay of the Niobrara without discovered fossils, and then, in barren slopes along the Beaver, the colored clays of the Fort Pierre group, containing many calcareous bowlders or concretions filled with Inoceramus, Ammonites placenta, Baculites, Scaphites, Helicoceras, Heteroceras, Ancyloceras, and Ptychoceras.

The Cretaceons exposures on the lower Beaver, on the Cheyenne above its mouth, and on Old Woman Fork have been described on preceding pages. On the northwest side of the Hills the Fort Benton and upper groups were not examined. The most extended and continuous examination of the formation was made during the exploration of the Belle Fourche from Bear Lodge to its junction with the south fork of the Cheyenne, and the ascent of the latter stream to the mouth of French Creek. For this whole distance the river runs tortuously in a valley from one to two miles in width, cut in the soft rocks of the different groups of the Cre- 
taceous. The low angle of dip, the similarity of the different groups in lithological character, their too frequent concealment under grassy slopes, and the absence of fossils for long stretches, rendered a true estimation of their thickness and extent a matter of difficulty.

From the point where the Dakota sandstone dips under the river and gives place to the overlying Fort Benton, to the acute northern bend of the river the following beds are exposed. The section is given in descending order.

4. Gray clay, with many calcareous iron nodules; capping the bluffs at the bend of the river. (The summit of the bluff carries many water-worn fragments

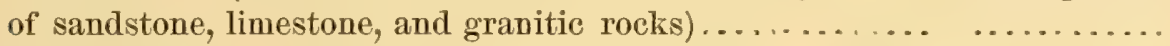

3. Dark gray shales, weathering light gray; stratified in distinct layers, with bands of white sandstone at the base ....................... 200

2. Black or very dark plastic elays ........................... 100

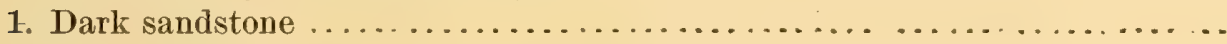

In the absence of fossil remains a true reference is not easily made. The bed numbered " 2 " is evidently the Fort Benton clay; the one numbered " 3 " is probably the representative of the Niobrara; while the capping gray clays with calcareous nodules may indicate the base of the Fort Pierre.

The river is cut through these beds for a long distance below the bend, and for some ten miles southeast of the bend " 3 " of the above section forms the immediate banks of the river, the beds being nearly horizontal. By the southward course of the river the valley east of the bend is cut back upon the dip, so that at a point about ten miles below the bend the Fort Benton clays again appear and form the banks for a considerable distance.

About half way between the north bend and the mouth of the Redwater a local change of dip brings the Dakota sandstone above the surface of the river, and for a short distance it shows a cliff of 75 feet. This soon disappears, however, and gives place again to the Fort Benton and Niobrara. These dip slightly toward the east and north, and for some distance above the mouth of the Redwater the valley is cut in the gray clay of the above section (Fort Pierre group ?).

Judging from the efflorescence on its surface, this clay contains con- 
sidurable quantities of soluble salts. Its full thickness was not ascertained, but a cliff cut in it was found to be nearly 200 feet in height.

The surface of the country north of the river is gently undulating, and but little scored by branching streams or ravines, so that along almost the immediate bluff of the valley wagons can be driven for a long distance without arrest by irregularities of the ground. It is destitute of water, and for long stretches almost destitute of vegetation. The same clay and the same surface features characterize the country bordering the river for a long distance west of the mouth of the Redwater.

Some little distance below Bear Butte Creek the Fort Pierre group is well distinguished as a gray clay, with calcareous nodules full of characteristic fossils. It was not fully connected with bed 4 of the last section, but its identity is highly probable. Among the fossils are Ammonites placenta, Baculites, and Inoceramus Sagensis.

Near the forks of the Cheyenne the following beds were found-

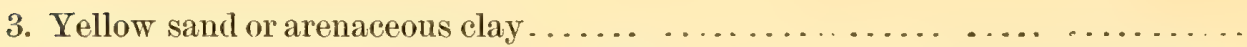

Feet.

2. Clay shales, light gray, darker in streaks, with impure limestones at base and a few limestone concretions with fossils $($ No. 4) . . . . . . . . . . . . . 110

1. Dark gray clay shales, with calcareous nodules full of Baculites, Inoceramus, Ammonites, etc. (No.4) ........................ thickness to river..

Beds 1 and 2 of the above section belong evidently to the Fort Pierre group, while bed 3 may possibly represent the Fox Hill.

Between the Cheyenne and the Hills a large area of country is underlaid by the Fort Pierre group, frequently exhibiting its characteristic barrenness of surface.

From the forks of the Cheyenne up the south branch to and beyond the mouth of French Creek the river is cut in the dark gray clays of the Fort Pierre group, and from the abundant limestone nodules we obtained many fossils. When freshly exposed these concretions are broken with the greatest difficulty, and in the operation the fossils are generally injured or destroyed. When, however, they have been exposed for some time and are somewhat decomposed they are readily broken, and the fossils with their beautiful nacre and colors are obtained with ease. In the beauty and abundance of 
its fossils this region of the lower Cheyenne can scarcely be excelled by any locality of Cretaceous fossils in the West.

The concretions are not uniformly scattered through the mass of the formation, but are found most abundant along two lines or horizons. One of these is near the base and the other near the summit of the series, and the intervening space is barren of fossils. On the South Cheyenne the greater number of forms collected were from the upper zone, which is here but a short distance below the base of the Tertiary. Some of the principal forms are: Cyncyclonema rigida, Pteria linguiformis, P. Nebrascensis, P.pseudopteria, Inoceramus sublevis, I. Sagensis, I Barabini, Nuculana bisulcata, $N$. subequilatera, Lucina occidentalis, L. ventricosa, L. subundata, Thracia subgracilis, Neara Moreanensis, Fasciolaria fusiformis, Fusus Cheyenensis, Aporrhais Meeki, Anchura sublevis, Lunatia concinna, Amauropsis paludinaformis, Akera glans-oryza, Deitalium gracile, Nautilus Dekayi, Scaphites nodosus, and Ancyloceras tricostatus.

Between Rapid and Spring Creeks and thence southward to French Creek and beyond are a series of outlying areas of the White River Tertiary, which rise in white bluffs above the plateau of Cretaceous. The character of the Cretaceous at their point of junction is illustrated in the following section observed near Spring Creek:

Tertiary.

Feet.

4. White plastic clays, with impure limestone at base and seams of chalcedony .150-200

3. Fine, white, quartz gravel, very loosely cemented ............... $5-8$

\section{Cretaceous.}

2. Plastic elas, gray or brown, with much iron oxide in seams; often variegated in color, pink, ash, red. and brown. (Fox Hills ?).................

1. Gray or drab clays, hardly distinguishable from the class at the level of the Cheyenne, 600 feet below ; containing within 100 feet of the top concretions full of the characteristic fossils of the Fort Pierre group, but associated with some indicative of the Fox Hills

The dip of the rocks along the Cheyenne in this vicinity is toward the south and east, but is low and barely perceptible. The surface of the country in the vicinity of Rapid Creek is flat, and broken only by the dry ravines that head back a short distance from the immediate bank of the 
river. On the east side of the river the Cretaceous strata extend southeastward in a broad flat mesa. Crossing it for six or seven miles one reaches the abrupt edge of the prairie and looks unexpectedly down upon the wonderful and wierd bad land basin of the White River, which falls away from the plain as though it had been sunk from a higher level by some catastrophe of nature. It is hard to realize that one has been gradually ascending in the geological scale while he crossed the even prairie, so that he now looks down upon a formation higher than any to be seen along the river; but such is nevertheless the case. The gentle dip of two or three, or perhaps four, degrees has carried down the Cretaceous until it is no longer visible even in the deepest water-ways, but is replaced in the topography by the middle portions of the White River Tertiary.

That the Cretaceous series once extended continuously across the area which is now elevated to form the Black Hills there can be no reasonable doubt. The strata have been elevated and tilted and their wasting edges outcrop around the Hills at various angles, but still they conform perfectly with the underlying rocks, sharing their curves and inclinations. This relation could not subsist if they had been deposited after the uplifting; and being deposited before it, there could have been nothing to prevent their continuity across its area.

SECTION IX.

THE TERTIA R .

There are no Tertiary strata within the area of the Hills, and all mention of the formation might have been omitted at this place but for the fact that the Tertiary deposits of the vicinity have furnished evidence bearing on the question of the age of the Hills. A brief account will therefore be given of the Tertiary of the Plains for the purpose of showing the general relations of the particular beds that have interest in this connection. 
The divisions recognized by Messrs. Meek and Hayden are as follows, beginning with the highest of the series:

4. Loup RIVER BEDS, Pliocene Tertiary; consisting of loose sand with some limestone; all of fresh-water origin, and containing the bones of Mastodon, Equus, Felis, Castor, Canis, Testudo, etc. These are exposed only on the Niobrara and the Loup fork of the Platte.

3. White RIVER GRoup, Miocene Tertiary; consisting of light colored elays, often arenaceous, and sometimes containing beds of limestone; all of fresh-water origin. They contain many fossil vertebrates, among which are Titanotherium, Oreodon, Rhinoceros, Testudo, and Equus. They occupy the bad-land country of the White River and extend over a large area south of the Black Hills and Chejenne Rirer.

2. ForT UnIon GRoup, Eocene Tertiary; consisting of clay, sand, and sandstones, with much iron in ferruginous concretious and many beds of lignite. The basal parts are of brackish-water origin; the upper portions contain only freshwater remains. These beds contain in places large quantities of leaves of dicotyledonous plants, Populus, Platanus, Sassafras, etc. The Fort Union beds occupy a large area, extending from the South Cheyenne on the west side of the Hills northward to the Missouri and far beyond.

1. JUDITH RIVER BEDs; consisting of sand and clay inclosing some beds of lignite. They occur only over a small area near the mouth of the Judith River and on the upper Missouri. The best authorities are rery nearly agreed in placing them at the summit of the Cretaceous series, and they are only added here to complete the joint section of the Cretaceous and Tertiary of the Plains.

Of these divisions the only ones which occur in the immediate neighborhood of the Black Hills are the Fort Union and White River; the former, according to Dr. Hayden, overlies the Cretaceous at no great distance from the Hills, on the north, west, and southwest. The latter also overlies the Cretaceous to the southward and eastward. In a northeastern direction a belt of Cretaceous outcrop follows the valley of the Cheyenne and separates the two Tertiary areas. On the opposite or southwest side of the Hills the Tertiary areas conjoin, and the White River beds were there observed by Dr. Hayden to overlie the Fort Union.

The precise age of the Fort Union beds has been the subject of much discussion, and by some investigators the propriety of referring them to the Tertiary rather than the Cretaceous has even been questioned. There is no need either to recite or to continue that discussion in this place, for the reason that no relation has yet been determined between the deposition 
of the Fort Union beds and the history of the Hills. The White River beds, however, have been definitely connected with that history, and of them we are fortunately able to say that their Miocene age is not called in question. Dr. Leidy and Professor Marsh, who have independently examined their profuse vertebrate fauna, are at one in their determination of age, and Professor Meek finds nothing in the scanty fresh-water molluscan fauna to conflict with their conclusion.

The partial section of the Fort Union group observed by the writer on Old Woman Fork has been described in the preceding chapter and needs no further mention. That chapter contains also a description of so much of the White River group as was seen by our party. In the latter part of the last section a description will be found of the lower strata of the group as they appear resting on the Cretaceous near the mouth of Rapid Creek.

The bed of gravel at the base of that exposure of the White River beds is only one of many evidences that there was an interval of time between the deposition of the upper Cretaceous beds and the deposition of the White River. The fact that they are in juxtaposition at this point, while to the west of the Hills the Fort Union group is interposed between them, is another evidence, and a third is derived from the disparity of age of the two formations as shown by heir fossils. It was during this interval of time that the principal uplift of the Hills occurred, and one of the chief witnesses to that fact is the same conglomerate at the base of the upper series.

The pebbles of the conglomerate are never more than two or three inches in diameter, and have such a large preponderance of white quartz that the whole bed has a very light color. It is so loosely cemented that outcrops are merely piles of loose pebbles, having all the appearance of a gravel beach on the sea shore. Indeed, it is evidently a shore deposit, the remains of the beach of the old fresh-water lake, formed before the waters attained their greatest height and while they were sorting over material brought by rivers from the neighboring Black Hills. Nearly the whole of the material seems to have been derived from the quartzes and quartzites of the various formations now exposed there, but Mr. Jenney succeeded in finding, mingled with these, not only the rose-quartz which is the com- 
panion of the granite of the Harney Peak region, but also a few fragments of the granite itself. It is thus known not only that the uplift was in existence at a time near the beginning of the White River lake period, but also that it had been so long in existence as to permit the wearing away of its upper portions so as to lay bare the granitic nucleus.

It is worthy of remark that while the deposits of the Cretaceous, from the demolition of which the White River Tertiaries were evidently largely formed, are dark, carbonaceous clays or shales, the latter are notable for their light color. This is probably due to the making over of the sediment in shallow water, whereby the carbonaceous matter was oxidized, leaving the accumulation nearly white in color. A similar phenomenon is to be seen in the work of the modern streams. The two branches of the Cheyenne, which flow such long distances through the Cretaceous and derive their drainage largely from its clays, always transport sediment of a light color. Held in suspense it gives the water a milky color, and precipitated on the bottom it appears as a white scum. Left on the banks by higher stages of the water, it takes the form of a light colored clayey material which dries in the sun to a hard white crust. So fine is it that on a windy day large white clouds of the material can be seen driving along the valley like clouds of smokes. The rationale appears to be that the finely divided silt derived from the Cretaceous clays has by constant exposure to the air had its carbonaceous coloring matter oxidized and burnt out.

SECTION X.

\section{THE VOLCANIC ROCKS AND VOLCANIC PEAKS.}

Frequent allusion has already been made to the volcanic peaks. Individually they are small in extent, but they derive importance from their number and from the fact that their uniformity of character over a large area shows the wide distribution of the conditions necessary to their production. 
They are curiously limited within the region of survey by a parallel of latitude. The line of $44^{\circ} 10^{\prime}$ divides the uplifted area-as marked out by the outcrop of the Dakota sandstone-into equal parts. South of the line there is no volcanic peak either in the Hills area or in the vicinity. North of it they dot the country in every direction. They do not seem to bear toward one another any relation of distribution or intensity of igneous action; and though the maximum effect is seen in Warren Peaks, the other peaks in that region do not appear to hold toward them any closer relation, except in position, than they do toward the other igneous peaks.

The main points of eruption are as follows: within the area of the Hills proper, Custer, Terry, and Crow Peaks and Black Butte; northeast of the Hills on the edge of the plain, Bear Butte; in the Red Valley on the northwest side of the Hills, Inyan Kara, Sun Dance Hills, a nameless peak northeast of Inyan Kara, and Warren Peaks of the so-called Bear Lodge range; on the Belle Fourche, Mato Teepee or Bear Lodge; and near the head of Little Missouri River, the Little Missouri Buttes. Besides these prominent peaks, all of which are indicated on the geological map, there are many others, less conspicuous, in the northern part of the main area of the Hills. Terry is the crowning peak of a group the remaining members of which lie to the north and to the south of that point. In the schist area at its northern end, east of Terry Peak, there are probably several small points of igneous rock. To the east of Black Butte, along the northeastern margin of the wooded area of the Hills and not far from the inner edge of the Red Bed limestone, several small peaks supposed to be igneous were seen from a distance. Farther to the northeast also there were observed several exposures of igneous rock that had barely penetrated or disturbed the sedimentary rock, and were only exposed by the denudation of the overlying formations.

The rocks which form these numerous extrusions have in general a close resemblance in structure and appearance, and are sometimes almost identical from several peaks. Specimens from nearly all the prominent peaks have been critically examined by Mr. Caswell, who finds that they have a common facies, although some fall into the division of rhyolite and others into that of sanidin-trachyte. The resemblances are on the whole more 
important than the differences, and leave little room to doubt that the peaks are to be classed together as the result of a single group of conditions and the product of a single period of eruption.

In the structure of the peaks the first fact that strikes the observer is their uniformly conical shape. To this rule Bear Lodge is the only exception, and this, with its symmetrical columnar shape, is the most remarkable of all. The peaks appear to be merely pointed or conical waves of igneous rock forced upward through the sedimentary strata, which are found disturbed and turned up around them only in their immediate vicinity. The metamorphism of the upturned strata is limited in extent, reaching only a few feet from their contact with the igneous rocks. There was observed no evidence of any overflow of the igneous matter,* but it is confined exclusively to the cores of the peaks. The view that they are the cores of extinct volcanoes or centers of igneous overflow is scarcely warranted by the observed facts. It would be expected, if such were the case, that the sedimentary rocks tilted around them would have been more metamorphosed by the igneous heat, and even though a large portion of the overflowing material was removed by denudation, it is scarcely possible that every indication of such an overflow could have been so completely destroyed. It would appear therefore that the igneous peaks, instead of being the product of violent volcanic action, are situated at a great distance from the central and maximum region of igneous action; and that instead of the material being ejected with great violence and at such a temperature as to cause it to overflow readily, it was forced upward through the sedimentary strata under great pressure and at such a temperature as to make it plastic rather than fluid. The occurrence of these trachytic peaks appears like a great pustular outbreak on the surface of the northern end of the Hills whereby the deep-seated igneous forces were relieved, or like the appearance of bubbles on the surface of a kettle of boiling tar.

The peaked character of the igneous points seems to be somewhat peculiar, for in the records of geological explorations in the Rocky Mountains it is not mentioned. Mr. Dawson, however, -in his report on the region

* Possibly an exception to this statement should be made, for, as related in the description of Terry Peak, rhyolite near the Deer Mountains was seen overlying quartzite belonging probably to the Potsdam. 
of the 49th parallel, describes the Sweet Grass Hills as having a similar peaked structure, around which the sedimentary strata, the Lignitic Tertiary, have a similar quaquaversal dip.* The rock also of these peaks, a "rhyolitic trachyte-porphyry", passing into "sanidin-trachyte", seems from the descriptions to be similar to the igneous rocks of the Black Hills.

The peaks have so little variety that it will not be profitable to describe them individually. A detailed account will be given only of the principal ones, viz: Custer Peak, Terry Peak, Bear Peak, Crow Peak, Inyan Kara, Sun Dance Hills, Warren Peaks, Bear Lodge, and the Little Missouri Buttes.

- Custer Peak stands at the eastern margin of the Carboniferous plateau, just within the area of the slates. It is a symmetrical, conical mass, and is a prominent landmark in the northern region of the Hills. Its height above the valley at its base is 675 feet, and its elevation above the sea is about 6,950 feet. It is very little higher than the neighboring edge of the plateat. The mass of the peak is so covered with fragnents of the rock that neither its intimate structure nor its relation to the prevailing rocks of the region could be well determined. The slopes of the sides show only a loose mass of angular fragments, over which the ascent was not a little difficult. On the extreme summit the rock is exposed in a $\mathrm{Y}$-shaped ridge, with the stem of the letter bearing north $35^{\circ}$ west. The rock has so perfect a vertical cleavage, following approximately the bearing of the ridge, that it might readily be taken for a bedded deposit; and in its close texture, uniformity, and color it so closely resembles the limestone of the Carboniferous, that it might almost be so mistaken on a superficial examination. Close inspection, however, reveals its igneous nature. It is a rhyolite of a light bluish gray color, and a fine-grained and uniform structure, containing occasional crystals of sanidin and bright black hexagonal tables of biotite.

To the east and northeast of Custer and within a short distance are two small peaks which appear to consist of igneous rock, but they were not examined closely. With this exception no other igneous points occur until the Terry Peak region is reached, about eight miles to the northwest. 122 et seq.

* Geology and Resources of the Region in the Vicinity of the 49th Parallel, by G. M. Dawson, p. 
The margin of the plateau west of Custer Peak is exceedingly broken and the composing rocks are not well exposed. A mile or so directly south, however, outliers of the Carboniferous limestone were seen in their horizontal position occupying the summits of conspicuous bluffs, and immediately west of the peak, within a short distance of its base, are small fragmentary outcrops of the Carboniferous, undisturbed and unchanged. East of the peak and within a half mile of its base there are outcrops of the Potsdam along the headwatess of Box Elder Creek, showing the usual character of the formation, lying nearly horizontal, and so far as observed entirely unaffected by proximity to the igneous peak.

Terry Peak is the crowning point of an igneous region of considerable extent, having a maximum development in a northwest and southeast direction. The region is deserving of careful study, but because of the great number of the points of exposure and the very rugged nature of the country it was impossible to wholly examine it even superficially in the time at our disposal. The peak stands upon the edge of the plateau; the Potsdam is extensively developed on its eastern side, and with it are occasional outliers of the Carboniferous. Its sharply pointed summit is the most conspicuous landmark in the northern region of the Hills and is visible from the Plains far to the north and east. Its altitude, by mercurial barometer, is 7,230 feet, and theie are but two summits in the Hills that outrank it. It rises fully 1,000 feet from its base.

The igneous group or range of which Terry is the highest point begins about three miles to the southeast in a cluster of peaks called the Deer Mountains, and there is a nearly or perhaps quite continuous chain of trachytic and rhyolitic outcrops all the way to Terry. The same line continues northward for a few miles beyond Terry.

The disturbance of the sedimentary strata is exceedingly local and confined to the immediate vicinity of the peaks themselves. Directly east of Terry Peak, and almost at its base, the Carboniferous limestone lies undisturbed, while against the ridge that culminates in the peak the Potsdam, much metamorphosed, was found at several places inclining at a high angle. The sides of the ridge and of the peak are for the most part covered by a talus of angular and slippery fragments of the rock, On the 13 в н 
summit of the peak the rock is well exposed, and three or four ridges of outcrop appear to radiate a few hundred feet from the central crest, while between them the slopes are composed of weathered fragments. The rock of the summit has a greenish gray color, and contains many conspicuous crystals of sanidin. In hand specimens it appears like a feldspathic porpliyry, but what seems to the unaided eye to be a groundmass is shown by the microscope to be crystalline and to carry a large amount of quartz The percentage of silica is so large that Mr. Caswell classes the rock with the rhyolites.

About a mile and a half to the eastward there is a dike of greenstone running north and south for some distance, cutting through the sedimentary rocks. It is probably connected with a small peak northeast of Terry which was reported to be composed of greenstone.

Near the base of Deer Mountains a rhyolitic rock was observed overlying quartzite that was thought to belong to the Potsdam. This may be either an overflow or an injection between strata, and it is the only case in which the igneous and sedimentary rocks were seen in this relation. In several places in the cañons contiguous to the igneous masses the Potsdam sandstone-here the best exposed of the sedimentary series-was found highly altered by the igneous rocks, which in many places penetrate it. It is frequently altered into a hard brownish rock with erystals of feldspar irregularly shot through the mass. Sometimes it is a hard granular rock with a conchoidal fracture, and in places the conglomerate is so hardened that it breaks as readily through the composing pebbles as in any other direction.

The igneous rocks of this region are varied in their appearance and texture.

Crow Peak is a pustular outbreak of volcanic rock through the Red Bed limestone twelve miles northwest from Terry Peak. Though it does not rank as one of the highest points of the Hills, it springs so abruptly from its immediate surroundings as to make it locally a very conspicuous point. Its approximate height above the Red Valley in its vicinity is 1,500 feet. As seen from the east or west it appears to be composed of two peaks closely united; the southern one is the rhyolite core, while the northern 
consists of the uplifted sedimentary strata, which are elerated higher on that side. The rhyolitic point is conical, with, however, a larger development in a north and south direction, so that the summit is a ridge several hundred feet in length. Along this barren ridge the rock crops out prominently. It has a distinct cleavage lengthwise of the ridge, and is divided thereby into plates which in some places are quite thin. The steep slopes of the sides are masses of loose and sliding fragments.

The rock is a light gray, compact, tough rhyolite. It has been forced through the sedimentary strata, which from the Potsdam to the Red Bed limestone are exposed around the base and are all more or less disturbed. The Red Bed limestone is least influenced and surrounds the peak in a gentle slope or bulge, while a long low swell or ridge extends for several miles northerly into the Red Valley, diminishing and finally dying out entirely. Within a few hundred feet of the peak the Carboniferous is seen in a cañon lying nearly horizontal, while it laps up against the base at an angle of $75^{\circ}$ or $80^{\circ}$. The Potsdam is exposed at several places in the cañon, having the usual character, while under the Carboniferous against the peak it stands vertical. It has been more or less completely metamorphosed into a hard quartzite, though none of the other sedimentary rocks appear to be in the least changed by proximity to the igneous mass.

Bear Butte rises from the level of the Plains on the northeastern side of the Hills about six miles from the edge of the foothills, and though its total elevation above the sea is but 4,570 feet, its abruptness and its height above the surrounding plain-1,200 feet-make it a conspicuous landmark. In structure it resembles Crow Peak, having a similar conical outline, and being an upburst of trachytic rock through the sedimentary strata, some of which are distinguishable all around its base. As seen from the south it is a simple cone, but from the east and west the summit appears as a ridge several hundred feet in length, with a trend about north $40^{\circ}$ west. The summit ridge is narrow and the rock, as in Crow Peak, has a vertical cleavage running with the length of the ridge. About the ridge are several bluffs which expose the rock in place nearly to the base, while the intermediate spaces, each like a cul-de-sac, are filled with loose fragments. These fragments are small, angular, and flat, and are so loosely aggre- 
gated as to render the ascent of the peak a toilsome task. Where they cover the side of the peak the entire slope is marked with zigzag paths a few inches wide that ascend at angles of from $20^{\circ}$ to $30^{\circ}$, crossing and recrossing each other in a perfect net-work. These are supposed to have been made by mountain sheep, but none were seen in the vicinity. On the summit and here and there on the sides of the peak are a few stunted pines, but its general appearance is barren and has led to the suspicion that its name was originally and more properly Bare Peak.

The rock is a gray trachyte, with weathering surfaces much darker than the fresh fracture, giving to the peak a somber appearance. It is hard, compact, and tough, and has a ring somewhat like phonolite.

The butte stands in the gray shales and clays of the lower Cretaceous, and around its immediate base are the uplifted strata of the Dakota sandstone, with partial exposures of the Jura and Red Beds. The base of the peak, however, is so much concealed by fragments of the igneous rock and by grassy slopes that there is little opportunity to examine the lower of the disturbed strata. A dense quartzite is visible in numerous places at the base of the peak standing vertical in a prominent ridge, but its continuity is not perfect around the peak. West from the summit ridge there are a series of imperfect outcrops, in curves concentric with the peak, which are thought to belong to the Red Bed scries. On the same side of the peak, close to the base and underlying the metamorphosed Dakota sandstone, the following strata were observed in a deep wash-out. They rise toward the peak with increasing angles.

13. Yellow sandstone.

Feet.

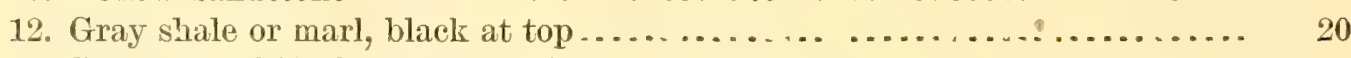

11. Sandstone, full of rounded grains............................ 1

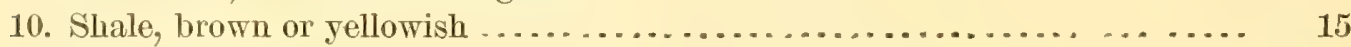

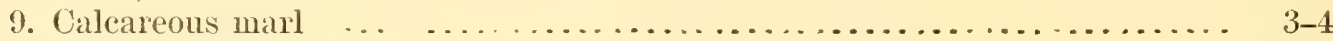

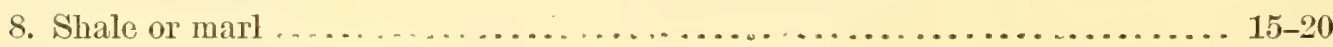

7. Calcareous warl ... ... . . .......................... 20

6. Yellow sandstone ................................... 10

5. Yellow, red, and green clays, becoming sandy at base ............ $30-35$

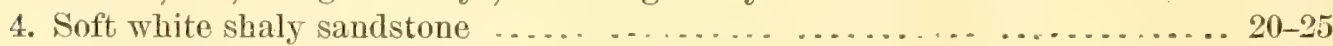

3. Greenish shaly sandstone; top somewhat argillaceous ............. 75

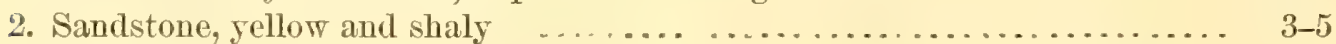

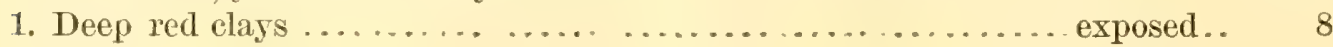


No fossils were discovered in these beds, but, with the exception of the red clays at the base, they are supposed to belong to the Jura. It is probable that they are upturned on all sides so as completely to encircle the uplift, but they are concealed by débris.

A short distance from the base of the butte no evidence can be seen of the close proximity of an igneous peak.

From this brief description it will appear that Bear Butte is an igneous extrusion, producing no dislocation or metamorphism in the strata through which it was protruded, except at its very base. It gives no indication that its igneous material ever overflowed as a true lava, but rather that, like the other peaks of this region, it was a huge viscid bubble, breaking through a great thickness of superincumbent strata.

Sun Dance Hills.-These two hills are in the northeastern bend of the great Red Valley, about eight miles southeast from Warren Peaks and twelve miles due north from Inyan Kara. They are the simplest and best illustrations of the pustular nature of the igneous ejections of the Black Hills. They are about three miles apart and are not very prominent except in the local topography. The higher of the two is 1,100 feet above the surrounding valley, while the eastern and smaller hill is, by estimation, not over 600 feet above its base. The rock is very similar to that of Bear Butte and Inyan Kara, a hard, gray, compact trachyte. The larger hill was ascended and found to have a ridge-like summit with its major axis pointing in a northwesterly direction. Around the bases no more recent strata were recognized than the red clays and limestone of the Red Beds, and these are but little disturbed. The limestone surrounds each in a gentle slope very like the broken edges of a piece of paper that has been punctured by a sharp pencil but it is in nowise shattered. It seems to conform to the little irregularities of the uplift almost like a flexible material.

Inyan Kara is the most prominent peak on the west side of the Hills. It is situated in the Red Valley, west of the limestone plateau. Its name first appears on the map of Lieutenant Warren, and as translated for him signifies "the peak which makes stone." Inyan signifies in the Dakota tongue "stone," but the word Kara is unknown in the language, and is probably a corruption of Ka-ga," to make" The summit of the peak is 
6,600 feet above the sea, and has an elevation of 1,300 feet above the bed of Inyan Kara Creek near by. The igneous mass of the peak occupies the center of what in form resembles a crater, for separated from it by an annular valley there is an encircling ridge or rim whose top is 500 feet below the summit of the peak. This rim is formed by the Red Bed limestone rising up from under the surrounding red clays at an angle of about $40^{\circ}$ and completely encircling the peak except at a narrow break on the northeast side where the drainage escapes. The limestone wraps around the outer slope of the peak like a cloak, conforming to all local changes in dip and bending without fracture. The upper red clays of the Red Beds lap up against this limestone, which appears as a breakwater raised against the turbulence of the billowy sea of the Red Valley. On the inside of the rim is the annular valley, surrounding the igneous nucleus and having a width, from rim to center of peak, of from one-half to three-fourths of a mile. It has evidently been formed by the denudation of the easily eroded strata beneath the limestone.

From the midst of this crater-like depression the peak rises so abruptly that there is but one side with an easy slope for climbing. The summit is a broad but very irregular area, whose larger dimension has a bearing about $30^{\circ}$ west of north and upon which the rock is well exposed. It is a hard, highly feldspathic trachyte, and on weathered surfaces large and well formed crystals of feldspar were seen in great abundance, giving the weathered mass a porphyritic appearance. In mass it is notably magnetic. The rock shows well marked cleavage or jointing planes, nearly vertical, in two series. The first runs toward the northwest and the second toward the west, dividing the rock into prisms and producing a quasi-columnar structure.

Though on a much larger scale, the entire upheaval being probably two or three miles in diameter, the peak has essentially the structure already described in Crow Peak and Sun Dance Hills. Among the uplifted beds surrounding Inyan Kara no strata were recognized excepting the Red Bed limestone and the underlying, impure, reddish sandstone, and beyond the immediate base of the outer slope no disturbance was indicated. Indeed, 
the red arenaceons clay is too nearly structureless to retain readily such evidence.

Warren Peaks are the crowning points of the "Bear Lodge range," an elevated, broken platean between the Redwater Valley and the Belle Fourche. The peaks are not remarkably prominent, but their total elevation above the sea, 6,830 feet, is equal that of some of the principal peaks in the Hills, while their height above the Red Valley immediately south is about 1,800 feet. The trachyte area to which they belong is the largest of the whole group, and covers fifteen or twenty square miles. Around this the strata of the sedimentary series are uplifted and arranged in concentric circling outcrops, so as to make a sort of miniature copy of the Hills. The trachytic nucleus has an extension from northeast to southwest of about eight miles, and a width of two or three miles. Its surface consists of high, rounded, grass-covered hills, with little or no timber, and from this rise the two or three more elevated points to which the name Warren Peaks has been applied. These more central points are surrounded by smaller and less prominent peaks, which are separated by deep ravines or gulches forming the lines of drainage. Besides this great nucleal mass of igneous rock, several outbursts, very local in character, were observed in the zone of encircling strata. The rock is a trachyte, dark gray in color, and containing frequently large and perfect crystals of sanidin which give it a porphyritic character. Small crystals of mica and hornblende are also prominent, and the rock yields more to weathering than that of some of the other peaks. In different portions of the district the rock varies somewhat in its character, though evidently of the same general nature. As a rule it is more highly crystallized than the trachytes farther south, the large, well formed feldspar crystals being more common and also the small crystals of mica and hornblende.

A short distance northeast of the central peaks an irregular, ill-defined ledge was found, traversing the trachyte for some distance in a northwest direction. It is varied in its composition, but consists mainly of a coarsely crystallized feldspathic rock, with the crystals imbedded in a fine-grained feldspathic matrix, the whole mass having a yellowish or reddish brown color. Near the middle the mass is irregularly intermixed with compact 
black limonite and manganese oxide, which, though closely associated, seem to remain distinct These oxides fill the spaces between the feldspar crystals and irregularly impregnate the rock, giving it a brecciated appearance. They often show a cubodial form, indicating that they are derived from the decomposition of pyrites, and small pieces of that mineral were found in the interior of several masses. Though gold is invisible, careful assays prove its existence in the mass, and from this source is probably derived a portion at least of the gold found in this region.

The encircling zones of sedimentary rocks include the Potsdam below and the Jura above. Their dip is quaquaversal and is usually quite regular, the angle varying from $20^{\circ}$ to $30^{\circ}$.

The Potsdam sandstone which immediately overlaps the base of the igneous mass has been greatly metamorphosed. Where the rock was shaly it has been changed into a hard fissile slate, scarcely recognizable as of sedimentary origin; and the pure sandstone strata have been converted into compact quartzite often of a very white color. In several places the igneous matter seems to have penetrated between the strata, which are scarcely distinguishable from the injected rock, and in many cases the metamorphosis appears to have been performed by the action of heated waters, for the sandstone was found penetrated irregularly by well formed crystals of feldspar. On the west side, near the middle of the formation, were found layers of argillaceous sandstone covered by the large branching fucoid peculiar to the Potsdam, and some of the upper layers of the sandstone are perfectly riddled with Scolithus holes. The Potsdam, Carboniferous, and Red Beds are well exposed in many of the cañons which radiate from the central area carrying the drainage eastward to the Redwater or westward to the Belle Fourche. On the south and east, facing Sun Dance Hills, the Red Bed limestone forms the outer slope, dipping under the red clay of the Redwater Valley. On the north and west, however, the Jura is well exposed and capping this the Dakota sandstone.

Though on a grander scale and exposing a larger area of igneous rock than the other centers of igneous extrusion, the Warren Peaks show the same character of pustular eruption.

The Bear Lodge (Mato Teepee).-This name appears on the earliest 
map of the region, and though more recently it is said to be known among the Indians as "the bad god's tower," or, in better English, "the devil's tower," the former name, well applied, is still retained. It stands on the immediate western bank of the Belle Fourche, about four miles southeast from the Little Missouri Buttes. It was not reached by the Warren expedition, but while the Raynolds expedition was in the vicinity of the Little Missouri River two attempts, the last successful, were made by Mr. Hutton to reach it. He recorded, however, no particular description of it, so that when we reached it in 1875 our examination had all the charm of novelty. Its remarkable structure, its symmetry, and its prominence made it an unfailing object of wonder. (See frontispiece) It is a great rectangular obelisk of trachyte, with a columnar structure, giving it a vertically striated appearance, and it rises 625 feet, almost perpendicular, from its base. Its summit is so entirely inaccessible that the energetic explorer, to whom the ascent of an ordinarily difficult crag is but a pleasant pastime, standing at its base could only look upward in despair of ever planting his feet on the top. At a distance it resembles not a little the unfinished Washington Monument in Washington City, with the difference, however, that Nature has completed her work.

Within a half mile of the banks of the Belle Fourche the shaft rises with its broad base of débris from the plateau formed by the lower Jurassic sandstone. Its dimensions were determined by Captain Tuttle, the astronomer of the expedition, who calculated them from measurements with the sextant. " The height of the summit above the river was found to be 1,126 feet, while approximately its elevation above the sea is 5,260 feet. The width of the summit from north to south is 376 feet, and the width at base is 796 feet. In an east and west direction the diameters are less.

The rock is a coarsely porphyritic sanidin-trachyte of a greenish color, closely resembling that of Terry Peak. In the mass it has a crystal-like structure on a grand scale, which from a short distance gives the column the appearance of a fascicle of gigantic fibers From the base, which is considerably broader than the body of the peak, each fiber-like crystal or column rises in a bold curve to the bottom of the vertical obelisk, which it then follows to the summit. The columns have generally a rectangular or 
rhombic section, but are sometimes triangular or hexagonal. With the exception of an occasional fracture each column or crystal continues to the very summit. The sides are of various dimensions, but average from two to four feet at the base. They diminish upward in the same ratio with the total column. Careful examination at the base shows that the columnar structure is not continuous below the portion of the peak exposed to view. The columns differ somewhat in size and position from those characteristic of basalt. The latter are commonly referred to contraction in cooling, occasionally combined perhaps with a concretionary action; and they are always formed perpendicular to a surface of cooling. In a dike they are perpendicular to the walls, and in an overflow to the atmospheric surface. They are rarely of any great length, and frequently they extend but a part of the way through the bed, ending irregularly in a structureless mass. In the Bear Lodge we have columns over six hundred feet in length rising perpendicularly from a seemingly massive base. It is exceedingly difficult to account for this as a result of cooling by comparison with any known basaltic phenomena; and, indeed, Bear Lodge, in its shape and structure, appears not to have been repeated elsewhere by Nature, but stands alone, unique and mysterious.

The strata from which this igneous column springs are not in the least disturbed at the nearest points where they could be examined, about 50 or 75 feet from the base, but the sandstones for some distance are converted into a compact white quartzite.

The Little Missouri Buttes stand on the plateau of Dakota sandstone about four miles west of Bear Lodge and near the divide between the headwaters of the Little Missouri River and the Belle Fourche. They are three in number, occupying three angles of a triangle, and are said to be called by the Indians "the buttes which look at each other." Though prominent landmarks, they rise only between four or five hundred feet above their base. They are about one-half or three-fourths of a mile distant from one another, but they are so thoroughly covered around their bases with débris that their intimate structure and relation could not well be determined. The Cretaceous sandstone forming the floor of the surrounding plain could not be ascertained to exhibit any disturbance or change of structure due to 
proximity to the igneous matter. Each peak has the same general conical form so often described, and a similar system of cleavage planes was also observed. Some cross-planes give locally an appearance of columnar structure. The rock is a greenish gray trachyte similar to that of the Bear Lodge, but though it contains many crystals of feldspar it is not so highly crystallized as the rock from the latter peak. At the base of the buttes in one or two localities a rock was found exceedingly light and cellular in structure, yellowish in color, and very like a volcanic tufa. As the result of a microscopic examination Mr. Caswell designates it a rhyolitic breccia, including fragments of both sandstone and rhyolite.

\section{S E C T I N X I}

\section{STRUCTURE AND AGE OF THE BLACK HILLS.}

It remains to consider the origin of the topographic forms which constitute the Hills. How and when did the plateaus, and peaks, and cliffs, and cañons, and valleys that make up its topography come into existence? The answer to the question is, in general terms, that the rocks were uplifted, and that being uplifted they were by the processes of erosion worn away and carved into the forms we have seen. (If the form of the uplift had been different, if the order and character of the rocks had been different, if the date of the uplift had been different, there would have been a different topographic result. A complete analysis of the resultant forms, taken in connection with the structure of the rocks and viewed in the light of the natural laws of erosion, should tell, first, the form of the displacement or uplift and, second, the date of its occurrence. Our analysis is unfortunately not so full as to afford either of these results in a satisfactory way, but it will at least give a fair idea of the methods by which they may be reached. In presenting the material and deductions the following order will be observed:

First, the form of the displacement will be considered; second, the relation of the topography to the form of the displacement and to the rock structure will be discussed; and third, the evidence which bears upon the 
date of the uplift will be assembled; finally, the age of the igneous masses will be considered, and the section will close with a summary of the geological history of the district.

\section{1.-The Form of THE DisPlaCEMent.}

If the reader will open the geological atlas at the page which gives a bird's-eye view of the Black Hills, he will obtain a clearer idea of the general structure than it is possible to convey by words.

Turning his attention first to the Archæan area just to the right of the middle of the view, he will see that it presents a series of undulations without any evident system. Around it there is a continuous cliff facing toward it, so that it is on a grand scale walled in. The rock of this cliff is the Carboniferous limestone. On the right hand side of the Archæan (the eastern side) the Carboniferous has a considerable inclination which earries it at once out of sight. At the left it has a very gentle dip, causing it to form a plateau instead of a ridge, but at the farther edge of this plateau its dip suddenly increases and carries it out of sight; so too at the north (or in the distance) and at the south (or in the foreground). The Carboniferous outerop is completely surrounded by a line of high dip and its limits are given thereby. With the aid of the view it is easy to understand that the same limestone strata once extended completely across the oval area marked out by the zone of high dip, and that there was no exposure whatever of the Archæan until it was denuded by the erosion and destruction of a portion of the Carboniferous. The first step then toward restoring the form which the rocks acquired by displacement but lost by erosion is the replacement in imagination of the Carboniferous beds over the area where now the Archæan only is exposed.

Outside of the Carboniferous and completely encircling it is the Red Valley, marking the outcrop of the soft clays of the Red Bed and Jura formations, and outside of the Red Valley there is an encircling ridge popularly known as "the foothills" and carrying the outcrop of the Dakota sandstone. The sandstone and the soft beds beneath it conform to each other and to the Carboniferous limestone and dip in the same direction, so that the foothills consist everywhere of a monoclinal ridge, having a dip 
away from the Hills and toward the Plains. But although the Dakota sandstone is assumed to be parallel to the Carboniferous limestone beneath it, its dip is not necessarily the same as that of the nearest outcrop of the Carboniferous. On the whole its inclination is somewhat gentler, and in the variations of this inclination we find recorded local details of the form of the great displacement. To restore the Dakota sandstone over the whole of the oral area circumsciibed by its outcrop taxes the imagination more heavily than the restoration of the Carboniferous, and the tax increases with one's appreciation of the magnitude of the quantities dealt with. The space to be filled has a length of nearly ninety miles and a breadth half as great, and the total thickness of the formations that were removed from it-the Dakota sandstone, the Jura, and the Red Beds-is about 900 feet. Nevertheless the evidence is such as no geologist would hesitate to accept, and to restore the uplift to its full proportions we must carry these formations over the entire area of the Carboniferous, actual and restored, building on everywhere a thickness of from 800 to 1,000 feet. Over the Red Valley the thickness to be added is not so great, for a part of the Red Beds, and in some places a part of the Jura also, there survive, so that only the missing portions need be supplied. The amount to be added varies from 300 feet at the foot of the Dakota cliff to 900 feet at the margin of the Carboniferous, and its precise value at any particular point is to be determined by a study of the local outcrops and the local dip

The work of restoration does not end with the reconstruction of the Dakota sandstone. Outside of the foothills the view shows a number of monoclinal ridges smaller and less persistent than the Dakota ridge, but agreeing with it in the fact that the composing strata are inclined away from the uplift. These ridges mark the position of the harder members of tine upper Cretaceous rocks, and testify to the fact that those rocks were affected in common with the Dakota sandstone by the upheaval. We do not know their full thickness, because in the neighborhood of the Hills they have everywhere lost something by erosion, but whatever that thickness was-and it was not less than 600 feet-it must be rebuilt over the area of the Hills in order to restore the uplift to its full proportions.

Let us assume that we know the thickness of each of the formations 
involved in the displacement, and that we know the altitudes of all points in the Hills. Then by examining the rock at any point and determining to what part of the stratigraphic series it belongs we can estimate what depth

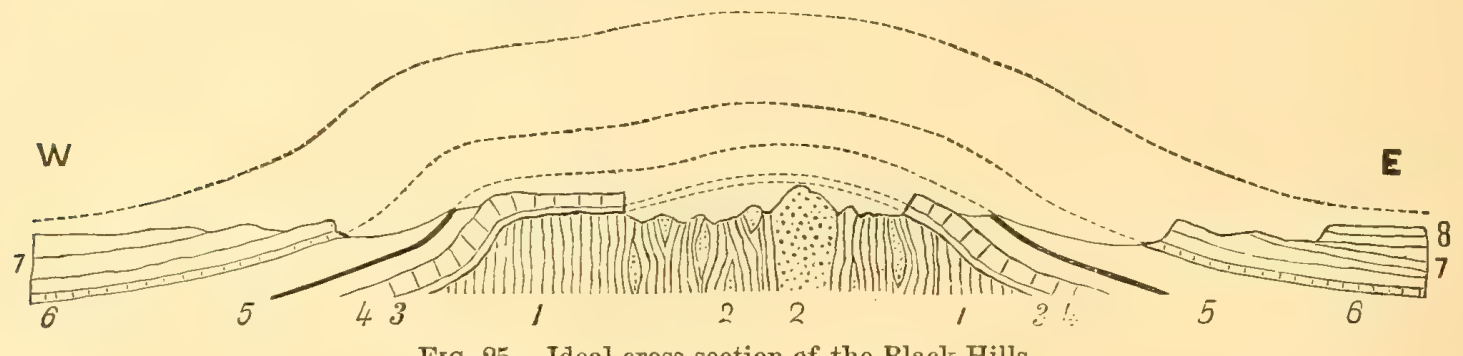

FIG. 25.-Ideal cross-section of the Black Hills.

The vertical seale is about six times the horizontal. The dotted lines indicate the portion of the uplift removed by erosion.

1. Archæan slates and schists.

2. Granite.

3. Potsdam, resting unconformably on 1 and 2.

4. Carboniferous.

5. Red Beds, with included limestone.

6. Jura.

7. Cretaceous.

8. White River Tertiary, resting unconformably on 7 .

of rock has been removed, and by adding this to the known altitude of the point deduce the local altitude of the restored uplift. By repeating this process at a great number of points we can determine the corresponding points of the ideal surface and attain to a definite conception of its form. Or if we take into consideration the fact that the inclination or slope of the ideal surface must be everywhere very nearly identical in direction and degree with the dip of the visible rock beneath it, then it will suffice to determine a few points only by the additive method, and fill in the intervening space by simply copying the slopes observed in the rocks beneath. I think this latter is the process of reconstruction which the mind employs when it contemplates such vestiges of erosion, either in nature or in a view like the one before us.

In the present case we do not know the thickness of all the formations, but our only conspicuous ignorance is with reference to the highest formation of all, the upper Cretaceous, and is therefore not serious ; for any error in the estimate of that affects only our determination of absolute height, and not our determination of form. Each of the formations, too, varies in thickness at different points of its outcrop, and may be assumed to have varied within the area from which it has been removed; but these irregu- 
larities, though amounting sometimes to hundreds of feet, are too small to introduce any serious error in our conclusions. It is unnecessary to burden these pages by a detailed presentation of the facts we have used in deducing the form of the uplift; we will merely describe it Many of the facts are recorded in the geographic and topographic maps and in the bird's-eye view, and still others have been detailed in the descriptions of the formations in the earlier portions of the chapter.

(The first important feature of the uplift is that it is flat-topped. It belongs to the same order of displacement as the Uinta Mountains and the Kaibab Plateau.* The top is not absolutely flat, but relatively so, and the inclination all about the periphery is very much greater than any inclination upon the upper surface. The extent of this tabular top is shown on the geological map by the combined outcrops of the Carboniferous and Archæan. It is oval in form, with a length of seventy miles and a width of forty. Its general trend is about $10^{\circ}$ west of north, but its axis is not a straight line; its eastern side is more strongly curved than its western, and gives an impression, borne out by other evidence, that its median line has a decided curvature, the concavity of which is toward the west. ) The highest part of the table is nearer the eastern edge than the western, and it is perhaps true that the entire top slopes toward the west; certainly that portion deduced from the study of the Carboniferous plateau does so.

The descent from the tabular summit is steeper at the east and west than it is at the north and south; that is to say, the table is more definitely bounded at the sides than it is at the ends. On the east side the surface bends over gradually until it acquires an inclination of about $30^{\circ}$, and then curves still more gradually at the base of the uplift until it loses its inclination and merges with the imperceptible slope of the strata of the Plains. The same is true on the west side, with a single exception. At a point near Camp Jenney the descent is, for a short distance, so steep as to be almost vertical.

At the south end the greatest inclination is not more than $15^{\circ}$, and the curves which connect this with the table above and with the datum plane below are exceedingly gentle. / There is a sort of prolongation of the uplift,

* Geology of the Uinta Mountains, J. W. Powell, py. 11-17. 
not as a sloping table but as a low anticlinal which gradually descends and fades away to the southward. The form of the prolongation is realized by the outerop of the Dakota sandstone which ceases at that point to be a simple monoclinal ridge and spreads out into a triangular table sloping to the southeast and southwest.| Here again a glance at the bird's-eye view will give a more definite idea than can be conveyed by a description.

At the north, or rather at the northwest, for that is the direction of the other extremity of the axis, there is a similar prolongation of the uplift, but it is on a far greater scale. An anticlinal nearly as broad as the main tuplift extends for at least forty miles beyond the end of the table, and is itself somewhat tabular. Where it adjoins the main table it is decidedly lower, and the two surfaces are connected by a gentle flexure. Thence it descends slowly to the northwest, and it probably merges gradually with the datum plane in that direction. Our observations, however, did not extend to its limit. On its northeastern edge it is limited by a definite flexure, which in its southward prolongation merges with the eastern flexure of the main uplift. Its southwestern limit shows no such flexure and is not well defined.

The extreme height of the uplift as referred to its datum plane-that is the maximum amount by which a stratum in the arch of the Hills rises above its prolongation in the surrounding Plains-is estimated to be 6,600 feet. This height is found in the crest of the main uplift, near the eastern edge of the tabular top. The western edge of the tabular top is about 800 feet lower. The altitude of the southward anticlinal extension, where it is crossed by the Cheyenne River, is about 1,800 feet above the datum. The northern prolongation, where it joins the main uplift, has a central height of about 8,300 feet, just one-half of the full height of the main uplift. Where it is crossed by the Belle Fourche River its height is 2,200 feet. The total volume of matter here lifted above the general surface, or, in other words, the solid contents of the restored dome of rock, is 4,200 cubic miles.

In this description no allusion has been made to the displacements associated with the igneous rocks. Those displacements modify the form and destroy the simplicity of the great displacement, but they have no discernible relation to it except the relation of superposition. Whether 


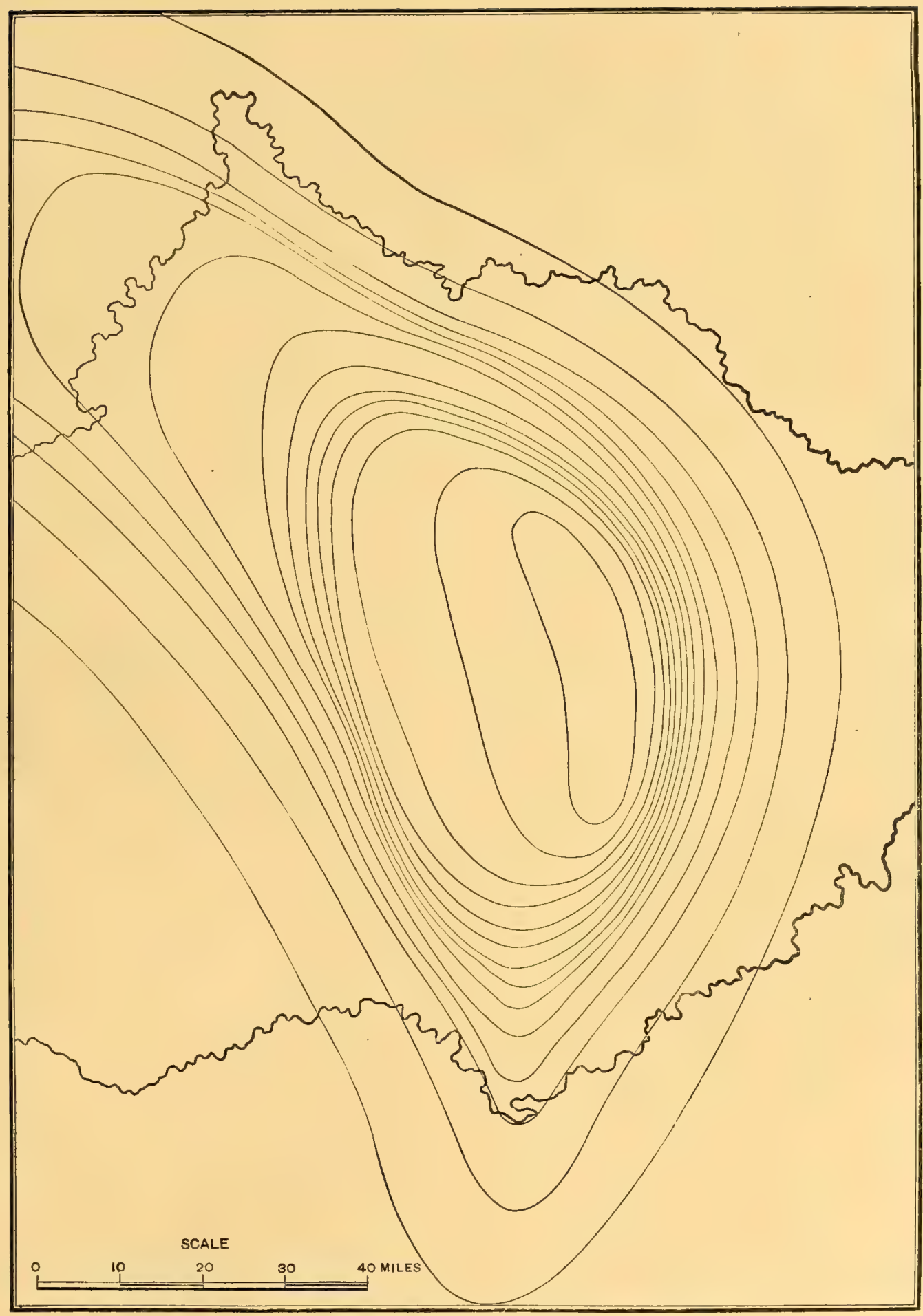

Fig. 26.-Contour Map of the Black Hills Displacement.

The vertical interval between contours is 500 feet.

The upper irregular line shows the position of the Belle Fourche River; the lower of the South Fork of the Cheyenno. 

they were formed before or during or after the uprising of the great arch, there is nothing in their distribution to suggest that they are in any wise dependent upon it or closely related. Some of them are near the crest of the arch, some are where the rocks are steeply inclined at the side of the arch, many are on the gentle slopes of the northern prolongation, and at least one is entirely outside of the Hills. They are so much smaller than the protuberance on which they rest that they seem to be merely superficial phenomena-a sort of skin disease upon the surface of a tumor.

But however insignificant the volcanic disturbances may appear when contrasted with their vast orographic associate, they are by no means unimportant when considered by themselves. About each of the igneous cores the upbent strata expose circular outcrops. Evidently their present condition has resulted from protracted waste under the play of the elements, and if we could restore the portions which have disappeared to the form which they had immediately after the upthrust of the molten rock, we should have mountains of very respectable proportions. It is safe to say that when the trachyte of Warren Peaks was forced up beneath the Potsdam sandstone, it lifted it to a height of 3,500 feet, carrying with it all of the strata that then rested upon it, and forming a mountain 3,500 feet in height and six or eight miles in its smaillest diameter.

In the accompanying diagram, Figure 26, all uplifts known to be caused by volcanic action are ignored. (The orographic uplift, pure and simple, is represented by the method of contours.) It has no pretension to minute accuracy, but it may be trusted to give a veracious rendering of the main features of the displacement. (The outermost curve of all is intended to be drawn at the limit of the displacement, and represents the base of our ideal dome where it joins the plane of reference. The next curve is the 500-foot contour, and represents the intersection of our ideal dome with a plane parallel to the datum plane and 500 feet above it. So of all the other curves, the vertical interval between two adjacent lines being in each case 500 feet.) The courses of the two forks of the Cheyenne are marked upon the diagram, partly to aid in giving it a geographical position and partly to illustrate the fact, to which we shall again have 14 B II 
occasion to advert, that the rivers flow directly across the mountain instead of going around it.

In speaking of the elongated dome of strata which we have reconstructed in the imagination, we have been careful to make use of the adjective "ideal," and to this we have given a double meaning. The dome is ideal because we have constructed it as a logical deduction from a mass of observed facts, but it is also ideal because it never had a real existence. We have excellent reason to believe that when the uplift began the site of the Hills was either dry land or the bed of a shallow lake, so that the rising arch was subject to the attack of the elements either at its inception or immediately after. The higher it rose the greater was its exposure and the more rapidly was its summit worn away. When it reached the full measure of its magnitude as an orographic protuberance, its destruction by elemental warfare had progressed so far that the magnificence of our ideal structure was very far from realization. Of the slowness of the uprising of the mountain we have no evidence in what we were able to glean during our hurried study. For aught that we learn from local observations the mountains may have shot up with the speed of a growing vine, but in the growth of other mountains there are many things to show that their progress was secular, and upon no plausible theory of the origin of mountains can it be supposed that their birth-labor is other than exceedingly slow. The earthquake is but the passing pang that records a unit of progress; it is only by the combination of many such units, separated often by wide intervals of time, that the great result is accomplished.

\section{2.-THe RElation OF THE TOPOGRAPHY tO THE STRUCTURE.}

There are two conditions which more than any other determine the forms of mountains. The first and most important is the rock structure. The second is the drainage system, or the arrangement of the lines of drainage. The rock structure always determines the type of the resultant form, and usually it is largely concerned in the determination of the drainage system.

The rock structure of a mountain is the arrangement of the various masses which compose it. When those masses are chiefly sedimentary rocks, as in the present case, the structure is readily divisible into two 
parts: first, the order of sequence and the thickness of the several strata, and, second, the position in which they lie, or their altitudes and angles of dip. The position of the strata of the Black Hills is given by the form of the displacement. The thickness and character of the several beds have been described in the preceding sections.

Considering the beds of the conforming series from Potsdam to Cretaceous simply with reference to their ability to resist erosion, we have the following classification:

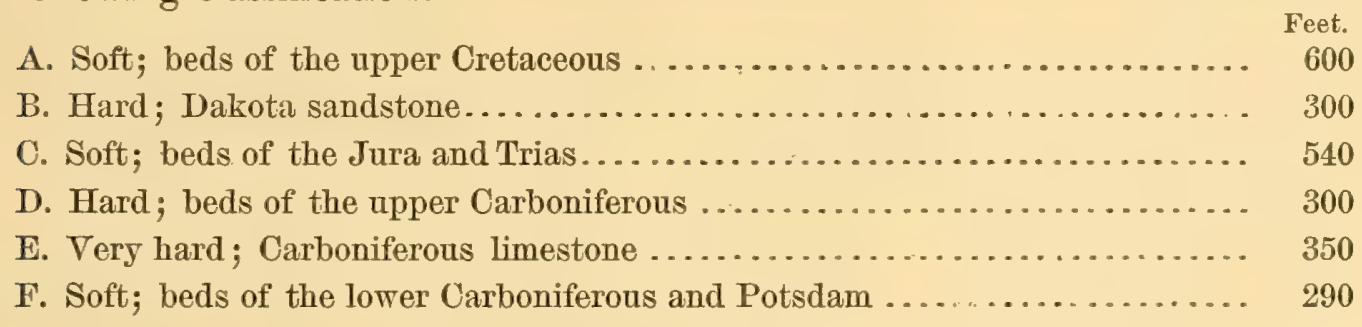

Here are three zones of soft rock separated by and alternating with two zones of hard rock. From the summit of the uplift all these rocks have been removed by erosion. About its flanks each of them outcrops in a ring. The degradation of the dome has been rudely equivalent to the paring of a slice from its summit, so that the successive envelopes of rock are laid bare in concentric rings, just as the leaves of an onion bulb are laid bare when a slice is cut from the side. Here, however, the resemblance ceases, for the resistance to atmospheric degradation is greater with hard beds than with soft, and they have not been carried away so rapidly. The result is that the outcrops of the zones of hard rock have a relatively great altitude and constitute ridges, while the outcrops of the soft zones are relatively depressed. Taking them in order from circumference to center, we have the upper soft zone (A) composing the plain from which the Hills rise; then the first hard zone (B) represented by the ridge of foothills; then the second soft zone (C) marked by the Red Valley; then the second hard zone (DE) constituting the Carboniferous ridge on one side and the Carboniferous plateau on the other; and finally the third soft zone (F) marked by the central area.

Within the circle of the Potsdam there is exposed an entirely distinct. series of rocks with a structure of its own, which has no apparent relation 
to the post-Cretaceous displacement. Here too the contrast of hard and soft has determined the main features of the topography. The strata have a nearly vertical position and trend obliquely across the area of their exposure. Their hard members are quartzites; their soft, slates and schists. The former stand in ridges; the latter underlie valleys.

Within the newer series of rocks there are masses of trachyte, exotic bosses, forming no part of the sedimentary series; within the older series are unstratified masses of granite, lenticular in form and exotic in origin. The trachyte is harder than any of the sedimentary rocks; the granite rivals the quartzite in durability. Wherever these intrusive bodies have been laid bare in the progress of the degradation they form eminences; peaks in the case of the trachyte, ridges in the case of the granite.

In this manner the main topographic features of the Hills have been made to give expression to the main facts of the geological structure. The eminences point out the hard rocks; the valleys the soft. The arrangement of hill and valley betrays to the geologist the character of the displacements and the position of igneous masses. When, however, we leave the consideration of the main features and descend to details, we find that the arrangement of the lines of drainage has had much to do with the determination of the surface features.

The drains as a rule cross the strike of outcropping strata at great angles, often at right angles, and wherever a ridge dependent upon the rock structure is intersected by a line of drainage it is cleft to its base. The Carboniferous ridge which curves about the eastern side of the Hills is

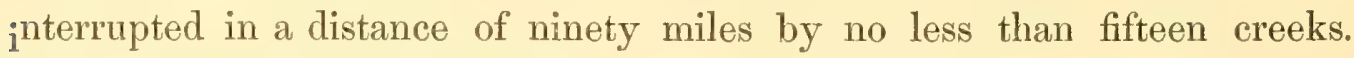
The Dakota ridge in making the circle of the Hills is crossed by twentyseven waterways. At every such intersection the absolute continuity of the ridge is broken, but the interruption is so brief that the imagination fills the hiatus without effort, and the structural continuity of the ridge is not called in question. Indeed, if one who stands at the side of a ridge looks obliquely down its course he finds it a matter of difficulty to discover the points where it is divided. So, too, in the Archæan district; the streams intersect the quartzite ridges at high angles and divide them by narrow cañons, interrupting their continuity but not otherwise impairing their ridge 
character. If the drainage system of the Hills were different the forms of the surface would be different, but they would still give expression to the character of the rocks and to the displacements.

On the whole, the drainage system is well adapted to the display of the intimate relation of rock structure and topography. A great number of small streams radiate from the Carboniferous plateau, and flow independently, without combinations among themselves, until they pass beyond the foothills. These streams are received by the forks of the Cheyenne which embrace the district of the Hills. As a consequence, the facilities for the transportation of débris are approximately equal in all directions, and the rate of degradation by erosion is conditioned almost solely by the constitution of the rocks. The inequalities of surface therefore-the results of differential degradation-give a symmetrical and faithful representation to the rock structure.

In the northwestern extension of the Hills the case is somewhat different The low prolongation of the uplift is crossed at right angles by the north fork of the Cheyenne. A series of outcrops is produced each of which circles about and returns to itself. On a map this arrangement might appear very similar to that of the outcrops about the main uplift, but it is essentially very different, and it depends no more upon the rock structure than it does upon the disposition of the drainage. The displacement at this point is essentially an anticlinal, and the river in traversing it first descends stratigraphically, crossing successively lower and lower beds, and then, having passed the axis, crosses the same beds again in inverse order. The outcrop of each stratum runs to the right and left from the point where it is first crossed, rising as it goes and curving in its course until it becomes parallel to the river on each side of the valley. Then after passing the axis of uplift the two lines curve again toward the river, and descending as they approach, finally meet under the water, having completed the circuit. The river has cut down through the upper soft zone, the upper or Dakota hard zone, and the greater part of the middle soft zone. The rocks of the latter alone exhibit complete circuits. The Dakota sandstone nearly completes its circuit, but the circle of this outcrop at one point. 
touches the eircle of its outcrop about the main body of the Hills, and each is broken for a short space at the contact.

\section{3.-The AGE OF THE HILLS.}

The age of the Hills is the age of the uplift. There is some reason to suspect, as we have said in another place, that the locality was marked by an elevation or ridge before the Potsdam sandstone was deposited, but the present existence of the Hills as an upland district depends upon and dates from the disturbances which took place after the accumulation of the entire series of conforming strata. From the base of the Potsdam to the top of the Cretaceous all of the strata are parallel and conformable, and above the Potsdam they comprise none of those fragmental deposits which mark the neighborhood of mountains undergoing erosion. All of the strata are upbent together in the flanks of the great arch. If the arch had been formed during the accumulation of the series the beds deposited after the formation would not conform to the dip of the others, but would either abut against them or else overlap their worn edges. We are assured therefore that the movement did not begin before the end of the period represented by the Cretaceous strata.

The next formation succeeding the Cretaceous in the region of the Hills is the Fort Union group, but our single observation of the group afforded no means of judging whether it shared the movements of the older beds. Following it in order of time is the White River group, and of this our knowledge is more satisfactory. The conglomerate which was found at its base on the east side of the Hills, and only fifteen miles distant from the foothills, proves by the size of its pebbles that a mountain was undergoing degradation close at hand during its formation, and leaves no doubt that the Black Hills were then in existence. The discovery by Mr. Jenney of débris from the granite, mingled with the predominant quartz and quartzite of the conglomerate, shows further that the degradation of the uplifted mountain had progressed so far that at some point a water-course had pierced all the sedimentary beds and laid bare one of the granite masses. The time consumed by this erosion could not have been inconsiderable and it preceded the earlier deposits of the White River Miocene lake. The 


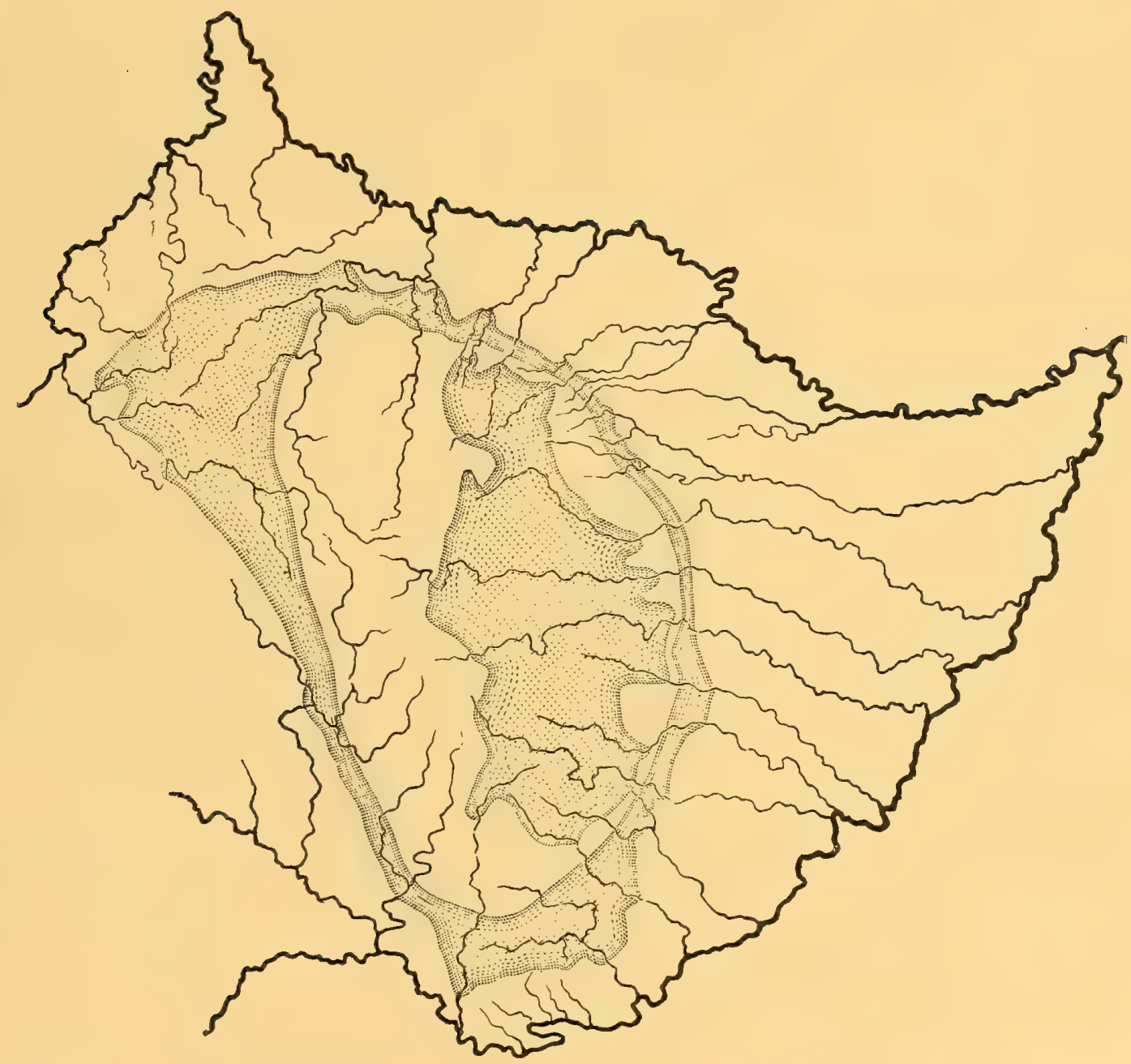

FIG. 27.-Diagram to exhibit the relation of the Drainage System of the Black Hills to the Zones of Hard and Soft Strata.

The central dotted space shows the Archæan area of soft rocks. The annular clotted zone shows the outcrop of the soft Red Beds and Jura. The intervening white zone shows the outcrop of the hard Carboniferous beds. 

inception of the uplift must therefore have been early in Tertiary time, and the same evidence shows that by the middle of the Tertiary it was in great part, if not entirely, completed. For unless the uplift had approached somewhere near its present dimensions the granite would not have stood sufficiently high above the level of the Tertiary conglomerate to render the transportation of its pebbles practicable.

The evidence derived from the stratigraphy shows, then, that the uprising of the Hills took place either wholly or in chief part during the interval of time between the completion of the Cretaceous formation and the beginning of the Miocene Tertiary.

Further light upon the history of the displacement is thrown by the drainage system. An attentive study of the arrangement of the streams shows that in their relations to the rock structure they fall into two classes. The first class includes all the creeks which drain the central area of the Hills. The second includes the two rivers, branches of the Cheyenne, which flow. past the Hills and receive the waters of the creeks. / With slight exception the creeks flow in the direction of the dip of the strata, or, if we use the classification of Powell, are "cataclinal." Rising for the most part near the center of the uplift, they run outward in all directions, just as the rocks dip outward in all directions. If the dome of strata were formed under a lake or sea and then laid bare by the recession of the water, it would be natural that the drainage system created by the rain upon the rounded surface should show a descent everywhere in the direction of the dip. If the top of the uplift appeared above the water before the uprising was completed, the result would be the same, and it would not be far different if the scene of the uplift was a plain instead of a sea bed, provided the uprising was not of exceeding slowness. In either case the arrangement of the drainage is a distinct consequence of the uprising and would be classed as "consequent." It is difficult to conceive of any system of drainage except a consequent system, in which all the streams are cataclinal, and it is therefore extremely probable that the creeks of the Hills acquired their positions and directions either during the formation of the uplift or else when it was laid bare by a retiring lake. In either case the drainage system is consequent upon the uplift. 
The relation of the rivers to the rock structure is entirely different. The Belle Fourche, or North Fork, approaches the uplift from the west, and, with a northeasterly course, runs directly across it-not at its highest point, but at a place where the height of the arch is more than 2,000 feet (see Figure 26). In like manner the South Fork crosses the southern spur of the uplift, and in its meandering passes in and out of the flank of the arch in a manner that seems entirely independent of the dip of rocks. If the reader will turn to the bird's-eye view, he will see that the South Fork, which flows from left to right across the foreground, first crosses the series of hog-backs in a direction opposed to their dip, and then on the opposite side crosses the hog-backs somewhat in the direction of their dip. In its middle course it traverses the arching plateau of the Dakota sandstone, cutting a gorge several hundred feet in depth and passing out on the opposite side; and then, after having escaped completely from the obstruction, it turns back, and in a loop several miles in length carves a second cañon in the same sandstone.

In their relation to the rock structure these water-ways are manifestly inconsequent, that is to say, their directions were determined by conditions entirely independent of the uplift of the rocks. In Powell's classification two kinds of inconsequent drainage are recognized, the one called "antecedent," and the other "superimposed." Antecedent drainage is produced when an uplift, occurring in a region the drainage system of which is already established, progresses so slowly that the corrasion of the streams keeps pace with it and their positions remain unchanged. Superimposed drainage is produced when a system of streams which originally pertains to one rock system is transferred vertically downward to a different and unconforming rock system, the latter being brought to light by prolonged denudation

If the Belle Fourche and the South Fork are antecedent to the Black Hills uplift, then the region must have been dry land when the uplift began, and, if subsequently submerged, cannot have received enough sediment to clog their channels. If, on the other hand, they are superimposed upon the uplift, we may be equally confident that they acquired their courses on the surface of a series of sediments laid down subsequent to the uplift and 
reposing unconformably on its flanks. Knowing as we do that the White River Miocene was deposited after the completion or approximate completon of the uplift and that it lay against the flanks of the Hills (upon the south at least), we cannot hesitate to decide that the rivers were superimposed. If they existed before the formation of the Hills they were completely blotted out by the Tertiary lakes and their sediments, and the assumption that they did so exist is entirely gratuitous. Whenever the water of the lakes finally retired from the region of the Hills, the rivers began to flow in what were then the lowest lines of the surface and there they have flowed ever since.

The courses of the creeks were fixed and their work of erosion was commenced when the uplift first exposed its summit to the rain. They are precisely as old as the Hills, and they have been the agents of the degradation of the uplift At first they may have descended directly to a sea or lake, but when the White River conglomerate was formed their lower courses were upon a plain which bordered a lake. Afterward the lake rose and carried its shore to the flanks of the Hills, and some or all of them discharge their water directly into the lake. When at last the lake was withdrawn, the branches of the Cheyenne River came into existence upon its bed, receiving the discharge of the creeks and completing the present drainage system.

The coincidence of the directions of creek courses with the directions of the dip must be understood to be only approximate. Each creek in the course of its history has sunk alternately through soft and hard strata, and while in the soft strata it has deviated from its original place by the process of meandering. In a few cases streams of considerable size have so far shifted their courses as to form unions with each other before escaping from the foothills, but such instances are rare. There is, however, one general exception to the rule of cataclinal drainage which deserves fuller mention.

When the displacement began its summit was necessarily a divide or water-shed, from which the water flowed in all directions. In the absence of any disturbing cause this water-shed would remain as steadfast as the drainage lines all through the period of degradation. Knowing of no disturbing cause, we may assume that the existing water-shed in the Hills holds 
the same position as the original water-shed, and marks, therefore, the position of the summit of the uplift at the time of its inception. An inspection of the geological map, or of Figure 27, shows that the main water-shed has a north and south trend and runs near the eastern edge of the Carboniferous plateau. The summit of the uplift, as shown by the contours of Figure 26, corresponds very nearly with the central part of the Archæan area. Its trend is parallel with that of the watershed, but it lies fifteen or twenty miles farther east. Thus it would appear that the portion of the uplift which took the lead at the start was afterward overtaken and exceeded by another portion, so that the present summit or axis of upheaval is not the original axis of upheaval. They both fall within the tabular top of the main uplift, and the present difference between them is only a few hundred feet.

Notwithstanding the eccentricity of the main water-shed, the creeks of the Hills afford a rare example of consequent drainage. It does not often happen upon the slopes of the most symmetrical uplifts that so large a number of water-ways assume and adhere to centrifugal and independent courses. So perfect a drainage system could hardly have been established except under the most favorable circumstances, and this seems to preclude the idea that the uprising began upon a land surface. If it took place in a region subject to subaerial conditions, there must have been a pre-existent drainage system, and that system could not but have an influence upon the new system inaugurated by the uplift. It seems more probable that the movement began under water, imparting its curves to a surface smoothed by the spreading of sediments, so that when it was subjected to meteorologic influences its surface was an exact representation of the displacement and guided the new drainage in perfect accordance with the dip of the rocks.

The evidence derived from the drainage system appears to show then, first, that the Hills began to rise before the desiccation which eventually succeeded the Cretaceous; second, that the form of the uplift was changed during its progressive increase, the maximum line shifting from west to east; and, third, that the flanks were so far buried by Miocene sediments as to be given a new river system when the lake water was finally withdrawn. 
This last conclusion has an important bearing in another direction. The general degradation of the Hills has made little progress since the time of the Miocene conglomerate. Some drainage line or lines had then cut so deeply as to touch the granite, and at the present time the bottom of the deepest valley in the same vicinity is only 2,000 feet lower. Two thousand feet would be an incredibly small amount of erosion in a mountain district for the indicated interval of time if the conditions of erosion had always remained as they are now. But the difficulty lessens when it is known that the erosion was retarded first by a long lake period, during which the water-ways of the Hills were in part clogged by their own débris, and second by a long period of slow general degradation, during which the accumulated lake sediments were little by little carried away and the "base level of erosion" was slowly depressed.

\section{4.-The AGe of the igneous Rocks.}

The igneous masses have so much in common, both in the character of their material and in their relation to the stratified rocks, that they are assumed to have a common epoch of formation, and whatever is determined with reference to one is by analogy ascribed to the whole. Unfortunately our evidence is not at all precise, and serves only to indicate certain widely separated time limits, between which the bosses of trachyte and rhyolite were formed.

In nearly every locality of igneous rock the adjacent sedimentary rocks were found to have undergone some modification either of character or of position. Wherever a clay or sandstone was seen in contact with the intrusive mass it was found to have been more or less metamorphosed by the original heat; and about many of the peaks the strata are upturned at considerable angles in such way as to leave no question that their flexure is a phenomenon of the volcanic event. In all such cases it is evident that the modified strata are older than the associated intrusives: In different places all members of the sedimentary series from Potsdam to Dakota were found upturned around igneous centers, and at a single locality, Bear Butte, the same influence was found to extend to the Fort Benton group, No. 2 of the Cretaceous. The higher members of the Cretaceous and the 
strata of the Tertiary nowhere lie in such proximity to the igneous peaks that their structural relations could be made out. All, therefore, that we can learn from the relation of the exotic masses to the strata is that the epoch of their introduction was later than the Fort Benton Cretaceous.

The opposite limit is shown by the contents of the Miocene conglomerate. At the base of the White River deposit Mr. Jenney found not only granite and quartzite from the Archæan, but pebbles of trachyte, and these could only have been derived from the Black Hills bosses. The lavas were, therefore, introduced, solidified, and at some point subjected to erosion before the beginning of the Miocene.

The indicated interval comprises the Niobrara, Fort Pierre, Fox Hills, Judith River, and Fort Union epochs; a period of time represented by a total depth in the upper Missouri region of about 4,000 feet of sediments. The date of igneous activity is, therefore, very far from established, and its relation to the uplift of the Hills is not even determined. The trachytes may have been in place, and even ancient, when the uprising began, or they may have been forced up while the greater movement was in progress and well advanced.

A study of the drainage here affords no aid. A rising current of molten rock cannot flow with secular slowness through colder rocks on account of the interchange of temperatures and resulting congelation; and for this reason an uplift of strata by volcanic force is of necessity catastrophic. In all ordinary cases antecedent drainage is thrown back and turned aside, and a local system consequent to the new mountain takes its place. The drainage of the igneous uplifts of the Hills is essentially, though imperfectly, consequent, but no conclusion can be drawn from the absence of an antecedent system.

\section{5.-Summary of the history of the Hills.}

Putting together the salient events recorded by the character and arrangement of the rocks, as well as by the arrangement of the drainage lines, we have the following history:

The older Archæan was first laid down. It consisted in chief part of shales and with these were some sandstones. Over it, and probably after 
an interval during which some erosion and metamorphism took place, the newer Archæan was deposited. Its constitution was about the same, but it was characterized by a greater amount of sandstone. At about the same time a large quantity of igneous rock was introduced between layers of the older Archæan, and there solidified, taking the form of granite. The record is then blank for a period of great duration, and it is only known that at some time during that period the Archæan strata were altered to the condition of crystalline schists and quartzite, and were subjected to a vast displacement and erosion, whereby their worn edges were left in a vertical position over the whole area of their present exposure. In this interval there may have been many alternating epochs of sedimentation and erosion. We only know that the closing epoch was one of erosion, and that the locality of the Hills was part of a large tract of dry land.

The next chapter is one of sedimentation. The ocean advanced slowly over the sloping land, sorting and rearranging with its waves and currents the débris that lay upon its surface, and forming the Potsdam conglomerates and sandstones. For a time a ridge of the Archæan seems to have formed an island in the Potsdam ocean, where the Hills now stand, but it was eventually overwhelmed and covered by the shifting sand. After this first advance the waters seemed to have retired for a while, for the Black Hills show no trace of great formations that were accumulated elsewhere; but there was no local displacement and no deep-cutting erosion, and the sediment of the returning ocean was spread in apparent conformity over that which marks the Potsdam invasion. The new flood was deeper than the old, and it deposited at first only limestones, but after a time it became shallower, and in the latter part of the Carboniferous period many beds of sand were interpolated among the calcareous deposits.

Up to this time the ocean was full of life, but now the conditions were changed in some way, and life seems to have been banished. Perhaps there was a glacial epoch, and all forms that could not migrate perished; or perhaps the local waters were by some revolution cut off from the general ocean, and, like the Dead Sea, became saturated with a poisonous mineral. When life at last returned the sea was so shallow that the (Jurassic). deposits were ripple-marked, but there was no exposure of land surface. 
Salt water seems to have covered the surface continually to the close of the Mesozoic, and it was probably succeeded without interval by the fresh water of a Tertiary lake.

Before the water retired the uprising of the Hills began, and as soon as the arch of strata appeared above the surface an erosion commenced which has not yet ceased. Afterward a second Tertiary lake laved the flanks of the uplift, half buried its foot with sediments, and then disappeared. Upon its dry bed the courses of the modern rivers were traced. The streams that had been transporting detritus from the Hills and casting it into the lake now found their way to the rivers and transferred their burdens to them. Little by little, but continuously, they have eaten away the substance of the Hills ever since. The cañons they have cut, and which appeal to our eyes as marvelous monuments of their industry, are the least of their results. Since their labor began they have demolished and removed one half of the entire mass of the uplift. Modest and feeble as they seem, it is their ambition patiently to toil on until no vestige of the Hills remains. 
U. S. GEOGRAPHICAL AND GEOLOGICAL SURVEY OF THE ROCKY MOUNTAIN REGION.

J. W. POWELL, in Charge.

\section{MINERAL RESOURCES}

OF THE

\section{BLACK HILLS OF DAKOTA.}

Br WALTER P. JENNEY, E. M. 



\section{CH A P T E R IV.}

\section{MINERAL RESOURCES. \\ By Walter P. Jenney. \\ SECTION I. \\ INTROD UCTION.}

The Black Hills are pre-eminently a gold-producing region; the metamorphic rocks constituting the gold-field cover an area of nine hundred square miles, extending north and south through the central portions of the Hills for a distance of seventy miles, with a breadth of from five to twenty five miles.

Gold occurs in the following formations:

I. In veins of quartz more or less ferruginous traversing the Archæan schists and slates.

II. In strata of slate mineralized and altered by the action of waters depositing silica and iron pyrites.

III. In the conglomerate forming the lower layer of the Potsdam sandstone, resulting in this case from the denudation of the ledges in the Archæan rocks.

IV. In trachyte and porphyry intruded at the time of the elevation of the Hills in the interval between the Cretaceous and Tertiary periods.

$\mathrm{V}$. In deposits in the slates and sedimentary rocks produced by the intrusion of the trachyte and porphyry.

VI. In placer gravels resulting from the decomposition and erosion of the above formations in Tertiary and recent time. 
The miners, for convenience in making laws to govern the recording and locating of claims, have divided the gold-field into different districts, which division I shall follow as closely as possible in considering the value and character of the gold deposits.

\section{SECTION II.}

\section{THE FRENGH CREK DISTRIOT。}

In the French Creek district is embraced all the area of granitic and schistose rocks surrounding Harney Peak and forming the southern portion of the Hills, bounded by Spring Creek on the north, and including the placer gravels in the valleys of Wiwi Creek, Custer Gulch or French Creek, Amphibious, Minnekata, and Red Cañon Creeks, streams draining this region and emptying into the south fork of the Cheyenne.

Before discussing the value and extent of the gold deposits it is necessary to describe briefly the topography and geological formation of this district, which presents, in the immense development of granitic rocks, a feature peculiar solely to this section of the Black Hills.

The Harney Peak range, and the country included between it and the foothills on the eastern slope, is an exceedingly rugged and mountainous region, heavily wooded with pine and cut into innumerable deep ravines by a net-work of small streams flowing in a general southeasterly direction, but sinking before they reach the plains. These small creeks are full of beaver dams, and the bottoms of the gorges are overgrown with a perfect jungle of oak, elm, birch, elder, and grape-vines, making it almost impossible to descend the valley of the stream, and compelling the explorer in this wilderness to travel across the steep and broken rocky ridges, where, except he be fortunate enough to climb some of the few commanding peaks, he cannot see but a short distance in any direction, owing to the denselywooded and broken character of the region. It is useless to look for any main divide which can be followed in traversing this mountainous section; the whole area is broken into innumerable granite peaks and ridges without any apparent system whatever, except that the drainage is in a general southeasterly direction toward the open plains. The effects of erosion are 
everywhere strongly marked, and the peculiar topography of the region is due to the resistance of the hard granite and the yielding of the micaceous schists to the action of time and water.

The prominence of the granite, which in huge, serrated ridges rises on every side, is due more to erosion than to any elevation caused by its intrusion; yet the granite, though so unyielding, shows by the rounded and pinnacled forms assumed by the peaks that time has affected it as well, but in a less degree.

To the northeast of Harney Peak is an area of slates, which properly belongs to the Spring Creek district, but with that exception this section is almost universally granitic; the schists, wherever they occur, being concealed by the débris resulting from the denudation of the granite ridges that tower far above the surface of the softer rocks.

Harney Peak, having an altitude of 7,403 feet above the sea, is the culminating point of this great intrusion of granite, and forms the most conspicuous landmark in the Black Hills, visible from the plains to the south and east for a distance of more than fifty miles from the foothills.

The park region, at the west and southwest of Harney Peak, is a most agreeable contrast to the inaccesssible wilderness to the east. Broad glades of level grass land extend between the parallel ridges of granite and groves of pine cover the rocky hills wherever there is sufficient soil to support their growth. Isolated peaks of granite, rounded by erosion and weathering into dome-shaped and castellated forms, rise from the open and level surface, which everywhere is carpeted with the finest grass, giving a beautifully picturesque and park-like scenery to the region.

The smooth surface of the parks and the peculiarities in the topography are due to the parallel ridges of granite resisting the denudation, which has excavated the broad swales in the intervening softer schists, and indicates that the original surface of the formation was far above the present level.

The granite is comformable to the stratification of the inclosing schistose rocks, having been intruded between the layers; the only direction in which the micaceous rocks are readily fractured. This conformability is not perfect, as it would be were the granite the result of metamorphic 
action on a layer of the schists, but the granite ridges often occur traversing the park as a broken range of lenticular peaks on the same line of fracture, resembling, on an enormously-magnified scale, a well-known form of segregated quartz-veins. Narrow dikes of granite traverse the schists, often not more than 2 or 3 feet in width and of regular thickness, continuing uniformly for several hundred yards parallel to the stratification, and being harder than the schists, have been left by erosion standing like walls several feet above the surface of the ground. Where the surface of contact of the granite and the schists is exposed, the sides of the dike are seen to be smooth surfaces, often beautifully marked with slickensides exceeding in the polished and striated markings any specimens of the walls of mineral veins which have ever come under my notice.

The sides of the lenticular masses of granite forming the low ridges show slickensides and vertical striated surfaces, but not nearly in so marked a degree as the narrow dikes.

The granite is very coarsely crystalline, largely composed of white or flesh-colored feldspar, intermixed with quartz and mica (muscovite), with black tourmaline in large hexagonal crystals as an associated mineral. Quartz occurs disseminated through the mass of the feldspar in. small grains and in nodules between the crystals. Segregated veins and irregular masses of quartz occur in the granite ridges, generally white, vitreous, or translucent, frequently of a beautiful deep rose-color, but everywhere apparently free from any traces of valuable minerals or any considerable quantity of gold.

The schistose rocks are in great variety, mica-schist being the prevailing form, often garnetiferous, and merging into talcose, chlorite, and quartz schists.

The minerals found in the schists are few in number. Small garnetcrystals are very abundant; a few specimens of hornblende, epidote, and staurotide were seen, but they occur but rarely in these rocks. Veins and ledges of ferruginous quartz are found traversing the schists between the granite ridges or dikes to which they are parallel. These ledges are not true fissure-veins; that is, they do not intersect the strata at an angle to the stratification, neither are they segregated veins, but occur filling continuous 
and regular fissures between the lamellæ of the schists formed in the folding of the rocks, and are in fact interlaminated fissure veins:

The quartz is often mixed with a large proportion of brown and yellow oxides of iron, resulting probably from the decomposition of pyrites, and the gold now found in the gravel-deposits along the streams has been derived from the disintegration and denudation of these ledges in the schists.

But little prospecting could be done in the numerous quartz-veins of this district for want of time and proper tools. The miners reported gold in small quantities from several veins which they discovered and opened.

Near the stockade on French Creek a mass of schist was noticed, about 150 feet in length, upturned on edge and completely inclosed by a broad rim of granite. This fragment of schist was traversed by a ledge of quartz and limonite several feet in width, conformable to the stratification, and cut off at each end by the subsequent intrusion of the granite. From the uniformity in the composition and appearance of the granite from all parts of the Harney Peak range, the dike character of the ridges, the presence of slickensides, and the observed instances of inclosed fragments of schists, I can but regard the granite of this region as injected. There are occurrences of small, narrow veins of feldspar leading from the granite into the schist, probably deposited by chemical solutions accompanying the intrusion, which would seem to indicate that the fluidity of the injected granite was due more to the presence of water than to the intensity of the heat.

French Creek rises in the level park country southwest of Harney Peak, among granite, gneiss, and schistose rocks, and flows in a general easterly and southeasterly course about fifteen miles, until, entering a deep cañon in the limestone formation, it sinks among the bowlders in the bed of the channel and disappears before reaching the foothills, continuing as a dry arroyo, with water-holes at intervals, to the Cheyenne. Near its head it is a sluggish stream with long stretches of slack water; in midsummer, notwithstanding frequent showers of rain, drying up to a chain of water-holes. A few miles below the stockade it is swelled by springs and side branches to a creek 10 to 15 feet in width and about 8 to 12 inches deep, flowing with a moderately-rapid current until it is lost in the cañon.

Gold was discovered in gravel bars on French Creek early in August, 
1874, by Ross and McKay, miners accompanying the expedition under command of General G. A. Custer, but from want of time they were unable to ascertain definitely whether the gold existed in paying quantities, although obtaining by a few days' work quite encouraging prospects.

About three weeks later this field was visited by the Rev. S. D. Hinman, with an escort from the agencies on White River, in search of a suitable location for a reservation, but not finding any evidences of gold, on their return they threw some discredit on the reports of the existence of the precious metal in the Black Hills.

A party of twenty-five miners from Sioux City reached French Creek December 23, 1874, and built a stockade and cabins near the location of General Custer's camp. They passed the winter prospecting very industriously for gold in the vicinity, opening several quartz ledges in the schistose rocks of the park and sinking pits on the flats and gravel bars along the stream.

Before cold weather was over and the frost out of the ground, so that the diggings could be opened on a scale large enough to practically test the richness and extent of the gravel deposits, these miners were removed by the military to Fort Laramie.

When I reached French Creek, June 16, 1875, about fifteen miners were found camped four miles above the stockade, where they had been at work for several weeks, and had staked off claims, built small dams, and were digging ditches preparatory to commencing sluicing on the bars along the banks of the stream. These miners were very enthusiastic in regard to the mineral wealth of the gulch; they were reporting from 5 to 27 cents to the pan from the pay gravel, and made the most extravagant statements as to the yield which would be obtained as soon as they commenced working with sluices. But they were working under unfavorable circumstances; the water-supply was very small, not exceeding 50 miner's inches, with every indication that it would soon fail entirely, and the grade of the valley was so small that it was difficult to get a good head of water for sluicing. On testing, by washing, the pay gravel from the different prospecting holes already opened, with a pan, and weighing the gold obtained, it was found that the usual yield along the stream was from four to eight colors to the pan (about one-tenth to one-fifth of a cent), and, in favorable and some- 
what limited localities, from half a cent to as high as one and a half cents were obtained from the gravel from off bed-rock. The gravel bars were rich enough in gold to pay if extensively worked under more favorable circumstances, but too poor to yield a remunerative return for the labor employed, except in a few limited deposits of gravel near the extreme head of the stream.

The next day the following dispatch, embodying all the information in regard to the gold-field that had been obtained to date, was sent by courier to Fort Laramie and telegraphed to Washington:

\section{Camp on French Creek, Near Harney Peak,}

To Hon. E. P. Surti, June 17, 1875.

Commissioner of Indian Affairs, Washington, D. C.:

I have discovered gold in small quantities on the north bend of Castle Creek, in terraces or bars of quartz gravel.

Arrived here yesterday. About fifteen miners have located claims on the creek above here, and have commenced working. Gold is found from Castle Creek southwardly to French Creek at this point; the deposits are almost wholly in Dakota. The region has not been fully explored, but the yield of gold thus far has been quite small and the reports from the richness of the gravel bars are greatly exaggerated.

On French Creek the deposits of gravel are very unfavorably situated. The water-supply is small and failing, and the grade too little to admit of the tailings being carricd off by the stream.

The prospect at present is not such as to warrant extended operations in mining.

WALTER P. JENNEX, E. M., Geologist Exploration of the Black Hills.

The fact of the existence of gold caused considerable excitement among the soldiers and teamsters of the escort, and quite a number were busily engaged in prospecting along the creek, sinking holes to the bed-rock wherever there was the slightest indication of a deposit of gravel, or cleaning out old prospecting shafts dug by the miners the preceding winter, and panning the pay gravel, which had been reported to be so rich in gold. But the results of their labor were so discouraging-generally only a few small "colors" would be obtained from a pan of gravel, and rarely more than three-quarters of a cent to the pan in the richest layer of pay dirt from off bed-rock-that after a few days they abandoned the search for the precious metal and did not resume it for more than two weeks, until the discovery of a very encouraging prospect on a bar near the stockade caused 
a renewal of the excitement for a time, an account of which will be given farther on.

In examining the gravel deposits along the valley of French Creek advantage was taken of the numerous prospecting shafts already sunk by the miners, and in the few places remaining untried which gave any indication on the surface of the existence of valuable underlying gravel beds, shafts were sunk to bed-rock by the miners assisting me in the work. The first tests were made by washing several pans of the pay gravel in the usual manner, and if the result obtained was at all encouraging the deposit was more extensively tested by washing a measured quantity of the pay dirt in a rocker and weighing the gold obtained. Finding that the best prospects in the gulch were from gravel from a prospecting shaft on a dry branch of French Creek about five miles above the stockade, the following test was made to determine as aecurately as possible the richness of the deposit:

The shaft was first eleaned out and a sufficient quantity of the pay gravel drifted out from off bed-rock, carefully averaged, measured, and washed with the greatest care in a rocker, every precaution being taken to prevent any appreciable loss of fine gold carried over the riffles by the muddy water. The result was as follows: 9 buckets gravel $=3.12$ cubic feet, gave 0.370 gram of gold in small flat scales and grains; 0.370 gram $=5.7$ grains troy $=\$ 0.23$, or about one and one-fourth cents to the pan.

This would indicate a yield of $\$ 1.87$ per cubic yard of the pay gravel which formed a layer on bed-rock about a foot in thickness.

In the above calculation an average bucket of gravel is taken at 600 cubic inches, or 75 buckets equal one cubic yard. A pan is about half a bucket, giving 150 pans of dirt to a cubic yard. I have estimated the value of the gold to be $\$ 19.50$ per ounce in gold coin.

The gravel from a shaft some distance below on the stream, tested in a similar manner, gave the following result : 10 buckets dirt $=3.42$ cubic feet, yielded 0.020 gram gold; 0.020 gram $=0.3$ grains troy $=0.012$ cent, or 9 cents per cubic yard, equal to one-twentieth of a cent to the pan. This latter gravel was very poor in gold, but that washed in the preceding test was correspondingly richer than the average of the gravel opened at that time along the creek. Near the stockade the result of the prospecting 
showed that the richest gravel was from a hole sunk to bed-rock on the bank of the creek, four pans of the pay dirt giving $\frac{3}{4}$ grain troy $=3$ cents gold, or $\frac{3}{4}$ of a cent to the pan. Washing twelve buckets of this gravel in a rocker yielded $4 \frac{1}{4}$ grains troy of gold $=17$ cents, or $\$ 1.12$ per cubic yard; nearly the same result as was obtained with the pan.

Most of the prospecting holes had been sunk early in spring, when the ground was full of water and the locations selected with regard to the rimrock, so that the bed-rock might be reached before the depth of the shaft became so great that it would be flooded with surface water. In order to test the deeper channels in the flats near the stockade, a place was selected where the configuration of the surface of the ground indicated an old channel filled with gravel to the present surface of the bar.

A shaft 5 feet by 7 feet was sunk to bed-rock, which was reached at a depth of 15 feet, passing through gravel filled with large water-worn bowlders 2 to 3 feet in diameter. Four men were constantly employed for three days in sinking this shaft; the bowlders had to be broken with sledges and hoisted out with a windlass, and the water was so troublesome as to require constant bailing to keep the shaft dry. The bed-rock was found to be granite. On cleaning up the whole surface the size of the bottom of the shaft and panning the gravel not a color of gold was obtained, a result which was unlooked-for by the miners, the gravel passed through having been quite promising in appearance.

Having forwarded to Washington a written report embodying the results of the prospecting and exploration made up to date, (June 25), I left French Creek, and, accompanied by my miners, made an excursion north; for the purpose of examining the valleys of Spring and Rapid Creeks, and on my return, July 8, I found that some new discoveries had been made, and considerable work done by the miners in my absence.

A party of miners about five miles above the stockade had put in a small sluice, and reported that they obtained by one day's work 27 pennyweights of gold, or nearly $\$ 27$; three men being employed in shoveling the gravel into the sluice. Unfortunately the work on this bar was stopped by the stampede to the new discoveries in Spring and Castle Creeks before 
it could be thoroughly tested and the richness of the deposit proved to be constant and regular.

John W. Allen, of Cheyenne, an experienced miner, and one of the best prospectors I ever knew, in a letter to the Chicago Inter-Ocean, gives the results of this sluicing, in which he assisted the owners of the bar:

Cheyenne, Wroming Territory, August 30, 1875.

To the Editor of the Inter-Ocean:

I waited last spring for the country to be thrown open by this Indian treaty now pending, and, becoming impatient, I concluded to do as hundreds of others did, to start into the Hills, and on the 12th of July landed in Custer Park, and being an experienced miner, $\mathrm{I}$ had doubts in regard to French Creek paying, because of there being: no fall to the creek and scarcely any water. But I found one set of sluice-boxes about to be set up, and I went to work and helped to fix them, and then worked one day and weighed the dust, and found that the ground paid $\$ 9$ per day to the hand of fine dust, although I am sure this creek will not average that all the way through the gulch.

JOHN W. ALLEN.

John Roberson, an old California miner of the "days of '49," had discovered very good prospects on an elevated bar near the stockade, and, building a dam, conveyed the water from the creek in a small ditch to the face of the drift. In the mean time the soldiers had become quite excited over the discovery, and were hard at work with pans and rockers washing the pay dirt from off bed-rock. For several days they were quite successful. From 16 to 26 colors were obtained to the pan One soldier found a piece of gold valued at 20 cents; another a small nugget weighing about a pennyweight, worth 97 cents, and 24 buckets of gravel gave on washing an average of 12 cents gold. On drifting in on the bar the pay streak rose, and was found among the bowlders nearly 18 inches above the bed-rock. The section of this gravel deposit was as follows:

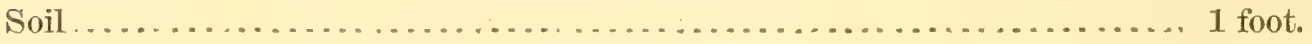

Gravel and bowlders .................................... 4 feet.

Clayey compact gravel containing the gold.....................6 inches.

Decomposed bed-rock and bowlders ......................... 1 foot.

Micaceous schist forming bed-rock. 
The sluices were soon in place, and this, bar most thoroughly tested, under the direction of Mr. Roberson. The result of the first day's work of eight hours, four men being employed most of the time, was 2 pennyweights 8 grains troy of coarse gold, valued at $\$ 2.30$.

The second day not only the gravel was put through the sluice, but the whole surface of the bed-rock exposed by both days' work was most carefully cleaned up and washed. The return, however, was but 1 pennyweight 9 grains troy of gold, equal to $\$ 1.10$.

The work of both days may be summed up:

4 men 1 day, result ....................................... \$2 30

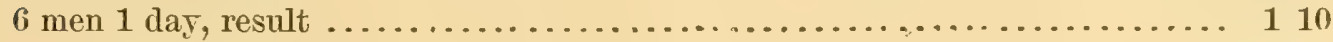

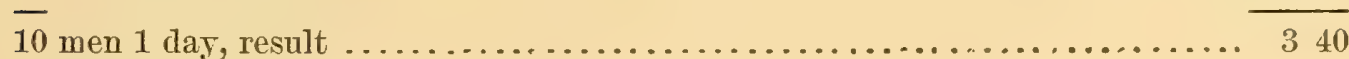

or a yield of 34 cents per day per man.

This result was a disappointment to every one, and seemed to indicate that the richness of the gravel at first obtained was due to a concentration of the gold on rim-rock, and that the cleaning of the bed-rock probably yielded only a very small proportion of the gold, the greater quantity being derived from the compact gravel.

The gold obtained was in coarse, flat scales, or small, spongy grains, and was quite deceptive in its appearance, nearly all the miners guessing the weight of the dust very much too high.

Gold was found in small quantities in gravel deposits along the numerous creeks flowing east from Harney Peak, but the region is so inaccessible, and so many difficulties are encountered in attempting to prospect it, that but little could be done by myself and assistants in that area, while the rush to the discoveries on Spring and Castle Creeks carried all the miners in the Hills far to the north, and left this region but partly prospected.

Some prospecting was done on Amphibious, Minnekata, and Red Cañon Creeks, small streams draining the southern portion of Custer Park. On Amphibious, near its headwaters, a few colors of gold were obtained from small gravel deposits, but the water-supply was so small, the stream being dry at the time, that prospecting was very difficult. About five miles below. the head of this creek a number of dry ravines enter it from the east, cut- 
ting deep into the schists and slates. In these ravines float quartz wais found, showing, on breaking, visible particles of gold, but the quartz was not traced to the ledge from which it had been originally derived.

Minnekata or "Hot Water" Creek, so named by the Indians from the warmth of the water, which has a temperature of $74^{\circ}$ Fahr., although rising in large warm springs in the Carboniferous limestone, has a deep deposit of quartz-gravel on its east bank, about two miles below its source. This gravel is derived from the wash from the Hills, and is composed of bowlders of rocks and quartz cemented by sand and lime to a loosely cohering conglomerate, forming a bluff on the bank of the stream. Similar deposits are to be seen at intervals among the foothills at the edge of the plains all along the eastern slope from this stream as far north as the Box Elder.

On Red Cañon Creek several tests were made of the gravel deposits, but nothing of value found. This stream is on the extreme western edge of the gold-fields, and rises partly in the limestone, contains but little water, and drains but a limited area of the schistose rocks.

The gravel deposits elevated above the present level of French Creek showed often a local concentration of gold on the outer edge of the bedrock from the repeated washing away of the gravel by floods or heavy rains, leaving the gold contained in it behind. Though giving a very encouraging prospect at first, on driving an open eut a few yards into the bar where the gravel was undisturbed, the richness of the pay dirt rapidly decreased until it equaled the true average of the whole deposit, thus showing that the result at first obtained was only a "rim-rock prospect."

The richest layer in the pay gravel was rarely on bed-rock, but usually from 10 to 20 inches above it, forming the upper surface of the stratum of compact clayey gravel mixed with fragments of decomposed bed-rock which had caught and retained the greater portion of the gold.

The gravel-bars along French Creek, for several miles above and below the stockade, were examined wherever there was the slighest indication or probability of gold existing in paying quantities with results similar to those already given, and, as might be expected from the level character of the valley, the gravel deposits were richest around its head branches, 
and proved regularly poorer in gold as the distance below its source increased.

Excepting Castle Creek no stream in the Hills was prospected the past season to anything like the extent that the gravel deposits on French Creek were subjected to. The whole bottom of the valley for nearly six miles was full of prospecting pits. Each new party of miners on arriving in the Hills first visited Custer Gulch, as it was called, and expended their surplus energy and enthusiasm in sinking a number of prospecting holes before proceeding elsewhere in search of gold. But the results obtained by these miners were very poor, except in a few localities in dry sags and gulches about the head of the creek and in a limited number of elevated bars along the stream above the stockade.

The gold obtained from the placer gravels on French Creek was in small flattened scales and grains, quite uniform in size, mixed with very little fine dust, and nearly free from magnetic-iron sand. It showed but little action of water, and the garnet crystals associated with it were often quite perfect and searcely rounded by attrition. The greater portion of the gold seems to be derived from the quartz ledges in the schistose rocks, and not from the intruded granite; for in side gulches, where the rocks were wholly composed of granite, I failed to detect any traces of gold.

The gravel of the placers is a mixture of water-worn quartz mingled with a less proportion of bowlders from all the rocks at present found in the region, including granite and fragments of the harder schists and slates.

The pay gravel is composed of the heaviest pebbles, with some clayey sand and large quantities of red garnet crystals derived from the schists. It is soft, rarely cemented to a conglomerate, and easily washed in a sluice. The layers of the gravel are porous and not clayey enough to be impervious to water, allowing it to pass freely through, and causing considerable inconvenience in prospecting.

The exploration and prospecting on French Creek, both by the geological party and the miners, showed, up to the time I left the gulch, a general diffusion of fine gold in the gravel beds, but little concentrated in the deposits, and found in small quantities throughout the whole breadth of the valley. 
The water-supply at the head of French Creek was very small and uncertain, totally inadequate for extensive working of the gulch, while the flatness of the valley is also a serious obstacle to the successful working of the gravel bars if water should be brought from Castle Creek for that purpose; which cannot be done until the richer deposits on that creek are exhausted.

Above the stockade there are localities where the gravel will pay fair wages for sluicing, using the limited water-supply of the creek and working only the richest places in the beds. I regard the poverty of the French Creek deposits, compared with those afterward discovered on the streams farther north, to be due to a deficiency in the source of supply, owing to the small area drained by the stream, the small amount of denudation to which the ledges in this area have been subjected, and to a want of sufficient grade in the valley to cause a concentration of the gold into a pay ehannel.

Had all the gold diffused through the valley of French Creek been concentrated into a narrow lead or pay channel, it would have made claims as rich as the most enthusiastic miner would have desired.

\section{SECTION III.}

\section{SPRING CREEK DISTRICT.}

Spring Creek rises among the parks in the central portion of the Hills to the west and northwest of Harney Peak, and is formed by the union of a number of small brooks, some heading in the limestone at the western edge of the Beaver Creek Plateau, others in the granite of the Harney Peak range, or with numerous ramifying branches drain the schistose rocks of the parks.

Just below where the main branch, flowing from the south, rising among the granite and metamorphic schists of the parks, unites with Newton's Fork, coming from the talcose and quartz schists in the direction of Castle Creek, a remarkable change is seen in the topography of the region and the character of the rocks; and Spring Creek, becoming a fine and rapid stream, heads eastward into a new geological formation-the second 
division of the Archæan strata of the Black Hills. We have left to the south and west a region of feldspathic granite, mica schist, talcose and quartz schists, with crystalline or rose quartz, mica, garnets, and feldspar as the characteristic minerals, and enter a parallel belt of massive gray quartzites, argillaceous and siliceous slates, in which the prevailing minerals of the schists are no longer seen.

The change in the character of the rocks produces a corresponding change in the topography of the region; the soft mica-schists had been worn by erosion into broad parks and valleys, intervening with rounded peaks and ridges of the harder strata, but the massive quartzites and hard siliceous slates, resisting denudation, have been left in steep and high rocky hills, through which the stream, winding and twisting among the peaks, has cut a narrow gorge several hundred feet in depth.

This ridge of hard slates and quartzites near the contact of the two formations is an extension of the line of uplift of the Harney Peak range. Although the granite does not extend as far north as this point by several miles, yet the extreme hardness and uniformity in composition of these rocks, enabling them to resist erosion, may be in part due to the metamorphic action accompanying the intrusion of the granite forming this range. Following the course of the stream, which soon enters a cañon among the higher peaks of the ridge, the dip of the formation is observed to change from a general westerly direction to a well-marked easterly dip. The sections of the quartzites exposed in the walls of the cañon show a contorted and irregular folding of the strata, but scarcely a quartz vein of noticeable size occurs in the cliffs, although the composition of the rocks is extremely siliceous; a most decided contrast to the superabundance of quartz distributed through the mica-schists of the older formation about the heads of this stream. Spring Creek, emerging from the cañon, winds through a broad and beautiful valley, bordered by groves of pine for nearly five miles. Long level tracts of fertile bottom lands, destitute of trees and covered with a rank growth of the finest grass, extend on either bank of the stream, while both on the north and south small open valleys reach far back among the broken and rolling hills, the bright green grass of these glades contrasting strongly with the darker color of the pine forest 
covering the slopes and rocky ridges. For nearly twenty miles this stream flows in a general easterly course, crossing the slate and quartzite formation at right angles to the bedding of the strata. Where the hard quartzites predominate in the hills, the creek has cut a deep gorge or cañon through them; but where the softer clay-slates prevail in extensive belts, the stream flows through an open valley, inclosed by low rolling hills and bordered by broad level flats of grass land. Finally, entering a cañon in the limestone formation near the foothills, the water sinks among the bowlders in the bed of the stream and disappears, from whence a dry arroyo, fringed with trees, continues to the plains.

In the Spring Creek district I include, for convenience of description, all the area of the Hills drained by that stream, and also a district of clayslates northeast of Harney Peak, giving rise to a small branch known as Whiskey Creek, flowing six to eight miles south of Spring Creek, in the same direction, and sinking in the foothills.

The head branches of Spring Creek drain an area of nearly one hundred and fifty square miles, elevated about 6,000 feet above the sea, characterized by low, rounded hills and ridges, wooded with pine of medium size, interspersed with numerous small parks and grassy valleys, well watered by the springs and brooks forming the sources of this stream. The prevailing rocks of this region are mica-schists, often garnetiferous and merging in all gradations into talcose and quartz-schist and strata with thin slate-like lamellæ, containing but traces of mica.

Quartz oceurs, distributed abundantly in the schists as thin segregated veins, parallel to the bedding, or in irregular bunches, not continuous in the strata. It is found crystalline, white, red, or rose tinted, and, with the exception probably of gold, appears to be free from any other minerals.

The abundance of quartz forms a serious annoyance in prospecting for ledges, the whole country being covered with float quartz of every variety, rendering it difficult to trace fragments found to contain gold to the veins from which they were derived. The first tests for gold on Spring Creek were made on a small branch flowing west from Harney Peak and emptying into the main stream about three miles above Newton's Fork. The gravel, resulting from the wash of the granite of the Harney Peak range, 
failed to give a trace of gold on panning, but on descending the branch and testing the gravel, as soon as we had entered the mica and quartz schists, small colors of gold were obtained.

The different strata were encountered in the following order in proceeding down this branch :

1. Coarsely crystalline white feldspar granite of the Harney Peak range.

2. Metamorphic schist (gneiss).

3. Mica-schist, with segregated quartz veins, containing traces of amorphous graphite.

4. Quartz-schist, having a slaty structure alternating with strata of mica-schist; the whole formation dipping $45^{\circ}$ west.

In descending Spring Creek, the first gravel bars are seen about five miles above Newton's Fork, elevated from 20 to 40 feet above the present level of the stream on flat points and benches of mica or quartz schist.

On making an open cut into these bars on bed-rock the gravel is found to be almost exclusively composed of quartz, and to yield, on panning, small quantities of gold, from one color to half a cent to the pan. Better results were obtained from drifts run in on bed-rock in the flats near the edge of the stream. The gravel is full of mica and small garnet crystals, resulting from the disintegration of the schists, and the gold is associated with black sand and bright scales of iron ore.

To test the deeper channels in the flat, a shaft 5 by 8 feet was sunk with considerable difficulty to bed-rock, which was reached at a depth of $13 \frac{1}{2}$ feet, passing through the following deposits :

Brown-colored, loose light gravel .

Compact white quartz-gravel, containing about half a cent to the pan of coarse scale

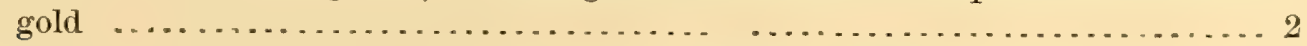

Loose quicksands with bowlders, yielding only fine colors of gold ......... 4

Decomposed bed-rock, with colors of coarse scale gold .................. $1 \frac{1}{2}$ Bed-rock; lamellar, talcose-schist.

The quicksand was so loose that water flowed in such quantities into the shaft as to keep one man employed constantly bailing to enable the others to work. The gravel was panned regularly for every six inches $16 \mathrm{~B} \mathrm{H}$ 
depth of the shaft, and the pay dirt and gravel from off the bed-rock tested by washing a number of pans and comparing the results. Scales of mica largely composed the lighter gravels and white quartz, and slightly waterworn garnet crystals were found in the more clayey layers. The pay streak was not on bed-rock, but nearly 6 feet above it, in the first compact layer of gravel.

Finding a number of prospecting pits in the vicinity, which had been sunk by a party of miners from French Creek, I had the pay dirt from these holes tested, and obtained results similar to the above. Encountering the miners, they informed me that they had experienced great difficulty in reaching bed-rock on account of water, and that nothing had been found by them up to that time better than the deposits in Custer's Gulch. Spring Creek at this point was 8 feet wide and 6 inches deep, with a moderate current, probably at this time (June 25) affording 250 to 300 miner's inches of water. The placer gravels of this portion of the Spring Creek district may be classed as elevated bars and gulch deposits. The elevated bars are bank of quartz-gravel, occupying flat points and rocky benches at the bends of the creek from 10 to 40 feet above the present channel, and formed by the stream when ages ago, it flowed at that level through the valley.

The gulch deposits cover the bottom flats of the valleys along every branch where there is flowing water, and are much more extensive in area than the higher bars, and include gravel-deposits resting on bed-rock near the present water-level, old channels of the stream, filled with gravel and soil, winding through the flats, and the more recent placers occupying the present bed of the creek.

The result of prospecting on this branch of Spring Creek seemed to show a general diffusion of gold in nearly paying quantities through quite extensive gravel deposits, which in many respects resemble the bars in Custer's Gulch. The water-supply was, however, considerably greater, and the grade or descent of the valley sufficient to enable the deposits to be worked with much less expenditure of time or labor, so that, were the deposits of equal richness, they would be more valuable here than on French Creek. These head branches were, however, only partially prospected up 
to the time I left the district (August 1), and Newton's Fork was comparatively untouched, the whole attention of myself and miners being giren to practically testing the value of the richer deposits situated some miles below. While I am writing hundreds of miners are hard at work prospecting this region, and the valuable deposits, wherever they exist, will soon be found and made to give up the gold they contain and have held uselessly locked up for ages. At this period in the exploration I was camped with a small party of my miners about a mile below the junction of Spring Creek and Newton's Fork for several days. We had been prospecting the head branches of the stream with results which were not as encouraging as the appearance and character of the gravel deposits would indicate should be obtained.

The mountainous region to the north and east, embracing the valleys of Spring and Rapid Creeks, was unknown and unexplored. The expedition led by General Custer the preceding summer had passed around this rugged area to the west and north, following the valley of the Box Elder, on leaving the Hills, and the miners who were on French Creek had not as yet attempted to penetrate it in search of gold.

I had noticed to the east the change in the geological formation of the country, and regarding the belt of clay slates and quartzites as more favorable to the production of valuable placer-deposits of gold than the metamorphic mica-schists with their superabundance of crystalline quartz, I decided to descend the stream far enough to insure the concentration in the placers of any gold resulting from the denudation of the ledges in the slate formation, and there prospect and test the, richness of the gravel deposits and prove the value of the district.

Locating in the valley of Spring Creek, about eight miles below Newton's Fork, near where the immense quartz formation known as the Mammoth ledge crosses the gulch, a few hours' prospecting resulted in the discovery of gold in paying quantities in the placer deposits of this stream. June 29, 1875, Thomas H. Mallory, one of the best prospectors associated with me the past season, noticed a line of large bowlders extending across the stream, forming a dam or riffle, and, suspecting that rocks of that size and weight must rest on bed-rock, waded into the creek, and turning 
over a bowlder, dug from beneath it a blue gravelly clay, a shovelful of which gave on washing six flat scales of gold about a tenth of an inch in diameter, or five cents to the pan. Putting all my force of miners at work in this place, several of the bowlders were rolled to one side, affording a passage for the stream and decreasing the depth of water above the riffle. On examination the pay gravel was found to be a deposit about 35 feet in width, crossing the creek and extending into the banks on either side. resulting from the decomposition of a stratum of soft clay-slate in the bedrock, which had caught and retained the gold swept over it by the stream, The deposit consisted of-

1. Loose gravel of slate and quartz, with small bowlders, containing traces of gold; thickness, about 6 inches.

2. "Pay streak," a compact gravel, full of small red garnet crystals, rich in coarse gold; from 3 to 6 inches in depth.

3. Plastic blue clay mixed with rotten slate bed-rock, yielding gold in paying quantities, but not as rich as the garnet-gravel; thickness, 1 to 2 feet.

4. Lamellar clay-slate, soft and decomposed, forming bed-rock.

The "Mammoth" quartz ledge crossed the bed of the creek just below this rich deposit, and subsequently it was found that the line of bowlders forming the riffle had lodged in the soft slate above the upper side of the ledge, as shown in the accompanying sketch.

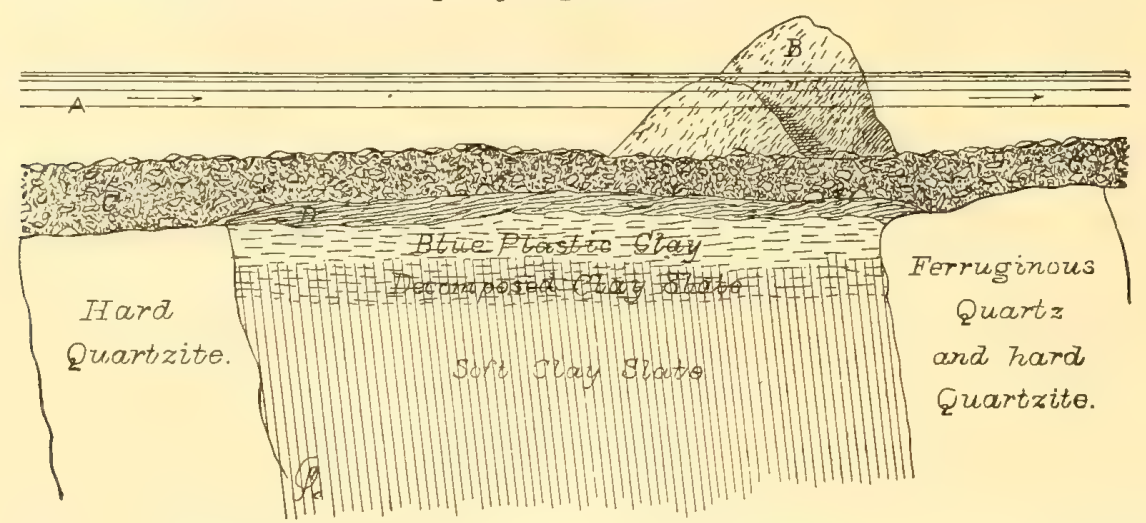

FIG. 28. Longitudinal section of the bed of Spring Creek at the point of original discovery.
A. Water of stream.
B. Riffle of large bowlders.
C. Loose gravel and bowlders, poor in gold.
D. Pay streak heavy red garnet-gravel; auriferous. 
A number of pans of the pay gravel were washed with a result of from one to two grains troy of coarse gold, or 4 to 8 cents to the pan. The average of the whole thickness of clay and gravel was nearly 4 cents to the pan, while the pay streak would give returns considerably higher if washed separately. A pit was sunk in the bank of the creek, and the pay streak found equally rich. At a depth of 5 feet from the surface several inches of garnet-gravel overlaid a yellow clay a foot in thickness, resting on rotten slate and quartz bed-rock The average result on panning the clay and gravel of this pit was about 4 cents to the pan. Subsequently I saw the soldiers of the escort obtain from 10 to 15 cents to the pan from the pay streak in this pit. After prospecting for several days in the vicinity it became evident that my small force of miners unassisted could not in a season properly examine the gravel deposits along this section of Spring Creek, and after exploring Rapid Creek I returned to this locality July 14, with Captain Burt's and Captain Munson's companies of the Ninth Infantry. The fact that gold had been struck in paying quantities caused the first stampede in the Hills, and nearly two hundred miners followed me from French Creek, staked out claims, established a mining district, and rendered me subsequently great assistance in prospecting the region.

After a few days' work, comparing my results with those obtained by the miners who had staked claims for several miles along the creek above and below my camp, the following dispatch was, through the kindness of Col. R. I. Dodge, commanding the escort, sent by special courier to Fort Laramie and telegraphed to Washington:

\section{Cayp on Spring Creek, Black Hills of Dakota,}

To Hon. E. P. Sммнस, July $17,1875$.

Commissioner of Indian Affairs, Washington, D. C.:

I have discovered gcld in paying quantities in gravel bars on both Spring and Rapid Creeks, from twenty to thirty miles northeast of Harney Peak.

The deposits are the richest yet found in the Hills, and are very favorably situated. There is a good head of water in the streams, amply sufficient for working purposes.

The gold is derived from quartz ledges of enormous dimensions in a belt of clayslate and quartzite twenty miles in width, crossing the Hills in a northwesterly direction at this point. The clay from the bed of the stream near camp yields from 4 to 8 
cents to the pan, and several pieces of about the value of a dollar have been found by the soldiers. I am engaged in prospecting the value and extent of the region.

WALTER P. JENNEY, E. M., Geologist Exploration Black Hills.

In order to test the richness of the gold deposits in the bed of the creek, it was necessary to turn the water out of its present channel. With the assistance of the soldiers a dam was built across the stream above the point of discovery and the water of the creek conveyed by a ditch 1,000 feet in length across a bend and returned to the channel below the place we wished to test, leaving comparatively free from water about 400 yards of the former bed of the stream. Before reporting definitely on the richness of the new discovery I wished to test on a practical scale the gravel from the different bars, and for this purpose constructed from rough boards, whip-sawed from the native pine, a small box sluice 10 to 12 inches in width, formed of two boxes 14 feet in length. This work had consumed more than a week. In the mean time the soldiers who were not employed in assisting me had been hard at work in the bed of the creek above the riffle washing the clay-gravel in pans and rockers with quite remunerative results. Several ragged and irregular pieces of gold with oxide of iron adhering in the cavities had been found, weighing from $\frac{3}{4}$ pennyweight to $1 \frac{1}{2}$ pennyweight and worth from 75 cents to a dollar and a half. From 5 to 15 cents to the pan was usually obtained from the pay streak, and the soldiers sometimes washed out nearly a dollar's worth of gold in three or four hours' work with a pan. From twenty buckets of dirt taken from the bed of the stream and washed in a rocker 2 pennyweights of gold, or nearly $\$ 2$, was cleaned up, while the pay gravel in places yielded as high as 75 cents from five buckets of the top gravel-equal to $\$ 11.25$ per cubic yard.

Working as they did, often waist-deep in the water of the creek, under many disadvantages from want of skill and tools, letting their tailings fall back into the holes from which they dug the pay dirt, and, from the pasty and clayey character of the gravel, obtaining but a portion of the gold which it contained, the above results are quite remarkable. For, despite all drawbacks, from an area about twice the size of the floor of a wall-tent ( 8 by 18 feet), not less than one and a half ounces of gold were obtained. 
The water leaking through the dam and that derived from a number of small springs in the bed of the creek produced a stream of about 30 miner's inches flowing through the channel from which the creek had been turned, causing great annoyance and difficulty in working, which could only be entirely obviated by constructing a bed-rock drain sereral hundred feet in length; an undertaking that would consume too much time.

To exclude the water from the strip of pay gravel crossing the creek at the original discovery, while testing it, a wing-dam was built around the deposit, and the pit kept moderately dry by continuous bailing. The sluice was placed in position, the first box into which the gravel was shoveled being left open, and a longitudinal riffle placed in the second to catch the gold. A sufficient head of water was brought in a small conduit from the main ditch, and the gravel, clay, and decomposed bed-rock, covering a space 8 feet by 9 feet, dug out to a depth of 18 inches, and put through the sluice. The result, on cleaning up after four hours' work, was one-third of an ounce troy of coarse scale gold, worth $\$ 6.48$. This was obtained from four cubic yards of gravel, from which the soldiers had previously taken the cream of the deposit, and quite a large portion of the material sluiced was tailings that had been once worked. The next day the sluicing was continued at the same place, a fresh portion of the creek-bed being inclosed by a wing-dam. The result of six hours' work was one-half ounce troy of gold, equal to $\$ 9.72$. The result of the work of both days may be summed up as follows :

$$
\begin{aligned}
& 4 \text { hours' work produced } \frac{1}{3} \text { ounce troy gold }=\$ 6.48 \\
& 6 \text { hours' work produced } \frac{1}{2} \text { ounce troy gold }=9.72 \\
& -\quad-
\end{aligned}
$$

Five men were employed in these tests, one of whom was constantly at work bailing the water leaking through the wing-dam into the pit, while the others picked up bed-rock, shoveled the gravel into the boxes, and tended sluice. They worked, however, under so many disadvantages that, with a sluice of proper size and a bed-rock drain, two men could have easily done the same work in the same time, with probably a somewhat increased yield of gold. But even charging this return of $\$ 16.20$ with the labor of 
five men for ten hours, the result was $\$ 3.24$ per day per man, and with economical and skilfull working on a larger scale the clean-up should equal at least one-half ounce, or $\$ 10$, to the hand. The soldiers had been panning previously from this spot for two weeks and worked out the richest of the gravel, and on weighing the gold in their possession I found that they had obtained about $\$ 32$ from the area I had sluiced in both days' work, which measured 216 square feet and had been excavated 18 to 20 inches in depth; or 12 cubic yards of gravel put through the sluice had yielded $\$ 16.20$ in addition to that obtained by the soldiers, giving $\$ \mathbf{4 8 . 2 0}$ as the total yield, or about $\$ 4$ per cubic yard. The water leaking into the pit gave a great deal of trouble, preventing the bed-rock from being properly cleaned up, and the blue plastic clay, on being shoveled into the sluice, even after puddling, rolled into balls and washed through the boxes unchanged, carrying with it any gold which it contained. On testing the tailings which concentrated under the tail of the sluice, I found that considerable gold had in this way been swept through and lost, the sluice being too short to properly work so clayey a gravel. The soldiers rockered the heaviest of these tailings and the lumps of clay, obtaining about $\frac{1}{2}$ pennyweight of seale gold from them. Large quantities of red garnet crystals were caught in the riffles, together with cubical crystals of iron pyrites and round water-worn pieces of hematite iron ore. No quicksilver was employed, as I wished to procure a sample of the gold in its natural state for assay.

The richest layer in the deposit was the lower part of the red garnet gravel where it rested on the upper surface of the blue plastic clay. Pieces taken from this contact showed, on breaking, scales and particles of gold contained in it. The bed-rock, as far as we dug into it, about a foot below its surface, contained coarse gold in small quantities, probably caught in crevices in the rock before it decomposed. The soldiers, under the direction of John Roberson, for two days sluiced the gravel from the bed of the creek below the riffle, but found the bed-rock either a hard massive quartzite, worn by water smooth and level, or a ferruginous quartz with masses of crystalline iron pyrites-the outcrop in the creek of the Mammoth ledge. The gravel was loose and poor in gold, and the character of the bed-rock prevented it from ever retaining any gold swept over its surface by the 
stream. Only about 25 cents and $\$ 1$ were obtained by these tests. Afterward they put in a wing-dam just above the area I had sluiced out, and found a few square feet of the clay-gravel, but above that the bed-rock pitched up stream and changed to a hard quartzite, with loose, poor gravel. The result of about six hours' work was $\$ 2.70$ gold, mostly obtained from the small quantity of clay-gravel adjoining my pit. No one attempted to follow this deposit far into the flats on the banks of the stream, though it gave equally good results at either end, and may have been continuous for some distance across the bottom. In review of this deposit, it may be described as a strip of plastic clay crossing the bed of the creek, and resulting from the decomposition of a strata of soft clay-slate located on the rise of the bed-rock, while both above and below was a hard massive quartzite, smooth and water-worn, but protecting the slate from being rapidly cut away by the current of the stream. The sample of gold obtained by this test was submitted to Mr. Ricketts, assayer at the School of Mines, New York, for the determination of its fineness and value per ounce. The results of two assays, each made in duplicate, are annexed, showing that the gold from this district is very pure, being $946 \frac{4}{10}$ fine, or $22 \frac{3}{4}$ carats, and, just as it is washed from the placers, is worth $\$ 19.44$ to $\$ 19.63$ per ounce.

Certificate of assay.

SchOOL OF MiNeS, New York, January 6, 1876.

SIR : The sample of placer gold from Spring Creek, Black Hills of Dakota, submitted to me for examination, contains, by assay of raw dust without previous meltingGold 937.8 fine. Silver 45.9 fine. Base metal 16.30

Total 1000.00

The excess of base metal is due to the presence of oxide of iron adhering to the particles of gold.

The value in gold coin of one ounce troy of dust isGold

Total

Very respectfully,

Walter P. Jennex, E. M.

P. DE P. RICKETTS, E. M. 
Certificate of assay.

\author{
SCHOOL OF MiNES, \\ New York, January 6, 1876.
}

Sin: The sample of placer gold from Spring Creek, Black Hills, submitted to me for examination, contains, by assay of the melted bar, made by sampling about one ounce of the raw dust and melting to free it from oxide of iron-

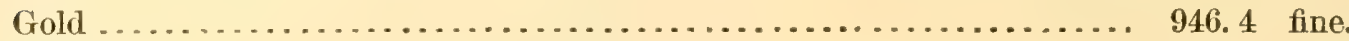

Silver............................................ 50.4 fine.

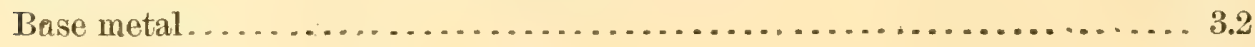

Total.............................. $\overline{1000.00}$

The value in gold coin of one ounce troy of melted dust is-

Gold ................................................... \$19.562

Silver ............................................ 0.062

Total . . . . . . . . . . . . . . . . . . . . . . . . . . . . . . . 19.624

NotE.-The value of pure gold per ounce troy is $\$ 20.67$; the value of pure silver per ounce troy is $\$ 1.24$.

Very respectfully,

Walter P. Jenney, E. M.,

P. DE P. RICKETTS, E. M.

Geologist Black Hills Expedition.

About 100 feet above the original discovery an attempt was made to test the creek-bed by building a wing-dam to keep out the water and sinking a prospecting hole inside of it. But after a day of hard work we were obliged to abandon the working at a depth of 4 feet, springs of water bursting through the gravel and flooding the pit. From three to four colors of gold were obtained from the loose gravel.

In a broad gravel flat a quarter of a mile below this point a prospecting hole was sunk to bed-rock, which was reached at a depth of 6 feet, and found to be hard quartzite, covered with loose gravel, resting on a surface worn as smooth as a floor by the water. Several pans of dirt were washed from this pit, but not a color of gold was found. Another pit located in an old channel had to be abandoned at the depth of 5 feet, quicksand being struck so fluid that it flowed into the working and caused the walls of the pit to cave in.

Two prospecting holes in the flat where the Mammoth ledge crossed the gulch struck a cement of quartz-pebbles and oxide of iron so hard as to be penetrated with great difficulty. The same cement, several feet in thick- 
ness, could be seen capping the ledge on the hill near the creek, but on panning it failed to give a trace of gold. Near my camp a small sluggish branch entered the creek from the south, and about half a mile above its mouth a prospecting hole was sunk in the flat. After passing through about 6 feet of soil, gravel, and bowlders, a black, peaty muck was encountered and penetrated a depth of 7 feet, when the water, bursting in, flooded the hole, and a pole 5 feet long was easily thrust down through the muck in the bottom of the shaft, but failed to reach any compact layer of gravel.

A similar experience was the result of a hole put down by "California Joe" on his claim below camp. After passing through 6 feet of large bowlders and compact gravel a deposit of black muck was struck, and finally an old beaver dam, composed of sticks and mud, was passed through, resting on another layer of muck, at which point the work was stopped by the water. The valley below the Mammoth ledge was contracted in width, and appeared to have been gradually filled up since it had been excavated. Bed-rock was reached in only two places, although a number of shafts were sunk by the miners, and in these cases the rock was hard and the gravel poor in gold.

The hills bordering the stream were composed of thick strata of massive quartzite upturned on edge, and the narrowing of the valley was doubtless due to the hardness of this belt of rocks, resisting denudation and the forces which excavated it Above the original discovery for nearly five miles the valley was broad and open, with rolling and broken hills of siliceous and clay slates, with occasional belts of quartzite. Here the gravel deposits were very broad and extensive; flats, in places a quarter of a mile wide, extended along the banks of the creek, while elevated bars were to be found at the bends of the stream and sides of the valley, which promised to be very valuable. One of the most noted of these older deposits of the stream, discovered the past season, was the celebrated "Stand-off Bar," concerning the ownership of which there promised at one time to be a serious difficulty, that was only avoided by the determination of its discoverers to "stand-off" all intruders. John W. Allen, the present recorder of the district, in a letter to the Chicago Inter-Ocean, thus describes this deposit, which proved to be so rich that the owners caved in the drift on leaving the 
Hills, to prevent any stragglers from working the bar during their enforced absence :

\section{Cheyenne, Wroming Territory,} August 30, 1875.

\section{To the Editor of the Inter-Ocean :}

After prospecting a short time in the park we moved to Spring Creek or Jenney's Gulch, and on the morning of the 20 th of July we commenced prospecting Stand-off Bar. We did not work more than half an hour until we panned out 25 cents to the pan, found coarse gold, and ran across the bar about 35 feet. From the last pan of dirt taken out of the face of the drift we got one pennyweight and three grains, or what we term a good dollar, to the pan. This is about one mile up Jenney's Gulch, above Professor Jenney's discorery. We panned several pans that weighed from 25 cents to 50 cents and from 78 cents to 93 cents to the pan ; it ranged all the way from 10 cents to \$1. *** We prospected also on Castle Creek, and have proven beyond a doubt there are good placer-mines there as well as on Spring Creek. We also found good six-dollar-per-day diggings on Rapid Creek; and had not the military order arrested our work, we would soon have had plenty of the yellow metal out of the ground to have shown the world that the Hills are very rich. While we were preparing sluice-boxes, whip-sawing lumber, \&c., preparatory to working our ground, we got the "grand military shake," and had to leave our claims and the Hills. * * *

JOHN W. ALLEN.

Having returned to the Hills after the withdrawal of the military forces, Mr. Allen writes me, under date January 2, 1876 :

Our bar (Stand-off) pays $\$ 1$ in gold per hour per man employed; have on hand 26 ounces of bankable gold dust taken out inside of three weeks.

Mr. James Allen, of Cheyenne, who visited Spring Creek at that time, writes :

I prospected ten pans of dirt from Stand-off Bar and got for my trouble \$5.3a.. I am perfectly delighted with the country. If anything, it is better and more extensive than has been represented. A company known as the "Montana company" had only been in the gulch three weeks when I got there; during that time they had built two houses, cut a ditch near a quarter of a mile in length, whip-sawed their lumber for sluices and set them running, and had taken out near $\$ 1,000$ in nice, coarse, bankable dust.

The claim's worked by this company are situated below Stand-off Bar, and $I$ understand that the pay dirt was obtained by a drift run in 50 feet on the rim-rock of an elevated bar, as high as $\$ 110$ being obtained in one day's work by three men. The companies could not run their sluices more than six hours during the warmer part of the day, owing to cold and frost, yet obtained from $\$ 6$ to $\$ 7$ per day per man as the result of this limited work. 
Owing to the numbers of small springs in the flats, it is doubtful if they will be worked until covered bed-rock drains can be constructed to remove the surplus water and admit of dry working. The more elevated and easily worked bars will first be attacked and made to give up the gold which they contain. Near the point of original discovery the soldiers found opposite their camp on the hill-side a small deposit of gravel, 2 to 3 feet deep, which proved to be quite rich, yielding from 12 to 19 cents to the pan by actual weight.

Just above where the Mammoth ledge outcropped on the south side of the valley was a hill of cement-gravel which gave colors on rim-rock, and on sinking a shaft in the center of the hill we passed through a hard cement of quartz pebbles, gravel, and bowlders, but after a week's work failed to get bed-rock at a depth of 22 feet owing to the extreme hardness of the conglomerate, which was cemented by oxide of iron, probably deposited by. ferruginous springs, the iron of which was derived from the decomposition of pyrites in the ledge. The gravel from this shaft failed to show gold on panning, perhaps owing to the particles of gold being inclosed in the hard lumps of the cement. It promised to be a good deposit to hydraulic, as that process would break up the cement and set the gold free. Two or three miles below this point there were some quite extensive gravel deposits, where a small branch entered the creek from the north, that were reported to prospect well by the miners who located claims on these bars. But lower down the stream flowed through a deep rocky gorge cut in the slates, with gravel deposits at intervals along its course wherever the gorge was not contracted into a narrow cañon. This portion of the stream, extending from the original discovery to the point where the creek sinks in an impassable cañon in the limestone near the foothills, a distance of ten or twelve miles, can scarcely be said to have been prospected at all the past summer. In places the water flowed over the bare slates, and there are no gravel deposits; but at the bends and forks of the stream bars of considerable size were seen.

Below, where the creek sinks in its bed, are bars composed of quartz and slate gravel intermixed with a large proportion of limestone and sandstone bowlders. These deposits undoubtedly contain gold, but I was una- 
ble to prospect them, there being not a drop of water in the vicinity at the time of my visit (July 3); but in the spring this stream probably flows out into the plains, and these dry arroyos and placers can then be worked.

The available water-supply furnished by Spring Creek for working purposes varies with the season of the year, being probably greatest in April, May, June, and July, the rainy months, and least in October, November, and December, when there is little precipitation of moisture.

In turning Spring Creek from its channel a ditch $2 \frac{1}{2}$ feet wide and 2 feet deep, with a grade of 2 inches in 30 feet, was entirely filled, besides about 30 miner's inches which leaked through the dam; and the available quantity of water at that time (July 25) I estimated at not less than 350 miner's inches. During the summer months Spring Creek will afford from 300 to 800 miner's inches of water for mining purposes, the quantity varying with the season and the yearly rainfall. I had no instruments to accurately measure the grade of the valley of this stream, but by an aneroid barometer I found that the descent of the main stream from Newton's Fork to where the creek enters the limestone is about 1,400 feet in a distance of nineteen miles, or an average grade of 74 feet to the mile. The descent, however, is less than this for the more open and broad portions of the valley, probably 50 or 60 feet to the mile, and greater in the narrow, rocky cañons. The gold of this district occur's in the placers in coarse, flat scales, thick and heavy, intermixed with very little fine dust, and often shows brown oxide of iron adhering in the cavities of the larger pieces.

The assays made by Mr. Ricketts, of the School of Mines, show that this gold is $22 \frac{3}{4}$ carats, or 946 fine, equal to the average of the best Australian placer gold, and exceeding that from California. It is found associated with small water-worn red garnet crystals, nodules of hematite iron ore, magnetic iron sand, and crystals of iron pyrites, but no other minerals were detected.

The average proportion of gold in the native gold of California, as derived from assays of several hundred millions of dollars' worth, is eight huudred and eighty thousandths, while the range is mostly between 870 and 890. (Prof. J. C. Booth, of United States mint, in a letter to the author, of May, 1867.) The range of the metal of Australia is mostly between 909 and 960, with an average of 925. (Dana System Mineralogy, fifth edition, 1868.) 
The gold appears to be derived from the decomposition of the slates and quartzites, as well as from the denudation of the quartz ledges traversing these rocks. The source of supply of the gold is immense. The side valleys and gulches are often excavated for miles along the outcrops of the gold-bearing slates, and the quartzites, with their inclosed reins, have acted as feeders to the placers of the main valley. Over a very extensive area these rocks have been enormously eroded and the resulting material swept away. The gold it originally contained has- been partly caught and retained in the gulches; the rest, intermixed with gravel and bowlders from the metamorphic rocks, and also from the limestone and recent formations in the foothills, being carried far out on the plains and scattered broadcast over their surface, so that very little can be ever recovered. From the results of the prospecting done in this district up to August 1, 1875 , when I left the gulch, it would be inferred that the character of the bed-rock strongly influenced the deposition of the gold. Where the bedrock was a hard, massive quartzite, the water had worn it smooth, and no gold was to be found on its surface, while the gravel above it was loose and poor in the precious metal; but where the bed-rock was soft, easily decomposing slates, it had caught and retained the gold swept over its surface by the stream, and the gravel above, compact from the clay produced by its decay, was also rich in gold. In the flats and creek bed, when a stratum of soft slates is found crossing the gulch below, a high and hard bar with valuable deposits should be sought for.

In discussing the area drained by the headwaters of this stream, the characteristics of the schistose rocks covering that section have been already given. The main valley of the creek is excavated wholly in the rocks of the second division of the Archæan, the slate and quartzite formation extending as a belt fifteen miles in width from the granite on the eastern slope of the Harney Peak range to the northern part of the Hills near Crow Peak. On Spring Creek the general strike of the strata is northwest and southeast, with a dip from northeast $60^{\circ}$ to vertical, while locally the rocks are seen dipping west at high angles. The rocks of this formation are altered sediments, consisting of hard, massive gray or brown quartzites, lamellar quartz-slates, and soft clay-slates. By metamorphic 
action of waters holding silica in solution, or by the preponderance of clay or sand in the original sediments, these rocks inperceptibly merge into each other, and the strata of quartzite often cannot be distinguished from jasper or pure quartz veins except by position and structure. There is a most remarkable uniformity in the hardness and composition of these rocks, not only for long distances along the outcrops of the same strata, but throughout the whole extent of the geological formation of this belt rocks from widely different localities most closely resembling each other. The metamorphic action seems to have been the product of the mechanical force producing the folding and upturning of the strata in Archran time The quartz veins are not igneous injections, but chemical precipitations from waters holding silica in solution, partly, at least, derived from the wall-rocks of the veins, and undoubtedly formed during the folding of the strata, at which time the gold must also have been deposited. The lower layers of the Potsdam prove this, as they contain in places bowlders from both the veins and the wall-rock identical in hardness and appearance with the rocks in the immediate vicinity. This chemical deposition of silica would seem to be similar to the silicification of wood, the solution replacing the original rock atom by atom, and samples of quartz were seen where the original rock blended so imperceptibly with the white quartz that it is difficult to explain the formation of the quartz in any other way. Quartz occurs in the slates either as interlaminated fissure-veins, coinciding with the stratification and often quite extensively developed, or as short and thin veins, following for a few yards the jointing planes of the slates. It is in the quartzites, however, that the greatest development of quartz is to be found in this district. Strata of sedimentary rock have, by the action of water containing silica and iron in solution, been transformed into hard quartzite intermixed with ferruginous quartz in all proportions throughout the entire thickness and extent of the bed, until it resembles, on its outcrop, an immense ledge of quartz and vein matter, traversing the slates for long distances across the Hills. On examination, however, these peculiar formations are found to be altered sediments. There is no fluccan or casing to the ledges, and in the most favorable positions for the existence of slickensides they are seen to be wanting. 
One of the most remarkable is known as the Mammoth ledge, which crosses the valley of Spring Creek near the original discovery of gold. The stream has cut its channel through the formation, leaving a bluff from 20 to 30 feet high on the north side of the valley, exposing a fine section of the ledge. Near the base of the bluff the quartz is intermixed with a large proportion of yellow and brown oxides of iron, which has evidently resulted from the decomposition of iron pyrites. Where the ledge outcrops in the bed of the creek the quartz is found to be full of masses of crystallized pyrites, the water having protected it from oxidation. The ledge is bounded on the west by silicious clay-slates, containing minute garnet crystals, and having a general northwest and southeast strike, and a dip, indistinctly marked, about northeast $60^{\circ}$. The section, commencing at the west, is as follows:

1. Quartzite and ferruginous quartz, interlaminated and mixed with iron ore; width 90 feet

2. Gray, hard, barren quartzite; 50 feet.

3. Ferruginous quartz, mixed with quartzite, clay-slate, and iron ore (limonite); 200 feet.

4. Hard gray quartzite, forming the eastern boundary of the formation.

This ledge was a study for a mineralogist. It contains undoubted segregated veins of milky quartz, changing in a short distance into cellular, rotten quartz, mixed with limonite iron ore. Some of these masses of vein matter are 10 to i 5 feet wide, and continuous for short distances; at other places the quartzite became ferruginous, and merged into brown jasper, or, becoming more pure in its composition, changed to white quartz, as though the silica had replaced, atom by atom, the particles of the original sediment during the metamorphosis of the strata. This view seemed most reasonable in viewing the peculiarities of the banded quartz and black quartzite; each rock, while perfectly distinct, seemed to be the result of the difference in the capacity of the layers of the original sediment to allow the silicated solutions to pass through it.

There were no evidences of the comb structure so often seen in mineral veins, but everything pointed to segregation as the cause of the 17 B H 
formation. This ledge is remarkably persistent and continuous across the country. It was traced for four miles from Spring Creek in a southeast direction, and was reported by the miners to extend north to Rapid Creek, a distance of eight miles, still preserving its great width undiminished. A small gulch emptying into Spring Creek from the south was excavated its whole length in the outcrop of this immense quartz formation. The gravel deposits near its head are entirely made up of the disintegrated fragments of the ledge. On the south bank of the creek the quartzite is yellow and brown in color, and resembles impure jasper. . On breaking, it showed sometimes visible particles of gold, but samples of the rock submitted to Mr. Ricketts, assayer at the School of Mines, proved to contain but traces of the precious metal. The same result was obtained from iron pyrites from the bed of the creek. The oxides of iron from portions of this ledge were bright-yellow in color, resembling plumbic ocher, but on testing with a blow-pipe they were found to contain neither lead nor silver, but were merely a variety of limonite. The most promising ferruginous quartz from this ledge was roughly tested at the time of its discovery by crushing several pounds in an iron mortar and panning carefully, but only a color of gold was obtained; and it is doubtful if these immense quartz formations are of any value except as having furnished gold to the placer gravels.

In the bluff formed by this ledge, on the bank of the stream, are several small caves, penetrating the rock for 10 to 15 feet, like drifts in a mine, which proved to have been formed by the decomposition and washing away of soft clay-slate inclosed in the quartz. There are not less than three of these quartz formations crossing the valley of Spring Creek. One, two miles below the Mammoth, is characterized by a great development of "ribbon-quartz," thin bands of white quartz, and black quartzite or slate altemating in the ledge, giving it a banded or ribbon appearance. In places the rock became a pure white quartz, and, by its superior hardness resisting denudation, formed the crests of the rocky hills and ridges, and could be traced for a long distance across the country.

The only minerals besides gold found in the Spring Creek district were iron pyrites and the oxides resulting from its decomposition. A miner (Mr. Blake) brought me samples of a rock which he supposed to be black sul- 
phuret of silver. He had found it while wandering about in the Hills, having been lost for some time in this vicinity, On testing it with a blowpipe, it proved to be only clay-slate, and did not contain a trace of metal. It was soft, jet-black in color, with a luster resembling very closely the mineral for which he had mistaken it.

Up to the time I left the gulch (August 1, 1876) no valuable quartz ledges had been discovered, the attention of every one having been given to prospecting the placers. The gravel deposits of the Spring Creek district, especially for several miles above and below the point of discovery, are extensive in area and very favorably situated for working. The watersupply is ample, and the fall of the stream sufficiently great to enable water to be carried above the tops of the elevated bars without difficulty and with little expense, while there is room and grade enough in the flats, in places, admitting of bed-rock flumes being finally put in, and the whole thickness of the gravel flats, as well as the tailings from the elevated bars, being economically worked. Timber of suitable size and quantity for the construction of sluices, flumes, and trestles is to be found growing abundantly in the immediate vicinity, as well as for various house-building purposes and fuel. The gold is coarse, heavy, and easily saved in sluices, and contains but little silver or impurities to decrease its value. Thus it may be concisely stated, that the gold-placers of this district, worked by the systems and processes which the experience of twenty-five years has led the miners of the Pacific slope to adopt, will pay a handsome return for the labor required to open the deposits and extract the gold.

\section{WHISKEY CREEK.}

A small area of the Spring Creek district remains to be described, comprising the extreme southern end of the belt of clay-slates and quartzites included between Spring Creek and the granite ridges and spurs extending east from Harney Peak. The surface of this region is rugged and broken, though not as mountainous as the granitic area to the south about the headwaters of Wiwi Creek. The valleys and glades are covered with groves of burr-oak of medium size, the crests of the hills with pine, while. the bottoms of the ravines and gulches are thickly overgrown with alder, 
birch, hazel, and hornbeam. The greater portion of this area of slates is drained by the numerous branches of Whiskey Creek, a small stream with from 30 to 50 miner's inches of water (July 20) flowing east from the Harney Peak range, about six to eight miles south of Spring Creek, and sinking before it reaches the plains. Near the head of this stream, at the junction of the granite with the slate formation, a huge mass of slates, standing on edge, 30 feet in height, wa; observed projecting from a crag of feldspar granite. The fragment of slates was only partly inclosed in the granite, so that the north side of the lenticular peak was composed of slates, while the south was wholly granite. It was probably a "horse" in the granite dike. In the southeastern part of this area, near the foothills, is quite an expanse of Potsdam sandstone and Carboniferous limestone, but near where the water sinks in Whiskey Creek the limestone belt encircling the Hills is not more than a mile in width. With the exception of the presence of granite peaks among the slates, the general character of the rocks is similar to that of the Spring Creek Valley, and fine crystals of staurotide, mostly twins in lamellar schists, resembling the specimens of that mineral from Lancaster, Mass., were found near the granite ridges. In the lower part of the valley of Whiskey Creek small gravel benches occur along its banks, but gold was not discovered in paying quantities except below where the water sinks in the bed of the stream among the limestone Red Bed formations of the foothills.

From the fact that the area drained by this stream is almost identical in the character of the rocks with that of the Spring Creek district, although less extensive, I consider that there are good reasons to expect that, at least in some localities, gold may be found in paying quantities in the gravel deposits of Whiskey Creek and its tributaries.

The gold deposits discovered in the dry ravines and arroyos among the Red Beds where the dry bed of this stream winds through the low hills at the edge of the plains will be described in the section on The Deposits of Auriferous Gravel in the Foothills. 
SECTION IV.

\section{CASTLE ANI RAPID CREEKS.}

Rapid Creek is formed by two main branches-Castle Creek and the North Fork-each heading in the limestone divide near Crook's Tower, one of the most elevated portions of the Black Hills. It is the only stream on the eastern slope of the Hills flowing a continuous stream of water during all seasons to the Cheyenne. The other creeks sink among the foothills, and during the greater portions of the year are marked by dry channels traversing the plains. Though second in size to Spearfish or Redwater in volume of water, Rapid Creek is the largest stream rising in the Black Hills. From its extreme source in the springs issuing from the limestone at the head of Castle Creek to the point where it empties into the south fork of the Cheyenne, its length, omitting the minor bends, is not less than one hundred miles. Throughout its course it is characterized by a rapid current, the descent of the valley being about 3,200 feet from the source of Castle Creek to the edge of the plains at the foothills, and nearly 800 feet in traversing the open plains a distance of forty-five miles to the Cheyenne. The area drained by Rapid Creek and its tributaries has been divided by the miners into the Castle Creek and the Rapid Creek mining districts, the north fork not having been located as a district the past season, although gold was discovered in considerable quantities on that branch.

\section{THE CASTLE CREEK DISTRICT.}

Castle Creek, near its source in the limestone, is a small stream fed by numerous little springs issuing from the sides of the valley, and every few hundred feet the creek is dammed by the beaver, producing marshy ponds and boggy tracts of bottom land. At the head of the creek groves of tall slender spruce cover the hill-sides, separated by narrow open glades of grass land extending between the low hills, producing most pleasing views; but farther down the stream the spruce is replaced by pine, and the valley is berdered by cliffs of Carboniferous limestone, whose castellated appearance suggested the name of the stream. 
The limestone is almost horizontal in its bedding, and the stream gradnally cutting deeper throngh the strata as it descends finally exposes the Potsdam sandstone at its base, resting unconformably on the upturned edges of schistose rocks. Here the lower layers of the Potsdam are seen to be a coarse yellow or brown conglomerate, closely filled with pebbles of white quartz, in places nearly uniform in size, from 1 to 2 inches in diameter, worn smooth and round by the action of water. The schistose rocks are exposed in great variety, dipping first west as we descend the stream and then east at high angles. The strike is in a general north and south to northwest and southeast direction.

The rocks of this section evidently belong to the first division of the Archæan, and can be traced south across the park country to the French Creek district, where they are interlaminated with dikes of feldspar granite; but no granite is found in this vicinity. The schists are often very micaceous, although a gray talcose quartz-schist, having a slate-like structure, appears to be the prevailing rock, occurring in broad belts interstratified with mica-schist. These rocks, though distinct in bedding, insensibly merge into each other in character; mica-schist, from a preponderance of mica, becoming a soft, easily-decomposing rock, often highly garnetiferous, while with a greater proportion of quartz it passes into a fine-grained micaschist, or ultimately to a quartzite with only traces of mica.

Chlorite schist and talcose schist are extensively developed on some of the branches of this stream, and strata frequently are found completely filled with small red garnet crystals often not more than one-thirty-second of an inch in diameter. Quartz-occurs as segregated veins, usually not continuous for any great distance, locally expanding into bunches and irregular masses of quartz, following the stratification of the schists, but not crossing the bedding. These irregular deposits of quartz were very abundantly distributed through the rocks; often strings of lenticular masses of quartz followed a line of lamination in the schists, or thin veins could be traced for short distances coinciding with the stratification. They were not, however, true continuous fissure veins, but irregular segregations formed during the folding and metamorphism of the strata. The quartz is usually milk white and crystalline, sometimes vitreous, transparent, and stained and coated at 
its jointing planes and surfaces with oxide of iron, but apparently free from iron pyrites and metallic minerals. These quartz ledges must, however, contain, at least, traces of gold, and furnish it to the placer gravels. Small bright-green crystals of ripidolite in flat scales are inclosed in the mass of the quartz; and green chlorite, full of red garnet crystals, incases the veins when traversing the talcose and chloritic schists. Proceeding down the valley the rocks gradually change in character, becoming less micaceous, with a greater development of talcose and quartz schists, in places approaching a clay-slate.

Castle Creek, having made a most remarkable bend of eight miles to the north, the greater portion of the distance through a narrow and deep cañon, resumes its former southeast course in a valley excavated among the quartzites and clay-slates of the second division of the Archæan. An attempt was made to explore this cañon by myself and miners; but owing to the prevalence of fallen timber and tangled thickets of small trees and bushes filling the bottom of the gorge, we were unable to traverse it with horses beyond a point about seven miles below where Custer's trail leaves the creek. The exact line separating the two formations, the schists and the slates, was not seen, but the dip was observed changing from west to east, the quartz veins becoming less abundant in the rocks and free from mica or chlorite, and more continuous and regular in formation. Thin quartz veins followed the jointing planes of the slates as well as the stratification of the formation. The quartz was locally ferruginous and cellular from the decomposition of pyrites, and had more of a mineral-bearing appearance. It is evident from the change in character of the rocks that the line of contact of the mica-schists and clay-slates must pass in a general northwesterly direction from Spring Creek, near its union with Newton's Fork, across the hills and the cañon of Castle Creek until it is concealed beneath the limestone ridge between Crook's Tower and Custer Peak. Castle Creek enters the cañon in its north bend among the mica-schists, forming a continuation north of the rocks of the French Creek district, and emerges among clay-slates and quartzites identical with the rocks of the lower valley of Spring Creek, and easily traced across the hills to that district. Near the head of a small branch of Castle Creek, entering it from 
the south just below the cañon, the clay-slates were observed, forming the upper portion of a cliff resting unconformably on the schists at its base. Both formations were, however, upturned on edge at different angles, and it is possible that this apparent unconformability of the two divisions of the Archæan may have been the result of a "fault" formed during the folding of the schists and slates. The point where this unconformability was observed was almost exactly on the supposed line of eontact between the two formations. At short distances to the east and west the peculiar characteristics of the rocks of the different divisions were unmistakably exposed in the cliffs and outcrops of the strata. From the difference in lithological character in the rocks of the two formations, the resemblance between specimens of the schists and slates from the Black Hills and samples from well known Laurentian and Huronian of Canada and Lake Superior, as well as the observed superposition of the slates and quartzites on the talcose and mica schists, we have been led to regard the clay-slate formation as of more recent geological age than the mica-schists so extensively developed on the head branches of Castle, Spring, and French Creeks. This subject will be found treated more fully in the section on the metamorphic rocks by Mr. Newton. On examining specimens of the Archæan rocks in the possession of Prof. T. S. Hunt, I find that schists from the French Creek district resemble closely the "Mont Alban," or White Mountain series of Professor Hunt, which he regards as older than the Huronian.

I was informed by. Mr. A. H. McKay, one of the miners who accompanied the expedition of General Custer, that Ross and himself failed to find gold in prospecting on Castle Creek; but on a small branch in the north part of Elk Horn Prairie they obtained the first "color" of gold from the Black Hills July 28, 1874, and during the six days the expedition remained camped on French. Creek they improved the time and got gold enough to prove its occurrence in the placer gravels of that stream.

Gold was discovered on Castle Creek, above the cañon, June 12, 1875, by the miners assisting me in the work of prospecting. It was found in small gravel deposits along the creek and in the gulches leading into the stream from the south. About two or three miles below the point where Custer's trail leaves the valley a bar, covering an area of two acres, gave, 
on prospecting, nearly a cent to the pan of fine gold. This deposit of gravel was 4 to 5 feet in thickness, composed of quartz and slate pebbles, resting on bed rock of mica-schists, elevated about 6 feet above the water of the creek, and so favorably situated for working that the gravel could be sluiced with very little expense or trouble. Several pits were sunk in the flats near the channel of the stream, but failed to reach bed-rock, owing to springs of water, which could not be kept down by bailing. Small gravel benches were found on the sides of the cañon below this bar, which gave four to six colors of gold to the pan, but were of too limited area to be valuable.

Above the cañon on the main creek and its branches are small elevated bars and quite extensive flats of gravel, which were scarcely prospected at all by the miners who staked claims on this creek on the larger placers below the bend. The gold from this portion of the stream is in small, flat grains, resembling that of French Creek, and probably similarly derived from the quartz veins in the schists.

In July, while I was engaged with my assistants in testing the value of the placers on Spring Creek a party of miners discovered gold in paying quantities on Castle Creek below the north bend, and quite a stampede took place to the new diggings. When, three weeks afterward, I visited the new discovery, I found nearly one hundred and fifty miners camped along the valley prospecting the claims they had taken. Most of these men were old Montana miners, and, working together in companies, had done a surprising amount of work for so short a time. Nearly every claim had been prospected enough to prove its value, and preparations were being made to enable them to work with sluices on a large scale. In one place a bed-rock drain had been dug nearly a quarter of a mile in length, from 3 to 9 feet deep, to drain a gravel flat where the pay dirt gave, by several tests which we made, from 5 to 15 cents to the pan of coarse rusty gold. The gravel was at least 80 per cent. water-worn clay-slate, in fragments of small size, intermixed with quartz bowlders and pebbles from the ledges. The pay dirt not only was found as a compact clayey gravel on bed-rock, but also in several pits and drifts occurred in one or more thin layers of clayey gravel 2 or 3 feet above it. The bed-rock was soft, shelly clay-slate, easily dug several feet in depth with pick and shovel, and holding gold in 
its crevices as far below the surface as decomposition had penetrated the substance of the rock.

Very few large bowlders were seen in the gravel deposits, the pay dirt, as well as the whole thickness of the bars, being mostly a slate-wash, easily treated in sluices with a low grade and slow current of water, owing to the lightness of the material operated upon. The gravel deposits are flats along the course of the stream, filling the bottom of the valley, and elevated bars on slate benches, 10 to 30 feet above the creek, often quite extensive at the bends of the stream. Several pits had been sunk to bedrock in the flats, reaching it at a depth of 12 to 15 feet, and in every case striking on bed-rock pay dirt yielding from 3 to 10 cents to the pan. The elevated bars showed in places 10 to 12 feet of gravel, and the drifts run in on rim-rock exposed the bed-rock pitching in toward the center of the bar. A number of these high bars were tested by my assistants, with a return from the pay streak of from 3 to 15 cents to the pan. The gold was coarse, flattened scales and rounded grains, stained a rusty-brown color by a thin coating of oxide of iron, derived from the presence of iron pyrites in the slates.

This portion of Castle Creek, extending from the bend to its junction with the north fork of Rapid Creek, a distance of about eight miles, is in a very mountainous and broken region. The valley is deep, and in places quite narrow, and surrounded by high, steep hills of clay-slates, occasionally intersected by a stratum of ferruginous quartzite mixed with white quartz, similar to the Mammoth ledge on Spring Creek. It is not necessary to dwell particularly on the wealth of this district, as there is no doubt that the gravel deposits on this part of Castle Creek will prove remunerative when opened. They are very favorably situated for working. The water supply is quite large, with a grade of at least 76 feet to the mile. The gravel is easily mined and sluiced, and the gold coarse and readily saved, even without the use of quicksilver. Castle Creek at this point is a fine rapid stream of water, averaging in June and July 10 to 12 feet in width, with a depth of 12 inches, probably yielding 300 to 500 miner's inches of water. 
RAPID CREEK.

The north fork of Rapid Creek, heading in several small branches just west of Custer Peak, where the limestone of the divide bounds the area of slates, is slightly larger than Castle Creek, and near its union with that stream it winds through a deep and narrow cañon in the slates. Gold was discovered in paying quantities on this branch by the miners, but the claims were not prospected enough to determine the value of the placers up to the time I left the Hills. For four miles below the forks Rapid Creek winds and twists through a deep and contracted cañon, cutting across a belt of very rugged and broken peaks, an extension of the ridge from Harney Peak northwest to this point. Vertical cliffs of slates rise several hundred feet on either side of the stream, surmounted by high rocky hills, covered with pine, the greater portion of which has been killed by fire, leaving the bare and decaying trunks standing. The bottom of the gorge is choked with a dense mass of tall spruce trees, tangled with bushes and fallen timber, making it necessary at the time we first explored the cañon to wade our horses along the channel of the stream. Afterward the miners cut a trail down the cañon, making the journey on horseback along its rocky bed less difficult. There are a few high bars along the sides of the cañon, covered with dead and fallen spruce trees; but the main gravel deposits are found in the bottom of the gorge itself.

Below the cañon the valley of Rapid becomes more open, and large and extensive gravel flats and high bars are seen on either bank of the stream. In places the valley contracts among steep and rocky hills to a narrow gorge, but does not become a cañon until fifteen miles below the fork, where the stream enters a limestone formation, whence, for a distance of four miles, it is almost impassable for horsemen. Only near the forks has the timber been destroyed by fire, and elsewhere through the valley of this stream the hill-sides are covered with pine of good quality, while near the foothills small groves of oak and elm grow along the banks of the creek. In the more open portions of the valley broad grass flats skirt its banks or cover the high gravel bars situated at the numerous bends of the 
stream. Among the rocky hills these flats are wanting, and the forest extends nearly to the water's edge.

Rapid Creek flows in a parallel course to Spring Creek, at a distance of four to eight miles to the north, and cutting through the same belt of clayslates and quartzites; the description of the rocks of the Spring Creek district will apply, with some slight modifications, to the rocks of this valley.

The immense belts of quartz and quartzite so marked on Spring Creek are not so prevalent on Rapid Creek, but the soft gray and black clay-slates, with small ferruginous quartz seams, are here extensively developed. The clay-slates have a tendency to split, under the action of frost and the atmosphere, into long, slender prisms, parallel to the bedding of the rock. In some of the cliffs benches of these slates have weathered out, and the fragments falling down lie in regular piles like cord-wood along the face of the rocks. These prisms are about 4 feet long, with an irregular rhombic section 3 or 4 inches across They readily split into smaller prismatic fragments an inch wide and a foot or more in length. The slates contain minute crystals of iron pyrites, and the surfaces of the prisms are stained with oxide of iron resulting from its decomposition. Other strata of slates are lamellar in structure, and split into thin plates like roofing slate. Both forms make excellent bed-rock to catch and retain gold.

A mile above a small branch entering Rapid Creek from the north, is a low hill, composed of trachyte intruded between the slates. This was the only occurrence of igneous rock seen in this geological formation south of Custer Peak, with the exception of the granite of the Harney Peak range. On this branch float quartz was found, which on breaking showed small particles of gold, but it could not be traced to the vein from which it had been derived.

Samples of quartz brought in by the miners from the hills between Rapid and Box Elder Creeks gave, on crushing, two or three ounces in a mortar, and panning from four to six fine colors of gold. Gold was discovered in paying quantities in a number of places along this portion of the valley; but the miners who staked claims in this district did not open the placers, and prospected the bars only enough to prove the presence of gold. These 
deposits of gravel, including both the high bars and narrow flats in the cañon, are known to be valuable, resembling those of the Spring Creek district, so closely as to render it unnecessary to again minutely describe them. Geologically, Rapid, Castle, and Spring Creeks belong to one district, as they are characterized by the same prevailing rocks and quartz veins, and the gravel deposits, being formed by rapid streams, with considerable volumes of water and heavy grades, naturally resemble each other.

Reports from Rapid Creek, December 31, 1875, state that "the cañon is located from head to mouth, and 10 cents to the pan is considered a low average prospect in the pay streak." The water supply is ample for working purposes; at least double that of Spring Creek. The current is so rapid that it is difficult to estimate the volume of the stream without making accurate measurement. It varies somewhat with the season, probably between 1,000 and 2,000 miner's inches; being greatest in May and least in the fall and early winter months.

The descent of the valley, omitting minor bends, is from 70 to 80 feet to the mile, measured in straight lines. In places the grade is fully 90 feet; a most advantageous circumstance in working the placers.

Rapid Creek emerges from the cañon in the limestone at the edge of the plains, and flows through the most beautiful valley in the Hills. Long flats, covered with a rank growth of bottom grass, line its banks, which are lotted by groves of oak and elm. The side gorges and ravines cutting through the Red Beds and the variegated sandstone of the top of the Carboniferous expose cliffs several hundred feet in height, pictured with sandstone of all shades of color from yellow through pink to the darkest red. A trail known to the Indians as the "Race Course," following the Red Valley, and completely encircling the Hills at the edge of the plains, crosses Rapid Creek a mile below the cañon. At this point several large springs of cold water, free from even traces of gypsum, emerge from the Triassic limestone, and pour each from 50 to 100 miner's inches of water into the creek. Three miles farther down a small branch enters Rapid Creek from the north, formed by a number of fine springs of water issuing from the foothills about two miles north of the stream, and affording about 39 miner's 
inches of water (August 1, 1875), which will prove useful in working the gravel bars in that vicinity.

Rapid Creek, above the springs, is a fine stream of water, from 20 to 25 feet wide and 10 to 15 inches deep, with a very swift current. Probably the volume or the water is not less than 2,000 miner's inches in July, and below the springs 2,500 inches is not too great an estimate for the available water. For at least five miles along the valley below the mouth of the cañon the stream is bordered by the largest gravel bars and flats discovered in the Hills, reaching out to the low ridges of Jurassic foothills, among the level plains, and capping broad benches of limestone and Red Beds at the sides of the valley. The amount of gravel brought down by Rapid Creek and piled up in these deep and extensive deposits is very large; not only low hills below the cañon are covered by high bars at several different elevations, but the broad flats along the stream are made up of a deep deposit of gravel, composed mostly of limestone and sandstone, intermixed with some slate and quartz. Several attempts were made by $\mathrm{my}$ assistants to sink prospect holes on these flats along the banks of the creek, but the pits had to be abandoned at depths of from 9 to 12 feet before reaching bedrock, on account of striking springs of water. The loose gravel from these holes gave one or two colors of gold to the pan, but it was probably quite a distance to bed-rock where we stopped working, as the gravel was open and full of small bowlders. To work these flats, if they are found to contain gold in paying quantities, will require the outlay of considerable labor or capital to drain the bed-rock, but the grade of the valley will admit of long covered bed-rock drains being put in for this purpose.

At the mouth of the cañon the stream flows along the face of the limestone cliffs, and the largest high bars are on benches on the north side of the valley, from 20 to 30 feet above the present level of the creek. Open cuts were driven into these bars on bed-rock, finding nearly 20 feet of gravel and about a foot of pay dirt on soft limestone bed-rock, giving an average of three colors of gold, or about half a cent to the pan. Similar results were obtained in prospecting several smaller gravel points at the bends of the cañon for a mile above these bars; and, taking into account the ease with which these gravel deposits can be ground-sluiced off, with the great vol- 
ume of water available for the purpose so near at hand, I think that it is possible to work them with a good profit. Where the Indian trail ascends the hill on the south side of the valley are three large elevated bars. The lowest, at an elevation of about 40 feet above the creek, covers about four acres, and appears to be 30 feet in thickness. A drift run in on bed-rock showed a foot of compact cement gravel full of nodules of hematite iron ore resting on the soft sandstone of the Red Beds, which gave, on testing, an average of three colors, or about one-third of a cent to the pan.

The bed rock pitched into the center of the bar, which was composed of bowlders and gravel, at least 50 per cent. being limestene and sandstone, the rest slate, quartzite, and quartz in all the varieties found in the area drained by this stream. Above this bar were two others, at elevations of 100 and 300 feet above the creek, which have been described in the chapter on "The Deposits in the Foothills." A similar deposit covers the foothills on the opposite side of the ravine, just east of the lower bar; but with this exception all the elevated bars are on the north side of the valley, which extends into the plains a mile and a half wide, bounded on the south by a bare range of Red Bed hills. On the north, a continuous bar, 30 feet high above the flats, extends from the Indian trail down to the small branch heading in the cluster of springs about three miles below. This bar extends along the valley for three quarters of a mile, and occupies a triangular area of about two hundred acres, bounded by the small branch entering from the north. On the top it is as level as a floor, and on testing the gravel at its edge we obtained in a number of places three to five colors of quite coarse gold, or at least half a cent to a cent to the pan, although at the edges of the deposit the gravel was not over 20 inches thick, resting on soft red sandstone of the Red Beds. For want of time my assistants were unable to thoroughly prospect this extensive bar, but it was the opinion of John W. Allen, who made the discovery, that it would pay well when worked by bringing a good head of water on top and ground-sluicing the gravel and soft bedrock. Several bars of this character intervened between it and the Hills, which gave equally good results on prospecting. In places the bed-rock was soft, white, decomposed gypsum. Below the branch before mentioned 
there were no more elevated gravel bars seen, but along the banks of the creek gravel flats extend as far at least as the outermost ridge of foothills

I consider that the Rapid Creek district, including Castle Creek, is destined to be one of the most productive in the Black Hills. For forty miles along its course its banks are bordered by deep and extensive placers, forming the largest gravel deposits on any stream in the Hills.

\section{S E C T I O N V.}

\section{B OX ELDER A N ELK CREEKS.}

Proceeding north from Rapid Creek, a quite extensive area is passed over, which, while geologically a continuation of the clay-slate and quartzite belt, presents in its more level surface a strong contrast to the rocky and broken region to the south. This section is drained by two small streams, Box Elder and Elk Creeks, whose largest branches head almost at the very base of Custer Peak.

A view from the top of Custer shows a comparatively flat country, with low, rolling hills; in places groups of small broken peaks are noticed; but the topography is very different from that of the region about the forks of Rapid and Spring Creeks, where sharp serrated peaks rise, one beyond another, as far as the eye can reach, only exceeded in height and magnitude by Harney itself. It is a desolate-looking country. Most of the timber has been destroyed by fire and large areas are covered with dead pines. To the east, at a distance of ten or twelve miles, the limestone is seen crossing the hills in an irregular line in a northwesterly direction, and many of the slate ridges and peaks are, near the outcrop of the limestone, capped by it and the Potsdam sandstone-the remnants of the great sheet of Paleozoic rocks which once covered this area and has since been removed by erosion.

From the base of Custer Peak the course of each creek can be traced until it cañons in the limestone, generally flowing through small open valleys or broad grassy swales, which in places, however, are contracted into a rocky gorge in cutting across the occasional strata of hard quartzites. 
The belt of Carboniferous limestone encircling the area of metamorphic rocks is only about four miles in width at the foothills near Spring and Rapid Creeks, but to the north it becomes broader and extends a greater distance back from the plains into the hills, its western edge following along the north side of the valley of Box Elder as an irregularly broken cliff or wall. Soon after entering the limestone both Box Elder and Elk Creeks sink in their beds and disappear from five to eight miles from the plains. The water must escape through subterranean channels, as, a short distance below where it sinks among the bowlder, the bare limestone bedrock is exposed perfectly dry for some distance across the whole width of the bottom of the cañon.

Contrasted with the Spring or Rapid Creek districts, the area of slates is comparatively flat, and the grade or descent of the stream much less, becoming greater in the limestone cañon, where for long distances the Box Elder flows in a swift current over bare bed-rock. Box Elder is not a single or main powerful stream like most of the other creeks in the Hills, but an aggregate of numerous small branches formed by insignificant brooks, which do not unite until the stream enters the limestone. Many of these head branches are mere threads of water, or contain water only in occasional deep holes, and are dry during a greater portion of the year, the largest fork being but 6 to 10 feet wide and very shallow. Small ponds and broad marshy flats overgrown with a swamp of willows and low bushes are often encountered on the forks of this stream. They are produced by the beaver in damming back the water in the level valleys, and from the same cause large and deep beds of black peaty muck have been formed by the gradual deposition of vegetable matter in these still pools.

Elk Creek is a stream not quite as large as Box Elder, but resembling it in other respects. For three miles of its course it flows through a narrow and crooked cañon in the slates, then emerges into an open and flat valley, with broad grass flats skirting its banks, through which it winds for about three miles, and, entering the great limestone formation, sinks in the bed of the cañon and disappears. Where the dry ravine of this stream opens upon the red valley at the edge of the plains, several fine springs of excellent cold water burst out from under the Triassic limestone, and form a $18 \mathrm{~B}$ ㅍ 
considerable stream, flowing, however, but a short distance before it sinks and disappears. On lower Box Elder and on the divides along the valley of Elk Creek there is considerable pine timber which has escaped the extensive forest fires. The trees are, however, rarely above medium size, growing very thickly together in dense groves. The rocks of this section are clay-slates and quartzites, similar to those of the Spring Creek district.

The occurrence of a broad belt of specular slates containing a large percentage of hematite iron ore, which extends along Box Elder just above the point, where Custer's trail crosses it the second time, is peculiar to this district. Over quite an extensive tract iron is present in the rocks in quantities sufficient to strongly affect the compass. Thick strata of silicious slates, on being followed, are gradually found to become more and more ferruginous, until the rock is finally black and brilliant from the excess of particles of specular iron. Frequently the hematite occurs perfectly pure, interstratified in thin layers with white quartz, forming a peculiar rock, the brilliant black of the bands of iron ore contrasting strongly with the white stripes of quartz, resembling somewhat the jaspery specular ore of Lake Superior, except that the interstratified quartz is white and not red. These iron-bearing strata were upturned on edge, and often 600 to 800 feet broad, with an unknown extent in the direction of the strike. The hematite was so completely intermixed with the quartz as to seriously injure the commercial value of the ore. The thickest layers of pure specular iron which were seen did not exceed three inches in width; and, except the presence of large quantities of silica, the ore seems to be very pure and free from iron pyrites and phosphates.

Near Custer Peak an immense ledge of massive milk-white quartz extends north and south across the hills, conformable to the slates. Resisting denudation, it caps the ridges for a long distance like a wall, and large fragments detached from it cover the surface of the hill. Samples of the quartz from this ledge were assayed by Mr. Ricketts, of the School of Mines, but not a trace of gold was found in it. Where the slates are extensively developed the quartz veins are generally thin and inconspicuous. An occasional large ledge is, however, seen of the above character; but among the belts of quartzites broad strata, transformed into impure 
quartz, are found, similar to the "Mammoth ledge" on Spring Creek. One of these altered strata contained large masses of limonite iron ore intermixed with quartz, colored and stained by copper, and resembling closely some specimens of Colorado gold ores. It was a portion of a quartzite belt dipping $60^{\circ}$ to the south, and could be traced east and west for a mile across the low hills until the outcrop was concealed beneath the Potsdam sandstone. Several parallel strata of quartz and quartzite were found within a few hundred yards. That forming the "lode" was from 20 to 40 feet wide, a mixture of massive millk-white quartz and limonite iron ore, with considerable "gossan" ore, resulting from the decomposition of copper and iron pyrites. Samples were carefully taken from the bestappearing ore in the outcrop of this ledge and submitted to Mr. P. De P. Ricketts for assay, who reports that the quartz contains small quantities of gold, but, unless richer than the samples assayed, the deposit is of little value. Where the outcrop of this ledge was covered by the Potsdam sandstone the conglomerate forming the lowest layer of that formation was full of large rounded bowlders partly derived from it. Some of these bowlders were 3 to 4 feet in diameter, and contained all the varieties of rock found in the vicinity, including clay-slate, quartzite, ferruginous and ribbon quartz, and gossan ore, exactly as they occurred in the adjacent ledges, proving that very little change had taken place in the slates and the inclosed quartz veins since the commencement of the Potsdam period. Previous to the deposition of this conglomerate the slate and quartzite rocks were subjected to a very great erosion, which must have removed a great thickness of the strata, but since the elevation of the Black Hills the Archæan rocks in this district have been but little denuded, the remnants of the Potsdam sandstone capping hills and ridges from 50 to 150 feet above the present surface; and although the formations which covered this area at the close of the Cretaceous period have been swept away over extensive tracts, the erosion has extended but a short distance into the slates. In the Spring and Rapid Creek districts, however, the slates and quartzites have been very greatly denuded and furnished a large amount of material to form the placer gravels.

On Box Elder the gravel deposits seem to be largely composed of 
pebbles and bowlders from the disintegration of the Potsdam conglomerate, and only a small portion is derived from the more recent erosion of the slates. Partly from this cause and the flat character of the region, there are few elevated gravel bars on this stream of any practical value. The slate benches and low hills at the bends and forks of the creek are covered in places with a thin layer of gravel, which, wherever tested, gave never more than a color of gold.

There are a few low bars on the larger branches of Box Elder which may be found to contain gold in workable quantities, but the only gravel deposits of any size are in the, flats along the stream and its numerous branches. Several days were spent in prospecting on this stream by a party of twelve miners who were assisting me at the time, but we failed to find gold in paying quantities in any of the flats or bars which were tested. Prospecting in the cañon in the limestone, the bed-rock was found bare in many places, but not a color of gold was obtained either from the small gravel deposits or by "crevicing" in the bed-rock, though tests were made in every favorable-looking place for several miles down the cañon. Below where the water sinks a high bar was found at the forks of two cañons, nearly 100 feet above the present channel, but no gold could be found in it on panning.

The miners who prospected on Box Elder the past summer before they were removed from the Hills did not find gold in quantities enough to encourage them to stake out claims or form a district.

Elk Creek was explored by the topographical party, but was left untouched by the miners, very few being aware that such a stream existed. Gravel flats and low bars are reported on this creek between the cañon in the slates and the cañon in the limestone, which promised well as far as could be judged from external appearances. In reviewing this district, which it is but justice to state has been only very little prospected, I may record a small water supply which fails in many places in the smaller branches after August, a grade hardly greater than that on French Creek, and gravel deposits which are comparatively of moderate extent and not found to be rich in gold as far as they have been tested. 


\section{SECTION VI. \\ SPEARTISH AND BEAR BUTTE CREEKS.}

These streams, emptying into the Redwater and the Belle Fourche, drain the extreme northern section of the main range of the Black Hills. Rising near the limestone divide between Crook Tower and Custer Peak, a spur of the great western mesa, they cut through a narrow belt of slate, quartzite, and igneous rocks before entering the limestone formation encircling the Hills. This belt of slates, contracted between the two walls of Carboniferous limestone, is an extension of the quartzite and clay-slate formation covering so broad an expanse of territory on Spring and Rapid Creeks.

From the headwaters of Elk Creek it extends in a direction a little north of west for twenty miles until terminated by the limestone ridge between Spearfish and Floral Valley. Covering about one hundred and fifty square miles, this area of metamorphic rocks has up to the present time been only partly explored and prospected, owing to the exceedingly rugged and impenetrable character of the region. It may aptly be called a "pathless wilderness"; even game-trails are rarely seen, and the surface of the country is so cut up by numerous narrow and abrupt cañons as to be impassable for wagons, and extremely difficult and fatiguing to traverse, even with pack-mules. The bottoms of the cañons and gorges are choked with a tangled jungle of willow and grape-vines, and often beaver-dams extend from cliff to cliff, producing boggy mud flats, whose depths we tried to explore, but found no bottom in the fluid black ooze. Only in places can the walls of the cañons and ravines be scaled, while the ridges and divides, steep, and broken into innumerable sharp, serrated peaks, are covered by timber, frequently blown down by the wind and subsequently overgrown with thickets of aspen. The slow progress made through this wilderness soon wears out both horse and rider, and the former, instead of being an assistance, has to be led and pulled along most of the way. To find yourself at a "jumping-off place," the end of some sharp ridge between two streams, to descend hundreds of feet into the bottom of the cañon, to 
slowly climb the opposite side, at last reaching the top of the divide exhausted and out of breath, only to find that you are on the crest of another similar ridge ending in a few hundred yards; to continue this wearisome march for hours and only travel four or five miles in a straight line; such was one day the experience of the party on Bear Butte Creek.

The more mountainous character of the country and the greater prevalence of limestone in the area drained by Spearfish Creek make the cañons on that stream the deepest and longest found in any part of the Hills. One of the parties exploring Spearfish entered the main cañon near its source to the north of Crook Tower, and, being unable to extricate themselves and horses, were obliged to force their way through its whole length to where it opens out into Redwater Valley, some thirty miles from its head. Most of the distance they waded their horses down the bed of the stream, which in a swift current flowed over smooth limestone rock. In places the vertical cliffs of the cañon rose from the water's edge, and nowhere did they find a place where the cliffs could be scaled without abandoning the horses. The party reported that the rocks seen were mostly limestone. A narrow belt of slates for some distance forms the base of the cliffs, the tops being Potsdam sandstone or the limestone of the Carboniferous. This is also true for those branches of Spearfish rising near Terry Peak, where the Potsdam covers quite an extensive area, while the narrow cañons are cut through it into the slates.

Near Black Butte, at the mouth of Spearfish Cañon, the limestone forms the west wall of the main gorge, while the eastern branches drain a very mountainous track, consisting mainly of igneous rocks. Spearfish emerges from the cañon with a swift current, equaling, if not exceeding, Rapid Creek in volume of water, and, emptying into the Redwater, forms by the union a fine river, a branch of the Belle Fourche, known to the Indians as Deepwater.

Just above the mouth of the cañon several small streams enter Spearfish from the southwest, heading in the ridge between Spearfish and Floral Valley. On these branches a party of miners discovered rich placer deposits the past summer which have since been more fully prospected and developed. Wishing information in regard to the location of the new dis- 
covery, I wrote to Mr. T. H. Mallory, one of the original discoverers of the district, and received the following reply:

Hinc City, January 5, 1876.

Dear SiR: Iron Creek runs into Spearfish above Crow Peak. Bear Creek runs into Spearfish lower down and near the buttes. Sand Creek runs into Redwater. These streams all head nearly together, and they, with their smaller tributaries, make a large mining district. They are richer, too, than anything on this side of the hills. One pan of dirt on the discovery of Bear Creek contained $\$ 27$. I have a report that another small stream rumning into Spearfish from the sontheast is still better than any. thing yet found. How much truth there is in it Bottsford and I will know in a few days. I send you a little gold from Sand Creek; it has been retorted and does not look bright.

\section{W. P. JeNnEY.}

THOS. H. MALLORY.

The rocks of this new district are reported to be granite (trachyte ?) near the heads of the creek, and lower down the gulches the bed-rock is limestone, but equally good gold deposits are found upon it.

The sample of gold sent is quite different from that from Spring Creek, the particles being much smaller, more ragged and irregular in shape, and but little water-worn. So large a proportion of the gold is fine dust, that it is not easily saved without the use of quicksilver in the sluices.

Concerning the Bear Creek discovery, I have received the following communication from Mr. George W. Corey, of Cheyenne:

Cherenne, Wro., December 20, 1875.

Dear SIR: I have some fine specimens of Black Hills gold that I will send you. They were taken out of Bear Gulch by Frank George de Oliver, who would not sell them, but let me take them to send to you. He took out with a rocker in eight and a half days $\$ 165$. One lump which I have weighs one and a half ounces. * * *

\section{WALTER P. JENNEY.}

GEORGE W. COREY.

Bear Butte Creek drains the northeastern portion of the Black Hills, taking its name from a solitary igneous peak near which it flows, some eight miles from the main range among the open plains. This stream is formed by two main branches uniting in the Red Valley at the foothills; one, the east fork, rises to the north of Custer Peak; the other, known as Whitewood, heads near Terry Peak. None of the branches have flowing water within five miles of the edge of the plain, as they sink even before reaching the limestone formation. The east fork was only explored by the topo- 
graphical party; and, for want of time and suitable transportation, my assistants were unable to properly prospect and explore the branches of this stream.

Whitewood, heading on the east side of Terry Peak, unites with Deadwood, a branch rising on the northwest side, forming a swiftly-running stream flowing nearly 300 miner's inches of water, but sinking a short distance below the forks, and thence continuing as a dry cañon through the limestone to the plains.

Whitewood and its branches flow through narrow and deep gorges excavated in the slates and igneous rocks, with the Potsdam sandstone capping in many places the tops of the narrow ridges between its numerous branches. The base of the Potsdam is here the usual conglomerate of round water-worn quartz pebbles and small bowlders. The intrusion of the igneous rocks has penetrated the Potsdam as well as the slates and quartzites, and has often metamorphosed the sandstone so that it is unrecognizable, except that traces of its stratification are retained, and the strata are observed resting at a low angle unconformably on the upturned edges of the slates.

The most common form of this altered Potsdam is a brownish granular rock, full of feldspar crystals, irregularly distributed through its mass. Locally, this metamorphosed sandstone is seen as a hard granular rock, breaking with a sharp conchoidal fracture, without any traces of crystalline minerals, and specimens in their colored and burnt appearance resemble fragments of pottery ware. The slates and quartzites are similar to the rocks of the Spring Creek district, and broad strata of quartzite, intermized with limonite and white quartz, resemble closely the Mammoth ledge on that stream, except that here small ramifying veins of white quartz not more than half an inch wide intersect the dark-gray quartzite like a net-work; another evidence that these altered strata are the result of the action of solutions depositing silica permeating the formation. The strike of the slate and quartzite belt is observed to be east and west, at a point a few miles north of Terry Peak. This formation over great areas is concealed by the intrusion of large masses of igneous rocks, forming the more prominent peaks in the district, as Terry, Custer, Crow, Black Butte, \&c. 
The intrusions of trachyte in the slates usually form dome-shaped peaks, having penetrated or forced to one side the superincumbent strata of Potsdam and Carboniferous. Though in this region trachyte forms in places quite extensive ridges connecting the peaks and covering large areas, no narrow dikes were anywhere observed traversing the slates, and this occurrence of eruptive rocks in dikes so common elsewhere in the Rocky Mountains seems to be wanting in the Black Hills.

The time of this eruption of igneous rocks appears to have been coeval with the elevation of the Black Hills at the close of the Cretaceous period; the intrusion of feldspathic porphyry, forming Crow Peak, has upturned all the different formations from the Potsdam to the Jurassic; the Cretaceous, having been removed by erosion, is not seen in the vicinity. These igneous rocks are very varied in appearance and character, but may be generally classed either as trachyte or feldspar-porphyry, though merging in all gradations into each other, so that an exact classification is extremely difficult. Greenstone occurs both as an olive-green rock without any traces of crystallized minerals and breaking with a fracture-like jasper, and also with small feldspar-crystals scattered through its mass forming a greenstoneporphyry. The rock composing Terry Peak seems to be wholly composed of white feldspar, an aggregation of small crystals of that mineral, resembling a fine-grained granite, without quartz or mica Custer Peak is formed by the intrusion of a peculiar massive gray rock, with an exceedingly close and uniform texture, resembling a compact gray limestone in appearance more than an igneous rock. Black Butte, a high peak on the east side of Spearfish Cañon near its mouth, is made up of a genuine trachyte.

Near Camp Terry, a few miles north of Custer Peak, the prevailing rocks are garnetiferous mica-schists, resembling the rocks of the French Creek district. This occurrence of an area of schists in the clay-slate formation is not easily explained. Possibly the irregular line of contact between the two divisions of the Archæan may here extend a greater distance to the east. Among these mica-schists on the head branches of the east fork of Bear Butte Creek the soldiers found gold in the gravel deposits of the side gulches of the stream, and a piece weighing about half 
a pennyweight was obtained from one of their prospecting pits near Camp Terry. Gravel deposits of considerable extent are reported in the valleys of the branches of the east fork, but have not as yet been prospected by the miners. The area drained by this fork is more open and less rugged than the territory to the west, resembling the Elk Creek district, which it adjoins. Gold has been discovered by the miners on Deadwood and Whitewood Creeks and the numerous gulches running into them in the vicinity of Terry Peak. The placers are quite extensive, and in most places the bed-rock is reported to be near the surface, and the gold is doubtless derived from the disintegration and erosion of the igneous rocks as well as from slates and quartzites.

Having detected gold in similar trachytes in the Bear Lodge range, I consider its occurrence in rocks of igneous origin in this district as extrcmely probable. The following letter from Mr. T. H. Mallory, formerly one of my assistants in prospecting the gold field, gives the result of his explorations on the branches of Bear Butte Creek since the return of the expedition:

Hill City, DaK., January 31, 1876.

DEAR SIR: Botsford and I have just returned from a trip to the north. We made locations on Whitewood, a large stream that rises around the northeast side of Terry Peak and runs down to the Belle Fourche. Starting from the point where the creek runs into the lowlands not of the cañon, forming bars, up it to the west fork, or Deadwood, as it is ealled, there are no better paying mines for a poor man in the Hills. The ground prospects in the creek and on the bars, all the way down to bed-rock, an arerage of about two cents to the pan in fine gold. It is said to be the same on Deadwood. The length or extent of locations on these creeks begins at the mouth of Whitewood, and then running thence up Deadwood, makes a distance of twenty-five miles, all good mining ground.

A small gulch running into Deadwood, called Black Tail, is said to be good. These mines will certainly pay from $\$ 10$ to an ounce a day to the man when worked in the spring. They are easily opened, for the bed-rock is not deep, like it is on Spring, Castle and Rapid Creeks.

W. P. JENNEY.

T. H. MALLORY. 


\section{SECTION VII.}

\section{THE BEAR LODGE COUNTRY.}

Forming the extreme northwestern part of the Black Hills, and separated from the main range by the broad open valley of the Redwater, the Bear Lodge country has a geological system and topography which, while a miniature counterpart of that characterizing the main range of the Black Hills, is a distinct uplift, produced by the intrusion of the igneous rocks forming Warren Peaks. Covering an area of nearly one thousand square miles, mostly included between the Redwater and the Belle Fourche, this region takes its name from a singularly-shaped trachyte butte, "Mato Tipi," or "The Bear's Lodge." Surmounting a hill near the north bank of the latter stream, this butte forms the most conspicuous landmark in the region, resembling the base of a ruined and crumbling column, with its shaft nearly 500 feet in height, and the top 1,127 feet above the water in the Belle Fourche.

Warren Peaks, a cluster of high rolling hills, grass-covered, and nearly destitute of timber, are the most elevated points in the Bear Lodge range, almost equaling Harney Peak in height, their tops being from 6,700 to 6,800 feet above the level of the sea.

Occupying an area about four miles in diameter, these peaks are composed of coarsely-crystallized feldspar-trachyte, apparently destitute of quartz, but sometimes containing hornblende and mica, and often having in the arrangement of the crystals of feldspar, in a granular matrix, a structure-like porphyry. This rock, which is seen of different shades of gray, yellow, and reddish-brown, seems to be quite readily decomposed by atmospheric agencies, and, crumbling away, has given rounded surfaces and outlines to the hills and ridges. Standing on any of the higher of Warren Peaks, the view shows at once the distant character of the uplift and the peculiarities produced by it in the topography of the region.

The central peaks are surrounded by others of less elevation, between which ravines radiate in every direction like the spokes of a wheel from 
the hub, and give rise to small streams, flowing outwardly from the center, draining the area. Those to the southeast and south empty into the Redwater; the rest flow into the Belle Fourche or its branches.

To the north an extensive tract is observed wooded with pine of medium size. Scattered groves occur elsewhere on the ridges and in the ravines, but large areas are comparatively destitute of timber, and broad grass-covered divides are seen to the west and northwest between the streams emptying into the Belle Fourche.

To the east, across the broad valley of the Redwater, excavated in the gypsum and sandy clays of the Red Beds, Crow Peak is seen, an angular blue-black butte, forming the most northern peak in the main range of the Black Hills. Between it and Inyan Kara stretches the great limestone formation so extensively developed on Floral Valley and the head branches of the Redwater.

To the west (magnetic), some twenty miles away, Bear Lodge Butte and the Little Missouri Buttes appear in line. From this distance the former resembles in appearance the huge stump of a tree, its surface curiously striated vertically from top to base, and, being perched on the crest of a high, flat-topped ridge, it becomes a very prominent landmark, which, once seen, is so singular and unique that it can never be forgotten. Although the Bear Lodge country is an elevated region, and the different streams have a considerable fall before reaching the Belle Fourche, yet the topography is quite peculiar in the prevalence of long, flat-topped ridges or mesas between the narrow and deep valleys and cañons of the creeks This is due to the resistance to erosion offered by hard and continuous strata of sandstone of the Jurassic and Cretaceous formations, which are here almost horizontal in their bedding, with a gentle slope away from Warren Peaks.

In a series of annular belts the different geological formations outcrop around the central nucleus of Warren Peaks. In passing down any of the numerous radiating ravines of the streams for three or four miles all the several members of the section are successfully encountered in the order of their deposition, from the Potsdam to the Dakota sandstone of the Cretaceous. Upturned at an angle of about $20^{\circ}$ by the intrusion of the tra- 
chyte the Potsdam sandstone rests against the slopes of the outer circlo of hills. Its lower layers are so metamorphosed by the heat and chemical solutions accompanying the upheaval, that they merge imperceptibly into the igneous rock, until strata which are probably altered sandstone cannot be distinguished from coarsely-crystalline trachyte. Near the base of the Potsdam formation, between strata of unmistakable sandstone, a mass of feldspar-trachyte was observed, which had in the eruption escaped between the layers and slightly altered the adjacent surfaces of the inclosing rock. But more frequently the metamorphism seems to have been the result of the action of heated solutions forced between the layers of the sandstone, altering the surface of the fracture and transforming the sedimentary rock into a feldspar porphyry.

Layers of the soft brown sandstone extending horizontally for some distance had been altered in this manner, the rock being shot full of gray feldspar crystals, from one-fourth to one-half an inch long, irregularly distributed through it.

On the west slope of Warren Peaks a layer of blue slate occurred, inclosed in the trachyte, but conformable in its bedding to well-marked Potsdam about 50 feet above it, and was probably formed by the action of heat on a layer of clay-slate in the base of the Potsdam. Here this formation is full of fine specimens of the large fucoids so characteristic of the Potsdam sandstone in the Black Hills, and great masses of the upper layers of the rocks are perforated by the borings of marine worms. These fossils are found unaltered within a few feet of the trachyte, and would seem to show that the heat accompanying the upheaval of the range and the intrusion of the igneous rocks was not very intense. At the south of the peaks the whole thickuess of the Potsdan sandstone has been so metamorphosed that it camnot be recognized, except by the evidences of an indistinct stratified structure, and its position under the Carboniferous limestone. The altered sandstone on that side is a quartzite more or less porphyritic, with feldspar crystals merging in all gradations into a crystalline rock resembling trachyte. Even here the metamorphism seems to be more from the action of heated chemical solutions permeating the rock than from the direct action of heat, producing a semi-fusion of the Potsdam strata. The Carboniferous 
limestone succeeds the Potsdam, apparently conformable to it, and forms an eneircling range of low white hills around Warren Peaks, at a distance of two or three miles. The whole thickness of this formation is at least 600 feet, including the overlying massive sandstones.

The limestone shows but little evidence of metamorphic action, though in places the trachyte has broken through this formation and appears at the surface, altering slightly the upper sandstone. Beyond the belt of Carboniferous, which is nearly two miles wide, the Triassic limestone and the Red Beds occupy a narrow ring, succeeded by an expanse of sandstone and clays of Jurassic age, extending for miles across the country. The tops of the ridges are formed by a ferruginous massive sandstone, probably the Dakota sandstone, and where it has been removed by erosion the harder layers of the Jurassic cap the hills and the mesa divides between the stream.

In the interior area of Warren Peaks no Archæan strata were found, and the slates, quartzites, and schists so largely developed in the main range of the Black Hills were here entirely wanting. The rocks of this district seem to be singularly free from quartz in any form. About five miles southeast of Warren Peaks, near the head of a branch of the Redwater, a fault in the strata exposes a fine section of the Potsdam sandstone, with its lower layers full of slate and quartzite pebbles, but unfortunately the base of the formation was covered by a talus, and the rock on which it rested could not be seen. On the north side of the area of igneous rocks a trachyte composed of feldspar and black mica was observed, and near by several large loose bowlders of white quartz were embedded in the surface of the ground, but the ledge from which they were derived was not found. Black hornblende also appeared as a constituent mineral, associated with feldspar, in the rocks of this district.

Half a mile northeast of the central peaks a gold-bearing ledge was discovered and traced in a northwest and southeast direction for several hundred yards. On examination it was found to be irregular in shape, without any well-defined walls or boundaries, and merging on all sides into the adjacent trachyte rocks. The rocks composing this peculiar formation were exceedingly yaried in character and appearance, and a score of 
different rpecimens were collected in a radius of as many yards. The prevailing rock was a very coarsely-crystalline feldspar-porphyry, with a fine porcelain-like matrix, breaking with a sharp conchoidal fracture. The feldspar crystals were often very perfect, and from an inch to two inches long. Flat and thin crystals were common, often joined together, with the shorter axis of one reversed, as "twins." The specimens varied in color from light yellow or yellow-brown to gray, and large masses of rock in the middle of the "ledge" were made up of feldspar intermixed with irregular masses of limonite iron ore and black oxide of manganese. Bowlders of iron and manganese which would weigh several hundred pounds were scattered over the surface of the ground. The mineral was solid, compact, and exceedingly heary, but the two oxides were distinct in the mass, though often closely intermixed. Manganese and limonite occurred, filling the spaces between the large feldspar crystals and impregnating the rocks irregularly throughout until it resembled a "breccia." Evidences of an octohedral or cubical crystallization in the limonite indicated that it was derived from the decomposition of iron pyrites, and traces of the latter mineral were found on breaking the rock.

No gold could be detected in this formation by the eye; but, suspecting its presence, the different specimens collected were carefully sampled and submitted to Mr. P. de P. Ricketts for assay. The result showed the presence of a decided trace of gold, probably contained in the iron and manganese oxides.

Prospecting in the dry ravine $a^{\circ}$ short distance below this ledge, the gravel from off bed-rock was found to be largely composed of material derived from the disintegration of the ledge. Twelve fine colors of gold, or about half a cent to the pan, was obtained as an average of several tests, and each time nearly a pint of gravel and pebbles of manganese and limonite was left in the pan after washing out the lighter clay and feldspar. It would seem probable that the whole of the gold contained in the gravel in this ravine had been derived from the decomposition and denudation of the above ledge.

The occurrence of gold in trachyte without any quartz being associated with it has been previously reported from several mining districts in 
the West, but this is the first instance that has come under my personal observation.

Descending the ravine about half a mile traces of previous explorers were found. Several prospecting holes had been sunk near the stream and considerable work done in the vicinity, probably by a small party of miners early in the preceding spring, as small aspen trees which they had cut down in elearing the ground for working showed half-grown leaves dead and shriveled, but still clinging to the twigs. A number of these old prospecting pits were bailed out, the gravel obtained from off bed-rock, and tested by panning. But in no case did we find gold in paying quantities; half a cent to the pan being the highest result of the trials. It is probable that the miners who dug these holes obtained discouraging prospects, or they would not have abandoned the district without making it known.

Exploring a number of small streams rising near. Warren Peaks, flowing to the north and east, gold was found in gravel deposits in the flats along the banks of the creeks in several places, but nowhere in paying quantities, though from want of time we were unable to thoroughly test all the different ravines in this district. The cluster of hills of igneous rocks which have yielded the gold are but four to five miles across. The gravel deposits formed by the creeks extend, however, for some distance down the valleys, beyond the outcrop of the Potsdam, and are found resting on limestone bed-rock, so that the district is really elliptical in area and six to eight miles in diameter, covering an area of from forty to fifty square miles. The streams being small and the wash not very great, there were no high-gravel deposits, though one or two bars covering about an acre were observed occupying flats elevated 3 or 4 feet above the creek. The gravel was 2 to 5 feet deep, composed wholly of feldspar and the soft plastic clay resulting from its decomposition, intermixed with considerable iron and manganese pebbles derived from the ledges. The valleys of the creeks are not deep, but are narrow, contracted, and overgrown with thickets of willow, so that only at intervals are gravel flats of any considerable size found along their course. The most extensive of these bars were found near the outcrop of the limestone, the bed-rock being soft calcareous sandstone of the Carboniferous age. These deposits were situated 
so that they could be readily worked, but only yielded, on testing, from one-eighth to one-half a cent to the pan in very fine dust gold.

The gold is derived from the igneous rocks forming Warren Peaks, most of it apparently from the manganese and limonite ledge on the-northeast slope, as the largest quantities were found in the ravines heading near that point. The intrusion of the trachyte forming the peaks having disturbed the Cretaceous sandstone and the underlying beds, it is probable that the Bear Lodge range was coeval with that of the main range of the Black Hills at the close of the Cretaceous period, and that the gold in the trachyte was simultaneously. deposited. In reviewing this small district, which is very interesting scientifically, even if the deposits of gold should not be found of workable richness, it may be stated that the bars are of limited area, and usually shallow deposits of feldspar gravel. The gold is fine, and up to the present time has not been found in remunerative quantities. The water supply is small, but probably sufficient for working purposes during the spring months. The district is remarkable in the occurrence of gold without any quartz whatever being associated with it, and in the fact that the gold is derived from feldspar trachyte-porphyry of so recent a geological age.

\section{SECTION VIII。}

DEPOSITS OF AURIFEROUS GRAVEL IN THE FOOTHILLS.

A belt of gravel deposits, resting usually on the Red Beds near the edge of the plains, extends from Red Cañon Creek, in the extreme southern end of the Black Hills, all along the southeastern foothills, across the valleys of Minnekata, Amphibious, French, Wiwi, Whiskey, Spring, and Rapid Creeks to Box Elder, where the deposits thin out and disappear. On examination these gravel beds seem to be river deposits, though in places they cap hills 300 feet above the present bed of the nearest stream. Where the divides between the creeks are quite wide, at the edge of the plains, the gravel is seen to be thickest and most extensively deposited near the valleys of the streams, and to thin out toward the crests of the divides. The gravel appears to have been deposited by the water at the point where the power

19 в $\amalg$ 
of the stream became insufficient to transport farther in large quantities bowlders of this size and weight, and the beds resemble somewhat shore or estuary deposits, such as are formed near the mouth of a stream emptying into a lake or sea. These gravel banks have been formed since the elevation of the Black Hills, and the great Tertiary sea which gave rise to the extensive beds of that age in the valleys of White River and the South Cheyenne may have reached to the foothills of this range. A gravel "wash" from the Black Hills is found all over the surface of the plains to the north, east, and south of the range. Near the Cheyenne this gravel forms a conglomerate 6 feet in thickness between the top of Cretaceous No. 5 and the base of the White River Tertiary, and also occurs as scattered gravel and bowlders on the tops of the Tertiary hills, showing that it has been deposited since the close of the Cretaceous period, both before and after the later Tertiary. These gravel beds are made up of a mixture of bowlders and pebbles from all the harder rocks found in the different geological formations on the eastern slope of the Black Hills, including granite, trachyte, schist, slate, quartzite, and quartz in all its varieties, mixed with a variable proportion of sandstone and limestone from the disintegration of the Potsdam, Carboniferous, and Red Beds.

The preponderance of any particular rocks in the gravel seems to be the result of the position of the deposits and the circumstances of influencing the erosion which produced it. The more elevated beds contain a less proportion of limestone and sandstone bowlders, mingled with those from the Archæan rocks, than the deposits at lower levels, formed after deep gorges had been cut by the streams through the recent formations. A layer of gravel a few inches in thickness covered the lower foothills near Box Elder Creek, but the deposits were thin and spread out over a considerable area. It was impossible to prospect them for gold, as there was not a drop of water in the bed of the stream for several miles up the cañon. This peculiar formation of high gravel-capped hills does not become extensively developed north at the valley of Rapid Creek, although a thin wash of limestone and sandstone bowlders, mingled with a little quartz and slate, covers the foothills as far to the north and west as the forks of Spearfish and Redwater. 
Where Rapid Creek bursts through the foothills and flows out on the plains are very extensive gravel beds of this character, evidently deposited by the stream at different periods as they cover the tops of hills at three distinct elevations, respectively, at about 50 feet, 100 feet, and 300 to 350 feet above the present bed of the creek. The lowest of these deposits occupies benches and flat-topped hills formed of the soft red sandstone of the Red Beds. The gravel was mostly composed of limestone and sandstone bowlders, mingled with quartz, slate, and ferruginous quartzite. The next, also resting on the Red Beds, was of similar character; not more than 50 per cent. of the gravel was derived from the metamorphic rocks. Both of these deposits were on the side hills of the valley, in places forming banks or terraces 20 to 30 feet in height, and should properly be classed as high bars. The gravel from off bed-rock, obtained by drifting into the face of these bars a distance of 4 or 5 feet, gave one to two colors of gold to the pan. The highest gravel deposits were in places 30 to 40 feet in thickness, capping the tops of the hills of Carboniferous and Triassic limestones, often at a considerable distance from the present valley of the stream; the lower layers contained water-worn bowlders, 1 to 2 feet in diameter, of quarta, slate, quartzite, granite, and trachyte, both feldspathic and hornblendic, but scarcely a trace of limestone or sandstone rocks are found in these more elevated deposits. Wherever tested the gravel from off bed-rock gave small quantities of gold on panning.

On Spring Creek, below the limestone cañon, prospecting was out of the question for want of water, though it is probable that in the early spring months this stream flows out into the plains.

In the dry side ravines of Whiskey Creek, among the Red Beds, gold was discovered by a party of miners entering the Hills. Prospecting up a dry gulch, they obtained twenty-five colors of gold from the dirt shaken from the roots of a small bush growing in a narrow crevice in the bare sandstone bed-rock at the bottom of the ravine. This locality, known as the "Rosebush diggings," derived its gold from the gradual washing down into the ravines of the gravel deposits capping the hills by the action of occasional heavy rains, when for a short time a stream of water would flow through the gulch and sluice the gravel accumulated in it, the gold being 
caught in the crevices of the bed-rock, while the dirt was swept away. Prospecting in one of these side gulches, about half a mile from the main stream, the dirt from the crevices in the bed-rock was found to yield from 5 to 15 cents to the pan. The gold was in fine particles, associated with small red garnet crystals, derived from the schists in the neighborhood of Harney Peak. This ravine was excavated about 200 feet in depth through the Red Beds. Its bottom was formed of a pavement of the upper layers of the Carboniferous sandstone, while the hills on both sides were covered with a deposit of slate and quartz gravel which had furnished the gold.

A mile below, the small side gulches in the Red Beds afforded in places 5 to 10 cents to the pan of gold, but the supply of water at this time (July 20) was so small that the miners decided to give up prospecting in the vicinity and abandon the diggings until the spring rains should fill the water-holes and make it possible to work the pay dirt in rockers, if any deposits rich enough for that purpose should be discovered.

About five miles south of Whiskey Creek, at the edge of the plains, a conglomerate 30 feet in thickness caps hills 100 to 150 feet in height, of the soft sandstone of the Red Beds. The conglomerate is composed of granite, quartz and slate bowlders, cemented by sand and lime into a loosely-cohering "cement," the lower layers of which contain quartz bowlders 1 to 2 feet in diameter. The small gulches in the vicinity are full of the quartz gravel, resulting from the decomposition of the conglomerate, and undoubt. edly contain gold; but unfortunately there was not a drop of water anywhere to be found in the neighborhood, and I was obliged to relinquish the attempt to prospect them. Similar gravel deposits encircle the foothills, crossing the valleys of French, Amphibious, and Minnekata Creeks, and in this connection it would seem not inappropriate to give a tradition relating to the gold deposits in this portion of the Hills.

Toussaint Kensler, a half-breed Indian, who had worked in the gold mines of Alder Gulch, Montana, was confined in prison under sentence of death for murder. Escaping, he was not heard from for a long time; when he appeared at the agencies, having in his possession several goose-quills filled with gold dust, and a fossil skull which he had found in the Bad Lands on his way from the diggings he reported he had discovered. Being rear- 
rested, he was taken back to prison, and hung for the rime for which he was originally sentenced; but before the execution he drew a map of the locality where he claimed to have discovered gold, and the rontes traveled in going to and from the agencies, with the distances and names of the principal streams marked unmistakably in the sketch. He stated that he followed down Hat Creek to the south fork of the Cheyenne, crossed that stream, and on the second creek of any size entering the Cheyenne from the north below the mouth of the Hat Creek he discovered gold about ten miles from the Cheyenne, among low hills, but outside the main range of the Black Hills. He described the locality as among hills capped with high and thick gravel bars of large size. Here he found rich gravel, and in a short time obtained his sample of gold by washing the pay dirt in a small tin dish.

A tracing of the map drawn by Kensler is before me while I am writing. On comparing it with the map drawn by Dr. M'Gillycuddy, topographer of the expedition, I find that it agrees very closely with the latter in regard to distances, directions, and the bends of the Cheyenne, and that the stream on which Kensler discovered gold was either Amphibious Creek or French Creek, probably the former. Quite extensive gravel deposits are known to occur in the vicinity, and it is probable that Kensler was the first discoverer of gold in the Black Hills, obtaining his pay dirt from the small ravines and gulches among these gravel beds, where the gold had been concentrated by heavy rains. Should these elevated gravel deposits on further exploration be found to contain throughout their thickness sufficient gold to warrant working by the hydraulic process, water can be conveyed from the streams in the Hills to them in many places under a considerable head, as they are elevated only about 3,800 feet above the sea, while the streams, fifteen miles in the interior, are flowing through valleys at an elevation of 5,000 feet. On Rapid Creek, a large volume of water, at least 2,000 miner's inches, under a head of 75 feet to the mile, can be made available for working these high bars above the valley, at a moderate expenditure of capital and labor required to construct the flumes. Only two streams, Rapid and Minnekata, having gravel deposits of this character in their valleys, form a continuous stream of water to the Cheyenne; the 
rest all sink in their beds among the foothills, several miles from the plains. Among some of these dry ravines, cutting through the gravel deposits, miners in the future may make good wages washing the earth from the bottoms of the gulches in rockers during the early spring months, when there is sufficient supply of water in the vicinity.

\section{SECTION IX. \\ CONCLUSION.}

Very few minerals were found during the exploration, and until the quartz ledges have been more thoroughly prospected and opened it is premature to discuss the occurrence or non-occurrence of any of the valuable minerals or ores in the Black Hills.

A number of samples of quartz were taken from ledges in different parts of the gold field, and submitted to Mr. P. De P. Ricketts for assay, but were found to contain only traces of gold. The following is Mr. Ricketts's report in detail :

\section{School of Mines, Colunbia College, New York, January 24, 1876. \\ Certificate of assay.}

SIR: The samples of ores from the Black Hills, marked as below, submitted to me for examination, contain no silver, but gold as follows :

No. 1. Jasper, from Jasper Hill, Box Elder................... Gold. None.

No. 2. Porphyry ledge, Warren Peaks .................... Trace.

No. 3. Empress lode, Box Elder. . . . . . . . . . . . . . . . . . . . . . Heavy trace.

No. 4. Great Quartz ledge, Box Elder ....................... None.

No. 5. Lee Anna lode, Spring Creek........................ . . Trace.

No. 6. Sullivan's lode, Castle Creek............................. Heavy trace.

No. 7. Lode on Rapid Creek.............................. Trace.

No. 8. Iron pyrites from Spring Creek...................... Trace.

No. 9. Lode on Rapid Creek-quartz.......................... Heavy trace.

No. 10. Lode on Rapid Creek-quartz................................. . trace.

No. 11. Empress lode, Box Elder-quartz...................... None.

No. 12. Lode on Rapid Creek .............................. Trace.

The amount of gold found in each case was too small to weigh, although the charges of ore were large.

Very respectfully,

WAlter P. Jenny, E. M.,

P. DE P. RICKETTS, E. M.

Geologist Black Hill Expedition. 
Hematite iron ore exists in extensive deposits in the slates on Box Elder, but is so intermixed with quartz as to greatly deteriorate its value.

"Blue block" iron ore (siderite), weathering to limonite, was found of good quality in the black clay-shales of the Cretaceous on Beaver Creek. The deposit covered quite a large area, and consisted of three horizontal layers, respectively', 8 inches, 3 inches, and 5 inches thick, separated by a few feet of clay-shales. This ore closely resembles the block ores of the Coal Measures of Kentucky and Pennsylvania, which are worked in the small charcoal iron-furnaces scattered through the timbered districts.

Gypsum is found in beds from 5 to 12 feet in thickness, interstratified with the red clays of the Red Beds. Usually there are three or four of these layers of massive white or gray gypsum in the formation, but in places they seem to be wanting and to be replaced by sandy clays.

These Red Beds entirely surround the Black Hills, but are so exposed by uplift on the southern and eastern sides as to conceal partially the gypsum beneath the débris of the clays.

In Redwater Valley, in the northwestern portion of the Hills, and in the vicinity of Inyan-Kara and Sun Dance Hills, the gypsum beds are very prominent, and the mineral occurs in extensive strata, so exposed as to be easily mined should there ever be a demand for it.

The Carboniferous limestone which covers a large area of the Black Hills is very pure, and when burnt will make an excellent white lime suitable for building purposes. Building stone is everywhere abundant in the Hills, and of good quality, including granite, slate, quartzite, sandstone of all shades of color and degrees of hardness, limestone both white and gray, and many varieties of trachyte and altered sedimentary rocks.

Some of the soft variegated sandstone of the Red Beds is very ornamental, embracing every shade of color from yellow, through orange and pink, to the darkest red.

Springs, issuing from the black clay-shales of the Cretaceous on Beaver Creek, were found to be strongly acid and astringent to the taste, turning blue litmus red, and probably containing alum and free sulphuric acid. Similar springs were reported to be found near Buffalo Gate, on the southeastern side of the Hills. A yellow efflorescence resembling flowers of sul- 
phur in appearance is often seen on the surface of these clay-shales. On testing, it was found to be a basic sesquisulphate of iron, probably identical with a yellow salt of similar composition used in medicine.

In reviewing the gold deposits in the Black Hills, there are some peculiarities in the occurrence which require to be specially noticed.

The gold contained in the trachytes of the northern part of the Hills and the Bear Lodge range has been deposited in these rocks at the time of the intrusion, which was probably coeval with the elevation of the range at the close of the Cretaceous period. But the gold ledges in the schists and slates are of Archæan age, and formed during the folding of the metamorphic rocks.

There seems to have been no volcanic disturbance in the Black Hills since the elevation, and the occurrence of basalt capping gravel deposits, so common a feature in the California and Australian gold fields, is here entirely wanting. No fossil plants or the bones of extinct animals have as yet been found in the placers, whereby their age might be determined, but from their position they have been deposited not later than the Tertiary, and since the elevation of the Black Hills.

Very few minerals have been found associated with the gold, except garnets and magnetic iron sand. The occurrence of zircon, topaz, or platinum, so common in the gold-washings in other parts of the world, has not been observed in the Black Hills.

With the exception of a few of the gravel deposits in the foothills, which may be of shore formation, no deep leads or old channels filled with gravel were found, which could not be referred to the present streams and system of drainage, assuming only a greater rain-fall than at present, as numerous gravel beds occur in dry sags and gulches, where water rarely, if ever, forms now a running stream.

There are evidences of four distinct erosions having taken place in the geological history of the Black Hills. The first at the close of the Archæan, the second during the early Tertiary, the third in the Drift or Glacial period, and the fourth, the result of the action of the present streams and drainage in recent times.

After the elevation and folding of the schists and slates, the formation 
of the auriferons quartz veins, and probably the intrusion of the granite of the Harney Peak range, a most enormous denudation of the metamorphic rocks occurred, and the greater portion of the resulting material was swept away and lost. Only water-worn bowlders of quartz and the harder rocks remain, forming the conglomerate at the base of the Potsdam.

Most, if not all, of the area of metamorphic rocks was at one time covered by this conglomerate, and it is probable that the advancing Silurian ocean, at least in part, produced this erosion of the slates and schists. The conglomerate is often found to contain huge bowlders of quartz and quartzite derived from the ledges in the slates in the immediate vicinity, but nowhere were we able to find any pebbles of granite in the Potsdam, though fragments of soft clay, slate, quartzite, and quartz from its lower layers, and scales of mica are easily seen with a magnifying glass in the compact layers of this sandstone. Granite occurs abundantly in the Tertiary and more recent conglomerate, and I can only account for this absence of granite in the conglomerate of the Potsdam by supposing that the feldspar yielded more readily to decomposition by the atmospheric agencies of the Silurian period than it has from the same forces since the elevation of the Black Hills.

The Potsdam commences with the coarse conglomerate, a deposit formed by a shallow and advancing sea, which seems to have gradually deepened, as the sediments forming the sandstone regularly become finer in grain as we ascend.

Since the Cretaceous, the Black Hills have been above the ocean-level, probably attaining their present altitude by a slight additional elevation at the close of the Tertiary, strata of that age, on the Cheyenne, having a dip of $3^{\circ}$ to $5^{\circ}$ from the direction of this range. F'rom the Archæan to the Cretaceous, these sedimentary rocks are an evidence of denudation; of a wearing down of some continent, furnishing the enormous mass of material which now composes the extensive strata of slate, sandstone, limestone, and clay-shales.

The second great erosion succeeded immediately the elevation of the Black Hills, and occurred during. the early part of the Tertiary period. The resulting material forms the conglomerate between the top of No. 5 Cretaceous and the base of the Miocene or White River Tertiary. Only 
on the Cheyenne, between the mouths of Rapid and Spring Creeks, where this conglomerate, about 6 feet in thickness, caps hills of Cretaceous shales 500 feet in height, can the result of this erosion be identified. There the conglomerate is made up of small bowlders, round and water-worn, of granite, trachyte, slate, quartzite, and quartz, in all the varieties in which it is now found in the Black Hills, together with chert nodules from the Carboniferous limestone, and fragments of hard quartzite from the Cretaceous.

The third erosion occurred during the Glacial or Drift period, when thin beds of gravel, with occasional large bowlders, were strewn over the surface of the plains for a distance of fifty miles from the foothills, and rest equally on the surface of the different members of the Cretaceous and cap hills of the White River Tertiary. Some of these traveled bowlders are 2 feet in diameter, and are most abundant on the Cheyenne to the southeast of the Black Hills. They have evidently been transported by the agency of floating ice. Any current of water sufficiently powerful to carry bowlders of this size and weight would entirely remove and sweep away the soft clay-shales on which they rest. There was no evidence found that during the Quaternary period any extensive glaciers occurred in the Black Hills. Even the tops of the highest peaks showed no glacial scratches where the hardness of the rocks would insure their preservation. A few large bowlders of granite, 8 to 10 feet in diameter, were observed perched on the tops of rocky benches at the bends of the small streams flowing southeast from Harney Peak. They resemble those referred to glacial action in the Eastern States, but were possibly only the result of a peculiar weathering of the granite.

While there is little evidence of the presence of extensive glaciers in the Black Hills, the occurrence of large quantities of ice and snow in this elevated region during the Glacial period, with the necessary accompaniment of increased rainfall and river action, have probably been the agents which have caused this immense denudation of the sedimentary strata. And it seems almost necessary to assume the occurrence of an extensire lake surrounding the Hills during the Quaternary period, when the bowlders resulting from the erosion were transported by the agency of the floating ice to the places where they are now found. 
The whole area of the gold field in the Black Hills was, at the time of the upheaval of the range, covered by the Potsdam and subsequent formations. It is probable that the Potsdam conglomerate, formed by the primary erosion of the metamorphic rocks and their inclosed auriferous quartz ledges, contains considerable quantities of gold, and, by the disintegration and denudation of this conglomerate since the elevation of the Hills, the gold which it contained has been set free and concentrated anew in the placer gravels. This may in part account for the richness of some of the older and more elevated gravel deposits along the valleys of the present streams.

The fourth erosion in the Black Hills has taken place in comparatively recent times-since the Glacial period-and is still in progress, modifying the effects of the previous denudation, and often removing and redepositing the gravel beds resulting from them.

This last erosion is solely the work of time, frost, rainfall, and river action, as they occur at the present time, all working extremely slowly, but gradually wearing down the rocks, deepening the valleys and cañons of the streams, and, by working over the older auriferous gravels, increasing the richness of the bars and flats along the present beds of the streams. But the amount of gold swept into the valleys by the present forces and rainfall must be inappreciable, compared with that resulting from the enormous tearing down of metamorphic rocks and quartz ledges by the previous erosions. The placer miners have a saying that "Gold does not go down stream at the present day," else we would look for it in beaver dams and other similar places. Though it is true that fine gold will sluice through a cañon over bare bed-rock, and be deposited in the bars below the mouth, it being only a question of time how long a particle of gold is making the journey, no matter how many times it may be caught on bed-rock, only to be liberated by the wearing away of the rock or by freshets. Some of the richest placers found in the Hills the past season were thus situated below the mouths of the cañons of the streams, where the valleys widened out, allowing permanent gravel deposits to form, retaining the gold.

In conclusion, in reviewing the gold placers of the Black Hills, it should be noted that at best the gold field has been but partly prospected, 
and that it is extremely difficult to predict, even approximately, the value of any particular gulch or district until the gravel deposits have been completely opened and nearly worked out.

The causes and circumstances which have influenced the concentration of the gold in the placer gravels are but little understood, and erosion has often removed entirely the ledges which were the source of supply of the gold now found in the gulches.

The deposits of auriferous gravel in the Black Hills may generally be said to be favorably situated for working, and that the gold can be very cheaply extracted, with the expenditure of but comparatively little time or capital in opening the deposits.

Compared with some of the world-renowned districts in California and Australia, the placers at present discovered are not remarkably rich, yet there are claims already opened and worked which are yielding a very good return for the labor employed.

At Cheyenne the railroad is not more than two hundred and fifty miles from the gold fields; the roads over which machinery and supplies are transported are excellent, the grades usually easy, and the drives not long between water.

The climate of the Black Hills is wonderfully healthy and invigorating; wood, water, and grass are everywhere abundant and of the best quality.

There is gold enough to thoroughly settle and develop the country, and, after the placers are exhausted, stock-raising will be the great business of the inhabitants, who have a world of wealth in the splendid grazing of this region. 


\title{
C H A P TER V.
}

\section{CLIMATE AND RESOURCES.}

\author{
By Walter P. Jenny, E. M. \\ SECTION I. \\ C L I M A T E.
}

It is extremely difficult, in fact almost impossible, to determine definitely the climate of the Black Hills from observations extending over a portion of a single year, especially as we were continually changing our location and altitude during the progress of the exploration, never being in any place more than a few weeks; but I have tried to give the facts as I observed them, with all the possible collateral evidence based on the growth of plants and trees and the experience of previous explorers in this region. Naturally many obvious contradictions will be noticed, which I have in some cases tried to reconcile. In most instances I have given simply all the information that was collected concerning the climate and rain-fall of the Hills, that others, who have had greater and more extended experience than myself in the Western country, might digest my data and judge for themselves, should they not feel inclined to concur with my deductions.

During the growing season heavy dews were of regular occurrence at night, especially in the low bottom-lands along the streams, where the grass in the morning would be as wet as if it had rained hard for an hour. By experience we found it best to locate our camps on some slight elevation above the flats of the valley, to obviate the annoyance of having tents and camp equipage saturated with dew on breaking camp early in the morning. 
It is doubtful if there is a heavy snow-fall in the Black Hills. The miners who remained in the Hills during the winter of 1874-'5 report that there was never more than six inches of snow on the ground until April, when a heavy fall occurred at the time they were removed by Capt. John Mix.

In a few localities in the interior of the Hills I saw small trees which had been bent down by snow-drifts, but the streams showed no traces of freshets caused by snow melting in the spring. There was no drift-wood along their banks, and the bridges built by General Custer the previous summer were still in place, which a rise of a few inches would have swept away. The snow must be sometimes deep enough to hide trails and landmarks, as the main Indian trails leading through the Hills were marked by stones placed in the forks of the trees or by one or more sets of blazes, the oldest almost overgrown by the bark.

No hail-storms occurred in the Hills the past summer, which caused an injury to vegetation. Often during thunder-storms it would hail for a few minutes, owing to some sudden change of temperature in the storm. The central portion of the Hills is elevated from 2,000 to 3,000 feet above the foothills, or an altitude of 5,000 to 7,000 feet above the sea, and necessarily the weather is sensibly cooler. The thermometer seldom stands above $85^{\circ}$ Fahrenheit in the shade. In this elevated region thin ice formed occasionally at night in open dishes of water left exposed to the sky even in midsummer, and after September 1 thin ice formed nearly every night in still pools. This low temperature occurred just before daylight and was of short duration. It was owing to the great radiation and evaporation, due to the rarity of the air and the clearness of the sky, causing no corresponding reflection of heat back to the earth. It seemed to have no bad effect on vegetation, which flourishes bright and green until about September 8, when the first frosts began to change the color of the leaves of the plants.

The growing season in this elevated region is necessarily but a few months. June 10 the aspen trees at the head of Floral Valley, at an altitude of 6,600 feet, were just bursting into leaf, the grass was green but quite short, and by September 8 the plants in this same valley were col- 
ored by the frost, and vegetation, except the evergreens and grass, had ceased to grow.

From the equable temperature and pure air, the climate was found to be remarkably healthy. Scarcely any one was sick in the whole command during the time we remained in the Hills.

The temperature of many springs of water issuing from the Carboniferous limestone and the granite and metamorphic rocks in the central and elevated portion of the Hills was found to average $42^{\circ}$ Fahrenheit even in midsummer. The springs bursting out anong the foothills at the edge of the plains were not tested with a thermometer, but apparently the water was not as cold by several degrees.

Col. Richard I. Dodge, commanding the escort of the expedition, a close observer of nature, publishes the following article on the climate of the Black Hills, which is so excellect, that I take pleasure in quoting it entire:

The climate is sufficiently varied to suit the tastes of almost any person or class. We have no knowledge of the winter climate, except from the reports of the miners who built the stockade and passed several months of last winter on French Creek. These unite in commendation. The winter was cold, but clear; the temperature remarkably equable. There weie no storms of any disagreeable magnitude, and the first serions snow-storm occurred just before they were brought out, in March.

It is hardly fair to judge even of spring and summer climate by the experiences of a single year, more especially since we were almost continually moving; changing not only our position, but our altitude. If, however, the experiences gained under such cireumstances are to be regarded even as approximate tests, I can pronounce the climate of the Black Hills well-nigh perfeet. Scarcely a day was too hot; scarcely a night so damp or cold that we could not sit out and enjoy ourselves around the campfire.

There is no such thing as a hot night. Though extremely susceptible to heat, I slept not a single night in the Hills under less than the equivalent of two blankets, and many times, even in midsummer, I required more.

I have already mentioned that on the 10th day of June we encountered, in the elevated gorge named by Custer "Floral Valley," a sharp snow-storm, alternating with sleet and rain. This valley is more than 6,000 feet above tide-water. On French Creek, at an elevation of 5,800 feet, we had a severe, killing frost on the night of the 10th of August. There is abundant evidence that the season, in these very high altitudes, is too short for an agricultural country.

For fire weeks, from 14th June to July 20, Camp Harney, on French Creek, was the center of operations of our exploring and surveying parties. We had, therefore, a much better knowledge of its climate than of any other portion of the Hills. It is 5,620 feet above tide-water. The climate is superb. Though it sometimes felt hot by day and damp and cold by night, the thermometer was never above $78^{\circ}$ nor below $54^{\circ}$. "A 
series of observations (not so regular as might be wished) gave a mean temperature of $62^{\circ}$ and a daily variation of $14{ }^{\circ}$. A few similar observations at Camp Crook, on Rapid Creek, in the latter part of July, resulted in a mean temperature of $64^{\circ}$, with a daily variation of $20^{\circ}$. On the 24th of July, on Rapid Creek, a severe hail-storm sent the mereury from $84^{\circ}$ to $62 \circ, 22^{\circ}$ in half an hour. Camp Cook is at least a thousand feet lower in altitude than Camp Harney.*

The past winter of $1875-76$ has been unusually mild all through the Northern and Western States, and reports from the miners in the Black Hills speak in glowing terms of the delightful weather they have experienced; very little snow having fallen before February, the grass being green at the roots, and the stock, when not overworked, keeping fat and in good condition. The winter of $1874-75$ was correspondingly extremely severe; yet the Sioux City party of miners, who built the stockade and cabins on French Creek in December and January, report that the cold was not intense, and that their cattle kept fat on the grass in the vicinity, where the altitude is 5,600 feet above the sea.

The Black Hills, with their copious rain-fall, rise like a high wooded island from an ocean of grass-covered and treeless plains, watered by occasional and scanty rains. The rain-fall on the plains, far from yielding a constant and uniform supply of moisture, unfortunately is very uncertain and irregular, both in quantity and occurrence, and sometimes falls so far below the average that the grass almost perishes from the drought.

This arid character of the plains is not peculiar to the region immediately about the Black Hills, but is equally true in a general way for this whole belt of elevated plains, nearly five hundred miles in width, extending along the eastern slope of the Rocky Mountains from Mexico to the British Possessions. And the reason for the treeless character of this immense tract of country is to be sought in its location with respect to the adjacent ranges of the Rocky Mountains and to the oceans on both side of the continent.

From the north the winds, coming from the colder regions in the British Possessions, bring with them scarcely any moisture; while from the south, the direction of the prevailing winds and the character of the country is such that any supplies of rain from that direction are cut off. The winds

* The Black Hills, loy Richard Irving Dodge, Lieutenant-Colonel, United States Army. New York: James Miller, publishex, 647 Broadway, 1876. 
which sweep over the Pacific Ocean are chilled by contact with the elevated ridges and snow-clad peaks of the Rocky Mountains, and precipitate the moisture which they contain as rain or snow. Passing on, these winds descend on the heated surface of the level plains, where in summer the temperature is often as high as $100^{\circ}$ Fahrenheit in the shade. Becoming heated and rarified, they sweep eastward to the Missouri, having their capacity for holding moisture greatly increased, and no ordinary change of temperature will cause these winds to part with the little moisture which they possess. Thus it will be seen that, practically, these plains have to depend for their rain-fall on the supply of moisture derived from easterly winds coming from the Atlantic Ocean and the Gulf of Mexico. These winds, in passing over the Alleghanies and the Mississippi Valley, have been subjected to innumerable changes of temperature, and robbed of the greater portion of the moisture they originally contained, to the serious detriment of this immense belt of country. As would be expected from the above, it was noticed the past season in the Black Hills that the rain-storms of long duration were preceded by, or occurred during, the prevalence of easterly winds, which were chilled by contact with the colder and more elevated portion of the Hills, precipitating the moisture which they carried.

While encamped on Rapid Creek, near the edge of the plains on the eastern slope of the Hills, I had an excellent opportunity to observe the formation and condensation of rain-clouds during the succession of rainy days in July. The wind was blowing gently from the east and southeast. Out on the level plains it scarcely rained at all, though dense banks of clouds hung over them and detached masses of mist and fog were sweeping low over the more elevated foothills. The clouds would form over the plains and, drifting on to the Hills, conceal from view the highest peaks and ridges, chill, settle down to the level of the valleys, and immediately rain until the excess of moisture was precipitated, then rise and drift away; when a short interval would occur before the clouds would again sweep in and produce a shower.

On examining the accompanying maps of the Black Hills, it will be seen that nearly all the streams rise in the central or western portion and flow east, the slope of the country being in that direction. I think that $20 \mathrm{~B} \mathrm{H}$ 
this eastern slope of the Hills has a greater rain-fall than the western, judging from the growth of plants and trees, a fact which would coincide with the theory that the rain-producing winds came from the east and precipitated their moisture on that slope.

But the showers of rain and the thunder-storms which we so frequently experienced seemed to be independent of the easterly winds as a source of their moisture, and to be local in their origin and occurrence. Generally of short duration, they came usually from the west and passed rapidly by, raining hard for ten to twenty minutes, and leaving the grass and trees dripping with moisture and refreshed by their passage.

The winds which blow on the Hills from any direction pass over the plains for a great distance, and, gathering some moisture, part with it on being chilled by contact with the cold and elevated peaks in the interior. Thus the Black Hills may be said to have a local and limited rain-fall not directly dependent on the easterly winds, which, nevertheless, furnish the greater supply of moisture.

The rain-fall experienced in the Hills during the progress of the survey was very remarkable for the frequency and regularity of the showers and their short duration. It was varied by the occurrence of occasional long, steady rains, and damp, drizzly, or foggy days. From June 1 to August 1 it rained more or less at least twenty days in the month. Usually the sky would be overcast by clouds about 3 or 4 o'clock in the afternoon. A smart shower, lasting from a quarter to half an hour, would rapidly pass by from the west, and the sun would shine again and quickly dry up the ground. On one occasion I experienced, near Harney Peak, four distinct showers, accompanied by thunder and lightning, in a single day, which was otherwise warm and pleasant, the sun shining brightly except when it was raining. It was not unusual to have a shower during the day followed by another after midnight. After August 1 the showers were not so numerous and the rain-fall was appreciably less, although several rainy days occurred in both August and September.

Referring to my note-hook, I find the following record of the rain-fall observed while prospecting on Rapid and Spring Creeks:

June 26, rained steadily all the afternoon. 
June 27, a shower in the afternoon.

June 28 and 29, no rain where we were camped.

June 30, rained steadily all day, preventing any work being done.

July 1 , two showers during the day.

July 2, 3, did not rain.

July 4, rained hard all day.

July 5 , rained hard for half an hour in the afternoon.

July 6, showers all around on the Hills, but did not rain where we were.

July 7,8 , no rain.

July $9,10,11,12,13,14,15$, one or more showers each day, usually after 2 p. m.

From the above it will seem that it rained fifteen days out of twentytwo. Referring to the published reports of the expedition to the Black Hills under command of Gen. G. A. Custer, in 1874, I find that Colonel Ludlow mentions this fact of the frequent occurrence of showers in the afternoon, under date of July 27, while encamped on the head of Castle Creek, a branch of Rapid Creek.

This portion of the Black Hills never suffers from drought. No arid places are seen except on the summits of the limestone ledges. Springs are numerous, and very cold and pure. The soil is everywhere moist, and vegetation marvelously luxuriant and fresh. The warm currents of air from the plains condense as they ascend the slope of the hills, and robbed of their moisture in fog, rain, and heavy dews, which occur nightly. The clouds almost invariably formed in the afternoon, and interfered greatly with astronomical observations. (Report of a reconnaissance of the Black Hills of Dakota, made in the summer of 1874, by William Ludlow, captain of Engineers, \&c., page 13.)

Gen. G. A. Custer and Major Forsyth also mention, in their reports of the expedition, the refreshing showers of rain which were frequently encountered, and also the thick fogs, prolonged rains, and severe thunderstorms experienced while in the Hills. That this remarkable rain-fall, which was observed throughout the Black Hills during the progress of the exploration, was not the exhibition of a peculiarly wet season, I can only judge from the evidence given above by previous explorers during the preceding year and by such observations as I was enabled to make on the growth of plants and trees. In many places I noticed plants whose habits of growth I was well acquainted with, which require a considerable and 
regular supply of moisture for their maintenance, growing on dry, rocky hill-sides, exposed to parching winds and the heat of the sun, and flourishing and producing flowers and seed in perfection. On the tops of the mountains, near Harney and Custer Peaks, far above the level of any springs of water, I found patches of wild raspberries growing so thickly that the ground was covered with them. The bearing-canes, which are of a previous year's growth, were of full size and loaded with fruit, showing that the previous season had been equally favorable to their development. All along the eastern slope of the Hills burr-oak and elm trees, which require an abundance of moisture to sustain their growth, attain at least a medium size, and are found not only along the banks of the running streams, but growing in small grooves on the hill-sides and in the swales and valleys. On examining the pine timber in different parts of the Hills I found that the annual rings of growth were uniform in width. The coarseness of the grain of the timber, its softness, and the regular appearance of the full-grown trees, all indicate, independent of the species of tree, a uniform yearly growth, and consequently a regular rain-fall. From these evidences I think I may safely draw the conclusion that the season of 1875 in the Black Hills which I witnessed was not an unusually wet one, although the rain-fall may have been somewhat above the average. The average amount of rain for the plains surrounding the Black Hills does not, probably, exceed 15 inches for the whole year. To the north, in the valley of the Upper Missouri, it is about 12 inches.

From the nature of the work the past season it was impracticable to definitely determine the amount of rain-fall; but the presence of trees indicates conclusively that it must be at least 25 inches, and not much below that amount for more than a single successive season, or many of the trees would perish from want of moisture. The following tables, giving the rainfall in inches for the nearest localities to the Black Hills where observations have been made, are from the Smithsonian Institution tables and the records of the Signal Service of the United States Army: 
Mean amount of precipitation of moisture, as rain and melted snow, for each month in the year.

\begin{tabular}{|c|c|c|c|c|c|c|c|c|c|c|c|c|}
\hline Name of station. & $\underset{\Xi}{\Xi}$ & 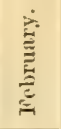 & 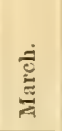 & $\underset{\vec{\Xi}}{\vec{\Xi}}$ & $\stackrel{\vec{z}}{\vec{z}}$ & $\underset{\Xi}{\Xi}$ & $\stackrel{\Xi}{\Xi}$ & 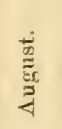 & $\frac{\stackrel{5}{E}}{\stackrel{E}{E}}$ & $\frac{\frac{5}{5}}{g}$ & 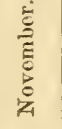 & 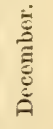 \\
\hline 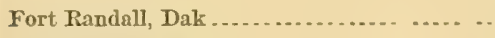 & 0.49 & 0.42 & 0.99 & 1.10 & 2.67 & 2. 30 & 1. 76 & 2.56 & 2. 43 & 1.09 & 0.41 & 0.30 \\
\hline Fort Pierre, Dak ..................... & 0.50 & 1.18 & 0.46 & 1.63 & 2.19 & 0.48 & 1.18 & 1. 66 & 1. 29 & 1. 08 & 1. 39 & 0.47 \\
\hline Fort Abercrombie, Dak................... & 0.52 & 0.66 & 1. 03 & 1.82 & 1. 82 & 2.18 & 3. 01 & 2.30 & 1. 07 & 1. 30 & 0.99 & 0.64 \\
\hline Fort Laramie, Wyo ..... & 0.61 & 0.46 & 0.84 & 1.06 & 3. 74 & 1.90 & 1. 63 & 1.37 & 1.17 & 0.97 & 0.84 & 0.57 \\
\hline
\end{tabular}

Mean amount of precipitation of moisture, as rain and melted snow, for the season and the whole year.

\begin{tabular}{|c|c|c|c|c|c|c|c|c|c|}
\hline \multirow{2}{*}{ Name of station. } & \multirow{2}{*}{$\frac{\sqrt[B]{n}}{\sqrt[E]{2}}$} & \multirow{2}{*}{ 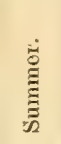 } & \multirow{2}{*}{$\mid \begin{array}{l}\stackrel{\Xi}{\Xi} \\
\stackrel{\Xi}{\Xi}\end{array}$} & \multirow{2}{*}{$\underset{E}{\stackrel{B}{\Xi}}$} & \multirow{2}{*}{ Year. } & \multicolumn{2}{|c|}{$\begin{array}{c}\text { Extent of } \\
\text { series. }\end{array}$} & \multicolumn{2}{|l|}{ Date. } \\
\hline & & & & & & Years. & Mo. & Beginning. & End. \\
\hline Fort Randall, Dak ........... & 4.76 & 6. 64 & 3.90 & 1.21 & 16.51 & 8 & 10 & 1857 & 1867 \\
\hline Fort Pierre, Dak . ............. & 4.28 & 3. 32 & 3.76 & 2.15 & 13.51 & 1 & 10 & 1855 & 1857 \\
\hline Fort Abercrombie, Dak ..... & 4.67 & 7.49 & 3.36 & 1.82 & 17.34 & 6 & 11 & 1860 & 1867 \\
\hline Fort Laramie, Wyo ................ & 5. 64 & 4.90 & 2.98 & 1.64 & 15.16 & 12 & 6 & 1849 & 1864 \\
\hline Cheyenne, Wyo ............. & 3.11 & 5.56 & 1. 98 & 0.37 & 10.02 & 4 & 4 & 1871 & 1875 \\
\hline Fort Buford, Dak . ..... & $\cdots$ & 6.49 & $\ldots$ & ...... & 11.75 & 8 & 0 & 1867 & 1874 \\
\hline
\end{tabular}

It will be noticed from a comparison of the above tables that the rain-fall for the whole Upper Missouri region follows the same general law, being greatest in the spring and summer months, from May to September, and least in autumn and winter, coinciding with the observations made in the Black Hills the past season. The season of 1875 was remarkably wet generally throughout the United States. At Cheyenne and North Platte, on the Union Pacific, 220 miles south of the Black Hills, the rain-fall was not above the average, but at Yankton and Bismarek, Dakota, situated nearly an equal distance north and east, it was unusually great, as is shown in the following table, compiled from the records of the Signal Service, United States Army:

\begin{tabular}{|c|c|c|c|c|c|c|c|c|c|c|c|c|}
\hline Name of station. & $\underset{\Xi}{\stackrel{\Xi}{\Xi}}$ & $\stackrel{\vec{E}}{E}$ & $\frac{\dot{3}}{3}$ & 惡 & $\vec{E}$ & $\stackrel{\mathscr{E}}{\Xi}$ & 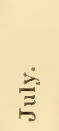 & 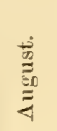 & 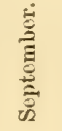 & $\frac{\stackrel{5}{0}}{\frac{3}{5}}$ & 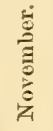 & 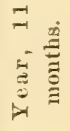 \\
\hline Chesenne, Wyo.... & 0.42 & 0.06 & 0.23 & 0.50 & 1. 20 & 0.29 & 4. 47 & 2.12 & 1. 34 & 0.60 & 0.84 & 12.07 \\
\hline Yankton, Dak ....... & 1. 07 & 1.51 & 1. 79 & 5. 26 & 2.04 & 9.21 & 5.53 & 4.95 & 5.33 & 0.14 & 0.12 & 36.95 \\
\hline Bismarek, Dak............ & 1. 05 & 1. 32 & 2. $00^{\circ}$ & 4. 22 & 3. 40 & 5. 02 & 1. 53 & 2. 89 & 1.85 & 2. 37 & 1. 33 & 27. 04 \\
\hline Torth Platte, Nebr. & 0.24 & 0.26 & 0.40 & 6.21 & 1. 69 & 1. 62 & 2.12 & 0. 66 & 1.40 & 0.14 & 0.52 & 15. 26 \\
\hline
\end{tabular}


Severe thunder-storms prevail in the Black Hills during the summer months. The clouds, instead of floating high in the air, sweep low over the elevated ridges, and the lightning is consequently peculiarly liable to strike the ground rather than to pass from one portion of the cloud to another and harmlessly expend its force. This causes some damage to the timber of the region. Often, in riding through the Hills, trees showing unmistakable marks of lightning would be seen, generally with the top shattered and a strip of bark about an inch wide torn out in a straight or spiral line from the top of the tree to the ground. Sometimes, however, only the splintered stump of what had once been a large tree remained, while the ground all around was strewed with fragments of the trunk, branches, and limbs.

It would seem that the pines growing in certain portions of the Hills were peculiarly liable, for some unknown reason, to be struck by lightning. On a hill near the headwaters of Spring Creek I counted twelve trees, growing on about two acres of ground, that were marked by lightning, and in a small park near by, among about one hundred trees, fourteen had been struck in previous years; some of them more than once. The most severe thunder-storms came from the west and traveled in an easterly or southeasterly course, the storm commencing with gusts of wind from the west, shifting to the north and northeast in the height of the tempest, and finally, as the storm passed by, blowing from the east or southeast.

A most terrific thunder-storm was encountered by myself and a small party of miners while camped on Box Elder Creek, August 7. The day had been pleasant but somewhat warmer than usual. About 3 o'clock in the afternoon a dense black cloud, extending like a wall across the valley, and rapidly advancing from the west, warned us of the approaching storm. Hardly had we completed our preparations to protect ourselves and provisions from the rain, when, preceded by violent gusts of wind that nearly prostrated every tent, the storm burst upon us. The rain, impelled by the violence of the wind, descended almost horizontally, and beat in torrents against the sides of the tents for about five minutes. Then, suddenly the wind shifted to the north, and came in sudden squalls of cold, piercing wind, chilling us through in a moment, and changing the rain instantly to 
hail, which was piled in winrows against every projection on the ground. Quickly veering back again to the west, the rain came, mixed with hail, driving before the blast. And then the storm raged with all its fury; flash after flash of chain-lightning followed in quick succession, extending vertically from the low, overhanging cloud to the ground, and striking at nearly every discharge among the trees on the surrounding hills. The thunder was incessant, and the crashing, increased by the reverberations from the surrounding rocky cliffs, was so continuous that it could not be referred to any particular flash. The wind shifted nearly all around the compass in the direction of the motion of the hands of a watch. The storm passed by in half an hour, the last rain coming from the southeast. The sun shone brightly once more, while to the east, down the valley, the cloud could be seen hiding everything from view, but illuminated every moment by flashes of lightning extending to the ground On examining several dishes which had been left out in the rain, I found that in about twenty to thirty minutes an inch of water had fallen. One of the miners came into camp shortly afterward and reported that he had been caught out on the top of a neighboring hill during the storm, and that two trees near hin were struck by lightning and thrown to the ground in fragments. The Indians are said to desert the Hills in the summer on account of the lightning, and I can easily understand that a band of superstitious Indians, after experiencing such a storm, especially if any of their number were injured by lightning, would forever forsake the locality.

SECTION II.

WATER SUPPLY.

To a settler in a new country no question is of greater importance than the purity and abundance of the supply of water, and in this respect the Black Hills are unequaled by any region in the "Great West."

A glance at the map shows, by the innumerable branches of the creeks and the intricate nature of the topography, that it is an extremely wellwatered country. Springs are found in almost every ravine. Nearly all the small head-branches of the creeks are running brooks of pure water, 
and streams of considerable size, and but a few miles apart, drain this region, affording a constant and regular supply of water for both stockraising and mining purposes.

The creeks which drain the gold field rise in numerous small springs, issuing from the granite and metamorphic rocks, and the water is consequently remarkably pure and free from mineral or organic matter. Those branches which head in the great Carboniferous limestone yield water suitable for most domestic purposes, the only drawback being a slight "hardness," due to the presence of carbonate of lime, which does not in the least affect the health of those using it.

Only among the foothills, where the gypsum of the Red Beds or the "alkali" derived from the Jurassic and Cretaceous shales has contaminated the streams draining these formations, is the water found to be unfit for cooking purposes and possessing purgative properties. Elsewhere throughout the whole area of the Black Hills included within the timber-line at the edge of the surrounding plains the water, both of the springs and running streams, is clear, cold, delicious to the taste, and extremely healthy. Early in June the temperature of the springs at the head of Floral Valley was found to be $39^{\circ} \mathrm{F}$., the elevation being 6,600 feet above the sea. In midsummer the water of a number of springs in the interior of the Hills was tested with an accurate thermometer, and found to vary between $42^{\circ}$ and $44^{\circ}$ F. After August 1, the past summer, the volume of all the streams in the Black Hills was somewhat diminished by the partial cessation of the lieavy rains, but none of the creeks stopped running, except that portion of French Creek above the Stockade, where the springs supplying the water are small and the grade very slight. From the character of the geological formations outcropping in the foothills and along the edge of the plains, all the streams rising in the Black Hills sink in their beds and disappear before passing through the belt of Carboniferous limestone, with the exception of Rapid Creek, which flows into the Cheyenne, and Spearfish and Redwater, which empty into the Belle Fourche. Large springs of good cold water burst out from under the Triassic limestone in the Red Beds at intervals along the inner rim of the broad Red Valley encircling the Black Hills. These springs will be very valuable to the future stock-raisers in this region, 
affording watering-places for the stock grazing in the open plains or among the foothills.

Spearfish and Redwater Creeks united pour a large volume of excellent water into the Belle Fourche, but the shales of the Cretaceous formation through which the river flows soon contaminate the water with alkali, giving it a slightly unpleasant taste, and causing it the past autumn to seriously affect the health of the escort. Probably at other seasons the water of the Belle Fourche deserves its name and reputation, but at the time we were camped on its banks (September 20) the stream was comparatively low and the water contained its maximum of impurities. The south fork of the Cheyenne is like most of the rivers in the plains, shallow, with a moderate current flowing through a broad level bottom, yet subject to sudden rises in spring and early summer. In places it cannot be forded on account of quicksands, even when the river is so low that the water is but a few inches deep.

The water of the Cheyenne is full of suspended mud, and contains traces of alkali derived from clays along its banks.

\section{S H C TION III.}

S OIL.

There is no better way to judge of the fertility of the soil of a new and unsettled region, where the rain-fall is abundant, than to examine the growth and character of the vegetation which it supports.

The Black Hills are an oasis of verdure among the open and level plains. A luxuriant growth of grass spreads over the whole region; even on the rocky hill-sides grass is found growing in the crevices in the rocks wherever there is a particle of soil for its support. A heavy forest covers the greater portion of this area, the trees growing thickly together and attaining full size, not only on the rich bottom lands of the valleys, but on the tops of the level limestone "mesas"; and the steep rocky ridges are clothed with pine of good size to their very crests. The soil on the main divides and ridges is not so deep as it is in the parks and valleys which have received the wash from the neighboring hill-sides, and these elevated 
tracts being most valuable for grazing purposes, will not be used for cultivation.

Even a casual examination shows that the soil of the valleys, the broad swales of the parks, and the bottom lands along the creeks is exceedingly rich and deep, being a dark-colored loam, resulting from the decomposition of the granite, limestone, and schistose rocks occupying the central area of the Hills. Often in sinking prospecting pits along the valleys in search of gold, the soil would be found to be a black peaty loam, from 2 to 3 feet in thickness, and frequently in the bottom-lands the soil was 4 feet in depth, resting on a gravelly subsoil.

In the parks and along the elevated limestone divide near Crook's Tower are numerous swales of rich grass-land between the low hills and ridges. The soil is deep and fertile, supporting a rank growth of herbaceous plants, but owing to the elevation above the sea and the short growing season of not more than three months the value of these tracts for cultivation has yet to be proved by experiment. In the valleys of Spring and Rapid Creeks are extensive bottom-lands, which would be excellent for farming purposes did not the underlying gravel contain gold in quantities sufficient to cause it to be mined out in the next few years, to the ruin or serious detriment of the land.

The whole valley of Rapid Creek, a mile and a half wide, from the foot-hills to the Cheyenne, a distance of 45 miles, is susceptible of irrigation from the stream, which carries at least 3,000 miner's inches of water in midsummer. The soil of this valley is deep and fertile, except near the Cheyenne, among the clay-shales of the Cretaceous, where the presence of alkali makes the grass thin and poor.

There are extensive tracts of good farming lands on the Redwater and Spearfish where they unite to form the Deep Water, a branch of the Belle Fourche. Colonel Dodge, the commander of the escort, regarded this locality as admirably suited for a military post.

The soil of the upper valley of the Belle Fourche, from Bear Lodge Butte to the point where it suddenly bends to the southeast, is reported by the topographical party to be excellent, and that broad flats of grass-land skirt its banks for miles. The valley of this stream below where it is joined 
by the Deep Water is injured by the prevalence of black Cretaceous clays and the usual accompaniment of alkali.

The South Fork of the Cheyenne has a broad level bottom, but generally so little elevated above the water in the stream as to be liable to inundate from floods. In places, however, some very good land is to be found in the extensive flats along that stream. Were the Blacks Hills as densely populated as the State of New Hampshire or Vermont, which they resemble in the character of the vegetation and climate, a very considerable proportion of the area would be subjected to cultivation. But the amount of arable land, or rather land that will in the next quarter of a century be cultivated in this region, is small compared with the whole area of fully six thousand square miles embraced in the Black Hills There is good land enough in the bottoms of the streams suitable for cultivation to amply support the population which will remain in the Hills after the present excitement shall have subsided and stock-raising become an established occupation.

Including the bottom-lands of the Cheyenne and the Belle Fourche and the arable land along the valleys of the streams issuing from the Black Hills, I estimate that not less than one-twentieth of the whole area is susceptible of cultivation, the remainder being covered by forest or forming stock-ranges of the finest description.

\section{SECTION IV.}

WILD FRUITS.

The fruits found growing wild in the Black Hills are an evidence of the adaptability of the country for raising the more valuable cultivated varieties, and hence I propose to consider the wild fruits which were found in this region much more in detail than they would otherwise deserve. The most useful is the red raspberry, which was found in large patches in the vicinity of Terry Peak, at an elevation of 6,500 feet above the sea. The plant is rather dwarf in size, the bearing canes being about 2 feet high, and August 15 were loaded with delicious fruit, resembling rery closely the cultivated variety "Knevit's Giant" in size, flavor, and productiveness.

A variety of black gooseberry was abundant on the western side of the 
Hills, near Inyan-Kara; the fruit was of a pleasant acid flavor and of good size, only differing from the ordinary western wild gooseberry in being blue-black in color instead of dark-red.

Several species of currants, including the black, red, and fetid varieties, were occasionally seen, but are valueless.

The wild western strawberry grows throughout the Hills. It is a very shy bearer, and the fruit is deficient in flavor

The bunch-berry, or cornel (Cornus canadensis), was found in the extreme northern part of the Hills. I have never seen it elsewhere, except in Maine and Nova Scotia.

Service-berries (Amelanchier canadensis) were quite plenty on Spring and Rapid Creeks in July. The common wild red plum grows in patches among the foothills, along the bottoms of the ravines The fruit was ripe about September 20

The only variety of grape noticed was a kind of frost-grape, found along the banks of the streams, near the edge of the plains.

Quite extensive patches of the two varieties of hazel-nuts were observed in the southeastern part of the Hills, associated with alder, white birch, iron-wood, white elm, burr-oak, sumac, the poison ivy (Rhus toxicodendun), the Virginia creeper, and many other plants of wide range and distribution.

Wild flax and wild hops attain a rank and luxuriant growth on the bottom-lands along the streams, and the soil and climate seem to be remarkably well suited to the growth of these plants.

The flora of the Black IIills bears quite a resemblance to that of Southern Maine and New Hampshire in the same latitude, and it is probable that many of the agricultural productions, fruits, and vegetables which can be grown in perfection there will also succeed in favorable portions of this region. The luxuriance with which the heavily seeded grasses known commonly as wild rye, cheat, and wild oats grow on the rich bottoms along the eastern slope, would indicate that an equally rank growth of the cultivated cereals and grasses is to be expected. Except at a low elevation among the foothills near the edge of the plains, the nights will probably be found too cool for the successful growth of Indian corn, which is a tropical plant, but oats, rye, barley, and wheat should yield well, and potatoes of the best quality may be produced in the fertile valleys. 
S ECTION V.

G R A Z IN G.

The grazing in the Black Hills is most excellent. Nine-tenths of the whole area is covered by a thick growth of the finest wild grasses. It constitutes the great future wealth of this region, and its value can hardly be overestimated.

Every one who visited the Hills the past season was enthusiastic over the luxuriance of the grass, which in the brightest green spreads over the surface of the parks, hill-sides, and valleys, adding greatly to the beauty of the scenery.

Cirralry officers, herders, scouts, and miners all were united in praise of the grazing. "California Joe" said of the valley of Spring Creek: "There's gold from the grass roots down, but there's more gold from the grass roots up." And no matter how rich the gold-placers in the Black Hills may prove to be, the great business in this region in the future will be stock-raising and dairy-farming.

Owing to the heavy dews at night during the growing season, to the frequent thunder showers, and the occurrence of occasional long and heavy rains, the grass grows all over the Black Hills wherever it can obtain a particle of soil for its support and a few hours' sunshine during the day.

Even in the clefts of the rocks, the sides of the steep ridges, and in the bottoms of the deep cañons, grass is found growing, depending on the scanty soil for its sustenance, and the little sunlight that pierces through the dense branches of the trees or penetrates for a short time the depths of the gorge.

Unlike the grass on the plains, which springs up in May and by July has turned yellow and cured to a natural hay, the grass in the Black Hills, stimulated by the abundance of moisture, continues growing all through the summer, remaining always fresh and green until its growth is checked by the frosts of autumn.

When the expedition reached the Hills, about June 1, spring was well advanced. The trees on the foothills were in full leaf, and the grass had 
evidently been growing for several weeks. On the top of the Beaver Creek plateau, at an elevation of 6,000 feet above the sea, the grass (June 5) was six inches high, and covered the whole surface of the level mesa, growing thickly under the shade of the pine forest, even to the very roots of the trees, giving the region the appearance of a smooth, well-kept lawn, with tall pines rising from the green carpet of grass.

The grasses in the Black Hills are almost endless in variety, every condition being so extremely favorable to their growth. In the interior of the country the shorter grasses prevail. But among the foothills on the rich bottom-lands of Rapid Creek the taller grasses, known as wild rye, crow's foot, cheat, and wild oats, attain a luxuriant growth. The grama, or buffalo grass, covers the valleys at the edge of the plains to the exclusion of the other varieties. It is considered the most nutritious wild grass in the Western country, curing to hay on the ground. But, when growing in an alkaline soil, it seems to rapidly lose its nutritive qualities after the seed ripens. Along the banks of the streams, where the soil is marshy, large patches of the scouring rush are found growing. It forms an excellent food for stock, for which they will desert the finest grasses, and feed upon it until they are full and can eat no more.

I had previously been engaged in explorations in Western Texas and New Mexico, but I was surprised at the quality of the grazing we found in the Black Hills, which resembled the grass growing in the oak openings in Central Texas, except that it was finer and freer from weeds and the coarser and less nutritious grasses. The escort of the expedition remained camped on French Creek for six weeks, and grazing for nearly one thousand horses and mules and three hundred head of cattle was found during that time within a mile and a half of camp, the grass commencing to grow again as soon as it was eaten off by the stock. For the requirements of the population that the Black Hills will support in the rext twenty years enough hay can be procured from the wild grasses; and should the demand in the future increase, an ample supply can be raised by sowing timothy or other cultivated varieties on the bottom-lands of the valleys. The best localities for hay are in the southeastern part of the Hills, on Amphibious, French, Spring, and Rapid Creeks, and in the valley of Rapid, between the foothills and the 
Cheyenne, where the taller grasses are abundant on the moist bottoms of the streams and side valleys.

On the plains in the valleys of the Cheyenne and the West Fork of Beaver Creek there are localities where sage brush and "prickly pears" cover the alkaline soil, and grass is only to be found in patches. But generally throughout the area of the Black Hills the grass uniformly covers the land, wherever there is soil for its support and the shade is not too dense for its growth. Except among the Red Beds in the foothills, sage-brush is never seen and cactus but rarely met with.

Over thickly-wooded areas, and in the mountainous and rocky region about Harney Peak, the grass is found only in patches in the few localities favorable for its existence. A similar region, comparatively destitute of grass, occurs in the northern part of the Hills between Terry and Crow Peaks, where the whole surface of the country is cut into innumerable cañons, and a species of ground ivy, called "kinnikinick," a plant probably of the dog-wood family, replaces the grass.

I estimate the total area of country destitute of grass, or where it only occurs in isolated patches, to be not more than six hundred square miles, or one-tenth the whole area of the Black Hills, the remaining five thousand five hundred square miles constituting some of the best ranges for cattle, horses, and sheep to be found in the whole Western country.

Cattle frequently perish on the plains in large numbers during the severe winters, not so much from the low temperature or intensity of the cold as from the piercing winds, accompanied by sleet or snow, that sweep with resistless fury over the level and unbroken surface of the ground, chilling the animals more than any ordinary degree of cold could possibly affect them in a more sheltered locality. In the Black Hills the wind may blow a gale over the mountain-tops and exposed ridges, but in the valleys the air will be comparatively at rest, the timber covering the hill-sides and ridges materially contributing toward making the valleys warm and sheltered. This will be of great advantage to the stock which may be wintered in the Hills, shelter being found everywhere from sudden or severe storms. The grass exposed on the hill-sides by the snow blowing 
away or melting, as well as the green twigs of the bushes and trees, will afford subsistence for the cattle during any heavy fall of snow.

The miners who have passed the winters of $1874-75$ and 1875-'76 in the Black Hills report that the grass remained green at the roots, and afforded good grazing, keeping the stock in good condition, if it were not overworked. Little snow was experienced until the early spring months, when the first heavy falls of snow occurred.

From the secluded and sheltered character of the valleys, the abundance of water, and the fine quality of the grazing, the Black Hills are well adapted for dairy-farming, the establishment of cheese and butter factories, and the raising and breeding of fine breeds of cattle and sheep.

The Black Hills are remarkably free from noxious insects, and grasshoppers and locusts are rarely met with in numbers sufficient to cause any appreciable damage to the grazing or vegetation. Only in one locality were they at all numerous. On Beaver Creek, in the southwestern portion of the Hills, near the plains, early in June grasshoppers were just hatching, and in a few weeks had grown large enough to strip the leaves from the bushes. Gnats and mosquitoes were sometimes found in the Hills, but never in numbers to cause any annoyance. Large flies were quite troublesome during a few weeks in July and August, but the first cool nights caused them to disappear.

\section{SE C TION VI.}

\section{T I M B E R.}

The Black Hills are a well-wooded country. The plenteous rains and showers in summer keep the vegetation growing unchecked by drought: The density of the forests clothing the hill-sides have from their somber hue, when viewed from a distance, given the name to this region, the "Black Hills," by which it is known also in the Indian dialects.

The following trees will yield timber in this section:

The heavy pine (Pinus ponderosa), often known as yellow or Norway pine, the most abundant and valuable tree in the Hills. 
Black and white spruce, found among the valleys in the central and northern portions of this region, covering a considerable area.

Burr-oak (Quercus macrocarpa), in small groves on the eastern slope, near the foothills.

White elm (Ulmus Americana), associated with the burr-oak, occurs along the valleys of the streams near the eastern and southeastern foothills.

Aspen, white birch, ash, mulberry, box-elder (negundo), iron-wood (horn-beam), and juniper grow sparingly in different parts of the Hills, but are of little comparative value.

The pine forests cover so extensive an area and will yield so large a proportion of the timber, that all the other trees combined may be neglected in comparison, though they will be found valuable in the future development of the country. The Norway pine is a tall, straight tree, free from limbs for one-half its height from the ground. The wood is white, soft, with a straight, somewhat coarse grain, free from knots, and splitting readily into "shakes," shingles, or other similar forms. The sap is more resinous than that of the white pine, and in this respect this variety approaches more nearly the pitch-pine of North Carolina, a tree which it somewhat resembles in its style of growth.

The transverse strength of the wood is not so great as that of white pine, but by proper care in using it in construction this deficiency can be compensated for and practically obviated.

On the bottom-lands in the lower valley of French Creek specimens of this pine were seen that were fully 100 feet in height, and would measure 35 to 40 inches through at the ground. Trees of these large dimensions are, however, rare in the Hills. Timber of from 12 to 24 inches diameter is common, while extensive tracts are covered by a dense forest of small slender pines from 50 to 60 feet high, and rarely less than 8 or more than 12 inches through at the ground.

The pine forests in the Black Hills, where the trees are of mature growth and uninjured by wind or fire, will furnish good straight saw logs from 30 to 50 feet in length and very uniform in thickness, with a gradual taper, averaging in diameter from 12 to 20 inches. 
The tall slender pines will be very useful to the settlers in this region, being well adapted for fencing and house-building purposes. The resinous character of the wood makes it a most excellent fuel, burning with a long smoky flame, giving out in intense heat, almost equaling in this respect the pitch-pine of the Southern States.

On the tops of the ridges and hills, where the trees are exposed to the violence of the storms, the timber is wind-shaken and injured in quality; but on the more sheltered hill-sides, the broad level mesas, and in the numerous valleys and parks, the trees are free from this evil, and are remarkably straight and regular in growth. Pines were sometimes encountered, blown down by the wind across the narrow ravines, the trunk of the tree, even when 1 to 2 feet in diameter, being broken short off by the violence of the fall on the rocks. This rarely happens with the spruce under similar circumstances, owing to the greater transverse strength of the wood.

The Black Hills have been subjected in the past to extensive forestfires, which have destroyed the timber over considerable areas. Around Custer Peak and along the limestone divide, in the central portion of the Hills, on the headwaters of the Box Elder and Rapid Creeks, scarcely a living tree is to be seen for miles. The timber, deadened by the fire and the trees left standing, their decaying trunks stripped of bark by weather or prostrated by the wind, cover the ground, crossing each other at all angles, forming an impassable abattis.

Some portions of the parks and valleys, now destitute of trees, show by the presence of charred and decaying stumps that they were once covered by forest, but generally the pine springs up again as soon as it is burnt off, though sometimes it is succeeded for a time by thickets of small aspens.

Along the eastern and northeastern slopes of the Black Hills, at a distance of not more than ten miles from the edge of the plains, the pine is partly replaced by burr-oak and white elm of moderate size. These trees are found in groves in the valleys and swales between the hills, and associated with white birch in the ravines of the streams. Neither the oak nor elm attains a large size, the trees averaging 30 to 40 feet in height and 10 to 15 inches through. 
The wood of the white elm is well known; that of the burr-oak resembles white oak, is strong and tough, ard will prove valuable for many purposes.

In the elevated portion of the interior of the Hills, especially along the valleys in the limestone formation, extending from Custer Peak to Floral Valley, and on the headwaters of Rapid, Castle, Elk, Bear, Butte, and Spearfish Creeks, two varieties of spruce, resembling the black and white spruce of the Northern States, are quite abundant. The trees are tall, growing thickly together, and will furnish logs quite uniform in diameter throughout their whole length. In the cañons, where the soil is rich, the white spruce attains a height of 100 feet, and is occasionally 2 feet in diameter at the ground. Usually, however, these trees are from 8 to 15 inches through, and will prove very valuable in constructing trestles and small bridges on account of the strength of the timber. The wood is white, fine-grained, and remarkably tough and elastic. The small slender sprucetrees are much sought after by the Indians, who visit the Hills in the spring for the purpose of procuring them for lodge-poles.

It is difficult to estimate accurately the area covered by valuable timber in the Black Hills. Taking into consideration that the foothills are but sparsely wooded; that there are extensive parks and valleys in the interior destitute of trees, or where there are only scattered groves of pine; that over an aggregate area of several hundred square miles the timber has been destroyed by fire, I estimate that one-half the surface included within the timber-line is covered by forest of more or less mature growth.

By careful measurements of the map, the area within the timber-line or outer boundary of the forest at the edge of the plains is three thousand eight hundred square miles. One-half of this, or one thousand nine hundred square miles, is covered by woods, including the large forests of young trees, as well as the sections of valuable timber.

Portions of this area are difficult of access, or the timber is wind-shaken and injured in quality, and the forests of small pine are relatively more extensive than the tracts of timber of a mature growth. Hence I estimate that one-fifth the above area of the Black Hills, or nearly eight hundred 
square miles, equal to 500,000 acres, is covered by timber of merchantable quality, suitable for cutting and sawing into lumber.

Col. R. I. Dodge, commanding the escort, by an entirely independent series of observations, estimates the merchantable timber at only about four hundred square miles, and comparing it with the pine forests of North Carolina, he says:

I estimate that there are in the two sections something over four thousand square miles of country more or less covered with pine. Of this, including the Red Valley, the parks, the bare bottoms, and valleys of creeks, I estimate that four-tenths are entirely without timber. Another four-tenths is composed of young forests, excellent for railroad ties, small buildings, fencing, \&c., but not yet fit for the saw-mill. Onetenth is wind-shaken or injured by lightning or fire, and one-tenth is good lumber. In other words, I think that this four thousand square miles will furnish not more than one-tenth of the merchantable lumber that would be obtained from an equal area of the virgin pine forests of Michigan or North Carolina. There is an abundance of lumber for all purposes of the country itself, but, except ties, it will not furnish any very large quantity for exportation.*

* The Black Hills, by Richard Irving Dodge, lieutenant-colonel, United States Army. James Miller \& Co., New York, 1876, p. 102. 
U. S. GEOGRAPHICAL AND GEOLOGICAL SURVEY OF THE ROCKY MOUNTAIN REGION.

J. W. POWELL, in Charge.

\title{
PALEONTOLOGY
}

OF THE

\section{BLACK HILLS OF DAKOTA.}

\author{
Br R. P. WHITFIELD.
}



Albany, N. Y., December 10, 1876.

Dear Sir: I herewith submit to you the following report on the fossils collected by the United States Geological and Geographical Explorations in the Black Hills of Dakota during the summer of 1875 , and placed in my hands for determination.

The report contains figures and descriptions of the fossils of the Primordial, Jurassic, and Cretaceous formations only, those of the Carboniferous not being deemed of sufficient interest to warrant the expense.

I have been under obligations to the officers of the Smithsonian Institution for the opportunity of making comparisons with their collections from the same formations, and to Dr. C. A. White for personal courtesies while so doing. I have also availed myself of the very valuable work of $\mathrm{F}$. B. Meek, esq., on the fossils of that region, lately published by the Department of the Interior, a copy of which was sent to me at his request at the earliest moment it could be obtained.

Very respectfully, yours, \&c.,

W. P. Jenney, E. M.,

R. P. WHITFIELD.

In charge Exploration of the Black Hills. 


$$
\text { . }
$$




\section{CHAPTER VI.}

\section{PALEONTOLOGICAL REPORT ON THE FOSSILS COLLECTED BY THE UNITED STATES GEOLOGICAL AND GEOGRAPH- ICAL SURVEY OF THE BLACK HILLS.}

BY. R. P. WHITFIELD.

SECTION I.

PRELIMINARY REMARKS.

The species described in the following pages were collected in and around the Black Hills during the expedition, and represent the different formations recognized, except the Carboniferous; from which, the fossils obtained were few and of little interest.

The horizon of the Potsdam formation of the Black Hills appears to be, so far as the fossils will serve to determine, about the same as that of Wisconsin and the neighboring States, and of some of the layers the lithological features are so nearly the same, that it would be difficult to distinguish between specimens from the two localities. The purplish-green quartzitic rock from the head of Red Cañon Creek, containing Lingulepis pinniformis Owen, sp., and several other Brachiopodous shells, appears to hold nearly the same relation to the rest of the group as does that at the Falls of the Saint Croix, from which the species was originally described, namely, near the base, the Red Cañon Creek beds resting immediately on the slates of older date (probably Huronian), while the Trilobitic beds and the soft friable layers occur at a horizon of about 100 feet below the Car- 
boniferous. The entire fauna of the Black Hills beds closely resemble that from Wisconsin; although the species are nearly all distinct, the generic fasces is the same throughout. Among the fossils from the higher parts of the formation there are quantities of Plante remains belonging to the genus Palceophycus, which I am informed cover the surface of the rocks over large areas where exposed, being densely matted together. These beds also hold a position similar to the plant beds of other localities.

The Jurassic formations seem also to be well represented in this region, and many of the beds are highly fossiliferous. The species are not numerous, but the individuals are extremely abundant, many of the slaty calcareous layers being so largely composed of organic remains, mostly Lamellibranchiates, as to be quite friable and easily broken in the hand, and some of the sandy layers have their surfaces densely covered with the separated shells of one or two species. The absence of Gasteropoda is a noticeable feature at all localities from which specimens have been brought, no example of this class of mollusks being present in the entire collection, from this formation. The few species of Fresh-water Gasteropoda described as probably from this horizon in the Smithsonian contributions (Paleontology of the Upper Missouri) being still doubtfully referred. This same absence of Gasteropoda is also noticed in all the collections of Jurassic age we have seen from the western countries, not more than three or four species having been obtained beyond those above referred to.

Among the Cretaceous fossils there are many forms of great interest, especially among the Inocerami and Cephalopoda. Among the former the forms described under the new generic name of Endocostea are interesting as affording light on a group of shells which, although long known, have not been fully understood, probably owing to the want of more and better material which this collection has afforded, the feature there described having previously been seen only on isolated poorly preserved specimens.

Among the Cephatopods of the Cretaceous there are some fine examples of the aberrant forms of the Ammonite Group, which show very conclusively that a rich field awaits the future collector in this region. In some of the localities of this formation from which collections have been brought there appears to be a difficulty in recognizing the divisions of the group 
proposed by Messrs. Meek and Hayden, as the fossils of two of the divisions are found intermingling at the same place and in the same layers. The specimens brought from the locality on Old Woman Fork of the Cheyenne are of this character; and there seems to be the same trouble among those from certain parts of Beaver Creek. The collection affords no specimens belonging strictly to the Divisions No. 1 and No. 3, though the beds were observed, but not collected from.

SECTION II.

FOSSILS FROM THE PRIMORDIAL ROCKS.

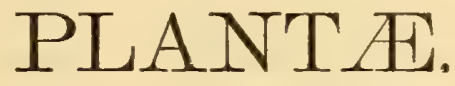

Genus PAL EOCHORDA.

PALAOCHORDA PRIMA.

Plate 1, fig. 2.

Palcoochorda prima Whitf., Prelim. Rept. Pal. Black Hills, 1877, p. 7.

Plants, the remains of which, as preserved on the surface of the rock, consist of narrow, linear, grass-like stipes, coiled or twisted without any regular order, leaving by their removal or decomposition flattened depressions of from one line to two lines in width and of an indefinite length, with rounded or obtusely-pointed extremities.

The examples in the collection before us are coiled, forming irregular curves, usually enrolled, but sometimes sigmoidal. The surfaces are smooth and structureless, presenting no marking whatever, although the substance is usually of a somewhat lighter color than the surrounding rock. The terminations are usually sharply rounded, and the whole appearance is more that of the impression of an Annelid than of a plant; though it is difficult to conceive of the preservation of anything other than a plant to leave such markings. We have referred them to the above genus, presuming them to be congeneric with those figured by Professor McCoy in his Synopsis of British Paleozoic Fossils, Plate 1 A, Fig. 3, although they are not elevated or rounded bodies, but flattened stipes. 
Formation and locality.-In the plant-beds of the Potsdam formation (probably Upper Potsdam or Calciferous). Head of Redwater Valley, Black Hills.

\section{Genus PAL PALAOPHYCUS OCCIDENTALIS.}

Plate 1, fig. 3.

Palceophycus occidentalis Whitf., Prelim. Rept. Pal. Black Hills, 1877, p. 7.

Remains consisting of strong, subcylindrical, flexuous stems or roots, covering the surface of the sandstone. The stems are more or less rounded, although frequently quite flattened, and varying in diameter from one-fourth of an inch to one inch, frequently bifurcating and sometimes dividing into threes. They are commonly interlaced with each other, but do not appear to coalesce, but are simply overlapped; the surfaces, although sometimes quite smooth, are generally marked by indistinct, longitudinal pits and ridges of greater or less extent, frequently occurring of an inch in length, while many are merely short, roughened depressions, which give a corrugated surface to the stems.

Judging from the specimens in the collection, we should suppose they often attain considerable length, as on a specimen measuring nearly ten inches the variation in diameter is scarcely perceptible, but occasionally one will be found to terminate in an obtuse point.

This species bears some resemblance to Fucoides duplex Hall (Foster and Whitney Lake Superior, p. 226, Plate A 23, Fig. 1), but does not present the longitudinal depression along the middle, as in that one, except near a bifurcation. It is very similar to $P$. tubularis Hall, from the Calciferous sandstone of New York; but is less ridged, and has a somewhat different mode of bifurcation from any of the specimens of that species which we have seen. If a larger number of the New York species were examined, however, it is possible that the resemblance might be much greater than at present supposed.

Formation and locality.-In the plant-beds of the Potsdam formation (probably Upper Potsdam or Calciferous). Head of Redwater Valley, Black Hills. 


\section{PALÆOPHYCUS, $s p$. ?}

Plate 1, fig. 1.

Besides the foregoing species of Palcophycus in the plant-beds at the head of Redwater Valley, there are layers covered in places with disjointed and almost characterless stems or rootlets of various sizes, ranging from a twentieth of an inch to those of nearly or quite one-fourth of an inch in diameter, and of various lengths. Some of them are straight and ridged, as though they had been hard cylindrical bodies; while many are more or less flexuous, and others have clavate terminations; but among them there are none preserving enough of form to characterize them as a species, or to place them positively in any established genus of value; we have therefore represented them only, leaving them doubtfully under the above genus, but without specific designation. Attention being thus directed to them may lead others to collect and examine them still further, by which means some light may be gained as to their nature and origin.

Very similar forms are common on certain layers of the Clinton Group of Oneida County, New York, where very similar conditions have existed; but so far as we are aware no positive determination has been reached as to their exact nature. Figures of these latter are given by Professor Hall in Vol. II, Paleontology of New York, Plate 9, Fig. 4, and others of corresponding character are common on the Portage sandstones of Western New York.

\section{INCERT AESEDES.}

ARENICOLITES, sp.?

Plate 2, fig. 25.

Some specimens of a hard white sandstone of the Potsdam Group, collected near Warren Peaks, in the northern part of the Black Hills, are filled with cylindrical perforations of an undetermined length, but measuring about two inches on the specimen in hand, were supposed to represent the existence of the genus Scolithus. The tubes are about one line in diameter, but are slightly variable in this respect, and have a somewhat rigid character, although by no means parallel to each other, and some- 
times slightly curved; still they give no evidence of bifurcating or anastomosing with each other, as is the case with Scolithus linearis. In these features they differ from that genus, and we are strongly inclined to consider them as having had quite a different origin. It has been suggested that they might have been the perforations or sheaths of the peduncles of linguloid shells, and the same suggestion was made by the writer some years ago to Professor Morse concerning some perforations in the sandstones of the same formation at Trempeleau, Wis.; but in this latter case the tubes are often found surrounded, or lined, by the fragmentary shells of Lingulas, and the sandstones contain on their surfaces shells of Lingula or Obolella; but these specimens furnish no such remains, nor are there any such brought from the localities from which these tube-bearing specimens were obtained. This fact would be rather against their linguloid origin, although they seem to be all vertical to the bedding of the rock. This latter feature, together with their rigid and somewhat uniform character, leads us to consider them as the burrows of some species of Annelid, rather than the cavities left by the removal of the remains of plants.* Another block of sandstone from Custer Peak, near the central portion of the Black Hills, has vertical tubes of a similar form, but of larger size; while a block of reddish sandstone, from the head of Redwater Cañon, is filled with irregular cavities of various sizes and shapes, being neither uniform in size or position, but which have all the appearance of broken drifted stems, of plants. These latter, coming from the same locality as the species of Cruziana contained in the collection, it is more natural to suppose may be the remains of vegetable organisms. These latter specimens are exactly similar to those figured by Dr. D. D. Owen in the Geological Report of Wisconsin, Iowa, and Minnesota, Plate $1 \mathrm{C}^{1}$, Figs. 1-8.

* Since writing the above I have seen and described, in the Geological Report of Wisconsin, specimens of a similar form that present indisputable evidence of their annelid character. 


\title{
BRACHIOPODA.
}

\author{
LINGULIDE.
}

Genus LINGULEPIS Hall.

LINGULEPIS PINNAFORMIS.

Plate 2, figs. 1-4.

Lingula pinnaformis Owen, Geol. Rept. Wis., Iowa, and Minnesota, p. 583, Pl. 1 B, figs. 4,6 , and 8 .

Lingula pinnaformis Owen, Repts. of Wisconsin, vol. 1, p. 21, fig. 3, and p. 435.

Lingula antiqua Hall, Foster \& Whitney's Lake Sup., part 2, p. 204, Pl. 23, fig. 2.

Lingulepis pinnaformis (Owen) Hall, 16th Rept. State Cab., p. 129, Pl. vi, figs. 14, 16.

Shell elongate-spatulate, rounded in front and on the sides, becoming narrowed and attenuate toward the beak, especially on the ventral valve, the cardinal slopes of which are long and slightly concave; apex of the valve very slightly truncate; width about three-fifths as great as the length in the most perfect individuals; surface of the ventral valve beautifully rounded over the body of the shell, becoming proportionally more sharply elevated along the middle on the narrowed portion, and almost subangular on the upper part of the beak. Dorsal valve shorter than the ventral, more broadly truncate at the upper end, and less regularly rounded on the surface, sometimes being slightly flattened in the lower part.

Surface of the shell polished, but presenting decided lines of growth, which, on weathered or partially exfoliated specimens, show a tendency to a lamellose structure; they are also marked in the latter condition by fine radiating lines, which are not apparent on the more perfect specimens.

The examples of this species before us are so exactly similar in their form and characters to those from the Falls of Saint Croix, that it is impossible to point out any differences that can be described.

Formation and locality.-In greenish-purple sandstone of the Potsdam formation, at the headwaters of Red Cañon Creek, Black Hills, Dakota. 


\section{LINGULEPIS CUNEOLUS.}

Plate 2, figs. $5,6$.

Lingulepis cuneolus Whitf., Prelim. Rept. Pal. Black Hills, 1877, p. 8.

Shells small, rather below the medium size, triangularly ovate in outline, or sometimes subcuneate; ventral valve triangularly ovate, with a sharp somewhat pointed beak, the width and length about as three and four, and the point of greatest width near the lower third of the length of the valve; cardinal slopes abrupt, scarcely convex; basal line rounded at the sides, but nearly straight in the middle; surface of the valve strongly convex, becoming almost subangular in the upper part; dorsal valve much shorter, proportionally, than the ventral, the length but little exceeding the width; side and base more rounded and the beak truncate; surface distinctly convex.

Surface of the shell apparently smooth, but usually exfoliated, in which condition a few fine radiating lines are visible.

This shell differs from L. pinnaformis Owen in size and in the more distinctly cuneate form of the ventral valve. At first sight it might be taken for the young of that species, but a little critical examination soon reveals marked distinctions in the truncation of the front margin, and especially in the form of the cardinal slopes, which are rounded and never concave, as in almost all ventral valves of that species. In consequence of this latter feature the beak does not appear so attenuated as in that one, although proportionally quite as long. In the general surface characters and form of the valves it corresponds with the genus Lingulepis, although we have not been able to distinguish the muscular impressions.

Were it not for the difference in the size of the shells, we should be inclined to think this might be the species figured by Messrs. Meek and Hayden (Paleontology of the Upper Missouri, p. 3, Plate 1, Fig. $1 a$ and $b$ ) as $L$. dakotensis; but as their figures appear to be of the natural size, we should suppose it to be very distinct, as all the specimens of our shell noticed have been small, none exceeding one-fourth of an inch in length.

Formation and locality.-In soft, friable sandstone of the Potsdam Group, at Red Cañon Creek, in the Black Hills, Dakota. 


\section{LINGULEPIS PERATTENUATUS.}

Plate 2, figs. $7-9$.

Lingulepis perattenuatus Whitf., Prelim. Rept. Pal. Black Hills, 1877, 1. 9.

Shell spatulate ${ }^{\circ}$ ' elongate-ovate, becoming acutely pointed toward the beak; sides below the middle of the length of the ventral valve rounded; front margin very regularly curved; cardinal slopes straight, or sometimes slightly convex; greatest width a little more than half the length of the ventral valve and sometimes nearly two-thirds as great. Surface of the ventral valve depressed convex, very slightly subangular along the middle above the lower third of the length, and a little more distinctly so in the upper part. Apex scarcely truncate. Dorsal valve considerably shorter than the ventral, broadly truncated at the upper end, the line of truncation being distinctly arched. Surface evenly convex. Structure of the surface of the shell polished, with fine, somewhat lamellose, lines of growth.

The shell, in many points, closely resembles $L$. pinnaformis Owen, but is a proportionally longer shell, and not exceeding one-half the size of the adult specimens of that species. When compared in shape, it is more elongate in front, the lower end of the shell forming a section of an ellipse rather than of a circle, as in that one; the cardinal slopes are convex and the valves proportionally longer, the apex being more elongated in proportion to the size of the body of the shell, but not so narrow. The two species are associated in the same blocks, and the dissimilarity between examples of the same size is so perceptible, that there will not be the slightest difficulty in recognizing them as distinct.

Formation and locality. - In greenish-purple sandstone of the Potsdam formation, at the headwaters of Red Cañon Creek, Black Hills, Dakota.

\section{LINGULEPIS DAKOTENSIS.}

Plate 2, figs. 10, 11.

Linguelepis pinnaformis (Owen) M. \& H., Pal. Upp. Missouri, p. 2, Pl. 1, fig. 1. Linguelepis dakotensis M. \& H., Pal. Missouri, p. 3.

"Shell subovate or ovate-subtrigonal, rounded in front and angular at the beaks, moderately convex; sides converging to the beaks with straight 22 B II 
or concave outlines. Beaks more or less produced, that of the larger valve attenuate and acutely pointed. Surface marked. by rather obscure concentric striæ, which are sometimes crossed by faint radiating lines, usually most apparent on exfoliated surfaces, and generally quite distinct near the front, on the interior surface, and on internal casts."

Although there are a number of fragmentary individuals of this species in the collection, there are none in a condition to figure or describe; we have, therefore, copied the original description, and also the figures from the Paleontology of the Upper Missouri, in order to give as perfect an exposition as possible of the fauna of this period, represented in this interesting region. The species differs from $L$. pinnaformis Owen, as it occurs at the Falls of the Saint Croix, and also from the same locality in its straight sides or cardinal slopes; in the more broadly rounded front, and in the somewhat more regularly convex valves.

Formation and locality.-In brown, somewhat ferruginous and friable sandstones of the Potsdam formation, at Castle Creek, Black Hills, Dakota.

\section{OBOLID AE. \\ Genus OBOLUS Eichwald. \\ OBOLUS? PECTENOIDES.}

Plate 2, figs. 18, 19.

Obolus pectenoides Whitf., Rept. on a Reconnaissance of the Black Hills of Dakota, by Capt. W. Ludlow, 1875, p. 103, Pl. - , figs. 1-3.

Shell rather small, transversely oval or broadly ovate, the length and breadth being subequal; apex of the larger valve very obtusely pointed; cardinal margins sloping from the beak, and inclosing an angle of from $110^{\circ}$ to $120^{\circ}$ in most cases, but often a much greater angle, or in many specimens the cardinal margin forms a segment of an elliptical curve; sides and base somewhat regularly rounded, the latter often being broadly rounded. Dorsal valve shorter than the ventral and proportionally more transverse. Exterior surface of the shell strongly lamellose; substance comparatively thick. 
'The specimens present in the collection are in a coarse friable sandstone and very imperfect, or in a harder band packed so closely together that it is impossible to isolate a perfect valve from those surrounding, so that the features are much obscured. The substance of the shell is the same as those used in the original description of the species, loc. cit, and on exfoliation presents the same peculiar radiating lines there indicated. The imperfect material has not afforded any further knowledge of the interior structure or muscular makings than there given.

Formation and locality.-In dark brown sandstone layers of the Potsdam formation, on Castle Creek, Black.Hills, Dakota.

\title{
Genus OBOl،ELLA Billings
}

\section{OBOLELLA POLITA.}

\author{
Plate 2, figs. 12, 13.
}

Obolus apollinus" Owen (not Eichwald), Geol. Surv. Wiscon., Iowa, and Minn., p. 501, etc., Tab. $1 \mathrm{~B}$, figs. 9, 11, 15, 20.

Iingula? polita Hall, Ann. Geol. Rept. Wisconsin, 1860, p. 24.

Obolella? polita Hall, 16th Rept. State Cab., p. 103, Pl. vi, figs. 17-21.

Shells small, short-ovate, being much the broadest below the middle of the length and narrowing above, somewhat abruptly so to the small, rather pointed beak of the ventral valve; basal line broadly but regularly rounded; surface convex, rather strongly rounded, most abruptly so in the upper part and becoming prominent and highly rounded toward the beak on the ventral valve, and more evenly rounded on the dorsal; surface of the shell smooth, or showing lamellose lines of growth on the weathered or partially exfoliated specimens. Interior of the shell not observed in any of the specimens present in the collection.

The shells referred to this species among the collections from the Black Hills differ very little from those from Wisconsin; they are rather more regularly ovate, not so wide below, nor so regularly narrowing toward the beaks, as the generality of those from that locality; the surface is slightly more lamellose and not so polished; but the specimens are all more or less weathered and less perfectly preserved, and are few in num- 
ber, so that the comparison is not a favorable one; still there is no doubt of the correct identification, as the differences are no more than might result from local causes.

Formation and locality.-In friable sandstone of the Potsdam formation, at the head of Redwater Cañon, Black Hills.

\section{OBOLELLA NANA.}

Plate 2, figs. 14-17.

Obolella nana M. \& H., Proc. Acad. Nat. Sci. Phil., Oet. 1861, p. 435.

Obolella nana M. \& H., Pal. Upp. Missouri, p. 4, Pl.1, fig. 1.

"Shell very small, subcircular or transversely suboval; moderately convex; rather thick; front broadly rounded; sides more narrowly rounded. Beak of dorsal valve short and obtuse. Ventral valve proportionally a little longer than the other, or about as wide as long, and having a slightly more prominent beak; without a distinct mesial ridge within; scar of anterior adductor muscle? located behind the middle; impressions of sliding muscles narrow; cardinal area rather narrow and flattened; groove for the passage of the peduncle shallow. Surface marked by a few concentric grooves or impressed striæ; exfoliated specimens showing small, regularly disposed radiating striæ."

The above is the description of the species as given by its authors in the Paleontology of the Upper Missouri, and agrees well with the many specimens before us from the same region of country. But we notice among them considerable diversity of form; different individuals varying from transversely oval to elongate triangular-ovate, as will be seen by reference to the figures on Plate II. The specimens vary very much also in the degree of convexity, many of them being flattened-discoid, while others are highly ventricose or become quite gibbous in the vicinity of the umbones. It is possible there may be more than one species among the specimens referred by us to this one; but as on many blocks, bearing an aggregate of several hundred individuals, the general similarity is so great, while the individual characteristics are so variable, we should not hesitate for a moment to consider them all as of the same species. One feature is quite noticeable, however, among them, that the transversely broad-oval speci- 
mens are almost always depressed-convex, while the narrower forms are more highly convex. But among them there are all grades of outline between the two extremes, and the variation in the convexity of the individuals is as gradual as the change in form; while the texture of the shell and the surface markings are the same throughout the whole. The shells are all minute, seldom attaining more than a line in length by a little less in width, or length and breadth subequal; some of the larger individuals, which are of the transversely broad-oval form, will measure about a line and half in width by a length somewhat less. We have not been able to satisfactorily see the internal muscular impressions, and have therefore copied Messrs. Meek and Hayden's figure showing these features.

Formation and locality.-In a hard quartzitic sandstone, of the Potsdam formation, of dark greenish-purple color, at the headwaters of Red Cañon Creek, Black Hills, Dakota.

\section{ARTICULATA. TRILOBITA.}

\section{CALYMENIDEE.}

\section{Genus CREPICEPHALUs Owen (? LOGANELLUS Devine.)}

\section{CREPICEPHALUS CENTRALIS.}

Plate 2, figs. 21-24.

Crepicephalus (Loganellus) centralis Whitf., Prelim. Rept. Pal. Black Hills, 1877, p. 10.

Species recognized only by the glabella and fixed cheeks, with a few imperfect fragments of the movable cheeks. The former parts, when united, are somewhat quadrangular in outline, broadest at the base and gently narrowing in front; glabella round-conical, higher than wide, the anterior end somewhat sharply rounded; surface highly convex and marked by three pairs of distinct lateral furrows, which are strongly directed backward in their direction from the margin, and on the larger specimens the posterior pair almost unite in the middle. Occipital furrow distinct, extending entirely across the base of the head; occipital ring 
strong, rounded, and in the older individuals supporting a short spine; dorsal furrows well pronounced, extending with equal clearness in front of the glabella. Fixed cheeks broad, more than equaling one-half the width of the glabella; palpebral lobes small and slightly angular, situated opposite the middle of the glabellit; ocular ridges distinct, directed anteriorly in passing from the eye to the dorsal furrow. Frontal limb short, not more than one-third as long as the glabella, one-half of its length formed by the strong, rounded marginal rim and furrow. Facial suture directed gently inward from the front of the eye lobe to the anterior margin, with but little curvature; behind the eye it is directed backward and outward at an angle of from $35^{\circ}$ to $40^{\circ}$ with the occipital line of the head, with a slightly sigmoidal curvature, giving an elongate triangular form to the posterolateral limbs.

There is considerable variation in the form and proportions of the glabella among the different individuals in the collection, the larger specimens being proportionally broader and the lateral furrows much more distinctly marked. On the smaller one figured the furrows are not distinct enough to indicate without exaggeration. The presence or absence of an occipital spine is also noticed, dependent apparently on the same cause. It is possible that the two individuals may belong to different species, but from their great similarity in other respects we feel confident that this is not the case.

This species resemble in some of its characters C.(Bathyurus?) angulatus $\mathrm{H}$. and W., from the same formation on the west side of Pogonip Mountain, White Pine, Nevada, described in the Geological Exploraton of the Fortieth Parallel, vol iv, p. 220, Plate 2, Fig. 28, but lacks the angular frontal limb of that species, and the facial sutures converge in front of the eye, while in that one they are slightly divergent. We know of no other species with which it is closely related, unless it should prove to be more nearly related to Agraulus Oweni M. \& H., Paleontology of the Upper Missouri, p. 9, Figs. $\mathrm{A}, \mathrm{B}, \mathrm{C}$, than we are inclined to believe; there are several particulars in which it differs very materially from their figures and also from the description given, that would at once mark it as distinct, if it were not that the imperfect material in both cases tend to lead to error. The difference in 
the width of the occipital lobe is a very marked one, and also the length of the frontal limb; while the form of the glabella varies much in being more distinctly conical than in that species..

Formation and locality.-In coarse sandstones of the Potsdam formation, at Castle Creek, Black Hills, Dakota.

\section{CREPICEPHALUS PLANUS.}

Plate 2, fig. 20.

Crepicephalus (Loganellus) planus Whitf., Prelim. Rept. Pal. Black Hills, 1877, p. 11.

Glabella and fixed cheeks, when united, subquadrangular in outline, narrowest across the eyes and slightly expanding in front, and more abruptly so posteriorly. Glabella very depressed convex, slightly conical and somewhat squarely truncate in front, the width across the base being equal to about three-fourths of the height above the occipital furrow, and that of the anterior end equal to about half the height; lateral furrows very faintly marked, oblique, and extending about one-third of the width from the margin. Occipital furrows not strongly marked, extending entirely across the base of the head; ring narrow and without spine. Dorsal furrows distinct, but not deep, extending around the front of the glabella. Fixed cheek wide, more than half as wide opposite the eye as at the middle of the glabella. Frontal limb of moderate length, at least as long as the width of the anterior end of the glabella, but its entire extent and anterior margin lias not been fully ascertained. Facial suture cutting the anterior border at right angles to the margin of the head and directed slightly inward to the eyes, behind which it is directed obliquely backward, at an angle of about $60^{\circ}$ with the base of the head, to the occipital furrow, belind which it runs more directly outward. Ocular ridges distinct. Palpebral lobes small and situated behind the middle of the head.

The species is only known by the glabella and fixed cheeks, and is remarkable only for its general flatness and want of prominent characters. There is no known species from the same formation either in the Wisconsin locality or from the more western regions that is so closely related to it as to be readily mistaken. C. (L.) quadrans H. \& W., Geological Fxploration 
of the Fortieth Parallel, vol. iv, p. 238, Plate 2, Figs. 11-13, from the slates above Call's Fort, North Wasatch Mountains, is perhaps as closely related as any, but differs in having the glabella more rounded in front and proportionally broader.

Formation and locality.-Associated in the same beds and locality with the preceding species.

SECTION III.

FOSSILS FROM THE JURASSIC ROCKS.

\section{RADIATA. ECHINODERMATA.}

ASTEROIDEA.

Genus ASTERIAS Linn.

ASTERIAS ? DUBIUM.

Plate 3, fig. 3.

Asterias? Aubium Whitf., Prelim. Rept. Pal. Black Hills, 1877, p. 15.

Several impressions of a species of Starfish, apparently of the genus Asterias, are present in the collection from a bed of light-red sandstone which occurs at a horizon of from 80 to 100 feet above the red Triassic beds.

The specimens are not in a condition to afford a full description of their specific characters. They are of small size, the rays being from three-fourths of an inch to one and one-fourth inches long, measuring from the center of the body. The rays are slender and flexuous, most of them being more or less curved in their direction and elevated along the middle, as shown on a gutta-percha cast taken in a natural mold of a group of three individuals. The upper surface is subangular, and in structure they are apparently composed of small nodiform plates, placed in longitudinal rows. The center of the body or disk is marked by an obscurely pentangular depression on the upper surface. None of the specimens show the under side of the body or rays, so that the characters of these parts are entirely unknown. 
The species appears to have been somewhat abundant, judging from the condition in which they are grouped on the sandstone, and although the specimens are obscure and too imperfect for positive determination and description, it has been thought best to designate them by name, as they will undoubtedly prove a characteristic form over a certain region and of a limited horizon. The sandstone is marked on the layers in which they are found, by ripple or wave marks, having a width of about three inches, and indicates a near proximity to a shore-line over the area where they were obtained, and that the individuals are probably stranded specimens. A single very imperfect impression of a Lamellibranchiate shell is present on the same fragments of rock, but too imperfect for determination.

Formation and locality.-In red sandstones of Jurassic age, 70 feet above the red beds, on the east side of Spearfish Creek, near its junction with the Redwater, Black Hills, Dakota.

\title{
CRINOIDEA.
}

PENTACRINID E.

\section{Genus PENTACRINites Miller.}

\section{PENTACRINITES ASTERISCUS.}

\author{
Plate 3, figs. $1,2$.
}

Pentacrinus asteriscus M. \& H., Proc. Acad. Nat. Sci. Phil. March, 1858, p. 49, ibid., Oct. 1860, p. 419.

Pentacrinites asteriscus M. \& H., Pal. Upp. Missouri, p. 67, Pl. iii, fig. 2.

Pentacrinites asteriscus (M. \& H.) White, Pal. Rept. Lieut. Wheeler's Rept. U. S. Geol. Surv. 100th Meridian.

Pentacrinites asteriscus? (M. \& H.) H. \& W., Geol. Expl. Fortieth Parallel, vol. iv, p. 280, PI. 6, fig. 16.

Messrs. Meek and Hayden describe this species from rocks of Jurassic age at the southwest base of the Black Hills, but none of them appear to have been obtained in the collections of Mr. Jenney's expedition. The figures on Plate 3, are from examples from the Big Horn Mountains, and are given for the purpose of presenting the form, which is so characteristic a fossil of this formation in the western part of the continent. 


\title{
BRACHIOPODA.
}

\section{LINGULID $\nexists$ E.}

\author{
Genus LINGULA Brug.
}

LINGULA BREVIROSTRIS.

Plate 3, figs. 4, 5.

Lingula brevirostris M. \& H., Proc. Acad. Nat. Sci. Phil. 1858, p. 50.

Ibid., Oct. 1860, p. 419.

Iingula brevirostris M. \& H., Pal. Up. Missouri, p. 69, Pl. 3, fig. 3.

"Shell subovate, varying to spatulate-ovate, very thin; lateral margins nearly straight or somewhat convex, generally converging a little towards the beaks; front subtruncate or abruptly rounded; cardinal extremity narrowly rounded. Beaks obtuse and apparently not extending beyond the cardinal margin."

The above is the author's description of the species as given in the Paleontology of the Upper Missouri, so far as it relates to the general form of the shell. The specimens which we have examined correspond very closely with their figures above cited, except that they are not usually as broad, proportionally, as their Fig. 3, but with Fig. $3 a$ they agree. The sides of the shells are slightly converging above the lower third of the length to the commencement of the cardinal slopes; the beak is obtusely pointed and short; the base rather sharply rounded than otherwise-that is, the curve is not that of a true circle, but rather paraboloid; but we have seen none of them which might be called subtruncate. The surface of our shells are not polished, being somewhat decomposed or exfoliated by the separation of the rather soft sandstone in which they are embedded. The shells are rather highly convex and somewhat inclined to angularity from the beak to near the middle of the length, below which they become slightly flattened on the central portion, though not enough to modify the form of the front outline. Fine concentric lines mark the surfaces on all the specimens. 
Formation and locality. - In red sandstones of Jurassic age, from 80 to 100 feet above the red beds referred to the Triassic, on the east side of Spearfish Creek, near its junction with the Redwater, Black Hills, Dakota.

\section{RHYNCHONELLIDAE. \\ Genus RHYNCHONELLA Fischer. \\ RHYNCHONELLA MYRINA. \\ Plate 3, figs. 6,7 .}

Rhynchonella sp.? M. \& H., Pal. Up. Missouri, p. 71, PI. 4, fig. 3.

Rlynchonella myrina H. \& W., Geol. Expl. Fortieth Parallel, vol. iv, p. 284, Pl. 7, figs. 1-5.

Shell of moderate size, subcircular or subtriangular in general outline, with moderately convex valves. Ventral valve depressed-convex in the middle portions, more sharply rounding upward along the cardinal slope, and marked by a broad, shallow depression along the middle in the anterior half of the shell, becoming somewhat more abrubtly bent upward in front; beak moderately large, pointed, and incurved. Dorsal valve more convex than the opposite and more generally rounded, the beak appressed and incurved within that of the ventral; middle portion of the valve elevated forward of the center, forming a broad mesial elevation corresponding to the depression of the other valve.

Surface marked by from twenty to twenty-eight distinct, rather angular, radiating plications, from four to eight of which are depressed in the sinus of the ventral valve, and a corresponding number elevated on the fold of the dorsal. These are crossed by distinct, often strongly-marked, concentric lines of growth and finer concentric striæ, which arch across the plications more or less abruptly according as they are more or less angular.

The shells under consideration are doubtless the same as those referred to by Messrs. Meek and Hayden loc. cit., and are also identical with those described under the name $R$. myrina $\mathrm{H}$. \& W. loc. cit., but are quite distinct from those given under the name of $R$. gnathophora Meek, Geological Survey California, Pal., Vol. I, Plate 8, Fig. 1, being proportionally broader, less equally convex, and much more finely plicated.

Formation and locality.-In white limestones of Jurassic age, above the red beds referred to the Triassic, at Red Cañon Creek, Black Hills, Dakota. 


\title{
LAMELLIBRANCHIATA. OSTREID A.
}

\author{
Genus OSTREA Linn. \\ OSTREA STRIGILECULA. \\ Plate 3 , figs. 8-12.
}

Gryphcea calceola var. nebracensis M. \& H., Pal. Upp. Missouri, Pl. 3, fig. 1 a-f.

Not Gryphcea calceola var. nebracensis M. \& H., loc. cit., p. 75, figs. A-E.

Gryphce calceola var. nebracensis (M. \& H.) H. \& W., Geol. Expl. Fortieth Parallel, p. 268, Pl. 7, fig. 11.

Ostrea strigilecula White, Geol. Surv. 100th Meridian, etc.

Shells of moderate size or smaller, very variable and irregular in form, but usually somewhat curved or subreniform in outline. Lower valve often attached to foreign bodies by nearly its entire external surface, and when separated shows a broad, irregular cicatrix, from the edge of which the sides and basal margins rise at a considerable angle, and form the cup of the valve of greater or less depth The posterior or cardinal portion of the valve is often quite shallow, while the basal or front border rises to a height equal to more than two-thirds of the entire length of the valve. Cardinal end of the valve narrow, triangular, and with a ligamental area of proportionally large size. Upper valve flattened or very depressed-convex. Surface of the valves strongly lamellose or concentrically ribbed and wrinkled; muscular impression large in most examples.

The shells of this species are extremely variable in character, it being quite difficult to select two specimens of the same form from a collection of a moderate number. The shell has been referred to Gryphaa; but, as has been remarked under the observations on the species in vol. iv, Geological Exploration Fortieth Parallel, p. 287, it presents, at many localities, the features of a true Oyster, and not those ascribed to the genus Gryphea. Since those remarks were written, Dr. C. A. White has described it under the name Ostrea strigilecula, considering it entirely a distinct species from the forms given by Meek and Hayden, Paleontology of the Upper 
Missouri, p. 75, Figs. A-E, as the normal forms of their G. calceola var. nebracensis, with which opinion we entirely agree. We have examined a large number of individuals from several widely-separate localities, and also masses of rock composed almost entirely of the shells, but find no specimens among them having the characters of the genus Gryphac, or with the specific features ascribed to the var nebracensis.

Formation and locality.-In rocks of Jurassic age, at a horizon of 350 feet above the red beds referred to the Triassic, east of the Belle Fourche River; also at an elevation of 300 feet at the same place, and at an elevation of 20 feet above the same horizon at the Belle Fourche; also at Sun Dance Hill and near Beaver Creek, Black Hills. The localities near the Belle Fourche are nearly opposite Bear Lodge Butte.

\section{Genus GRYPHÆA Lam.}

\section{GRYPHAEA CALCEOLA rar. NEBRASCENSIS.}

Plate 3, figs. 13-16.

Gryphcea calceola var. nebracensis M. \& H., Proc. Acad. Nat. Sci. Phil., Dec. 1861, p. 437. Gryphcea calceola nebracensis M. \& H., Pal. Upp. Missouri, pp. 74 and 75, figs. A-E.

Shells of moderate size, very inequivalve, and but slightly oblique; lower valve the largest, somewhat ovate in outline, strongly arcuate, and showing a tendency to trilobation in the lower part of the larger individuals; beak strong, incurved, and sometimes enrolled, but not truncated at the apex by any cicatrix of attachment, its substance much thickened by the solidifying or filling up of the rostral portion of the valve. Anterior side of the valve rather rapidly spreading for some distance from the beak, and below rounding abruptly to the narrow basal border; posterior side of the valve less expanded above, but often more so below, and distinctly lobed by a sulcus which marks the exterior from a little below the beak to the postero-basal border, which is in consequence sometimes strongly emarginate; ligamental area of moderate size, triangular, and concave; muscular impressions not very large and rather faintly marked, elongate-paraboloid or truncate-ovate, and situated behind the middle of the shell. "Upper valve ovate, nearly flat on the outside, or a little convex near the beaks; 
and more or less concave near the middle, usually concave on the inner side toward the cardinal extremity, which is thick and truncate; surface with rather distinct concentric marks of growth." (M. \& H.)

Exterior surface of the larger valve often marked by distinct and sometimes wiry, irregular, longitudinal striæ, which radiate from the apex and continue to below the middle of the valve.

Messrs. Meek and Hayden formerly united this and the preceding species (Ostrea strigilecula), under the same name, as a variety of Quenstedt's G.calceola. It appears to us, however, from an examination of specimens, that they are clearly distinct, generically as well as specifically, and that if the same variations of form occur associated with each other in the European localities, it is very probable that the two genera are also there represented as well as in our American formations.

Formation and locality.-In rocks of Jurassic age, Wind River Mountains.

\title{
PECTENIDE.
}

\section{Genus PECTEN Bruguieres.}

PECTEN NEWBERRYI.

\author{
Plate 4, figs. 12-15.
}

Pecten newberryi Whitf., Prelim. Rept. Pal. Black Hills, 1877, p. 16.

Shell of moderate size, suborbicular in outline, erect, and subequilateral, the height and length nearly equal. Valves depressed-lenticular in a transverse section when united; their surfaces depressed-convex, except along the sides of the valves near the cardinal slopes, where the surface is elevated so as to form a broad, rounded, fold-like border on this part, with a broad, undefined, shallow depression separating it from the body of the valve. Hinge line short; that of the left valve less than half as long as the shell below; straight, or a very little sloping outward from the apex of the valve, which is small, appressed, and not projecting above the line of the hinge Anterior side of the hinge a little longer than the other, the anterior wing being rounded at the extremity, more than as long again as the height above the body of the valve at its widest part; separated from the shell below by a very shallow, rounded byssal notch, and along the surface 
by a scarcely perceptible groove bordering the body of the valve. Posterior wing smaller, triangular, a little obtuse at the outer upper angle, and proportionally somewhat higher or longer on the lateral border than the anterior wing. Surface of the left valve marked, except on the fold and depression bordering the cardinal slopes, by strong, flattened radii, which are variable in strength, size, and distance, and are separated by flattened interspaces, usually of greater width than the ribs themselves. The surface is also marked by closely-arranged, distinctly-elevated, regular, lamellose, concentric lines, parallel to the outer margin, and coincident with the lines of growth, and are slightly arched backwards in crossing the radii. These latter markings also cover the surface of the folds of the cardinal borders and the cardinal auriculations.

A single right valve of small size, associated with a number of left valves on the same block, has the same general form and the same fold-like feature of the cardinal slope, but appears to be entirely destitute of the radii on the body of the valve, and the concentric markings are also much less distinct and regular than on the opposite valve. The anterior wing is also very small and obtusely triangular, but may have been somewhat mutilated. There can be little if any doubt, however, that this right valve belongs to the same species.

This species may be readily distinguished by the peculiar fold-like feature of the cardinal slopes and the character of the concentric markings; being entirely different in these respects from any other of the genus described from rocks of this age.

Formation and locality.--In reddish and buff-colored argillaceous limestones of Jurassic age, at T_— Springs, west of the Black Hills of Dakota.

\section{Genus CAMPTONECTES Agassiz. CAMPTONECTES BELLISTRIATUS.}

Plate 4, figs. 6-11.

Pecten bellistriatus Meek, Proc. Acad. Nat. Sei. Phil. July, 1860, p. 311.

Camptonectes bellistriatus M., Smithsonian Cat. N. A. Jurassic Foss., 1864.

Camptonectes bellistriatus M. \& H., Pal. Upp. Missouri, p. 77.

Shells large, circular or slightly oblate in outline; valves depressedconvex, or when united lenticular; the left valve perceptibly the most 
convex; hinge line nearly straight, varying from a little more than onethird to nearly one-half as long as the body of the shell below; posterior ear very short, usually not more than half as long as the anterior one, the extremity very obtusely angular, the posterior margin sloping rapidly backward to the junction with the body of the shell; anterior ear on the left valve flattened, of moderate size, the margin very slightly obtuse, and more rapidly sloping near the body of the valve. That of the right valve is separated from the body of the shell by a deep triangular notch or sinus, extending fully one-halt the length of the wing; surface of the auriculation marked by a single strong, flattened, and gradually widening rib, at a distance below the hinge line equal to its own width, and crossed by strong, somewhat lamellose lines parallel to the outer margin. Surface of the shell marked by very fine radiating lines or striæ, which diverge from the median line and curve rapidly in their direction toward the margin, and on the upper part of the shell are strongly recurved, so as to have an upward direction along the margin below the beak. The striæ are rapidly increased both by bifurcation and implantation, and are crossed by a few moderately strong concentric lines of growth, and by finer, regular, concentric striæ, only strongly marked on the interspaces of the radii, where they form transverse puncta along the depressions.

On the interior of the right valve, the space on the hinge line above the strong rib marking the anterior ear is crossed by rather strong vertical lines, which seems to be a character pertaining to the articulation of the valves, and on the posterior side the border is elevated, forming a distinct ridge similar to those on the hinge of Pleuronectia Swainson.

The shells of this species vary considerable in outline and degree of convexity; many of the right valves are somewhat squarish on the upper side below the auriculations, as in the interior of the right valve figured, in which case they are usually unsymmetrically curved along the basal border, while most are regularly orbicular, and occasionally they are slightly elongated. The degree of strength of the surface striæ is alse a point in which they differ in different localities; those from the Big Horn Mountains, which are usually of large size, are the most finely marked, and many smaller specimens from the Black Hills region having the striæ twice as 
strong. It is possible that there may be several species confounded under this name, but with the insufficient material yet brought in, it is impossible to separate them satisfactorily.

Formation and localities.-In rocks of Jurassic age, near Bear Lodge, on the Belle Fourche River, 20 feet above the Red Beds ; on Spearfish Creek, 300 feet above the Red Beds; in Redwater Valley, 350 feet above the Red Beds; and in the Big Horn Mountains.

\section{CAMPTONECTES EXTENUATUS.}

Plate 4, figs. 4, 5 .

Camptonectes extenuatus M. \& H., Proc. A. N. Sci. Phil., May, 1860, p. 184.

Camptonectes extenuatus M. \& H., Pal. Upp. Missouri, p. 78, Pl. 3, fig. 6.

Camptonectes (?) pertenuis M. \& H., ibid., Explan., Pl. 3, fig. 6.

Camptonectes (?) extenuatus (M. \& H.) Meek, Smithsonian Check List Invert. Foss., p. - . Camptonectes (?) extenuatus (M. \& H.) Hall \& Whitf., Geol. Expl. Fortieth Parallel, p. 290, Pl. 7, fig. 18.

Shell varying from small to rather above a medium size, somewhat ovate or suboval in outline, exclusive of the auriculations. Hinge line of the left valve straight, equal to a little more than half the greatest length of the body of the shell in an antero-posterior direction; posterior side short, but little more than half as long as the anterior. Auriculations large, triangular, the posterior one obtusely angular behind, the margin sloping rapidly backward to the junction with the body of the shell. Anterior auriculation convex on the surface between the cardinal line and the body of the shell below; lateral margin nearly at right angles to the hinge, its surface marked only by concentric lamellose lines. Body of the shell fourfifths as great in an antero-posterior line as the height from hinge to base, the anterior and posterior borders nearly equally rounded, the posterior side forming a little the longest curve; basal border more sharply curved. Beak small, rather sharply rounded, and somewhat appressed, not projecting above the hinge line. General surface of the valve strongly convex, most ventricose between the beak and the middle of the valve, and in some cases approaching angularity (perhaps from compression). Surface of the shell marked by fine radiating striæ, which diverge from the median line and are strongly curved as they approach the lateral border, and still more $23 \mathrm{~B} \mathrm{H}$ 
strongly toward the line separating the auriculations from the body of the shell. Also by finer concentrie strix crossing the radii, which are lamellose in their structure in the depressions between the ribs, with deep pits between them, giving a punctate character to the interspaces. Right valve of the species not observed.

The shell differs from $C$. bellistriata M. \& H. in the more elongate form, greater size of the auriculations, and coarser striæ of the left valve. We have no doubt, in our own minds, in regard to the proper reference of this species. The uniform small size of the type specimens is no reason why larger individuals might not occur, and there are also large numbers of individuals in the collection of the size of Fig. 5, and smaller, having exactly the same features as the type. It has been suggested that it might be C.platissiformis White (Geology of the Uinta Mountains, p. 93,) but that species is said to have the outline of $C$. stygius White, which this certainly has not.

Formation and locality.-In shaly limestones of Jurassic age about twenty feet above the red beds, east of the Belle Fourche River, near Bear Lodge, Black Hills.

\section{AVICULID E. \\ Genus Pseudomonutis Bronn. \\ PSEUDOMONOTIS (EUMICROTIS) CURTA.}

Plate 3, figs. 20-25.

Avicula curta Hall, 1852, Stansb. Rept. Great Salt Lake, p. 412, Pl. 2, fig. 1.

Avicula (Monotis) tenuicostata M. \& H., Proc. Acad. Nat. Sci. Phil., 1858, p. 50.

Monotis curta M. \& H., Proc. Acad. Nat. Sci. Phil., 1860, p. 418.

Eumicrotis curta (Hall) M., Smithsonian Check List Jurassic Foss., 1864.

Eumicrotis curta (Hall) M. \& H., Pal. Upp. Missouri, p. 81, Pl. 3, f. 10.

Eumicrotis curta (Hall) H. \& W., Geol. Expl. Fortieth Parallel, p. 289.

Pseudomonitis (Eumicrotis) curta (Hall) Meek, Geol. Surv. Mont. Idaho, Wyom. and Utah, 1872, p. 473.

Shell of moderate size, suborbicular in outline, very slightly oblique, and nearly equivalve, generally a little higher than wide; beaks subcentral or nearest to the anterior end; hinge short, usually less than half the length of the shell below, longest on the posterior side; left valve the most rotund 
and the beak small, but often approaching tumid, the apex incurved and extending a little above the hinge-line; anterior wing small, abruptly rounded toward the beak, its surface strongly curved toward the opposite valve near the cardinal margin, so as to leave a small byssal opening, or gaping at the anterior margin; posterior wing longer and somewhat flattened toward the extremity; surface of the valve marked by raised radiating lines, which are very variable in number and character on different individuals, and also by concentric lines which often form slight asperities or nodes in crossing the radii, especially on the sides and near the basal border of wellpreserved specimens; right valve slightly less convex than the left, with a smaller and less conspicuous beak, which does not extend beyond the cardinal line; anterior side characterized by a short and very narrow wing, separated from the body of the shell by a sharp, deep, and very narrow groove, the actual sinus scarcely extending within the limits of the wing, while the anterior margin of the valve below extends considerably beyond the extremity of the wing in a nearly parallel direction; posterior wing proportionally larger and compressed, the extremity angular and sometimes almost pointed, the posterior border of the valve running nearly at right angles to the hinge line, or slightly sinuate below; surface of the valve marked by strong concentric lines of growth, and on the body of the shell by obscure radii, which are often obsolete. Each valve is further characterized by a narrow, longitudinally striated ligamental area, extending nearly or quite to the extremities of the hinge line; and in the right valve the area is narrowed anteriorly, for the accommodation of the internal, slightly oblique fold of the shell, forming the depressed groove between the ear and the body of the shell. On the left valve there is a slight depression or break in the ligamental area beneath the beak, and an apparent depression on the right valve (these features of the area are obscure and a little uncertain on account of the small size of the specimen). Muscular impression as seen on a right valve rather large, and subcentrally situated.

We have considerable doubt as to any very close relations of this species to the genus Pseudomonotis, as typified by Monotis speluncaria Munster, or P. hawni M. \& H. All the Upper Carboniferous specimens of the latter species which we have examined appear to have a distinct notch or sinus 
between the anterior ear of the right valve and the body of the shell below. In this species there is no true notch, at least no sinus, the depression or groove separating the wing from the body of the shell being simply a fold of the shell projecting on the interior surface in form of a strong fold below the hinge area, just as it does in some specimens of the right valve of the the genus Meleagrina Lam., to which shell we are inclined to think them closely related. If the genus $P$ seudomonotis Bronn, must be retained for the $M$. speluncaria group, it seems to us it might be well to retain the name Eumicrotis, proposed by Meek and Hayden for that same group for this section, as it is equally applicable to these shells.

Formation and localities.-In rocks of Jurassic age, two miles south of the Belle Fourche River, near Bear Lodge Butte; on Beaver Creek; on Red Cañon Creek, near the Cheyenne; and in Redwater Valley, Black Hills.

\section{PSEUDOMONOTIS (EUMICROTIS) ORBICULATA.}

Plate 3, figs. 17-19.

Pseudomonotis (Eumicrotis) orbiculata Whitf., Prelim. Rept. Pal. Black Hills, 1877, p. 17.

Shell of moderate size, orbicular in outline, nearly equilateral, and subdiscoid. Left valve depressed convex, most rotund just below and anterior to the beak; beak small, full, slightly incurved, and projecting somewhat above the cardinal border. Anterior wing very short, almost obsolete, the anterior end regularly rounded from its extremity to and along the basal margin; posterior wing of moderate size and compressed, shorter than the shell below, the posterior margin rounding backward from its extremity to near the middle of the length of the valve, thence somewhat regularly rounded to the base. Surface of the valve marked by numerous unequal, slender, and slightly elevated radii, which are separated by wider flattened interspaces, also by irregular concentric striæ of growth, which often give a knotty or roughened surface to the radii where crossing them, especially toward the posterior border and near the outer margin. Right valve less convex than the opposite one, with a smaller inconspicuous beak, which does not project beyond the cardinal line. Anterior side of the hinge line characterized by a small and very obscure wing, which is reduced to a mere point, reaching to not more than one-third of the length of the very short 
anterior side of the hinge. The wing is separated from the body of the shell below, as in others of this division of the group, by a narrow and rather deep groove, but not by a distinct sinus. Posterior wing longer and compressed, but not extending to more than half the length of the body of the shell below. Surface of the valve marked, in all cases observed, by fainter radii than the left valve, but otherwise of similar character.

This species is closely related to $P$. (E.) curta Hall, but is much larger, several of the individuals measuring seven-eighths of an inch in length; and one specimen measures nearly an inch, while those of that species seldom attain to more than two-thirds of that size. The shell is also much less oblique, less convex, the radii sharper and not usually so distinct, although in this latter feature they both differ very materially among the different individuals; and the right valve is also distinctly marked by the radii, which is not the case in that one.

Formation and locality.-In calcareous clays of Jurassic age, ranging about 20 feet above the red beds, in Redwater Valley, Black Hills.

\section{Gends AVICULA Lam. \\ Subgenus OXYTOMA Meek. AVICULA (OXYTOMA) MUCRONATA.}

Plate 4, figs. 1, 2.

Pteria (Oxytoma) munsteri (Bronn) M. \& H., Pal. Upp. Missouri, p. 80, f. A. B. P. or Avicula (Oxytoma) mueronata M. \& H., loc. cit., p. 81.

Shell rather below the medium size, moderately oblique, the axis of the shell forming an angle of a little more than $45^{\circ}$ with the posterior hinge line, although somewhat variable in this respect. Body, exclusive of the wings, rather broadly and obliquely ovate, the greatest transverse diameter being obliquely across the shell a little below the middle of the height. Hinge-line very slightly declining on each side of the beak and somewhat shorter than the length of the shell below; posterior wing on the left valve about twice as long as the anterior, flattened or compressed on the surface and mucronate at the extremity, separated from the body of the shell below by a broad, but not very deep, sinus; anterior wing small, slightly rounded 
at the extremity and ventricose on the surface; beak moderately large, pointed, incurved, and extending above the cardinal line; body of the shell quite prominently convex, especially on the umbo; anterior margin of the shell slightly projecting in the upper part so as to leave a faint sinus below the anterior wing, and regularly rounding obliquely backwards and downward to the basal border below, with which it forms an almost regular curve to near the posterior basal extremity, which is sharply rounded. Right valve smaller than the left, very depressed-convex, becoming distinctly flattened toward the posterior margin and wing; beak small, pointed, but not projecting beyond the hinge line; posterior wing large; anterior wing small, and separated from the body of the shell by a depressed groove.

Surface of the right valve faintly marked by a few distinct radii. That of the left valve marked by a varying number of distant, elevated, raised radii, flattened on their surfaces and separated by interspaces of twice or thrice their width, bearing finer lines.

Messrs. Meek and Hayden refer this species with doubt to Avicula munsteri Bronn, and at the same time suggest the name $A$. (O.) mucronata, which we have adopted on the evidence of their suggestion, not having been able to compare them with European specimens.

Formation and locality.-In shaly limestones of Jurassic age, on the tops of the highest hills, two miles south of the Belle Fourche River, near Bear Lodge Butte, Black Hills.

\section{Genus GERVILLIA De France.}

\section{GERVILLIA RECTA.}

Plate 4, fig, 3.

Gervillia recta Meek, U. S. Geol. Surv. Terr., vol. ix, p. 66.

A single small right valve of a species of Gervillia occurs in the collection, which, so far as we can judge, appears to belong to the abovenamed species. The valve is very triangular in form, oblique and depressed convex, the body of the shell being scarcely distinct from the rather large posterior wing, and entirely destitute of any surface markings other than the ordinary lamellose concentric lines common to all the species of the genus; hinge line straight and about two-thirds as long as the extreme 
length of the body of the shell, measuring from the beak to the base with the obliquity of the valve. Anterinr ear very small and barely perceptible; beak not rising above the cardinal line, small, and somewhat compressed; outer margin of the posterior wing nearly at right angles to the linge line for some distance below, then directed backward to the extremity of the basal line; anterior margin very oblique to the hinge and parallel to the body of the shell

Having only a single right valve of the species, and that of small size, it is somewhat difficult to satisfactorily identify it; but there appears no feature on the shell that would contradict the reference.

Formation and locality.-In sandy limestone of Jurassic age, associated with Ostrea strigilecula and Mytilus whitei, near Sun Dance Hills, Black Hills.

\section{ARCID丑. \\ Genus GRAmmatodon M. \& H. GRAMMATODON INORNATUS.}

Plate 5, figs. 16-18.

Arca (Cuculloca) inornata M. \& H., Proc. Acad. N. Sci. Phil., March, 1858, p. 51.

Grammatodon inornatus M. \& H., ibid., Oct. 1862, p. 419.

Grammatodon inornatus M. \& H., Pal. Upp. Missouri, p. 90, Pl. iii, fig. 9.

Shell small, arciform, subrhomboidal in outline, with ventricose, arcuate valves, sometimes quite gibbous on the umbonal region. Valves a little less than twice as long as high between the cardinal and basal borders; hinge line straight, somewhat shorter than the shell below; anterior end rounded, extending a little beyond the antero-cardinal extremity; posterior end obliquely truncate, the longest point being at the extremity of the posterior umbonal ridge; basal line forming a broad semielliptical curve, being most strongly rounded at each end. Beaks large, strong, slightly incurved, strongly projecting above the body of the valve, subapproximate, and situated just bahind the anterior third of the length of the shell ; posterior umbonal ridge somewhat angular, most distinctly so in the upper part, becoming more obtuse below; posterior cardinal slope abrupt and very gently concave between the ridge and the cardinal line; anterior umbonal region rounded. 
Cardinal area narrow, slightly arcuate and apparently extending to the extremities of the hinge line. Surface of the shell marked by fine, irregular, concentric lines of growth, and also by a few indistinct radiating striæ, which are very faint and sometimes obsolete.

Interior of the hinge marked by two or three slightly oblique lateral teeth, which gradually increase in strength toward the posterior extremity, and on the anterior end by several, more oblique, shorter cardinal teeth. Muscular impressions small and somewhat obscure.

The shell is decidedly arciform in its general appearance, but the character of the hinge teeth at once separate it from the genus ARCA, and the absence of the elevated crest or ridge bordering the muscular impression equally distinguishes it from the genera Cucullea Lam. and Idonearca Con. Its relations to the genus Macrodon Lycette, are more intimate, and it is difficult, in the specimen which we have examined, to see where any distinct generic difference exists.

Formation and locality.-In rocks of Jurassic age, near the Black Hills; exact locality not given.

\section{MYTILIDE. \\ Genus MYTILUS Linn.}

\section{MYTILUS WHITEI.}

Plate 5, figs. 9-12.

IIytilus whitei Whitf., Prelim. Rept. Pal. Black Hills, 1877, p. 18.

Shell of moderate size, trapezoidal in outline, very oblique; hinge line slightly arcuate, as long or a little longer than the distance from the apex to the postero-basal extremity; anterior or byssal border long, distinctly concave from the apex of the beak to the junction of the basal border, the general direction being at an angle of about $45^{\circ}$, or within $45^{\circ}$ with the cardinal line; posterior margin a little more than half as long as the shell and nearly parallel to the anterior border, or slightly converging toward the base; basal margin short and more or less rounded, somewhat variable in different individuals. Beaks small, pointed, terminal, and incurved, with a short but distinct area-like space beneath them; umbones prominent, 
subangular, and with a slightly flattened or concave space on the anterior side, just below the apex of the beak. Umbonal ridge elevated, strongly arcuate and subangular, the surface of the shell sloping rapidly to the posterior and postero-cardinal margins. Anterior slope of the shell nearly or quite vertical, or sometimes a little concave near the middle of the length.

Surface of the shell marked by numerous strong but very irregular varices of growth, which give to the shell an extremely rugose appearance. Between the varices the surface is marked by fine lines of growth. No radiating lines or other surface markings beyond those described can be detected. Substance of the shell thick and strong.

The shell is a strongly marked and very characteristic species, and judging from the fragments in the hand specimens of rock must have been an abundant form in a certain layer at the locality where collected. We know of no American species of the genus having any close resemblance to this one.

Formation and locality.-In rocks of Jurassic age, associated with Jurassic fossils, near Sun Dance Hills, Black Hills.

\section{Genus VOLSELLA Scopoli. \\ VOLSELLA (MODIOLA) FORMOSA.}

Plate 5, fig. 15.

Modiola (Perna) formosa M. \& H., Proc. Acad. Nat. Sci. Phil., Dec. 1861 p. 439.

Volsella formosa Meek, Smithsonian Check List Jurassic Foss. N. A., 1864, p. 28. Volsella formosa M. \& H., Pal. Upp. Missouri, p. 86.

Shell ventricose, very elongate-ovate or subelliptical, widest across the shell at the end of the cardinal line, slightly arcuate, and becoming more curved with increased growth. Cardinal line rather more than half the length of the shell, slightly curved; beaks small, nearly terminal and appressed; anterior end broad, extending but little beyond the beaks, and sharply rounded below the middle of the width to the basal border, which is slightly concave; posterior margin convex, gradually declining from the extremity of the hinge line to the postero-basal extremity, where it is sharply rounded. Body of the shell highly convex, somewhat subangular along 
the umbonal ridge and flattened on the lower side of the beak and anterior end, cardinal slope slightly convex and abrupt.

Surface of the shell marked by fine lines or striæ, which are regularly radiating along the umbonal ridge and on the cardinal slope, while on the ventral region they strongly diverge from the umbonal line and reach the ventral border at right angles to the margin. The latter striæ are considerably finer than those of the cardinal slope and do not extend to or radiate from the anterior extremity of the shell, but have their origin along the umbonal ridge, thereby forming an entirely different system of striæ from those of the cardinal slope.

The specimens of the species which we have examined are of smaller size than those figured by Messrs. Meek and Hayden, and the umbonal ridge is more angular, while the surface of the valve below the beak for some distance from the anterior extremity is more compressed than shown in their figures. These are probably, however, only individual differences, though in the specimens examined are quite marked. The authors of the species compare it with Mytilus cancellatus Goldf. of Europe, and state that it may possibly prove to be identical; but specimens of that species which we have seen do not possess, at least do not show, the striations on the ventral side of the umbonal ridge as seen on those of this species.

Formation and locality.-In rocks of Jurassic age, near Big Horn Mountains.

\section{VOLSELLA PERTENUIS.}

Plate 5, figs. 13, 14.

Mytilus pertenuis M. \& H., Proc. Acad. Nat. Sci. Phil., March, 1858, p. 51.

Volsella pertenuis Meek, Smithsonian Check List N. A. Jurassic Foss., 1864.

Tolsella pertenuis M. \& H., Pal. Up. Missouri, p. 86, PI. 3, fig. 5.

"Shell small, very thin and fragile, narrowly oblong-oval, slightly arcuate; valyes convex along the middle, from near the beaks obliquely backward in the direction of the lower part of the posterior end. Extremities narrowly rounded, the anal end being a little broader than the other; base slightly arched behind the middle. Hinge nearly straight, and apparently rather less than half the length of the shell; dorsal margin forming a broad descending curve from the back extremity of the hinge posteriorly. Beaks small, subangular, and located at the anterior end, scarcely projecting 
beyond the margin. Surface marked by fine, rather obscure, lines of growth.

"Length, 0.73 inch; breadth, 0.26 inch; height, 0.30 inch."

The specimens of this species in the collection are internal casts in a fine red sandstone, associated with Lingula brevirostris M. \& H., and do not show the entire external features of the shell, although the concentric lines are preserved. The specimens agree pretty well with the above description and figures, except that the shell is not so arcuate as represented, nor so angular along the umbonal ridge, and the anterior end is somewhat narrower and less full on the buccal portion. In any of these features, however, shells of this class are very liable to vary very much among the different individuals of a species, as we plainly see in nearly all of the living species. Messrs. Meek and Hayden compare it with Modiola minuta as figured by Queenstedt (Des. Jura, Tab. 1, Fig. 36), and observe that they are at a loss to point out characters by which to distinguish it. As a 'general rule, we do not agree with the almost indiscriminate identification of species from our American formations with those of Europe, especially among the non-migratorial forms of life, but with shells of this class, which are frequently moored to floating wood or other substances, that are apt to be transported to great distances without material injury to the animals, we see no reason why the same species might not be an inhabitant of distant countries, and therefore think it even more than probable that this may be identical with the above-named species of Europe.

Formation and locality.-In fine-grained red sandstone of Jurassic age, at from 80 to 100 feet above the red beds referred to the Trias, east side of Spearfish Creek, near its junction with the Redwater, Black Hills.

\title{
CRASSATELLID E.
}

\section{Genus ASTARTE Sowerby.}

\author{
ASTARTE (?) FRAGILIS.
}

Plate 5, figs. 32, 33.

Astarte fragilis M. \& H., Proc. Acad. Nat. Sci. Phil., May, 1860, p. 183. Astarte fragilis M. \& H., Pal. Up. Missouri, p. 94, Pl. iv, fig. 7.

Shell small, thin, and fragile, transversely oval in outline, nearly twothirds as high as long, with depressed convex valves, most ventricose at the 
anterior third of the length, and gradually decreasing in convexity posteriorly. Beaks scarcely elevated above the cardinal line, small, pointed, strongly directed forward, and situated rather within the anterior fourth of the entire length of the shell. Anterior end short and rounded, the longest point opposite or a little below the middle of the height; basal line regularly and gently arcuate; posterior end more sharply rounded than the anterior, longest below the middle, the cardinal line sloping with a gentle convex curvature from the beaks to the longest point. No appearance of escutcheon or lunule exists on the examples under consideration. Ligament very small and external.

We have no hesitation in referring the specimens under consideration to the above-named species, but they certainly are not congeneric with the recent forms of Astarte. They seem to us to be much more nearly related to some of those referred to the genus Crrena, especially such as C. papua Prime; but as the internal features of the hinge have not been observed, it is impossible to fully determine their generic relations; and we have therefore left the generic reference as originally given by the authors of the species.

Formation and locality.-In shaly limestones of Jurassic age, at a horizon 350 feet above the Red Beds, at Redwater Valley, Black Hills.

\section{Genus TRAPEZIUM Humph. (= CYPRICARDIA Lam.)}

\section{TRAPEZIUM BELLEFOURCHENSIS.}

Plate 5, figs. 1-4.

Trapezium bellefourchensis Whitf., Prelim. Rept. Pal. Black Hills, 1877, p. 18.

Shell small, transversely elongate quadrangular, the length being from two and a half to three times greater than the height: dorsal and basal margins subparallel, the former very slightly arched and the latter scarcely concave, except in the older individuals, the smaller and medium-sized individuals being usually a little curved upward toward the posterior end; beaks small, nearly terminal, rounded on the umbones and very slightly incurved; posterior extremity truncate in the older specimens, rather squarely so below and rounding forward to the extremity of the hinge line 
above. In the smaller individuals it is narrower, somewhat sloping from above or obliquely truncate. Anterior end very slightly prolonged below the middle of the height and excavated beneath the beaks. A narrow linear escutcheon of considerable length is seen on many of the separated valves. Anterior muscular impression rather large and strongly impressed, as shown by the strong markings on internal casts; posterior impression not distinguishable; pallial line faint, and the space within its limits often marked by radiating lines, as in the recent forms of the genus.

Surface of the valves ventricose, with a distinctly angular umbonal slope in the larger specimen, but often obtusely rounded in the smaller ones. A broad but rather faint depression runs obliquely backwards from the beak to the middle of the basal border on many individuals, but is not always present. Surface of the shell marked by irregular concentric lines of growth parallel to the margin of the valve.

The species is closely allied to a form described by Mr. Meek (in MS.) under the name of Trepezium (Pachymya) truncata, but is proportionally very much more elongated than the specimens which are so labeled in the collection at the Smithsonian Institution. The shells have been exceedingly abundant in certain layers, being densely packed together, so that it is impossible to separate the individuals. They are quite variable in form at different stages of growth, the younger shells being transversely elongateovate, narrowed and rounded, or very obliquely truncate from above posteriorly, and becoming almost squarely truncate behind in the older specimens, the slight sinuosity of the basal margin being hardly noticeable until they attain to near their adult size.

Formation and locality.-In a hard and somewhat silicious limestone of reddish color, at a level of 350 feet above the Triassic beds east of the Belle Fourche River, near Bear Lodge Butte, Black Hills.

\section{TRAPEZIUM SUBEQUALIS.}

Plate 5, figs. 5-8.

Trapezium subequalis Whitf., Prelim. Rept. Pal. Black Hills, 1877, p. 19.

Shell small, transversely elongate, subelliptical, about twice and a half as long as high, or nearly so. Valves somewhat ventricose, with large 
tumid beaks situated a little nearest to the anterior end, and projecting above the general line of the hinge; hinge line, posterior to the beaks, about half as long as the entire length of the shell, straight, but gradually declining to the extremity; posterior end of the shell very obliquely truncate, being much the longest below the middle at the postero-basal angle; anterior end shorter, slightly contracted in front of the beaks, but rounded at the extremity and broader than the opposite end; basal margin straight or very slightly convex in the middle and strongly rounded upward toward each extremity. Body of the shell often distinctly angular along the posterior umbonal ridge and the postero-cardinal slope quite abrupt; some individuals, however, are obtusely rounded on the umbonal ridge. Surface of the shell marked by rather strong concentric ridges of growth, which are crossed on the rounded anterior end and middle of the valve by extremely fine radiating striæ, only detected near the basal portion of the larger individuals by the aid of a moderate magnifying power.

There may be some little doubt as to the true generic relations of this shell, but it possesses so many of the features of Trapezium that we have not hesitated to refer it to that genus; the almost subcentral and somewhat prominent beaks forms the strongest point of difference. It differs in this respect from the preceding species, as also in the general form of the valves and in the surface markings. The shells of the two species have nearly the same dimensions, and in their mutilated and imperfect condition, as seen imbedded in the rock, may readily be confounded, but the more prominent beaks and longer anterior end of this one will at once distinguish them.

Formation and locality.-In a hard white sandstone of Jurassic age, associated with Pseudomonotis curta, just above the Triassic red beds at Red Cañon Creek, Black Hills, Dakota. 
FAMILY uncertain."

Genus PLEURomyA Agassiz.

PLEUROMYA NEWTONI.

Plate 5, figs. 19,20 .

Pleuromya newtoni Whitf., Prelim. Rept. Pal. Black Hills, 1877, p. 20.

Shell of moderate size, transversely subovate or triangularly ovate, the greatest height being across the valve nearly on a line with the beaks. Valves strongly convex near the anterior end, and in a cardinal view acutely wedge-shaped, thickest opposite the beaks and rapidly decreasing posteriorly. Beaks large, strong, enrolled, and approximate, situated at or within the anterior third of the length of the shell, and projecting largely above the cardinal line. Hinge line not exceeding one-half the length of the shell, distinctly arched; anterior end obliquely subtruncate, longest below at its junction with the basal margin, and in some cases the anterior slope is distinctly flattened. Posterior end narrowed, the postero-cardinal margin rapidly declining from the extremity of the hinge line to the longest point of the valve, which is narrowly rounded and at about the middle of the height; basal margin very slightly constricted or emarginate, just within the anterior third of the length, by a faint sulcus, which passes from the surface of the umbo to the base of the shell; posterior to this it is strongly convex, and as it approaches the posterior third of the length is more strongly rounded upward to the extremity. Body of the valve convex, most ventricose on the umbones and along the middle of the valve; anterior umbonal ridge obtusely angular; anterior slope abrupt and sometimes flattened obliquely; posterior umbonal ridge scarcely defined or broadly rounded. Immediately behind the anterior umbonal ridge a broad undefined sulcus passes across the valve, slightly modifying the direction of the

* The family relations of this shell, as well as some others herein described, are not yet satisfactorily determined; and we do not like to refer them to a family to which we feel certain, from their characters as far as known, they have no resemblance or affinity; we rather prefer to leave them in doubt, and as subjects for future investigation. The reference of Pleuromya and Myacites to the same family with Anatina, we deem unnatural, as from the character of the shell and the consequent habits of the animal they must have been very far removed from each other in structural features, and thesé we deem the only sure and relialle means of classification. 
concentric lines. No appearance of escutcheon or lunule exists, nor of an external ligament.

Surface of the shell marked by numerous irregular concentric undulations, which are usually broad and undefined, but on some individuals have a slightly sharper character. The general surface beyond these undefined undulations appears to have been smooth, and we should suppose from its character that it had been semi-polished. Substance of the shell moderately thick. The features of the hinge and interior have not been fully ascertained. There appears, however, on the left valve a strong tooth-like process of considerable height, and in front of it a deep triangular pit, probably ligamental.

This species differs from Myacites (Pleuromya) subcompressa Meek (Sixth Annual Report United States Geological Survey of the Territories, 1872, p. 472), in being proportionally longer; more distinctly ovate or less triangular, the anterior end being of greater length in proportion to the rest of the valve; the beaks are larger and project farther above the cardinal line; the body of the shell is less flattened and the surface less strongly marked.

Formation and locality.-In shaly limestones of Jurassic age, on top of the highest hills two miles south of the Belle Fourche River, near Bear Lodge Butte, Black Hills.

\section{TANCREDIID E.}

\section{Genus TANCREDIA Lycett (= HETTANGIA Terquem.) \\ TANCREDIA ? INORNATA.}

Plate 6, figs. 9-13.

Astarte inornata M. \& H., Proc. Acad. Nat. Sci. Phil., May, 1860, p. 183. Astarte inornata M. \& H., Pal. Up. Missouri, p. 94, Pl. iii, fig. 12, $a . b$.

Shell transversely subelliptical, or transversely broad-triangular; extremities narrowly rounded and the basal border forming a broad, nearly regular semi-elliptical curve. Valves convex, most ventricose along the posterior umbonal portions. Beaks large, prominent, nearly subcentral and incurved, usually a little nearer the anterior end; cardinal line strongly 
arcuate, convex behind the beaks, and slightly contracted and a little concave just in front; anterior end much narrower than the posterior, and the longest point below the middle of the height. Lunule, as seen on the separated valves, very narrow-lanceolate. Surface of the shell smooth, or with obsolete lines of growth forming obscure concentric indulations. Frequently a very faint depression, or sulcus, passes from in front of the beaks to the antero-basal margin. The hinge line is marked by a rather strong, curved cardinal tooth in each valve, with corresponding cavity or pit situated beneath the beaks; the left valve having the tooth anterior to the pit, and reversed in the right valve; a small posterior lateral tooth appears to exist in the left valve, and may, possibly, in the right, but it has not been noticed. Muscular impressions small; pallial line with a broad, shallow sinus; interior margin of the shell smooth and thickened.

We have supposed this to be the shell described under the above name by Messrs. Meek and Hayden, as it agrees with their description and figure in its external characters. It appears, however, that they had not seen the internal features. In quite a number of specimens in the collection before us the internal features, as given above, are more or less clearly seen, mostly by the removal of the external shell, leaving the impression of parts of the hinge, and on some of the casts the pallial sinus is clearly marked. This Iatter feature is one that does not belong to the genus Tancredia, and it is with considerable hesitation that we have left it under that name; still, as we know of no other established genus to which it can be properly referred, we have preferred this rather than to propose a new division on insufficient grounds. The following species appears to have all the characters of Tancredia, except, perhaps, the pallial sinus, which has not been detected on any but the present form. They are, therefore, more nearly true Tancredia.

Formation and locality.-In shaly, arenaceous limestone of Jurassic age, at an elevation of 350 feet above the red beds referred to the Triassic, east of the Belle Fourche River, near Bear Lodge Butte, Black Hills. 


\section{TANCREDIA CORBULIFORMIS.}

Plate 6, figs. 5-8.

Tancredia corbuliformis Whitf., Prelim. Rept. Pal. Black Hills, 1877, p. 21.

Shell small, seldom measuring more than half an inch in length, very broadly ovate in outline and largest on the posterior side of the beaks, the length being a little more than once and a half the height; beaks large and full, slightly enrolled, almost central and strongly inclined toward the anterior part of the shell. Anterior end narrowed, strongly constricted in front of the beaks, giving a somewhat concave antero-cardinal line, the extremity acutely rounded; posterior end broadly rounded and, the postero-cardinal line convex to near the beaks; basal line regularly curved, except at the posterior part, where it becomes a little more abrupt. Body of the valve strongly convex, almost inflated on the umbo.

Surface of the shell apparently smooth, but under a magnifier showing faint, scarcely defined, lines of growth.

The species differs from T. inornata M. \& H., in its smaller size; more inflated valves; proportionally larger and more prominent beaks, and greater inequality in size of the anterior and posterior parts of the shell.

Formation and locality.-In sandy and somewhat shaly limestone of Jurassic age, 350 feet above the red beds of the Triassic, east of the Belle Fourche River, near Bear Lodge Butte, Black Hills.

\section{TANCREDIA BULBOSA.}

Plate 6, figs. 1-3.

Tancredia bulbosa Whitf., Prelim. Rept. Pal. Black Hills, 1877, p. 22.

Shell very small, the larger individuals not measuring more than threeeighths of an inch in length by a height of one-fourth of an inch; very broadly ovate in outline, being inflated and globuliform in the middle and posteriorly, and attenuate, narrowed and compressed toward the anterior extremity. Beaks strong, inflated, curving anteriorly and situated a little to the anterior of the middle of the shell; anterior end acutely rounded, the sides of the shell abruptly compressed by a broad, undefined, constricting sulcus, or depression, which passes obliquely across the valve from in front of the beaks to the basal border, in which it forms a distinct emargi- 
nation; posterior end broadly rounded and the postero-cardinal line strongly convex; antero-cardinal line constricted in front of the beaks and concave between them and the anterior extremity; basal line very convex for a little more than two-thirds of the length from the posterior end, where it becomes emarginate at the base of the oblique sulcus or depression which crosses the anterior part of the valve. Surface semi-polished, and under a magnifier showing fine lines of growth.

The species resembles $T$. corbuliformis herein described, but is a smaller shell, seldom occurring of more than half the usual length of that one, and is much more extreme in the unequal size of the anterior and posterior parts of the valve, besides being much more globose in form and having the anterior oblique sulcus of the valve much more strongly marked.

Formation and locality.-In rock of Jurassic age, associated with $T$. corbuliformis and T. inornata, at the same locality.

\section{TANCREDIA POSTICA.}

Plate 6, fig. 14.

Taneredia postica Whitf., Prelim. Rept. Pal. Black Hills, 1877, p. 22.

Shell small, transversely ovate, the height and length being about as three to five. Valves very ventricose, becoming tumid near the beaks and on the postero-cardinal part. Beaks large and but little elevated above the cardinal line, slightly enrolled and directed forward, situated at about one-third of the length from the anterior extremity; antero-cardinal line abruptly declining in front of the beaks to the middle of the height of the valve; anterior end narrow and sharply rounded; posterior end very broadly rounded and the postero-cardinal and basal margins subparallel behind the beaks, the extreme height of the shell continuing to the posterior end; antero-basal line strongly curving upward to the anterior end of the shell. Surface of the valves apparently smooth.

The shell differs from any of the preceding species in the greater length and proportionate size of the posterior portions of the shell, in the situation of the beaks, and in their strong anterior inclination, the others being much more erect than those of this species. It will be readily recog- 
nized by the inflated valve, subparallel cardinal and basal margins, and short anterior end.

Formation and locality.-In shaly limestones of the Jurassic formation, east of the Belle Fourche River, Black Hills, associated with the preceding species.

\section{TANCREDIA WARRENANA.}

Plate 6, fig. 4.

Tancredia warrenana M. \& H., Proc. Acad. Nat. Sci. Phil., May, 1860, 183; ibid., Oct. 1860, p. 418.

Tancredia warrenana M. \& H., Pal. Up. Missouri, p. 96, Pl. 3, fig. 7.

Shell small, subtriangular in outline, or triangularly ovate, moderately convex, and nearly two-thirds as high as long. Beaks proportionally large, projecting above the cardinal line, erect, pointed, and subangular; situated rather more than one-third of the entire length from the posterior end of the shell. Hinge line contracted in front of the beaks, and somewhat regularly sloping anteriorly. Anterior end of the shell much the longest, narrowed and compressed, rounded at the extremity, and, judging from the form of the shell as seen in separated valves, has been distinctly gaping; posterior end short, obliquely truncate and abrupt; basal line gently and regularly arcuate throughout; posterior umbonal ridge sharply angular, the posterior cardinal slope narrow and abruptly declining. Surface unknown.

The specimens of this species present in the collection are casts of the interior on layers of fine white sandstone, and do not preserve the surface features or any of the internal features of the shell.

Messrs. Meek and Hayden refer this species provisionally to the genus Trancredia, remarking that its form leaves little doubt of its relations to that genus. Our specimens are not in a condition to give any additional light on its generic relations, and we are therefore obliged to leave it as originally placed by its authors.

Formation and locality - In soft white sandstone of Jurassic age, associated with Pseudomonotis curta Hall and other Jurassic forms, at a horizon of 135 feet above the red beds of the Triassic, at Redwater Valley, southeast of Warren Peaks, Black Hills. 


\section{VENERIDAE.}

\section{Genus DOSINIA Seopoli.}

DOSINIA JURASSICA.

Plate 5, figs. 21-24.

Dosinia jurassica Whitf., Prelim. Rept. Pal. Black Hills, 1877, p. 23.

Shell of moderate size, subcircular or very slightly transverse in form, and for the gentus quite ventricose, with rather large, prominent beaks. Cardinal line arcuate, but less curved than the general circle of the shell, while the anterior end is more sharply curved and slightly angular and the posterior portion from the extremity of the hinge to the basal border very slightly flattened or truncate. Beaks anterior to the middle of the valve directed forward and approximate at their apices; lunule small and very slightly impressed; ligament proportionally long, but narrow, the shell at its margins slightly incurved. Body of the valve ventricose, most gibbous on the umbones and below, while anteriorly and posteriorly the shell is more compressed; umbonal ridges not defined.

Surface of the shell smooth with a few obsolete or faintly marked concentric irregularities, but no defined varices; fine concentric lines of growth are seen on the perfect shells under an ordinary magnifier. Inner margins of the valves smooth; muscular impressions, large but faintly marked, submarginal. Pallial line deeply sinuate, the apex of the sinus being directed toward the beak of the shell.

The shell is a well-marked species of Dosinia, so far as the characters have been ascertained, but the hinge structure has not been seen, none of the casts being in a condition to show the teeth. The casts are quite abundant on weathered specimens, where they have apparently been subject to the percolating action of mineral waters, which has partially destroyed them.

Formation and locality.-In Jurassic rocks at the top or the highest hills, two miles south of the Belle Fourche, and at a horizon 350 feet above the Triassic red beds, east of the Belle Fourche, and also on the east side of Spearfish Creek, near junetion with the Redwater, Black Hills. 


\section{PSAMMOBIID A. \\ Genus PSAMMOBIA Lam. \\ PSAMMOBIA ? PREMATURA.}

Plate 5, fig. 31.

Psammobia ? prematura Whitf., Prelim. Rept. Pal. Black Hills, 1877, p. 24.

Shell small, transversely elongated, with parallel dorsal and basal margins, the length equaling a little more than twice the height. Valves very depressed-convex and distinctly gaping at each end. Beaks small and inconspicuous, compressed, situated a trifle nearest the anterior end; the antero-cardinal line gradually declining with a very slight convexity to the narrowly-rounded anterior end; basal margin straight for more than half the length of the shell, rounding upward anteriorly and posteriorly; postero-cardinal line a very little lower than the apex of the beak, behind which it is straight to near the extremity of the shell; posterior extremity reaching its greatest length considerably above the middle of the valve, the margin being directed obliquely forward below to the end of the basal line. Surface of the valve regularly curved from beak to base and from the posterior umbonal ridge forward to the anterior extremity of the shell, forming nearly a level line; posterior to the umbonal ridge the shell is depressed, forming a broad oblique sulcus extending from behind the beaks to the posterior margin of the shell. Muscular markings faint. Pallial line not profoundly sinuate, but distinetly emarginate behind. Hinge and teeth unknown.

The species is only recognized by single valves, but the form is so precisely like that of some of the recent Psammobias that it seems unnatural to refer it to any other genus. The parallel dorsal and basal margins and the form of the posterior slope will readily distinguish it from any other shell in the rocks from this region.

Formation and locality.-In the sandy limestones of the Jurassic beds, east of the Belle Fourche River, near Bear Lodge Butte, Black Hills. 


\section{ANATINID AE. \\ Genus THRACEA Leach. \\ THRACEA ? SUBLEVIS. \\ Plate 5, fig. 34 .}

Thracea? sublevis M. \& H., Proc. Acad. Nat. Sci. Phil., May, 1860, p. 182 ; ibid., Oct. 1860, p. 418.

Shell rather below the medium size, transversely elongate with moderately convex valve, which appear to have been somewhat gaping at the posterior end. Beak large and wide, projecting somewhat above the hinge line, and situated a little in advance of the middle of the length; anterior end more broadly rounded than the opposite; basal line nearly straight or very slightly sinuate near the middle, and rounded upward at each extremity; posterior extremity more narrowly rounded than the anterior, and slightly oblique on the truncation; cardinal line sloping very moderately from the beaks posteriorly, and rounding more abruptly in front; surface of the valves very slightly impressed across the middle from the beaks to the base by a very broad, undefined depression; posterior umbonal ridge faintly marked, and the postero-cardinal slope rounded; anterior slope more abrupt

Surface marked only by a few irregular concentric undulations of growth parallel to the margin of the valve.

The specimens examined are single valves and imperfect, so that the relative convexity cannot well be determined There can be no doubt of their identity with those figured by Meek and Hayden as above cited; the specimens are all of smaller size, however, but agree in all other respects. They are preserved as casts in a white friable sandstone, and are associated with Pseudomonotis curta, Tancredia warrenana, and other Jurassic fossils.

Formation and locality.-In rocks of Jurassic age, at Redwater Valley, Black Hills. 


\title{
Genus NEARA Gray.

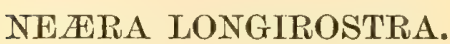

Plate 5, fig. 35.

Necera longirostra Whitf., Prelim. Rept. Pal. Black Hills, 1877, p. 24.

Shell very small, scarcely exceeding one-fourth of an inch in length; transversely elongate-ovate or clavate, widest anterior to the middle and narrowed behind, a little more than twice as long as high. Valves very convex, becoming inflated near the middle and on the umbones. Beaks proportionally large, erect, strongly projecting above the hinge line and situated in front of the middle of the length; anterior end large and broadly rounded, somewhat excavated beneath the beaks; posterior end narrowed, elongate, and very slightly recurved, and obliquely truncate above the umbonal angle; basal line strongly convex, more distinctly so just in front of the middle opposite the beaks, and broadly constricted behind; posterior umbonal ridge very faintly angular, and the cardinal slope rather abrupt.

Surface of the shell marked by a few concentric lines of growth, and crossed on the anterior and middle parts of the shell by a few proportionally strong elevated radiating ridges, to the number of eight or nine, with wider flattened interspaces.

The species is small, and being preserved in a friable sandstone the surface characters are not clearly defined, nor can any of the hinge or other internal features be seen.

Formation and locality.-In white sandstones of Jurassic age in Redwater Valley, Black Hills, associated with Pseudomonotis curta, Tancredia warrenana, and other Jurassic fossils.

\section{GASTROCHANID A.}

\author{
Genus SAXICAVA Bellerue. \\ SAXICAVA JURASSICA. \\ Plate 5, figs. 25-30.
}

Saxicava jurassica Whitf., Prelim. Rept. Pal. Black Hills, 1877, p. 25.

Shell small, elongate-subcylindrical, with subparallel dorsal and basal margins; beaks approximate, distinct, situated near the anterior end, and 
flattened on the exterior surface; umbonal ridge strongly marked and subangular, placed behind the middle of the valve. Anterior end narrowed and very slightly excavated below the beaks; postcrior extremity wider, and rounded on the margin, the sides being laterally compressed; basal margin very gently concave in the middle of its length. Body of the valves very broadly sulcated between the anterior end and the umbonal ridge, and somewhat inflated along the latter feature posterior to the middle of the length. Surface of the shell rather distinctly marked by concentric lines parallel to the margin, which are elevated and irregular, but not lamellose; also by a few strong undulations of growth. Just below the hinge line, on the postero-cardinal border, the surface striæ are slightly bent, and the surface of the shell very slightly angular. Internally, as seen on casts, the anterior muscular impression is narrow, and situated along the antero-basal margin. The pallial line appears to be strongly sinuate, and the dorsal margin shows evidence of a rather strong ligament. The casts of the burrows as seen in the rock are almond-shaped or very elongateovate.

A small fragment of argillaceous rock in the collection was found to contain quite a number of the burrows, and on being broken a few were found with the shells in position; but in an effort to develop them from the matrix the shell is usually removed from the casts, although some of it is at times retained, and it is from this rather imperfect material that the description has been drawn. The general form of the shell and also the external texture would seem to ally them with the angular group of the genus Lithodomus characterized by L. gruneri Phillippi, but the sinus of the pallial line would seem to forbid this reference.

Formation and locality.-In rocks of Jurassic age, at a horizon of 350 feet above the red beds of the Triassic, at Redwater Valley, Black Hills. 


\section{CEPHALOPODA. TETRABRANCHIATA.}

AMMONITID丑.

Genus AMMONITES Bruguiere.

AMMONITES CORDIFORMIS.

Plate 6, figs. 20-24.

Ammonites cordiformis M. \& H., Proc. Acad. Nat. Sci. Phil., March, 1858, p. 57.

Ammonites cordiformis M. \& H., Pal. Up. Missouri, p. 122, Pl. v, fig. 2.

Shell attaining a large size, lenticular in a transverse section; young individuals depressed-bi-convex, or slightly flattened for a short distance on the side bordering the umbilical area, but becoming much more ventricose in older individuals from the greater projection of the ventral or umbilical margin of the volution, the section of the volution in large specimens being nearly an equilateral triangle. Umbilicus of moderate size, the diameter equaling, or nearly equaling one-third the width of the outer volution; its sides vertical on specimens of a little more than two inches in diameter and larger, but on small individuals it is rounded, the parts of each volution exposed within the umbilicus not increasing in width equal to the increased size of the shell. Volutions sharply keeled on the back, and the edge finely denticulated or transversely ridged. Side of the volutions marked by transverse flexuose costa of very variable strength, which have a sigmoidal curvature in passing from the margin of the umbilicus to the dorsal carina, being strongly curved forward for the outer third of the distance, and are increased by bifurcation and intercalation, so as to number from three to six times as many on the dorsal margin as at the border of the umbilicus. On some of the larger specimens the ridges become obsolete, the surface being only marked by irregular striæ, having the same general direction in their passage across the shell as do the costæ where they exist.

The septa are moderately crowded, being placed so as to have the lobes of one pass within the area of that in advance, but not so as to inter- 
fere with the lines. The form of the different lobes and saddles cannot be obtained from any of the specimens of moderate size in the collection, they being too much mutilated, so we have copied the following description of these parts from the authors as above cited:

"The dorsal lobe is a little wider than long, and has two principal branches on either side, the two terminal of which are slightly larger than the others, and each provided with seven or eight unequal digitations. The dorsal saddle is about the size of the superior lateral lobe, contracted in the middle, and divided at the extremity into some four or five short, unequal, sinuous, and digitate branches. The superior lateral lobe is as long as the dorsal lobe, but narrower, conical in form, and ornamented with three or four lateral branches on the dorsal side, and two or three smaller ones on the ventral side; while its terminal branch is bipartite, and its margins, as well as those of all the other principal divisions, are more or less sinuous and digitate. The lateral saddle is smaller than the superior lateral lobe, and has on each side three or four short, obtuse subdivisions, with sinuous margins. The inferior lateral lobe is smaller than the lateral saddle, and divided at the extremity into two nearly equal, rather short branches, each of which is sinuous, and shows a disposition to give off short subdivisions on the outer side. The remaining lobes are very small, and obtusely digitate, the inner one showing a tendency to bifurcate."

The species is exceedingly variable in its surface markings, and also somerwhat so in the degree of convexity, the latter feature depending mostly on the age of the specimens; but the former variations are individual characters only, and are almost limitless among the individuals even from the same locality. The smaller specimen figured on Plate 6 has the primary costa numerous and crowded, and seldom dividing or increasing to more than twice the original number on approaching the dorsal margin; while the next larger individual figured has them more distant at the umbilicus, and dividing or increasing to the number of six to one in some parts, while on still other specimens many or most of the costa are obsolete.

Messrs. Meek and Hayden compare this species with $A$. cordatus Sowerby, and appear to be somewhat in doubt if it should not be referred to that very variable form. There are, however, differences in the form of 
the septa and in the character of the umbilicus when compared with specimens of the same size that would seem to distinguish them. A.cordatus does not appear to become so ventricose, nor are the volutions so nearly triangular in the larger individuals as in the western shells.

Formation and locality.-In rocks of Jurassic age, associated with other Jurassic forms, at a horizon 350 feet above the red beds referred to the Triassic, at Redwater Valley; also on the tops of the highest hills two miles south of the Belle Fourche River, near Bear Lodge Butte, Black Hills.

\section{AMMONITES CORDIFORMIS var. DISTANS.}

Plate 6, fig. 25.

Shell of moderate size, slightly cordiform in a transverse section of the volution, or approaching subquadrate, and distinctly keeled on the back. Volutions few in number, largely embracing, leaving a broad, open umbilicus equal to nearly one-third of the diameter of the entire shell, and in which is exposed less than one-third of the breadth of each volution. Umbilical margin of the volution abruptly rounded, sides depressed convex, somewhat flattened in the middle, slightly decreasing in convexity and thickness outward to about the outer fourth of the width, beyond which point the surface abruptly declines to the thickened, rounded, and prominent dorsal keel.

Surface marked by strong, distant, and abruptly elevated flexuous ribs or ridges, with concave interspaces; originating a little outside of the umbilical margin, they are directed, with a slight sigmoidal curvature, nearly across the volution, and are then directed abruptly forward along the dorsal slope for a distance nearly equal to one-half the width of the volution at the point of their occurrence, and form strong, wave-like ridges in crossing the dorsal carina. On the dorsal slopes there are also one and sometimes two additional ridges between the primary ones, but usually of a little less strength. The primary ridges sometimes form pointed spine-like nodes at their intersection with the intermediate or secondary ones; but this is not a constant feature, even on the same shell, and only occurs when the primary ridge dies out or bifurcates, forming two secondaries on the slope, 
which is an exceptional feature. Lines of growth apparently coincident with the ridges or nearly so.

We at first supposed this to be only a strong variety of $A$. cordiformis M. \& H., but on further examination are strongly inclined to the belief that it is a distinct species; but not having sufficient material to satisfactorily determine the question, we have left it under a varietal name for the present. Should, however, our suspicions prove correct, on the examination of additional material, it may need a distinct specific designation.

Formation and locality.-Found associated in the same shaly limestones of Jurassic age, with A.cordiformis, and other Jurassic forms, on the tops of the highest hills, two miles south of the Belle Fourche River, near Bear Lodge Butte, Black Hills.

\section{DIBRANCHIATA. BELEMNITID正. \\ Genus BeLemnites Agricola. BELEMNITES DENSUS. \\ Plate 6, figs. 15-19.}

Belemnites densus M. \& H., Proc. Acad. Nat. Sci. Phil. March, 1858, p. 58; ibid. Oct. 1860, p. 418.

Belemnites densus M. \& H., Pal. Up. Missouri, p. 126, Pl. iv, fig. 10, and Pl. v, fig. 1.

Calcified guard or shell attaining a large size, frequently nearly four inches long below the phragmacone, and often but little less than an inch in diameter at the thickest part; subcylindrical, ovate, or oval in section, and in the larger individuals sometimes obscurely subquadrangular; often somewhat laterally compressed; upper parts straight or sometimes slightly constricted, and more or less rapidly tapering below to an obtuse point, with a narrow, obscure, or faintly-marked groove along one side for some distance above the point, and in some cases extending almost to the lower end of the cavity occupied by the phragmacone. Phragmacone short (?), somewhat rapidly expanding from below upward, the sides diverging at an angle of a little more than $20^{\circ}$ and slightly curved, the convex side being 
opposite to the groove or cicatrix of the lower end of the guard. The cone is divided transversely by thin, very closely arranged septa, gradually increasing in distance with the increased growth of the cone. The lower half inch of a specimen containing about thirty-four septa, and the upper half of this space having only about ten or eleven. The septa are very gently and regularly concave throughout Apex of the cone subcentrally situated in the guard, the point being directed toward the side marked by the impressed groove or cicatrix, but above it is sometimes reversely excentric.

Substance of the guard thick and dense, with a very distinct prismatic structure radiating from the line of the constantly receding apex of the phragmacone, and in a transverse section often shows the successive concentric layers of which it is composed. Surface smooth.

The species is quite common in some of the Jurassic beds of the Black Hills region, and appears to be very variable in the proportional thickness of the guard, which is the only part found. In the smaller individuals it is usually much more slender than in the older ones, but as the increase in this direction is by concentric additions to the exterior surface, they may continue to grow in this direction long after they have attained their maximum.length. In the younger individuals the alveolar cavity is also more nearly central, and the eccentricity is added afterward, as may be seen by the weathered transverse sections showing the greater thickness of the concentric rings on one side of the cavity.

Formation and locality.-In Jurassic rocks on Beaver Creek, and at the top of the gray shales of the same formation, resting on the red marls of the Trias, east of the Belle Fourche, near Bear Lodge Butte, Black Hills. 


\title{
LAMELLIBRANCHIA'TA. MONOMYARIA. \\ PECTINID丑.
}

\author{
Genus SYNCYCLONEMA Meek.
}

SYNCYCLONEMA RIGIDA.

Plate 7, fig. 1.

Pecten rigida H. \& M., Mem. Am. Ac. Sei. and Arts, vol. v, new ser., Pl. 2, fig. 4. Pecten hallii Gabb., Cat. Cret. Foss., 158.

Syncyclonema rigida (H. \& M.) Meek, Smithsonian Check List Invert. Foss., p. 7. Syncyclonema rigida (H. \& M.) Meek, Pal. U. S. Geol. Surv. Terr., p. 27, Pl. 16, fig. 5.

Shell small, depressed-convex, erect or nearly so, truncate-ovate in outline, widest below the middle, and the height slightly exceeding the width; hinge line straight, nearly as long or about half as long as the greatest width of the shell below; auriculations distinct, the anterior one largest, broadly rounded on the lateral margin, and separated from the body of the shell by a very shallow notch only on the margin of the shell; posterior wing, small, obtusely angular, and not at all distinct from the body; sides of the right valve straight above the point of greatest width, and forming an angle of nearly $90^{\circ}$ with each other; base regularly rounded from the points of greatest width, where the margin is subangular.

Surface concentrically striate, with distinct even striæ, as preserved on the cast; hinge with a very distinct, triangular, concave cartilage pit in the center of the right valve; muscular impression, if the markings which we see are rightly interpreted, situated on the posterior side of the middle, and nearly apical, and extending along the posterior side just within the thickened border of the valve to near the middle of the height. Surface and substance of the shell unknown. 
Mr. Meek, in his description of the genus Srncyclonema, which is founded upon this species, does not mention the existence of a cartilage pit, nor give the form of muscular imprints. The specimen in hand, which is an internal cast in blackish limestone, shows the cartilage pit very distinctly and the muscular imprint quite plain. It is possible, however, that we may have mistaken the nature of the latter, being misled by the small size of the shell, but the structure is exactly like that of a muscular scar, although its position may be quite unusual. From the form of the external border of the anterior ear we should suppose the notch was iptended for the passage of a byssus.

Formation and locality.-In limestone of the Cretaceous, at the forks of the Cheyenne River, Black Hills.

\section{HETEROMYARIA.}

\section{AVIOULID 死.}

\section{Genus PTERIA Scopoli.}

PTERIA LINGUIFORMIS.

Plate 7, fig. 2, 3.

Avicula linguiformis Evans \& Shumard, Proe. Acad. Nat. Sci. Phil., vol. 7, p. 163. Avicula linguiformis (E. \& S.) M. \& H., Proc. Acad. Nat. Sci. Phil. Nov. 1856, p. 21. Pteria linguiformis (E.\& S.) Meek, Smithsonian Cheek List Inr. Foss., p. 9.

Pteria linguiformis (E. \& S. sp.) M., Pal. U. S. Geol. Surv. Terr., p. 32, Pl. 16, fig. 1.

The examples of this species in the collection are all more or less exfoliated and imperfect, and therefore do not present the natural surface of the shell, so that we obtain but little else than the general form. The shells are obliquely subovate or obseurely rhomboid in outline, very inequilateral and inequivalve; hinge line straight, nearly or quite as long as the body of the shell below, but projecting anteriorly and short behind. Anterior wing of the left valve of moderate size, acutely triangular, and pointed at the extremity; posterior wing long, the posterior margin nearly at right angles to the hinge line for a short distance below, and then directed obliquely backwards to the extremity of the shell; beak large and 
ventricose, projecting considerably above the cardinal border, slightly incurved and directed obliquely forward; body of the valve highly convex and very oblique; anterior and basal margins sloping backwards, with a shallow sinuosity below the anterior wing; posterior extremity obliquely rounded; ligamental area proportionally large and slightly concave. Right valve smaller and much less convex than the left; beak small, pointed, directed obliquely forward and not extending above the cardinal line; anterior wing apparently larger than on the left valve, much more convex and pointed; posterior wing of the same form as that of the left valve, but concave toward the upper edge. Muscular imprint large, subcentral, a little nearer the posterior margin and distinctly subreniform; pallial line composed of elongated pustules. Substance of the inner layers of the shell nacreous; outer layers, as far as ascertained, very finely prismatic.

This species appears to have been a common form in the seas of this region during the deposition of the rocks of the Fort Pierre Group, as the broken and comminuted shells are quite numerous in the dark concretionary layers of this formation at most of the localities from which collections have been made, though but few individuals are obtained in a good state of preservation. It is an easily recognized form.

Formation and locality.-In limestones of the Fort Pierré Group, on the South Fork of the Cheyenne River, near French Creek, and on Old Woman Fork, Black Hills.

\section{PTERIA (OXYTOMA) NEBRASCANA.}

Plate 7, fig. 4.

Avicula nebrescana E. \& Shumard, Trans. St. Louis Acad. Sci., vol. i, p. 38. Pteria nebrascana (E. \& S.) Meek, Smithsonian Inst. Check List Inv. Foss., p. 9. Pteria (Oxytoma) nebrascana (E. \&. S.) Meek, Pal. U. S. Geol. Surv. Terr., p. 34, Pl. 16, fig. 3 , and pl. 28, fig. 11.

Shell of moderate size and smaller, obliquely rhombic-ovate in form, very inequilateral. Left valve depresssed-convex, with a small, pointed, and suberect boak, slightly extending above the cardinal line and situated about one-fourth of the entire length from the anterior end; hinge line twothirds as long as the shell below; anterior wing very small, obtusely rounded; anterior margin gradually rounding below and forming a con$25 \mathrm{~B} \mathrm{H}$ 
tinuous curve with the antero-basal and basal margins; posterior basal margin more sharply rounded, and extended obliquely backward; posterioi' wing large, scarcely pointed at the extremity, and separated from the body of the shell below by a very broad shallow sinus.

Surface marked by closely arranged, rounded, radiating ribs, separated by flattened interspaces of twice their width, and increased in number by interstitial addition; about six or seven of the ribs occupy a space of a fifth of an inch at the margin of the largest valve seen, which is about one inch in its extreme height. The radii are crossed by very fine concentric lines of growth, but so fine as to scarcely form a feature of the shell except when viewed by the aid of a lens. Right valve of the shell only recognized by a few fragments associated with a large number of left valves, on the same block, and is apparently nearly or quite smooth.

Formation and locality.-In hard concretionary limestone of the Fort Pierré Group, on Sage Creek, Black Hills.

\section{PTERIA (PSEUDOPTERIA) FIBROSA.}

Plate 7, fig. 5.

Avicula? fibrosa M. \& H. (1856), Proc. Acad. Nat. Sci. Phil., p. 86.

Pholadomya fibrosa M. \& H., ibid, p. 286.

Pinna fibrosa Meek, Snithsonian Check List Invert. Foss., p. 9.

Avicula (Pseudopteria) fibrosa M. \& H., Sixth An. Rept. U. S. Geol. Surv. Terr., p. 489. Pteria (Pseudopteria) fibrosa Meek, Pal. U. S. Geol. Surv. Terr., p. 36, Pl. 17, fig. 17.

A single very imperfect example of a left valve of this species has been observed among the collections from the top of the gray shales of No. 4, on the Cheyenne River, near Rapid Creek. The surface is much exfoliated and the nacreous character of the shell destroyed. The shell is very oblique, the axis of the body forming with the hinge line an angle of about forty-five degrees. The valve is quite ventricose toward the beak, but becomes compressed and flattened below. Anterior wing small and obtusely pointed; surface of the shell marked by rather strong concentric undulations, and also by coarse, irregular, and unequal radiating folds of the substance, which are not true radii, but simply foldings of the shell. It may be readily distinguished from $P$. $(P$. sublcevis herein described by its larger size, greater obliquity, and by the surface folds. 


\section{PTERIA (PSEUDOPTERIA) SUBLEVIS.}

Plate 7, fig. 6.

Pteria (Pseudopteria) sublevis, Whitf., Prelim. Rept. Pal. Black Hills, 1877, p. 29.

Shell small, erect, subrhomboid or subovate in outline, left valve de. pressed-convex, most ventricose on the umbo and toward the beak, near which it becomes subangular. Hinge line shorter than the length of the shell below, and about two-fifths as long as the height; anterior wing minute, obtusely pointed, posterior wing moderate in size and convex, scarcely separated finm the body of the shell by a slight, almost imperceptibly depressed line; anterior side of the shell gradually receding from below the anterior wing to the basal border, which is rather sharply rounded, and the postero-basal margin a little more sharply rounded than the basal.

The surface of the valre, in all the specimens seen, is much exfoliated, so that the surface features are not positively known, but it has, apparently, been quite smooth; the substance of the shell remaining on the specimens is highly nacreous.

Several individuals of the left valve have been noticed in the collection, but none of the right have been recognized. Those seen all have the same character, and are of about the same size, being a little less than threefourths of an inch in length by about half an inch in width. It most nearly resembles in form $P$. (Pseudopteria) fibrosa M. \& H., Paleontology of the United States Geological Survey of Territories, p. 36, Plate 17, Fig. 17), but differs entirely in the surface features, being entirely destitute of the faint plications of that species.

Formation and locality.-In limestones of Cretaceous age, No. 4, Old Woman Fork, Black Hills.

Among the collections from the Fort Pierré Group there are large numbers of Inocerami, representing several of the species and varieties recognized by Mr. F. B. Meek, in his excellent work on the Upper Missouri Cretaceous formations, just issued by the Department of the Interior. But notwithstanding the careful manner in which these forms have been described and figured by that author, we find great difficulty in arriving at any very satisfactory conclusions as to the limits of species when so latroe 
a collection is examined. The species, as figured in the above-mentioned work, appear distinct enough and the lines of demarkation well drawn when a few individuals only are before one; but among the collections in hand we find the boundries crossed in every direction, so that we are at a loss in many cases for characters by which to separate the different forms there indicated; while there are still others among them so entirely different from any of those described and figured, that we are very reluctantly compelled to consider them as entirely distinct.

Among the forms representing those given under the names I. vanuxemi, I. proximus, and I. proxunus var. subcircularis and also as I. convexus and I. sagensis var. nebrascensis and I. balchii we find such gradually connecting links as to make it extremely difficult, if not impossible, to draw lines of distinction between them. Again, those resembling the forms given under the names $I$. cripsii var. barabini and $I$. temilineatus, are similarly united.

The forms which we had referred to $I$. sagensis and $I$. nebrascensis of Owen vary so greatly in the posterior prolongation of the shell, and also in the direction of the basal margin, as to defy all attempts to classify them by their form; and in the relative degree of convexity and the comparative distance of the surface undulations they are equally variable and unsatisfactory. We find also that the relative projection of the beaks and the width of the cartilage area, as well as the distance of the beaks from the anterior end, is subject to great variation. Although in the collections before us there are but few individuals which retain the right and left valves in contact, still of many of them we have both valves of similar size and form from the same locality and we find that the difference in convexity between the two valves is not in any case very great, and often scarcely perceptible. The beak of the left valve is usually larger, and projects more beyond the line of the hinge than that of the right, and the cartilage area is also a little wider. Perhaps if the real surface features of the shells were preserved on the specimens, more reliable characters for specific distinction might be presented, but the fibrous coating is almost always absent, being generally left in the matrix, and not collected; or perhaps in many cases removed by some action of decay before the shells are finally imbedded in the rocky sediment, so that in collections it is seldom that any part of this 
layer is retained on the specimens, except a little around the beaks or along the hinge margins.

Owing to these difficulties, the same that Mr. Meek has found to exist among his specimens, and also to the impossibility of giving a sufficient number of figures to show fully and clearly the variations which we have found among the examples in hand, we shall be obliged to follow very nearly the same specific limits which that author has found desirable; though we must confess that in some cases we should prefer rather to consider some of the forms found associated together in the same localities, and presenting only slight differences, as one and the same species, than to identify these far western forms with species described from Europe, as has been done by so many authors. We do not dispute their great resemblances, but believe them to be rather representative species than equivalent forms.

\section{Genus INOCERAMUS Sowerby. \\ INOCERAMUS PROBLEMATICUS ?}

Plate 7, fig. 11.

Mytilites problematicus Schlot., Petrafact., p. 312.

Inoceramus problematicus of authors.

The examples which we have doubtfully referred to this species, one of which is figured on Plate 7, Fig. 11, are all very imperfect, and, as in the case of that one, are mostly destitute of shell, being merely casts of the interior surface in a yellowish sandstone; consequently the characters retained are not sufficient to fully determine their specific relations. They are generally more or less obliquely-quadrangular or obliquely-subovate in outline, with flattened valves and rather sharp, pointed, almost terminal beaks, which project but little beyond the cardinal line; the hinge line is shorter than the shell below and nearly or quite at right angles to the anterior or buccal border; height of the shell usually greater than the length and widest below the middle of the height, the posterior border gradually receding from the extremity of the cardinal line, with a slight curvature, to the postero-basal angle; umbonal ridge subangular; anterior. slope abrupt and rather narrow. 
Surface of the casts marked by strong, irregular, concentric undulations parallel to the margin of the shell and generally increasing in size and strength with the increased growth of the shell.

Formation and locality.-In ferruginous sandstone of Cretaceous age, on the east fork of Beaver Creek, Black Hills. Probably of the Fort Benton or Niobrara Group.

\section{INOCERAMUS FRAGILIS.}

Plate 9, fig. 10.

Inoceramus fragilis H. \& M., Mem. Am. Acad. Arts and Sci., new ser., vol. viii, p. 388, Pl. 2, f. 6.

Inoceramus fragilis (H. \& M.) Meek, Pal. U. S. Geol. Surv. Terr., p. 42, figs. 1 and 2, Pl. 5, fig. 5.

Shell rather below the medium size, obliquely rhomboid-ovate in outline, with moderately convex valves and small, somewhat pointed and nearly terminal beaks, which scarcely project beyond the cardinal line; hinge line straight, shorter, and sometimes not more than two-thirds as long as the shell below; anterior border straight for some distance below the beaks, and at right angles with the cardinal line; posterior end obliquely rounded and prolonged in the direction of the postero-basal angle; basal line rounding at its junction with the anterior border and below, subparallel with or slightly diverging from the line of the hinge to near the postero-basal extremity, where it is somewhat sharply rounded. Body of the valve irregularly convex, most prominent on the umbonal ridge, which is often subangular and the surface somewhat flattened on each side, especially along the postero-cardinal slope; anterior margin nearly vertical.

Surface marked by fine, even, concentric lines and sometimes by concentric undulations, the latter, however, are not always fully developed and are frequently entirely obsolete.

There is considerable variation in the form of the outline of this shell among the different specimens, many of them being less oblique and rounded on the basal margin, the posterior extremity being less prolonged. They also differ greatly in the strength of the surface markings, some of them having the surface linings developed into irregular concentric folds of greater or less strength. The right valve is, so far as can be ascertained 
from the separated valves in the collection, usually more evenly convex than the left, being destitute of the slight angularity along the umbonal ridge.

Formation and locality.-In Cretaceous strata referred to the Fort Benton Group, on Beaver Creek, and on the eastern fork of the same, Black Hills. INOCERAMUS ALTUS.

Plate 9, fig. 11.

Inoceramus altus Meek, Geol. Rept. U. S. Surv. Terr. 1871, p. 302.

Inoceramus altus Meek, Pal. U. S. Geol. Surv. Terr. 1876, 1. 43, Pl. 14, fig. 1.

The specimens of this species present in the collection are all more or less imperfect and fragmentary; they are so strongly marked, however, that they are very readily distinguished from any other form yet observed. The shells are obliquely ovate exclusive of the alation of the hinge, which is usually absent, and strongly convex, especially on the umbones and along the umbonal ridge; the beaks are only of moderate size, strongly incurved, with a forward inclination, are pointed and terminal, and project somewhat beyond the cardinal line; anterior border short and nearly vertically rounded to the umbones, extending along the valve to a little below the middle, where it rounds into the basal margin; base prolonged obliquely backward in the direction of the umbonal ridge.

Surface marked by small, but very distinct, concentric undulations, which are remarkably uniform in size, being generally about an eighth of an inch in width or a little more, and not sensibly increasing with the increased growth of the shell. Substance of the shell, as preserved on the specimens, highly nacreous.

The example figured by the author, loc. cit., is of very much larger size than is indicated by any of ours, and the undulations somewhat more distant, increasing in size toward the margin, which is not the case with those under consideration. He also mentions radiating lines on the surface of what he speaks of as a cast. Our specimens all preserve more or less of the nacreous layers, and do not show radiating lines.

Formation and locality.-In limestones of Lower Cretaceous, probably of No. 2, as they are associated with I. perplexus and Scaphites wyomingensis. M. \& H., on the Belle Fourche, ten miles west of Crow Peak, Black Hills. 


\section{INOCERAMUS PERPLEXUS.}

Plate 8, fig. 3, and P1. 10, figs. 4, 5.

Inoceramus perplexus Whitf., Prelim. Rept. Pal. Black Hills, 1877, p. 31.

Shell rather below the medium size, erect, truncate subovate in outline, shortest at the hinge line and gradually expanding to below the middle of the height; valves convex; beaks terminal, slightly inclined forward, pointed and incurved; hinge line short and straight, not exceeding twothirds of the length below in any of the examples seen; anterior border straight or very slightly concave for more than half the height of the shell, when it unites with the deeply rounded basal border; posterior margin of the shell gradually widening from the extremity of the hinge line to the point of greatest width in an antero-posterior direction, which is rather below the middle of the height where it unites in a regular curve with the basal margin. Valves most strongly convex along the umbonal ridge, which is situated nearest to the anterior side of the shell and slopes gradually to the postero-cardinal portion, where it becomes almost flattened; while the anterior border is vertical, or sometimes slightly concave, for more than half the depth of the valve.

Surface of the shell marked by strong, irregular concentric folds or undulations parallel to the margin, and passing off on the vertical anterior border. Substance of the inner layers highly nacreous. Fibrous coating, when preserved, apparently thin.

This species is somewhat remarkable for its erect form and strong concentric undulations. In form it resembles the specimens of $I$. fragitis $H$. \& M., given by the latter author (Paleontology of the United States Geological Survey of the Territory, p. 42, Figs. 1 and 2), but in the surface characters it is entirely distinct from that species, and when compared with examples of that species having the characters of the original specimen is very readily distinguished. It also somewhat resembles I: ellioti Gabb., from the Cretaceous sandstones of San Francisco Harbor, California.

Formation and locality.-In concretionary limestone at the top of shales of Cretaceous No. 2, on the Belle Fourche, about ten miles west of Crow Peak, Black Hills. 


\section{INOCERAMUS SUBLFVIS.}

Plate 10, figs. 1-3.

Inoceramuss sublavis H. \& M., Mem. Am. Acad. Arts and Sci., new ser., vol. v., p. 386, Pl. 2, fig. 1.

Inoceramus sublavis (H. \& M.) Meek, Pal. U. S. Geol. Surv. Terr., p. 58, Pl. 12, fig. 1.

Shell below medium size, suboval in outline, moderately gibbous, with almost evenly convex valves, which are slightly more ventricose on the umbones; beaks small, inconspicuous, incurved, and situated near the anterior end; hinge line straight, two-thirds as long as the whole length of the shell; anterior end rounded, projecting but little beyond the line of the beaks, the greatest projection at about one-third the height of the valve, below which the border, including the base and posterior end, forms a nearly regular section of an oval curve.

Surface of the specimens, where a portion of the nacreous layers are preserved, presenting distinct, somewhat interrupted radiating lines, or lines of pustules, with a few very faint indications of concentric undulations.

A number of individuals among the collection, presenting similar features, we have referred to this species. Their regularly symmetrical form and smooth surfaces, marked by faint to distinct radiating lines, are features that at once attract attention and render them easily distinguishable among the other species of the genus. The radiating lines, as indicated on the exfoliated shells, are still more conspicuous on the complete casts of the interior, one of which is figured on the plate, and presents lines of elongated pustules, making a conspicuous feature.

Formation and locality.-In Cretaceous, No. 4, at the Forks of the Cheyenne; and about three miles east of Camp Jenney, Red-Water Valley, Black Hills.

\section{INOCERAMUS SAGENSIS.}

Plate 7, fig. 12; PI. 8, fig. 2.

Inoceramus sagensis Owen, Geol. Rept. Wis., Iowa, and Minn., p. 582, Pl. vii, fig. 3, 1852. ? Inoceramus nebracerisis Owen, ib., p. 582, Pl. viii, fig 1.

Inoceramus sagensis var. Nebracensis (Owen) Meek, Pal. U. S. Geol.Surv. Terr., p. 52, Pl. 13, fig. 2.

Compare Inoceramus convexus H. \& M., Mem. Am. Acad. Arts and Sci., new ser., vol. v, p. 386, Pl. 2; Pal. U. S. Geol. Surv. Terr., Pl. 12, fig. 5.

Compare Inoceramus balchii M. \& H., Proc. Acad. Nat. Sei. Phil., vol. xii, p. 180; Pal. U. S. Geol. Surv. Terr., 56, PI. 15, fig. 1. 
Shell large, the general form being oblate or more or less transversely broad-oval, with moderately convex valves, and large, somewhat tumid, and slightly incurved beaks, situated but a short distance from the anterior end and projecting above the line of the hinge. Hinge line staight, equal to about half or a little more than half the length of the shell below; anterior and posterior ends rounded, the former longest above the middle and the latter below the middle of the valve; basal line obliquely rounded, more or less prolonged behind in the direction of the umbonal ridge; extremity of the hinge line rounding to the posterior margin, with a long and gradually increasing slope. Valves most ventricose along the umbonal ridge and on the umbones, retaining considerable ventricosity toward the anterior margin, which is often quite abrupt, but sloping more giadually posteriorly, and becoming much compressed and flattened on the postero-cardinal extension.

Surface of the valves marked by strong concentric undulations of very varying size and distance, and often by finer concentric lining in the depressions between. Faint indications of radiating lines are also frequently seen on the exfoliated surfaces.

The specimens of this species are subject to very great variation; in fact, there is scarcely a single feature, that is in any degree constant in its character through many individuals. In convexity they vary from depressed convex to highly gibbous. They also differ exceedingly in the strength and number of the concentric undulations, some having been noticed where the undulations become obsolete and the shell suddenly geniculated, giving a strongly deformed character to the valves The extreme variation of the species has been noticed by others; and Mr. Meek remarks, under his description of the form on page 53, Paleontology of the United States Geological Survey of the Territories, when speaking of Dr. Owen's species, that "a careful study of our specimens, in connectiou with Dr. Owen's figures and description of his $I$. sagensis and I. nebrascensis, has led to the conclusion that the forms for which these names were proposed are not specifically distinct"; and in the following paragraph he further says, in speaking of the variation of the outline between his and Dr. Owen's figures of I. nebrascensis: "There appears, however, to be so many gra- 
dations in character of this kind, that to separate the form we have figured as a variety or species would require that we should, in the same way, separate almost every individual specimen under a different name." Taking into consideration these extensive variations, we are inclined to consider the different forms of this type as only varieties of the one species. Mr. Meek appears, from his description and remarks, to have considered his $I$. balchii as allied to $I$. vanuxemi, and consequently as allied to $I$. proximus Toumey; but from the character of the beak and that of the concentric undulations we should think it more nearly related to this form.

Formation and locality.-In Cretaceous beds of the Fort Pierré Group, on the Cheyenne River, near Rapid Creek; also at the top of the gray shales at the mouth of Rapid Creek, Black Hills.

\section{INOCERAMUS SIMPSONI.}

Plate 8, fig. 1.

Inoceramus simpsoni Meek, Proc. Acad. Nat. Sci. Phil. 1860, vol. 12, p. 312.

Inoceramus simpsoni Meek, Rept. of Expl. across the Great Basin of Utah, p. 360, Pl. 4, fig. 4 .

Shell very large, transversely and obliquely-ovate, with strongly convex and slightly unequal valves, which are the most ventricose along the antero-basal third of the shell, and gradually compressed toward the postero-cardinal margin. Right valve apparently the most convex on all the specimens examined, and the greatest convexity a little more forward than that of the left valve. Hinge line long and straight, extending from the beaks to about the posterior third of the valve, where it gradually slopes to the posterior extremity. Beaks of moderate size, not very prominent, and but slightly projecting beyond the line of the hinge in comparison with the size of the shell, situated near the anterior end of the shell, but not terminal; anterior end round and full, much narrower than the posterior end and gradually rounding into the basal line, which is broadly curved and prolonged in the direction of the umbonal slope; posterior extremity obliquely rounded from the end of the cardinal line to the postero-basal margin

Surface of the shell marked by numerous concentric undulations; which gradually increase in width from the beaks as the shell increases in 
size. Surface of the cast marked by oblique curving lines, or lines of pustules, which incline slightly forward as they approach the basal margin.

This species may be distinguished from any other form described by the great postero-basal extension of the valves, coupled with their moderate gibbosity. In its younger stages of growth, when within two inches in length, it has resembled the forms referred to $I$. vanuxemi by Mr. Meek, but that it would have been much longer in proportion to its height. The finer and more equal undulations and smaller beaks will readily distinguish it from $I$. sagensis Owen, or any of the forms referred to that group. The cartilage area appears to have been very narrow and linear; but the most noticeable feature, and one that will easily distinguish it, we think, when the valves are found in contact, is the greater convexity of the right valve, and apparent greater prominency of the beak of this valve, whereas the opposite is usually the case with all species of this genus. The beaks of the right valves are all broken, and we judge only of their size by the parts remaining. The specimen figured by Mr. Meek, loc. cit, differs from our figured specimen in being narrower posteriorly and in the slight constriction or sinuosity of the basal margin, but we do not deem these features of specific importance. The type of the species was from a lower horizon than most of those in this collection.

Formation and locality.-In Cretaceous rocks of the Fort Pierré Group, on Old Woman Fork; one specimen is marked as coming from the east fork of Beaver Creek, three miles west of Camp Jenney, Black Hills, at a probably somewhat lower horizon.

\section{INOCERAMUS VANUXEMI.}

Plate 7, figs. 8, 9 ; Plate 8 , figs. 4, 5 .

Inoceramus vanuxemi M. \& H., May, 1860, Proc. Acad. Nat. Sei. Phil., p. 180. Inoceramus mortoni M. \& H., Oct. 1860, Proc. Acad. Nat. Sei. Phil., p. 428.

Inoceramus proximus M., Pal. U. S. Geol. Surv. Terr., p. 53, Pl. 12, fig. 7; and var. subcircularis M., ib., p. 55, Pl. 12, fig. 2.

Compare Inoceramus proximus Toumey, Proc. Acad. Nat. Sci. Phil. 1854, p. 428.

Compare Inoceramus confertim-annulatus Rœmer, Kreid. von Texas, Pl. 7, fig. 4.

Shell of moderate or large size, with depressed convex to subdiscoid valves, subcircular to subovate in outline, with short, compressed, often 
inconspicuous beaks, which project but little, and often not at all, beyond the line of the hinge, and are situated near the anterior end, but not terminal; height and length of the valves subequal or longer than high; anterior end very short and rounded below the beaks, uniting in a more or less regular curve, according to the form of the shell, with the basal margin ; base generally somewhat regularly rounded, but often a little prolonged obliquely in the direction of the umbonal ridge; posterior end rounded, and the upper margin gracefully curving forward to the extremity of the cardinal line; hinge line straight, usually half as long or more than half as long as the shell below. Surface of the valves most convex on the umbones and along the umbonal ridge, which is low, rounded, and not distinctly defined; anterior slope usually more or less abrupt, and posterior slope and cardinal portion of the valve flattened or but slightiy convex.

Surface of the shell marked by strong, rather closely arranged, subangular concentric ridges, with regular concave interspaces. The ridges are variable on different individuals, but on the same specimen usually increase gradually and regularly from the beak outward with the increased growth of the shell, and on some specimens which we have referred to the species have finer concentric linings in the depressions.

The specimens of this shell before us, to the number of more than a dozen, varying from less than an inch to over four inches in height, are quite variable in the degree of convexity and outline as well as in the proportional strength and distance of the undulations, no two agreeing exactly in any of these particulars. For this reason we have considered the forms previously given as species and varieties cited above, which were obtained from the same region of country as our specimens, as probably belonging to one species. It is quite likely that those described by Dr. Roemer and Professor Toumey, loc. cit., are also identical forms, and that they should be all referred to I. proximus Toumey; but not having access to specimens of these we do not feel certain. Besides, those coming from distant parts of the country are more likely to prove distinct. We notice among the specimens of this type, as in those of I. sagensis, a tendency often to abrupt or sudden geniculation of the valves after attaining a certain size, and in such. cases the concentric undulations are usually very faint or obsolete beyond 
such point. The most marked and striking difference between this form and $I$. sagensis is in the size and form of the beak of the shell, these being small and compressed, those large and prominent. Several specimens of each valve are present in the collection before us.

Formation and locality.-In Cretaceous beds of the Fort Pierré Group, on the Cheyenne River, near Rapid Creek; on Old Woman Fork, and at top of gray shales near mouth of Rapid Creek, Black Hills.

\section{INOCERAMUS VANUXEMI, var.?}

Plate 7, fig. 10 .

The single individual represented by Fig. 10, Plate 7, presents such a marked departure from the characters of the other specimens in the collection, that we do not feel certain that it belongs to the same species, although of the same type. The form is erect, the height considerably exceeding the length of the valve, giving a broad oxate form, slightly truncate above by the hinge line, which is quite short, and the beaks compressed and entirely within the limits of the outline. The concentric undulations are very similar to the more closely arranged ones on the forms which we have referred to I. vanuxemi, and also to the form figured by Mr. Meek as I. proximus Toumey. The specimen is a left valve and quite depressed convex, although it has suffered accidental compression. A part of the right valve is also preserved, but in a much more mutilated condition and more compressed, so that we cannot judge of the convexity with certainty. Owing to the above-mentioned differences we have hesitated to include it under the same specific designation until further collections shall demonstrate the fact.

Formation and locality.-Near the top of the gray shales of the Fort Pierré Group, on the Cheyenne River, near Rapid Creek, Black Hills, Dakota.

\section{INOCERAMUS BARABINI.}

Plate 7, fig. 7; Plate 9, fig. 8.

Inoceramus barabini Morton, Synop. Org. Rem. Cret. N. A. 1834, p. 62, Pl. 17, fig. 3. Inoceramus cripsii var. Barabini (Morton) Meek, Pal. U. S. Geol. Surv. Terr., p. 49, Pl. 13, fig. 1 ; Pl. 12, fig. 3.

Inoceramus gibbus Toumey, Proc. Acad. Nat. Sei. Phil. 1854, vol. vii, p. 170.

Inoceramus cuneatus M. \& H., Proc. Acad. Nat. Sci. Phil. 1860, p. 181. 
Shell varying from medium to large size, transversely-ovate or subelliptical in outline, usually a little larger behind than in front of the middle of the length. Valves very convex, especially in the anterior half and along the umbonal slope, becoming more compressed and cuneate posteriorly, slightly unequal, the left being the largest; beaks proportionally large and slightly tumid on the umbones, but smaller and pointed toward their apices, slightly incurved, and nearly terminal, somewhat elevated above the hinge line, but not prominent; hinge line long, usually nearly or quite three-fourths as long as the shell below, and rounded at the extremity; anterior end very short, almost on a line with the beaks and rapidly sloping backwards from just below them to the basal line, giving a somewhat subcuneate character to the anterior extremity of the shell; posterior extremity rounded; basal line broadly rounded or forming a semi-elliptical curve, being more abruptly rounded at each end than in the middle, but generally slightly diverging from the cardinal line to behind the middle of the valve.

Surface of the shell marked by numerous irregular, concentric undulations of unequal size and strength, parallel to the margin.

Upon one of the smaller specimens of this species (see Plate 9, Fig. 8), we have been able to detect the outline of muscular scars. Those near the apex of the valve are quite distinct and easily recognized, but the larger or posterior scar is much more faintly marked, and we were under some doubt at first if it were rightly considered as a point for muscular attachment, but, after careful examination of this and a large number of individuals of different species, we think we are able to see faint traces of this larger scar, in a similar position, on several of them. The anterior scar is situated quite near the anterior end, and does not exceed a tenth of an inch in its greatest diameter. There are five small dot-like scars between this and the apex of the valve, some of them over the turn of the beak. No remains of the pallial line could be satisfactorily detected. It is probable that, like the pallial line of other shells of the Aviculidx, it was composed of isolated points of attachment, and in this case would be difficuit to trace, as the surface of many of the casts is covered with similar points.

In deference to the opinion of Mr. F. B. Meek, who has examined the original specimens of $I$. barabini, we have referred these western forms to 
that species, although from the figures and description given in the Synopsis of the Organic Remains we certainly should not have done so. We had previously tried to see Dr. Morton's types in the collections at Philadelphia, but did not succeed, owing to the absence of persons having charge; consequently we were compelled to depend upon the figures and descriptions above referred to until we received a copy of Mr. Meek's excellent work, in which he describes these forms and figures, the types above referred to. But we are not prepared to identify them with $I$. cripsii Mantell, nor with any shell conforming to Mantell's description; and the forms referred by authors to that species are so variable, that we can rely only upon the original type specimens.

Formation and locality.-In limestone of the Fort Pierré Group, Cheyenne River, near Box Elder Creek, and on Beaver Creek, two to three miles west of the Black Hills.

\section{INOCERAMUS TENUILINEATUS.}

Plate 9, figs. 12, 13.

Inoceramus tenuilineatus H. \& M., Mem. Acad. Arts and Sci., vol. viii, p. 387, Pl. 2, fig. 3. Inoceramus tenuilineatus (H. \& M.) Meek, Pal. U. S. Geol. Surv. Terr., p. 57, PI. 12, fig. 6.

Shell of rather large size, transverse, subovate or rhomboid-ovate in outline, with very ventricose, almost inflated valves, and large, inflated, slightly prominent, incurved, and nearly terminal beaks; hinge line shorter than the length of the shell below and rounded at the posterior extremity; cardinal and basal margins subparallel; the latter gently rounded in the middle and a little more abruptly so toward the ends; anterior end broad, obliquely truncate in a side view, projecting a little in the lower part beyond the line of the beaks, forming with the cardinal line an angle of from $95^{\circ}$ to $120^{\circ}$ in different individuals, but generally not more than $100^{\circ}$; posterior margin rounded, most strongly from below; anterior slope of the valves very abrupt and on some specimens nearly vertical for one-half the depth of the valves; posterior slope more gradually declining from the prominent umbonal portion of the valve, giving a somewhat cuneate form to the posterior half of the shell when viewed in a cardinal profile.

Surface of the shell marked by, sometimes indistinct, but often very 
strong, irregular concentric undulations; with finer ones in the broader interspaces, and crossed by indistinct radiating lines on internal casts. The fibrous coating, where preserved, appears to have been very thin on the younger portions of the shell, but toward the outer margin, in larger individuals, it attains a thickness of a sixteenth of an inch or more. None of our specimens are in a condition to show the surface of the fibrous coating, consequently we have not 'seen on them the fine concentric linings characteristic of the species.

There is, perhaps, no better marked, or more distinct, species than this among the Inocerami of the Black Hills region. It is most nearly related to the forms referred to $I$. barabini, but is easily distinguished by the larger and more prominent beaks, the inflated valves, and broad, abrupt anterior end, and the abrupt, concave posterior cardinal slopes, as well as the more nearly parallel basal and cardinal margins.

Formation and locality.-At the top of the gray shales of the Fort Pierré Group, on the Cheyenne River, near Rapid Creek, Black Hills, Dakota

Among the Inoceramus-like shells in the collection are two species, which are characterized by a strong and broad internal rib on each valve, extending obliquely backward from behind the beaks along the posterior umbonal slope to near the postero-basal angle of the shell, leaving upon the internal casts a concave depression or sulcus of greater or less depth, and increasing in width and depth from the beaks outward. This rib does not affect the outer surface, nor produce any external feature on the shell, being exclusively confined to the inner nacreous layers, and formed by the addition of successive coatings on the inner surface only and within the margin of the valve, so that it is seen only on the interior of separated valves, on internal casts, or on exfoliated specimens. From the interior of valves it is readily removed, even from the outer nacreous layers, as the feature is seldom developed at the edge of the shell during growth, but at a point some distance within the margin. It can sometimes also be detected on examples where the pearly layers are nearly all preserved, showing the margins of the depression faintly defined through the partially transparent substance. In such cases, however, it is only detected upon close observation.

All individuals of species possessing this feature do not have it devel$26 \mathrm{~B} \mathrm{H}$ 
oped to the same degree, and often it may not be developed until an advanced stage of growth, as in the case with the ridges bordering the muscular impressions of Cucullcea and allied forms; but this is no reason for considering it as an abnormal or accidental feature where it does exist, for in many cases its absence may have resulted from partial decay before final imbedding.

This feature has long been known to exist in shells of this group, but has generally been considered as of accidental occurrence and of no specific value. Dr. F. Røemer, in his work on the Cretaceous formation of Texas, figures a form possessing it, which he regards as belonging to $I$. cripsii Mantell, and also refers others to the same, apparently regarding it as only an abnormal feature and not of specific value. Still in his description of the figure on Plate VII, he applies to the shell the varietal name sulcatus, * descriptive of this very feature. Mr. Meek also mentions its existence on specimens which he refers to I. cripsii var. barabini, but which are probably distinct from that form and identical with one of those above referred to Some authors, however, have considered it of more importance. Mons. D'Orbigny founded his $I$. impressus $\dagger$ on the existence of this feature in his types, and Dr. Morton's I. alveatus is another example.

Considering the development of this feature to so great an extent, and in several species, not only in America but also in Europe and elsewhere, we deem it other than an abnormal or accidental one, and not only of specific importance, but as marking a distinct generic group, and propose for it the generic name Endocostea, under the impression and belief that it marks the line of recession of the larger or posterior muscular scar, as in the forms of Inoceramus on which this scar has been detected it occupies the same relative position.

\section{Genus Endocostea Whitf.}

Genus EndocosteA Whitf, Prelim. Rept. Pal. Black Hills, 1877, p. 31.

Shell resembling Iroceramus, being bivalve, with both sides convex, but more or less unequal, and composed of two layers, an outer vertically

* Not 1 . sulcatus Parkinson, from the Gault of England.

tThis species is referred to the genus Thetis by Woodward, See Woodward's Manual of recent and fossil shells. 
fibrous coating and an inner nacreous or pearly lining; hinge line straight, edentulous, with a narrow linear external cartilage area on each valve. Valves provided with an oblique intemal rib passing from behind the beaks, along the postero-cardinal slope, toward the postero-basal margin, marking the position of the posterior muscular imprint; other muscular markings unknown. Type, E. typica Whitf.

We have not been able to detect the anterior muscular scar or pallial line, except the latter as an irregular transverse line of small tubercles across the beak of internal casts in several cases, and a slight curving ridge, faintly marked on a smaller number of examples, passing from the apex along the anterior side for a short distance. The genus differs from Inoceramus so far as yet known only in the existence of the internal rib. The species now known are $E$. alveatus = Inoceramus alveatus Morton; E. impressus $=I$. impressus D'Orb.; E. sulcatus $=I$. cripsii var. sulcatus Rœmer, and E. typica Whitf., herein described.

\section{ENDOCOSTEA TYPICA.}

Plate 9, figs. 1-7.

Endocostea typica Whitf., Prelim. Rept. Pal. Black Hills, 1877, p. 32.

Shell of medium size, transversely-subovate, oblique and slightly inequivalve, the right side being the largest in the only example where they are preserved in contact. Valves strongly ventricose at the anterior end and on the anterior part of the umbonal region, becoming more compressed and attenuate behind and along the posterior cardinal portion, sometimes strongly depressed and concave between the cardinal line and dorsal slope. Hinge line straight, often two-thirds as long as the shell below and slightly rounded at the extremity; beaks small, incurved, projecting but little above the cardinal line and situated near the anterior end, but not quite terminal; anterior end short, sharply rounded at the antero-cardinal angle, and extending a little forward below for about half the height of the valve, when it rounds backward to the basal line, the upper part forming, with the cardinal line, an angle of about $95^{\circ}$ to $100^{\circ}$; posterior end nearly equal to or narrower than the anterior, and more sharply rounded, most strongly from below; basal line forming nearly half of an ellipse or semi- 
ovate figure, the widest part varying from in front of, to behind the middle of the length in different individuals.

Surface of the valves usually marked by very distinct concentric undulations, though sometimes they are only moderately developed; oblique internal rib strongly marked, narrow and pointed near the beak, and gradually widening and deepening posteriorly, the concentric furrows distinctly crossing, and leaving, on the deeply concave channel of the casts, corresponding depressions. Inner layers of the shell highly nacreous; outer prismatic layer very thin.

This species resembles Inoceramus barabini, as it is recognized in the same region, in the general form and in the subcuneate anterior end of the shell; but the transverse furrows are generally more distinctly marked and regular. It is readily distinguished by the oblique sulcus and by the opposite valve being largest, if the example above referred to, and figured on the plate, is rightly interpreted.

We have great doubts of the identity of the western forms with $I$. barabini Morton, from Alabama, and are inclined to believe they would be more naturally classed under a distinct name, as formerly done by Messrs. Meek and Hayden.

Formation and locality.-In limestone of the Fort Pierré Group, at Old Woman Fork of the Cheyenne River, Black Hills, where they occur very abundantly, densely packed together in the rock, and possessing the specific characters and the oblique sulcus in a remarkable constant degree.

\section{ENDOCOSTEA SULCATA.}

Plate 10, fig. 6.

? Inoceramus cripsii var. sulcatus Rœemer, Kreid. von Texas, p. 56, P1. vii, fig. 2.

? Inoceramus cripsii Rœmer, Texas, p. 100.

Not Inoceramus sulcatus Parkinson.

Compare Inoceramus convexa H. \& M., Mem. Am. Acad. Sci. and Arts, vol. 5, p. 386, Pl. 2, fig. 2.

Shell moderately large, transversely-ovate, with ventricose valves, most gibbous on the anterior central region, becoming more compressed behind and toward the posterior dorsal angle; beaks strong, tumid, situated near the anterior end, slightly enrolled and moderately projecting above 
the hinge line. Hinge long and straight; anterior end short and obliquely rounded; posterior end longer and rounded; base rounded or forming a short semi-elliptical curve. Surface marked by concentric undulations. Oblique sulcus well marked and broad.

A single individual, which we have referred to the above-named species, occurs in the collection. It is an internal cast of both valves, much weathered and somewhat displaced, as well as a little imperfect posteriorly, but still a well-marked species and entirely distinct from any other form. It is more ventricose than we should suppose Dr. Rœemer's specimen had been and the concentric furrows are less strongly marked, but otherwise very similar.

Formation and locality.-Loose, on the East Fork of Beaver Creek, Black Hills, probably from the Fort Pierré Group.

\section{INTEGROPALLIA.}

AROID 死.

\section{Subgenus IDONEARCA Conrad.}

\section{IDONEARCA SHUMARDI.}

Plate 11, figs. 8-11.

Arca (Cuculloca) shumardi M. \& H., Proc. Acad. Nat. Sci. Phil., vol. 8, p. 86. Cuculloca shumardi (M. \& H.), Proc. Acad. Nat. Sci. Phil., vol. 8, p. 285. Cucullca fibrosa (M. \& H.), Proe. Acad. Nat. Sci. Phil., vol. 12, p. 428.

Cuculloea (Idonearca) shumardi Meek, Pal. U. S. Geol. Surv. Terr., p. 86, Pl. 28, fig. 15 ; Pl. 29, fig. 4.

Shell obseurely trapezoidal or rhombic-ovate, usually a little longer than high, with strongly ventricose valves, which become almost inflated on the umbones and along the rounded umbonal ridge. Beaks large, inflated, moderately elevated, approximate, and slightly incurved, situated a little in advance of the middle of the length; hinge line straight, from half to two-thirds as long as the shell below; hinge-plate narrow and marked by three or four very oblique, neariy parallel, linear teeth on the posterior end, the sides of which are finely striated vertically, and by one or two similar ones on the anterior end. (The authors of the species state that 
there are small, irregular, intermediate transverse teeth in the center. These we have not seen, our specimens not showing this part of the hinge plate.) Hinge area of moderate height, marked by distinct, oblique, ligamental grooves, widely diverging from the center of the area; anterior end of the shell broadly and regularly rounded, and imperceptibly passing into the basal line; posterior end obliquely truncate, and directed backward to the posterior extremity, below the middle of the height of the valve; basal border more broadly rounded.

Surface of the valves marked by fine concentric lines of growth and by very fine indistinct radiating lines, which form pits at the concentric furrows, seen only by the aid of a lens. Anterior muscular imprint large and subcircular, situated close within the margin and near the extremity of the hinge line; posterior impression obliquely elongated, gradually increasing in width from above, and distinctly bordered on the inside by a thin elevated ridge, as in Cuculloea.

Formation and locality.-In beds of the Fox Hill Group of the Cretaceous, on the Cheyenne River, near Old Woman Fork, Black Hills.

\section{Genus NUCULA Lam. \\ NUCULA PIANIMARGINATA.}

Plate 11, figs. 5, 6.

Nucula planimarginata M. \& H., Proc. Acad. Nat. Sei. Phil., vol. 8, p. 85, ib., Nov. 1856, p. 21.

Nucula planimarginata (M. \& H.) Meek, Smithsonian Cheek List Invert. Foss., p. 8.

Nucula planimarginata (M.\& H.) Meek, Pal. U. S. Geol. Surv. Terr., p. 101, Pl. 15, fig. 8, and Pl. 28, fig. 16.

Shell rather above the medium size, transversely-ovate, about twothirds as high as long, with convex valves and somewhat prominent beaks, which are slightly incurved, and placed within the anterior third of the length of the valve; anterior end short, obliquely truncate, the longest point rather below the middle of the height, and rather sharply rounded; posterior end long and more broadly rounded than the anterior, basal margin strongly curved, having a semi-oval outline; cardinal line behind the beaks gently arcuate.

Surface of the shell not clearly determined, but, as far as can be ascer- 
tained, has been faintly concentrically striate, and there is also evidence on the exfoliated surface of fine obscure radiating lines.

On the internal casts the muscular imprints are distinctly marked, and of rather large size, the posterior scars oval and placed close to the cardinal line, and the anterior imprints of nearly the same size and form, but submarginal; pedal scars elongate oval, very much smaller than the posterior adductors, and placed a little in advance of them, and close beneath the hinge plate. Teeth numerous; evidence of about twenty-four can be seen on the posterior side of the beaks, and of about ten or eleven on the anterior side.

The specimens in hand are imperfect and much exfoliated, so that the entire features cannot be determined. They do not agree in all respects with the species to which we have referred them, being a little broader posteriorly and rather more excavated in front of the beaks anteriorly; still it is too nearly related to be considered distinct.

Formation and locality.-In limestones of the Fort Pierré Group, on the Cheyenne River, ten or fifteen miles west of the mouth of Beaver Creek, Black Hills.

\section{Genus NUCULANA Link. NUCULANA BISULCATA. \\ Plate 11, fig. 7.}

Ieda bisulcata M. \& H., Proc. Acad. Nat. Sei. Phil., 1861, p. 440.

Nuculana bisulcata Meek, Smithsonian Check List Invert. Cretaceous Foss., p. 8. Nuculana bisulcata Meek, U. S. Geol. Surv. Terr., p. 104, Pl. 15, fig. 4.

Shell quite small, not exceeding three-eighths of an inch in length, the extreme height rather less than half the length, subovate or subelliptical in outline; anterior end largest and broadly rounded; posterior end narrower and compressed, subangular below; basal line broadly curved and slightly constricted belind the middle; beaks full and strong, rather more than onethird of the length from the anterior end; cardinal margins sloping gradually from the beaks, the posterior side sometimes very slightly concave.

Surface of the valves convex, and narked by fine, even, concentric lines.

The specimens of this species are quite similar to $N$. subequilatera herein described, but are not more than one-third as long, and the cardinal line is 
much less concave behind the beaks, and the beaks nearer the anterior end of the shell and less prominent.

Formation and locality.-In limestone of Cretaceous age, on the Cheyenne River, near Box Elder Creek, and on the east fork of Beaver Creek, Black Hills.

\section{NUCULANA SUBEQUILATERA.}

Plate 11, figs. $3,4$.

Nuculana subequilatera Whitf., Prelim. Rept. Pal. Black Hills, 1877, p. 32.

Shell of small size, transversely elongate-subovate, with large, prominent, suberect beaks, which are placed a little in advance of the middle of the length, and are slightly incurved, but comparatively distant; valves convex, as seen on the casts, ventricose in the middle and below the beaks, and compressed toward the extremities, more particularly so posteriorly; hinge line abruptly bent between the beaks, the opposite sides forming an angle of about $140^{\circ}$, the posterior side slightly recurving in the outer part; anterior end of the shell sharply rounded; - posterior extremity acutely rounded near the extremity of the cardinal line, and rapidly sloping forward below to the basal margin, which is broadly curved and almost straightened in the middle.

Surface of the shell unknown, hinge plate marked by a large number of comparatively long, slender teeth, minute in the middle and gradually increasing in size and length outwardly; about twenty may, with difficulty, be counted on the posterior side of the beaks and about eighteen on the shorter side. Cartilage pit small; muscular imprints faintly marked. No sinus can de detected in the pallial line.

The species seems to be nearly related to Nucula (Nuculana?) equilateralis $\mathrm{M} . \& \mathrm{H}$, but the beaks are not central as in that species, but are situated at about two-fifths of the length from the anterior end, and the teeth are decidedly not obtuse, but on the contrary are very slender, as seen on the casts

Formation and locality.-In Cretaceous rocks on the Cheyenne River, near French Creek, Black Hills; supposed to be very near the top of the Fort Pierré Group. 


\author{
Genus YOLDIA Möller. \\ YOLDIA EVANSI. \\ Plate 11, fig. 1, 2.
}

Nucula evansi M. \& H., Proc. Acad. Nat. Sci. Phil., 1866, vol. 8, p. 84, and ext. p. 21. Leda evansi M. \& H., Proc. Acad. Nat. Sei. Phil., 1860, May, p. 185.

Leda (Yoldia) evansi M. \& H., ib., 1860, p. 429.

Yoldia evansi Meek, Smithsonian Check List Invert. Foss., p. 7.

Yoldia evansi (M. \& H.) Meek, Pal. U. S. Geol. Surv. Terr., p. 111, P1. 28, fig. 10.

Shell small, transversely elongate-elliptical, as long again as high. Valves depressed-convex, most ventricose on the umbones and becoming somewhat flattened posteriorly; beaks small and inconspicuous, located at about one-third of the length from the anterior end; hinge line straight and distinctly marked by a depressed longitudinal groove on each valve; seen only in a cardinal view; anterior end rounded; posterior end truncate; longest near the cardinal line and receding below; basal line very broadly curved.

Surface polished and marked by very fine lines of growth. Hinge line occupied by a large number of small, angular teeth, about twice as many on the posterior as on the anterior side of the beak; muscular impression and pallial line faintly marked, the latter rather deeply sinuate.

- The species may be easily recognized by the peculiar longitudinal groove along the hinge line when the shell is preserved.

Formation and locality.-In limestone of the Fort Pierré Group, on Old Woman Fork of the Cheyenne River, and near Rapid Creek, Black Hills.

\title{
LUCINID A.
}

\section{Genus LUCINA Bruguiers.}

\section{LUCINA OCCIDENTALIS.}

Plate 11, fig. 19-21.

Tellina occidentalis Morton, Jour. Acad. Nat. Sci. Phil., vol. 8, Pl. xi, fig. 3. Lucina occidentalis (Morton) M. \& H., Proc. Acad. Nat. Sci. Phil., Nov. 1856; Ext. p. 20. Iucina occidentalis (Morton) M. \& H., Smithsonian Check List. Invert. Foss., p. 12. Mold of Lucina ? Owen, Geol. Rept. Iowa, Wis. and Minn., Tab. vii, fig. 8.

Lucina occidentalis (Morton) Meek, Pal. U. S. Geol. Surv. Terr., p. 134, PI. 17, fig. 4. 
Shell of medium size or smaller, transversely-ovate, largest on the anterior side of the middle and opposite the beaks. Valves depressed-convex, being strongly lenticular in a transverse section when united. Beaks small, appressed, and inconspicuous, situated considerably anterior to the middle of the length; cardinal line slightly inclined from the beaks to the extremities, the two sides forming with each other an angle of about $140^{\circ}$; anterior end of the shell broadly rounded below the extremity of the cardinal line; posterior extremity more narrowly rounded and prolonged; basal line irregularly arcuate, being somewhat straightened behind the middle; posterior umbonal ridge distinct, the cardinal slope narrow and flattened or slightly impressed; escutcheon large, distinct, and rather deeply impressed; ligament of moderate size. Surface strongly marked by concentric lines of growth.

In the interior, the muscular impressions, as seen on an internal cast of small size, are well marked, the anterior one large and semi-lunate, the posterior one only about two-thirds as large and subcircular in form.

Formation and locality.-In Cretaceous strata, No. 4, on Cheyenne River, near Rapid Creek, Black Hills.

\section{LUCINA VENTRICOSA.}

Plate 11, figs. 14-16.

Lucina ventricosa H. \& M., Mem. Acad. Arts and Sci., vol. viii, p. 427.

Lucina occidentalis var. ventricosa (H. \& M.) Meek, Pal. U. S. Geol. Surv. Terr., p. 135, Pl. 17, fig. 3.

Shell of medium size, subquadrangularly-ovate, longer than high, a little widest anteriorly, narrower and truncate behind. Valves convex, lenticular in a transverse section when united; beaks small, appressed and inconspicuous, but little projecting above the general contour of the shell; anterior end rounded; basal line forming a broader curve; posterior truncate; umbonal ridge indistinct and the cardinal slope distinctly flattened, escutcheon deep, the margin sharply angular, the ligament occupying about twothirds of its length; lunular area slightly elevated. Surface marked by fine, irregular, concentric lines of growth; muscular imprints large and deeply marked. 
This species differs from $L$. occidentalis, with which it is associated, in being more nearly circular and more nearly equilateral, that one being much longer behind than before, while this one is nearly equal. It also differs in being wider posteriorly with a wider postero-cardinal slope, and also in having the beaks a little more inclined forward We have noticed specimens in several collections labeled $L$ occidentalis Morton, both separately and mingled with that species, but on comparing it with Dr. Morton's figures we find them to be of the more elongate form, and this one is certainly very distinct from those having that character before us. We noticed also that Mr. Meek, in the Paleontology of the United States Geological Survey of the Territories, just published, has placed it as a variety of $L$. occidentalis, expressing doubt, however, of the correctness of this view. They are certainly much more distinct than many of the recent forms of the genus considered as good species. Our specimens, which we have referred to the $L$ occidentalis, are, however, proportionally longer, posteriorly, than those he figures, and also much more like Dr. Morton's figures.

Formation and locality.-In beds of the Fort Pierré Group, near the top of the gray shales on the Cheyenne River near Rapid Creek, and at the same horizon at other localities near by. A few specimens undistinguishable from the above are marked "11 M. S. of Belle Fourche," Black Hills, Dakota.

\section{LUCINA (DIPLODONTA ?) SUBUNDATA.}

Plate 11, fig. 17, 18.

Lucina subundata H. \& M., Mem. Am. Acad. Arts and Sei., vol. viii, new ser., Pl. 1, fig. 6.

Lucina subundata (H. \& M.) Meek, Pal. U. S. Geol. Sur. Terr., p. 133, Pl. 17, fig. 2.

Shell small, orbicular in outline, with depressed convex valves; beaks small, rounded, distinctly projecting above the general contour of the shell and inclined forward; posterior side of the shell very slightly truncate, the cardinal slope narrow and distinctly arched in its course between the beaks and the posterior margin; basal line rounded, more sharply so at a point opposite the beaks; anterior to the beaks the cardinal surface of the shell 
is constricted, forming a slight fold within the margin. Surface of the shell marked by fine concentric striæ; ligament of moderate size, deeply seated within the borders of the valves, which are not inflected for its reception, but are distinctly so to form the short, deep lunule on the anterior side of the beaks.

The species is associated with the two preceding ones, but differs very materially in the details of structure, although closely resembling them in general form. The sulcus of the shell on the anterior border would place it in a different section of the genus from either of those; and the orbicular outline, narrow cardinal slope, deeply seated lunule, and more prominent beaks will also serve to readily distinguish them.

Formation and locality-At the top of the gray shales of the Fort Pierré Group, on the Cheyenne River, near Rapid Creek, Black Hills, Dakota.

\section{CRASSATELLIDAE.}

\section{Genus CRASsATELIA Lam. \\ CRASSATELLA SUBQUADRATA.}

Plate 11, fig. 12.

Crassatella subquadrata Whitf., Prelim. Rept. Pal. Black Hills, 1877, p. 34.

Shell small, subquadrangular in outline, with thin compressed valves and not prominent beaks, which are situated within the anterior third of the length; length of the shell exceeding the height; basal margin broadly rounded; anterior end short and narrowly rounded; posterior end broad and rounded truncate; posterior hinge line straight and subparallel to the basal margin Surface of shell unknown. Muscular impression small; the posterior one situated close beneath the extremity of the hinge margin, and the anterior scar submarginal. Pallial line not distinctly marked; margin of the valve crenulate.

The only specimen of this genus recognized among the collections from the Black Hills, is a small internal cast, answering to the above description, and apparently a true Crassatella. Although the hinge plate 
has not been seen, the cast has all the features usually possessed by casts of the typical forms of the genus.

Formation and locality.-In Cretaceous beds on the Cheyenne River. Probably from the Fort Pierré Group.

\section{Genus ASTARTE Sowerby. ASTARTE EVANSI.}

Plate 11, fig. 13.

Crassatella evansi H. \& M., Mem. Am. Acad. Sci. and Arts, new ser., vol. 5, p. 383, Pl. 2, fig. 9 .

Crassatella evansi (H. \& M.) M. \& H., Proe. Acad. Nat. Sci. Hist. Nov. 1853, p. $2 a$.

Crassatella evansi (H. \& M.) Meek, Smithsonian Check List Invert. Foss., p. 11.

Crassatella (Pachythorus) evansi Meek, Pal. U. S. Geol. Surv. Terr., p. 117, Pl. 17, fig. 6.

Shell of moderate size, triangularly-ovate in outline, with very ventricose valves and strong projecting incurved beaks, which are situated anterior to the middle of the valve; anterior and posterior cardinal margins rapidly sloping from the beaks, and forming with each other a little more than an angle of $90^{\circ}$, the anterior side being much shorter than the posterior. Anterior and posterior extremities rounded; basal line less strongly arcuate. Surface marked by concentric lines.

On the internal casts the muscular imprints are of moderate size, ovate and deeply marked, the pallial line simple and distinct, margin of the valves crenulate.

The species was originally referred to the genus Crassatella by the authors, and we have seen specimens labeled by one of them as C. (Pachytharus) evansi. We are not familiar with the characters of the genus Pachytherus, but can see no reason why this species should be classed elsewhere than under Astarte, as it seems to have all the features of that genus, and to be destitute of the internal cartilage pit of Crassatella. The examples in the collection before us are internal casts, and therefore we cannot be entirely positive of all the external features

Formation and locality.-In limestone at the top of the gray shales of Cretaceous, No. 4, on the Cheyenne River, near Rapid Creek, Black Hills. 


\section{VENIELLIID AE. \\ Genus VENIELLA Stoliczka. \\ VENIELLA HUMILIS.}

Plate 10, figs. 7-13.

Cyprina humilis M. \& H., Proc. Acad. Nat. Sci. Phil. May, 1860, p. 179.

Venilia humilis (M. \& H.) Meek, Smithsonian Check List, Invert. Foss., p. 13.

Veniella humilis (M. \& H.) Meek, Pal. U. S. Geol. Surv. Terr., p. 155, P1. 30, fig. 5.

Shell of moderate size; transversely oblong or trapezoidal, or transversely-oval; the length considerably exceeding the height and often, in casts, the condition in which they are usually obtained, much less than two-thirds as high as long; the thickness through the united valves but little less than the height, which is greatest at about the anterior third of the length. Beaks large, tumid, inflated on the umbones, slightly angular, strongly incurved and approximate, directed forward, and situated nearly vertically above the anterior end of the shell; hinge line arcuate, much shorter than the length of the shell and gradually declining toward the posterior extremity, which is obliquely truncate and longest below; basal line somewhat regularly curved; anterior end rounded. Umbonal ridge angular or more or less rounded angular, and strongly arcuate in its direction from the beaks to the postero-basal angle of the valve. Ligament external and of moderate size. - Surface covered by strongly marked lines of growth. Internally, the muscular impressions are distinctly marked, the anterior very deep. Cardinal teeth strong, lateral tooth having the form of an elevated angular ridge fully one-third as long as the valve.

The species is a strongly marked and rather abundant one, but is quite variable in its proportions in different individuals; the length and height, as seen on casts, varying from once and a half to nearly twice the height. The substance of the shell is thick and massive, especially along the cardinal border, and when entirely removed the casts appear much more elongated in proportion than when the shell is preserved.

Formation and locality.-In ferruginous sandstone of Cretaceous No. 5, on the Cheyenne River, near Old Woman Fork, Wyoming. 


\section{Genus SPH ERIOLA.}

\section{SPHARIOLA TRANSVERSA.}

Plate 10, figs. 14-16.

Sphariola transversa Whitf., Prelim. Rept. Pal. Black Hills, 1877, p. 34.

Shell of rather large size, subspheroidal, a little transverse, or, longer than high exclusive of the projection of the beaks, the outline of the margin of the valve being slightly oblate or transversely broad-oval, and nearly symmetrical. Valves highly inflated on the central area and umbones, with strong, highly elevated, strongly incurved, subcentral beaks, which are slightly curved forward and subangular on the umbonal ridges.

Surface of the shell marked by sublamellose concentric lines of growth, which form strong distant undulations in some cases toward the extremities of the shell.

Internally the muscular impressions are large and subcircular, and the pallial line simple and entire. The cardinal teeth, as obtained by a gutta-percha mold from a natural cast, consist of two tuberculiform teeth beneath the beak, and the laterals are represented by a strong oblique fold or ridge, passing from near the beak to within a short distance of the posterior border of the hinge plate, where it is marked, or divided, by an impressed pit, which may be accidental.

Compared with S. obliquata Meek, this shell is more equilateral, the beaks more nearly central, and the shell less oblique. It differs from $S$. moreauensis of the same author in having much larger beaks, which are more strongly enrolled and the shell is also more transverse.

Formation and locality.-In ferruginous sandstone of Cretaceous No. 5, on the Cheyenne River, near Old Woman Fork, Wyoming. 


\title{
SINUOPALLIA.
}

\section{VENERIDAE.}

\author{
Genos DOSINIA Scopoli.
}

DOSINIA MISSOURIANA ?

Plate 11, figs. 25, 26.

g. Cytherea missouriana Morton, Jour. Acad. Nat. Sci. Phil., vol. 8, Pl. xi, fig. 2.

? Cytherea missouriana (Morton) M. \& H., Proc. Acad. Nat. Sci. Phil. Nov. 1856, p. 20.

? Dione missouriana (Morton) Meek, Check List Invert. Foss. Smithsonian Inst., p. 13.

Cytherea deweyi M. \& H., Proc. Acad. Nat. Sci. Phil., vol. 8, p. 83.

Meretrix deweyi M. \& H., Proe. Acad. Nat. Sci. Phil., vol. 12, p. 185.

Callista deweyi M. \& H., Proc. Acad. Nat. Sci. Phil., vol. 13, p. 143.

Dione deweyi Meek, Smithsonian Check List Invert. Foss., p. 13.

Callista (Dosciniapsis?) deweyi M., Pal. U. S. Geol. Sur. Terr., p. 182, Pl. 17, fig. 15.

Shell rather below a medium size, transversely subtriangular in outline, with ventricose valves, which are most elevated on the umbones and gradually declining toward the basal line; being cuneately cordate in a section from the beaks to the basal line where the valves are united. Beaks of moderate size, or for the size of the shell somewhat large, pointed, incurved, and directed forward, situated much nearer the anterior end; posterior cardinal line arcuate; posterior and anterior extremities of the shell rather sharply rounded, the anterior most distinctly so, and the cardinal line on this side slightly contracted below the beaks; basal line broadly curved, more abruptly rounded toward the extremities.

Surface marked by fine, irregular lines of growth; muscular impressions large and submarginal. Pallial line deeply sinuate, the sinus acutely angular, and directed obliquely forward and upward, reaching to a little behind the middle of the valve.

The specimens of this species in the collection are in rather poor condition, having the shell considerably exfoliated and broken, but they reveal the form of the muscular imprints and pallial line very satisfactorily. The structure of the hinge plate, however, cannot be made out. The subtri- 
angular form of the shell and gibbous umbones will serve as distinguishing marks. We have some hesitation in referring this form to Dr. Morton's Cytherea missouriana simply from the fact that his figure above cited is somewhat more distinctly triangular than any of the specimens we have seen, and their outline would correspond rather better with that of Astarte evansi $=$ Crassatella evansi $\mathrm{H} . \&$ M, but the valves are not represented quite as ventricose as is the case with that shell, and it is scarcely possible that Dr. Morton would have referred a shell of that character, as perfectly preserved as his figure would indicate, to the genus Cytherea.

Formation and locality.-In limestone of the Fort Pierré Group, on the Cheyenne River, ten or fifteen miles west of the mouth of Beaver Creek, Black Hills.

\section{Genus THETIS Linn. THETIS CIRCULARIS.}

Plate 11, figs. 22 to 24 .

Tenus? circularis II. \& H., Proc. Acad. Nat. Sci. Phil., Nor. 1856, p. 8.

Cyclina? circularis Meek, Smithsonian Check List Iuvert. Foss., p. 13.

Thetis? circularis (M. \& H.) Meek, Pal. U. S. Geol. Surv. Terr., p. 190, PI. 17, fig. 8.

Shell small and very thin, subcircular and subglobose, with proportionally large, elevated, pointed, and incurved beaks, which are directed obliquely forward, and situated a little in advance of the middle of the valve; border of the valve circular, except at the postero-basal margin, which is slightly extended and obtuse; hinge line very arcuate; ligaments small and rather deeply seated, owing to the prominence of the back of the umbones of the valves Surface marked only by fine concentric lines of growth, and when entire and in good condition appears to have been quite smooth. Muscular imprints faintly marked, the anterior most distinct and submarginal; pallial line deeply sinuate, the sinus narrow, angular, and directed obliquely upward toward the apex of the valve; lobes of the pallial line digitate.

The small size of the shell and its rotund and gibbous form will readily distinguish it from any other species.

Formation and locality.-In beds of the Fort Pierré Group, near the forks of the Cheyenne River, and near the mouth of Rapid Creek, Black Hills, Dakota. 


\section{FAMILY ? \\ Genus LEIOPISTHA Meek. \\ Subgenus CYMELla Meek. \\ LEIOPISTHA (CYMELLA) MEEKI. \\ Plate 11, figs. 27, 28.}

Leiopistha (Cymella) Meeki Whitf., Prelim. Rept. Pal. Black Hills, 1877, p. 35.

Shell of moderately large size, transversely-oval in outline, about once and a half as long as high. Valves very convex, with large, tumid, incurved beaks, which are located a little more than one-third of the entire length from the anterior end of the shell, and are considerably elevated above the cardinal line; anterior and posterior ends of the valve broadly and nearly equally rounded, and the basal line between the longest points of the shell forming a very regular and nearly symmetrical semi-oval curve; cardinal line sloping gradually on both sides of the beak, the anterior side marked by a narrow, lanceolate, lunule-like depression; and the posterior side by a larger, broader area, bordered by an elevated ridge. Concentric undulations of the surface, strong and distinct, continuing their sharpness to the margins of the cardinal depressions, and gradually increasing in strength with the increased size of the shell to below the middle, beyond which point they become flattened and fainter; about twenty-seven may be counted on the entire surface. The concentric undulations are crossed by comparatively strong, radiating costæ, which do not mark the depressions between the undulations, but exist only on their flattened surfaces. The radii are strongest on the central parts of the shell, and become gradually finer and closer toward the lateral extremities, and are visible on the anterior end to the margin of the cardinal depression, but on the posterior end are not seen to exist quite so far. The crests of the radii appear to have been marked by a row of minute puncta, seen only under a magnifier, three and four existing to each undulation. The surface of the shell is also marked by fine, somewhat wrinkled, concentric lines of growth, especially on the larger parts of the valve, but apparently confined to the outer coating of 
the shell, which has the appearance of a thick epidermis, and in some places is excorticated.

We were at first inclined to consider this as C. undulata M. \& H., but on strict comparison with Mr. Meek's description in the Paleontology of the United States Geological Survey of the Territories, which we have just received, have concluded it to be a different species. It differs in the greater size and more robust habit, also in the comparatively stronger undulations, and in having the radiating costæ continuing to the anterior end, if not to the posterior also. The outline of the shell also differs somewhat.

Formation and locality.-In Cretaceous strata at Deadman's Rapids Upper Missouri. Probably of No. 5.

\section{ANATINID $A$. \\ Genus THRACIA Leach. \\ THRACIA SUBGRACILIS.}

Plate 11, figs. 29, 30.

Thracia subgracilis Whitf, Prelim. Rept. Pal. Black Hills, 1877, p. 36.

Shell small, transversely ovate, and slightly inequivalve. Valves convex, ventricose in the middle, but becoming quite compressed and almost constricted behind; anterior part large, forming nearly or quite four-fifth, of the entire bulk of the shell, the extremity rounded; basal line full in front of the beaks and constricted or sinuate behind; posterior end narrow and subtruncate; anterior cardinal line long, nearly on a line with the beaks, and very slightly convex; posterior to the beaks the cardinal line is constricted and narrowed; beaks small and compressed, appearing as if directed backward.

The surface of the only specimen is imperfect, the shell being in great part removed, but where preserved is marked by concentric lines of considerable strength, approaching in character to undulations rather than striæ. The beaks are small and marked along their apices, and for a short distance below, by a slight notch or slit from the removal of a narrow ridge which has marked the interior of the shell, as in Anatina, and supporting the car- 
tilage pit. The shell, in its external form, has all the features of Thracia, being slightly inequivalve and twisted when viewed in profile, and also in the character of the surface markings. The muscular impressions and pallial line cannot be distinguished through the remaining shell and we are therefore in doubt concerning these features. It bears considerable resemblance to Thracia gracilis M. \& H. (see Paleontology of the United States Geological Survey of the Territories), but is proportionally shorter and somewhat more contracted in height posteriorly.

Formation and locality.-In Cretaceous rocks, probably near the top of No. 4; near French Creek, on the Cheyenne River, Black Hills, Dakota.

\section{Genus NEARA Gray. \\ NEAERA MOREAUENSIS}

Plate 11, fig. 31.

Corbula moreauensis M. \& H., Proc. Acad. Nat. Sci. Phil., vol. 8, p. 83.

Necra moreauensis M. \& H., ibid., vol. 12, p. 185.

Nexra moreauensis Meek, Pal. U. S. Geol. Surv. Terr., p. 239, Pl. 17, fig. 11.

Compare Neara ventricosa M. \& H., ibid., p. 238, Pl. 30, fig. 3.

Shell minute, semi-globular, as seen in separated valves, with a small, narrow, projecting posterior end, or if the valves are united would be globular, with the extended posterior surface marked with concentric strix or undulations, which, in proportion to the size of the shell, are quite strong. The posterior extension of the valves is not more than one-fourth, or perhaps one-fifth the height of the anterior part, and the surface depressed to a corresponding degree.

We are at a loss to which of Messrs. Meek and Hayden's species to refer our shell, as they are so nearly alike, except in the character of the surface, and occur in the same formation. More especially is this trouble evident from the fact that the greater portion of the shell of our particularly minute specimen has been removed, only a little remaining on the anterior margin.

Formation and locality.-In limestone of the Cretaceous, at the forks of the Cheyenne River, Black Hills. 


\title{
GASTEROPODA. SIPHONOSTOMATA.
}

\author{
FASCIOLARIIDE. \\ Genus FASCIOLARIA Lam \\ FASOIOLARIA (CRYPTORHYTIS) FUSIFORMIS.
}

Plate 12, fig. 12.

Rostellaria fusiformis H \& M.., Mem. Am. Acad. Arts and Sci., vol. v, 2d ser., p. 333, Pl. iii, fig. 10.

Gladius ? cheyennensis M. \& H., Proc. Acad. Nat. Sci. Phil., vol. 12, p. 422.

Gladius cheyennensis (M. \& H.) Meek, Smithsonian Check list Invert. Foss., p. 20.

Fasciolaria (Cryptorhytis) cheyennensis Meek, Pal. U. S. Geol. Surv. Terr., p. 365, Pl. 19, fig. 13.

Shell of moderate or large size, fusiform, spire elevated, composed of six or more somewhat rounded or slightly ventricose volutions, gradually increasing in size to the last, which is rather more gibbous above the middle, very rapidly contracted below, and extended to form a slightly twisted anterior beak of moderate length, which, with the aperture, forms rather more than one-half the entire length of the shell. Aperture obliquely-ovate, obtusely pointed above, prolonged and extended into the canal below; outer lip thin and sharp; inner lip thin and slightly coated; volutions marked by strong, flexuous, vertical plications or folds, and by finer intermediate striæ of growth; suture deep and distinct The vertical folds terminate abruptly just below the suture line, leaving a narrow, smooth, and slightly concave space bordering the suture. Columellar fold not seen on our specimens.

This is a distinct and well-marked species, and will not be readily confounded with any other described from American rocks. It is most nearly related to Fusus martinez Gabb (Geological Survey California, Paleontology, vol. 1, p. 83, PI. 18, fig. 3), but will be readily distinguished by the absence of the revolving lines of that species. Mr. Meek compares it with Voluta monodonta Binkorst, a European species, and with Voluta rigida Baily, as identified from India under the name Fasciolaria rigida by Stoliczka; but 
remarks that it differs from the former in the flexuous character of the vertical folds, and from the latter by the possession of only one, instead of several, plaits on the columella.

This species was originally described by Messrs. Hall and Meek under the name Rostellaria fusiformis, and subsequently placed with doubt under the genus Gladius by Meek and Hayden, with the new specific name Cheyennensis, as the name fusiformis had been previously used by Mons. Pictet and Roux for a species of Rostellaria, and by Valenciennes for a species of Fasciolaria. But as Mr. Meek has subsequently proposed a new subgeneric name, with this species as the type, it will necessarily revert back to the original specific name fusiformis if the new subgeneric name Cryptorhytis is to be adopted. We have, therefore, thus referred it.

Formation and locality.-In limestone of the Fort Pierré Group, on the Cheyenne River, near Rapid Creek, Black Hills.

\section{FASCIOLARIA (CRYPTORHYTIS) CONTORTA.}

Plate 12, fig. 10.

Fusus contortus M. \& H., Proc. Acad. Nat. Sci. Phil., vol. 8, p. 65.

Pleurotomaria contorta M. \& H., Proc. Acad. Nat. Sei. Phil., vol. 12, p. 185.

Turris contorta M. \& H., ibid., 422; and Meek, Smithsonian Check List Invert. Foss., p. 22. Turris (Surcula?) contorta (M. \& H.) Meek, Pal. U. S. Geol. Surv. Terr., p. 385, Pl. 31, fig. 7.

Shell fusiform, spire elevated, number of volutions not determined

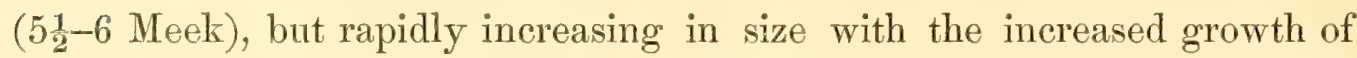
the shell, ventricose and obtusely angulated in the middle, the outer one more rapidly increasing on the aperture side. Volutions marked on the angulation by strong, distinct, vertical costa or folds, which do not quite reach the suture above or below; about twelve of them have occupied the outer volution on the largest specimen. Aperture long-pyriform, narrowed below and extended into the moderately long, slightly twisted canal. Columellar lip twisted, and marked by a single distinct, very oblique fold, which is situated above the middle of the length. Surface unknown.

The examples of this species in our possession are internal cast, with portions of the shell remaining only as a white calcareous powder, easily removed; and by breaking the larger figured example and brushing away 
the powdery portion, the impression of a distinct fold, very oblique in its direction, was revealed, the existence of which removes the species from the genus to which it has been referred, and proves its close Jurassic relations to $F$. (C.) fusiformis H. \& M. The specimens under consideration appear a little more slender than the figures given by Mr. Meek, loc cit, but the presence of the shell on his specimens will readily account for this seeming difference.

Formation and locality.-In limestones containing a mingling of the fossils of Nos. 4 and 5 of the Cretaceous formations of this region, on Old Woman Fork of the Cheyenne River, Wyoming.

FASCIOLARIA (PIESTOCHEILUS) CULBERTSONI.

Plate 12, fig. 11.

Fusus culbertsoni M. \& H., Proc. Acad. Nat. Sci. Phil., vol. viii, p. 66.

Fusus culbertsoni (M. \& H.) Meek, Smithsonian Check List Invert. Foss., p. 22.

Fusus haydeni (Evans \& Shum.) Meek, Pal. U. S. Geol. Surv. Terr., p. 360.

Fasciolaria (Piestochilus) culbertsoni (M. \& H.) Meek, Pal. U. S. Geol. Surv. Terr., p. $360, \mathrm{Pl} .32,1$.

Shell attaining rather more than a medium size, elongate-fusiforme; spire produced and slender; aperture elongate, much lengthened below; volutions moderately convex below the middle and appressed in the upper part and below the suture; columella straight, slightly thickened. Surface marked by numerous elevated revolving striæ, generally, but not always, with flattened interspaces, and crossed by strong transverse striæ of growth, which have a broad ventral curvature in crossing the appressed upper part of the volution, and are then directed forward, with a broad curve, across the swell of the volution; below this they are directed parallel to, and along the anterior rostration.

The specimens of this species in the collection are imperfect, and do not afford material for a full description. The number of volutions cannot be made out, nor can the entire features of the columella be seen. Mr. F. B. Meek states that the columella has an obscure fold in the upper part, which our specimens, although much larger than any figured by that author, show no evidence of. 
Formation and locality.-In Cretaceous beds near French Creek, Black Hills; thought by the collectors to have come from the upper part of the Fort Pierré Group, but the species is given by Mr. Meek only as from the Fox Hill's beds, No. 5.

\section{Genus FUsUs Lam.}

\section{FUSUS SHUMARDI.}

Plate 12, figs. $z, 8$.

Fusus Shumardii H. \& M., Mem. Am. Acad. Arts and Sci., vol. v, 2d ser., No. 391, Pl. 3, fig. 6.

Shell small, with a moderately elevated spire and rather short rostral beak; volutions about six, strongly ventricose, and marked by comparatively strong, slightly oblique, vertical costæ or folds, which are directed forward on the lower part of the upper volutions and again recurved below, as seen on the body whorl, and also by finer striæ of growth between the folds. The folds are crossed by numerous elevated revolving lines, with wider interspaces; suture well marked and distinct; aperture obliquely ovate, obtusely pointed above, and continued below into the short, narrow, rostral canal; columellar lip slightly thickened, but without visible folds or plaits

The specimen used is imperfect at both extremities and much of the surface shell removed; enough remains, however, to furnish the specific characters. The species may possibly belong to Mr. Meek's genus Trachytriton; but although the vertical folds are distinctly marked where the shell is entirely removed, there is no evidence of revolving lines on the spaces between them, as required in the diagnosis of that genus.

Formation and locality.-In a ferruginous sandy limestone on the east fork of Beaver Creek, Black Hills, associated with fossils referred to the fort Benton Group.

\section{FUSUS CHEYENNENSIS.}

Plate 12, fig. 9.

Fusus cheyennensis Whitf., Prelim. Rept. Pal. Black Hills, 1877, p. 37.

Shell small, spire slender and elevated; the number of volutions unknown, but probably six or more, strongly rounded, the last one somewhat ventricose above the middle, but attenuate below; aperture semi-ovate, being 
rather straightened on the inner side and slightly produced below ; volutions crossed by numerous vertical folds or plicæ, which are very slightly bent backwards in their course across the volution. Surface of the shell unknown.

The specimen from which the description is drawn is an internal cast, and therefore the external characters cannot be given in detail. The species is, however, so entirely distinct from any of the forms known from this region, that there is no fear of its being confounded with any of them.

Formation and locality.-In gray shales near the upper part of the Fort Pierré Group, on the Cheyenne River near Rapid Creek, Black Hills.

\section{APORRHAID EE. \\ Genus APORRHAIS Dillwyn. \\ APORRHAIS NEWBERRYI.}

Plate 12, fig. 4.

Anchura? newberryi Meek, Rept. on Capt. Macomb's Exp., p. 129, Pl. 11, fig. 5.

Shell small or of moderate size; spire elevated, composed of about four subangular volutions, exclusive of the body whorl, as seen on the back of the shell; apical angle about $40^{\circ}$. Volutions marked by a distinct angulation about one-third of their height above the suture line, and the body volution by a second smaller carination a short distance below the first; also by fine revolving lines, which alternate in their degree of strength; three of the stronger ones may be counted above the carination on the back of the outer volution, with a narrow smooth space above the carina, one strong and two smaller lines between the carinations, and five strong ones with finer ones between on the lower side of the volution. Outer lip expanded and extended in two long, slender, diverging digitations, corresponding to the carination on the outer volution, the lower one directed slightly forward in the direction of the coil of the shell; margin of the lip bordered by a thickened rounded rim; anterior prolongation or canal not observed; posterior canal extended along the spire to the summit, where it is deflected and extended beyond to an unknown length; callus of lip coating the entire spire and upper part of body volution, obscuring or concealing the revolv- 
ing lines of the surface; callosity thin and smooth, without tubercles. No vertical folds exist.

The species is so entirely distinct from any of the described forms of this group of shells from our American rocks, that an elaborate comparison seems unnecessary.

Formation and locality.-In limestones of the Fox Hills Group, on the Rio de la Plata. Collection of Dr. J. S. Newberry.

\section{APORRHAIS MEEKI.}

Plate 12, fig. 5.

Aporrhais meeki Whitf., Prelim. Rept. Pal. Black Hills, 1877, p. 37.

Shell of moderate size, with a low, very obtusely-pointed spire, which is composed of only three ventricose or rounded volutions, exclusive of the apertural expansion, and which rapidly increase in size; apical angle nearly $80^{\circ}$ Volutions marked by numerous sharply-elevated, revolving lines, with concave interspaces both above and below the middle. Outer lip expanded and extended into two diverging carinated digitations of an undetermined length, which are deeply grooved on the inner face, the upper one being directed slightly backward toward the spire, and the other one slightly downward and more strongly forward in the direction of the coil of the shell; anterior beak, judging from the part remaining, moderately long and stout; posterior canal extending along the spire to the summit, where it appears to have become free and deflected; callous slight (?), coating the upper volutions over a part of their extent.

This species differs from any previously-described form of this group in the short obtuse spire, combined with the two digitations of the outer lip, and the posterior canal, which extends to the summit of the spire.

Formation and locality.-In limestone of the Fort Pierré Group, at the top of the gray shales of this formation, on the Cheyenne River near Rapid Creek, Black Hills. 


\section{APORRHAIS (GONIOCHEILA) CASTORENSIS.}

Plate 12, fig. 1.

Aporrhais (Goniocheila) castorensis Whitf., Prelim. Rept. Pal. Black Hills, 1877, p. 38.

Shell small, with a moderately-elevated spire, composed of about four flattened or very slightly ventricose volutions, which are crossed by fine, flexuous, vertical folds, strongly directed forward in their course across the whorl, and also marked by fine, thread-like, revolving lines; suture distinct; apical angle about $40^{\circ}$, but slighty variable on different individuals. Body volution proportionally large and very strongly angular, or even carinate, along the middle, flattened or slightly concave on the upper surface, and rapidly contracted below to the short, pointed, rostral beak. A second rather indistinct carination marks the surface a little below the first, but seldom or never extends to the margin of the lip. Outer lip expanded, strongly carinate on the back, and projecting in the middle to form a short, obtuse, slightly recurved digitation, and posteriorly extending along the spire to the base of the second volution above.

This species somewhat resembles $A$. biangulata M. \& H. (Paleontology of the United States Geological Survey of the Territories, p. 322, P1. 19, Fig. 6), but differs in the subdued character of the lower carination and in the strongly uniangular form of the body volution. Among a number of specimens none show the posterior canal extending above the point described, nor any evidence of a second digitation to the lip. The surface markings are quite superficial, but few specimens showing them, appearing quite smooth from slight exfoliation.

We are extremely averse to describing new species of this group of shells, as from their extreme liability to variation with different degrees of development they are easily mistaken, and we have feared that this might prove, on the examination of a larger and better collection of specimens, to be only a form of $A$. biangulata M. \& H., above referred to, but the single strong carination and the fact that it comes from a lower geological horizon and distant locality has induced us to separate it under a new name.

Formation and locality.-In ferruginous sandy limestone on the east fork of Beaver Creek, Black Hills. Associated with fossils of the Fort Benton Group. 


\section{Genus ANCHURA Conrad.}

\section{ANCHURA ? SUBLEVIS.}

Plate 12, fig. 6.

Aporrhais sublevis M. \& H., Proc. Acad. Nat. Sci. Phil., vol. 12, p. 178.

Aporrhais sublevata (misprint) M. \& H., ibid., 1860, p. 428.

Anchura? sublevis Meek, Smithsonian Check List Invert. Foss., p. 19.

Anchura? sublevis (M. \& H.) Meek, Pal. U. S. Geol. Surv. Terr., p. 327, Pl. 19, fig. 3.

Shell small, with an elevated, slender spire; volutions about seven in number, distinctly convex, with well-marked suture lines; body volution a little more ventricose than the preceding, very slightly angular, and extended below into a slender, pointed, rostral beak; lip not expanded, but the margin making a strongly sigmoidal curve, being broadly sinuate above and extended forward below the middle, again receding to the beak. Volutions marked by numerous fine, sigmoidally-curved, vertical folds, having the same direction as the margin of the aperture, and also by fine, closelyarranged, thread-like, and elevated revolving lines. Aperture obliquely ovate, pointed above and below.

On some specimens we notice a tendency in the vertical folds to form varices on opposite sides of the shell, similar to those of Triton and Ranella; mostly confined to the two larger volutions, and we strongly suspect that the true generic relations of the shell have not been properly ascertained; also that the specimen in hand, although quite numerous, as also those used and figured by Mr. Meek, are all young shells, with the adult features of the aperture yet undeveloped.

Formation and locality.-In limestone of the Fort Pierré Group, near Box Elder Creek, Black Hills, Dakota 


\section{ANCHURA (DREPANOCHEILUS) NEBRASCENSIS.}

Plate 12, figs. 2, 3.

Rostellaria nebrascensis E. \& S., Proc. Acad. Nat. Sci. Phil., vol. vi, 164.

Aporrhais nebrascensis (E. \& S.) M. \& H., ibid vol. 12, p. 423 ; Gabb, Synop. Cret. Foss., p., 39 .

Anchura (Drepanocheilus) nebrascensis (E. \& S.) Meek, Smithsonian Check List Invert. Foss., p. 19.

Anchura (Drepanocheilus) nebrascensis (E. \& S.) Meek, Pal. U. S. Geol. Rept. Terr., p. 326 , Pl. 19, tig. 5 .

Shell small, to moderate size; fusiform, exclusive of the outer lip; spire elevated but moderately robust, about equal in height to the body volution; composed of five or six moderately ventricose whorls, which gradually increase in size; suture line distinct. Outer volution proportionally large and bicarinate in the middle; outer lip expanded, and the margin extended in the form of a short, falciform, recurved digitation which is strongly angulated on the back, corresponding to the upper carination of the body volution. The lip is also slightly curved backward and upward near its junction with the spire, forming a deep sinuosity on the inner face. The lower extremity of the body volution is extended in form of a short pointed beak, channeled on the inner face.

Surface of the shell marked by fine revolving lines and by small vertical folds, which are flexuous, and directed forward on the lower part of the volution

The specimens which we have referred to this species vary considerably among themselves, and all seem to be more robust than those figured by Mr. Meek, loc cit.; still, from their variability, we conclude they are all of the one species. Indeed the species of this entire group are extremely variable, according to the degree of development, especially in the characters pertaining to the aperture and the strength of surface markings, and we are inclined to believe that the same species may often pass beyond the limits of genera, as now recognized.

Formation and locality.-In Cretaceous limestone on the east fork of Beaver Creek, three miles west of Camp Jenney, Black Hills. 


\section{HOLOSTOMATA.}

NATICIDE.

Genus LUNATIA Gray.

LUNATIA CONCINNA.

Plate 12, fig. 13.

Natica concinna H. \& M., Mem. Am. Acad. Sci. and Arts, vol. v, p. 384, Pl. iii, fig. 2.

Natica moreauensis M. \& H., Proc. Acad. Nat. Sci. Phil., vol. 8, p. 64, and 282.

Natica (Lunatia) moreauensis M. \& H., Proc. Acad. Nat. Sci. Phil., vol. 12, p. 422.

Lunatia moreauensis (M. \& H.) Gab. Syn. Cret. Moll., p. 58.

Lunatia moreauensis (M. \& H.) Meek, Smithsonian Check List Invert. Foss., p. 20.

Shell of medium size, subglobose or very broadly rhombic-ovate; erect, with strongly ventricose volutions, of which four may be counted on the example figured, the last one forming the great bulk of the shell. Spire low; sutures very distinct, deep, but not channeled; aperture obliquely ovate, nearly once and a half as high as wide, obtusely pointed above and rounded below; inner lip straightened, slightly callous and spreading upon the body of the shell; umbilicus moderate; outer lip thin and comparatively sharp. Surface marked by fine transverse lines of growth and by faint revolving lines, seen only by the aid of a lens, except on the larger part of the body volution, where a few may be detected with the naked eye.

Formation and locality.-At the top of the gray shales of the Fort Pierré Group, on the Cheyenne River, near Rapid Creek, and a specimen undistinguishable from it, in its condition as an internal cast, from a much lower position on the east fork of Beaver Creek, Black Hills.

Genus VANIKORA Quoy \& Gaimard.

VANIKORA AMBIGUA.

Plate 12, fig. 14.

Natica? ambigua M. \& H., Proc. Acad. Nat. Sci. Phil., vol. v, p. 64.

Fosar? nebracensis M. \& H., Proc. Acad. Nat. Sci. Phil., vol. 12, p. 423

Vanikora ambigua (M. \& H.) Meek, Smithsonian Check List Invert. Foss., p. 18.

Shell small, naticoid, subglobose or obliquely subglobose, spire moderately elevated, volutions ventricose and separated by rather distinct suture 
lines. "Aperture ovate, very oblique, obtusely angular above, and rounded below; outer lip sharp, joining the whorl above nearly at right angles, slightly reflexed at its junction with the columella below; axis apparently perforated by a very small umbilical opening which is not covered by the lip."

Surface of the shell marked by very distinct, impressed, revolving lines, with wider, flattened interspaces; the lines most strongly marked below the middle of the outer volution, and crossed by irregular concentric lines of growth, which have a decided tendency to form fascicles or transverse folds on the body volution.

Our specimen of the species is imbedded in hard limestone, so as to entirely conceal the aperture side of the shell; we have therefore quoted Mr. Meek's description of these parts from the Paleontology of the United States Geological Survey of the Territories, p. 330.

Formation and locality.-In limestone of the Fort Pierré Group, on the Cheyenne River, Black Hills.

\title{
Genus AMAUROPSIS Morch.
}

\section{AMAUROPSIS PALUDIN AEFORMIS.}

\author{
Plate 12, fig. 16.
}

Natica paludinaeformis H. \& M., Mem. Am. Acad. Sci. and Arts, vol. v, p. 389, Pl. iii, fig. 3.

Amauropsis paludinaformis (H. \& M.) M. \& H., Proc. Acad. Nat. Sci. Phil., vol. 12, p. 185.

Amauropsis paludinaformis (H. \& M.) Meek, Smithsonian Check List Invert. Foss., p. 20.

Amauropsis paludinaformis (H. \& M.) Meek, Pal. U. S. Geol. Surv. Terr., p. 318, Pl. 19, fig. 15 .

Shell subovate or elongate-ovate, spire moderately elevated, forming a little more than one-half the entire height above the aperture; volutions four and a half to five, convex, the last one ventricose and somewhat produced below, but not rostrate; suture very distinct and channeled; aperture oblique, semi-ovate, or nearly semi-circular, the inner side being nearly straight; upper angle acutely rounded, more broadly rounded below, the columellar side of the base almost subrimate; outer lip thin and sharp; columellar lip scarcely thickened; umbilicus scarcely perceptible or closed. 
Substance of the shell thin; surface marked by fine closely-arranged revolving striæ and by transverse lines of growth, which give an undulating character to the revolving lines.

Formation and locality.-In limestones of the Fort Pierré Group, on the Cheyenne River, near Box Elder Creek, Black Hills.

\section{TROCHID E.}

\section{Genus MARGARITA Leach.}

\section{MARGARITA NEBRACENSIS.}

Plate 12, fig. 15.

Turbo nebracensis M. \& H., Proc. Acad. Nat. Sci. Phil., vol. 8, p. 64. Margarita nebracensis M. \& H., Proc. Acad. Nat. Sci. Phil., vol. 12, p. 185.

Margarita nebracensis M. \& H., Pal. U. S. Geol. Surv. Terr., p. 298, Pl. 19, figs. 8 and 9.

Shell small, turbinate, height and width nearly equal; spire regularly conical, composed of from four to five rounded, ventricose volutions, which increase gradually in size with the increased growth of the shell, the last one appearing very slightly subangular just below the middle; suture line deep and well marked; umbilicus apparently of moderate size (somewhat obscured in the specimen used), and rather angular at the margin. Surface marked by very fine, even, and quite regular revolving lines, and by a narrow, very obscurely depressed space just above the angularity of the outer whorl; also by fine, transverse striæ, which are gathered into small folds just below the suture and near the margin of the umbilicus, and have a strongly oblique backward direction above the periphery, and cross more directly below.

Formation and locality.-In limestone of the upper part of the Fort Pierré Group, on the Yellowstone River, 150 miles above its mouth. 


\section{PULMONIFERA. ?}

\section{SIPHONARIID AE. ?}

\section{Genus ANISOMYON, M. and H.}

A few examples only of this genus are found in the collections from the Black Hills. These few represent four of the species previously described from this region. The generic characters of the group are well marked on all the species we have examined, but there appears to be some doubt as to its family relations. Mr. Meek's latest expressed opinion seems to be that they are most nearly allied to the Siphonariida, and therefore that they are pulmoniferous in their structure. To this conclusion the break in the right side of the muscular imprint would naturally lead, for although the interruption is not large, and often quite slight, still it is an interruption, and would only occur through some organic feature of the animal; the natural inference would therefore be that it was for the protrusion of an air-conducting siphon, or at least that it indicated a step in that direction. Still, so far as our examinations extend, there has been no depression of the interior surface of the shell, as is usually the case in most if not all the species of Siphonaria.

ANISOMYON ALVEOLUS.

Plate 12, fig. 20.

Helcion alveolus M. \& H., Proc. Acad. Nat. Sei. Phil., vol. 8, p. 68. Anisomyon alceolus M. \& H., Amer. Jour. Sei. and Arts, vol. 28, 2 d ser., p. 35. Anisomyon alveolus (M. \& H.) Meek, Pal. U. S. Geol. Surv. Terr., p. 292, PI. 18, fig. 4.

Shell small, elongate-oval or narrowly elliptical in outline, the length about once and a half the width, with rounded anterior and posterior extremities; apex a little in advance of the middle, minute and apparently recurved; elevation of the shell, in our specimen, about half or a little more than half as great as the greatest width, the surface of the sides and ends very gently convex. The surface, judging from the exfoliated specimen, has been slightly marked by concentric undulations; anterior muscular imprint on the right side long and narrow and a little obliquely placed: 
Mr. Meek appears to think there may be some doubt of the true specific relations of this form; that it may possibly be only a young, or a variety of A. subovatus. The resemblance is indeed quite striking, differing in our specimens only a little in the degree of elevation, slightly in the relative position of the apex, and somewhat in its greater length.

Formation and locality.-In limestones of the Fort Pierré Group, on Old Woman Fork of the Cheyenne River, Black Hills.

\section{ANISOMYON SUBOVATUS.}

Plate 12, fig. 19.

Helcion subovatus M. \& H., Proc. Acad. Nat. Sci. Phil., vol. 8, p. 68. Anisomyon subovatus M. \& H., Am. Jour. Sci. and Arts 2 d ser., vol. 28, p. 35. Anisomyon subovatus (M. \& M.) Meek, Pal. U. S. Geol. Surv. Terr., p. 291, Pl. 18, figs. $5 d$, and 6 .

Shell of moderate size, oval, slightly ovate or broadly elliptical in outline, the length and width as seven to five, or nearly so; ends somewhat regularly rounded; sides nearly straight in the middle or only very slightly convex; height of the shell equal to a little more than half the width; apex small, recurved even on the internal cast, situated a little less than one-third of the entire length from the anterior end; anterior slope of the shell forming nearly a straight line from the apex to the front margin; posterior slope quite convex; sides slightly convex. Surface of the shell apparently marked by moderately strong concentric undulations, as indicated on the internal casts.

Muscular imprints quite distinct, the anterior ends large, situated directly on a line with the apex of the shell, the left side rapidly narrowing posteriorly to near the middle of the posterior slope, where it is perceptibly widened again on the right side, the anterior portion is oval and a little oblique, the interruption is quite slight, and the posterior continuation linear, with a second faint interruption farther back. Anterior line connecting the opposite sides narrow, crossing the apex of the shell. There is some variation among the individuals of this species, as is indicated by $\mathrm{Mr}$. Meek's figures, given in the Paleontology of the United States Geological Survey of the Territories, and of course the description given above will 
not agree in its details with all specimens that may properly be referred to the species.

Formation and locality.-In limestones of the Fort Pierré Group on Old Woman Fork; associated with A. alveolus and Endocostea typica.

\section{ANISOMYON PATELLIFORMIS.}

Plate 12, figs. 17, 18.

Helcion patelliformis M. \& H., Proc. Acad. Nat. Sci. Phil., vol. 8, p. 68. Anisomyon patelliformis M. \& H., Am. Jour. Sci. and Arts, vol. 28, p. 35, Pl. 1. Anisomyon patelliformis (M. \& H.) Meek, Pal. U. S. Geol. Surv. Terr., p. 290, Pl. 18, figs. $5 a, \bar{b}, c$, and $f$.

Shell of medium size, slightly ovate or very broad-oval in outline, the width equaling about four-fifths of the length. Surface of the shell elevated, the extreme height about equaling one-half of the greatest width; apex obtuse and apparently very little incurved, situated nearly over the anterior end or but little within a vertical line above the margin; anterior margin of the shell rounded; posterior end a little more broadly rounded and the sides forming regular elliptical curves. Anterior slope abrupt and slightly concave; posterior slope highly convex; lateral slopes concave in front of the middle and convex behind. Surface of the shell unknown; that of the cast marked by nearly obsolete undulations; muscular impressions very distinct, the anterior portions large and subcircular, posterior parts narrower, except at the right posterior angle, where it again widens, interruption distinct; anterior connecting band linear, crossing the summit of the shell at a distance posterior to the apex, equal to about one-fifth of the length of the shell.

Our specimens of this shell differ somewhat from those figured by Mr. Meek, but not sufficiently so to be considered of much importance. The apex is more obtuse and slightly inclined downwards, and is also situated nearer the anterior margin, while the elevation of the shell and also its relative convexity are greater.

Formation and locality.-In limestone of the Fort Pierré Group, on Old Woman Fork, Black Hills; associated with A. alveolus and A. subovatus. 


\section{ANISOMYON BOREALIS.}

Plate 12, figs. 21-23.

Hipponyx borealis Mort., Jour. Acad. Nat. Sci. Phil., vol. 8, 1842, p. 210, Pl. xi, fig. 6. Helcion carinatus M. \& H., Proc. Acad. Nat. Sei. Phil., vol. viii, p. 68. Anisomyon borealis M. \& H., Am. Jour. Sci. and Arts, vol. 28, 2d ser., p. 35. Anisomyon borealis (M. \& H.) Meek, Pal. U. S. Geol. Surv. Terr., p. 288, Pl. 18, fig. 9.

Shell of large size, subcircular or very short ovate in outline, widest behind the middle. Summit elevated; apex pointed or slightly recurved, laterally compressed, and in the specimens in hand almost overhanging the anterior margin of the shell; anterior slope short, abrupt, and concave; posterior slope long and convex, the greatest elevation of the shell being a little behind the apex; lateral slopes concave in front of the middle and convex behind; surface of the shell angulated along the middle of the posterior dorsal region, and also between this and the sides, the median angulation the most extreme. Also by indistinct, irregular, flexuous, radiating lines of varying strength, and by stronger concentric lines of growth. There are also six distinct hair-like radiating grooves passing from the apex toward the margin at subequal distances from each other, which appear to be mostly superficial, although sometimes visible on partially exfoliated specimens. Muscular impressions not observed.

On one of the specimens referred to this species, and which is a partial cast of the interior, there are three radiating ridges passing from the apex to a considerable distance along the surface; one of them being situated near the median angulation, the others, rising from below and in front of the apex, pass along the sides of the cast for more than half an inch. The former of these ridges we judge to be only a line indicating a fracture of the shell; the others are evidently a part of the muscular markings, and most probably represent the anterior connecting muscular band seen on other species. Here, however, it crosses in front and just below the apex of the shell.

Judging from the figures given by Mr. Meek, the species is a very variable one; our specimens are of the form represented by his profile figure $9 b$, but less elevated.

Formation and locality.-In limestone of the Fort Pierré Group, Cheyenne River, Black Hills. 


\title{
TECTIBRANCHIATA.
}

BULLIDE.

\author{
Genus HAMINEA Leach. \\ HAMINEA STBCYLINDRICA.
}

Plate 12, fig. 24 .

Bulla subcylindrica M. \& H., Proc. Acad. Nat. Sci. Phil., vol. 8, p.270 (not of D’Orb., 1847). Bulla speciosa (M. \& H.) Meek, Smithsonian Check List Invert. Foss., p. 16, Proc. Acad. Nat. Sci. Phil., vol. 12, p. 185.

Haminea subcylindrica (M. \& H.) Meek, U. S. Geol. Surv. Terr., p. 272, Pl. 18, fig. 10.

Shell of moderate size, elongate-oval or slightly ovate in form, with rather sharply rounded extremities; upper end marked with a small central umbilical pit or depression indicating the position of the sunken spire, and the outer volution elevated but little above the preceding one; lower extremity somewhat extended and narrowly rounded from the short, slightly curved, columellar-like inner lip around the base of the aperture; aperture very narrow above but gradually widening below, and strongly arcuate throughout; outer lip thin and sharp, lower umbilical slit minute. Surface of the shell marked by fine impressed revolving lines, many of which have a somewhat alternating character, and are crossed by finer concentric lines of growth.

The shells of this species which we have in hand are none of them entire cr full grown, but their specific features are well marked. It is the only one of the group we have noticed in the collection, although several others have been described from the Cretaceous formations of this region. It is readily distinguished from the others by the form of the shell.

Formation and locality.-In limestones of the Fort Pierré Group, on Old Woman Fork of the Cheyenne River, Black Hills.

\section{Genus AKERA O. F. Muller. AKERA GLANS.ORYZA. Plate 12, fig. 25.}

Akera glans-oryza Whitf., Prelim. Rept. Pal. Black Hills, 1877, p. 38.

Shell minute, not exceeding one-fifth of an inch in length, and the diameter being about twice and a half less than the length; cylindrical in 
form, with a very low, truncated spire, which consists of about three or three and a half volutions, the outer margins of which are bordered by an elevated knife-edge carina, giving a deeply channeled convolute character to the spire, the center scarcely rising above the level of the outer carination. Body of the outer volution very slightly rounded near the margin of the flattened spire and distinctly so to the base below. Aperture as long as the shell, narrow above and gradually widening and rounded at the base. Columella curved and apparently reflected upon the preceding volution. Axis imperforate.

Surface of the shell marked by very fine, revolving, impressed lines, strongest near the top of the volution and on the lower third; also by finer transverse striæ of growth parallel to the margin of the aperture, and indicating by their direction that the central portion of the outer tip is a little in advance of the top and base.

Formation and locality.-In limestone near the top of the Fort Pierré Group, on the Chyenne River, near French Creek, Black Hills, Dakota.

\title{
PROSOPOCEPHALA. SOLENOCONCHE.
}

\author{
DENTALIID 王. \\ Genus DENTALIUM Linn. \\ DENTALIUM GRACILE.
}

Plate 12, fig. 26.

Dentalium gracile H. \& M., Mem. Am. Acad. Arts and Sci., vol. v., new ser., p. 303, Pl. 3, fig. 11.

Dentalium fragile M. \& H., Proc. Acad. Nat. Sci. Phil., vol. 8, p. 69.

Dentalium gracile (H. \& M.), Pal. U. S. Geol. Surv. Terr., p. 266, Pl. 18, fig. 13.

Shell slender, tubular, very gradually and regularly tapering throughout, circular in a transverse section and moderately thick; very generally arcuate from end to end, the degree of flexure in the length of one inch, measured on the concave side, being less than a sixteenth of an inch. 
Surface of the shell marked by fine, rather deep, longitudinal flutings of varying width, with the ridges between very slightly flattened on the surfaces; the whole crossed by extremly fine transverse striæ of growth; indicating the inner side of the apertural margin as the longest. Inner surface of the tube smooth.

Formation and locality.-In limestone concretions at the top of the gray shales of the Fort Pierré Group, on the Cheyenne River, near Rapid Creek, Black Hills.

\title{
CEPHALOPODA. TETRABRANCHIATA.
}

\author{
NAUTILIDE. \\ Genus NAUTILUS Breynius.
}

NAUTILUS DEKAYI var. MONTAN AENSIS.

Plate 16, figs. 10-11.

Nautilus dekayi var. montancensis Meek, Pal. U. S. Geol. Surv. Terr., p. 498, Pl. 27, fig. 2.

Shell attaining a large size, subglobose in form, the length somewhat greater than the width. Volutions rapidly increasing in size, rather sharply rounded on the periphery, very slightly flattened on the sides, and again more rapidly expanding near the umbilical region. Umbilicus closed, though in exfoliated individuals appearing as if open by the removal of the shell. Aperture deeply reniform, a little more than twice as wide as long and sharply rounded at the sides Septa distant, deeply concave, their lines of junction with the outer shell passing across the volution without curvature. Siphuncle small; in some parts situated exactly central, and in others nearly central between the dorsal and ventral borders of the septa. Outer surface of the shell not observed; but on the slightly exfoliated outer chamber seems to have been marked by concentric lines of growth directed strongly forward on the sides, and on the dorsal region to have had a broad, deep, retral curvature, indicating a deeply bilobed margin.

The specimens of this variety are very closely related to $N$. dekayi Morton, the differences not being sufficiently marked to be noted except on 
critical examination. The principal variation consists in the more nearly central position of the siphuncle and slightly more distant septa. These features, however, are not more marked than may often be noticed among different individuals of a species when obtained from one locality, and we are therefore strongly inclined to doubt the propriety of separating it, even as a variety, from those referred by its author to $N$. dekayi. We are the more strongly confirmed in this opinion from the fact that in the specimen we have figured the siphuncle is so nearly central in its position in the fourth septum from the outer chamber as not to be readily detected by measurement, while on the opposite side of the shell, in the smaller part of the same volution, its position is much nearer the ventral border, showing in the same individual as great a variation as between those referred to the two forms.

Formation and locality.-In limestone of the Fort Pierré Group of the Cretaceous, on the Cheyenne River, near Rapid Creek, Black Hills, Dakota.

\section{AMMONITID AE. \\ Genus PRIONOCYCLUS Meek. \\ PRIONOCYCLUS WYOMINGENSIS. \\ Plate 14, figs. 1-3.}

Ammonites (Prionocychus) serrato-carinatus Meek, Geol. Surv. Terr., 1870, p. 298 (Hayden). A mmonites serrato-carinatus Meek, ibid.

ivot Ammonites serrato-carinatus Stoliczka.

Prionocyclus wyomingensis Meek, Pal. U. S. Geol. Surv. Terr., p. 452, note.

Shell attaining a medium or large size, subdiscoid and laterally compressed. Volutions flattened on the sides in the younger stages and strongly keeled on the dorsum, becoming proportionally wider and more convex with increased age, and the keel strongly developed, rounded, and serrated. The lateral diameter of the volution of a specimen which measures about $1 \frac{1}{2}$ inches across is about two-thirds the dorso-ventral diameter, but considerably more when they attain a diameter of three inches. Umbilicus large and open, exposing four-fifths to five-sixths of the diameter of the inner volutions, the margin of the volutions being abruptly rounded. 
Surface of the shell marked by transverse ridges, which are extremely variable in strength and in the manner of their grouping on different individuals and at different stages of growth, there being generally a stronger ridge developing nodes at each extremity, with from two to five smaller ones between. The inner nodes are often formed by the coalescing of two or three of the ridges, though sometimes single; the outer nodes are obliquely longitudinal and flattened on the back, formed by the thickening of the principal rib or by the union of two or more. On the dorsum the ribs continue, but are much subdued and subequal, and directed strongly forward, forming crenulations in crossing the keel.

Septa rather simple and closely arranged; the lobes and saddles of the adjacent ones passing within each other, as shown on small individuals. Those of larger individuals not observed.

This species was first indicated by Mr. F. B. Meek in Dr. Hayden's report of 1870, as Ammonites serrato-carinatus; but, on learning that this name had been previously used for a similar species, he subsequently proposed the specific name Wyomingensis to be used, providing the two should be found to belong to the same section; and as we found it so labeled in the collection at the Smithsonian Institution, we infer that he intended to adopt the name, and we have therefore so used it.

Formation and locality.-In silico-calcareous layers of Division No. 2, Cretaceous, on the east fork of Beaver Creek, near Camp Jenney, Black Hills.

\section{SCAPHITID A. \\ Genus SCAPHITES Parkinson.}

\section{SCAPHITES NODOSUS.}

Plate 13, fig. 12.

Scaphites nodosus Owen, Rept. Geol. Surv. Iowa, Wis. and Minn., 1852, p. 580, tab. 8, fig. 4 .

Scaphites nodosus (Owen) M. \& H., Proc. Acad. Nat. Sei. Phil., vol. 12, p. 420.

Scaphites nodosus (Owen) Gabb., Synop. Moll. Cret. Formation, p. 32.

Scaphites nodosus (Owen) Meek, Smithsonian Check List Cret. Foss., p. 24.

The examples of this species in the collection are so exactly similar to the figure given by Dr. Owen (Report on the Geological Survey of Iowa, 
Wisconsin, and Minnesota, Pl. 8, Fig. 4) that there can be no reasonable doubt as to their being the same variety of this very variable species, to which the name $\boldsymbol{S}$. nodosus was originally applied. None of the varieties figured by Mr. Meek in the Paleontology of the United States Geological Survey of the Territories approach the features presented by this form very closely or sufficiently near to be considered typical, but this we have deemed best to retain under the original name of the species. It appears to be intermediate between Mr. Meek's varieties brevis and plenus. The general form of the shell is ovate, considerably longer than high, and very ventricose; the inner volutions forming only about half of the length of the shell, and much less than half the bulk. The volutions are closely coiled, leaving but a very slight umbilical opening; the body volution is somewhat regularly arcuate on the periphery and straight on the ventral or umbilical margin of the deflected portion; the aperture recurving and its margin forming an angle of nearly a hundred degrees with the straight ventral border of the deflected portion, the whole shell sensibly contracting above the line of the deflected part to near the aperture, and still more abruptly so just at its border.

The surface of the shell is marked by rather distinct, subangular, sinuous costæ, which bifurcate so as to form three, four, or five times as many on the broadly-rounded dorsum, which they cross with a slight forward curvature, and also by two rows of rather strong, distinctly elevated nodes or tubercles on each side, situated, one about one-third or nearly onethird of the width of the volution from the margin of the umbilical line, and the other near the border of the rounded dorsum, the latter range being longitudinally compressed, so as to form thin angular nodes. Both ranges of nodes are traceable nearly as far as the volutions are seen.

The septa are rather complicated and somewhat variable in the different forms and varieties of the species; they, however, all have a general resemblance to each other, presenting nearly the same elements in each, and having similar characteristics, which mark them as belonging to the same group or type. These features are shown in the diagram illustrating S. nodosus on Plate 13, Fig. 9. 
Formation and locality.-In limestone at the top of the gray shales of the Fort Pierré Group, on the Cheyenne River, near Rapid Creek, Black Hills, Dakota.

\section{SCAPHITES NODOSUS var. BREVIS.}

Plate 13, fig. 8, 9.

Scaphites nodosus var. brevis Meek, Pal. U. S. Geol. Surv. Terr., p. 426, Pl. 25, fig. 1.

This variety differs from the typical form of S. nodosus Owen, in being less ovate, the deflected portion being rather shorter, and in the more compressed form of the shell as seen in profile, and also in the narrowly rounded dorsum. The costæ are somewhat finer on all of the examples we have seen, and the nodes smaller, and not commencing at so early a stage of growth; while the inner range of nodes is usually obscure or only seen on the deflected part of the body volution. The most conspicuous differences are the compressed form of the shell and the more narrowly rounded dorsum.

Formation and locality.-The examples of this variety are found associated with the typical form at the top of the gray shales of the Fort Pierré Group, Cheyenne River, near Rapid Creek, Black Hills, Dakota.

\section{SCAPHITES NODOSUS var. QUADRANGULARIS.}

PJate 13, figs. 10, 11.

Scaphites nodosus var. quadrangularis Meek, Pal. U. S. Geol. Surv. Terr., p. 428, PI. 25, figs. $2-4$.

Shell discoidal, with latterally compressed volutions, and the dorsum of the deflected part of the outer volution somewhat flattened. General outline of the shell slightly ovate, the outer coil being somewhat deflected from the general curvature of the involute parts, and the extremity again recurved, so as to bring the ventral margin nearly or quite to the dorsal limit of the preceding volution, and the margin of the aperture nearly at right angles to the ventral line of the deflected portion.

Surface of the shell ornamented by fine, somewhat sinuous, transverse, bifurcating costæ with narrow concave interspaces, and also by two ranges of nodes on a part of the last volution. The outer ranges of nodes are situ- 
ated on the angles of the flattened dorsum, but become obsolete on the outer third of the volution, where the dorsum is also sharply rounded. The inner ranges consist of smaller nodes, and are situated near the border of the umbilicus. The septa closely resemble those of the typical form of $S$. nodosus Owen, but are arranged so elosely as to interfere or interlock with each other.

This variety differs from the typical form of $S$. nodosus in the same direction, but still more widely than the variety brevis Meek, being more compressed laterally, more distinctly flattened on the back of the body whorl, and the costæ are still finer than in that variety, while the deflection is less extreme and the ventral border of that part more curved.

Fsrmation and locality.-This variety has been obtained from beds of the Fort Pierré Group, at the top of the gray shales of that formation on the Cheyenne River, near Rapid and French Creeks, and also from beds which contain a mingling of the fossils of this and the succeeding group on Old Woman Fork, Black Hills.

Scaphites nodosus var. plenus, M. \& H., Proc. Acad. Nat. Sci. Phil., 1860, p. 420; and Pal. U. S. Geol. Surv. Terr., p. 429, PI. 26, fig. 1.

This form differs from the typical $S$. nodosus in being much more ventricose as well as larger, while in the strength of the costæ it corresponds closely to that one. The nodes are represented in the figures given as being round and somewhat tumid. We have not recognized this form among the collections brought from the Black Hills by Professor Jenney's party. Mr. Meek cites the Yellowstone River, one hundred and fifty miles from its mouth, as the locality of the specimens referred to this variety.

\section{SCAPHITES WARRENI.}

Plate 13, figs. 1-4.

Scaphites warreni M. \& H., Proc. Acad. Nat. Sei. Phil., vol. 12, pp. 177, 420. Scaphites warreni M. \& H., Smithsonian Check List Invert. Foss., p. 24.

Scaphites warreni (M. \& M.) Meek, Pal. U. S. Geol. Surv. Terr., p. 420, Pl. 6, fig. 5.

Shell of moderate size, transversely subovate in general form; regularly coiled in the earlier stages of growth; the volutions rounded and 
strongly involute, the outer embracing the inner so as to leave only a minute umbilical opening, and in some cases the umbilicus is entirely closed, concealing the inner coils. Outer volution large and deflected in nearly a straight line for some distance, then recurved and extending nearly to the center of the straightened portion. Aperture considerably contracted and hood-shaped. Lateral diameter of the outer volution and of the deflected portion somewhat exceeding the dorso-ventral diameter; the form of a transverse section being equal to the larger two-thirds of a broad ovate figure. The chamber of habitation in the large individual figured on Plate 13, Figs. 2 and 3, extends to about the middle of the straight portion of the outer volution.

Surface of the shell marked by closely arranged, subangular costx, which are even and of uniform size on the back and to near the middle of the sides, where from four to seven of them unite in forming broad, rounded folds, which contract in width on approaching the umbilicus and become prominent and angular. On the involute parts of the shell the costæ are directed nearly straight across the volution, but on the deflected portion they have a slightly forward curvature in passing from the ventral to the dorsal portion, and the costal folds are stronger and more distant.

Septa rather simple in their structure and closely arranged. The siphonal lobe is about as wide as long, and provided with two bifurcating branches on each side, the inner fork of each being longer than the outer, and both minute. First lateral lobe much smaller than the siphonal lobe, and divided into two principal branches, with a broad, rounded sinus between, the dorsal side provided with three nearly equal spurs, one above the other, and the ventral side with two larger spurs, each of which is minutely bifureate at its extremity. Second lateral lobe long and narrow, with a club-shaped extremity, marked by three minute points on the dorsal and two on the ventral side. Third lateral lobe minute, narrowly linear, and perfectly simple. Fourth lobe barely perceptible as a slight indentation. First sinus consisting of three nearly equal, cordiform divisions, separated by secondary lobes, the first long, narrow, and simple; the second larger, narrow, and clavate, with four minute terminal teeth. Second sinus 
consisting of two divisions, the first cordiform and the second simple and rounded. Third sinus composed of two parts, both slightly flattened on their upper surface. Fourth sinus simple, with a slight indentation at the middle. The sinuses are all broad and the lobes very narrow. Siphuncle not observed.

This species is a well marked and easily distinguished form among the fossils of this region, and appears to be quite abundant at some localities. It is very closely related to $S$. aqualis Sow., and not readily distinguishable from it, except in the form of the aperture, which in that one seems to be bordered by a thickened margin, while in this one it is contracted to about two-thirds the size of the shell, with the edge rather thin, or thickened very slightly only on the inner surface. The shell is quite variable in size at different localities, but appears to retain the full, ventricose form of the volutions and other specific features to quite a remarkable degree.

Formation and locality.-In Lower Cretaceous shales at the outer edge of Camp Jenney, east fork of Beaver Creek, Black Hills, Wyoming.

\section{SCAPHITES WYOMINGENSIS.}

Plate 13, figs. 5-7.

Scaphites warreni var. wyomingensis M. \& H., Pal. U. S. Geol. Surv. Terr., p. 421, figs. 61,62 .

The shells of this species closely resemble those of $S$. warreni M. \& $H$. in many of their features, but differ very materially in the general form and proportion, as seen in the specimens from the Black Hills localities. They are always much smaller, and the volutions are laterally compressed, so that their relative diameters are scarcely more than as two to three, as seen on the involute parts, but widen rapidly on the deflected and recurved parts, so that near the aperture the lateral diameter is greater than the dorso-ventral. The deflected portion is also always proportionally longer than in that one, the surface marking very much finer, and those on the straight portions have a more strongly forward curvature. The septa have the same general character as in $S$. warreni, but the digitations of the lobes are smaller and less distinct, presenting about the same features in the extreme adult shell as is possessed by the septa of the rep- 
ceding volution of that species; giving to these a very immature aspect The finer character of the costa of this species depends in a great degree upon the smaller size of the shell, as there are about the same number of small costæ between each of the stronger ones; but there are also one or two more of the stronger folds on this species, on the deflected portion of the shell, than in that one.

The principal differences, therefore, between the two shells, and those which we deem to be of specific importanice, are, the greater length of the deflected part, the laterally compressed form of the volution, and the different direction of the costæ on the straight part of the shell. The two forms are associated at the same localities, and even occur in the same-hand specimen of rock; but we think there is no difficulty in distinguishing them. The examples before us present strong variations and points of difference, when compared with the figures of the variety given by Mr. Meek (Paleontology of the United States Geological Survey of the Territories, page 421, Figs. 61,62 ), especially in the straightness of the deflected portion and in the more compressed form of the volution; in fact these variations from his figures are so great, that we were in doubt of the correctness of the identification, until we submitted an example to the author's inspecion, by whom they were pronounced positively identical. We are of the opinion, however, that they are specifically distinct from S. warreni, and have so classified them.

Formation and locality.-In shales and limestones of the Cretaceous, on the Belle Fourche, and on the east fork of Beaver Creek, Black Hills. Probably of the Fort Benton Group.

\section{GeNus HELICOCERAS D'Orb.}

\section{HELICOCERAS STEVENSONI.*}

Plate 14, figs. 5-8.

Helicoceras Stevensoni Whitf., Prelim. Rept. Pal. Black Hills, 1877, p. 39.

Shell large and robust, with an elevated, moderately tapering spire, which is composed of strong, cylindrical, disconnected, dextrally-coiled

*Named in honor of Prof. John J. Stevenson, of New York City, the eminent geologist, who has" done so much good work among the Cretaceous rocks of the West. 
volutious, sharply enrolled and leaving an umbilical opening equal to or a little greater than one-half the diameter of the volution encircling it. The volutions are at first widely disconnected and rapidly descending, but become more closely coiled below, and in the lower part of the example figured are but slightly disconnected.

Surface of the shell marked by strong, rounded, annulating costæ, passing entirely around the shell, and separated by wider concave interspaces. On the upper surface of the volution the costæ are strongly directed backward, but are recurved, and on the outer face are directed gently forward below and within the umbilicus. The costæ are further ornamented by two irregular rows of strong, obliquely-rounded, tuberculose nodes; the upper range being situated along the middle of the volution, and the other half way between it and the center of the basal surface. The nodes of the two ranges, although usually placed on the same costa, are not constantly so, but frequently alternate, and in very many cases two of the costæ unite at the lower node, continuing only as one on the lower side of the volution.

Septa rather distantly arranged, leaving considerable space between them, the convolutions of a single septum occupying a space on the periphery of the shell equal to from two-thirds to three-fourths of the diameter of the volution at the point examined. Siphonal lobe longer than wide, and deeply divided at the extremity into two principal branches, each of which is again deeply divided, and the divisions furnished with numerous serrated digitations. First lateral lobe very large and unequally divided into two principal branches, the outer one of which is the largest, and each is again divided and furnished with numerous compound digitations. The second lateral lobe is much smaller than the first and similarly divided, but the divisions are smaller and less complicated (the inner half of this lobe has not been distinetly traced). First lateral sinus rather large and deeply cleft in the middle by an auxiliary lobe, the lower end of which is divided into several digitations. Second lateral sinus shorter and comparatively more spreading than the first, and also deeply divided in the middle by a simple auxiliary lobe, having four spurs on each side. Other lobes and sinuses not observed. Siphuncle rather small, marginal, and passing along the middle of the volution. 
This species would appear, without critical examination, to be somewhat closely related to Heteroceras? angulatum M. \& H. (Palentology of the United States Geological Survey of the Territories, p 484, Pl. 21, Fig. 3), more especially as their species is stated to be "dextral (?)", and their figures, being placed base upward-which may be seen by the position of the nodes-are liable to mislead; but if critically examined will be found, from the direction of the costr, to belong to a sinistral shell, as they incline in an opposite direction to those of a dextral shell. Mr. Meek states, loc. cit., that the fragment figured is supposed to be from the deflected part of the shell, and for this reason is placed provisionally, with doubt, under the genus Heteroceras. It is, perhaps, impossible for one to feel positive that a shell of this group has not been or would not be deflected at some period of growth, unless a perfect adult individual is obtained. Our shell figured shows no evidence whatever of any tendency to become deflected; still it is known to be imperfect, as it is septate to within an inch of the outer extremity, and we cannot, therefore, feel positive of its true generic relations. The upper part of the spire has, however, been very loosely coiled, or widely disconnected, becoming more compact with increased growth; in this respect being the reverse of shells belonging to the genus Heteroceras. Owing to this feature, and the absence of any evidence of the generically required deflection in the adult stages, we have considered it most natural to refer it to Helicoceras.

Formation and locality.-In limestone of the Fort Pierré Group, on the west side of Beaver Creek, Black Hills.

\section{Genus HETEROCERAS D'Orb.}

\section{HETEROCERAS NEWTONI.}

Plate 15, figs. 1-4.

Heteroceras Newtoni Whitf., Prelim. Rept. Pal. Black Hills, 1877, p. 40.

Shell dextral, of moderate size, composed of from two and a half to three loosely coiled, disconnected, and rather rapidly-increasing volutions, forming the rather low but somewhat rapidly-spreading spire, below which point the shell is deflected to an unknown extent; transverse section of the shell circular, or nearly so; umbilicus very wide in the upper part of the 29 в н 
spire, but scarcely increasing in diameter with the increased growth of the shell above the deflected portion, the increased diameter of the tube about equaling the increased diameter of the whorl.

Surface of the shell ornamented by low, subangular, transverse ridges or costæ, which pass entirely around the shell, and are separated by wider concave interspaces; also by two longitudinal rows of obliquely rounded nodes, the upper one of which is placed at or just below the periphery, and the other at about one-eighth of the circumference of the tube below the first, and on the line of the same ridge with it. Transverse costæ arranged in sets of three, two of each set coalescing to form the oblique nodes, the third one passing around the tube, without interruption, midway between the two adjacent pairs of nodes. The direction of the costæ is strongly backward on the upper inner surface of the volution, then recurving and passing obliquely forward in crossing the outer face of the shell from above to the base, and also within the umbilicus; siphuncle small, marginal, situated as far above the upper line of nodes as the distance between the two lines.

Septa approximate, the extremities of the lobes of one slightly interfering with those of the saddles of the next adjacent, but not interlocking; the space occupied by the convolutions of the lobes and sinuses of a septum is equal to three-fifths of the diameter of the tube at the position of the septum measured; the ramifications of the lobes are sharply angular and pointed. The siphonal lobe is longer than wide, deeply divided at the extremity into two rather long, compound, digitate processes, and a short, bifid, median process. First lateral lobe very deeply and unequally divided, and the branches widely spreading, and deeply serrate-digitate; second lateral lobe very much smaller than the first, and less spreading; antisiphonal lobe single, longer than wide, deeply digitate on the side, and divided into four small, unequal digitations at the extremity; sinuses large, spreading, and deeply cleft by auxiliary or secondary lobes.

The type specimen of the species is imperfect, but preserves one and one-third volutions; the volutions are entirely disconnected, and increase rapidly in size, while the umbilicus retains the same diameter, the upper volutions appearing to have been not more closely coiled than those pre- 
served. The outer extremity of the specimen retains a part of the deflected portion, which is bent downward as well as outward, and is septate nearly to the end. The species appears to be related to $H$. ? nebracensis $\mathrm{M}$. \& $\mathrm{H}$. (Paleontology of the United States Geological Surrey of the Territories, p. 480, Pl. 22, Fig. 1, $a, b, c$ ), but differs, however, in the more rapidlyincreasing volutions, in the disconnected whorls, simple costæ (i.e., not bifurcating), in the position of the siphuncle, and in the details of the lobes and sinuses.

Formation and locality.-In limestones of the Fort Pierré Group, on the west side of Beaver Creek, Black Hills.

\section{HETEROCERAS ? NEBRASCENSE.}

Plate 15, fig. 6, and Plate 14, fig. 9.

Ancyloceras? nebrascense M. \& H., Proc. Acad. Nat. Sci. Phil., vol. viii, p. 71. Turrilites nebrascense M. \& H., ibid., p. 280.

Helicoceras? nebrascense Meek, Smithsonian Cheek Llist Invert. Foss., p. 25.

Heteroceras? nebrascense Meek, Pal. U. S. Geol. Surr. Terr., p. 480, PI. 22, fig. 4.

Shell moderately large and robust, with a low, rapidly-contracting, dextrally-coiled spire, having an apicial angle of about $50^{\circ}$, and composed of a small number of rapidly-increasing volutions, which are in close contact with each other, as far as observed in the example figured, and coiled so as to leave an umbilical opening of large size in the upper portion of the spire, which apparently increases but little in diameter with the increased growtl of the shell. Transverse section of the volutions circular or nearly so. Surface of the shell ornamented by strong, subangular, transverse ridges or costæ, which pass entirely around the shell and are divided by concave interspaces. The costæ on the smaller volution of the specimen are often duplicate, and cross the face of the volution with a strong forward direction in passing from above to the lower side, but are directed strongly backward from within the umbilicus on the upper surface. On the larger volution the costæ are usually simple, but sometimes bifurcate, and pass more directly across the shell. The costæ are ornamented by two irregular rows of strong, rounded nodes on the older parts, situated one near the periphery and the other just above the base of the volution. 
The septa are arranged at considerable distance from each other, leaving an open space between. The convolutions of the lobes and sinuses are very complicated, and are divided and branched much as in other species of the group from the same locality. The details of their structure may be seen by reference to the diagram on the plate. Siphuncle of moderate size and situated just above the middle of the volution

The species differs from either of the related forms here described in the proportional elevation of the spire and the compactly-coiled volutions, being much less elevated than Helicoceras stevensoni, and more elevated than Heteroceras newtoni. The tube also increases more gradually than that of the latter species, and forms a smaller umbilical opening. They also differ materially in the details of the septa. The specimen figured, as far as preserved, shows no evidence of the deflection of the outer volution; but the compact volutions would seem to indicate relations with Heteroceras rather than with Helicoceras.

Formation and locality.-In limestone on the west side of the east fork of Beaver Creek, Black Hills ; supposed to belong to the Fort Pierré Group of the Cretaceous section, but which also contains a mingling of forms of No. 5 of the same section.

\section{Genus ANCYLOCERAS D'Orb.}

\section{ANUYLOCERAS JENNEYI.}

Plate 16, figs. $7-9$.

Ancyloceras Jenneyi Whitf., Prelim. Rept. Pal. Black Hills, 1877, p. 42.

Shell of moderate size, composed of two or more (?) rapidly-increasing volutions, enrolled on the same plane, and entirely disconnected, the inner ones apparently leaving a broad, open, umbilical space. Shell rather rapidly increasing in size with increased age. Volutions slightly flattened on the back, vertically compressed, and transversely oval in section; the vertical diameter being only about two-thirds as great as the dorso-ventral in the larger parts of the shell, the greatest height being nearest to the ventral margin. 
Surface of the shell marked by strong, distant, transverse, encircling ridges, which are directed slightly forward in passing from the dorsal to the ventral margin, and in crossing the latter they become nearly obsolete. Occasional intercalated ridges occur at irregular distances on the dorsal side. Intercostal spaces concave. The shell is further ornamented by two lines of obtusely-rounded nodes, which are situated on the ribs at the angles of the flattened dorsum.

Septa somewhat complicated and closely arranged, so that the inner lobes interfere with the extremities of the sinuses of the preceding ones, but on the dorsal portion they are more distant. Siphonal lobe longer than wide, deeply divided at the extremity, and terminating in two large, strongly-serrated digitations, having one or two lateral spurs on their outer sides. First lateral lobe large, deeply bipartite, each branch terminating in two or three unequal digitations, and with several smaller spurs on the sides above. Second lateral lobe much smaller than the first, deeply bipartite, with numerous strong spurs irregularly arranged along the margins. Antisiphonal lobe long, narrow, and simple, but with long lateral serrated spurs and a slightly tripartite extremity. First and second sinuosities rather large, deeply divided by large auxiliary lobes into two principal branches, which are again deeply divided. Third sinus smaller than the others, and divided into two principal branches. The margins of all lobes and sinuses deeply serrated.

The species is described from an imperfect individual and a second smaller fragment of a larger specimen. They consist only of the convolute parts, and show no evidence of the deflection of the tube. It is possible they are not rightly referred to the genus Ancyloceras, but are more nearly related to the genus Anisoceras of Pectet, which differs from the former genus in being irregularly helicoid. The example figured of Plate 16, Figs. 7-9, would seem to have been somewhat irregularly coiled, but this may possibly be the effect of distortion, as the smaller coils of the shell are considerably displaced. It differs from Ancyloceras also, as defined by Mr. F. B. Meek (Paleontology of the United States Geological Survey of the Territories, p. 409), in having the terminations of the lobes bipartite instead 
of tripartite; but this character does not appear to hold good among many of those referred to the genus; and, as we have not seen the septa of the type species, we are uncertain if it is an original feature of the genus or only an erroneously added one.

Formation and locality.-In limestone referred to the Fort Pierré Group of the Upper Missouri Cretaceous, on the east fork of Beaver Creek, three miles west of Camp Jenney, Black Hills.

\section{ANCYLOCERAS TRICOSTATUS.}

Plate 15, figs. 7, 8 .

Ancyloceras tricostatus Whitf., Prelim. Rept. Pal. Black Hills, 1877, p. 43.

A single fragment of a sinistrally helicoid shell, the volutions of which have been entirely separate and coiled upon the same plane, with a rapidlyincreasing curvature, appears to possess features entirely distinct from those of any described species. The form of the volution has been quadrangularly ovate in section, vertically compressed, with the greatest vertical thickness at about the inner third of the width, and slightly flattened on the dorsum. The shell is marked by a line of strong angular nodes on each dorsal angle, and by closely-arranged subangular encircling ridges or costa, which are directed slightly forward in crossing from the ventral to the dorsal margin on the upper side of the volution, and much more strongly so in crossing from the upper to the lower side of the dorsal flattening, and are recurved below and on the umbilical surface. The costæ are arranged in sets of three, the two adjacent ones of which unite in the nodes on the upper and lower dorsal angles, while the third ridge of each set encircles the shell between the nodes of two adjacent sets. Intercostal spaces concave.

Septa very complicated and distant, the spaces between two adjacent ones equal to about one-third of the space occupied by the convolutions of a single septum at the point indicated. The dorsal lobe is almost twice as long as wide, deeply divided at the lower extremity by a broad, tridentate sinus, each division being again divided into two widely-divergent dentate 
branches. There are also two lateral dentate spurs above on each side of the lobe. First lateral lobe large but slender, divided into two principal widely-divergent branches, each of which is again divided, and furnished with several strong dentate spurs on their margins; two other spurs of similar character exist on each side of the lobe, one just below the bifurcation and the other some distance above. Second lateral lobe smaller than the first, deeply divided, with the branches less divergent, but again divided, and the inner branches trifurcate, the outer branches short and strongly dentate. Antisiphonal lobe small and simple, marked by one small spur on each side above and two larger curved and dentate ones below; the central termination being minutely tridendate at its extremity. First lateral sinus large, very deeply divided into two principal branches, each of which is deeply divided above and strongly lobed on the sides. Second sinus smaller, less deeply and unequally divided, the outer half smallest and deeply lobed, the other less deeply so. Antisiphonal sinus very large (considering the parts separated by the antisiphonal lobe as one sinus), the antisiphonal lobe dividing it nearly to the base, and the divisions again very deeply divided and deeply lobed on the sides. Siphuncle small, situated between the lines of nodes and marginal.

This species differs from Ancyloceras Jennyi, in being sinistrally coiled, and in the character of the ridges of the surface and angular nodes. We know of no other species described with which it is enough related to require a comparison.

Formation and locality.-In limestone at the top of the Fort Pierré Group, on the Cheyenne, near French Creek, Black Hills.

\section{Genus PTYCHOCERAS D'Orb.}

In his remarks on the genus Ptychoceras (Paleontology of the United States Geological Survey of the Territories, p. 410), Mr. F. B. Meek has advanced the opinion that these shells have possibly been folded upon themselves a second time in their more advanced stages of growth, as in the case of Diptychoceras Gabb; or that they may have even been bent backward again, as is supposed to have been the case in the genus Soleno- 
CEnas Conrad (Hamulus annulifer Mort.). We have in this collection quite a number of individuals of the species herein described under the name $P$. meekamum, several of which show the prolonged curved portion of the smaller limb, and two individvals of $P$. crassum; but all the evidence furnished by these specimens is of a character opposed to either of these suppositions. The peculiar bending of the smaller limb of the first of these species would seem to preclude the probability of the larger part of the shell following the curvature of the earlier and returning over its extremity so as to infold it; while the assumption of old age characters in the contraction of the distance between the rings, as seen on several of them near the end of the tube, would seem to indicate that neither of these theories is correct; but that the shell is essentially complete at about this stage of growth. Beyond this, among all the individuals of these two species observed, none of them are septate beyond the commencement of the fold, and at this point the septa are more crowded than below. We are also much inclined to believe that the folding of the siphonal surface of a cephalopod upon itself, after having coiled in the opposite direction, is a feature seldom observed.

Although several of the examples of $P$. meekanum, before us, show the bending of the smaller limb, as seen in the example figured, none of them are perfect at the smaller extremity; so we are still uncertain as to its character or form during the earlier stages of its existence. In the rock, forming the matrix of some of these specimens, we have noticed fragments of a smell Ammonite-like shell, having the same form of section and surface markings with the smaller parts of these, and we have been induced to infer that possibly they may be the earlier portions of the same shell, and that possibly, in its younger stages, it may have been minutely planorbiform; but the fragments are two imperfect to determine the question.

We have also noticed another feature on the larger individual of $P$. crassum (Plate 16, Fig. 3), which we had at first supposed to be the result of accident; but which on further examination we find to be a thickening of the external surface of the shell, and which does not in any way interfere with or affect the septa or the internal portion of the shell. It com- 
mences at the suture between the two limbs, and continues over the outer surface of both, retaining the form of the shell, surface characters, and lines of nodes throughout its entire substance. On the side of the specimen seen in the figure the shell is mostly removed by exfoliation, but on the opposite surface it is retained in great part, and shows a thickness of about a twelfth of an inch at the smaller end, and less than a sixteenth of an inch at the larger extremity of the specimen. If the thickening had been from the inside, it would have affected the inside of the tube and the parts along the junction of the two limbs; but this is seen not to be the case when the shell is broken. From this feature of the external thickening of the shell we have thought it possible that it was an internal appendage of the animal, like that of SPIRula, and that it probably became enveloped within the substance of the mantle at the period at which the bending or folding of the shell took place, even though it may have been external during the earlier stages of growth.

\section{PTYCHOCERAS MEEKANUM.}

Plate 16, figs. 1, 2.

Ptychoceras Meekanum Whitf., Prelim. Rept. Pal. Black Hills, 1877, p. 44.

Shell of small size, subcylindrical or vertically compressed, giving a somewhat oblate-transverse section, very gradually increasing in diameter with the increased length; smaller limb slender, gently curved or bent in the middle of its length, so as to give the earlier and middle portions of the shell an angle of about $135^{\circ}$ to each other. Larger limb, or outer chamber, closely appressed and slightly embracing the smaller, and extending to near the middle of the curvature.

Surface of the entire shell marked by strong, simple, sharply angular, oblique, encircling ridges, with wider, deeply-concave interspaces, very regularly increasing in distance from the apex outward; and on the dorsal region by two longitudinal rows of spines or spiniform tubereles, situated at about or nearly one-sixth of the circumference of the tube from each other, and on the crests of the ridges. The encircling ridges are directed obliquely forward in passing from the ventral to the dorsal surface in the 
smaller limb, but have the opposite direction on the larger limb; space between the lines of nodes very gently concave.

Septa approximate, but more distant than the surface ridges of the shell, deeply lobed and the lobes and sinuses somewhat complicated. The dorsal or siphonal lobes are nearly as wide as long, broadly forked at the extremity, and the outer side of the forks marked by several short, rounded digitations. First lateral lobe divided into two diverging branches, with lobed margins. Second lateral lobe narrower and more slender than the first, and more deeply forked; the divisions being marked by short, rounded digitations. Ventral, or antisiphonal lobe small, but deeply forked, and the margins sinuous. Sinuses nearly equal in size, each of them deeply divided in the middle by an auxiliary lobe; slightly bifid in the first and second sinus, but simple in the third; division of the sinuses, marked by short, rounded digitations. Siphon of moderate size, marginal and placed between the lines of nodes.

Before entering upon a critical study of the specimens before us, we had supposed them to be identical with Ptychoceras mortoni M. \& H, and hesitated to consider them as distinet; but there are so many points of difference, and the variations are so great, that it appears impossible to avoid this conclusion, and equally difficult to unite the two forms here mentioned. More especially is this the case if any reliance is to be placed on the structure and lobation of the septa. We are quite well aware that this latter feature is one liable to great variation, dependent upon the growth of the individual; but the lobations in the septa at the smaller extremity of the specimen figured is much more complicated than that shown by Mr. Meek to exist in the type specimen of $P$. mortoni. Besides the difference in the septa, the form of the tube varies in being wider than high, the reverse of that species, and the antisiphonal surface of the tube is always flattened, and the costa always simple.

Formation and locality.-In limestone of the Fort Pierré Group, on Beaver Creek, Bỉack Hills. 


\section{PTYCHOCERAS CRASSUM.}

Plate 16, figs. 3-5.

Ptychoceras crassum Whitf., Prelim. Rept. Pal. Black Hills, 1877, p. 45.

Entire form of shell unknown. The portion preserved is rather robust in habit and the shell much thickened, except on the ventral surfaces. Transverse section subcylindrical or slightly compressed in a dorso-ventral direction, the larger limb being concave on the ventral side and slightly embracing the smaller part. Tube regularly increasing in diameter with increased growth. Shell ornamented by strong, sharply angular, encircling ridges, which are directed forward in passing from the ventral to the dorsal sides of the smaller limb, but have the opposite direction on the larger part; also by two longitudinal lines of pointed nodes, or spines, on the dorsum, which are separated by a moderately wide, slightly concave space.

Septa distant, one septum nearly equaling two of the transverse ridges, except near the bending of the tube, where there are two of the septa placed nearer to each other, beyond which the shell is not septate. Lobes and sinuses of the septa somewhat complicated; the siphonal lobe longer than wide, and broadly forked at the extremity First lateral lobe large, divided into two principal branches, the outer one being again deeply divided and the margins of the branches serrato-digitate. Second lateral lobe smaller than the first, divided into three short serrate digitations. Antisiphonal lobe small and simple, marked only by two short digitations on each side. First and second sinuses much larger and broader than the lobes, deeply divided in the middle by a small serrated auxiliary lobe, and the divisions each again divided and serrate. Antisiphonal șinus a little smaller than the others, but more deeply divided by the antisiphonal lobe, and the branches again deeply divided. All the margins of the lobes and sinuses are characterized by small rounded serrations. Siphuncle of moderate size, marginal, and situated between the lines of nodes.

The distinction between this and the preceding species, consists in its large size, more robust habit, and thicker shell, and in the more distant and much more complicated septa. It is still further removed by these characters from $P$. mortoni $\mathrm{M} \& \mathrm{H}$., as well as by the simple ridges.

Formation and locality.-In limestone of the Fort Pierré Group, on Old Woman Fork, Black Hills. 


\section{S E C T I O N V. \\ SYNOPSIS OF SPECIES FROM THE BLACK HILLS, NOTICED \\ IN OTHER WOIKS, NOT DESCRIBED IN THIS REPORT. \\ POTSDAM SPECIES.}

Lingulepis prima (Conrad) Meek.

Mr. Meek recognizes a form under this name from the central parts of the Black Hills, in the Paleontology of the Upper Missouri (Smithsonian contribution), p. 3, Pl. 1, Fig. 2.

Hyolithes gregaria $=$ Theca gregaria M. \& H.

Mr. Meek gives this species as from the Big Horn Mountains (Paleontology of the Upper Missouri, p. 5), and we remember having seen remains of a similar or identical form in the collection of Colonel Ludlow's expedition of 1874 .

Agranlos? - sp. ?, in Pal. Up. Missouri, p. 10.

Mr. Meek cites a species as above from the sandstones of the central Black Hills.

\section{JURASSIU SPEOIES.}

Ostrea englemanni Meek, Pal. Up. Missouri, p. 73.

A single imperfect valve of this species too poor for use occurs among the fossils from southeast of Warren Peak, in the Redwater Valley.

Trigonia conradi M. \& H., Pal. Up. Ilissouri, p. 83, Pl. 3, fig. 11.

Southwest base of Black Hills, in Lower Jurassic

Unio nucalis M. \& H., Pal. Up. Missouri, p. 92, Pl. 3, fig. 13.

In Jurassic rocks, southwest base of Black Hills.

Astarte inornata M. \& H., Pal. Up. Missouri, p. 94, Pl. 3, fig. 12.

Southwest base of Black Hills, in Jurassic rocks.

Tancredia? aquilateralis M. \& H., Pal. Up. Missouri, p. 96, Pl. 3, fig. 8.

In Jurassic beds, southwest base of Black Hills. 
Protocurdium shumardi, M. \& H., Pal. Up. Missouri, p. 98, figs. $a$ and $b$.

Southwest base of Black Hills, in Jurassic rocks.

Myacites (Pleuromya) nebrascensis and M. (P.) subellipticus M. \& H.

Are both cited as occurring at the southwest base of the Black Hills (Paleontology of the Upper Missouri, pp. 100-101), but we have not been able to identify either of them among the collections.

Thracia? arcuata M. \& H., Pal. Up. Missouri, p. 102, Pl. 4, fig. 8.

From near the middle of the Jurassic, at the southwest base of the Black Hills.

Pholadomya humilis M. \& H., Pal. Up. Missouri, p. 104, Pl. 4, fig. 3.

Lower part of Jurassic, southwest base of Black Hills.

Planorbis veturnus M. \& H., Pal. Up. Missouri, p. 107, Pl. 4, fig. 1.

Southwest base of Black Hills.

Valvata? scabrida M. \& H., Pal. Up. Missouri, p. 113, Pl. 4, fig. 2.

Southwest base of Black Hills, in Jurassic rocks.

Viviparus gilli Meek, Pal. Up. Missouri, p. 115, Pl. 4, fig. 3.

Southwest base of Black Hills.

Lioplacodus veternus M. \&. H., Pal. Up. Missouri, p. 116, with figs.

Southwest base of Black Hills and head of Wind River.

Ammonites henryi M. \& H., Pal. Up. Missouri, p. 123, Pl. 4, fig. 9.

Southwest base of Black Hills.

Scrpula _ sp. ?, Pal. Up. Missouri, p. 128.

Southwest base of Black Hills, lower part of Jurassic.

CRETACEOUS SPECIES.

Websteria cretacea Meek, Pal. U. S. Geol. Surv. Terr., p. 3, Pl. 28, fig. 3.

A small coralline-like body from the Fox Hills Group of the south fork of the Cheyenne River. 
Terebratula helena Whitf., Rept. of a Reconnaissance of the Black Hills of Dakota, by Lieut. Col. Ludlow, p. 103, Pl. —, figs. 5-10.

A large species, related to $T$. harlani Mort. From No. 4, northeast Black Hills, north of Belle Fourche.

Ostrea congesta Courad.

Abundant on the Cheyenne River, near the Black Hills, Niobrara Group.

Gryphcea vesicularis Lam.

Mr. F. B. Meek cites this species with doubt as from the Fort Pierré Group, on the Cheyenne River, near the Black Hills.

Nucula subnasuta H. \& M., Mem. Bost. Acad. Arts and Sci., 1856, = Yoldia subnasuta Meek, Check List Smith. Inst., p. 8.

Sage Creek, upper part of No. 4.

Yoldia ventricos $a=$ Nucula ventricosa H. \& M., Mem. Acad. Arts and Sci., new ser., vol. v, p. 385, Pl. 1, fig. 11

Sage Creek, Fort Pierré Group.

Caprinella coraloidea H. \& M., Mem. Bost. Acad. Arts and Sci., 1856, p. 380, Pl. i, fig. 3, $=$ Icthyosarcolithus coraloidea (Gabb.) Meek, in Check List Smith. Inst. Cret. Foss., p. 5.

In upper part of No. 4, Sage Creek.

Sphariola? warrenana Meek, Pal. U. S. Geol. Surv. Terr., p. 138.

A species nearly related to $S$. transversa, herein described. From the Fox Hills Group, near the eastern base of the Black Hills.

Callista (Dosiniopsis) nebrascensis M. \& H. = Callista nebrascensis M. \& H. $=$ C. deweyi var. robusta M. \& H., and Dione nebrascensis Meek. See Pal. U. S. Geol. Surv. Terr., p. 184, figs. 15-17.

A species closely related to $C$. deweyi Fort Pierré Group, Cheyenne River, Black Hills.

Callista (Aphiodina ?) tenuis (H. \& M.) Meek, Pal. U. S. Geol. Surv. Terr., p. 188, =Cytherea temuis H. \& M. = Meretrix tenuis M. \& H., also Dione? tenuis Meek.

South fork, Cheyenne River, Black Hills, Fort Union Group. 
Tellina (Peroncea ?) scitula M. \& H. (= Tellina scitula M. \& H.), Pal. U. S. Geol. Surv. Terr., p. 197, Pl. 30, fig. 1.

South branch of the Cheyenne River, Fox Hills beds.

Actoon subellipticus M. \& H., Pal. U. S. Geol. Surv. Terr., p. 280, Pl. 19, fig. 16, = Solidula (Actconina?) subelliptica M. \& H.

Crow Creek, near Black Hills, in the Fort Pierré Group.

Cinutia (Oligoptychia) concinna (H. \& M., sp.) Meek, Pal. U. S. Geol. Surv. Terr., p. 284, = Actceon concinnus H. \& M.; Avellana concinna Meek; Avellana subglobosa M. \& H.

Sage Creek, Black Hills, Fort Pierré Group.

Acmae occidentalis (H. \& M., sp.) Meek, Pal. U. S. Geol. Surv. Terr., p. 295, = Capulus occidentalis H. \& M.; Tectura? occidentalis. M. \& H.

Sage Creek, Black Hills, Fort Pierré Group.

Margaritella flexistriata (E. \& S., sp.) Meek, Pal. U. S. Geol. Surv. Terr., p. 302, PI. 19, fig. $\mathrm{H},=$ Solarium flexistriatum E. \& S.; Margaritella flexistriata M. \& H.

Sage Creek, Black Hills, Fort Pierré Group.

Closteriscus tenuilineatus (H. \& M., sp.) Meek, Pal. U. S. Geol. Surv. Terr., p. 308, Pl. 19, fig. 10, =Fusus ? tenuilineatus H. \& M. and Tritonifusus? tenuilineatus Meek.

Sage Creek, Black Hills, Fort Pierré Group.

Gyrodes conradi Meek, Pal. U. S. Geol. Surv. Terr., p. 310, figs. 33-36.

Cheyenne River, Fort Pierré Group.

Odontobasis constricta (H. \& M., sp.) Meek, Pal. U. S. Geol. Surv. Terr., pp. 352, 353, figs. 41,42 , =Fusus constrictus H. \& M. and Buceinum? constrictum M. \& H.

Sage Creek, Black Hills, Fort Pierré Group.

Odontobasis ventriosa Meek, Pal. U. S. Geol. Surv. Terr., p. 354, fig. 43, Pl. 19, fig. 1.

Near mouth of Sage Creek, Black Hills, Fort Pierré Group.

Baculites compressus Say, Am. Jour. Sci. and Arts, vol. ii, p. 41, 1821.

Abundant at Sage Creek and Great Bend of the Missouri. 
Baculites ovatus Say, Am. Jour. Sci. and Arts, vol. ii, p. 41, 1821.

Sage Creek and other places in the Black Hills, Fort Pierré Group. This and the above species are represented by numerous fragments in the collection, but it has been thought not desirable to illustrate either of the species, as they have been so frequently given by others.

Baculites grandis H. \& M., Mem. Am. Acad. Arts and Sei., vol. v, n. ser., p. 402, Pl. 7, fig. 1.

Cheyenne River, Black Hills, Fort Pierré Group.

Baculites aspera Morton, Synop. Org. Rem. Cret. Group U. S., p. 43, Pl. 1, figs. 12, 13.

A few fragments are present in the collection from the Fox Hills beds at the eastern base of the Black Hills.

Ancyloceras uncum (M. \& H.) Meek, Pal. U. S. Geol. Surv. Terr., p. 409, Pl. 21, fig. 1, $=$ Ancyloceras (Hamites) uncum M. \& H.

South fork Cheyenne River, Black Hills, Fort Pierré Group.

Scaphites larvaformis M. \& H., Proc. Acad. Nat. Sei. Phil., viii, 58; Meek, Pal. U. S. Geol. Surv. Terr., p. 418, Pl. 6, fig. 6.

Eastern base of Black Hills, Fort Benton Group.

Scaphites conradi (Morton) Meek, Pal. U. S. Geol. Surv. Terr., p. 430, Pl. 36, fig. 2, = Ammonites conradi Morton; ? Scaphites pulcherrimus Rœmer; Ammonites danc D'Orb.; and Ammonites nebracensis Owen.

Eastern base of Black Hills, Fox Hills Group.

Placenticeras placenta (=Ammonites placenta De Kay and others), see Pal. U. S. Geol. Surv. Terr., p. 465, Pl. 24, fig. 2.

This species is well represented in the collection by some large individuals from the Black Hills, in bed No. 4.

Heteroceras? angulatum (M. \& H.) Meek, Pal. U. S. Geol. Surv. Terr., p.484, PI. 21, fig. $3,=$ Helicoceras angulatum M. \& H.

Head of south branch of the Cheyenne River, Black Hills, Fort Pierré Group. 
SECTION VI.

LIST OF FOSSILS DESCRIBED IN THIS REPORT. POTSDAM GROUP.

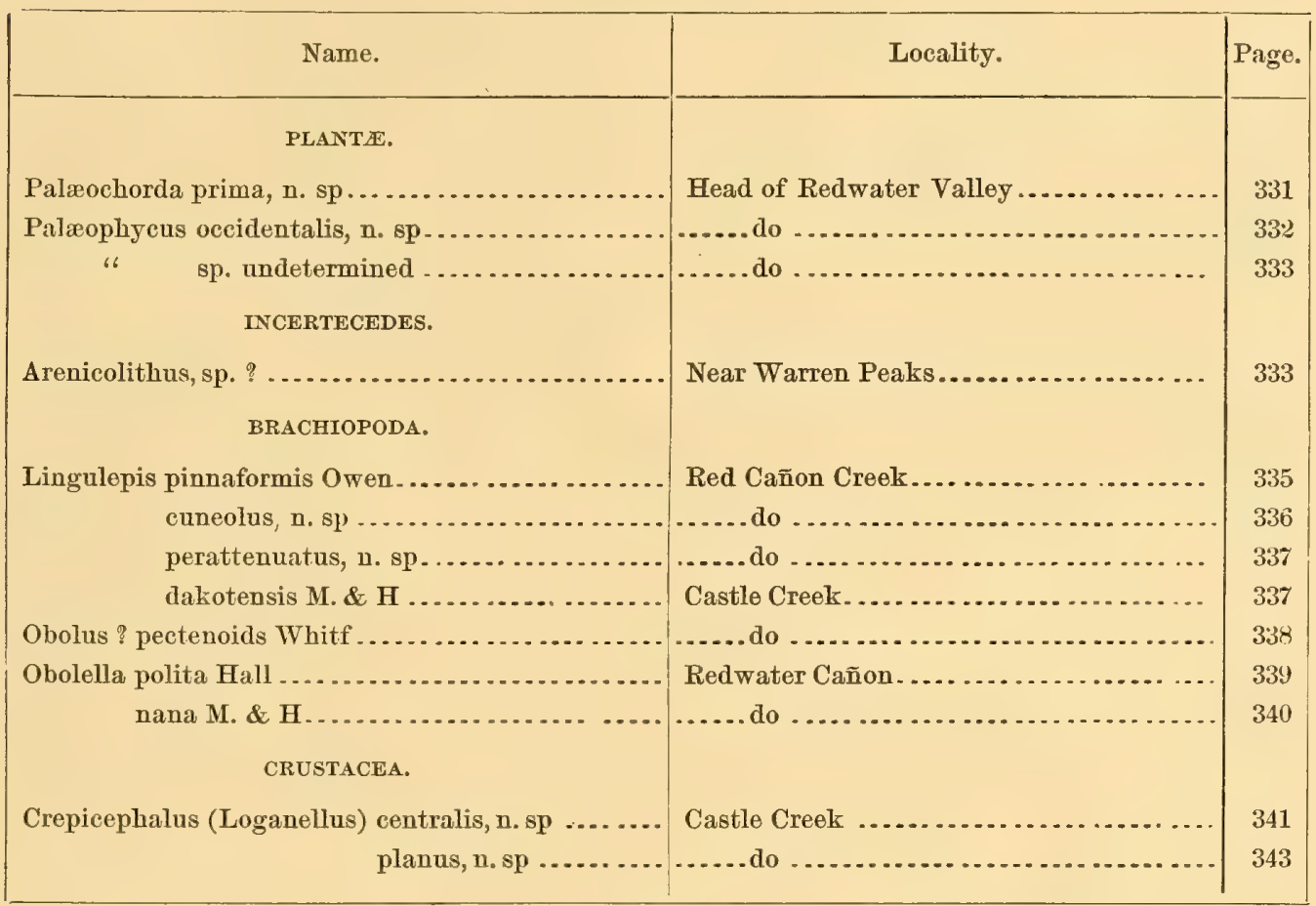

JURASSIC.

\begin{tabular}{|c|c|c|}
\hline RADIATA. & & \\
\hline Asterias ? dubium, $\mathrm{n} . \mathrm{sp}$. . . . . . . . . . . . . . . & 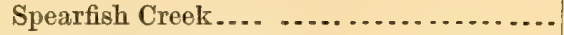 & 344 \\
\hline 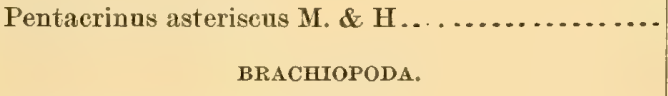 & Big Horn Mountains .................... & 345 \\
\hline Lingula brevirostris M. \& H.................. & Spearfish Creek..................... & 346 \\
\hline $\begin{array}{l}\text { Rhynchonella myrina } H . \text { \& } \mathbf{M} \ldots \ldots \ldots \ldots . . . . . . . . . \\
\text { LAMELLIBRANCHIATA. }\end{array}$ & Red Cañon Creek .................. & 347 \\
\hline Ostrea strigilecula White..................... & $\begin{array}{l}\text { Belle Fourche River, Sun Dance Hills, and } \\
\text { near Beaver Creek. }\end{array}$ & 348 \\
\hline Gryphra calceola var. nebrascensis M. \& H...... & Big Horn Mountains ..................... . & 349 \\
\hline 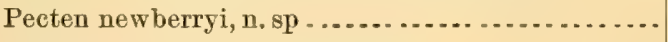 & West of the Black Hills........ & 350 \\
\hline Camptonectes bellistriata Meek.................. & (September 12 and 20 ) & 351 \\
\hline extenuatus M. \& H . & East of the Belle Fourche................ & 353 \\
\hline
\end{tabular}

30 В $\mathrm{H}$ 


\begin{tabular}{|c|c|c|}
\hline Name. & Locality. & Page. \\
\hline LAMELLIBRANCHIATA-Continued. & & \\
\hline $\begin{array}{r}\text { Pseudomonotis (Eumicrotis) curta Hall ........... } \\
\text { orbiculata, n. sp ...... }\end{array}$ & $\begin{array}{l}\text { Two miles south of the Belle Fourche, \&c.. } \\
\text { (September 19)* .............................. }\end{array}$ & $\begin{array}{l}354 \\
356\end{array}$ \\
\hline Avicula (Oxytoma) mucronata M. \& H ..... ...... & Two miles south of the Belle Fourche .... & 357 \\
\hline Gervillia recta Meek, in MS ...................... & Sun Dance Hills ....................... & 358 \\
\hline Grammatodon inornatus M. \& H............... & Locality label not legible ............... & 359 \\
\hline 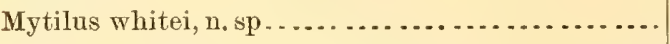 & Sun Dance Hills ...................... & 360 \\
\hline Volsella (Modiola) formosa M. \& H .............. & Big Horn Mountains . ................ & 361 \\
\hline pertenuis M. \& H.. & $(\text { September } 20)^{*}$........... & 362 \\
\hline Astarte fragilis M. \& H.............. . & Redwater Valley .......................... & 363 \\
\hline 'Trapezium bellefourchensis, $\mathrm{n} . \mathrm{sp}$..... & East of the Belle Fourche ............. & 364 \\
\hline subequalis, n. sp ......... & Red Cañon Creek ....................... & 365 \\
\hline Pleuromya newtoni, n. sp . ............... & Two miles south of the Belle Fourche. & 367 \\
\hline Tancredia (?) inornata M, \& H ........ & East of the Belle Fourche ......... & 368 \\
\hline corbuliformis, $\mathrm{n} . \mathrm{sp} . . . . . .$. . & ...... do ..................... & 370 \\
\hline bulbosa, $\mathrm{n}, \mathrm{sp} \ldots \ldots . . .$. & 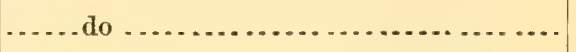 & 370 \\
\hline postica, n. sp. ......... & ...... do.......... & 371 \\
\hline warrenana $\mathrm{M} . \& \mathrm{H} . . . . .$. & Redwater Valley ................. & 372 \\
\hline Dosinia jurassica, n. sp................ & East of the Belle Fourche, \&c........... & 373 \\
\hline Psammobia ? prematura, n. sp ........... & ..... do $\ldots . . . \ldots . . . . . . . . . .$. & 374 \\
\hline Thracia sublevis M. \& H . ............... & Redwater Valley .................. & 375 \\
\hline Nesera longirostra, n. sp ......... & ...... do .......................... & 376 \\
\hline Saxicava jurassica, n. sp .................... & ...... do ......................... & 376 \\
\hline CEPHALOPODA. & & \\
\hline Ammonites cordiformis M. \& H .... & Redwater Valley . . . . . . . . . . . .... & 378 \\
\hline var. distans ................... & Two miles south of the Belle Fourche .... & 380 \\
\hline 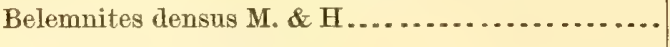 & East of the Belle Fourche................ & 381 \\
\hline
\end{tabular}

CRETACEOUS.

\begin{tabular}{|c|c|c|c|}
\hline Systematic name. & Division. & Locality. & Page. \\
\hline LAMELLIBRANCHIATA. & & & \\
\hline Cyncyclonema rigida $\mathrm{M} . \& \mathrm{H} . \ldots . . . . .$. & & Forks of the Cheyenne River.......... & 383 \\
\hline 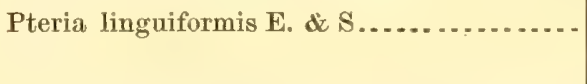 & 4 & $\begin{array}{l}\text { Cheyenne River, near French Creek, } \\
\text { \&c. }\end{array}$ & 384 \\
\hline (Oxytoma) nebrascana E. \& S...... & 4 & 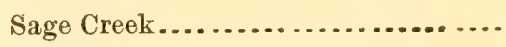 & 385 \\
\hline (Pseudopteria) fibrosa M. \& H ..... & 4 & Cheyenne River, near Rapid Creek... & 386 \\
\hline sublevis, u. sp ....... & 4 & Old Woman Fork......... & 387 \\
\hline Inoceramus problematicns Schlot ..... & 2 and 3 & East fork of Beaver Creek...... & 389 \\
\hline fragilis $H \& \mathbf{M} . .$. & 2 and 3 & Beaver Creek ................... & 390 \\
\hline
\end{tabular}

* Only indication of locality given. 
LIST OF SPECIES DESCRIBED.

CRETACEOUS-Continued.

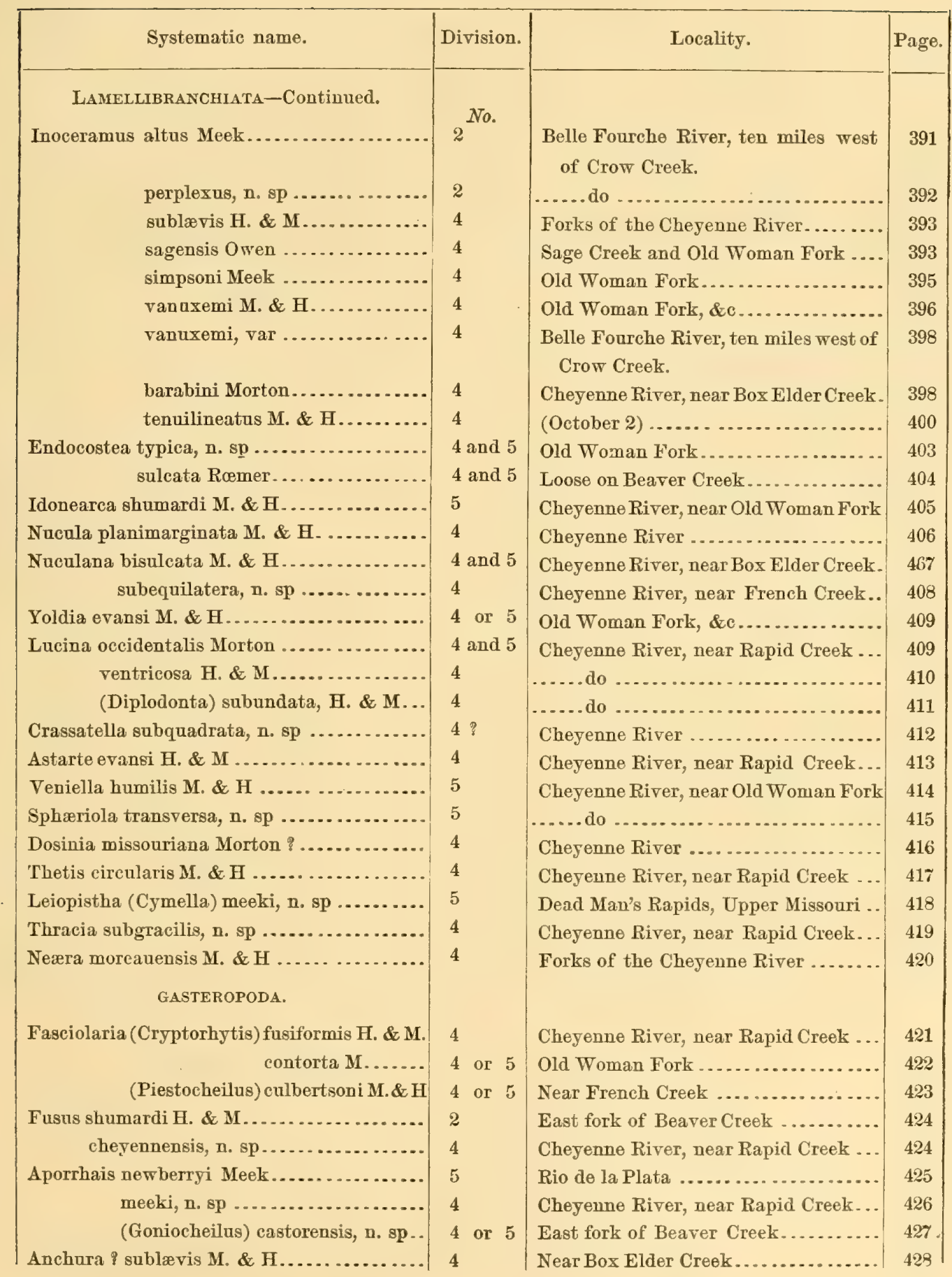


CRETACEOUS-Continued.

\begin{tabular}{|c|c|c|c|}
\hline Systematie name. & Division. & Locality. & Page. \\
\hline $\begin{array}{l}\text { GASTEROPODA-Continued. } \\
\text { Anchura (Drepanocheilus) nebracensis E. } \\
\text { \& S. }\end{array}$ & $4 \stackrel{\text { No. }}{\text { or } 5}$ & East fork of Beaver Creek ...... & 429 \\
\hline Lunatia concinna H.\& M.................. & 4 & Cheyenne River, near Rapid Creek... & 430 \\
\hline Vanikora ambigua M. \& H.............. & 4 & Cheyenne River..................... & 430 \\
\hline Amanropsis paludinæformis $\mathbf{H} . \&$ M ........ & 4 & Cheyenne River, near Box Elder Creek. & 431 \\
\hline Margarita nebrascensis M. \& H......... & 4 & $\begin{array}{l}\text { One hundred and fifty miles above } \\
\text { mouth of Yellowstone. }\end{array}$ & 432 \\
\hline Anisomyon alveolus M. \& H............. & 4 & 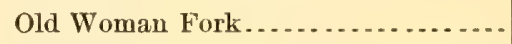 & 433 \\
\hline subovatus M. \& H............ & 4 & . & 434 \\
\hline patelliformis M.\& H........... & 4 & 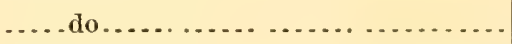 & 435 \\
\hline borealis Morton................ & 4 & Cheyenne River ................. & 436 \\
\hline Akera glansoryza, n. sp.................. & 4 & Cheyenne River, near French Creek.. & 437 \\
\hline Haminea subcylindrica M. \& H............ & 4 & Old Woman's Fork ................. & 437 \\
\hline $\begin{array}{l}\text { Dentalium gracile H. \& M .................. } \\
\text { CEPHALOPODA. }\end{array}$ & 4 & Cheyenne River, near Rapid Creek... & 438 \\
\hline Nautilus dakayi var. montanensis Meek.. & 4 & .....do............ & 439 \\
\hline Prionocyelus w yomingensis Meek....... . & 2 & East fork of Beaver Creek .......... & 440 \\
\hline Seaphites nodosus Owen................. & 4 & Cheyenne River, near Rapid Creek... & 441 \\
\hline var. brevis Meek.......... & 4 & .... do................. & 443 \\
\hline quadrangularis Meek. & 4 & ... do do.................. & 443 \\
\hline plenus M. \& H. .. & 4 & 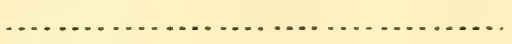 & 444 \\
\hline warreni M. \& H..... ....... & 2 & East fork of Beaver Creek .......... & 444 \\
\hline wyomingensis M. \& H...... & 2 & 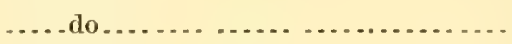 & 446 \\
\hline Helicoceras stevensoni, n. sp.......... & 4 & West of Beaver Creek............. & 447 \\
\hline Heteroceras newtoni, n. sp ........... & 4 & ... do.............................. & 449 \\
\hline ? nebracensis M. \& H....... & 4 or 5 & East fork of Beaver Creek............ & 451 \\
\hline Ancyloceras jenneyi, n. sp............ & 4 & 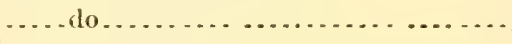 & 452 \\
\hline tricostatum, $\mathrm{n} . \mathrm{sp} \ldots . . . .$. & 4 & Cheyenne River, near French Creek.. & 454 \\
\hline Ptychoceras meekanum, n, sp.......... & 4 & Beaver Creek ............................. & 457 \\
\hline crassum, n. sp......... & 4 & Old Woman Fork............. & 459 \\
\hline
\end{tabular}





\section{P A L E O N T L O G Y.}

\section{P L A T E I.}

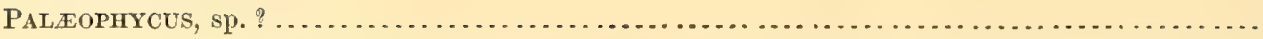

FIG. 1. View of a fragment of sandstone having its surface covered with the disjointed stems.

PALÆOCHORDA PRIMA

FIG. 2. View representing the surface of a fragment of sandy shale, with several specimens of the species.

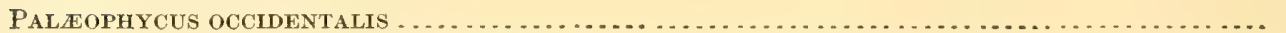

FIG. 3. View of a slab of sandstone, which is covered with stems of the ordinary form and size, some of which show the mode of bifurcation. 

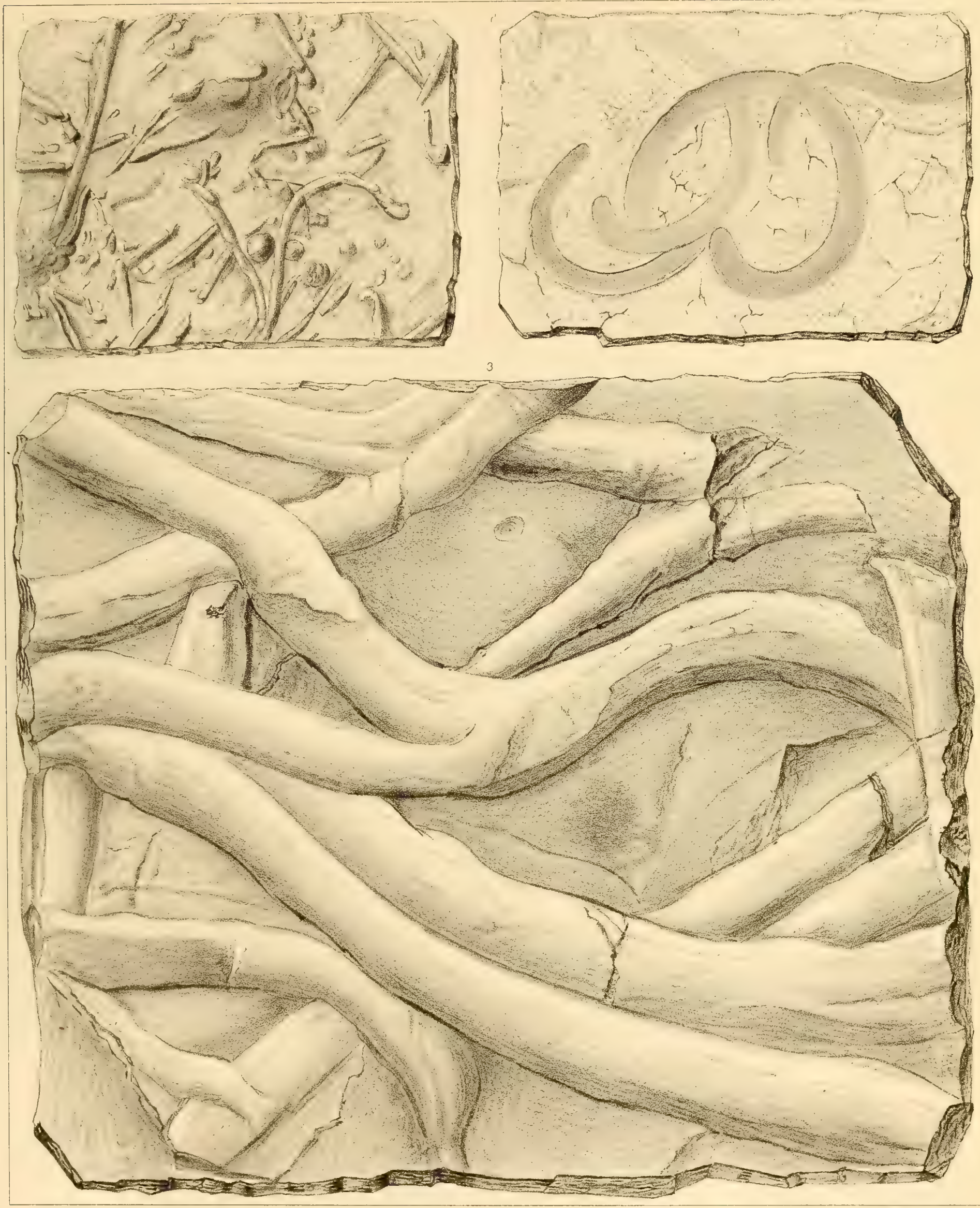




\section{PA L EON T OLOGY.}

\section{PL A I E I I.}

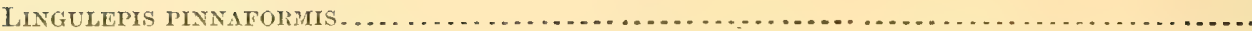

Figs. 1, 2. Views of the dorsal and ventral valves of the ordinary form from the greenish purple sandstone at the headwaters of Red Cañon Creek, southwest of the Black Hills.

FIGS. 3, 4. Views of two specimens, dorsal valves, from the friable sandstones of Castle Creek, west of the Black Hills.

LINGULEPIS CUNEOLUS

Figs. 5, 6. Enlarged views of what are supposed to be the dorsal and ventral valves.

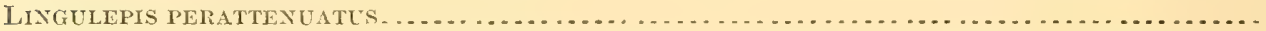

FIGs. 7, 8. Views of two dorsal valves, showing a slight variation in form. Enlarged.

FIG. 9. Enlarged view of a ventral valve.

LINGULEPIS DAKOTENSIS

FIGS. 10, 11. Copies of Mr. Meek's figures, showing ventral valves of this species.

OBOLELLA POLITA

FrG. 12. Enlarged view of a dorsal (?) valve.

FIG. 13. Enlarged view of a ventral valve, showing the prolonged beak.

OBOLELLA NANA

FIG. 14. Enlarged view of a specimen of the broad oblate form.

Fig. 15. Enlargement of a more circular specimen.

Frg. 16. Enlargement of an elongated specimen. This and the specimen Fig. 14 show the extremes of variation among the specimens on one block of sandstone.

Frg. 17. View of the interior, enlarged. The figure is a copy of that given by M. \& H., Pal. Upp. Missouri, Plate 1, Fig. 3.

ObULUS? PECTENOIDFS

FIGs. 18, 19. Enlarged views of two valves, one of which retains the shell almost entire and the other exfoliated, showing the radiating lines.

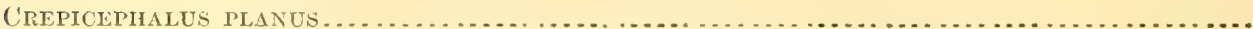

FIG. 20. View of the specimen described, showing the characters as given.

Crepicephalus centralis

FrG. 21. View of the glabella and fixed cheeks of a large individual, showing the broadly conical form.

Fig. 22. View of another individual, showing the narrow form of glabella.

FIG. 23. Profile view of the last specimen, showing the elevation and curvature of parts.

FIG. 24. View of an imperfect cheek referred to this species, being associated with it on the sarne block.

ARENICOLITES $s p . ?$

FIG. 25. View of the specimen from. Warren Peak, showing the form, relative size, and direction of the tubes. 


$$
\begin{aligned}
& \text { - } 000000 \\
& \text { - } 0000 \\
& \text { - } 0000 \\
& \text { c } \\
& \text { a } \\
& \text { a } \\
& \text { iding } \\
& \text { a }
\end{aligned}
$$





\section{P A L E O T O L O G Y}

\section{P L A T E I I .}

Pentacrinttes asteriscus.

FIGs. 1,2. Enlarged views of two of the disks, showing the extremes of variation of acute ness in the angles of the star-like points.

Asterias ? DUbIUNi.

FIG. 3. View of a fragment from a larger block, showing three individuals, as obtained by gutta-percha from the natural impression.

LINGULA BREVIROSTRA.

Figs. 4,5. Views of what appears to be a dorsal and a ventral valve, natural size.

RHYNCHONELLA MYRINA

FIGS. 6,7. Views of two ventral valves, showing the extremes of variation in the number of plications.

OSTREA STRIGILECULA

FIG. 8. View of the interior of an upper valve of the ordinary form at the localities mentioned under the description.

FIG. 9. Interior of a small lower valve of the thin, flat variety.

FIG. 10. A profile of the same individual, showing the slight elevation of the margin.

FIG. 11. External or basal view of a larger deep valve, showing the sear of attachment.

FIG. 12. Side view of another similar specimen, showing the great elevation of the margin at the anterior border and below the cicatrix of attachment.

GrYPHAA CALCEOLA var. NEBRASCENSIS.

FIG. 13. View of the interior of a specimen from the Big Horn Mountains, restored in front. Introduced for comparison.

Fig. 14. External view of the same specimen.

Frg. 15. Profile view of the same.

Fic. 16. Profile of another imperfect specimen, showing the striæ of the surface.

Pseudomonotis (EUMicrotis) orbiculata.

FIG. 17. View of the convex valve of the ordinary size.

FIG. 18. View of a right valve, twice enlarged, showing the very small ear.

FIG. 19. Enlargement of the surface striæ from the specimen Fig. 19.

PSEUdOMONOTIS (EUMICROTIS) CURTA.

FIG. 20. View of a left valve of the ordinary form and size, enlarged to two diameters.

FIG. 21. Enlarged riew of the right side of a specimen, showing the characters of the hinge Three diameters.

FIG. 22. A still further enlargement of the upper part of the shell, showing the generic features of the shell.

Fig. 23. Profile of the specimen, Fig. 21, enlarged to correspond.

FIG. 24. Enlargement of the interior of a left valve.

FIG. 25. Enlargement of the interior of a right valve, showing the character and construction of the ear-like fold in the shell. 


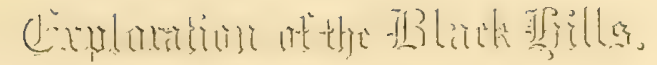

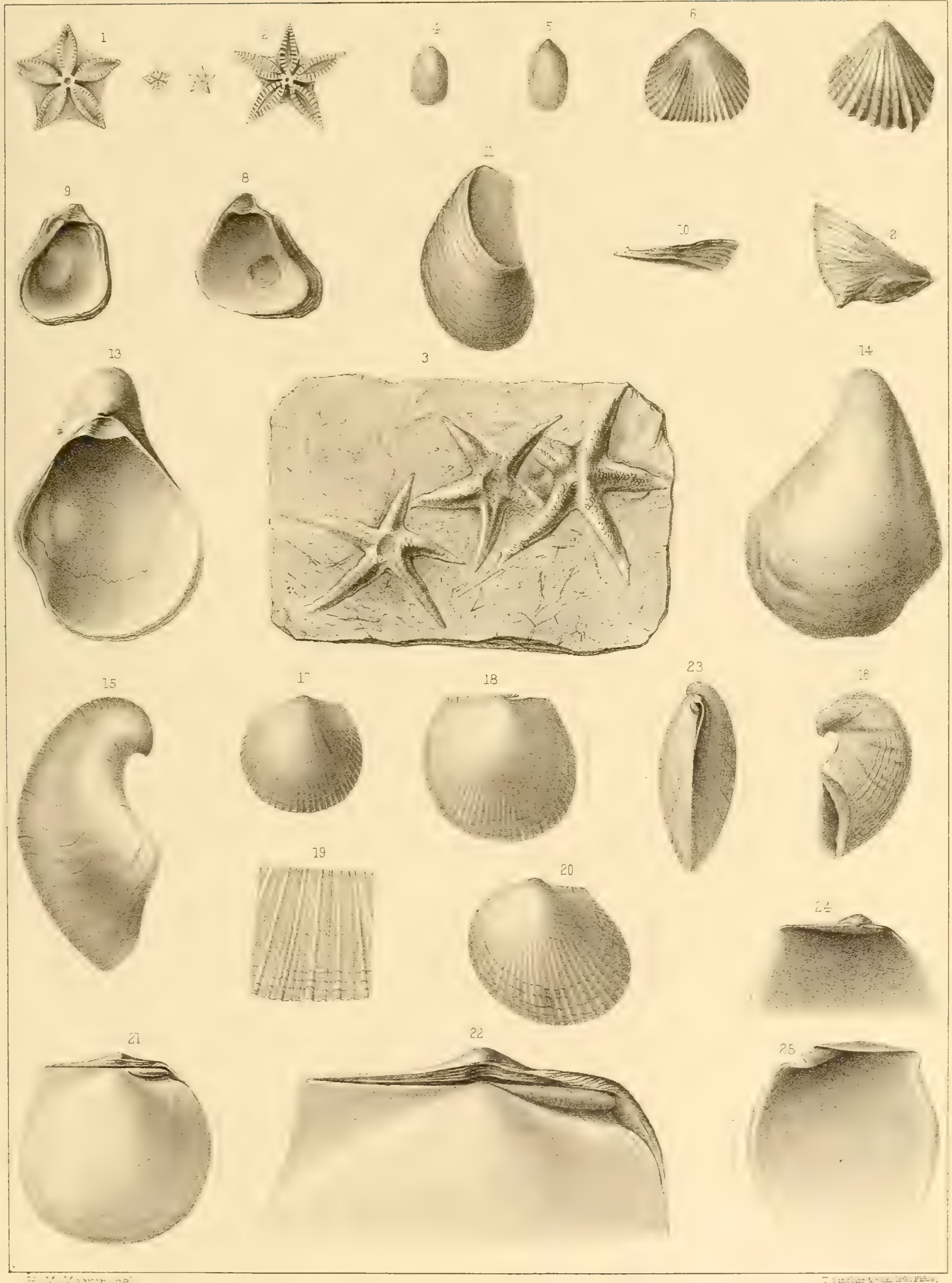






\section{PALEONTOLOG Y.}

\section{PLATE I V .}

Page.

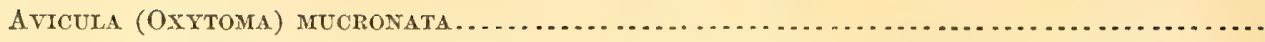

FIG. 1. View of a left valve partly restored, showing the usual form of the specimens.

FIG. 2. View of the right valve enlarged to twice the natural size, posterior margin restored to correspond with the lines of growth.

GERVILLIA RECTA

Fig. 3. View of a left valve, natural size.

Camptonectes extenuatus.

FrG. 4. View of a very large left valve of the species from a locality east of Belle Fourche.

FIG. 5. View of smaller specimen, from the same leoality, from which the surface shell has been removed, the condition in which they are usually found.

CAMPTONECTES BELLisTRIATA

FIG. 6. View of a right valve, the surface partially exfoliated. From Belle Fourche.

FIG. 7. View of a left valve, imperfect on one side, showing the surface stria. From Belle Fourche.

FIG. 8. View of the interior of a large right valve from Big Horn Mountains, showing the features of the type form of the species.

Fig. 9. Exterior of a left valve, showing the surface striæ.

FIG. 10. Exterior of a right valve; no striæ are visible on the specimen, whether from exfoliation or naturally so is not readily determined. All right valves seen have the surface smooth.

FrG. 11. Enlargement of the surface as seen on specimens Figs. 6, 9.

Pecten Newberryi

FIG. 12. View of a left valve, imperfect on the anterior side of the cardinal line.

FIG. 13. View of another individual, showing the entire form.

FIG. 14. Enlargement of the suxface, showing the elevated concentric striæ.

FIG. 15. View of a right valve associated with the preceding, and supposed to be of the same species. 
2TITASSIC.

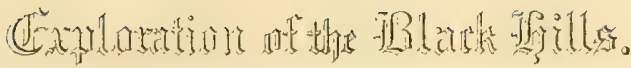

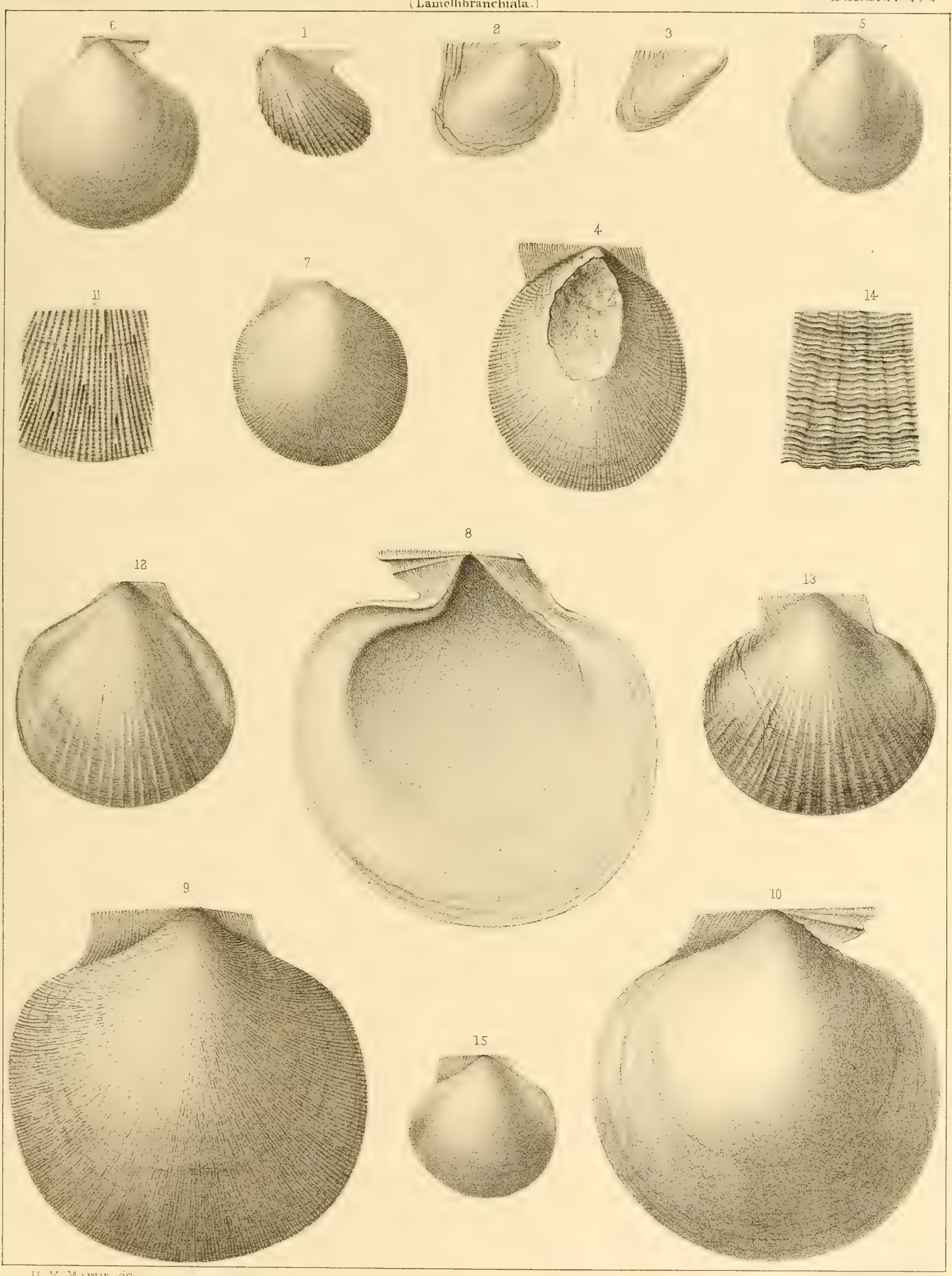

II $\mathrm{W}_{\mathrm{i}} \mathrm{Mu}$ de

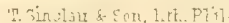





\section{•}

- 
TRAPEZILM BELLEFOURCHEXSIS.

lig, 1. View of the left side of a specimen enlarged, showing the usual form.

FIG. 2. Outline cardinal view of the same, slightly restored at the anterior extremity.

FrG. 3. View of a right valve, imperfect, of a broader form, and showing the cast of the anterior muscular imprint.

FIG. 4. View of the left side of a broad form, showing the outline entire, but imperfect over the body of the shell.

Trapezium subequalis.

Fig. 5. View of a large left valve, natural size.

FIG. 6. A right valve of slightly different form.

FIG. 7. Enlargement of a similar right valve, but more constricted on the basal margin.

FIG. 8. Ontline cardinal view, restored from the last specimen.

Mytilus Whitei.

FIG. 9. View of a left valve of the ordinary size.

FIG. 10. Profile view of the same, looking upon the buccal side.

FIG. 11. View of a right valve, which is slightly more arcuate than Fig. 9.

FIG. 12. View of another left valve, which is even straighter than Fig. 9, and has a less oblique hinge.

Volsella pertenuis

Fig. 13. View of a left valve, natural size.

Fig. 14. Profile view, constructed from separated valves.

VOLSELIA (MODIOLA) FORMOSA.

FIG. 15. View of a left valve of small size.

Grammatomon inornatus.

Fig. 16. View of a right ralve, natural size, showing the prevailing form and size, also showing radiating striæ.

FIG. 17. An enlarged view of a cast of a left valve, showing the hinge features as seen on the cast.

Fig. 18. Outline cardinal view as constructed from separated valves.

PLEIROMYA NEWTONI.

Frg. 19. View of a left valve of the prevailing form.

FIG. 20. View of a larger right valve.

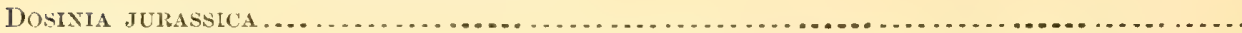

Figs, 21, 22. Views of left valves of the usual form and size.

FIG. 23. Cardinal view of the specimen Fig. 22.

FIG. 24. View of the cast of a right valve, showing the pallial line and sinus.

SAXICAYA JURASSICA

FiG. 25. View of an internal cast, natural size.

Fig. 25. View, enlarged, of the left side of a specimen retaining a portion of the shell, and showing the pallial sinus on the cast.

FIG. 27. Enlarged cardinal view of the specimen, Fig. 25, showing the angularity of the umbonal ridge.

Frgs. 28, 29. Enlarged cardinal and right views of a large individual, retaining a large part of the shell.

FIG. 30. View of one of the casts of the burrows as separated from the surrounding clayey matrix.

PSAmmoria? PREMatura.

FIG. 31. View of the specimen described, which is an internal east, showing the muscular imprints and pallial line.

Astarte (?) FRAGILIS

FIGS. 32, 33. Right and cardinal views, enlarged, of a specimen which we have supposed to belong to this species.

THRACIA？ SUBLIEVIS .

FIG. 34. View of a right valve referred to this species, by error on plate, made Fig. 24.

FIG. 35. View of a left valve enlarged, showing the characters of the species. 


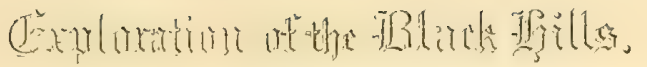

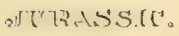

I.auclibranchiala

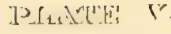
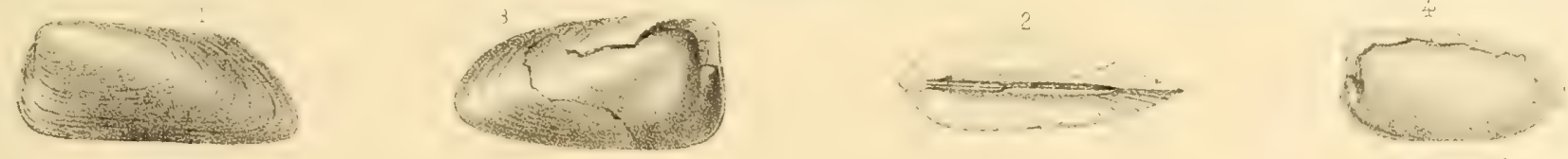

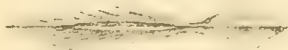
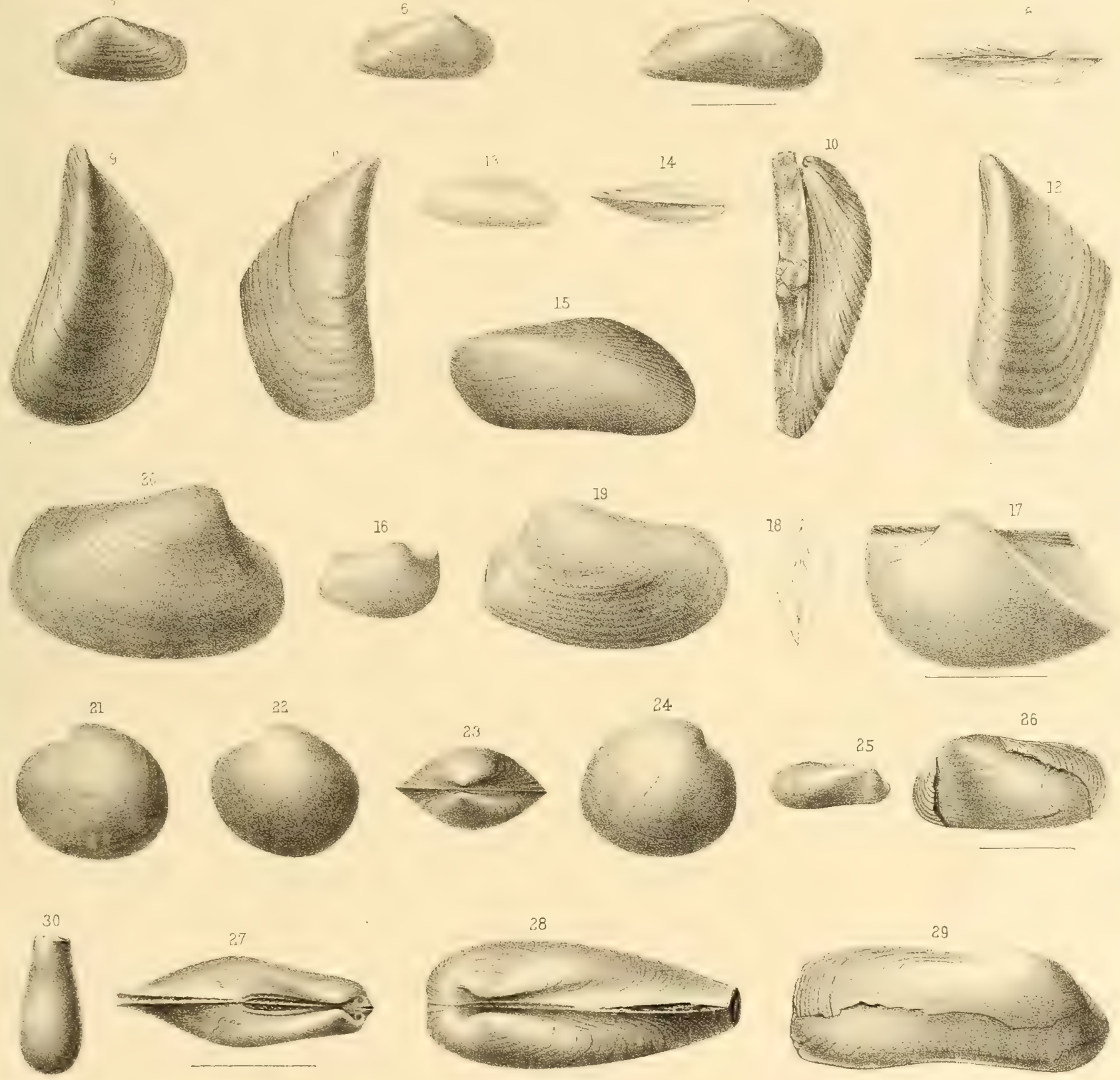

31
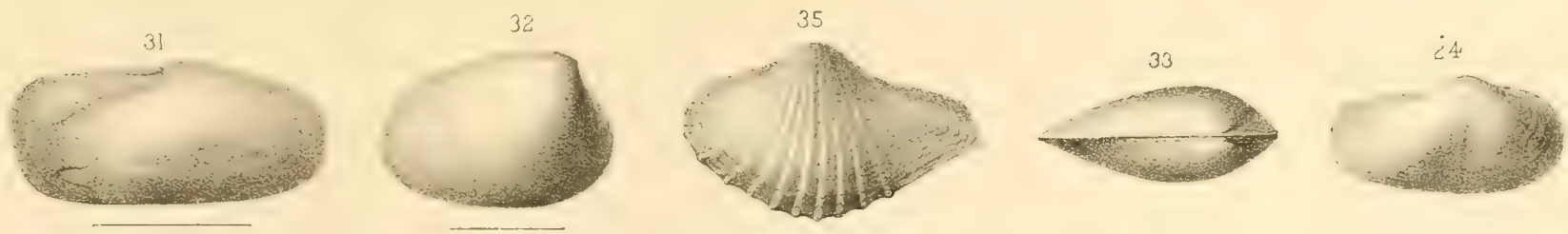




\section{PALEON T O L G Y. PLA TE V I.}

TANCREDIA BULBOSA

FIG. 1. View of a right ralve enlarged, showing the prevailing form.

Fig. 2. A left valve slightly more extended at the posterior end.

FIG. 3, Outline cardinal view, showing the convexity of the valves.

TANCREDIA WARRENANA

FIG. 4. Enlarged view of a right valve, showing the features of the prevailing form.

TANCREDIA CORBULIFORMIS

FIG. 5. Enlarged view of a right valve.

Fig. 6. Enlarged view of a left valve.

Frg. 7. Enlarged view of the right side of an internal cast, showing the muscular imprints.

Frg. 8. Cardinal view of the same specimen.

TANCREDIA (?) INORNATA

Frg. 9. A right valve, natural size, showing the general features of the species.

FIg. 10. View of an internal cast of a left valve, showing the form of the muscular imprints and a pallial sinus.

FIG. 11. View of a larger and proportionally longer left valve showing a slight difference in the pallal sinus, and may, with the change in form, indicate a distinct species.

FIG. 12. Enlarged cardinal view of an internal cast, showing the impression of the cardinal and a lateral tooth, and the muscular scars.

Fig. 13. Enlarged view of another specimen preserving the shell along the hinge, and showing the projecting cardinal tooth.

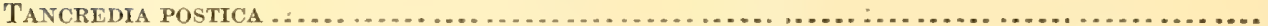

FIG. 14. View of a right valve, enlarged, showing the great breadth of the posterior part of the shell.

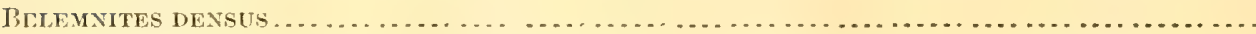

FIG. 15. View of a young individual.

FIG. 16. View of a large specimen broken off near the base of the alveolar cavity.

FIG, 17. Section of the upper end of the specimen, Fig. 16, showing the excentricity of the alveolar cavity.

FIG. 18. Longitudinal section of a specimen, showing the concentric layers.

FIG. 19. Longitudinal section of another individnal, showing the phragmacone in place, with some of the septa preserved.

AMMONITES CORDIFORMIS ?

Fras. 20, 21. Side and profile views of a moderately sized individual, showing the prevailing form.

FIG. 22. View of a small specimen from the Big Horn Mountains, in the collection of the Smithsonian Institution.

FIG. 23. View of another individual, showing a different arrangement of the costa.

Fig. 24. Diagram of a septum, copied from the Pal. Upp. Missouri, Plate v, Fig. 2 c.

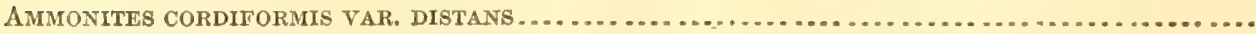

Frg. 25, Lateral view natural size of the specimen used in description. 


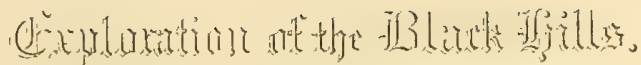

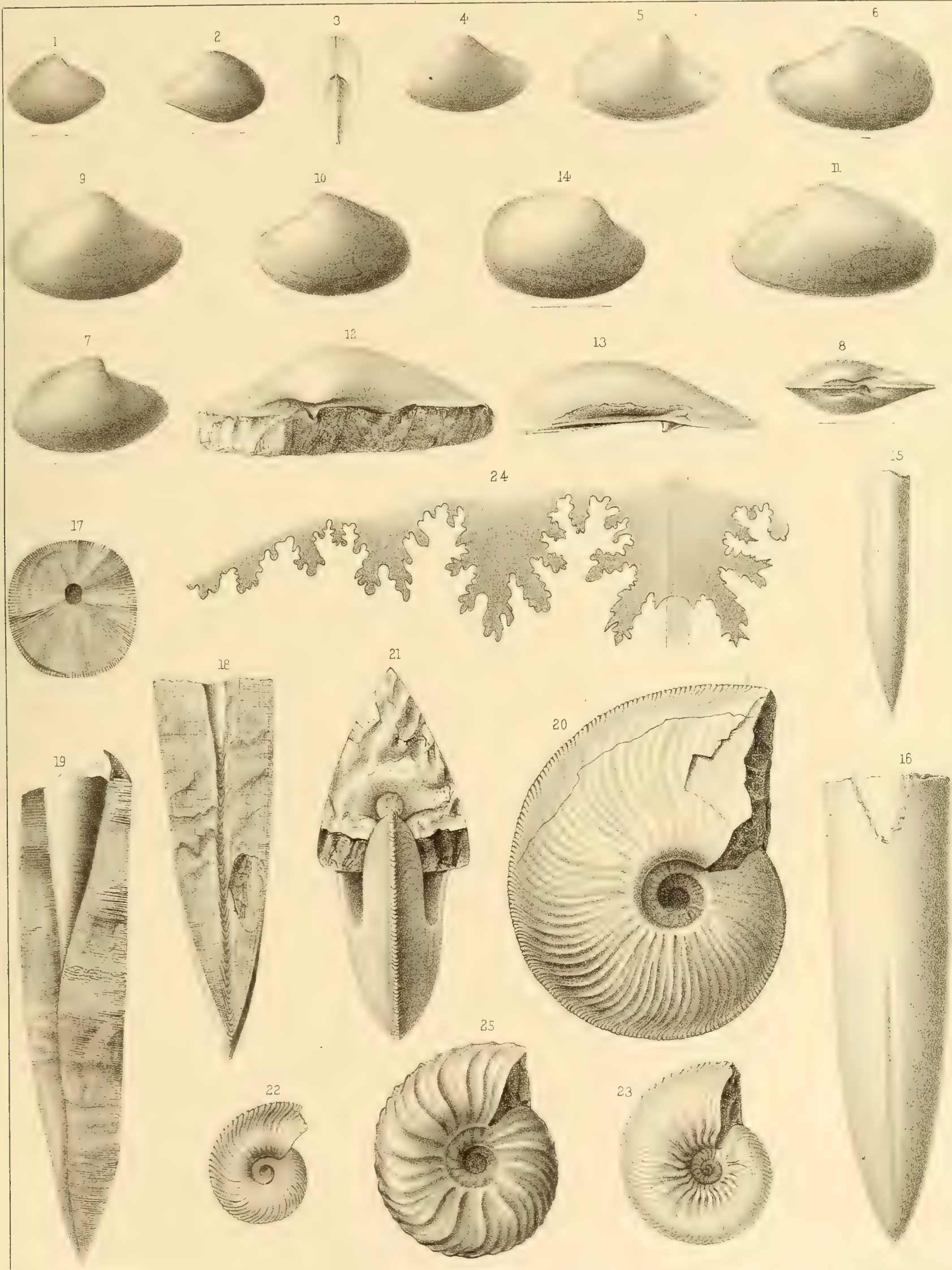






\section{P A L E O T OL OGY.}

\section{PLATE V II.}

SyNCYCLONEMA RIGIDA H \& M

FIG. 1. Enlarged view of an interior cast of a right valve, showing the filling of the cartilage pit and what appears to be the muscular impression.

Pteria linguiformis E. \& $\mathrm{S}$

FIG. 2. View of the left valve of an imperfect specimen.

FIG. 3. View of the right side of the same, showing the muscular marking and pallial line.

Pteria (OXytoma) nebrascana E. \& S

FIG. 4. View of a large left vaive, natural size.

Pteria (Pseudopteria) fibrosa M. \& H

Fig. 5. Restored view of a left valve.

Pteria (Pseudopterla) sublevis Whitf.

FIG. 6. View of left valve of the ordinary size and form, preserving the small anterior wing.

INOCERAMUS BARABINI Morton

FIG. 7. View of an imperfect right valve of this form.

INOCERAMUS VANUXEMI M. \& H.

FIG. 8. View of a small individual representing the var. subcircularis $\mathbf{M}$.

FIG. 9. View of a left valve representing the form referred by Mr. Meek to I. proximus Toumey.

FIG. 10. View of a left valve of the variety described in this vol. p. 398.

INOCERAMUS PROBLEMATICUS Schlot. ?.

FIG. 11. View of an imperfect specimen of a right valve referred with doubt to this species.

INOCERAMUS SAGENSIS O.

FIG. 12. View of a right valve of rather large size, presenting the ordinary features of the species. 


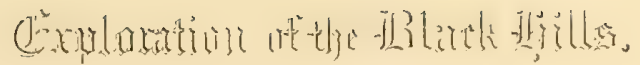

CTR FA"LACH OUS

lamellibranchiata

PIATE: Vll

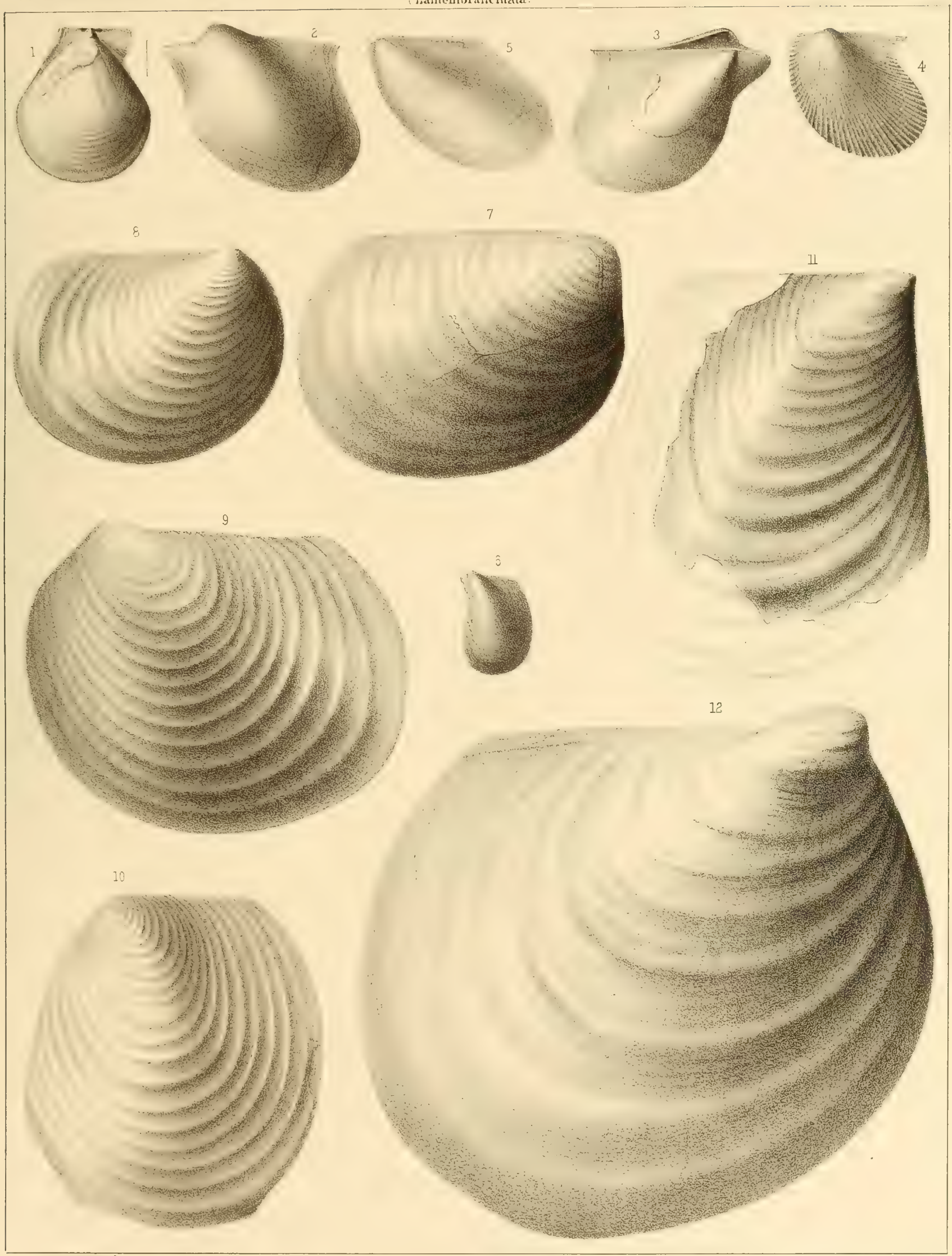

प U. Irartin del 



\section{PALEON TOLOGY.}

\section{PLATE VIII.}

INOCERAMUS SIMPSONI Meek

Frg. 1. View of the right side of a specimen, showing the form, size, surface marking, and radiating lines of pustules, and also an area representing the muscular impression near the postero-basal margin.

INOCERAMUS SAGENSIS O

FIG. 2. Cardinal profile view of the specimen, Fig. 12, Plate 7.

INOCERAMUS PERPLEXUS Whitf

FIG. 3. Anterior profile of the specimen, Fig. 5, Plate 10.

INOCERAMUS VANUXEMI M. \& $\mathrm{H}$.

Fig. 4. Cardinal profile of the specimen, Fig. 8, Plate 7, var. subcircularis M.

FiG. 5. Cardinal profile of the specimen, Fig. 9, Plate 7, representing the form referred by Mr. Meek to I. proximus Toumey. (In a letter to the anthor, Mr. Meek stated that he is very doubtful of the correctness of this reference, not having seen Professor Toumey's specimens, which were never figured.) 


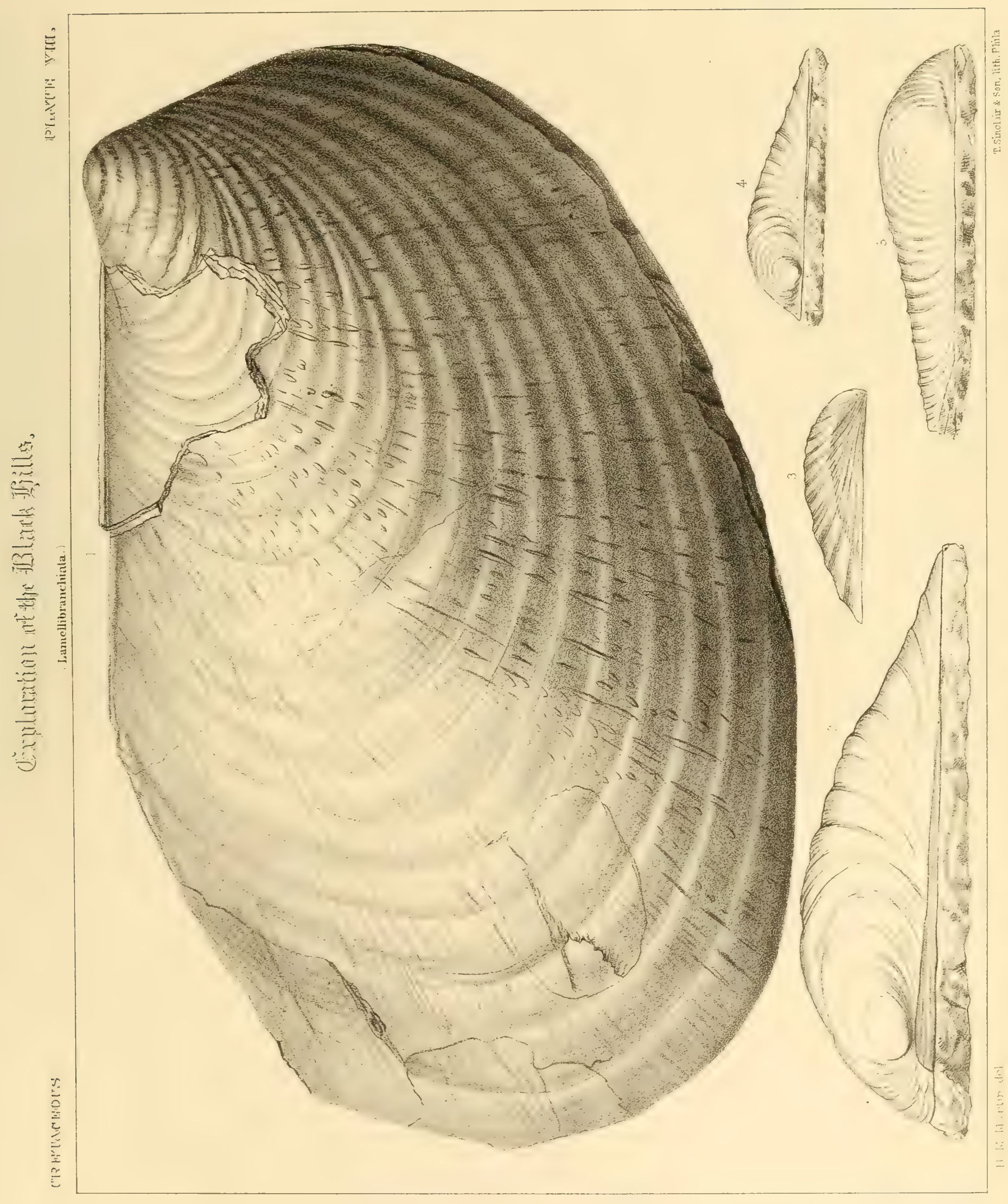






\section{P A L E ONTOLOG Y.}

\section{P L A T E I X.}

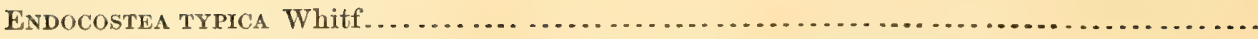

FIG. 1. View of a cast of a left valve of medium size, with the ridge extending to the edge of the cast.

FIG. 2. View of a partially exfoliated right valve, showing the impression of the ridge in the upper part and the substance remaining below, but easily traceable.

FIG. 3. View of a larger right valve, retaining about one-half of the substance of the ridge, the margin of the remaining portion being very perceptible.

FIG. 4. View of the left side of a still larger specimen, partially exfoliated, showing the ridge less developed. A part of the shell here remains, which, if removed, would make the impression still deeper.

FIG. 5. Cardinal view of the specimen, Fig. 4, showing the right valve the largest.

FIG. 6. Outline cardinal view of the hinge of a small individual, showing the area after the fibrous coating has been removed.

FIG. 7. View of the interior of the left side as obtained by a gutta-pereha impression from the natural cast.

INOCERAMUS BARABLNI

FIG. 8. View of a specimen of the form usually referred to this species, from this locality, showing the muscular impressions, anterior and posterior.

INOCERAMUS SIMPSONI? Meek

FrG. 9. View of a young, slightly distorted specimen, referred with doubt to this species.

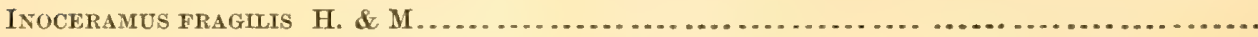

FIG 10. View of a large left valve, having the characters of the type of this species.

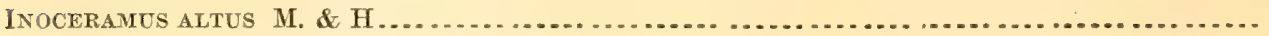

FrG. 11. View of an imperfect left valve of this species.

INOCERAMUS TENUILLNEATUS H. \& M

FrG. 12. View of the right side of a large, well formed specimen of this species, preserving a rim of the outer fibrous coating around the margin of the valve.

FiG. 13. Anterior profile view of the same, showing the great rotundity of the shell. 


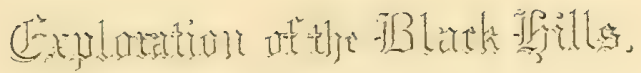

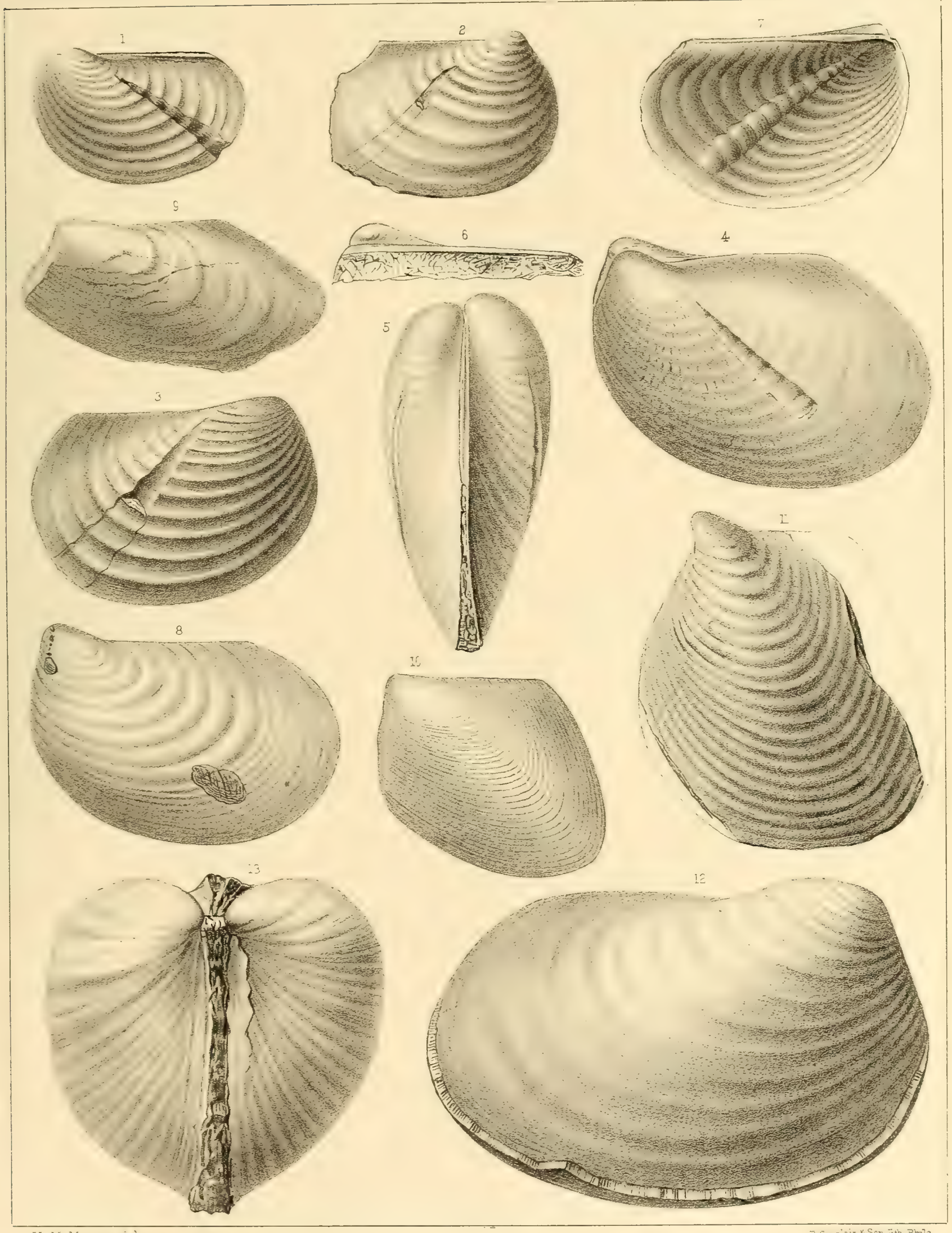






\section{PALEONTOLOGY.}

\section{PLATE X.}

LNOCERAMUS SUBLFVIS H. \& M

FIG. 1. View of the right side of a specimen retaining both valves, and most of the nacreous layers of the shell.

FiG. 2. View of the left side of an internal cast of both valves, showing the pustulose markings of the surface and near the postero-basal margin, what is evidently the muscular impression.

FIG. 3. Cardinal riew of the same cast, showing the convexity of the valves.

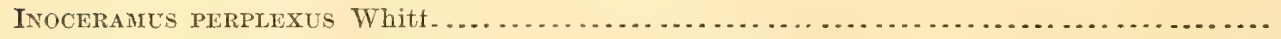

FIG. 4. View of an imperfect left valve, showing the general form of the shell and the undulations of the surface.

FIG. 5. View of a very perfect right valve, retaining all the features of the nacreous shell, The profile, Fig. 3, Plate 8 , is of this specimen.

Exdocostea sulcata Romer.

Fig. 6. View of the left side of an internal cast of both valves, showing the right valve projecting above the left, and also the sulcus of the left valve.

VENTELLA FUMiLIS M. \& H

Fig. 7. View of the exterior of a right valve as obtained by a gutta-percha impression in the natural mold.

FIG. 8. View of a specimen retaining a part of the natural shell.

FIG. 9. View of a cast of the right valve, showing an elongate form.

FIG. 10. The left side of a specimen of the ordinary form.

FIG. 11. The right side of a more quadrate form.

Frg. 12. Anterior profile of a cast showing the muscular impressions and marks of teeth.

FIG. 13. The interior of a left valve as obtained from a gutta-percha impression in the natural mold, showing the teeth, muscular impressions, and pallial line.

\section{SPHZRIOLA TRANSVIRSA Whitf .}

FIG. 14. Anterior profile view of an imperfeet individual retaining both valves, showing the convexity of the shell.

FIG. 15. Lateral view of the left side of the same specimen, with the beak of the right valve in outline.

FIG. 16. View of the interior of a left valve as obtained from a gutta-percha cast in the natural mold, showing the hinge and the muscular impressions. 


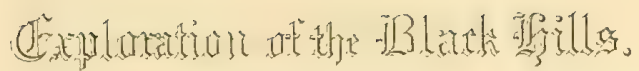

CREPREE DTS Lamellibranchiata.

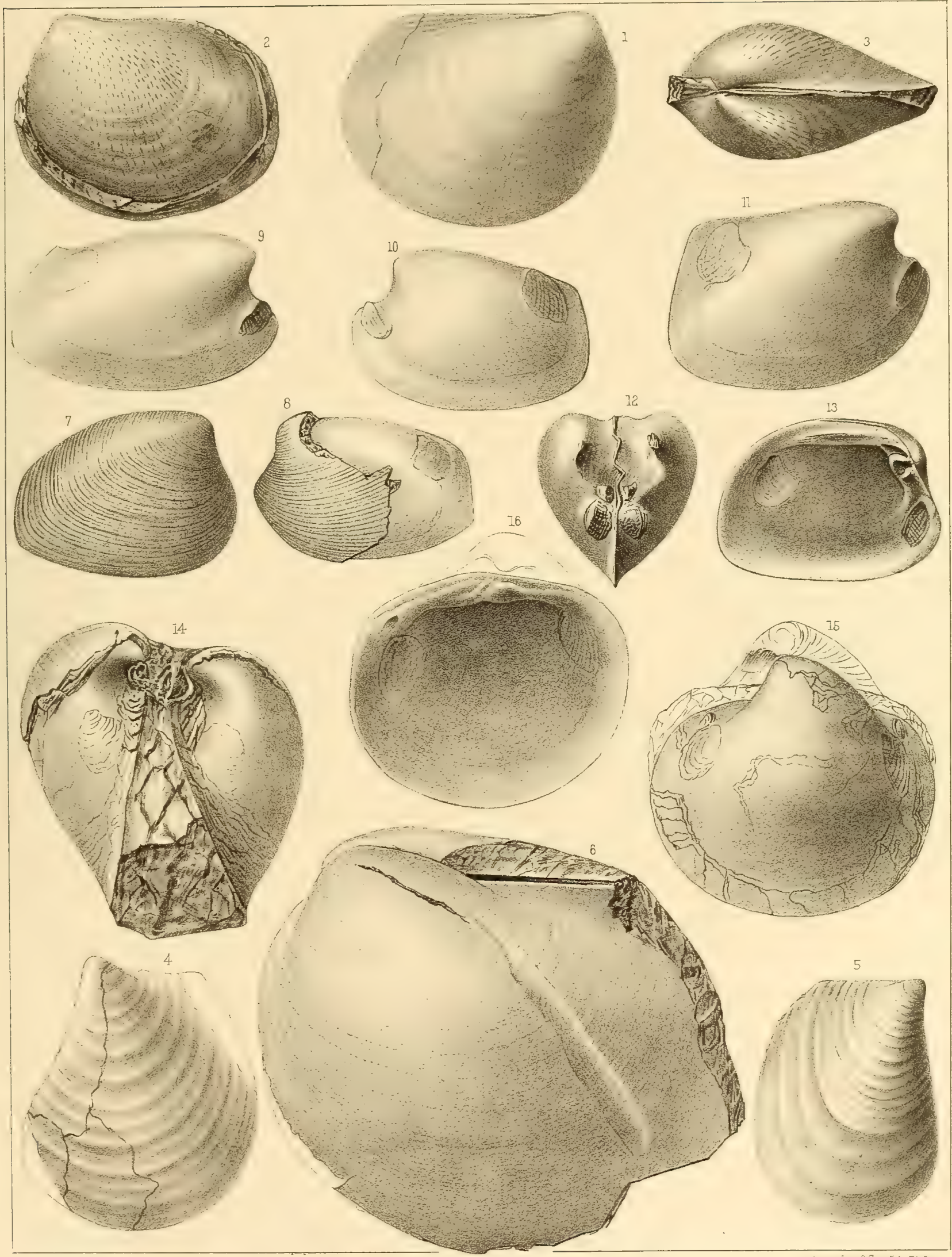

H. M Martin del 


Frg. 1. Enlarged view of a cast of a left valve, showing the teeth, muscular imprints, and pallial line.

FIG. 2. Linlarged outline cardinal view of a specimen retaining the shell, showing the groove extexding along the hinge.

Nucutaxa subequlatera Whiti.

Frg. 3. Enlarged view of the left side of an internal cast, showing the form and muscular imprints.

Fig. 4. Enlarged cardinal view of the same, showing the impression of the teeth.

NUUULA PLANHLReinata M. \& II

FIG. 5. View of the left side of a partially exfoliated specimen, showing the general form.

Fro. 6. Enlarged cardinal view of the same, showing the impression of the hinge, along which the shell is more completely removed.

Nuculana Bisulcata M. \& H

Frg. 7. Enlarged view of a specimen, showing the form and surface markings.

IDONEARCA SHUMARDI M. \& H...

FIG. 8. View of the right side of a specimen of medium size, showing the form and general character.

Fig. 9. Cardinal view of the same, showing the cartilage area.

FIG. 10. Posterior view of an internal cast, showing the impressions of the ridges bordering the muscular imprints.

FIG. 11. View of a large individual having the valves a little displaced and showing the posterior hinge-teeth.

Crassatella subquadrata Whitf . . . . . . . . . . . . .

FIG. 12. View of the right side of the cast, natural size.

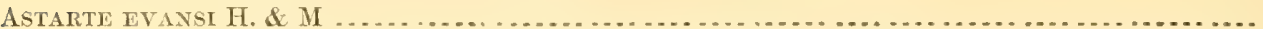

FIG. 13. View of the right side of an internal cast, showing muscular scars, pallial line, and crenulated margin.

LuCiNa VENTRICosA H. \& M

Fig. 14. View of the right side of a well-formed specimen of medium size, showing the general charneter of the species.

FIG. 15. ' ardinal riew of the same, showing the cardinal depressions and ligament.

FIG. 16. View of an internal cast of a large individual.

Lucina (Diplodonta?) subundata H. \& M.

FIG. 17. View of the right side of one of the Iarger indıviduals, showing the narrow, curved posterior slope and anterior furrow.

FiG. 18. Cardinal view of the same, showing the ligament and depressions.

LrCINA DCCIDENTILIS Jort

FIr. 19. View of a well-formed specimen of typical form.

FIG. 20. Cardinal view of the same, showing the almost obsolete lunule.

Fig. 21. Internal cast of a small individual.

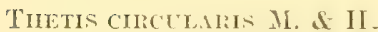

FrG. 22. View of the right side of a specimen of ordinary form.

FIG. 23. Cardinal view of a similar specimen, showing the incurved beaks and the convexity of the valves.

FrG. 24. View of a partial cast, showing the character of the pallial line and sinus.

Dosinia missouriaya Mort. ?

FrG. 25. Vier of the left side of a specimen referred to this species.

FIG. 26. View of the opposite side showing the pallial sinus.

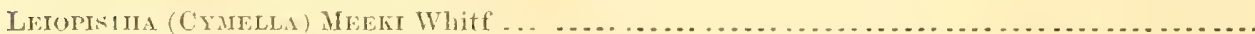

FrG. 27. View of a right valve of the species, natural size.

FIG. 28. Cardinal view in outline, showing the areas bordering the hinge, over which the rays and concentric folds do not extend.

THRACIA sÜBgRaCILIS Whitf.

Fig. 20. View of the right side of the specimen, showing the form, am the slit in the beak.

FIG. 30. Cardinal view of the same, showing a slight twisting of the valves in the crooked hinge line.

FIG. 31. Enlarged view of a left valve, showing the features as described. 


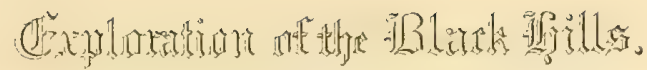

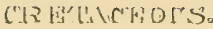

Lamellibranchiata.)

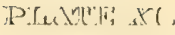

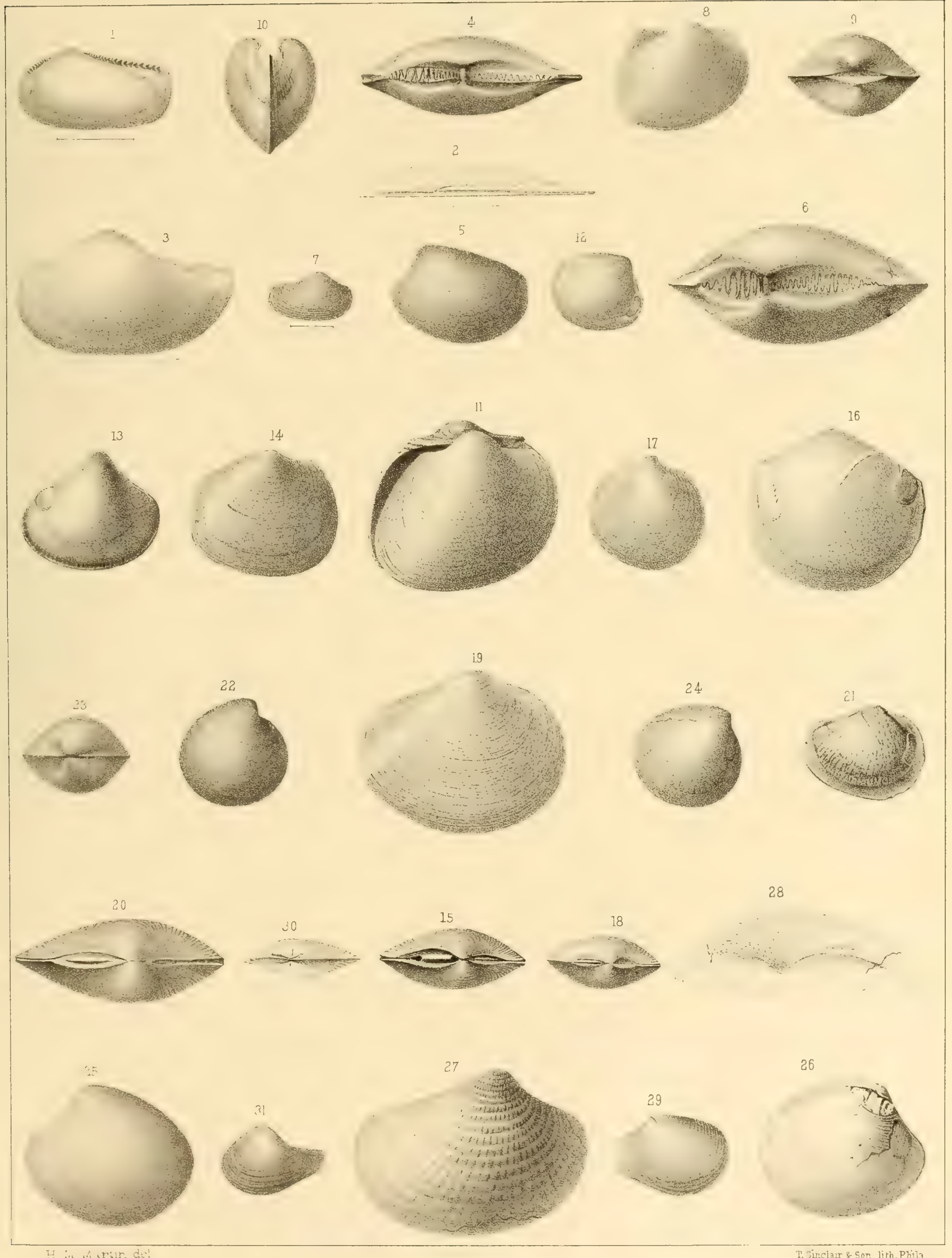





\section{PA L E ON TOL O G Y. \\ P L A T E X I I.}

Aporrhais (GONTOCHEILA) CASTORENSIS Whitf

FIG. 1. Enlarged view of a specimen, showing the extent of the posterior canal along the spire. The expansion of the lip is seen a little more extreme on one other indivirlual.

Anchura (Drepanocheilus) nebrascensis E. \& S. .

FIG. 2. View of a small individual, the labial spine strongly directed backward.

FIG. 3. A larger individual, varying somewhat in the form of the labial projection.

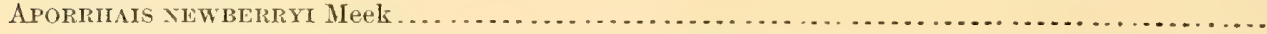

FIG. 4. View of a specimen imperfect at the anterior end, but showing the labial spines for some extent, though broken, and the posterior canal extending beyond the top of the spire.

APORRHAIS MEEKI Whitf.

FIG. 5. View of the imperfect specimen, which, however, shows the characters of the species.

ANCHUR.1 ? SUblevis M. \& H...

FIG. 6. Enlarged view, showing the features of the species generally observed and the stronger varices on the right side of the second and third volutions.

Fusus shumardi H. \& M

FIG. 7. View of an imperfect individual, preserving the striæ in part.

FIt. 8. Eulargement of the surface.

Fusus CHEYENNENSTS Whitf

FiG. 9. View of the specimen described, which is an internal cast.

Fasciolaria (Crytorhytis) contorta Meek's sp.

Fig. 10. View of an imperfect individual, preserving the two lower volutions, and showing their form and surface characters.

Fasctolaria (Piestocheilus) culbertsoni M. \& H

FIG. 11. View of a specimen, preserving the two lower volutions, showing the surface characters and form of the apertare.

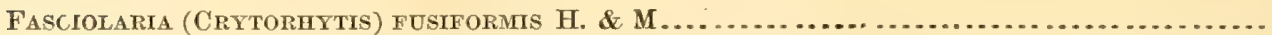

Frg. 12. View of a fragment from the collection of Dr. Newberry, showing the lower volutions with their characteristic markings.

Lunatia CONCINNA H. \& M

FrG. 13. View of a specimen of the species, showing the form of shell and aperture.

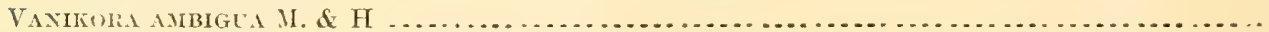

Fig. 14. View of a specimen, enlarged, showing the character of surface and form of shell.

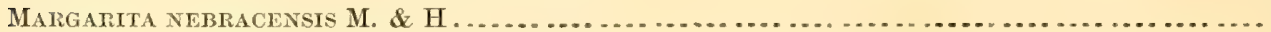

FIG. 15. Enlarged view of a specimen, showing the general features of the species.

AMAUROPSIS PALUDIN

FIG. 16. View of the back of a specimen, natural size.

AMISOMYON PATELLIEORMIS M. \& H

FIG. 17. Vertical view of an internal cast of this species, showing the muscular impression.

FIG. $1 \curvearrowright$. Profile view of the same, showing the elevation of the beak and its anterior position.

ANISOMYON SUbOVATUS M. \& H

FIG. 19. View of a cast, showing the form of the shell and muscular imprint.

ANISOMYON ALVEOLUS M. \& H.

Frg. 20. Vertical view of a partially exfoliated specimen, showing the muscular imprint in part.

ANISOMYON BOREALIS Mort

FIG. 21. Vertical view of a specimen preserving a part of the shell

FIG. 22. Profile view of an imperfect specimen. retaining the shell.

FIG. 23. View of a fragment, showing the radiating lines.

HAMTNEA SUBCXLINDRICA M. \& H.

FIG. 24. Enlarged view of a specimen, showing the surface features and form of aperture.

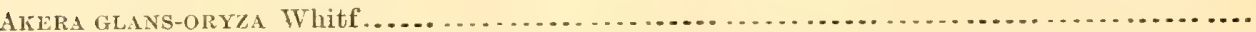

FIG. 25. View of a specimen, greatly enlarged, showing its form and characters.

Dentalium gracile H. \& M.

Fig. 26. View of an imperfect specimen, preserving the featares of the species. 


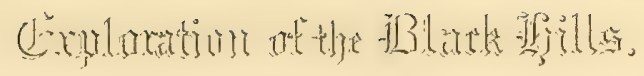
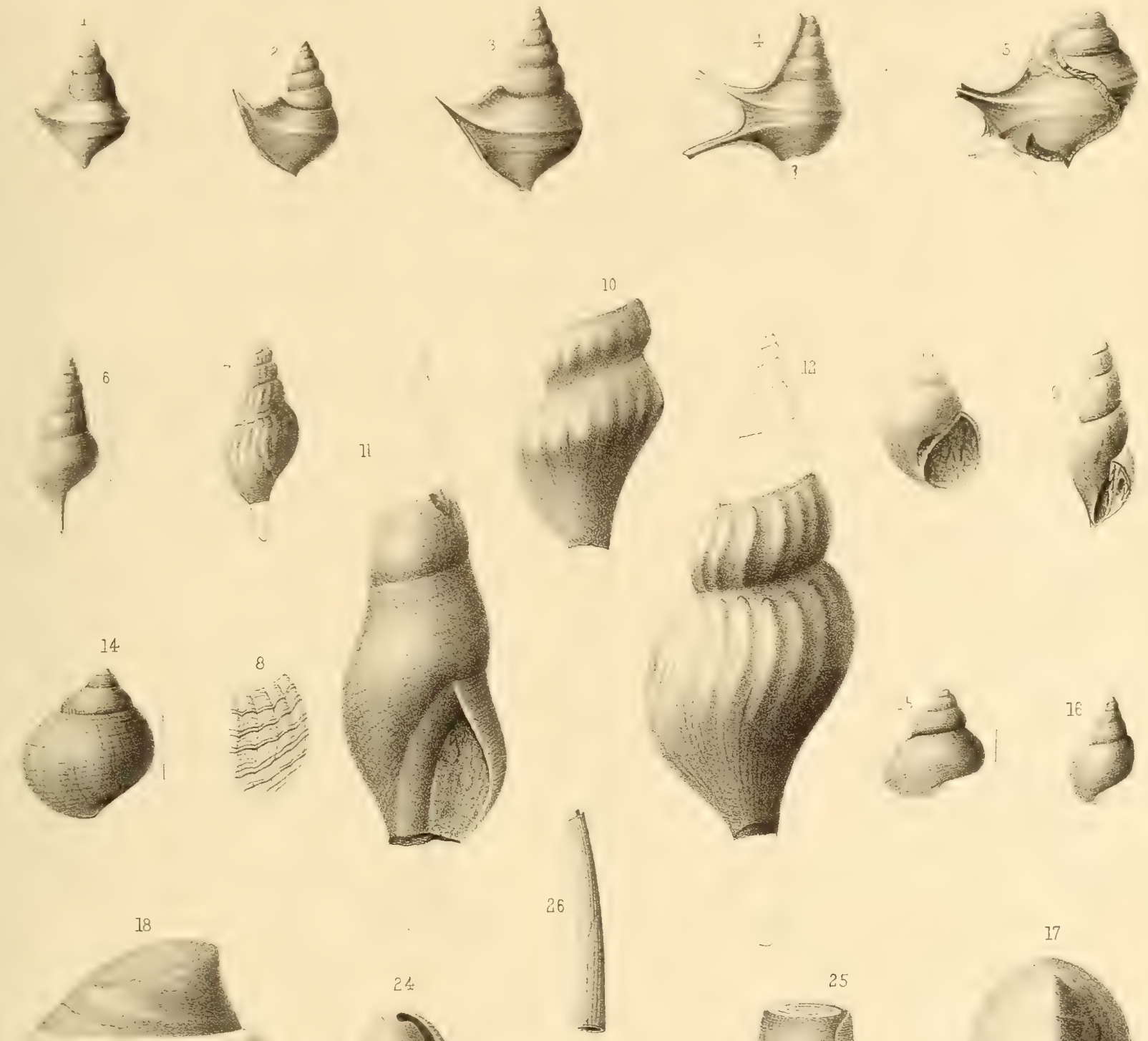

4.
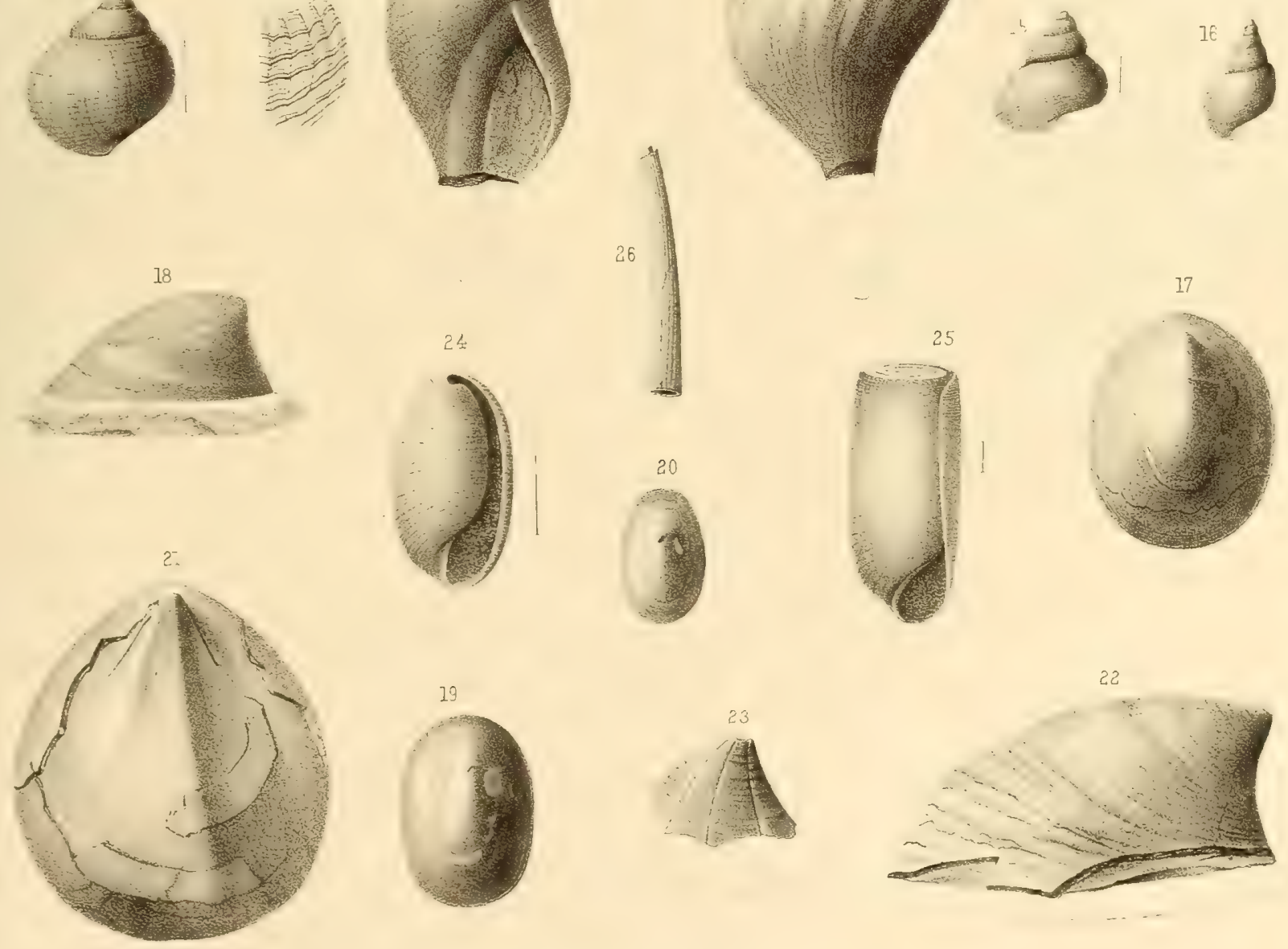

H. M. Martin del.

T Sinctair \& Son, iith. Prila 



\section{PA L E ON T OL OGY.}

\section{P L A TE XIII.}

SCAPHITES WARRENI Meek

FIG. 1. Side view of a small, entire specinen, showing the costre of the deflected portion directed forwart more than is usual in this species.

FIG. 2. Lateral view of a large individual, with coarser costæ than the last.

Frg. 3. Profile view of the same, showing the ventricose form of the volutions.

FrG. 4. Diagram of the second septum from the outer chamber of another large, imperfect individual. Enlarged to two diameters.

SCaphites wyomingensis Meek

FIG. 5. Lateral view of a specimen of tho usual form and character of the variety as obtained from the Black Hills.

FIG. 6. Lateral view of a larger individual, slightly imperfect at the aperture.

FIG. 7. Vertical profile view of the last specimen, showing the narrow inner volution.

SCAPHITES NODOSUS var. BREVIS Meek

FIG. 8. Dorsal protile of an imperfect, septate portion of a large individual, showing the markings and the relative thickness of the volution.

FrG. 9. Diagram of one of the outer septa enlarged to one and a half diameters, showiug the general features of those of the group.

SCAPHITES NODOSUS var. QUADRANGULARIS M. \& H

Fig. 10. Lateral view of a very perfect specimen, showing the features of the variety as obtained at this locality.

Fig. 11. Profile view of the same, showing the flattened dorsum.

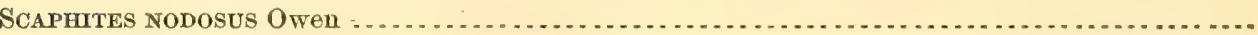

FIG. 12. Lateral view of a large individual, imperfect at the aperture, brit presenting the characters of Dr. Owen's typical form. 


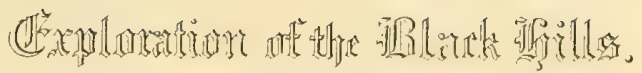

Cephalopoda.

PLANEE XXIT,
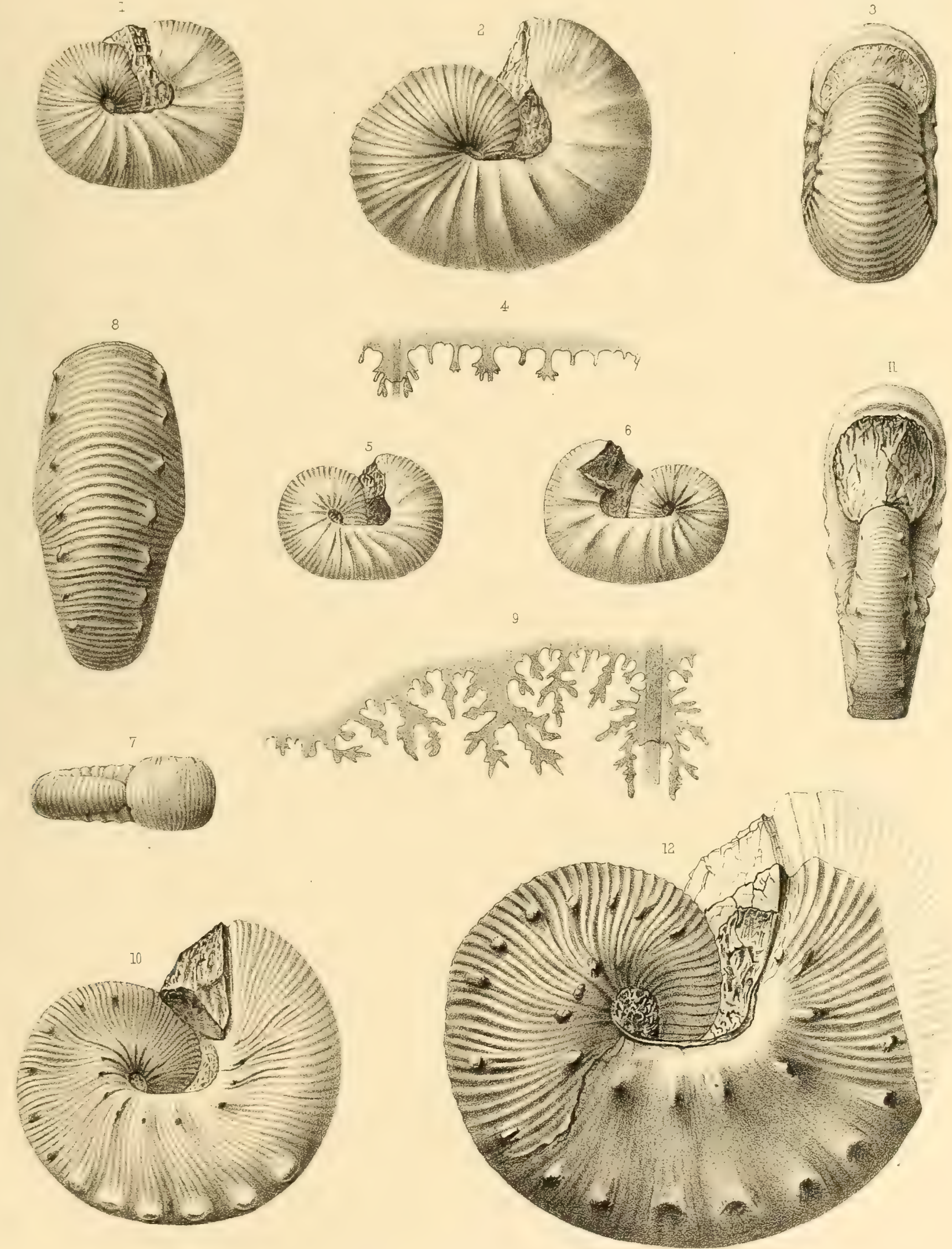


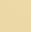

, + 


\section{P A LEONTOLOG Y.}

\section{PLA T E XIV.}

Prionocyclus Wromingensis Meek

FIG. 1. View of a small specimen of the species.

FxG. 2. Back view of the same, showing the carina and continuation of the ridges.

FxG. 3. Lateral view of a larger individual, showing the arrangement of the costæ.

* Helicoceras (Heteroceras?) simplicostatum Whitf... . . . . . . . . . . . . . . . . . (See foot-note.)

FIG. 4. View of the fragment, showing the features described.

Helicoceras stevensoni Whitf

Fig. 5. Lateral view of a large specimen, showing the features of the shell.

FIG. 6. View of the opposite side of the same specimen.

Fra. 7. Basal view of the same, showing the size of the umbilicus.

Fig. 8. Diagram of the dorsal and first lateral lobes of a septum, together with a part of the second lateral lobe, as far as could be obtained without endangering the specimen. Enlarged to two diameters. Obtained from the middle volution of tho specimen figured.

Heteroceras? xebrascense M. \& H.

FIG. 9. Diagram of a septum from the lower volution of the specimen figured. Enlarged to two diameters. See also Pl. 15, Fig. 6.

* The fragment figured is the non-septate portion of a dextrally-coiled shell of large size, marked by simple, angular, revolving costæ, which are nearly vertical on the dorsal side of the shell, and distant about an eighth of an ịch between crests. Intercostal spaces concave. At somewhat regular distances, of about one-fourth of the revolution, there is a distinctly stronger costa, which is irregularly nodose on the dorsum. Septa unknown. It is a distinet and strongly marked species.

Formation and locality.-In ferruginous sandstone, East fork of Bever Creek, Black Hills. Fort Benton Group. 
2.Ne

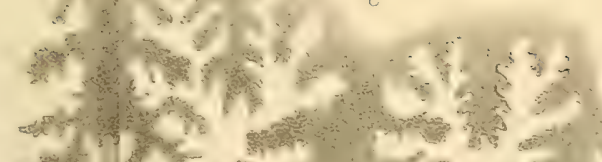

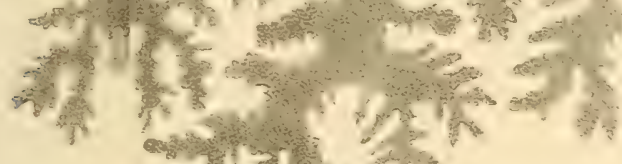

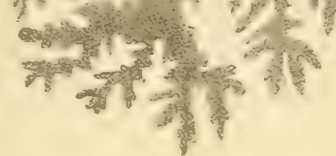

का

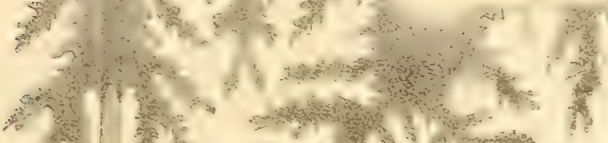

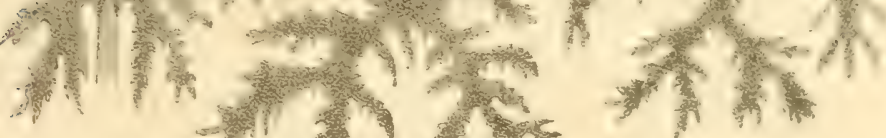

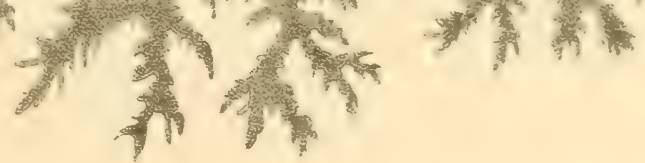
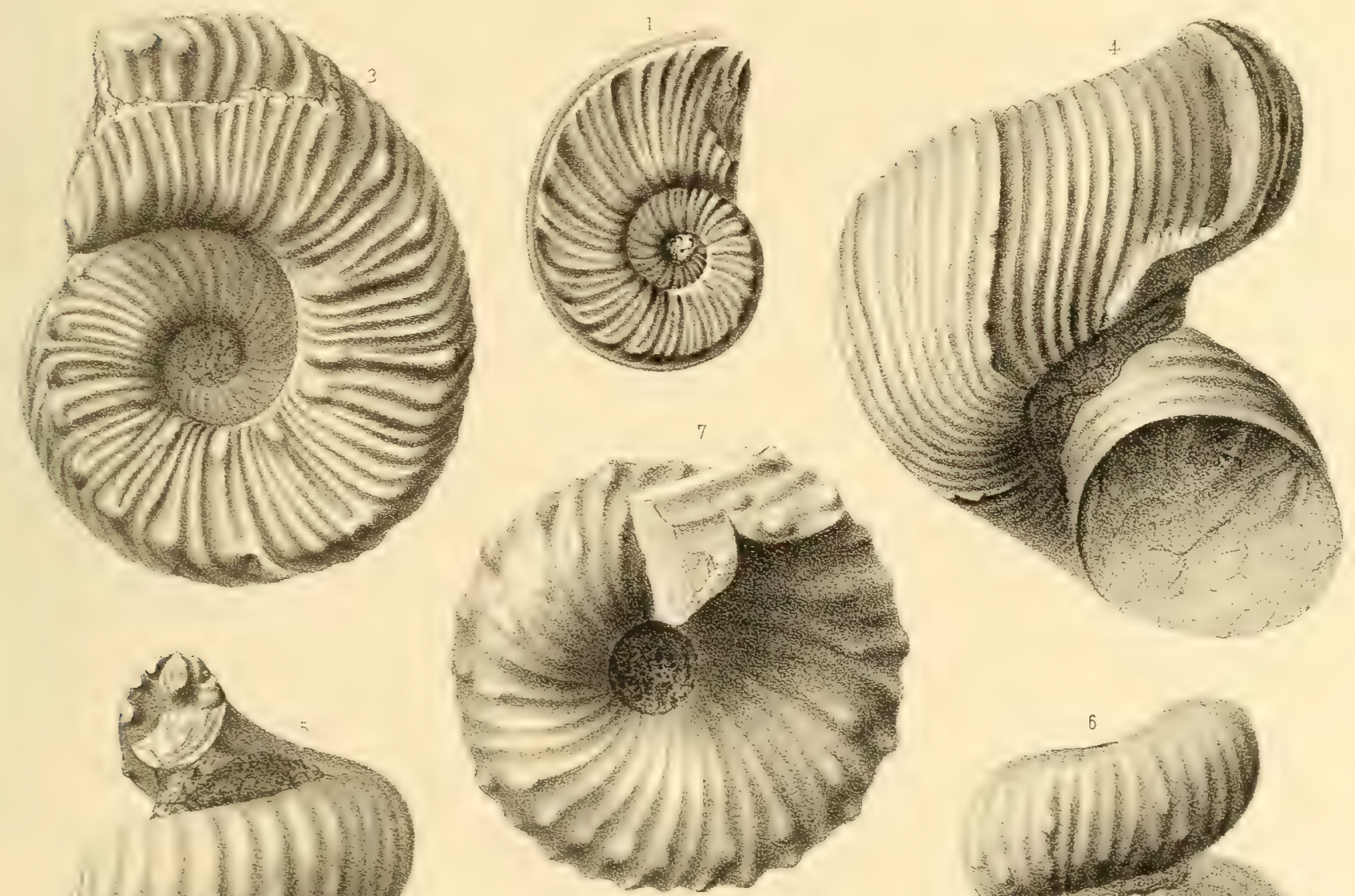

i 1 (n)

( $)$
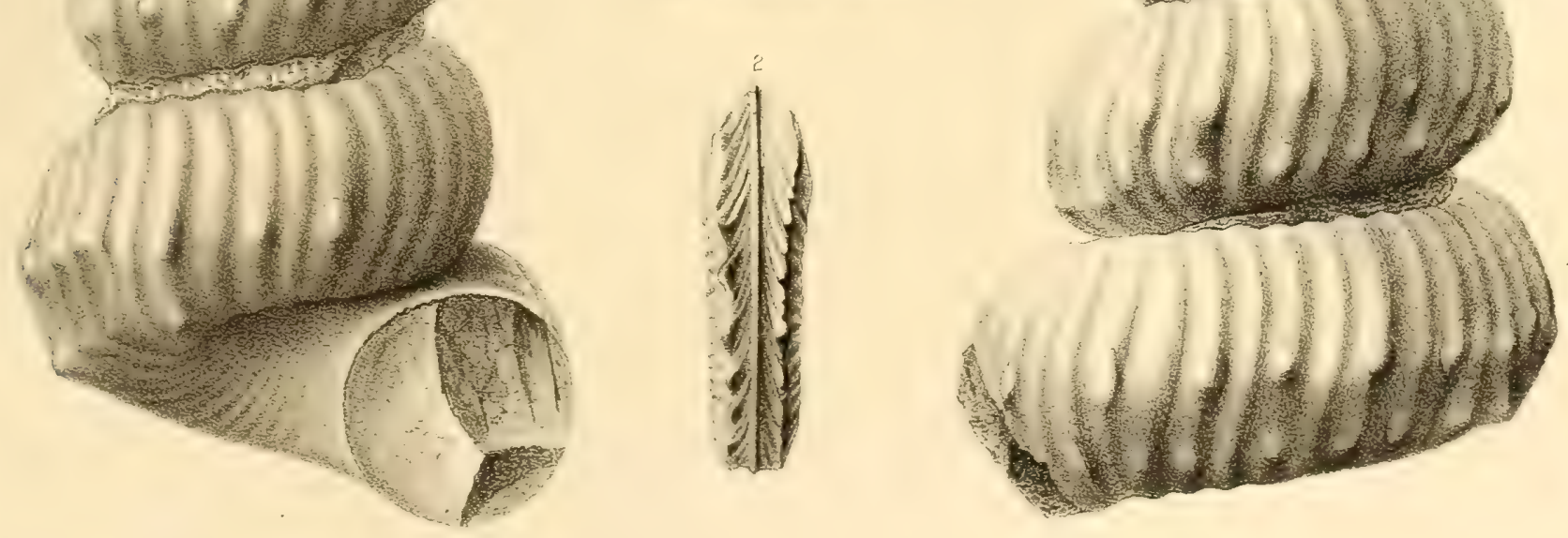



\section{PALEONTOLOGY.}

\section{PLATE X V .}

Heteroceras NEWTONI Whitf

Frgs. 1, 2. Views of the opposite sides of the type specimen, showing the rapidly expanding tube, and preserving the surface characters.

FIG. 3. Vertical view of the same individual, showing the broad umbilical opening and the commencement of the deflection of the outer end.

FIG. 4. Diagram of a septum from near the larger extremity of the specimen. Enlarged to two diameters.

ANCYLOCERAS JENNEYI Whitf

FiG. 5. Enlargement, to one and a half diameters, of a septum from a small fragment of a specimen, showing some variations as compared with that shown on Plate 16, Fig. 9. See also Pl. 16, Figs. 7-9.

Heteroceras? Nebrascense M. \& H.

Fig. 6. Lateral view of a specimen referred to this species, showing two volutions of the septate shell. See also Pl. 14, Fig. 9.

ANCYLOCERAS TRICOSTATUS Whitf

IIG. 7. Lateral view of the fragment, showing the triplicate character of the costæ, and the obtusely triangular nodes on the dorsum.

FIG. 8. Enlarged diagram of a septum from near the commencement of the outer third of the fragment. 'Two diameters. 


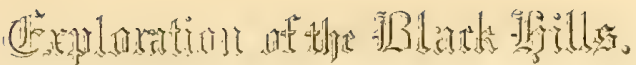

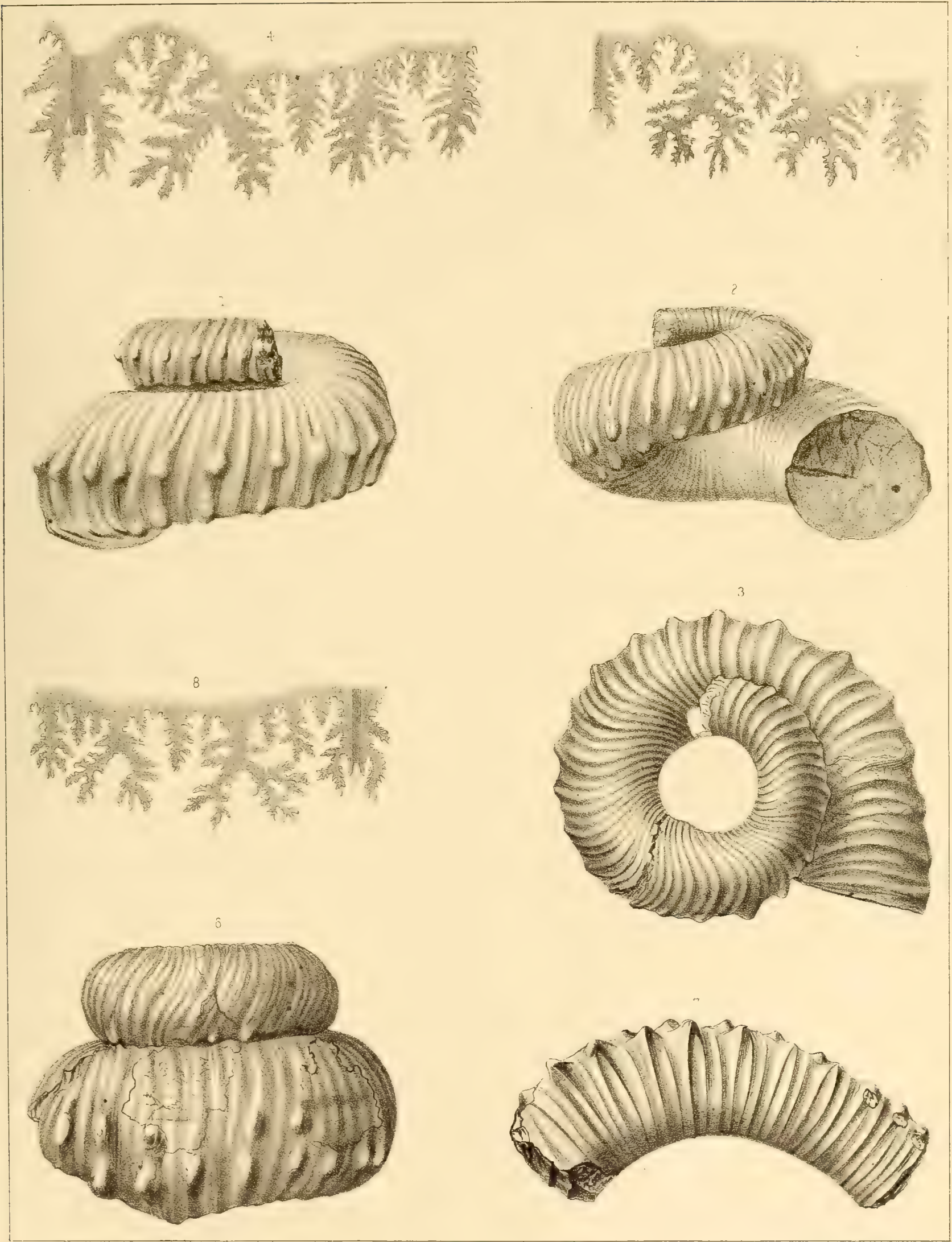

E M i \& RPW ¿क 



$$
\text { - }
$$




\section{PALEONTOLOG Y.}

\section{PLATE X VI.}

Ptychoceras MeekanUm Whitf

FiG. 1. Lateral view of a specimen preserving the curved extension of the smaller limb, and also showing the commencenent of old age characters, in the closely arranged rings near the outer end of the larger limb.

FiG. 2. Diagram of a septum from just within the bend of a similar specimen. Enlarged to two diameters.

Ptychoceras crassum Whitf

FIG. 3. Lateral view of the specimen deseribed, natural size.

FIG. 4. Dorsal view of the same, showing the features of this part of the shell.

FIG. 5. Diagram of a septum from another iodividual, enlarged to the same extent as Fig. 2.

FIG. 6. Sectional diagram of the specimen, showing the thickness of the shell.

ANCXLOCERAS JENNEYI Whitf

FIG. \%. Lateral view of a specimen of the species, preserving an outer volution, and parts of the inner smaller coil.

FrG. 8. Dorsal view of the outer part of the same, showing the ranges of nodes, not exactly the same on the opposite sides.

FIG. 9. Diagram of a septum from near the middle of the larger coil. Two diameters. See also Pl. 15, Fig. 5.

NAUTILUS DEKAYI var, MONTANBENSIS Meek

FIG. 10. View of the inner side of a specimen, showing the breadth of the shell and the distance of the septa.

FiG. 11. Lateral view of the same specimen, showing the rate of increase in the coils. The apparent umbilical perforation arises from the exfoliation of the shell. 


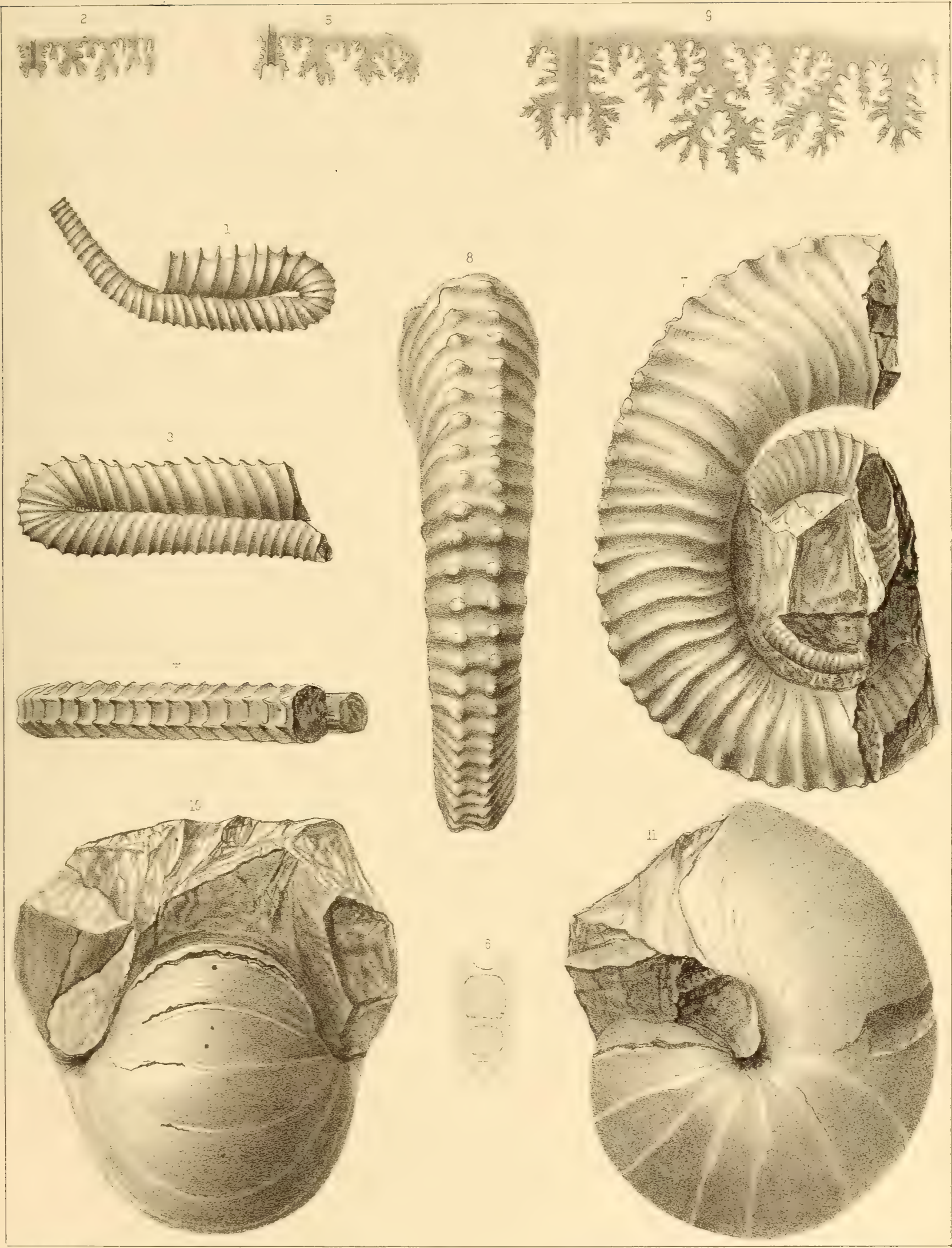


U. S. GEOGRAPHICAL AND GEOLOGICAL SURVEY OF THE ROCKY MOUNTAIN REGION.

J. W. POWELL, in Charge.

\section{MICROSCOPIC PETROGRAPHY}

OF THE

\section{BLACK HILLS OF DAKOTA.}

BY J. H. CASWELL. 



\title{
CHAPTER VII.
}

\section{MICROSCOPIC PETROGRAPHY.}

\author{
By JoHN H. CASWELL. \\ S E C T I O N I. \\ Q UARTZITES.
}

Quartzite is a granular to compact mass of quartz, having in general a splintery fracture and a white or gray color.

Granular quartzite is made up of small to minute grains of quartz, always possessing, however, a crystalline structure. It is difficult to distinguish it in certain phases from a crystalline sandstone; and in some cases the quartzites resemble the sandstones, although the cementing material is always wanting in the former. Again, some quartzites undoubtedly contain rounded grains or pebbles of quartz.

Schistose quartzite consists of a compact mass of quartz, which splits with more or less ease into plates, having also a somewhat stratified structure. This is occasioned by the presence of crystals of white or brown mica arranged in parallel layers. These rocks belong really to the schists, and pass into mica-schist by preponderance of the mica. In the other extreme they are pure quartzite, when the mica is present in such small quantities that it may be considered a secondary ingredient. The mica crystals are often very distinctly grouped in parallel rows.* This structure was observed in the quartzite from Rapid Creek [13], which has also an indistinct schistose cleavage, although there is no stratification visible to the naked eye. The granular variety of quartzite is represented by the rocks from Hall's Cut-off [38] and from Hall's Water [209], which are highly 
crystalline and have rather a splintery fracture. There is some mica present in equally distributed crystals, but not at all grouped in layers or rows.

The quartzite from French Creek [208] possesses the rounded grains, but without cementing material, while in those from Amphibious Creek [205], Terry Peak [206], Red Cañon Creek [207], Box Elder Creek [200] and [201], the rounded grains are cemented together by some material which has the appearance of having once been in solution. It is sometimes silica, and at other times of an argillaceous nature: In the latter case the rocks are sandstones rather than quartzites

The secondary minerals often occurring in quartzite are, besides the mica already mentioned, principally orthoclase, hornblende, magnetite, cyanite and garnet. With the exception of cyanite, all were observed to be present in these rocks.

The quartzite from the Stockade, French Creek [17] is a grayish, finegrained rock of quite dark color, containing numerous small, dark, longshaped erystals having a high luster. An examination of the thin section under the microscope shows that it is composed of crystalline quartz in small grains full of cavities, black particles of magnetite and microlites, the latter probably hornblende. Scattered through the mass are also larger, irregular, broken erystals of hornblende, strongly dichroitic, and in some cases still showing the characteristic cleavage lines of the angle of $124^{\circ}$. With crossed nicols they are of a fine dark-green color, changing, upon turning the polarizer, to a lighter yellowish-green Some rather opaque, non-polarizing masses are probably decomposed feldspar. The magnet readily attracts particles of magnetite from the pulverized rock.

The quartzite from Hall's Cut-off [38] is quite different from the above. It is of a lighter color and contains mica in small spangles, abundantly scattered through the mass. The microscope shows the quartz to be very clear, containing some cavities, highly crystalline and giving beautiful colors with the polariscope. The mica seems to be somewhat decomposed, although it occasionally shows the laminations peculiar to its structure. Large, isotropic crystals of garnet are present and are easily recognized. There are also black, opaque masses of magnetite, submetallic in reflected light. 
The quartzite from Rapid Creek [73] is gray in color and very uniform and compact in structure. Under the microscope, the quartz is crystalline and pure, containing microlites which have the sharp edges of crystals, and also small greenish leaves of mica arranged in parallel rows and pointing in one direction. This structure gives a little schistose character to the rock. Magnetite, as usual, is present in sharp angular grains, and also some mica.

No. [75], from the same locality, is more pinkish in color, and in the section shows crystalline quartz with cavities and microlites, the latter being faintly dichroitic. There is much more mica than in [73], which fact brings it nearer to mica-schist in character.

Jasper [92], from Jasper Hill, Box Elder Creek, is of a red color, with veins of white quartz through it. Under the microscope, the quartz is seen to be very fine granular, with a reddish-brown pulverulent pigment, which is no doubt oxide of iron. There are also some opaque, dark, cubical and triangular crystals with hollow centers, the remains of decomposed pyrite.

In the quartzite from Box Elder Creek [200], which is from light-gray to flesh color, the quartz grains are somewhat rounded, and in the interstices, often surrounding the quartz particles, is seen a cementing material which has the appearance of having flowed in streams through the crevices when in solution, so as to fill up all to a solid mass. This allies the rock more to the sandstones than to crystalline quartzites like the former ones. There is some mica and a little orthoclase present, and in the quartz are cavities and long, exceedingly slender microlites, similar to those in specimen [169].

The color, structure, and appearance under the microscope of [201], also from Box Elder Creek, are the same as the above, except that there is less nica.

The quartzite, however, from Amphibious Creek [204] is crystalline, the quartz being sharp and angular in outline, and full of very large cavities and microlites. There are also masses of fibrous, dichroitic hornblende in great abundance, and some mica. The mineral observed as hornblende does not show any lines of cleavage, but it has not the appearance of mica, and in the weathered parts of the rock these masses have become 
decomposed, leaving small empty holes in the rock, which appearance is not often found with mica. There is no cementing material present.

The next rock [205], also from Amphibious Creek, is much darker than the preceding, being of a brown color. In the section, it is seen that the quartz is in rounded grains, cemented together by a material showing the wavt-like lines and traces of a former fluidity, as mentioned before. In some parts of the slide this is very dark and almost opaque from oxide of iron, the edges of the quartz grains also being colored very dark brown by the same pigment. Quite striking is the appearance of the brightly polarizing cementing mass, which is penetrating silica, between the darkbordered quartz grains. This rock is again rather a sandstone than a quartzite.

The specimen from the locality southeast of Terry Peak [206] has a decomposed, earthy luster of reddish-brown color, plainly showing the presence of much oxide of iron. Under the microscope, it was observed that the quartz grains were rounded, but with very little cementing material between them, although large masses of opaque oxide of iron were scattered abundantly through the rock. Needle-like microlites were seen in the quartz, and in the rock some brown mica and occasionally a little hornblende.

The rock from Red Cañon Creek [207] consists also of rounded grains of quartz, held together by a very dark or black cement. Nothing else of note was observed, except some magnetite.

In [208], from the mouth of French Creek, the quartz is in grains a little rounded, but pure and clear, with very little or no cementing mass. There is some mica, opaque and probably weathered. The rock is of a light-reddish color.

The quartz in [209], from Hall's Water, is very pure and crystalline, containing microlites and eavities, the former being in the shape of short, stout crystals. The white mica is very clear and transparent, polarizing finely, and showing lines of lamination. There is also some brown mica present, and a few garnets are easily recognized by their isotropic behavior with crossed nicols. The rock is very light colored, with glistening spangles 
of mica scattered through it, and is similar to [38]. It is a characteristic crystalline quartzite.

That from Warren Peaks [210] is similar in color and fuster to the above, though a little more reddish. In the section, the quartz is observed to be sharp and crystalline, with a few crystals of transparent mica through it and occasionally some brown mica.

In [211], from the mouth of French Creek, the quartz is again crystalline and clear, containing very large cavities and good sized microlites, strongly dichroitic, changing from yellowish-green to red with the analyzer alone. They may be hornblende, as there are some larger crystals having the same peculiarity. The brown mica present is much less dichroitic. The color of the rock is light-gray.

The rock from Amphibious Creek [212] is made up of rounded grains of quartz, which are full of particles of a black mineral, probably magnetite, and exceedingly minute microlites. The section is so opaque from the presence of large quantities of oxide of iron that it is difficult to render it sufficiently transparent for observation.

In [215], from French Creek, the quartz is very pure and crystalline, with numerous cavities and microlites. There are also transparent mica and some opaque masses, probably a darker and weathered mica.

The rock from Rapid Creek [202] is a glauconitic limestone. Under the microscope, the mass of rock consists of a whitish crystalline mineral, which polarizes feebly, changing only from light to dark, while the lines of cleavage are very distinct. This mineral has in every way the appearance of calcite. Sparingly scattered through the limestone are pellucid and brilliantly polarizing grains of quartz. There are also some brown masses and occasionally a rounded, green body of finely granular texture. These are the glauconite grains, the brown ones being the same almost entirely decomposed. In some cases merely a thin, brown crust remains lining the inside of the cavity. The hand specimen was not at hand to examine and compare with the observations in the section.

The glauconitic sandstone [203] from Rapid Creek shows under the microscope that it consists of quartz and glauconite in about equal proportions, held together by a dark-brown cement. The quartz grains are mostly 
rounded, a few only being sharp and angular, and in some are cavities and microlites. The glauconite bodies have a bright grass-green color, their texture being tolerably uniform, with the exception of a few dark spots and cracks in the larger ones. The grains vary in size from quite small to very large oval, while the forms and shapes are also different, depending upon the plane of section. Some are long and narrow and others round or oval; the large ones are bean-shaped and quite symmetrical, a few being broken and of angular outlines. They do not change color in polarized light. A few columnar and banded bodies in the cementing mass are fragments of shells curved in form. The cement is quite abundant and is colored very dark-brown by oxide of iron, which is in numerous small, round grains, seldom having a square outline.

\section{S E C TION II.}

\section{MICA-SCHISTS AND SLATES.}

The rocks described in this section belong chiefly to the two classes of schists and slates. Mica-schist is a crystalline mixture of mica and quartz, both minerals being present generally in good sized crystals; and, even when of minute size, their crystalline character can be distinctly seen under the microscope. Examples of the above cases are the rocks [1], from French Creek, which is a very fine-grained mica-schist, and [13] and [27], which have a coarser structure, while [69], from Rapid Creek, is almost a compact rock, showing, however, the crystaline mica and quartz under the microscope.

Mica-schist has the schistose structure more or less marked, accordingly as the mica or quartz predominates. When the rock becomes more homogeneous in character and of a darker color, being micro-crystalline in structure, with a slaty cleavage and appearance, it is called mica-slate, the "Thonglimmerschiefer" of Cotta and Zirkel. This is an intermediate rock between mica-schist and clay-slate, differing from the former in closely resembling a clay-slate, and from the latter in being distinctly made up of crystalline quartz and mica, which can easily be observed under the microscope in a thin section of the rock. The specimens from Rapid Creek $[64],[65],[67]$ and [71] are mica-slates answering to this description. 
The true clay-slate consists also of quartz and mica, but nerer crystalline, being so homogeneous and amorphous in structure that Zirkel defines it as made up of "microscopic mica scales and dust-like quartz grains." This distinction is quite apparent under the microscope, when none can be made between the two hand specimens. Note the resemblance between [64], [65] and [74]; while the two former are quite micaceous, the latter [74] is nearly a true clay-slate, showing scarcely a trace of crystalline structure. By the dwindling in size, then, of its constituent minerals, mica-schist graduates into mica-slate and argillaceous mica-slate as it comes nearer to clay-slate in character.

I would also note that the variation in these rocks from French Creek and Rapid Creek may be due to metamorphic influences of different degrees.

The mica-schist from the Stockade, French Creek [1], has a gray color, inclining to greenish, and is evidently very rich in mica. Under the microscope, quartz in abundance was observed containing numerous cavities, some quite large, and also microlites. Occasionally, there are large, pellucid masses of this crystalline quartz. The mica is of two kinds, one greenish-brown and dichroitic, the other being in the form of long white crystals, sharply defined and clear, but not possessing any dichroism. These crystals generally point in the same direction, and are sometimes bent and curved around a quartz grain and also imbedded in the leaves of brown mica. They show longitudinal lines of lamination, polarize brightly, giving red and green colors, and are undoubtedly white, transparent muscovite. The brown, dichroitic biotite is quite irregular in shape, and in large plates and leares, and changes in polarized light only to a darker greenish-brown. An abundant black mineral, sometimes having a hexagonal section, although of minute size, and a submetallic luster, is considered to be in part magnetite and in part small crystals of mica. The structure of the rock is erystalline.

Mica-schist from the same locality [13] is quite different from the preceding, it being much coarser in structure and colored reddish by oxide of iron. In the section, the quartz is seen to be predominant and in large clear masses, containing cavities and small, well defined, dichroitic hornblende crystals. The latter are sometimes of large size and so strongly 
dichroitic that they change from brown to green and red with the analyzer alone. They are also abundant in the rock. The brown mica occurs in large masses, irregular in shape and sometimes striated very distinctly. It polarizes only from brown to very dark-brown, being also dichroitic. Some long, transparent crystals of white mica, similar to those in [1], are not at all dichroitic, and show very little change of color even with crossed nicols. There are also a few crystals of orthoclase present, quite large and tolerably well defined in form. A large, banded crystal may be cyanite. This rock is a mica-schist, but approaching gneiss in character.

The rock [24] from the Stockade, French Creek, has a general greenish color, caused by large crystals of hornblende imbedded in a whitish feldspathic mass. Under the microscope, large, green, strongly dichroitic crystals of hornblende are at once remarked. The lines of cleavage are very distinct, and the sections showing these lines give the most marked change of color with the analyzer alone from yellowish-brown to darkgreen. Quartz is also quite abundantly present in grains, having cavities and microlites. Orthoclase makes up with the quartz the groundmass of the rock. It is partially decomposed, so that it is somewhat cloudy and opaque, but it occasionally shows colors in polarized light and also cleavage lines. There is a little magnetite present. This rock is a hornblende-gneiss, although it scarcely shows any lines or marks of the stratification peculiar to gneiss, owing to its very crystalline structure.

The mica-schist [27] from Amphibious Creek is gray in color, with red spots in it of oxide of iron, and has a orumbling, weathered appearance. In the section, the rock appears to be made up of quartz, transparent, crystalline and in large masses, and mica. The former contains unusually large and fine cavities, microlites, and also some short, stout, dichroitic hornblende crystals. The mica is quite dark and nearly opaque, but still changes to a darker brown when observed with the analyzer alone. It is scattered through the rock in large, irregular masses. A small piece of a granular and polarizing mineral noted is no doubt a fragment of orthoclase, not being nearly as transparent as the quartz.

The rock from French Creek [40] has a crystalline luster, but a very slight schistose character. It is very dark-green, the macroscopical 
hornblende crystals being predominant and easily recognized, with white spots or faint layers of feldspar or quartz and some pyrrhotite through it. Under the microscope, beautiful crystals of hornblende were seen, varying in color from pale yellowish-brown to dark-green and red. The pale crystals, being sections across the vertical axis, show the characteristic cleavage lines and a strong dichroism very finely. This hornblende, which is greatly in preponderance over the other constituents, is very crystalline, although the masses are irregular in outline. Next in importance is the orthoclase, distinguished from the quartz by a little less transparency and more fissures and cleavage lines; it is quite abundant in crystalline grains The quartz is present in grains and masses of tolerably good size, which polarize in very brilliant colors. It contains cavities and microlites, and is of about the same quantity as the orthoclase. Quite remarkable is the comparatively large amount of plagioclase present. This occurs in large crystals, with very delicate but well defined twin lamellations or banding, some of the crystals being very beautiful. Some garnet crystals, as hexagonal sections imbedded in the hornblende, were noted, as they are isotropic in behavior. There is also some magnetite. The structure of the rock is coarsely crystalline, and much fresher than [24], with more hornblende; some plagioclase, and titanite. It is a hornblende-gneiss, and the section observed in polarized light presents a beautiful appearance, owing to the great variety of brilliant colors.

The rock [64] from Rapid Creek is very dark indeed and fine-grained and slaty in character, so that it can be cleaved into flat, tolerably smooth pieces. Thin veins of white quartz traverse it at right angles to the stratification, and are occasionally of considerable thickness. In the section, it was observed that the rock consists largely of quartz in rounded grains, large and small, and dark colored nearly opaque mica, and has a distinct schistose structure. Sometimes a large mass of mica is seen, but most of it is in very small particles, fibrous in character. The veins of quartz are of course conspicuous, polarizing as well as the grains with bright colors. A little triclinic feldspar and one small hornblende crystal were noted in the slide.

The fibrous character of the groundmass, so plainly of a schistose 
structure, with the larger masses of mica and quartz, place the rock as midway between mica-schist and clay-slate, but it belongs more to the schists than the slates. It is therefore a mica-slate.

The slate [65] from Rapid Creek is similar in appearance to the preceding, but much more homogeneous and slaty, cleaving easily into very thin pieces. Under the microscope, was observed, as before, quartz grains and dark mica in a very fine groundmass of a schistose structure. There are fewer large masses of mica than in [64], the rock approaching more nearly the clay-slates. A little plagioclase was also noted. This is again a mica-slate.

The specimen [67], from the same locality, shows a precisely similar character to [64] and [65], even to the presence of a small piece of plagioclase.

The rock from Rapid Creek [69] resembles the preceding ones, but is much more compact and has a greenish color, differing also in the absence of any macroscopical mica. Under the microscope, the difference is remarkable; quartz in pure, clear grains predominates, between which are small long-shaped crystals of white mica arranged in the same parallel direction, so as to occasion the slightly schistose character of the rock. These mica crystals are almost exactly like those in [1] from French Creek, but much smaller. The large, brown masses are wanting, however, there being only one such piece in the slide. Remarkable is the abundance of magnetite in good sized grains, which have a beautiful submetallic luster. The magnetite seems to follow in part the lines of direction of the mica crystals. The quartz contains microlites, but they were too minute for determination. From the above observations, this rock is an exceedingly compact and finegrained mica-schist, as it does not have the fibrous groundmass of the slates [64], [65] and [67].

The next, however, from lower Rapid Creek [71], is very much the same as [64] and [65], except that the color is quite reddish and the appearance weathered. In the section, it was noted that the groundmass is quite fibrous in structure and that there is less quartz scattered through it. The mica appears quite black, opaque, and negative in behavior in polarized light. There is also a reddish-brown mineral in considerable 
abundance, probably hematite as a resultant of decomposition, or it may be only weathered mica. The fibrous structure mentioned before arises in all likelihood from the interlacing of very small mica crystals This rock is a mica-slate.

The slate from Rapid Creek [74] is almost black in color, and of a uniform, homogeneous structure, cleaving easily into long columnar fragments. It resembles much more a true slate than any of the preceding, a fact which the microscopical examination undoubtedly proves. The structure of the rock was observed to be very fine-grained indeed, apparently consisting of minute crystals arranged in parallel rows, with an occasional dark line between them. There is but little quartz present, and that in very small grains; also in lines parallel to the stratification. The small crystals are a little dichroitic, this being observed in some of larger size, which might determine them to be mica. Magnetite is present, particularly in one large mass surrounded by quartz. The homogeneous character of the rock macroscopically and also as seen under the microscope, together with the absence of much quartz, decides this rock to be a clay-slate, although it is not quite as uniform as true roofing slate.

The schist from Box Elder Creek [81] is of a dark-green color, with veins of white quartz running through it, the mica being greatly in excess. Under the microscope, the mica was observed to make up most of the rock and to have a fine brownish-green color. It is but slightly dichroitic when cut parallel to the lamination, but in the cross sections of prismatic shape it is strongly so. The fine green color in polarized light at first indicated hornblende, but there was no satisfactory evidence found of the characteristic cleavage lines, which could hardly fail to be present in such a crystalline rock had the mineral been hornblende. It was determined, consequently, to be magnesia-mica, of which the dark-green color and strong: dichroism are usual peculiarities. There is considerable quartz present, quite crystalline, and having interspersed through it small, transparent, green crystals of mica. This rock is a mica-schist, the mica predominating, but of a different character from any of the preceding, being perfectly fresh and erystalline, without any traces of weathering or decomposition.

The rock from Iron Ledge, Box Elder Creek [85], is lighter in color $31 \mathrm{~B} \mathrm{H}$ 
and quite soft. In the section under the microscope, there appears to be principally quartz, with irregularly shaped particles of a brown, partially altered mica arranged in rows as if stratified. This mica is not generally dichroitic, but an occasional long prismatic section is quite strongly so. Between the quartz grains microlitic, needle-like crystals, pointing in one direction, probably occasion the schistose character of the rock, and are mica crystals. It is a mica-schist of similar character to the former ones [69].

No. [86], from the same locality as the preceding, is much lighter in color, being brownish-white and quite hard. On the cross fracture it shows very plainly a schistose structure. An examination of the section under the microscope showed considerable white, but rather opaque, mica, and partially decomposed orthoclase in a fibrous groundmass, strongly recalling a similar appearance of the mica-slates previously described. There is also a little quartz in small transparent grains, but subordinate in quantity. Some plagioclase was also noted; it is weathered, but still shows the colored banding of the twinned crystals quite plainly. The orthoclase is rather muddy, giving, however, considerable color in the fresher portions, where traces of the cleavage were also quite well marked. These minerals are confused and ragged in outline, so as to render the examination somewhat unsatisfactory. The fibrous groundmass and preponderance of the orthoclase over the quartz makes the rock a feldspathic mica-slate, or a clayslate partially metamorphosed and intermediate between that rock and gneiss.

The dark-green rock [97] from Box Elder Creek has a slightly greasy feel, and is weathered on the surface to a light-yellowish crust. Under the microscope, it shows in polarized light with crossed nicols a dark ground, with evenly distributed white spots of irregular shape, and occasionally some yellowish crystals almost entirely altered to an opaque, black mineral or magnetite. This mineral is also present in great abundance, sometimes having an indistinct crystalline form. The section in ordinary transmitted light has a pale-green color. The whitish particles have a needle-like, crystalline form, with a fibrous structure, while the yellowish crystals, being much broken, resemble olivine in process of alteration into magnetite and opaque, black serpentine-mass. The fibrous, feathery and 
thread-like appearance of the general mass of the rock determines it to be serpentine, which a blowpipe test confirmed. It has probably been formed by an alteration of the slates, which theory an exact observation of its occurrence would perhaps support.

\section{SECTION I I .}

\section{RHYOLITE, TRACHYTE, AND PHONOLITE.}

The recent eruptive rocks, formerly known under the name of the trachyte group, have of late been divided into several classes, depending upon their structure and the presence or absence of the minerals, quartz, and oligoclase, or other triclinic feldspars.

The quartz-bearing trachytes are called rhyolite and quartz-trachyte, while those free from quartz are subdivided into sanidin-trachyte and sanidin-oligoclase-trachyte, accordingly as the sanidin occurs in them alone or accompanied by oligoclase. In close relationship and analogy to these rocks are andesite, consisting generally of oligoclase and hornblende or augite, and phonolite, which latter has sanidin for its chief constituent, with nephelite, nosite, and various decomposable zeolites. While sanidin-oligoclase-trachyte, by the addition of quartz, falls into the class of the acid trachytes or rhyolite, so on the other hand, by the gradual diminution of the sanidin, it becomes andesite. In this rock the oligoclase occurs in combination with hornblende as well as augite, and andesite is accordingly divided into hornblende-andesite and augite-andesite. As with trachyte, quartz is sometimes an ingredient, and causes a subdivision of both kinds of andesite into quartz-bearing hornblende or augite-andesite, the former being called dacite, and those free from quartz.

'The glassy forms of trachyte vary greatly in appearances and structure, and are known as obsidian, trachytic-pitchstone, pearlite, spherulite, \&c. They may be regarded as masses of the same composition as the varieties of trachyte already mentioned, but solidified under circumstances preventing a crystallization of their constituent minerals. As may be inferred, they vary in every respect similarly to the crystalline member of 
the class to which they belong, as is shown by a chemical determination of the silica and composition.

Of the varieties of rocks mentioned above, there are represented in the specimens from the Black Hills thus far examined rhyolite, sanidin-trachyte, sanidin-oligoclase-trachyte, and phonolite; no andesite was observed.

Rhyoulte.-Rhyolite is quite different in general appearance from sanidin-trachyte, in that it is much more compact and fine-grained or felsitic in structure. It consists of a groundmass, in which are visible in most cases crystals of sanidin and biotite or hornblende, with small grains of quartz. Its most predominant colors are white, yellowish and greenishwhite, light-gray, pearl-gray, greenish-gray, and sometimes pale-red. In many cases the quartz can only be detected in the thin section with the aid of the microscope. The groundmass varies greatly in structure and appearance from a crystalline, or micro-granitic, and micro-felsitic to a felsitic, spherulitic, half-glassy and glassy character *

The first or coarsely crystalline structure is somewhat granitic in appearance, so much so that the geological occurrence must be relied upon to a great extent to distinguish the rhyolite from granite-porphyry or feldspar-porphyry. This form of the groundmass does not occur very frequently, but there is an example of it in the rocks [101] and [103] from Terry Peak, which, according to the occurrence given, pass gradually into well defined rhyolite or trachytic rock

A characteristic peculiarity of the compact groundmass of rhyolite is a banded appearance, caused macroscopically by an alternation of two colors, geneially dark-gray and pinkish-violet, in parallel, narrow bands. These colors, in a great number of shades, are often in layers as thin as mere lines, so that the rock has somewhat the appearance of banded agate, the most delicate markings being scarcely visible to the naked eye. From examination under the microscope by Zirkel, these bandings and also the wavy, fluidal appearance are produced "by a different amount of coloring particles (needles and grains of ferrite and opacite) alternating in layers, and by a band-like alternation of different varieties of structure, generally

For a minte aud detailed classification of the various microscopical types of the groundmass see Zirkel's Microscopieal Petrography of the Survey of the Fortieth Parallel, p. 203. 
with a gradual passage between one another." Occasionally, the rock splits easily into flat slate-like plates. These appearances were observed in the Black Hills rocks as [127], [135], \&c. This groundmass has again a. resemblance to burnt clay, with broad, reddish bands in a light-yellowish mass of a porous and rough texture. The groundmass has also a halfglassy or glassy structure, with the character of obsidian, pearlite, \&c, with but few imbedded crystals. This form of rhyolite is called half-glassy or hyaline-rhyolite by Zirkel, and includes obsidian, pumice-stone, pearlite, \&. which belong geologically to the rhyolites.

A determination of the percentage of silica is necessary, when the rhyolite is of a very compact, felsitic texture with but few crystallized minerals, such as quartz and sanidin, to explain its nature. In such a case, the amount of silica, the microscopic behavior of the thin section, and the geological association must all be called into requisition.

A rough, decomposed, porous structure with numerous holes and cavities is frequently the character of the groundmass. The most usual, however, is a fing-grained or micro crystalline texture, generally of a lightgray color, appearing almost compact; a close examination being required to see the minute crystalline points. The microscope shows the mass to consist of small sanidin crystals, quite rough or ragged in form, and closely interlaced. Of this kind are the Black Hills rhyolites [135], [147] and [152]. The imbedded crystals are not very abundant, sometimes entirely wanting, and are sanidin and occasionally biotite.

Spherulites, often present in the felsitic groundmass, are small, round, fibrous masses of a distinctly radiated structure. They vary greatly in size, from very minute to quite large, and are not very sharply separated from the groundmass. When the fibers are arranged on a line instead of around a center, the structure thus produced is very peculiar and interesting; it is called axiolite by Zirkel, and is stated to belong chiefly to rhyolites.

As rhyolite is the acid variety of trachyte, owing to the presence of quartz, the silica percentage of the groundmass is always much higher than that of sanidin-trachyte. In the Black Hills trachytes it varies from 67 to nearly 80 per cent., while Zirkel gives the analysis of a rhyolite 
having silica as high as 82 per cent. The percentage of silica in these rocks was determined, as well as the amount dissolved in hydrochloric acid. The loss in acid, however, cannot be considered of very much value, owing to the change in the constituents of the rocks from weathering, which materially increases the proportion of the soluble part and causes it to appear as if there were decomposable minerals present. Notwithstanding this uncertainty, the results of both determinations are given further on in the table on page 526 .

From the characteristics mentioned, the varieties of rhyolite are distinguished by Zirkel as follows:

Crystalline-gramlar - of a granitic character.

Felsitic-

Porphyritic-

a felsitie groundmass, without separated crystals.

Half-glassy or glassy-

a felsitic or crystalline groundmass, with imbedded erystals.

consisting entirely, or in very large part, of glass, obsidian, pearlite, \&c.

Almost all of the Black Hills rhyolites belong to the porphyritic variety, as they generally have large sanidin, biotite, and other crystals porphyritic in a fine-grained groundmass. Other varieties oceur in a few instances, which will be mentioned in the detailed description of the thin sections under the microscope.

Quartz is the most important of the crystalline minerals separated from the groundmass. It occurs in grayish and transparent, round grains or crystals, which have a distinct line of demarkation between them and the groundmass. Macroscopically, they can be distinguished from the sanidin crystals, which are in most cases also brilliant and glassy, by their different luster and conchoidal fracture, while sanidin has a good cleavage The hardness of the quartz assists in the distinction. It is sometimes crystallized in the form of doubly terminated crystals, with prismatic faces. In the thin section under the microscope, the quartz appears either in rounded grains or crystals. It can be distinguished from sanidin microscopically by its greater pellucidity, polarizing in brilliant colors, and its lack of cleavage lines. The crystalline form is also of great assistance, when the resemblance between the two minerals makes the distinction doubtful. It often contains microlites and brownish glass bodies, which latter inclusions are sometimes hexagonal in shape. Characteristic for the quartz in trachytic rocks, as 
differing from that of granite and gneiss, \&c., is the absence of any fluid inclusions, * so usual in the latter rocks. Instead of these are particles of volcanic glass, called glass inclusions, which are never found in granitic rocks. The crystals of quartz are generally of sharply defined outline and often twinned, which latter occurrence is most clearly seen in polarized light, as shown in [127], Plate I, Fig. 1.

Sanidin, the chiet constituent of trachytic rocks, occurs in transparent crystals, full of fissures, cracks and cleavage lines. The crystals in rhyolite, however, are not so large as those usually in sanidin-trachyte. The form and the crystals as seen in the thin section varies greatly, from large, rectangular sections to long, columnar crystals, the latter being often very small. The sections are also six and eight-sided Carlsbad twin crystals are of frequent occurrence, the two parts giving different colors in polarized light, according to the position of their optic axes. The crystals polarize in quite brilliant colors, often much resembling quartz in transparency and appearance, the distinction, however, being made by the general rectangular form and the fissures and cleavage lines of the sanidin. In very small and irregularly shaped, often ragged, crystals, sanidin makes up almost entirely the groundmass of many of the rhyolites. These small crystals are only visible in polarized light, being seen with tolerable distinctness when the nicols are crossed.

Plagioclase, or oligoclase, occurs quite frequently, but always subordinate to the sanidin. It can be easily recognized under the microscope by its characteristic colored banding in polarized light, caused by the twin lamellation of the triclinic crystals. In some cases when this is not so distinct, dependence must be placed upon the more weathered or decomposed condition of the smaller, needle-shaped crystals. Plagioclase crystals often interpenetrate those of sanidin, the two forming together a symmetrical crystal, one end being sanidin and the other plagioclase. It is also seen as minute crystals, inclosed in large sanidins. Inclusions are less frequent than in sanidin.

* Zirkel, in the Microscopical Petrography of the Survey of the Fortieth Parallel, p. 197, mentions the occurrence of a fluirl inclusion in rhyolitic quartz, hut concludes that the quartz itself is a foreign inclusion in the rhyolite. 
Biotite occurs in many of the rhyolites and is characterized by its brown color and distinctly marked lines of lamination. It is strongly dichroitic when the sections are rectangular, or cut about parallel to the prismatic faces, and not at all so when the sections are hexagonal in outline, or parallel to the basal pinacoid. Biotite crystals often have a border of magnetite grains, which is quite characteristic, as in the section figured in Plate I, Fig. 2.

Magnetite, in small black grains generally quite uniformly distributed through the groundmass, with an occasional larger mass, is of frequent occurrence and is recognized by its submetallic luster in reflected light.

The groundmass, even when macroscopically compact and of uniform texture, in the thin section under the microscope, is seen to consist of small feldspar microlites or crystals, interwoven and interlaced so as to form a solid mass. In some cases, these crystals are of larger size, but they always have ragged or forked terminations. This formation of the groundmass can be best seen with crossed nicols, when a portion of the small crystals are light, the others being dark. By then turning the slide on its center the dark crystals become light and those previously light, dark, thus proving that the entire groundmass is an aggregation of microlitic feldspar crystals. In a few cases, a more uniform or glassy groundmass and on the other hand a more crystalline appearance were observed and are mentioned in the detailed description of the thin sections. The majority of the Black Hills rhyolites have a crypto-crystalline or felsitic groundmass, uniform in texture and often colorless; but no truly glassy groundmass occurs, the crystalline prevailing.

Trachyтe.-The trachytes proper are distinguished from the rhyolites and quartz-trachytes by the absence of quartz, having consequently a much smaller percentage of silica, and by the preponderance of crystallized sanidin, either alone or with oligoclase.

These minerals are imbedded in a rough, porous groundmass, which is more or less crystalline. It generally has a dull luster and light, white, or light-gray colors, though dark varieties sometimes occur. The variation in the color of trachyte is due to the groundmass, the petrographic composition being always identical. Hornblende, magnetite, and biotite are the 
most frequent accessory minerals, and Zirkel has recently proved the pres. ence of augite.

Trachyte has been divided, according to the character of its feldspars, into sanidin-trachyte and sanidin-oligoclase-trachyte; but, as the triclinic feldspar or plagioclase has been shown by the microscope to be almost always present with the sanidin, this distinction cannot be considered very exact, nor can the line be sharply drawn been the two varieties. It being the same with the Black Hills trachytes, these names are only used as convenient to indicate the predominant composition of the various rocks. The silica percentage in these sanidin-trachytes varies from about 56 to 65 per cent.

Owing to the occurrence of augite mentioned above, a new variety, augite-trachyte, has been introduced by Zirkel.

The sanidin occurs generally in tabular or columnar crystals, varying greatly in size, but having a bright luster and the characteristic structure, being traversed by numerous fissures. The crystals are very frequently composed of colorless zones, one completely surrounding the other in the form of the crystal, but each varying a little in such a way that the external shape is different from the interior commencement. This formation is easily observed in the thin sections under the microscope, when the zones, often of extreme delicacy, are distinctly seen by reason of their different colors in polarized light. This structure of sanidin is much oftener met with in trachyte than in rhyolite. For examples see Plate II, Fig. 1, and also the section of the rock [141-2].

As inclusions, sanidin contains in great abundance particles of colorless or brownish glass, hornblende microlites, grains of magnetite, \&c., with which the larger crystals are often crowded. Occasionally, these interpositions are arranged in zones as the crystal has increased in size, and particles which appear to be only fragments of sanidin are seen from this grouping of the inclusions to be crystals having an irregular contour, the interior zones showing the sharper form. Again, there is sometimes an opaque kernel of these inclusions, around which a more transparent rim of feldspar has been deposited. Portions of the groundmass are also found as inclusions in the sanidin crystals. Fluid inclusions were formerly consid- 
ered as always absent from the feldspars of trachytic rocks, but Zirkel mentions several cases as occurring in the sanidin both of rhyolite and trachyte in the rocks of the "Fortieth Parallel." Twin erystals according to the Carlsbad law are very frequent, even the minute crystals often showing this peculiarity in polarized light. Broken crystals are also observed, which give rise to the explanation that the magma while soft had moved after the crystals were formed or separated from the groundmass. The fragments lie near each other and have the same rough, jagged line of fracture, while the intervening space has been filled up again by the groundmass This is well exemplified in one instance in the Black Hills trachytes, there being a large sanidin crystal broken in two parts and the fragments displaced by another sanidin mass (Plate II, Fig. 2).

Plagioclase is very often present with the sanidin, sometimes in large crystals, finely banded, and when subordinate in quite small crystals the bands are distinct enough for recognition under the microscope.

Hornblende occurs in trachyte quite frequently as large crystals, which are green or brown in color. They often have inclusions of magnetite and a border or rim of magnetite grains similar to that of biotite. Glass particles are also often included by the large crystals. The lines of cleavage and the dichroism can be observed in most cases, which serve to distinguish it from angite. Its sections are distinguished from biotite under the microscope by the cleavage lines, as well as by the different position of the optic axes. With hornblende the sections parallel to the base are the most strongly dichroitic, while those parallel to the prism are not at all or very slightly so. The contrary is the case with biotite. The hornblende prisms, columnar crystals, and microlites, often abundant in the groundmass, are generally green and vary greatly in size in the same rock from crystals to very minute needles, as in [123]. The terminations are also different in character, some being sharp with distinct crystal faces, while other erystals have rough, ragged, or forked extremities. In some trachytes, there is but little homblende present.

The brown crystals of biotite are often met with, and are easily recognized by being strongly dichroitic in the prismatic sections. The hexagonal, basal sections have under the microscope an olive-brown color, are 
not very transparent and not at all dichroitic (Plate II, Fig. 4). The prismatic sections are deeply striated, quite transparent, and have a light yellowish-brown color. The crystals are often partially decomposed, becoming quite ragged, broken and opaque and full of magnetite crystals and grains, which latter form a border completely around the edge of the crystal (Plate I, Fig. 2). This, when carried further, changes the biotite crystal into an aggregation of magnetite grains in the form of biotite, of which only an occasional transparent particle remains to show the origin of the mass. Biotite generally occurs in trachyte in large crystals and not in small scales or leaves.

Magnetite occurs in great abundance as grains, large masses and sharp crystals.

Minute, colorless needles of apatite have been noticed in all trachytes, almost without exception, being most readily found when included in the large crystals of sanidin or hornblende. It may therefore be regarded as a constituent of the rock, although in minute quantities, and only discoverable in the thin section under the microscope. In the Black Hills rocks, it is of frequent occurrence.

Zirkel reports tridymite to be a distinct ingredient of some trachytes, in the form of small six-sided scales or leaves, arranged in groups somewhat as tiles or slates on a roof, but none was satisfactorily determined to be present in these rocks.

Titanite and angite are occasionally noticed, but were not found in the rocks under examination.

The groundmass, as seen under the microscope, is generally quite crystalline, being usually made up of thickly crowded feldspar microlites, with needles and grains of green hornblende, and magnetite grains. A fluid-like structure is often recognized from the position of the hornblende crystals, which appear as if imbedded in a mass flowing in streams around a large sanidin crystal or grain of magnetite. There are several fine examples of this structure among the trachytes [123] and [159-162] (Plate II, Fig. 3). The number of the feldspar microlites can only be truly appreciated by turning the slide on its center between crossed nicols, in order to cause all the crystals successively to become bright by changing their 
optical position. Sometimes a little glass mass is seen between the microlites, but very sparing in quantity.

Sanidin-oligoclase-trachyte, also characterized by its lack of quartz, consists of crystallized sanidin and oligoclase, with biotite and hornblende as accessory minerals. The entirely feldspathic groundmass is composed of a fine-grained or crystalline aggregation of these minerals, in which crystals of the same minerals are imbedded. The oligoclase can be distinguished from the sanidin by its twin lamellations, and is often present in greater abundance than the sanidin.

The Drachenfels trachyte is a rock of this class, and some from the Black Hills [144], [149], [151], and [157] (Plate II, Fig. 2), are of a similar character and may be regarded as the most typical of those thus far examined.

Phonolite.-Phonolite is a compact, dense rock, standing in appearance between trachyte and basalt, from which latter it differs in its lighter color, lower specific gravity, schistose structure, lack of olivine and the constant presence of sanidin, all of which characteristics place it nearer trachyte than basalt. Phonolite has a more compact groundmass than trachyte, and is also free from quartz.

The microscope has proved what the chemical analyses have always indicated, namely, the presence of nephelite as an essential constituent of all phonolites, and of nosite in nearly all. This occurrence of nephelite satisfactorily explains the large percentage of soda in the portion of rock soluble in hydrochloric acid, as well as the frequent presence of zeolites as products of decomposition in the cavities and cracks.

Phonolite consists, then, of sanidin, hornblende, and nephelite, sometimes nosite, in a compact or crystalline groundmass. The sanidin crystals are generally sharp in outline, except when the rock is partially decomposed, in which case the formation of zeolitic minerals affects them also, so that they lose their form and become filled with a fine fibrous mass. They include minute, pellucid crystals of nephelite, generally in a row near the edge of the crystal, and also exceedingly small, almost colorless hornblende microlites.

Nephelite is found in all true phonolites in great abundance in the 
groundmass in crystals having the general form of hexagonal prism and base. In the thin section under the microscope, it is seen in its peculiar hexagons and rectangles, the former being sections parallel to the base and the latter parallel to the vertical axis. Consequently, the hexagons become simply light and dark with parallel and crossed nicols, the polarized light passing through the optic axes, while the rectangles polarize quite brilliantly, being most distinctly seen when the nicols are crossed about $45^{\circ}$. When the crystals are cut obliquely, the section will have an irregular shape, the sides of the hexagon not being equal. This is not caused by any irregularity in the crystal, but by the position of the plane of section. Square forms occur, which polarize brightly and therefore are sections cut parallel to the vertical axis from prismatic crystals as thick as they are long. There are generally more hexagons than rectangles, which arises from the fact that the nephelite crystals are arranged with their basal faces parallel to the schistose structure of the rock, while the fragments used for thin sections are most conveniently obtained and ground parallel to the same schistose formation. The nephelite crystals in phonolite frequently have inclusions of microlites, the presence of which in the hexagons as well as in the rectangles proves the two sections to be from the same mineral. Apatite in section also gives hexagons, but the sections in the other plane are those of long slender needles, while the crystals of nephelite are short and stout. Again, nephelite often make up a large part of the groundmass of phonolite, while apatite occurs in most every case only sparingly in needles.

Hornblende in small, green columns or microlites is present in almost every phonolite, and these crystals often have forked or split terminations. Besides these, there are also grains, minute in size and larger crystals and masses.

Nosite has peculiar forms, consisting of a nearly transparent central part, which is often covered with a striation of black lines at right angles to each other like a net-work, and a dark, opaque border, quite irregular in shape. It is isotrope, changing simply from light to dark, but its peculiar and striking appearance causes it to be easily recognized. It is also dusty or filled with a great number of dark dots, as if shaded by points. This is 
the beginning of decomposition, which, when further advanced, causes a slight polarization of a newly formed mineral.

Magnetite also occurs in phonolite quite frequently.

The groundmass is usually crystalline and, for the trachytic phonolites or those containing considerable feldspar, a fluid-like structure is very characteristic. Of the Black Hills rocks, the specimen [139] from Black Butte is a phonolite, being made up of sanidin and hornblende, with nephelite in great abundance.

Examination of the thin sections.-The rock [101] from the top of Terry Peak has a light-gray to pinkish color, large crystals of feldspar, with small ones, being thickly crowded together in a feldspathic groundmass, in which quite small, black needles and crystals are occasionally visible. It has a somewhat porphyritic structure, except that there is very little groundmass to be distinguished macroscopically from the crystals. In the section under the microscope, the rock appears to consist of large and weathered or dusty crystals of orthoclase or sanidin, with numerous large and small, columnar hornblendes imbedded in a partially crystalline, quartzose groundmass, made up of feldspar and quartz granules and some large quartz masses. No mica was observed, except a few opaque, white, and decomposed masses, which may have been muscovite when fresh. The sanidin is quite dusty, but the interior of some of the crystals is still clear enough to give color with polarized light, a few of the small ones being quite transparent. Their outlines and crystalline form are very distinctly defined against the brightly colored groundmass, very interesting being the appearance of a bright line around the cloudy central portion, having the usual termination of base and hemi-orthodome, while outside of this line the crystal is finished flat and quite opaque and the terminal faces replaced by one plane, making the exterior form rectangular. This is the very characteristic, zonal formation of sanidin, which is not so often observed in the orthoclases of granite. There are some twin crystals; and the interior of some of the large crystals is filled up with the groundmass, leaving only a dark rim of the feldspar. A very little plagioclase was noted, distinguished by its twin lamellations.

Quartz is in small grains, evenly distributed through the groundmass, 
there being an occansional large piece. It contains microlitic necelles of hornblende and but few cavities.

Hornblende is quite plentiful in long, prismatic crystals and also as minute needle-like microlites in great abundance. The crystals are of a fine green color and dichroitic, but generally with ragged terminations, a few of them only being sharply defined in form.

The groundmass is crystalline, and consists of feldspar, associated with quartz and hornblende needles, the latter being thickly crowded together. The percentage of silica was determined to be 72.35 , this large amount being due to the quartz in the groundmass.

The general behavior of the feldspar is much like that of granitic or felsitic porphyry, particularly the impellucid border and the fibrous radiating aggregation of the large crystals, while again some appearances of the groundmass are rhyolitic. Were it not for the geological occurrence given as passing gradually into a trachytic rock, it would have been classed as granite-porphyry. Unfortunately, no more exact observations could be made as were intended, so that the rock must be provisionally named a crystalline rhyolite of granitic character, until some future examination shall confirm or change this determination. The rock [103], from the same locality, presents no essentially different appearance from the preceding, though it is somewhat fresher and the feldspar crystals more transparent. Silica is 71.13 per cent.

The rhyolite [109] from southeast of Terry Peak is of a light greenishgray color, with lustrous transparent crystals of sanidin plentifully scattered through it. The rock is quite compact in texture, being hard and tough. With the microscope, were observed sanidin, plagioclase, quartz and some hornblende in a groundmass, which is an aggregation of very small needlelike microlites. The large amount of silica present ( 75.09 per cent.) confirms the determination of the quartz in the thin section.

The sanidin is abundant in fine, clear crystals, both large and small polarizing brilliantly. Some are twinned according to the Carlsbad law, one part of the twin with crossed nicols being blue and the other colorless. They also contain inclusions of glass, magnetite and small rectangular plagioclase crystals, the latter showing very plainly, owing to their different color from 
the sanidin. The plagioclase is quite fresh and has distinct lines of twin lamellation, its crystals being both prismatic and rectangular in shape. It is also occasionally grown upon the extremity of a sanidin in such a manner as to form one large crystal together; an occurrence noted by Zirkel as quite frequent. Some of the sanidin, but oftener the plagioclase crystals, have a dark border or rim entirely around the edge, as if from decomposition.

The quartz is not as distinct and easy to determine as the feldspars, but is present in comparatively large, roughly shaped hexagonal crystals, quite transparent and containing an abundance of microlites sharply defined in the clear mass. These masses do not polarize very brilliantly between crossed nicols, except upon turning the slide. It is also in irregular masses and small grains, all having the microlites, the smaller grains giving brighter colors in polarized light.

Hornblende is very sparingly present in small bright-green crystals. Some brown films of oxide of iron were also noted.

The groundmass consists of an aggregation of fine microlites, interlaced and piercing the innumerable small grains of sanidin and quartz, so that with a high power the needles may almost be separately distinguished.

The sanidin-trachyte [113] from the ridge east of Terry Peak is quite different from the preceding. It is of a decided greenish color, with yellowish-brown ferruginous veins through it. In the section, the sanidin is in long, columnar and almost needle-shaped crystals, which make up the greater part of the rock, but which are not very pellucid. Some are rectangular and twinned, but all are quite dusty in appearance. The brown masses may be remains of a mica, as they polarize somewhat and are quite transparent The crystalline form of the sanidin is quite distinct in a few of the larger crystals, and around the only large group of sanidins a fluid-like structure in the arrangement of the needle-shaped crystals and microlites is very apparent, being also seen in other parts of the section. The silica is lower than in [109], being 58.33 per cent. The groundmass is composed of grayish, minute microlites, in which are imbedded the slender feldspar crystals mentioned above.

The rhyolite [120] from the hill southeast of Terry Peak has a flesh- 
colored appearance as to the groundmass, with numerous, very lustrous and glassy sanidin crystals and a few large grains of quartz, the two being macroscopically distinguished by the latter not showing any cleavage. There is also some pinkish feldspar in the groundmass. In the section, were observed large, clear sanidin crystals, some being cloudy and rather opaque, and a few large and very clear, rounded quartz masses, all in a finely crystalline, feldspathic groundmass containing also numerous small quartz grains. The large sanidins are very pellucid and generally show numerous fissures and cleavage lines. They have also a dark border of alteration and frequent cases of intrusion of the groundmass into the center of the crystal In the last respect they are similar to those of [101] and [103]. The other crystals are entirely cloudy or altered to almost opaque masses, which, however, still preserve their outline distinct from the groundmass. The quartz present, both large and small grains, polarizes in a brilliant blue color. Some dark-brown particles are probably remains of decomposed biotite. The groundmass is crystalline, being made up chiefly of small, ragged feldspar crystals and opaque ones, so that with crossed nicols the crystals are white on a dark ground and quite conspicuous, as are also the blue quartz grains. The silica pereentage is 72.27 . There is some similarity between this rock and [101], [103], [124] and [140].

The sanidin-trachyte [123] is from the same locality as the preceding, but differs widely in appearance. It is bluish-green in color, somewhat glassy and quite compact. White feldspar crystals are visible, and small green needles in the groundmass can be seen with the loupe. In the section, there are large and somewhat cloudy sanidin crystals, around which, with a remarkable and beautiful fluid-like structure as if hardened at the time of flowing, is a brightly polarizing groundmass, full of green hornblende crystals from large size to microlitic needles, the majority being of medium size. The sanidin is generally in rather prismatic and rectangular crystals, quite dusty and opaque, or having occasionally a clear and polarizing central mass. There is a large erystal, which polarizes in very irregular blotches of color, with a very pellucid interior. In this point it bears some resemblance to the large feldspars of [101] and [103], as also in the abundance of hormblende prisms. At the angles and edges it appears 32 в н 
almost as if small portions of the crystal had been broken off by the action of the once fluid groundmass, which completely envelopes these fragments while carrying them away.

The hornblende crystals are very conspicuous as small yellowish-green blades; they are sharply terminated and outlined, the sections in the different planes affording long, slender, and small rhombic forms, respectively. It is, of course, rather rare that any of these crystals, which lie in every possible position, are cut so nearly at right angles to the vertical axis as to afford a perfect rhombic section and to show the lines of cleavage, but it was observed in a few cases with the careful use of an objective of very high power. The crystals are also plainly dichroitic, changing with one nicol from yellowish-green to a deep-green. A few large hornblendes show this characteristic more plainly, but they are not so sharply terminated. On the other hand, some are so minute as to be just discernible in great quantities in the mass, sometimes heaped up or collected in bunches in a re-entrant angle of a sanidin crystal, and filling also the interstices between the larger prisms. The groundmass is colorless, but polarizes in tolerably bright colors-red, blue and yellow-as if it were feldspathic In its appearance, it shows distinct signs of a former fluidity so marked and general in all parts of the section that the wave-like structure is a striking feature. These waves, so to speak, sometimes meet the opposing extremity of a crystal and divide into two streams, one on each side, leaving at the point of division quite a number of the hornblende crystals crowded together and heaped up like logs in a river when an island has interrupted their motion down the stream. Again, the once fluid mass fills all the fissures, cavities and cracks in the feldspar crystals, the very small fissures containing only the microlites of hornblende, as if the larger blades had been prevented from entering. The whole phenomenon is quite interesting. A little magnetite is present, but in small quantities only. The rock contains 63.56 per cent. of silica, and 8.58 per cent. is soluble in hydrochloric acid.

The sanidin-trachyte [124] from southeast of Terry Peak is of a gray color, containing large crystals of sanidin and numerous small, dark hornblende crystals. It is also quite porous in structure, the holes resembling cavities which have been once filled by some crystallized mineral. Under 
the microscope, the sanidin appears to constitute the greater mass of the rock, being in some places quite clear and pure. The crystals, however, are very indistinct in outline, and are apparently aggregated to one mass. There is hornblende in abundance in large, fine, green crystals, somewhat decomposed and including grains of magnetite of good size, although they are but slightly dichroitic. Nearly every crystal has magnetite either in it or adhering to it. Occasionally, several hornblende crystals are grouped about a large grain of magnetite. This is quite a usual characteristic of trachyte. The hornblendes vary in size from quite large and clear, green crystals to small blade-shaped or prismatic erystals with ragged terminations. There is a little biotite present, and an occasional apatite crystal. Magnetite, besides that mentioned as inclusions, is scattered abundantly through the rock in large to very small grains, approaching a little to a crystalline form The groundmass is feldspathic, and has a fine-grained structure resembling a fibrous microlitic aggregation.

The rock contains 57.75 per cent. of silica, and the soluble portion in hydrochloric acid amounts to 13.48 per cent.

The rhyolite [125] from near Deer Mountains has a porous appearance, caused by numerous empty cavities, the mass of the rock itself being quite compact. Its color is pale-brownish to pink, having an indistinct banding of two colors, light and darker brown. Upon close examination, quite a number of quartz grains of good size can be seen, while many of the empty cavities have a very plain imprint of the quartz crystals that formerly filled them. With the loupe, a granular structure is recognized, but no crystals of any mineral except the quartz already mentioned. In the section under the microscope, it consists apparently of whitish, opaque, rounded bodies, with large and very clear quartz masses in a partly granular and isotropic groundmass, in which are also numerous small quartz grains. The rounded bodies are somewhat fibrous in structure, and generally have a narrow, transparent rim, and are probably imperfectly formed spherulites. They are aggregated in large masses, leaving only small interstices of the groundmass between them, so that the greater part of the rock is made up of these masses. They resemble spherulites a little, and a faintly hexagonal shape is also noticeable. The large quartzes polarize 
very brilliantly, but are irregular in form and have inclusions and irruptions of the groundmass, as well as black specks and some rectangular crystals of an undetermined mineral. Magnetite occurs in small grains, but very sparingly, and mica and hornblende are present only in a very few crystals. The groundmass is colorless and quite transparent, polarizing with crossed nicols in white irregularly shaped grains in a dark ground, this latter being the isotropic portion. There are also some needle-shaped, white microlites. The absence of any defined crystalline structure, and the partially glassy character of the groundmass is remarkable and different from the other rocks.

The rock [127] from the same locality has more the characteristic appearance of rhyolite. It is very compact indeed and slightly banded in color, which is a light-gray, inclining to greenish. The banding resembles faint traces of a fluid-like structure, although this was not observed in the section. Scattered through the rock are macroscopical crystals, colorless, but very brilliant; part of these are sanidin and some are quartz, the distinction being made by the presence or lack of cleavage, sometimes, however, difficult to observe. A few dark crystals of mica are also to be seen.

In the section, it consists of large, clear quartzes, with numerous small, rectangular sanidin crystals in a fine-grained groundmass, with biotite and some hydrated oxide of iron films. The silica present is 73.22 per cent., this large amount being due to the quartz.

The sanidin occurs occasionally in large rectangular crystals, but it is mostly in small ones, quite uniformly scattered through the groundmass. They do not polarize very brilliantly, and in some cases contain microlites and glass inclusions. They may be distinguished from quartz by being less transparent and more uniform in shape. The quartz is exceptionally fine in this section, some of the crystals being twinned so that one crystal with crossed nicols will be brilliant, while the other remains dark, making the line of twinning very marked. There are two such examples in the slide, one of which is shown in Plate I, Fig. 1. It contains a few cavities and microlites, but not to any marked extent. There are also small grains and crystals through the groundmass.

The biotite is in its characteristic, yellowish-brown prismatic crystals, showing very plainly the lines of lamination. They are strongly dichroitic, 
turning from quite pale-brown to dark greenish-brown, almost black, upon revolution of the analyzer alone. When cut parallel to $0 \mathrm{P}$ it is more olivebrown and is not dichroitic.

The groundmass is pale-brown in color, half-glassy in character and inclines a little to a microlitic texture, with traces of a fluid-like structure. In it are numerous small, black specks, but no magnetite was observed.

The rhyolite [131] from southeast of Terry Peak has a light yellowishbrown color, with broad reddish, parallel bands across it. It is quite compact and fine-grained, and of a peculiar appearance like burnt clay. The outside surface is weathered to a very dark-brown, the light shade showing on a fresh fracture.

In the section, the groundmass appears quite finely crystalline, being made up of small, rather dusty crystals of sanidin, with some magnetite and an abundance of quartz in small rounded grains. The silica in the rock is 72.22 per cent.

The sanidin through the groundmass is easily seen with crossed nicols, as the indistinctly rectangular crystals are then light on a dark ground. They are, however, quite cloudy and the outlines are not at all sharp. The quartz polarizes brilliantly in colors, blue and yellow, and is present mostly in irregularly shaped grains of small size, many of which have inclusions of the groundmass with microlites and magnetite. They seldom have any crystalline form, and are in considerable abundance. Magnetite is in small submetallic grains; also a little biotite, none of which, however, is dichroitic. Nothing very peculiar was noted in the groundmass, except that the reddish bands, colored by iron, were plainly seen in the section.

The rhyolite [134] from the top of Custer Peak is very homogenous in appearance and structure. It has a light-gray color and a fine-grained texture, with an occasional small, black needle of biotite visible. In the section, is seen a colorless groundmass, in which are numerous quartz grains, abundant magnetite, a little biotite and sanidin as in the preceding rock, seen as faintly defined crystals on a dark ground. The silica present amounts to 68.62 per cent.

The sanidin apparently constitutes the greater part of the groundmass, but the outlines of the crystals are very irregular and in general scarcely 
separated from the surrounding mass When the nicols are crossed it polarizes faintly, so that the feldspathic portions of the rock appear tolerably bright and white, while the groundmass remains dark; the distinction, however, being made with some difficulty. On the other hand, the quartz strikes the eye at once with its brilliantly colored and sharply defined grains. It is scattered quite abundantly through the rock, but rather in groups and irregular streaks or veins, the larger particles seldom being seen isolated. It contains as inclusions some microlites and small cavities. The biotite occurs quite abundantly in very ragged and irregular crystals of a greenish color; the prismatic sections are dichroitic, while the basal ones are browner in color. It is too much decomposed to show any laminations and it is difficult to distinguish from hornblende, except by reason of the different position of the optic axes of the two minerals. Magnetite in small granules is quite uniformly distributed through the rock, and by its appearance on the light groundmass aids in giving the rock the characteristic rhyolitic appearance. There are also some brown films of hydrated oxide of iron. The groundmass is crypto-crystalline, but does not possess any microlitic structure.

The rhyolite [135] from the same locality has a similar appearance to the preceding, being of a compact, uniform texture, very fine-grained, and of a light-gray color with a few macroscopical black crystals of biotite and quartz masses. The slide under the microscope also resembles that of [134], but is a little finer grained in structure and has a few large and unmistakable biotite sections.

As before, the sanidin crystals appear as faintly outlined light spots on a dark ground, but there is one crystal quite transparent and sharply defined. The quartz grains are abundant and give bright colors-blue, red, and yellow-with polarized light, containing also microlites and black particles. Most of the biotite is present in the ragged, decomposed crystals as in [134]; one crystal, however, of a light-brown color is still quite transparent and fresh. It is very strongly dichroitic, changing with one nicol to a very dark-brown, almost black. It has also a border of magnetite grains of good size completely around it, which makes it a very conspicuous object in the almost colorless groundmass. A similar one is shown in 
Plate I, Fig. 2. A second crystal, of the hexagonal basal section, has magnetite grains, not only as a border, but also filling up the central part and leaving only a small amount of brown mica. This residue is not at all dichroitic, thus agreeing with the plane of section determined from its crystallographic outline. In both cases, the magnetite grains are much larger than those scattered through the groundmass, the latter particles being very numerous and quite small. The groundmass is crypto-crystalline as before. The amount of silica is 72.33 per cent.

The rock [137], also from the top of Custer Peak, is again a rhyolite, and very similar to [134] and [135], the sanidin in the colorless groundmass, together with the quartz and magnetite, presenting no essential differences. The example of biotite, with its border of magnetite grains, is much finer than in [135] and is figured in Plate I, Fig. z. The groundmass is a little more microlitic in structure. In the rhyolites thus far examined, there was found in the sections but little, if any, fluid-like structure, the groundmass being more granular and crystalline in character.

The rock [139] from Black Butte is a phonolite, and very different in appearance and behavior from the trachytes and rhyolites. The groundmass has a grayish-brown color and a greasy or waxy luster, with darkgreen, irregularly shaped streaks and masses through it. It is quite compact or crypto-crystalline, and weathers to a white mass. An occasional whitish crystal can be distinguished with the aid of the loupe.

In the thin section under the microscope, it is seen to consist of a groundmass composed mostly of nephelite, with sanidin, nosite and green hornblende, in which latter mineral are imbedded transparent hexagons and rectangles of nephelite (Plate I, Fig. 3). The rock gelatinizes very strongly in hydrochloric acid, the soluble portion being 24.08 per cent. Boiled in nitric acid and tested with ammonic molybdate, it gives but a very faint reaction for phosphoric acid. The silica is quite low, only 56.32 per cent.

The erystals of nephelite, very conspicuous and abundant, are quite uniformly distributed through the rock, the characteristic sections being very distinct. The hexagons vary somewhat in size, a few quite large ones being present, and all have similar inclusions, probably glass particles as they are brownish in color. No needle-like microlites were found in any 
of the small crystals, but one large mass had a green, columnar microlite and a few acicular ones. Some of the nephelite has become cloudy and thick, probably from decomposition. In the rectangles are seen the same kind of inclusions as in the hexagons, near the center in both cases, which proves quite conclusively that the two forms of sections belong to the same mineral, the crystals of which are short, stout, hexagonal prisms with the basal pinacoid. The hexagons are sections cut parallel to the base; and, the optic axis being coincident with the vertical axis, they are consequently simply refracting and dark between erossed nicols. On the other hand, the rectangular sections are of a bluish-white color when the nicols are crossed, so that in the dark field they are quite conspicuous. In a mass of hornblende are several of the two forms of sections lying close together which show this behavior perfectly, the hexagons remaining dark, while the rectangles become bright in striking contrast. In the illustration (Plate I, Fig 3) they are drawn when both are light, in order to show. the outlines distinctly. There are also a few square nephelite sections, which polarize quite brilliantly.

The hornblende is in irregularly shaped green masses, crystalline and dichroitic, but very thickly crowded with transparent nephelite crystals It has the appearance of being large crystals much broken and separated, so as to resemble broad bands through the rock. It is also quite abundant in fine needles through the groundmass.

Although nosite is a frequent constituent of phonolite, it was only after much consideration that it was determined to be present in this rock. The two particularly large and distinct sections, one shown in Plate I, Fig. 4, were at first named sanidin, but a closer examination revealed the fact that the fresher parts of the crystals were simply refracting, remaining dark with crossed nicols, which could not be possible if they were sanidin. Again, the peculiar dusty appearance, parts of the crystal being lighter that others, and a dark border around the edge are all characteristic of nosite. The two sections mentioned are five-sided, different in this respect from the usual forms of sanidin. They are not very transparent, except in places which have been altered to a doubly refracting mineral, probably natrolite, as is often the case. These altered parts are faintly bright with crossed 
nicols. The deciding peculiarities, then, are the form, the dusty or dotted structure, the simple refraction, the dark border and the behavior of the decomposed portions of the crystals Besides these two large sections, there are quite a number of smaller nosite crystals more irregular in shape, some being hexagonal and others rectangular, more opaque and in varying stages of alteration, though they are still partly isotrope.

The sanidin is in the form of indistinct, long, rather roughly shaped masses and columnar microlites, lying between the nephelite crystals and showing with the hornblende a distinct, curved and fluid-like structure in places, and particularly around the two large nosite crystals mentioned above (Plate I, Fig. 4). The columnar, somewhat fibrous-looking crystals polarize with tolerable distinctness with crossed nicols. No magnetite nor biotite were found. Besides the minerals already described, no other groundmass is discoverable as the rock is made up of sanidin, nephelite, and hornblende in intimate union, the structure being quite crystalline.

The strong gelatinization, large amount soluble in acid, and low silica percentage of this phonolite all aid in confirming the above determinations, and it is to be hoped that more observations of its geological occurrence will be made at some future time.

The sanidin-trachyte [140] from Black Butte is light-gray, inclining a little to yellow in color, but has not the uniform and fine-grained appearance of the rhyolites. Scattered through it, small yellow spots and dark needles of hornblende can be seen with the loupe. Under the microscope, the section shows the rock to be mostly sanidin, in clear, roughly shaped crystals and partly in masses, with abundant long, prismatic crystals or blades of homblende. It is quite similar to [124] and [171].

The sanidin, besides being the mass of the rock, is also seen in indistinct crystals, which have many irregular lines of fissure and also contain long, needle-like, colorless microlites, probably apatite, and hornblende crystals and fragments. Most of it has a cloudy or dusty character, which is seemingly caused by innumerable short, stout microlites of exceedingly minute dimensions scattered in quantities through it.

The hornblende crystals are of a fine green color, and some have 
sharply defined terminations and angles. They are also dichroitic and scattered plentifully through the rock.

As in [171] there seems to be some transparent glass mass, which is perfectly isotrope and of a very different texture from the sanidin. The yellowish spots in the hand specimen are seen in the section to be of very irregular shape, but transparent. An occasional yellowish, opaque and hexagonal crystal may be decomposed mica or feldspar, but its exact nature could not be determined. Some magnetite in large masses is present, but sparingly. The groundmass, as mentioned before, is entirely feldspathic, clear and cloudy in irregular masses, and showing, perhaps, traces of a slight fluid-like structure. The percentage of silica is 58.53, and the amount dissolved in hydrochloric acid 18.59 per cent.

The rock $[141,142]$ from Crow Peak is a rhyolite containing plagioclase, and is much more crystalline than the preceding, having macroscopical sanidin crystals plainly imbedded in a groundmass. They are white and very transparent. There are also some black crystals of hornblende and empty cavities, which were formerly filled with the latter mineral. In the section, the microscope shows the rock to consist of large, clear crystals of sanidin and plagioclase in a crystalline groundmass, also containing broken biotite crystals and some quartz in grains and crystals.

The sanidin in this rock is very beautiful, being unusually large and transparent. The crystals are sharp in outline and sometimes terminated on both ends, showing numerous faintly marked zones parallel to the edges. Many of them are twinned, the different colors of the two parts being very conspicuous. Numerous microlites are included, some of them tolerably large, columnar in form and quite long. Others again are in short, stout crystals, distinctly showing prismatic and terminal faces. The former may be apatite and the latter hornblende. Magnetite and small biotite folia are also among the inclusions of the sanidin. The colors in polarized light are very brilliant, but are in irregular masses or blotches in the same crystal; near one edge a bright red predominating, then yellow, turning gradually to a greenish-yellow, with spots of red and blue. All these colors are interlaced, often penetrating from the edges in lines and points one into the other. 
The plagioclase is often crystallized inside of the sanidin and upon the edges of the crystals. The banded appearance of the twin lamellations is so broad and beautiful as to resemble greatly that of labradorite; a few of the independent crystals are very large.

There are numerous quartz grains of irregular shape throughout the groundmass and occasionally a large mass more regular in form. The biotite is in very large, broken, and decomposed crystals, either long, prismatic in shape or in hexagonal plates. Although both forms are much torn and broken and but faintly dichroitic, the distinct laminations can be easily seen. It is, moreover, quite dark and opaque in many places. Magnetite occurs in small grains, abundantly scattered through the groundmass and also in quite large masses, having the usual submetallic luster. The groundmass is crystalline very distinctly indeed, being an aggregation mostly of rectangular and ragged sanidin crystals, with some quartz, magnetite, and a little biotite in small brown leaves. The silica was determined to be 67.36 per cent.

The sanidin-oligoclase-trachyte [144] from between the forks of Bear Butte Creek is brownish in color and of a very rough texture, with macroscopical crystals of feldspar, between which can be seen dark-green needles and crystals of biotite. In the section, were observed large and tolerably clear sanidin and plagioclase crystals in a fine-grained, light-brown groundmass with biotite and magnetite.

The large sanidin crystals are quite clear, and give fine colors in polarized light, but there are still a great many fissures and cracks, along which they are cloudy and altered. Microlites, as beautifully distinct long needles and tolerably stout prisms and rounded glass masses, are among the many inclusions of these sanidin crystals. The colorless needles are probably apatite, with which are associated magnetite and biotite. Some of the sanidins are twinned, the two parts polarizing differently. The plagioclase is in large crystals and of distinct outline, although they are often formed in conjunction with the orthoclase. The twin striations are in some cases very broad and distinct, while in other crystals they are so fine and delicate as to resemble the sanidin striations arising from structure. Generally they are sharp and plain. The crystals have similar inclusions to those of the 
sanidin, but not quite so abundant. The biotite is very dark and much decomposed, but still shows the characteristic, deep furrows and a strong dichroism. The sections are very abundant and quite large. Magnetite is thickly scattered through the groundmass in small grains and sometimes in large masses, while there are also some very opaque and thick films of oxide of iron of a dark reddish-brown color, in which the large magnetite grains are imbedded

The groundmass is made up of small irregularly shaped feldspar crystals, of very indistinct outlines, and but feebly polarizing, mixed with minute grains of magnetite and brown biotite. It has the peculiar trachytic appearance, which cannot easily be mistaken, and a partly fibrousmicrolitic structure. This rock borders closely upon the rhyolites, but its macroscopical rough, ragged and porphyritic appearance and structure differ so widely from the fine-grained and uniform light-gray characteristies of the former as to place it among the trachytes proper. The silica amounts to 65.46 per cent, and 10.09 per cent. is soluble in hydrochloric acid.

The rhyolite [147] from the north peak of Inyan Kara is a compact, fine-grained and very light-gray rock, with only an occasional white sanidin crystal and black biotite needle visible. Under the microscope, the section appears to consist of a great quantity of small, bright sanidin crystals in a groundmass, with biotite and magnetite. The silica present is 73.18 per cent.

The similarity of the small sanidins to large ones is very easily seen in their clearly defined outlines and numerous twinned crystals. They have inclusions of microlites. There is one group of large and very transparent crystals in the slide, which polarize in very beautiful and brilliant colors showing some banding, all of which, however, is not that of plagioclase. The bands of color, except in one case, are not exactly parallel and resemble more the varying colors of sanidin. Biotite is in brownish masses and leaves of small size, and also in very minute black needles, which are partly altered to magnetite, a few being still dichroitic. Magnetite grains, as in almost every one of these rocks, are plentiful. Some quartz in rounded grains and polarizing in bright colors is present. 
The groundmass is mostly made up of the small sanidin erystals mentioned before, but between them appears to be a very fine partially microlitic mass, which remains dark with crossed nicols.

The sanidin-trachyte [149] from the central peak of Inyan Kara is dark in color, being gray, inclining to greenish. Macroscopical crystals of sanidin are visible, as well as some black prismatic hornblendes. It is very different from the preceding rhyolites, having much less luster and being darker.

In the section, it is immediately seen that sanidin is in great preponderance, the groundmass being composed of it and there being also a great many large, fine crystals. Hornblende and biotite, with magnetite are scattered through the groundmass in large and small erystals and grains. There is also some plagioclase. The large sanidin crystals are very characteristic, polarizing in fine colors and showing the different colored zones of the formation of the crystals. Sometimes a well formed section with perfect outline has a very different color from the more roughly shaped mass forming the exterior coating, the interior for instance being light brown and faintly zoned, while the other part is a brilliant purple. This zonal structure is quite usual in this rock and is shown in Plate II, Fig. 1. The inclusions are long and very delicate prismatic microlites, which may be apatite.

The hornblende is present in large crystals, somewhat broken and full of fissures, but still polarizing quite strongly from yellowish-green to darkgreen, although they are but faintly dichroitic Many of them have crystals of sanidin and magnetite imbedded in the interior, the form of the sanidin being quite perfect. Besides these large crystals, there are innumerable quite small and irregular ones, many of which in quite a striking manner are tipped with magnetite on both ends, and nearly every one has a large grain of magnetite in some part of it. Not to be confounded with the hornblende is the biotite, which occurs in large crystals, very much decomposed and broken to such a degree that their former outlines are shown only by the rows of magnetite grains till remaining in their stead. The biotite is light-brown and strongly dichroitic, changing to very darkbrown upon turning one nicol; it is also deeply striated and full of magnet- 
ite. In a few instances the plane of section is parallel to the base, when it is not at all dichroitic. It is not so plentiful as the hornblende, which is distinguished from it by its fine green color in almost every case. There are a few large plagioclase crystals, which have quite sharp bands of color, but they are so much grown together with the sanidin that it is difficult to discern any dividing lines between the two. From the preceding description, it is readily understood how abundant the magnetite is through the whole rock, giving at almost every point its bright luster. Long, colorless apatite needles in considerable abundance can also be recognized without difficulty in the groundmass.

The groundmass is coarsely crystalline and composed of irregularly shaped sanidin crystals which polarize in bright colors, mixed with hornblende, biotite, and magnetite. There does not appear to be any isotropic glass mass between the above ingredients. The percentage of silica was found to be 60.51 , which, with the observations already noted, determines this rock to be undoubtedly a normal sanidin-trachyte.

The sanidin-trachyte $[150]$ from a locality five miles northeast of Inyan Kara has a much duller and more weathered look than [149], being also less crystalline in its structure. The color is dark-gray, mottled with greenish spots, which have disappeared on exposed surfaces, leaving empty cavities.

In the section, it is observed to consist of sanidin and hornblende in a somewhat fibrous groundmass with but very little magnetite. The sanidin crystals are very much confused with the surrounding mass and ragged in their outlines, but occasionally there are some twins. In the simple crystals, cloudy streaks resemble the dusty-looking parts of the groundmass. From the variation of color in the large masses of sanidin it is quite easy to make out their polysynthetic nature, being built up of a number of small crystals. The hornblende is in fragments and small, sharply defined crystals, quite dichroitic and sometimes showing the lines of cleavage.

The groundmass consists of cloudy or dusty masses and crystals of sanidin, which only faintly betray their outlines with crossed nicols The rock is similar to [124].

The sanidin-trachyte [151] from the north peak of Inyan Kara 
resembles both in color and luster [149], being dark-gray, with macroscopical sanidin crystals and black needles of hornblende. In the thin section under the microscope, it is exactly the same, namely, a crystalline mixture of sanidin, hornblende and magnetite. The sanidins have the same zonal structure as before, as well as the marked difference between the interior and exterior parts of the crystal. The colorless, long, prismatic microlites of apatite are also present and a few masses of plagioclase and biotite. The large, green hornblende individuals are different from those of the scarce, brown and dichroitic biotite, because the former are fresher and much greener than is usual for biotite. Again, if they are biotite, it is remarkable that more of them are not cut parallel to $\infty \mathrm{P}$, considering how plentifully they occur in the slide; for all the green, non-dichroitic sections in the above case would be sections parallel to $0 \mathrm{P}$, which theory their long, prismatic shape hardly seems to warrant. The biotite crystals also have a border of magnetite grains, which appearance was not observed with the green hornblende, although they include large grains of magnetite. The cleavage lines are very indistinct and difficult to make out, but in a few cases they seem to be decisive.

The groundmass is, as before, a coarsely crystalline mixture of feldspar, magnetite and small crystals of hornblende.

The rhyolite [152] from Inyan Kara (?) has a light-gray color and is quite homogeneous in structure, being fine-grained, with numerous very small biotite needles imbedded in the mass, resembling [147] the rhyolite from Inyan Kara. Under the microscope, it seems to be made up of sanidin crystals, with biotite and magnetite in a partially crystalline groundmass. The sanidin is in crystals of moderate size, quite transparent and having the characteristic zone structure, and also twinned crystals. The slender, biotite needles are abundant and generally dichroitic. The difference in the plane of section is strikingly shown in this slide, there being a large hexagonal form of a fine brown color, which shows no change upon a revolution of the nicol, while the prismatic forms change from light to dark-brown. The biotite has magnetite grains through it, as usual in these rocks. Magnetite in small grains of uniform size is quite evenly distributed through the mass, though there is an occasional large piece. The 
groundmass exhibits the peculiar half-fibrous and half-crystalline appearance of the rhyolites, as if it consisted of microlitic needles of sanidin between the larger but still indistinct crystals, which only betray their form by being of a faint whitish color with crossed nicols.

The sanidin-trachyte [157] from the hill west of Inyan Kara has the most characteristic appearance of a normal trachyte of any of the rocks examined. Its color is light grayish-white, with occasional reddish and brownish spots and cavities, which have the shape of biotite crystals, the latter having disappeared and left only a little magnetite. At first sight these cavities seem to be black needles of mica, but a closer examination shows that they are empty holes. An occasional glassy sanidin may also be seen. The microscopical examination of the thin section showed some very beautiful and interesting sanidin crystals in a crystalline groundmass of feldspar, with magnetite and a little biotite. It resembles [149], but has no hornblende. The amount of silica is 61.88 per cent

The sanidin crystals are quite transparent, but are colored in irregular blotches and spots in polarized light, owing to their composite character. They include colorless needles of apatite, considerable magnetite and biotite, the needles being sometimes grouped in a sort of star around a grain of magnetite. The larger and more perfect erystals are quite rectangular in shape, and have the usual zonal structure of sanidin. The interior portion of the crystal has a very perfect form, being terminated with the base and hemi-orthodome, while the exterior, rectangular form is made by an additional growth of feldspar in a different optical position, or of a different nature. The result is that the interior, well formed crystal polarizes a violet color, while the exterior shell or coating is deep blue, making a distinct contrast. In other cases it is yellow and blue. There were also observed some very nice twin crystals, both from interpenetration and juxtaposition. The most interesting occurrence is that of a large sanidin crystal, Iong and rectangular in shape, which has been broken by a fragment of feldspar so as to cause the larger piece to be pushed out of place. The former continuity of this crystal is shown by the fact that the two pieces polurize a fine deep blue at the same time, while the irregular fragment is yellow. By revolving the analyzer or slide the colors change- the crystal 
to yellow and the fragment to blue. In either case the appearance is striking, and is not often met with in such a perfect condition. It is shown in Plate II, Fig. 2.

Magnetite grains, large and small, are in abundance all throigh the rock, the occasional large masses having a fine luster. Long, colorless needles of apatite of quite good size are often noticed in the groundmass, and also exceedingly minute dark colored needles, probably biotite. The larger biotite crystals are very ragged and indistinct, being so much decomposed as to scarcely show any traces of dichroism Some of the feldspar crystals are faintly banded, but are not all plagioclase, the lines being too irregular.

The groundmass is erystalline and composed of sanidin masses, with grains of magnetite and a little biotite. There are slight traces of a fluidlike structure in parts of the groundmass.

The sanidin-trachyte [159-162] from Bear Lodge Butte has a greenish color, with very glassy and transparent sanidin crystals porphyritic in the groundmass, in which can also be seen large, green hornblende crystals. Some of the sanidin has become opaque white, giving the rock a rough and spotted look, which is added to by the small hornblende blades thickly sprinkled between the white sanidin. The appearance of the rock in the thin section immediately recalls that of [123], already described. It consists of very large sanidins in a groundmass, full of small hornblende microlites and blades and having a fluid-like structure, and also large, fresh and green hornblende crystals with magnetite in large grains. See Plate II, Fig. 3. The sanidin crystals are very large and quite clear, but have cloudy or dusty streaks and spots through them, though with few inclusions of any marked character, except occasionally a hornblende crystal. The cloudy portions are sometimes almost entirely opaque These are the result of alteration and are the macroscopical white spots. The outlines of the crystals are quite sharp and distinct from the groundmass, most of them being terminated by two planes. The hornblendes are very conspicuous in the slide, their colors being from greenish-brown to a vivid green and dark-green, and their outlines very clean and sharp. Most of them have a hexagonal form, with two sides longer than the others, while a few, especially one large crystal, have eight sides, six being predominant. 33 в н 
These crystals are strongly dichroitic, changing from greenish-brown to green, and especially so when cut about parallel to the base, as is shown by the more distinct cleavage lines. All of the large crystals have very marked fissures and lines, some of which, however, arise from lamination, but in some the cleavage lines at the angle of $124^{\circ}$ can be seen, these being the most strongly dichroitic. They have inclusions of small sanidin crystals, large grains of magnetite and some glass masses. Hornblende is also present in very abundant small, prismatic, or blade-shaped crystals, thickly distributed through the groundmass. Their terminations are quite rough, forked and ragged, and not nearly so sharp as the similar crystals in [123]; they are but faintly dichroitic. Grouped with two large hornblendes and a mass of magnetite was observed a colorless mineral, irregular in shape, and with quite a different structure from the sanidin. It polarizes faintly, and is probably some zeolite or calcite, but its exact nature was not determined.

The groundmass is feldspathic, polarizing white with crossed nicols, and appears to be an aggregation of small, needle-like feldspar crystals, in which are imbedded the small hornblende prisms. This whole mass shows a very plain fluid-like structure, as if it had flowed around the large sanidins in streams and become suddenly congealed, thus preserving the unmistakable signs of the former fluidity of the rock. This appearance is not so marked as in [123], but sufficiently plain to be easily noticed under the microscope. The silica was determined to be 60.77 per cent., and the amount dissolved in acid was 15.33. This large percentage of soluble minerals may be due to the abundant hornblende and partly also to the presence of some zeolite or calcite.

The rhyolite [166] from the north peak of Inyan Kara is of a gray color, compact and homogeneous in structure, with a few lustrous sanidin crystals visible to the naked eye. It resembles the rocks [147] and [152] from the same locality. An examination of the thin section under the microscope revealed its composition to be of small sanidin crystals, with magnetite and dark-brown biotite needles, the latter being almost opaque. Occasionally, a very large and clear sanidin is seen having the zonal structure mentioned before. The small crystals are of sharp outline and dis- 
tinctly shaped forms, many being twinned. The biotite prismatic crystals are very small indeed, but are thickly scattered through the rock. The magnetite is generally in very small grains. The groundmass appears to be of a fine fibrous or microlitic structure, filling the interstices between the sanidin crystals. It is feldspathic in nature and dusty, so that it polarizes but feebly, and there is less quantity than at first sight appears. While one set of the sanidin crystals are bright with crossed nicols, those in a different position are dark and might be mistaken for the groundmass. Upon revolving the slide, however, the crystals respectively change their appearance, the gereral aspect of the rock remaining the same, while there are some crystals always bright and conspicuous.

The specimın $[167,168]$ from Little Missouri Buttes is a sanidin-trachyte, but approaching phonolite in structure and in the presence of some zeolitic minerals. Its color is a quite dark, dirty-green, with an abundance of white, glassy sanidin crystals conspicuously scattered through the groundmass. A few blact hornblendes can be also seen. The structure of the groundmass is quite compact, with the sanidin from very small to large crystals imbedded in it. On the surface of some of the large sanidins is a yellowish-brown coating or crust of alteration. Under the microscope, the rock appears made up of large sanidin crystals, some clear and some dusty or decomposed, in a yellowish-green, fibrous groundmass, with a few green hornblende and brown biotite crystals. The sanidins are quite well defined in form, showing generally the six-sided sections corresponding to prism, base, and hemi-dome. Some are very transparent and give a fine blue or yellow color in polarized light, while others seem to be altered, having become quite cloudy from numerous small acicular or fibrous microlites in nature like the groundmass, so that only small portions of the crystals give any color. This alteration commences in streaks across the clear crystal, eventually affecting the whole mass; in a few cases a radiated zeolite has been formed in the fissures and also in the interstices between two sanidin crystals. The transparent crystals are characteristic and have cleavage lines in two directions. The inclusions are portions of the groundmass and small, pale-greenish columnar crystals and dark needles. Besides these are numerous round and long cavities in rows and scattered through the crys- 
tals; their brownish color shows them to be probably glass inclusions. There are a few dark-green hornblende crystals rather prismatic in shape, but also tabular and irregular ones, which are strongly dichroitic. Some of them are altered into a dark reddish-brown substance, notably two quite large hexagonal sections. The brown, resultant mineral does not polarize nor is it at all dichroitic. There are also a few plagioclases present, and the single grain of magnetite discovered has an unusually brilliant luster. In some of the sanidin crystals and also filling up fissures is a granular mineral, which polarizes faintly like sanidin, but with a rougher surface. Its exact nature could not be determined, but it is probably zeolitic. The radiated, transparent mineral already mentioned is quite remarkable and conspicuous, as it gives bright blue, yellow, and red colors in polarized light. It is a zeolite, presumably natrolite, and gives a phonolitic character to the rock, shown by the very large percentage of the soluble portion.

The groundmass is very fibrous in character, being composed of a grent quantity of long, capillary, yellowish-green needles closely interlaced and grown together. They may be hornblendic. 'The silica present is 59.06 , and 29.25 per cent. is soluble in hydrochloric acid, but no nephelite could be found in the rock or thin section.

The rock [169] occurring at the contact between the trachyte and sandstone at the base of Little Missouri Buttes has a very porous, spongy structure, full of large, rounded cavities, so that it is much like pumice to the touch. In the mass are seen quartz grains, white, decomposed crystals, dark-colored spots, and some transparent sanidins. It has an earthy, dirtyyellow color, but is hard and resonant. In the section, it was observed to consist of large grains of quartz, sanidin crystals and a little plagioclase, with fragments of another rock, a rhyolite, imbedded in a rather opaque cementing mass of volcanic character.

Many of the sanidin crystals are so much decomposed as to be nearly opaque and whitish in color, while others are very clear and transparent, having inclusions of microlites. Some of the smaller feldspars are banded like plagioclase. The quartz grains are rounded, polarizing, of course, in brilliant colors, and are easily recognized. They contain long, hair-like microlites, besides an abundance of cavities and some prismatic-shaped 
crystals that may be hornblende. Quite remarkable is the appearance of fragments of rhyolite, similar to those already described [147], [152], [166], in which all the constituents are plainly to be seen, small sanidins and biotite in a fine-grained groundmass. The color of these fragments is quite different from the surrounding rock mass. The groundmass of the rock under examination is granular and has an earthy color, with darker spots through it, being also full of small holes and sanidin crystals, so that is no doubt trachytic. It is a rhyolitic breccia, which has inclosed fragments of both the sandstone and the adjoining rhyolite.

The sanidin-trachyte [171] from Warren Peaks has a grayish color, faintly mottled with white and red spots, there being, however, no feldspar crystals visible to the naked eye. In the section, its composition appears to be sanidin in large, indistictly defined crystals in a fibrous groundmass, with a great number of small, prismatic hornblende crystals.

The greater part of the rock is sanidin in a partly dusty and opaque condition and almost in one mass; it is also in the form of some quite clear crystals, confused in outline with the mass around them. These clear crystals are sometimes twinned and have inclusions of hornblende, while the cleavage lines and fissures are prominent and distinct. The opaque, white crystals have a little more distinct outlines and are most easily seen in reflected light. The hornblendes are very thickly scattered through the rock, seemingly more plentiful between the clear sanidins. They have generally a prismatic shape and ragged or forked terminations, with an occasional large crystal of more distinct outline. They are slightly dichroitic from brownish-green to a fine deep-green, but the cleavage lines are almost obliterated. The rich green color of the small crystals makes them very conspicuous objects in the field of the microscope. Between some of the opaque sanidins was noted a colorless, transparent, isotropic mineral which could not be satisfactorily determined. It may be glass or calcite. Very little magnetite was seen, but considerable brown oxide of iron in spots. The groundmass is almost entirely sanidin aggregated to one mass, with fibrous streaks traversing the rock in every direction. These streaks contain most of the lormblende columns; and in parts of the slide may be observed a slight fluid-like structure around the smaller sanidins. This 
rock is very similar to [124] from Terry Peak, although this has larger hornblendes and an abundance of magnetite, which is lacking in the rock in question. The resemblance between the two hand specimens is not so marked, [124] having large porphyritic sanidin and hornblende crystals, while [171] is more uniform and compact. There is a similarity in structure to [123] and [159], the small hornblende prisms in the two latter, however, being much more numerous and the rocks in a fresher condition.

The sanidin-trachyte [173] from southwest of Warren Peaks is lightgray in color, and quite compact and uniform in structure. It has an occasional large, glassy sanidin, while the entire rock is thickly besprinkled with tiny, green hornblende crystals, easily seen with a loupe. Under the microscope, the section appears to consist entirely of sanidin, partly in well defined, clear crystals and partly in a cloudy mass, scattered through which are seen the green hornblendes.

The clear sanidins present a new feature as yet not observed in any of these rocks, namely, inclusions of small, rounded, light-brown glass masses. These particles do not polarize at all and are abundant in almost every crystal, having sometimes hexagonal and rectangular forms. They are also partially transparent. It is interesting to note that the single macroscopical sanidin crystal in the hand specimen contains near its center a light yellowish-brown, spherical inclusion about the size of a small mustard seed, undoubtedly of the same character as the glass masses observed in the slide, which unfortunately does not happen to have a large sanidin in it. There are also a few transparent hornblende microlites in the sanidin. The hornblende crystals are of a fine green color, slightly dichroitic and prismatic in shape, somewhat similar to those in the preceding rock, but broader and more sharply terminated.

The groundmass, if any can be distinguished between the sanidin crystals, is cloudy and thick, but more granular than microlitic and having but very slight traces of any fluid-like structure. The rock is similar to [171], but not so much weathered, both the hornblende and sanidin being sharper and more crystalline in form.

The rock [174] from north of Warren Peaks is quite interesting and different from any of the other specimens and rather difficult to determine. 
It has a grayish-green groundmass quite crystalline in structure, through which in great abundance are large, black, lustrous biotite crystals and smaller, green columns of hornblende. Besides these there are numerous particles of a white mineral; some are small and hexagonal in shape and others quite large and crystalline, one in particular having a crust on the surface as if it had filled up a cavity in the rock. In this large mass lies a transparent crystal of calcite, which, with many of the smaller masses, effervesces in acid. The harder, white particles of more hexagonal form do not effervesce and are probably apatite. The rock does not gelatinize in acid, but, treated with nitric acid and ammonic molybdate, gives an abundant yellow precipitate, thus proving the presence of apatite as described in the examination of the thin section. It has 52.02 per cent. of silica, and 23.14 per cent. is soluble in hydrochloric acid. The rock is a trachyte, with the accessory and accidental minerals apatite and calcite.

In the section under the microscope, is seen a feldspathic groundmass, in which are very abundant biotite, hornblende and apatite crystals, with magnetite grains and colorless masses of calcite. The sanidin is in indistinct and not very transparent crystals in the groundmass, which seems to consist of the same mineral. The crystals are bright with crossed nicols, when their shape can be made out with tolerable ease, while an occasional good rectangular section may be seen. The hornblende is very abundant in large, pale-green, prismatic crystals, which give very beautiful bright colors, green, red, blue, \&c., in polarized light. There are also numerous small crystals, which are quite sharply and distinctly terminated, but they show little dichroism, the majority being cut parallel to the vertical axis. A few sections, however, parallel to the base. have the cleavage lines and are dichroitic. The hornblende has inclusions of magnetite and sometimes of calcite.

Much more conspicuous is the biotite in its very large and strongly dichroitic, light-brown sections. It is very plentiful in the rock, from long, slender crystals and small fragments to large, brown and almost opaque, hexagonal basal sections. The lines of lamination are distinctly marked, and inclusions of magnetite and calcite are very frequent. Remarkable is a group of hexagonal sections, in which are white, calcite masses, including 
in their turn sharp, square crystals of magnetite, forming a double inclusion not often met with (Plate II, Fig. 4). The partially altered biotites are very dark, full of magnetite and nearly opaque, while the light-brown, transparent prismatic sections often have apatite inclusions. The magnetite is very abundant in large grains and masses. Apatite is present and is recognized in the hexagonal white sections, which change only from light to dark with the revolution of the nicols. The long, slender sections parallel to the prism are seen to be doubly terminated by a pyramid, while they are of a faint violet color with crossed nicols. The basal sections are quite sharp and clear in outline, and of large and small size, the latter being most brilliant That this mineral is apatite and not nephelite is confirmed by the chemical reaction obtained for phosphoric acid as well as the form of the long, acicular prismatic sections, which are more usual for apatite than nephelite. The pyramidal terminations belong also to apatite, the crystals of which in this rock are unusually large and fine. The calcite is in irregular, colorless masses, which appear to fill up cavities and also to be inclusions in hornblende and biotite. It changes only from light to dark, and does not have in the section any of the usual lines of twinning and cleavage. A fragment broken from the large mass previously mentioned showed the characteristic cleavage very distinctly under the microscope, while the effervescence with acid also proves its character. It may be the result of decomposition, or more probably it has been formed in the cavities of the rock from extraneous sources as an infiltration.

The groundmass is made up of sanidin crystals, confusedly intergrown and interlaced, a few of which are still fresh enough to show their forms as bright sections between crossed nicols, while the whole mass is also sufficiently clear to make its structure apparent.

The sanidin-trachyte [175] from southwest of Warren Peaks has a dark-green color and is very compact and solid, resembling [123] and [167]. Scattered through it are whitish crystals of feldspar, quite conspicuons in the green mass. The thin section is seen under the microscope to consist of a remarkable mass of delicate, acicular microlités of hornblende, in which are a few sanidin and large hornblende erystals, with magnetite. The sanidin crystals having a distinct outline are rather scarce. They are 
quite transparent and include a great many microlites, and the needles of the groundmass press into the crystal along the border in such quantities as to explain perhaps the formation of the rock. The solid mass consists for the most part of clear and transparent sanidin, which, however, has been pierced through and through and filled up with vast numbers of yellowish-green hornblende needles, leaving an occasional crystal free, which now behaves in polarized light in a similar manner to the mass in the interstices between the microlites. The green color of the rock results from these microlites. A similar structure, but with much larger hornblende crystals, can be observed in the rocks [123] and [159-162], the fluid-like structure in the latter being also much more marked. In the slide now under examination, this structure is indistinct, being best seen around a sanidin crystal as if the force of the crýstallization had pushed the microlites closer together. There are a few quite large, yellowish-green hornblendes, which are dichroitic, although not very strongly so, and show some traces of cleavage lines. They include grains of magnetite and one in particular contains a piece of magnetite about onethird of its size, which conforms to the shape of the hornblende as if it was the result of a secondary formation. The section of [124] has a similar occurrence of hornblende and magnetite. The hornblende has also brown spots through it, the beginning of alteration. Magnetite in small grains is present, but not very abundantly, and must not be confounded with very minute black biotite needles.

The greenish color of the microlitic groundmass can be seen to the best advantage with reflected light.

The sanidin-trachyte [178] from the top of Warren Peak is a characteristic looking rock, with enormous sanidin crystals in a light-grayish groundmass, with iron-brown spots in it. Some of the crystals are from one to two inches in length. In the section, the rock appears to be very porous and to consist of a fine groundmass, in which are the large crystals, with some hydrated oxide of iron and nearly decomposed biotite The large sanidins present no remarkable appearances, while the feathery or fibrousmicrolitic groundmass has been previously described as characteristic of trachyte. The biotite has become so nearly opaque and brown as to lose all of its peculiarities, except the rough, hexagonal outline. But little mag- 
netite can be seen, it having been altered to limonite. There are through the slide a few veins of a partly fibrous mineral, having the appearace of filling up a fissure; and in some parts of the section an indistinct fluid-like structure was observed.

The rock [187] from Gold Ledge, Warren Peak, is felsitic, compact and porcelain-like in structure and appearance. On a fresh fracture it is light-gray in color, mottled with pale-yellow spots of a resinous luster, and some black spots. It weathers to an iron-red or brown, so that large parts of the rock have the various intermediate shades from white, through fleshcolor, to dark-red. A few large, opaque white sanidin crystals can be seen, which are exceedingly hard, as if altered to some siliceous mineral. The yellowish spots, and also some of a bluish-white, milky color, resemble chalcedony or opal, which minerals occur in trachytic rocks. In the thin section, the felsitic groundmass remains cloudy and not at all transparent and in it are seen dusty and cloudy sanidins, partially altered to a radiated, brightly polarizing chalcedony or quartz mass. Some of the smaller, rectangular shaped ones are entirely changed to this chalcedony, which affords a dark or colored cross in polarized light. This cross revolves and changes color, following the motion of the prisms, and is due to the radiated or fibrous structure of the chalcedony. The sanidin crystals are quite cloudy and have lost all their crystalline characteristics except the external form, which can still be recognized against the dark groundmass by reason of their slight transparency. They do not polarize at all, remaining dark between crossed nicols. Twinned crystals can be seen occasionally, and in one case the alteration to chalcedony has begun at the twin line. A few reddish spots and blotches of oxide of iron are scattered through the rock sometimes surrounding a sanidin crystal, but no other mineral constituents were observed. The rock is evidently trachytic in nature and might be called a felsitic rhyolite, with chalcedony or opal as a result of infiltration or secretion. The silica was determined to be 79.89 per cent., much higher than any of the other Black Hills rhyolites. This rock, and the following one [192], occurs, according to Mr. Jenney's report, p. 47, in a "ledge of irregular shape, without any well defined walls or boundaries, and merging on all sides in the adjacent trachyte rocks." From the fact of 
the evident chalcedony druses in [192], it may be inferred that the brightly polarizing mineral in [187] is of the same nature.

The specimen [192], also from Gold Ledge, Warren Peaks, has an exceedingly compact, jaspery or felsitic, reddish-brown groundmass, in which are imbedded large, whitish sanidin crystals, quite lustrous on their cleavage faces. There can also be seen small, dark colored druses, which appear to be lined with a bluish-white mineral of botryoidal form like chalcedony. The sanidin crystals have tolerably sharp outlines, being quite conspicuous in the red mass, and, by the difference in luster between two parts of the same crystal, it is noticed that some are twinned. The groundmass resembles hornstone or jasper in its compactness, and has the cavities of chalcedony very abundantly scattered through it.

In the section under the microscope, the sanidin is conspicuous by reason of its translucency and behavior in polarized light. The cleavage lines are very distinct, and the only noticeable inclusions are small, round particles of red oxide of iron. The groundmass is of a whitish color, transparent in places, but quite filled with small, red, ferruginous granules, which occasion the color of the rock. The cavities mentioned are quite numerous and are filled with chalcedony, its usual formation in layers conforming to the shape of the cavity being plainly seen. In the interior of the druses, between the layer of chalcedony, is some transparent, erystalline quartz, as is often seen in geodes. The feldspar is more like sanidin than ordinary orthoclase, having fissures and cracks and being also quite transparent, while the groundmass has also a rhyolitic appearance the same as that of [187], but with the addition of particles of oxide of iron. The rock is a variety of rhyolite, in the cavities of which the quartz or chalcedony has been secreted at the same time as the iron granules, greatly changing its appearance.

The sanidin-trachyte [213] from Whitewood Creek, has a groundmass of a bluish-gray color, in which are numerous opaque, white feldspar crystals. The rock is quite porous and full of holes, left empty by the weathering of the sanidin crystals. Under the microscope, the section shows a fine groundmass consisting chiefly of minute sanidins, in which are a few quite large and well defined but cloudy sanidin crystals, with mag- 
netite, and some very spáring quartz grains. The sanidins still retain their rectangular outline, although they have become quite dusty and even opaque. With crossed nicols they polarize faintly white so as to be plainly seen, a few giving pale blue and yellow colors. One crystal, broken and twinned with a second so as to resemble a geniculation, is quite interesting. The fissure lines in these crystals polarize in bright colors, thus being very distinct in the cloudy mass. A few brilliant grains were named quartz; they are rounded and of irregular shape, containing some microlites and round cavities, but may be sanidin, as some uncertainty as to their nature still remains. The occurrence of biotite with a border of magnetite grains has been often mentioned, and in this section the border is seen, but the interior is partly or entirely composed of transparent quartz. One of these formations has an hexagonal shape, but they are generally prismatic. The biotite in only a few cases retains its greenish color in the small fragments, around which the magnetite border is quite conspicuous. Magnetite is scattered quite uniformly through the groundmass in minute grains, with some large and sharply defined masses.

The groundmass is made up of minute and almost feathery sanidin crystals, which, although very indistinct, are faintly white with crossed nicols, showing also very sparing traces of a fluid-like structure. The rather low percentage of silica, 61.98, gave rise to the uncertainty as to the quartz grains in the rock. Amount dissolved in acid is 9.93 per cent.

The rhyolite [214] from Terry Peak (?) is fine-grained, with small, white feldspar crystals. The rock is quite full of pores, which contain hydrated oxide of iron, but is otherwise tolerably homogeneous. In the section under the microscope, it is seen to consist of large and cloudy crystals of sanidin, with large grains and masses of magnetite, brown biotite and abundant quartz grains in a groundmass of rery small and indistinct sanidin sections. The large crystals of sanidin are in every way analogous to those in [213], being cloudy and opaque while still retaining a distinct outline. Many of the erystals are banded. The quartz is in clear grains, having brilliant colors and microlitic inclusions. The biotite is mostly so decomposed that it is very brown and opaque, with, however, a good crystalline form. It is very abundant through the rock, much more 
so than in [213], and is also in part altered to magnetite. The latter occurs in large masses, mostly in former biotite crystals, but is very sparing in the groundmass and not at all so uniformly distributed as noticed before. Large, opaque, brown masses of hydrated oxide of iron are also present.

The groundmass is very fine indeed, it being very difficult to trace any outline of the small sanidin sections, which appear as mere whitish spots. A few colorless, but sharp and clear apatite needles were recognized. One of them of columnar form has a very distinct black center, with a light exterior border. The whole appearance of the rock, both in hand specimen and section, shows it to be considerably weathered.

The section of feldspar from the granites of the Black Hills is orthoclase very beautifully striated, so that it much resembles plagioclase. It is similar to the striation of the amazon stone from Siberia, and differs from the banding of plagioclase because the lines are not exactly parallel, but rather pointed and sometimes at right angles to each other. It is a beautiful example of this occurrence of banded orthoclase. Zirkel, in the N. Jb. f. Min. 1872, p. 12, explains this banding of orthoclase in polarized light as due to particles of some foreign substance, arranged in layers and strata, so that between them is seen the pure and clear feldspar, which causes the phenomenon by its bright colors. The dark bands are made up of longshaped cavities, varying somewhat in size, and yellowish needles and leaves. When these bands are interrupted by a layer of clear orthoclase, the rows of cavities become very thin and finally disappear in the feldspar with delicate comb-like borders, very beautiful, but not to be confounded with the striations arising from the twin lamellation of triclinic feldspar, the latter being sharper, more exactly parallel to each other and more distinctly defined. This feldspar has inclusions of long needles of apatite, hornblende and probably mica. Masses of uncrystallized orthoclase run through it in irregular shapes, and some quartz and magnetite are also to be seen. 
Silica determinations and amount soluble in hydrochloric acid.

\begin{tabular}{|c|c|c|c|}
\hline No. & Rock and location. & Silica. & $\begin{array}{c}\text { Sol. in } \\
\text { acid. }\end{array}$ \\
\hline 101 & Rhyolite (granitic), top of Terry Peak.... & 72.35 & 4.56 \\
\hline 103 & Rhyolite (granitic), top of Terry Peak.... & 71.13 & 3.12 \\
\hline 109 & Rhyolite, southeast of Terry Peak... & 75.09 & 2.92 \\
\hline 113 & 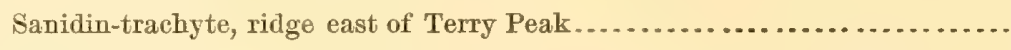 & 58.83 & $16 . \varepsilon 8$ \\
\hline 120 & Rhyolite, southeast of Terry Peak ................................... & 72.27 & 3.74 \\
\hline 123 & 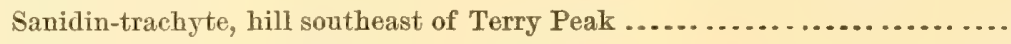 & 63.56 & 8.58 \\
\hline 124 & 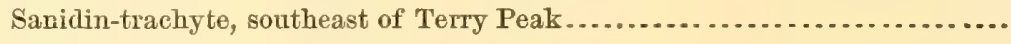 & 57.75 & 13.48 \\
\hline 127 & Rhyolite, near Deer Mountains............... & 73.22 & 6.67 \\
\hline 131 & Rhyolite, southeast of Terry Peak............ & 72.22 & 5.31 \\
\hline 134 & Rhyolite, top of Custer Peak................. & 68.62 & 5.62 \\
\hline 135 & 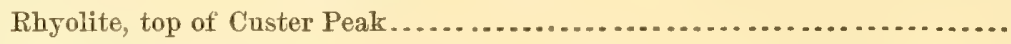 & 72.33 & 5.61 \\
\hline 139 & Phonolite, Black Butte.................. & 56.32 & 24.08 \\
\hline 140 & Sanidin-trachyte, Black Butte...... & 58.53 & 18.59 \\
\hline 141 & 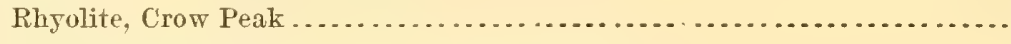 & 67.36 & 3.54 \\
\hline 144 & Sanidin-oligoclase-trachyte, Bear Butte Creek ..................... & 65.46 & 10.09 \\
\hline 147 & 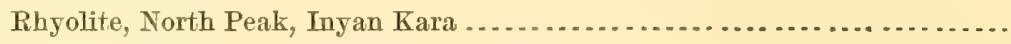 & 73.18 & 4. 21 \\
\hline 149 & Sanidin-trachyte, Center Peak, Inyan Kara......... & 60.51 & 6.32 \\
\hline 157 & Sanidin-trachyte, hill west of Inyan Kara...... & 61.88 & 6.55 \\
\hline 161 & 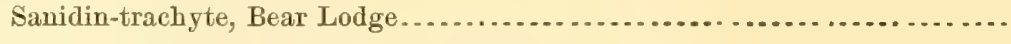 & 60.77 & 15. 33 \\
\hline 167 & Sanidin-trachyte (phonolitic), Little Missouri Buttes................. & 59.06 & 29.25 \\
\hline 174 & 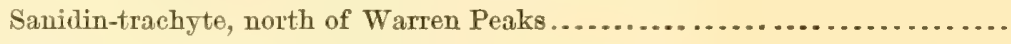 & 52.02 & 23.14 \\
\hline 187 & Rhyolite (quartzitic), Gold Ledge, Warren Peaks ..................... . & 79.89 & 6. 45 \\
\hline 213 & 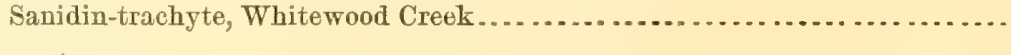 & 61.98 & 9.93 \\
\hline
\end{tabular}

[139] gelatinizes strongly in hydrochloric acid and does not give any phosphoric acid reaction with ammonic molybdate.

[174] does not gelatinize, and gives an abundant yellow precipitate with ammonic molybdate, which, after solution in ammonia, gives a crystalline precipitate with magnesia mixture, proving the microscopic determination of apatite. 
The various rhyolites and trachytes fall into three groups, according to their similarity to each other, as follows:

\section{RHYOLITES.}

[127]_Near Deer Mountains.

[131]-Southeast of Terry Peak.

[134]-Top of Custer Peak.

[135]-Top of Custer Peak.

[137]-Top of Custer Peak.

[152]-Inyan Kara?

[147]-North Peak, Inyan Kara.

[166]-North Peak, Inyan Kara.

[141-142]-Crow Peak.

SANIDIN-TRACHYTES

(normal).

[149]-Center Peak, Inyan Kara.

151]-North Peak, Inyan Kara.

[157]-Hill, west of Inyan Kara.

[178]-Top of Warren Peaks.

[144]-Between forks of Bear Butte Creek.

SANIDIN-TRACHYTES

(with hornblende, microlites, \&c.).

[123]-Hill, southeast of Terry Peak.

[159-162]-Bear Lodge.

[124]—Southeast of Terry Peak.

[140]-Black Butte.

$[150]$-Northeast of Inyan Kara.

[171]-Warren Peaks.

[173]_Southwest of Warren Peaks.

[175]-Southwest of Warren Peaks.

In some cases felsite-porphyry resembles trachytic rocks, especially rhyolite, so closely as to make the distinction between them extremely difficult, and the last group, which differs considerably from the normal sanidin-trachytes, might have been named felsite-porphyry were it not for their low silica percentage and occurrence with the trachytes.

In conclusion, the writer desires to express his obligations to Mr. Arnold Hague, of the Survey of the Fortieth Parallel, Dr. Egleston, Mr. Julien and Dr. Waller, of the School of Mines, New York, and other friends, who have given him valuable suggestions and assistance in the examination of these interesting rocks. 



\section{,}




\title{
MICROSCOPIC PETROGRAPHY. P L A T E I.
}

\author{
DRAWN FROM NATURE BY JOFL H. CASWELL.
}

FIG. 1. Rhyolite ( $\frac{2}{8}{ }^{\prime \prime}$ objective, $\times 88$, polarized light) [127], near Deer Mountains, containing twin crystal of quartz, the two parts not being distinguishable in ordinary light. Biotite in prismatic and basal sections, and small, rectangular sanidin erystals in the groundnass. (See p. 500.)

FiG. 2. Rhyolite (2" öbjective, $\times 88$, polarized light) [137], top of Custer Peak. Biotite crystal with border of magnetite grains and lines of lamination. Brilliantly polarizing quartz, abundant magnetite and indistinct sanidin crystals in the crystalline groundmass. (See p. 503.)

FiG. 3. Phonolite (1 nephelite in a large hornblende mass. Inclusions of the same nature in both sections. Groundmass consists of sanidin. (See p. 503.)

Fig. 4. Phonolite (2/' objective, $\times 88$, polarized light) [139], Black Butte, containing large, dusty nosite crystals, with nephelite sections and small hornblendes in the feldspathic groundmass. Fluid-like strueture around the nosite crystal. (See p. 504.) 




\title{
M I CROSCOPIC P.ETROGRAPHY. PLA T E II.
}

\author{
DRAWN FROM NATURE BY JOHN H. CASWELL.
}

FIG. 1. Sanidin-trachyte ( $2^{\prime \prime}$ objective, $\times 25$, polarized light) [149], Center Peak, Inyan Kara. Zona structure of sanidin crystals; the purple zone is of the same color as the rest in plain light. Hornblende erystal with inclusion of a small sanidin and magnetite; also small hornblende fragments and needles with magnetite grains through the crystalline gronndmass. Apatite in hexagonal sections, and much decomposed biotite in large forms. (See p. 509.)

FIG. 2. Sanicin-trachyte ( $2^{\prime \prime}$ objective, $\times 25$, polarized light) [157], hill west of Inyan Kara, showing fine sanidin crystals, one of which is broken by an irregular mass. Near the edge is part of a twinned crystal. Abundant magnetite as inclusions, as well as in the groundmass. (See p. 512.)

FIG. 3. Sanidin-trachyte ( $2^{\prime \prime}$ objective, $\times 25$, polarized light) [159-162], Bear Lodge, showing large sanidin and hornblende crystals, with some magnetite in a groundmass full of hornblende microlites and having a distinct fluid-like structure. (See p. 513.)

FrG. 4. Sanidin-trachyte ( $\frac{2}{8}{ }^{\prime \prime}$ objective, $\times$ 88, polarized light) [174], north of Warren Peaks, having group of hexagonal biotite sections with double inclusions of calcite and magnetite. Palegreen hormblendes with colorless apatite sections and magnetite in a groundmass composed of indistinct sauidin crystals. Calcite mass near the edge. (See p. 518.) 


\section{,}


U. S. GEOGRAPHICAL AND GEOLOGICAL SIJRVEY OF THE: ROCKY MOUNTAIN RFGION.

J. W. POWELL, in Charge.

\section{B O T A N Y}

OF THE

\section{BLACK HILLS OF DAKOTA.}

BY ASA GRAY. 



\section{CHA P TER VIII.}

B O T A N Y.

BY ASA Grax.

LIST OF PLANTS COLLECTED BY THE BLACK HILLS SURVEY.

\section{POLYPETALA.}

Clematis alpina Mill., var. occidentalis, subvar. tenuiloba.

Stems very short, hardly, if at all, climbing; divisions of the leaves lanceolate or ovate-lanceolate and acute or acuminate, pinnately 3-7-cleft or parted, the longer and narrower lobes commonly almost linear; sepals acuminate; staminodia all linear, hairy, and more or less antheriferous, not half the length of the sepals, little exceeding the true stamens. All the American forms, which are confined to the Rocky Mountains, from the Black Hills of Dakota to New Mexico, agree in having only narrow and antheriferous exterior stamens or staminodia, none of which are dilated into petals, and the foliage is finer than in any of the ordinary forms of the old world species, except Ledebour's Atragene macropetala and Regel's A. alpina var. tenuisecta. In Pl. Fendlerianæ I had referred the American form to $A$. Ochotensis; but it is best to regard it as an independent variety of that polymorphous species which takes the name of Clematis alpina. The present form of it (tenuiloba) is so remarkable for the fine dissection of its leaves that it would most naturally pass for a distinct new species. It appears to be the analogue of Regel's $A$. alpina var. temuisecta.

Clematis ligusticifolia Nutt.

Anemone Patens var. nuttalliana Gray. 
A. MUl'TIFIDA DC.

A. Cylindrica Gray.

Thalictrum dioicum Linn.

Ranunculus aquatilis Linn. var. TRIChophyllus Chaix.

$\mathrm{R}$ rHombolneus Hook.

$R$. BREvicaulis Hook, a variety of the next.

R. affinis R. Brown var. Cardiophyllus, Gray.

Delphinium biculor Nutt. ex Watson.

ACONItUm Fischeri Reichenb.

Argemone mexicana Linn.

Arabis drummondiI Gray.

Vesicaria alipina Nutt.

Erysimum asperum DC.

Sisymbrium Canescens Nutt.

Polanisia trachysperma Torr. \& Gray.

Viola canina var. sylvestris Regel.

Viola delphinifolia Nutt.

Helianthemum canadense Michx.

Cerastium arvense Linn.

Malvastrum coccineum Gray.

Linum PeRenne Linn.

Geranium carolinianum Linn.

G. Richardsoni Fischer \& Meyer.

G. Incisum Nutt.

Polygala alba Nutt.

.Thermopsis rhombifolia Nutt.

Lupinus oRnatus Dougl var.

L. argenteus Pursh var.

Petalostemon violaceus Michx.

Psoralea esculenta Pursh.

P. ARgophylla Pursh.

Glycyrrhiza lepidota Nutt.

Astragalus caryocarpus Ker

A. Hypoglottis Linn. 
A. adsurgens Pallas.

A. GRACILIS Nutt.

A. ALPinus Linn.

A. ABoriginum Richardson.

A. Simplicifolius Gray.

Oxytropis lamberti Pursh.

O. CAMPESTRIS Linn. var.

Vicia americana Muhl.

V. AMERICANA var. LINEARIS Watson (Lathyrus linearis Nutt).

LATHyRus ochroleucus Hook.

Hedysarum GaNescens Nutt.

SopHora SERICEA Nutt

Spirea betulifolia Pallas.

Geum rivale Linn.

G. triflortim Pursh.

Potentilla nivea Linn. var. dissecta Watson.

P. hippiana Lehmann.

P. ARguta Pursh. a dwarf form.

P. FISSA Nutt.

Rubus nutkanus Moçino.

R. TRIFLORUS Richardson.

Rosa blanda Ait.

Amelanchier canadensis var. alnifolia Torr. \& Gray

Lithophragma tenella Nutt.

Epilobium angustifolium Linn.

Gadra coccinea Nutt.

Gayophytum racemosum Torr. \& Gray.

Enothera Biennis Linn.

E. Chry SAntrha Michx.

E. serrulata Nutt. var. DRUMmondi Torr. \& Gray.

E. pinnatifida Nutt.

E. caspitosa Nutt.

Carum (edosmia) gairdneri Gray.

Thaspium trifoliatum Gray. 
Crmopterus glomeratus Nutt.

Musenium divaricatum Nutt.

Cornus canadensts Linn.

II. GAMOPETALÆE.

Vateriana sylvatica Richardson.

Galium boreale Linn.

Liatris scariosa Willd.

L. punctata Hook.

Aster (macheranthera) tanacetifolius H. B. K.

A. Levis Linn.

A. MULTIFLoRus Ait.

Aster falcatus Linn.

A. SIMPlex Willd.

A. PTARMicoides Torr. \& Gray.

ERIGERon PUmilum Nutt.

E. glabellum Nutt.

E. macranthum Nutt.

E. strigosum Muhl, var.

Gutierrezia euthamie Torr. \& Gray.

Solidago nemoralis Ait. and var. Radula Torr. \& Gray.

S. SPECIOSA Nutt. var. angustata Torr. \& Gray.

S. Missouriensis Nutt.

S. RIGIDA Linn.

Chrysopsis villosa Nutt.

Echinacea angustifolia DC.

RUDBECKIA HiRTA Linn.

Helianthus Rigidus Desf.

H. strumosus Linn.

H. PETIOLARIS Nutt.

Helianthella uniflora Torr \& Gray.

Gaillardia aristata Pursh.

Actinelua acaulis Nutt.

Achillea millefolium Linn.

Artemisia ludoviciana, Nutt. 
Antennaria margaritacea R. Brown.

Senecio integerrimus Nutt.

Lygodesmia Juncea Don.

Hieracium canadense Michx.

Troximon marginatum Nutt

T. CUSPIDATUM Nutt.

MUlgedium pUlchellum Nutt.

Campanula rotundifolia Linn.

Arctostaphylos UVA-URSi Spreng.

Dodecatheon meadia Linn. var.

ANDrosace SEPTENTRIonalis Linn.

Lrsimachia ciliata Linn.

Solanum rostratum Dunal.

Colinsia tenelua Nutt.

Pentstemon glaber Pursh.

P. acuminatus Dougl.

P. GRANDIFlorus Nutt.

P. cristatus Nutt.

P. ALbIDUS Nutt.

P. GRACILIS Nutt.

Castilleita Pallida Kunth var. SePtentrionalis Lindl.

Verbena bipinnatifida, Nutt.

Monarda Fistulosa Linn.

Saluita lanceolata Car.

Lophanthus antsatus Benth.

Mertensia oblongifolia Nutt.

M. Lanceolata DC.

ERITRICHIUM GLOMERATUM DC.

ECHINOSPERMUM REDowskit Lehm.

Gilia spicata Nutt. var. capitata Gray.

Phlox longifolia vars. Stansburyi, brevifolia Gray.

Convolvultis (Calystegia) sepium Linn.

Apocynum aNdRosamifolium Linn. 


\section{ㅍI. APETALAE.}

Oxybaphus nyctagineus Sweet.

Eriogonum multiceps Nees.

Comandra pollida A. DC.

Euphurbia marginata Pursh.

E. HEXAGONA Nutt.

Humulus lupulus Linn.

Abies alba Michx.? Foliage only.

\section{MONOCOTYLEDONES.}

Calochortus nuttaliit Torr. \& Gray.

Specimens in flower and with mature fruit. This is noted as an insectcapturing plant, flies having frequently been found fast among the bristles that fringe the gland of the petals, where they had perished. Those who have the advantage of seeing this and similar species alive, either in their native haunts or in cultivation, should learn whether these bristles manifest any irritability. The petals are evidently white or whitish, except the claw and the purple blotch above it. The well-formed mature capsules are 2 or 3 inches long, triquetrous-lanceolate, four or five lines in diameter. There is hardly any doubt that Nuttall's Calochortus luteus was correctly referred to this species. Although apparently Wyeth did not obtain mature fruit, Nuttall's description, "capsule linear-oblong, three-sided," and "the capsule much like that of a tulip," suffice to show that his plant ought not to have been referred by Mr. Baker to his section "Platycarpus." The only species of that section likely to be found about the sources of the Columbia is C. nitidus Dougl., to which belongs C. eurycarpus of Watson, and both its ovary and pod are broadly oval in outline. The C.nuttallii of Baker's Revision of Tulipeæ is evidently made up of more than one species, viz, of Hall and Harbour's 549 (misprinted 529), which is C. gunnisoni, and for the rest probably of $C$. nitidus. If the specimens cited from Nuttall, Burke, and Bell really belong to $C$. nuttallii, they cannot have well-formed fruit. The misunderstanding of this latter species accounts for the introduction of. C. leichtlinii Hook. J., Bot. Mag. + 5862, which is plainly our C.nuttallii. Lilium PHILAdelphicum Linn. Prosartes lanuginosa Don. 
Zygadentus gladucus Nutt.

Amianthium nuttalliI Gray.

IrIS tolmieana Herbert.

SistrinchiUm Bermudiana Linn.

Tradescantia virginica Linn.

Agrostis scabra Willd.

Muhlenbergia glomerata Tin.

VILFA HETEROLEPIS Gray.

V. cuspidata Torr.

Calamagrostis canadensis Beauv.

Bouteloua curtipendula Gray.

B. oifgostachya Torr.

Glyceria aquatica Smith.

Bromus кalmi Gray.

B. ciliatus Linn.

Triticum violaceum Hornem.

Elymus canadensis Linn.

Phalaris arundinacea Linn.

Andropogon furcatus Muhl.

CRYPTOGAMIA.

Cheilanthes landginosa Nutt.

Pellesa atropurpurea Link.

Asplenium filix-Fcemina Bernh.

Aspidium filix-mas Swartz.

Struthiopteris germanica Willd.

Onoclea sensibilis Linn.

Woodsia scopulina Eaton.

Equisetum arvense Linn

E. sxlvaticum Linn.? 

U. S. GEOGRAPHICAL AND GEOLOGICAL SURVEY OF TIIE ROCKY MOUNTAIN REGION. J. W. POWELL, in Charge.

\section{ASTRONOIIY AND BAROIETRIC HYPSOMETRY}

\section{OF THE \\ BLACK HILLS OF DAKOTA.}

By HORACE P. TUTTLE. 

Washington, D. C., July 1, 1876.

SIR: In obedience to your orders I have the honor to present herewith my report of the astronomical and barometric work done in the Black Hills of Dakota and Wyoming, during the summer of 1875, while attached to the party under your direction

Very respectfully, your obedient servant,

\section{HORACE P. TUTTLE,}

Astronomer.

Walter P. Jenney, Geologist in charge. 



\section{CHAPTER IX.}

\section{ASTRONOMY AND BAROMETRIC HYPSOMETRY. \\ By Horace P. Tuttle. \\ SECTION I.}

THE ASTRONOMICAL WORK.

\section{General remarks.}

My appointment was dated April 13, 1875, and I was ordered to report to you without delay, which I did on the 24th of the same month; at Chicago, Ill., and with the other members of the party arrived at Cheyenne on the 27 th of April.

The funds at the disposal of the Department of the Interior, and which could be used for the purpose of purchasing instruments for our outfit, was very limited, but the Hon. E. P. Smith, Commissioner of Indian Affairs, under whose immediate direction our party was, authorized the purchase of one new marine chronometer, one sidereal pocket chronometer, and also to hire one or more marine chronometers, as I might deem expedient.

Upon my arrival in New York, I proceeded to the store of Messrs. T. S. \& J. D. Negus, where I found that they had selected for the expedition one of their new marine chronometers, No. 1572; they also showed me a Parkinson \& Frodsham marine chronometer, No. 3192, which had an extremely small rate, and which they offered to loan to the expedition. As this chronometer was considerably lighter than the usual marine chronometers, I at once signed a contract for its loan to the expedition. Sidereal pocket chronometer, No. 54004, Duval, was purchased at the same time, and performed most admirably during the time we were in the field. 
Believing that after our arrival in the country to be surveyed, wagons would have to be dispensed with, and that we should have to take to the saddle, I did not think it advisable to take more than two large chronometers; and my experience in the field during the past summer showed that I was correct; for had I taken more, some of them would have had to be turned into other hands and would have been of no use to me, and most likely would have been ruined. As it was, the two chronometers received from the Messrs. Negus did not pass out of my hands from the time of leaving Cheyenne, in May, until our return there in October.

From Stackpole \& Brother the department authorized the purchase of one transit theodolite, one astronomical and one lunar sextant, and two artificial horizons. These instruments were all new and of the very best workmanship, as are all instruments which come from the hands of these celebrated makers. For the rough country in which we had to work, the theodolite was not well suited from its great weight, but a lighter one could not be procured.

\section{Longitudes.}

Upon my arrival at Cheyenne I learned something definite about the character of the Black Hills country, and it at once became evident that the only thing to be done, so far as longitudes were concerned, was to measure "meridian distances" from point to point, obtaining the chronometer errors and rates as often as our delays would permit, until we should arrive at some prominent point in the Hills, where our theodolite could be brought into use. From the nature of the country we were to visit, it was simply out of the question to start from Cheyenne or Fort Laramie with the errors and rates, and then trusting to chance of obtaining them again on our return, and deducing therefrom the longitudes. This would have been the proper method to have pursued had we been going to a country easy of access and travel, but not in a rugged country like that which we visited; and my only course was to follow the more complicated method of "meridian distances."

It was my intention to have combined my chronometric longitudes with those deduced from occultations, or in case of accident to the chro- 
nometers, to have deduced the longitude of some elevated point from occultations alone; but, unfortunately, the only two good occultations which occurred during our presence in the Hills, viz, a Scorpii, on June 16, and $\alpha$ Virginis, on August 6, were both lost. The first occurred while we were at Camp Harney, a place almost exactly on the meridian of Harney Peak, and after making very correct observations for the local sidereal time and getting my telescope in position, I had the mortification to see the moon sink behind the western slope of Lookout Mountain five minutes before the occultation took place. The second was lost by the failure of our ambulance containing my telescope to meet us at our appointed rendezvous. Both of these stars were of the first magnitude and disappeared behind the dark limb of the moon. The loss of these occultations was disheartening to me in the extreme, as they would have enabled me to have fixed our positions within a mile.

Observers in the field do not place that degree of confidence in longitudes obtained from occultations, to which I think them entitled; and from my long experience I am led to believe that the indifferent results generally found from observations made in the field are greatly owing to the want of experience in the observers themselves, and to errors in the exact local time. With a 2-inch telescope, or that of a theodolite, stars as small as the third magnitude will be easily seen close to the dark limb of the moon, when she is not more than five days old. A single observation of an immersion by a practiced observer, under the above conditions, will give the longitude to within three seconds of time, and in this statement I have the concurrence of some of the most eminent astronomers in the country.

The longitudes of the more prominent peaks in the Black Hills deduced from my chain of "meridian distances" agree very nearly with those of Captain (now General) G. K. Warren, who explored the western, southern, and eastern portion of the hills in 1857. His longitudes were, I believe, determined by moon culminations, which, next to occultations, is the safest and surest way of determining absolute longitudes, when the base or prime meridian is very far distant. From our triangulations the relative positions of Bear Butte, Dodge Peak, Custer Peak, Crow Peak, Terry Peak, Inyan Kara, Warren Peaks, and Bear Lodge are correctly located with 35 B II 
reference to Harney Peak and its longitude as given by the chronometers. This triangulation was wholly performed by the topographer, Dr. MeGillycuddy, in addition to his duties as topographer, and the true azimuth of a great many points in the Big Horn range ascertained; but unfortunately our map will not be on a scale large enough to take in anything beyond the Black Hills proper.

\section{Latitudes.}

Observations for latitude were made at every camp when the weather was favorable, principally by double altitudes of Polaris; while at the most important camps, such as Harney Peak, Bear Lodge, and the junction of the forks of the Cheyenne, by both north and south stars. During our various trips up and down the numerous streams, circum-meridian observations of the sun were made daily, being rarely lost by cloudy weather. So accurate were the courses run by the topographer that the differences of latitude found by observation, and that platted from courses and distances, seldom varied more than a few hundred yards in a run of twentyfive miles.

My observations for time and latitude were all made with a sextant attached to a small tripod of my own invention, weighing less than two pounds. So convenient is this arrangement that the contact of the direct and reflected image of a heavenly body can be observed with the same accuracy as the passage over the wire of a transit instrument.

An observer who is familiar with the use of a sextant can by this method easily obtain the latitude of his station to within one second of are in a single night, provided his instrumental errors have been carefully ascertained, which unfortunately is seldom the case. Here the hands are relieved from the weight of the sextant, which soon becomes tiresome, especially with a heavy instrument. This contrivance permits the sextant to move in azimuth without any sensible friction, while a delicate tangent screw is used to bring the face of the instrument instantly into a vertical plane. The sextant and clamp are instantly detached from the tripod and readily replaced without aid of artificial light.

The computations have been performed by the usual methods and need not be detailed. The determined positions will be found in the table at the end of the report. 


\section{SECTION II.}

\section{MAGNETIC VARIATION.}

The variation was frequently obtained by means of the needle of the theodolite. Owing to the smallness of the circle surrounding the needle, there was an error of reading of $\pm 5^{\prime}$ in every reading, but the mean of several readings was always taken. Great local disturbances were found at one place on Box Elder Creek, and also on the summit of Inyan Kara. At one spot on Box Elder the prismatic compass. was entirely useless for some miles, while at Inyan Kara so great a magnetic power did the rock possess that a small fragment, when brought near the needle, would carry it completely round the circle. In preparing the table at the end of the report all observations made in the vicinity of rock recognized as magnetic were omitted. Ten stations in the Black Hills show a range from $15^{\circ} 16^{\prime}$ east to $15^{\circ} 50^{\prime}$ east, and give a mean of $15^{\circ} 33.3^{\prime}$ east.

\section{S ECTION III.}

\section{B A R O METRIC WORK.}

The meteorological instruments were furnished by Mr. James Green, and were of the best quality. They consisted of two mountain barometers (mercurial), five aneroid barometers, and a number of thermometers.

The mercurial barometers were read regularly in our camps, but the smallness of our party rendered it ordinarily impracticable for us to carry them when we ascended peaks They were observed, however, on the highest points of all, Harney and Terry Peaks.

The deduced altitudes will be found in the table. The base station was in each case the signal office at Cheyenne, and the computations were according to the method and with the tables given by Guyot. The observations and computations are omitted except in the case of the peaks.

HEIGHT OF HARNEY PEEK.

Our barometrical base at Cheyenne was about one hundred and eighty miles distant, but a glance at the weather-map on the day on which observa- 
tions on Harney Peak were made shows that there was no local disturbance east or west of a line joining Cheyenne and the center of the Black Hills, and the deduced height of Harney can be considered as very near the truth, not more than 50 feet in error, I think.

The height of Terry, as deduced from barometrical observations on August 20, and from a zenith distance from Harney, agree within 12 feet.

The observations on Harney were all made on the highest point, which gave us much trouble and risk of life and limb to reach. The mean of four of Green's compensated aneroid barometers gave as the height of Harney 7,440 ) teet.

As my altitude of Harney is so widely different from that found by Colonel Ludlow, in 1874, I give both observations and computations here complete.

The altitude of the railroad track at Cheyenne is, according to an elaborate investigation by Mr. James T. Gardner, 6,075.28 feet, and by measurements by Dr. McGillycuddy and myself, with a theodolite, the cistern of the standard barometer in the signal office is 9.58 feet above the rails. This gives for heigbt of cistern above the sea-level $6,085.86$ feet, exactly one geographical mile.

Observations made on the summit of Harney Peak, July 25, 1875, lat. 430-.52' N. Observer, H. P. TutTLE.

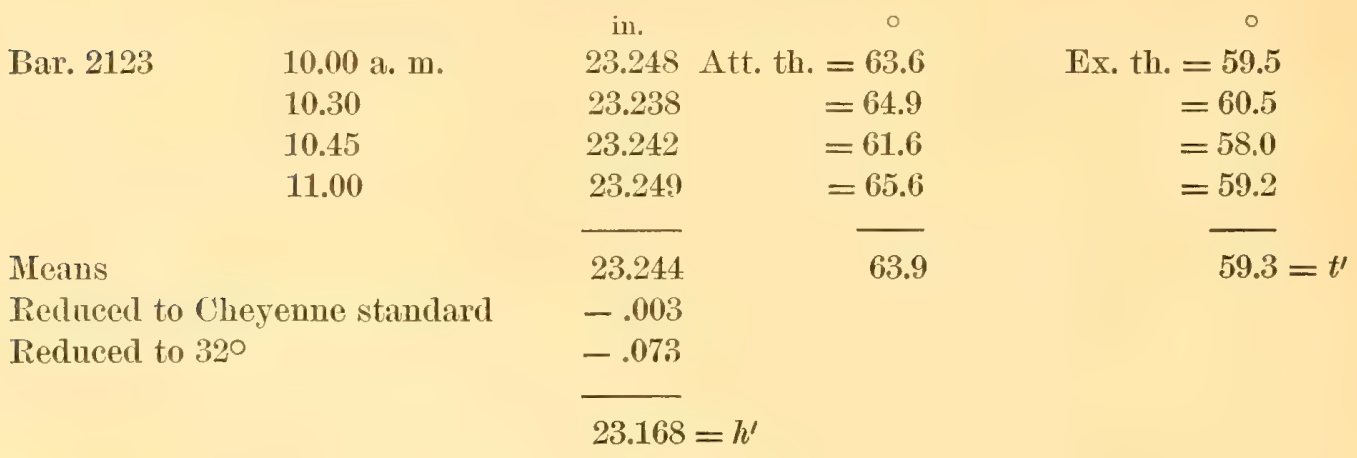


Observations made at Signal Station, Cheycnne, July 25, 1875 , lat. $41^{\circ} 08^{\prime}$.

Observer, A. C. Dobbins, U. S. A.

\begin{tabular}{|c|c|c|c|c|}
\hline Standard bar. 133. & $\begin{array}{l}7.00 \mathrm{a.} \mathrm{m} . \\
10.19 \\
12.00 \mathrm{~m} .\end{array}$ & $\begin{array}{c}\text { in. } \\
24.270 \\
24.256 \\
24.260\end{array}$ & $\begin{aligned} \text { Att. th. } & =61.0 \\
& =63.0 \\
& =69.0\end{aligned}$ & $\begin{array}{r}\text { Ex. th. } 58.0 \\
62.0 \\
65.0\end{array}$ \\
\hline $\begin{array}{l}\text { Reduced to } 32^{\circ} \text {. } \\
\text { From Guyot's }\end{array}$ & les we have & $\begin{array}{l}24.262= \\
\left\{\begin{array}{l}61.6= \\
59.3= \\
-120.9=\end{array}\right.\end{array}$ & $\begin{array}{l}=h \\
t \\
t^{\prime} \\
=t+t^{\prime}\end{array}$ & \\
\hline
\end{tabular}

Table I for $h 24.262$ inches $=23,156.7$

$h^{\prime} 23.168$ inches $=21,951.2$

Difference $=\mathrm{D}=1,205.5=$ approx. diff. level.

$\begin{aligned} \frac{\mathrm{D} \times\left(t+t^{\prime}-64\right)}{900} & =+76.2 \\ \mathrm{D}^{\prime} & =\overline{1,281.7}=\text { second approx. diff. }\end{aligned}$

Table III for $\mathrm{D}^{\prime}$ gives $+\quad .1$

Table IV for $\mathrm{D}^{\prime}$ gives $+\quad 3.0$

Table $V$ for $h=24.26+\quad .7$

1,282.5 Harney Peak above Cheyenne.

6,085.9 Cheyenne above the level of the sea.

Feet 7,369.4 Harney Peak above the level of the sea.

HEIGHT OF TERRT PEAK.

Observations made on the summit of Terry Peak, lat. 44 20', August 20, 1875.

Observer, Henry Nhwton.

\begin{tabular}{|c|c|c|c|c|}
\hline Bar. 2120 & $\begin{array}{l}9.30 \text { a. m. } \\
10.00 \\
11.00 \\
3.00 \text { p. m. }\end{array}$ & $\begin{array}{c}\text { in. } \\
23.404 \\
23.408 \\
23.420 \\
23.448\end{array}$ & $\begin{aligned} & \circ \\
\text { Att. th. } & =58.5 \\
& =58.5 \\
& =60.5 \\
& =67.5\end{aligned}$ & $\begin{array}{c}\circ \\
\text { Ex. th. }=56.0 \\
58.0 \\
62.0 \\
61.0\end{array}$ \\
\hline $\begin{array}{l}\text { Means } \\
\text { Corrected } t \\
\text { Reduced to }\end{array}$ & ndard & $\begin{array}{r}23.420 \\
+.006 \\
-.068\end{array}$ & 61.2 & $t^{\prime}=59.2$ \\
\hline
\end{tabular}


Observations made at Signal Station, Cheyenne, August 20, 1875.

Observer, A. C. DobBins, U. S. A.

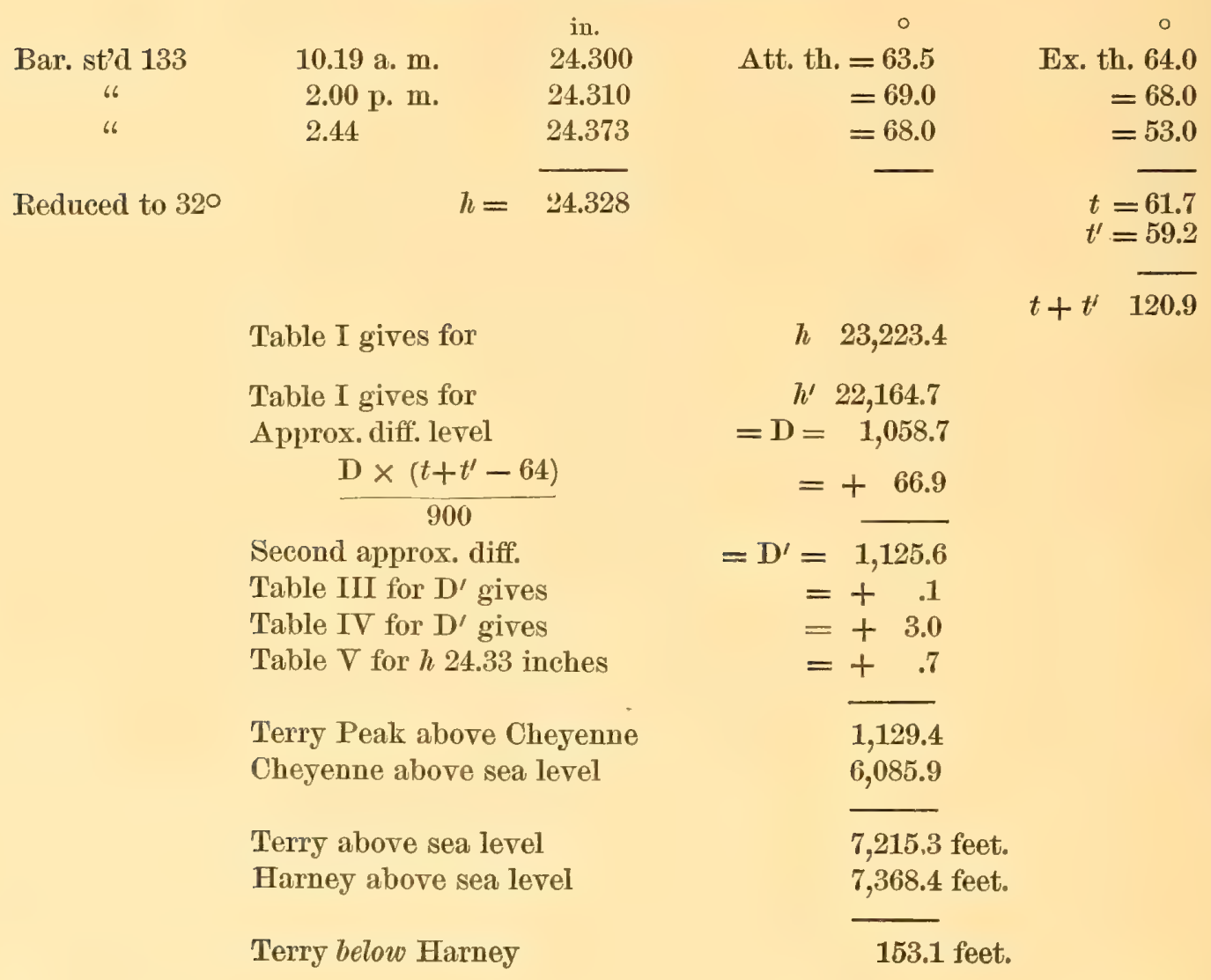


TABLE OF POSITIONS AND ALTITUDES OF CAMPS AND OTHER POINTS.

\begin{tabular}{|c|c|c|c|c|c|c|}
\hline 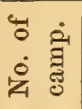 & Date. & Place of observation. & Longitude. & Latitude. & $\begin{array}{l}\text { Magnetic } \\
\text { variation. }\end{array}$ & $\begin{array}{l}\text { Altitude } \\
\text { above } \\
\text { the sea. }\end{array}$ \\
\hline & $\begin{array}{c}1875 . \\
\text { May } 18\end{array}$ & Fagan's Ranch & $\begin{array}{c}0,1 " \\
\ldots . . . . .\end{array}$ & $\begin{array}{ccc}\circ & 1 & 11 \\
41 & 27 & 28\end{array}$ & 01 & $\begin{array}{l}\text { Feet. } \\
6,240\end{array}$ \\
\hline & May 19 & Oren's Ranch..... & ............. & $4159 \quad 13$ & .... & 5,570 \\
\hline & May 23 & Fort Laramie, flag-staff . .... . & $10432 \quad 1$ & 421230 & $1521 \mathrm{E}$. & 4,590 \\
\hline 1 & May 24 & Platte River........... & & c...... & $1524 \mathrm{E}$. & 4,570 \\
\hline 2 & May 25 & Rawhide Creek.. & $\cdots$ & $4224 \quad 4$ & $1524 \mathrm{E}$. & 4,380 \\
\hline 3 & May 26 & ...... do ............ & & ........ & - $\ldots . . . .$. & 5,000 \\
\hline 4 & May 27 & Niobrara River ............ & $\ldots \ldots \ldots$ & $4246 \quad 0$ & $1520 \mathrm{E}$. & 5,080 \\
\hline 5 & May 28 & Old Woman Fork....... & & 425615 & $1530 \mathrm{E}$. & 5,160 \\
\hline 6 & May 29 & ...... do ............... & $\cdots$ & $43 \quad 555$ & $1533 \mathrm{E}$. & 4,785 \\
\hline 7 & May 30 & South Fork Cheyenne ....... & $\ldots$ & 431937 & .......... & 4,600 \\
\hline 8 & May 31 & 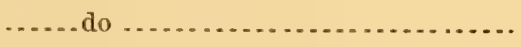 & & $43265 \%$ & $1525 \mathrm{E}$. & 4,400 \\
\hline 9 & June 1 & Beaver Creek................. & .. & 433258 & $1533 \mathrm{E}$. & 4,250 \\
\hline 10 & June 2 & ..... do ............... & $\cdots$ & 433258 & $\cdots$ & 4,300 \\
\hline 11 & June 3 & Camp Jenney ....................... & 1035948 & 434846 & $1516 \mathrm{E}$. & 4,700 \\
\hline 12 & June 9 & East Fork Beaver (near its head).... & ........... & ......... & …..... & 6,000 \\
\hline 13 & June 10 & Floral Valley.............. & $10355 \quad 5$ & 44811 & $1533 \mathrm{E}$. & 6,600 \\
\hline 14 & June 11 & Castle Creek ........... & (.......... & 44210 & $\cdots$ & 6,400 \\
\hline 15 & June 12 & Southwest Fork Castle Creek .... & 1033959 & $\begin{array}{lll}44 & 1 & 2\end{array}$ & $1550 \mathrm{E}$ & 6,133 \\
\hline 16 & June 20 & Camp Harne & 1032051 & $4346 \quad 9$ & $1540 \mathrm{E}$. & 5,373 \\
\hline 17 & June 25 & Amphibious Creek.......... & (.... & 433914 & & 5,243 \\
\hline 18 & June 26 & ...... do & ... & $43 \quad 36 \quad 3$ & & 4,626 \\
\hline 19 & June 27 & Amphibious Creek (Buffalo Gap) ..... . & ............ & $\begin{array}{lll}43 & 31 & 2\end{array}$ & $1530 \mathrm{E}$. & 3,634 \\
\hline 20 & June $2 s$ & Amphibious Creek and Cheyenne.... & 1025946 & 432519 & & 3. 127 \\
\hline 21 & June 29 & Burntwood Creek......... & 103651 & $4340 \quad 7$ & & 4350 \\
\hline 22 & July 1 & French Creek ............ & 10398 & 434246 & & 4,840 \\
\hline 23 & July 5 & Pleasant Valley .................. & ........... & 434035 & & 5,152 \\
\hline 24 & July $\quad 6$ & Red Cañon Creek............. & 103348 & 43338 & $1545 \mathrm{E}$. & 4,532 \\
\hline 25 & July 7 & ...... do .................... & 1033424 & $4327 \quad 3$ & ... & 3,850 \\
\hline 26 & July 8 & Red Cañon and Cheyeme........ & & 431820 & $1526 \mathrm{E}$. & 3,360 \\
\hline 27 & July 10 & Sweetwater Creek............... & & 432130 & & 3,800 \\
\hline 28 & July 12 & Cascade Creek, headwaters of. & & 432656 & & 3,900 \\
\hline 28 & July 13 & Falls of Cascade Creek.... & & 432352 & & 3,230 \\
\hline 28 & July 13 & Junction with Cheyenne.......... & & $4323 \quad 2$ & & 3,200 \\
\hline 29 & July 15 & 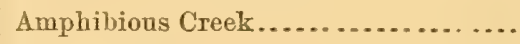 & & - . . & & 4,900 \\
\hline 30 & July 17 & French Creek .......... & & 434319 & & 4,700 \\
\hline 31 & July 18 & ..... do .................. & & 434313 & & 4,300 \\
\hline 32 & July 19 & ...... do ......................... & & $\begin{array}{lll}43 & 41 & 9\end{array}$ & & 4,000 \\
\hline 33 & July 20 & Wi-wi Creek .............. & & 434652 & & 5,200 \\
\hline 34 & July 23 & North Fork French Creek. & & & & 6,150 \\
\hline
\end{tabular}


TABLE OF POSITIONS AND ALTITUDES OF CAMPS AND OTHER POINTS-Continued.

\begin{tabular}{|c|c|c|c|c|c|c|}
\hline 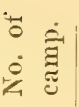 & Date. & Place of observation. & Longitude. & Latitude. & $\begin{array}{l}\text { Magnetic } \\
\text { variation. }\end{array}$ & $\begin{array}{c}\text { Altitude } \\
\text { above } \\
\text { the sea. }\end{array}$ \\
\hline & 1875. & & 0,11 & & & Feet. \\
\hline 35 & July 24 & Harney Peak........................ & 1032025 & 435157 & $1516 \mathrm{E}$. & $7,363.9$ \\
\hline 36 & July $\quad 30$ & Spring Creek... & 1031637 & 435824 & $\ldots \ldots . . . . .$. & 4,700 \\
\hline 37 & Aug. 1 & Newton Fork.......... & 1032346 & $4357 \quad 4$ & $1539 \mathrm{E}$. & 5,050 \\
\hline 38 & $\operatorname{Aug} \cdot 3$ & Southwest Fork Castle Creek ........ & 103308 & $\begin{array}{lll}44 & 4 & 0\end{array}$ & & 5,000 \\
\hline 39 & Ang. 6 & Spring Creek........................ & ............ & 435944 & - & $\ldots \ldots$ \\
\hline 40 & Aug. 8 & Camp Crook ........................ & 1031823 & $44 \quad 342$ & - & 4,650 \\
\hline 41 & Aug. 10 & Rapid Creek....................... & ........ & $44 \quad 539$ & …. & 4,550 \\
\hline 42 & Aug. 11 & ...... do & (............ & $44 \quad 3 \quad 37$ & ...... & 3,750 \\
\hline 43 & Aug. 1:3 & Camelko Creek....................... & 1031240 & 44716 & - - & 4,475 \\
\hline 44 & Aug. 14 & Box Elder. . . . . . . . . . . . & Noon obs .. & 4486 & - & 4,775 \\
\hline 45 & Aug. 15 & Gum Creek . . . . . . . . . . . . . . . . & $\ldots$ do $\ldots . .$. & 441134 & : & 4,925 \\
\hline 46 & Aug. 16 & Forks of Box Elder................... & $\ldots$ do $\ldots .$. & 441326 & & 5,225 \\
\hline 47 & Aug. 16 & Box Elder. . . . . . . . . . . . . . . . . . . & ........... & 441344 & & 5,400 \\
\hline 48 & Aug. 17 & 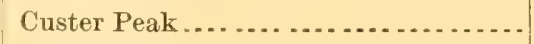 & 1033311 & 441447 & ... & 6,967 \\
\hline 49 & Aug. 18 & 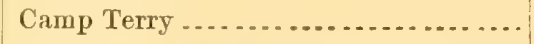 & & 441752 & & 5,550 \\
\hline 50 & Aug. 22 & Southwest Branch Elk Creek. ......... & $\ldots \ldots \ldots$ & 441746 & & 5,100 \\
\hline 51 & Aug. 24 & 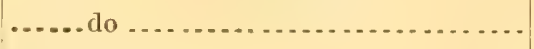 & Noon obs.. & 44184 & - & 4,045 \\
\hline 52 & Aug. 24 & Rear Butte Creek. . . . . . . . . . . . . . . & $\ldots$.... do .... & 442438 & - & 3,750 \\
\hline $5: 3$ & Aug. 26 & Bear Butte...... & 1031411 & 442859 & & 4,573 \\
\hline 54 & Aug. 28 & Bear Butte Creek.................... & $\cdots$ & 442727 & $\ldots$ & 4,000 \\
\hline 55 & Aug. 29 & Spearfish Creek .................... & 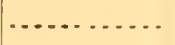 & 442914 & & 4,450 \\
\hline 56 & Aug: 31 & Redwater Creek ........... & & 443213 & & 3,900 \\
\hline $5 \%$ & Sept. 1 & Sun Dance Camp .................. & $\ldots \ldots \ldots$ & 442446 & ... & 4,900 \\
\hline 57 & Sept. 1 & Sun Dance Hill (western)........... & Noon obs . . & $4423: 30$ & & 6,400 \\
\hline 58 & Sept. 2 & Camp Bradley ........................ & (1....... & 441425 & & 5,200 \\
\hline 58 & Sept. 3 & Summit of Inyan Kara............... & Noon obs ... & 441229 & - . - . - n & 6,563 \\
\hline 59 & Sept. 4 & 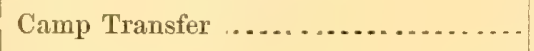 & (............. & 44711 & $1545 \mathrm{E}$. & 6,100 \\
\hline 59 & Sept. 6 & 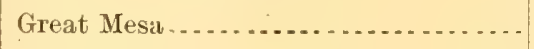 & Noon obs .. & $44 \quad 7 \quad 47$ & & 7,140 \\
\hline 60 & Sept. 7 & Crook Tower . . . . . . . . . . . . . . . . & $\ldots$ do $\ldots$ & 44943 & & 7,323 \\
\hline 60 & Sept. 7 & Floral Valley ..................... & (............ & 441137 & . & 6,050 \\
\hline 61 & Sept. 8 & Redwater .... & Noon obs.. & 441834 & & 5,475 \\
\hline 62 & Sept. 8 & 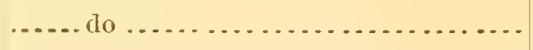 & $\cdots$ & $\cdots \cdots$ & & 4,140 \\
\hline $6 \ddot{3}$ & Sept. 9 & Southwest Branch Redwater...... & $\ldots \ldots \ldots$ & $\ldots \ldots . . .$. & & 4,900 \\
\hline 64 & Sept. 11 & South Fork Belle Fourche River ...... & Noon obs.. & 442547 & & 5,600 \\
\hline 64 & Sept. 11 & 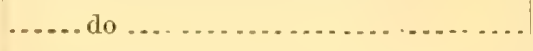 & .......... & $4428 \quad 9$ & & 4,600 \\
\hline 65 & Sept. 13 & 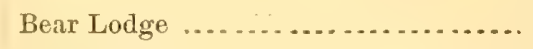 & 1042900 & 443541 & & 5,263 \\
\hline 66 & Sept. 14 & Belle Fourche ..................... & 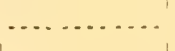 & $44 \quad 45 \quad 1$ & & 3,870 \\
\hline 67 & Sept. 15 & Belle Fourche, great bend of ......... & $\cdot$ & 445656 & - & 3,560 \\
\hline 68 & Sept. 16 & Belle Fourche ..................... & & 444746 & & 3,300 \\
\hline 69 & Sept. 17 & 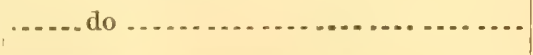 & - . . . . & 444217 & (1...... & $\cdots$ \\
\hline
\end{tabular}


ASTRONOMY AND BAROMETRIC HYPSOMETRY.

TABLE OF POSITIONS AND ALTITUDES OF CAMPS AND OTHER POINTS-Continued.

\begin{tabular}{|c|c|c|c|c|c|c|}
\hline 峁 & Date. & Place of observation. & Longitude. & Latitude. & $\begin{array}{l}\text { Maguetic } \\
\text { variation. }\end{array}$ & $\begin{array}{c}\text { Altitude } \\
\text { above } \\
\text { the sea. }\end{array}$ \\
\hline & 1875. & & 0,11 & 0,11 & 01 & Feet. \\
\hline 71 & Sept. 19 & Belle Fourche . . . . . . . . . . . . . . . . & $\ldots \ldots \ldots \ldots$ & 443740 & $\ldots \ldots \ldots$ & 2,970 \\
\hline 72 & Sept. 20 & 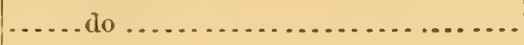 & ............ & 442920 & ....... & 2,870 \\
\hline 73 & Sept. 24 & 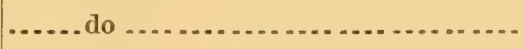 & - . . . . . . & 442136 & $\ldots$ & 2,480 \\
\hline 74 & Sept. 25 & ..... do & (........... & 442110 & .. & (....... \\
\hline 75 & Sept. 26 & 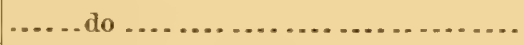 & ............ & 442024 & $\ldots$ & ....... \\
\hline 76 & Sept. 27 & $\begin{array}{l}\text { Junction of North and South Forks of } \\
\text { Cheyenne. }\end{array}$ & $1023119^{*}$ & 442653 & - & 2,470 \\
\hline 77 & Sept. 28 & South Fork of Cheyenne............. & ........ & 441451 & ..... & 2,500 \\
\hline 78 & Sept. 29 & 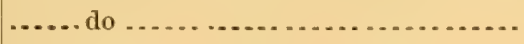 & & 44328 & & 2,630 \\
\hline 79 & Sept. 30 & 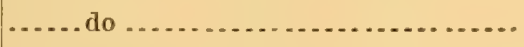 & & 435432 & -.... & 2,680 \\
\hline 80 & Oct. 4 & 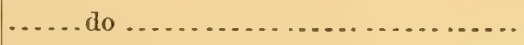 & & $43: 3622$ & $\ldots$ & ........ \\
\hline 81 & Oct. 7 & $\begin{array}{l}\text { Spotted Tail Agency, 1,200 feet south- } \\
\text { east of flag-staff. }\end{array}$ & $\cdots$ & 425045 & .. & 3,760 \\
\hline 82 & Oet. 9 & $\begin{array}{l}\text { Red Cloud Agency, 2,000 feet south of } \\
\text { flag-staff. }\end{array}$ & $\cdots$ & 423959 & $\ldots$ & 4,290 \\
\hline 83 & Oct. 10 & White River...................... & $\ldots \ldots \ldots$ & 42382 & $\ldots \ldots \ldots$ & 4,600 \\
\hline 84 & Oct. 11 & Niobrara River .................. & ........... & 423449 & ......... & 4,970 \\
\hline
\end{tabular}

* Not reliable.

MISCELLANEOUS.

\begin{tabular}{|c|c|c|c|c|}
\hline & Longitudo. & Latitude. & $\begin{array}{l}\text { Magneti, } \\
\text { variation. }\end{array}$ & $\begin{array}{c}\text { Altitude } \\
\text { above } \\
\text { the sea. }\end{array}$ \\
\hline & 0,11 & 0,11 & 0, & Feet. \\
\hline 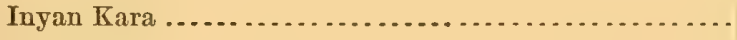 & 1041557 & 441232 & (......... & 6,870 \\
\hline 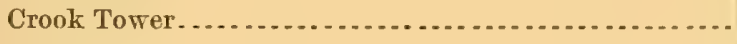 & 1034350 & $44 \quad 932$ & .......... & 7,325 \\
\hline Custer Peak. .......... & 1033311 & 441444 & ........... & 6,932 \\
\hline Terry Peak . . . . . . & (............. & 441959 & .... & 7,215 \\
\hline 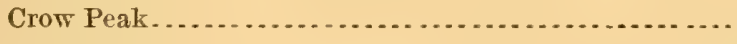 & ............ & 442912 & $\mid \ldots \ldots$ & ...... \\
\hline 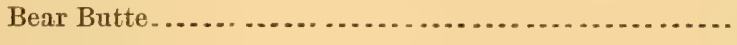 & 1031420 & 442859 & & \\
\hline 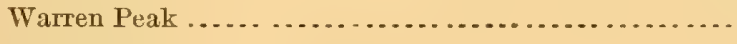 & ............ & 442912 & $\ldots$. & \\
\hline Sun Dance Hill (western base) ..................... & $\ldots \ldots$ & $4423 \quad 39$ & $\cdots$ & \\
\hline Harney Peak. . . . . . . . . . . . . . . . . . . . . & -.... & & -.... & 7,368 \\
\hline
\end{tabular}




\section{S E C T I O N I V. \\ SU P P L E M E N T.}

In the summer of 1877 I was an assistant of R. J. Reeves, esq., United States Astronomer and Surveyor, who had a contract for running so much of the boundary line between Wyoming and Dakota as lies between the parallels of $43^{\circ}-45^{\circ}$ of north latitude. The longitude of our starting-point had been determined in 1874, and depended upon the longitude of Sidney, Nebr., which had been established by telegraph. I think that our starting-point can, therefore, be considered as very nearly correct. Our line ran through the western portion of the Black Hills, and by estimate one and one-quarter miles east of Camp Jenney, the longitude of which, as given by my chronometers, is $103^{\circ} 59^{\prime} 48^{\prime \prime} .0$ west of Greenwich. Assuming the correct longitude of our line to be $104^{\circ} 03^{\prime} 05^{\prime \prime} .85$, the correct longitude of Camp Jenney is $104^{\circ} 04^{\prime} 35^{\prime \prime}$. This will make the longitude of Camp Jenney, as given by my chronometers, $4^{\prime} 47^{\prime \prime}$ too far east; and as the longitudes of all other places given in the table depend upon this determination they will be in error to this amount. The meridians on our large map of the Black Hills are made to conform to our boundary line of 1877 .

Early in 1877 the telegraph line was extended to Deadwood, in the northeast portion of the Black Hills, and later in the season Capt. W. S. Stanton, Corps of Engineers, determined, by telegraphic signals from Detroit, the longitudes of a great many places not only in the Hills, but of places south nearly to Cheyenne.

I quite agree with Capt. W. A. Jones, Corps of Engineers,* that the use of box or marine chronometers for determining longitudes in a mountainous country is most unsatisfactory. It makes no difference how carefully they may be handled their rates cannot be depended upon.

One and perhaps the principal cause of the variations in the rates of chronometers is the rapid changes in the height of the barometer in ascend-

* Report of a Military Reconnoisance to Northwestern Wyoming in 1873. Washington, 1874. 
ing and descending high mountains. Every large change in the height of the mercury will have a corresponding effect on the rate of the chronometer.

From some experiments madè by Prof. W. C. Bond at the Cambridge Observatory in 1856 , it was found that when at a mean pressure of $29^{\prime} .90$ a chronometer which had a daily gaining rate of one second, when put under the glass receiver of an air-pump and the pressure brought down to $20^{\prime} .00$, the daily rate increased to nine seconds.

It is yet to be determined whether or not the decrease in the force of gravity from the sea level to the very high altitudes to which chronometers have been carried may not have some sensible effect on the delicate moving portions of a chronometer. 



\section{N DEX.}

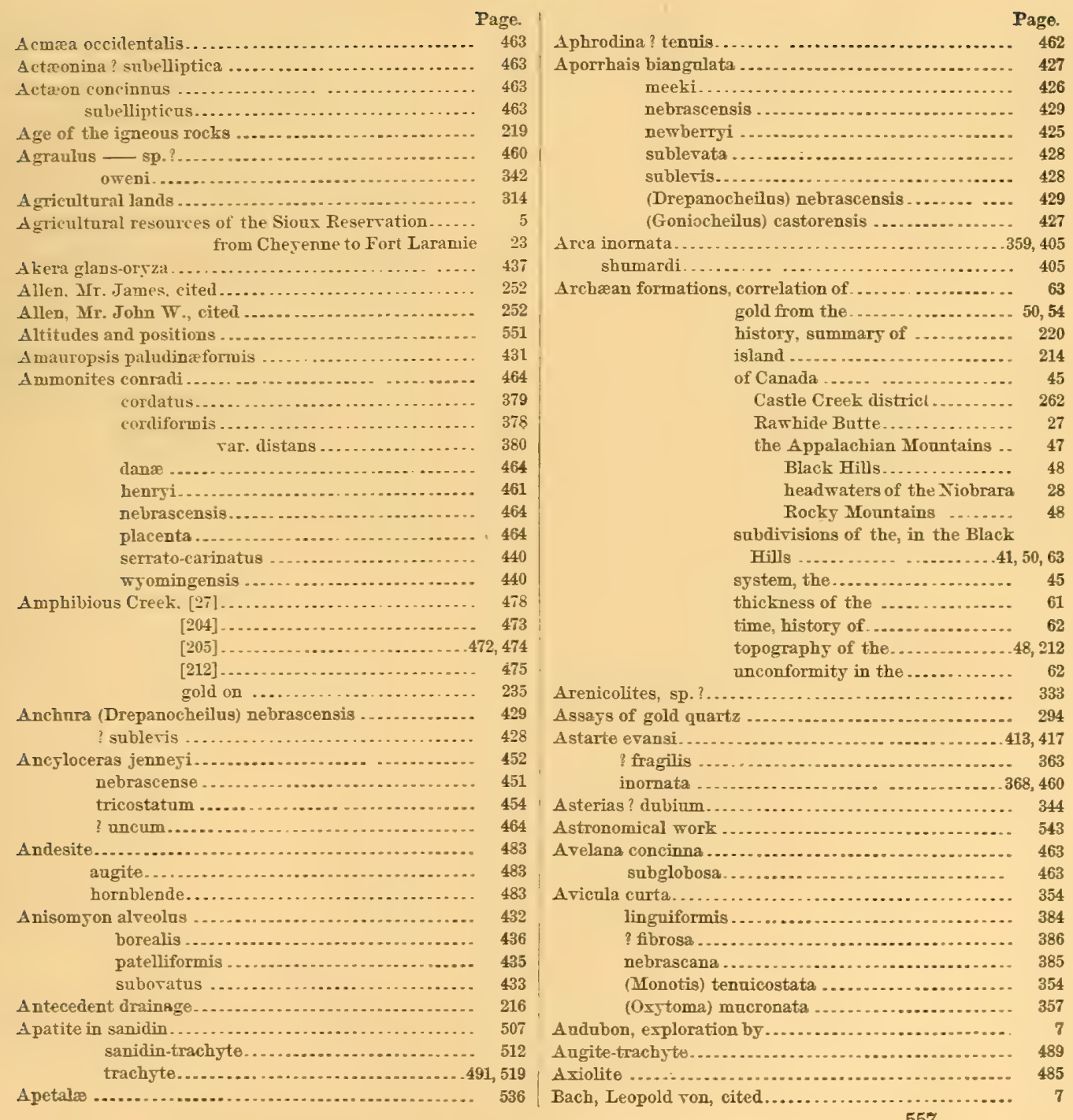




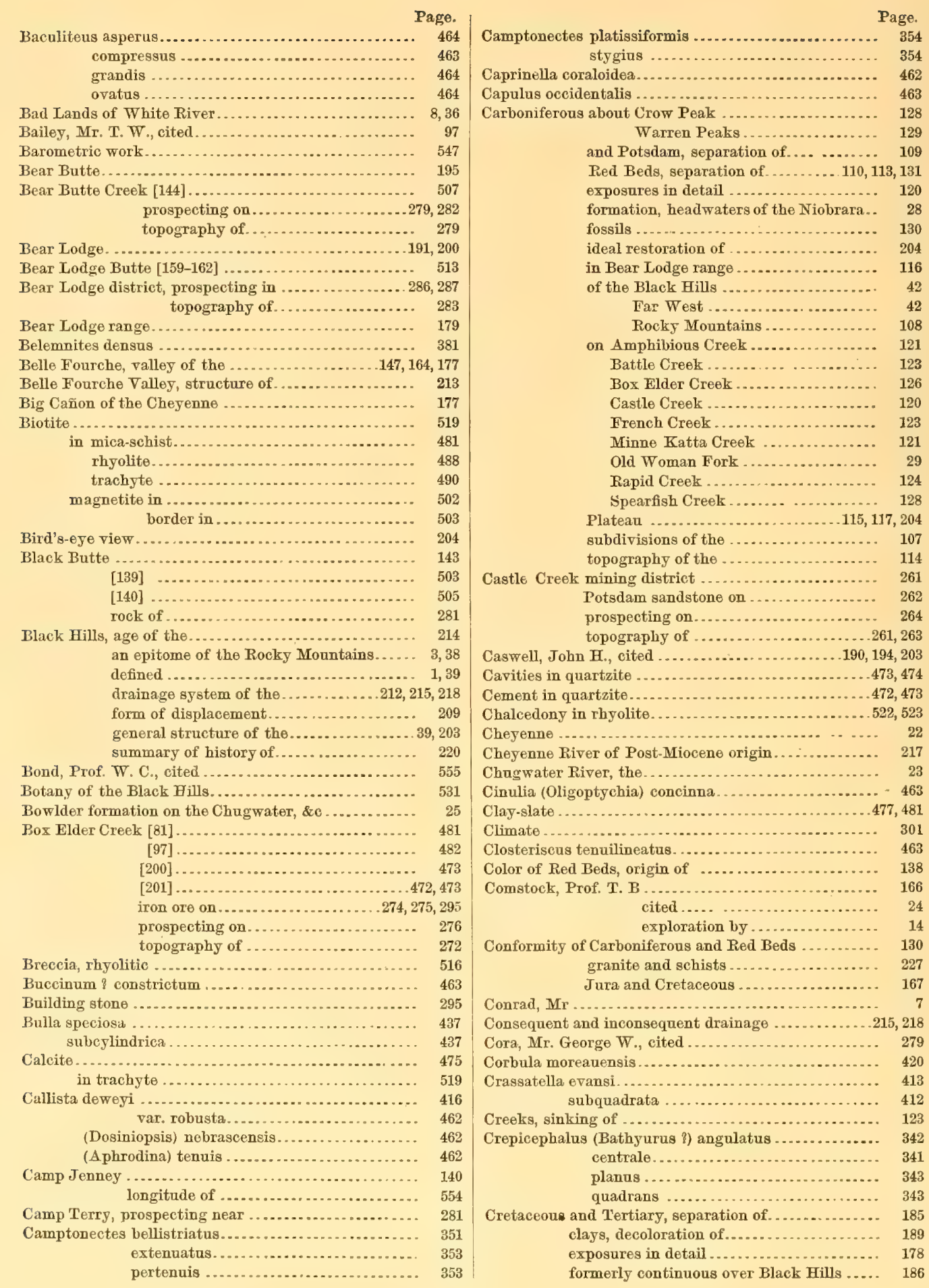




\begin{tabular}{|c|c|}
\hline Page. & Page. \\
\hline Grotaceous fossils. & Dodge, Col. R. I., on timbe \\
\hline in Belle Fourche Valle & Dosinia Jurassica ...... \\
\hline of the Black Hills.. & missouriana ?....... \\
\hline Far West... & Dosiniopsis deweyi. \\
\hline on Beaver Creek .. & nebrascensis... \\
\hline French Creek .... & Double inclusion of magnetite and \\
\hline Minne Katta Creel & tite $\ldots \ldots \ldots \ldots \ldots$ \\
\hline Old Woman Fork & Drainage of the Black Hills...... \\
\hline Rapid Creek .... & system of the Black Fills. \\
\hline Red Cañon Croek.. & Drepanocheilus nebrascensis...... \\
\hline South Fork of the C & Ehrenberg, Dr., cited............. \\
\hline Plateau & Elk Creek, topography of. ... \\
\hline sectic & Emmons, Professor \\
\hline$\ldots 176$ & Endocostea .............. \\
\hline upper beds of the & alveata ............. \\
\hline row Peak ........... & impressa ............... \\
\hline$[141,142] .$. & suleata............... \\
\hline Cruziana ....................... & typica................. \\
\hline Cryptogamia............... & Eozoon canadenso................. \\
\hline Cryptorhytis fusiformis......... & Epidote ................ \\
\hline Crystalline quartz in mic & Erosion, epochs of ....... \\
\hline .... 472 & Eruptive (see Igneous) ................ \\
\hline quartzite............ & Eumicrotis curta......................... \\
\hline Cucullæa fibrosa. & orbiculata ............ \\
\hline inornata & Evans, Dr. John, exploration by .... \\
\hline shumardi ........ & Examination of thin sections..................472, 477,494 \\
\hline Culbertson, Dr. T. A., exploration by .................. & Fanny Peak........ \\
\hline Custer, General G. A., cited ......................... 16 & Farming lands ..... \\
\hline exploration by & Fasciolaria (Cryptorhytis) contorta ............. \\
\hline Custer Gulch & fusiformis \\
\hline Custer Peak ...... & (Piestocheilus) culbertsoni. . \\
\hline .. 501 & Feldspar from granites ............................... 70,525 \\
\hline .. 503 & microlites. \\
\hline Custer Peak, rock of ... & porphyry.. \\
\hline Cyanite in mice & Felsite-porphyry.... \\
\hline 472 & (n.................... \\
\hline Cyclina ? circularis............. & Flora of Black Hills, Jenney on ........................ $315,32_{0}$ \\
\hline Cymella Meeki....... & Fluid inclusions in rhyolite ........... \\
\hline Csprina humilis ...... & 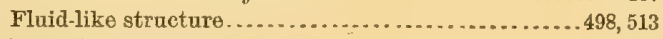 \\
\hline Cypricardia... & Fosar ? nebracensis ................. \\
\hline Cytherea deweyi ...... & Fossil plants from $\Delta$ biquiu....... \\
\hline missouriana. & Middle Park ..... \\
\hline tenuis. & near Moqui villages.... \\
\hline acite .......... & Fossil wood, ore bearing ........................... 149 \\
\hline Dakota Indians ............. & Fossils, Carboniferous .............................110, 130 \\
\hline Dakota sandstone, ideal restoration of................ & Cretaceous ...............................185, 383 \\
\hline phy of... & Jurassic........................162, 165, 166, 168, 344 \\
\hline Dawson, Mr. G. M., cited........ & of the Potsdam ............................ 87,107 \\
\hline Dr.J.W., cited................................. & Tertiary. \\
\hline Deadwood Creek...................................... $\quad 280$ & (1) \\
\hline prospecting on.. & why not found in Red Beds. \\
\hline Decoloration of dark clays ........................... 189 & 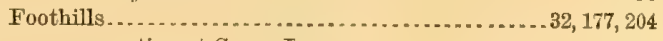 \\
\hline Deer Mountains. . & section at Camp Jenney.................... \\
\hline [125̄] & 289 \\
\hline Dentalum fr & prospecting in .............. \\
\hline gracil & Fort Union group on South Fork of Cheyenne ........ \\
\hline (n) & French Creek [40]... \\
\hline missouriana ................................... & {$[208] \ldots$} \\
\hline nebrascensis .. & 475 \\
\hline ? tenuis ........................................ & described .......... \\
\hline Devonian formation, absence of ..................... & district, topography of \\
\hline Dews & prospecting in. \\
\hline Diplodonta sulundata............................ 411 & mining district ... \\
\hline Displacement pr sducing the Black Hills, form of ... 204,209 & mouth of $[208] \ldots$. \\
\hline . & {$[211]$} \\
\hline 137 & 315 \\
\hline .. 303 & \\
\hline
\end{tabular}




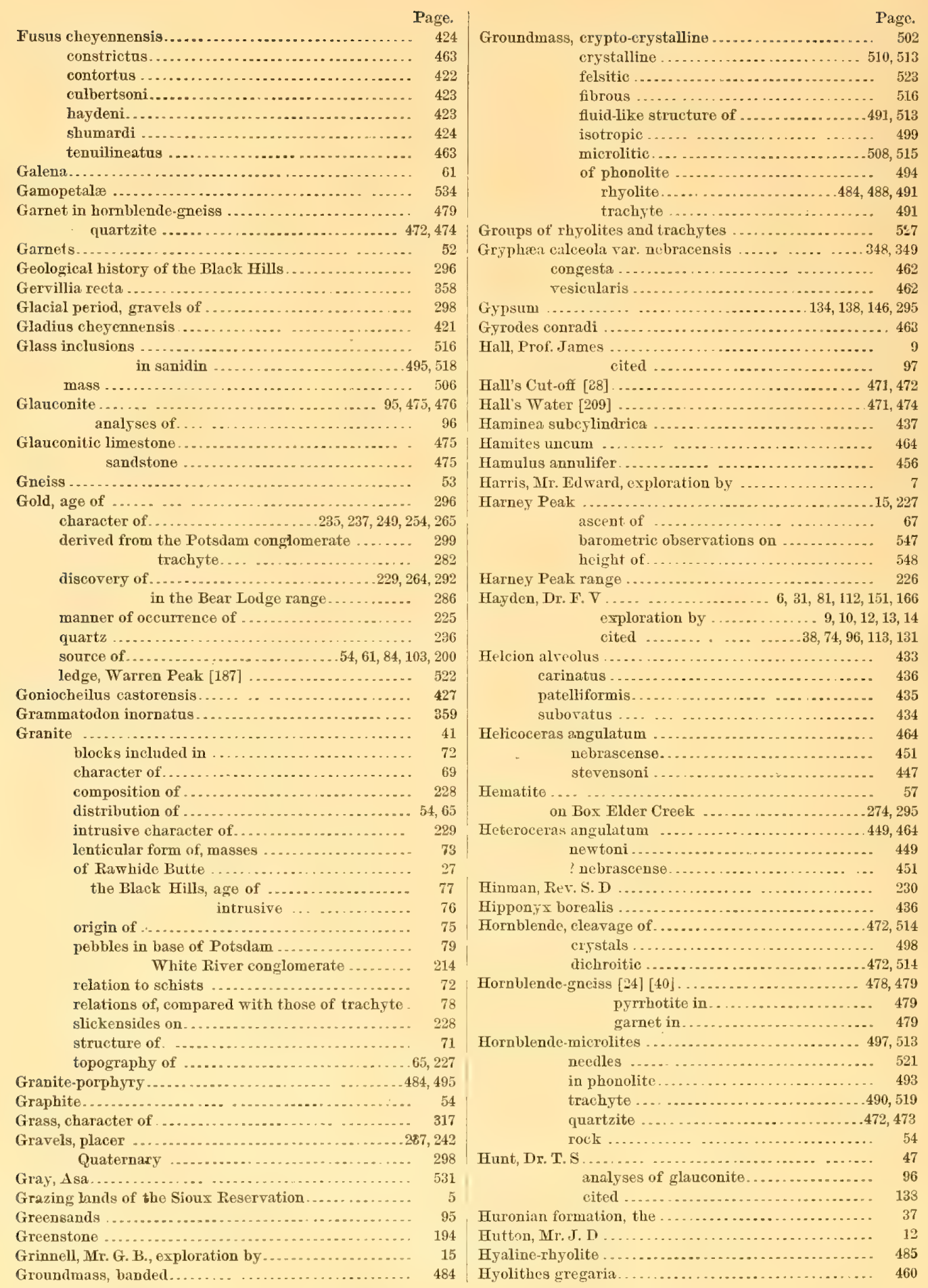


Icthy'osarcolitlus coraioida

Ideal restoration of the Black Hills uplift

Igneous displacements, relation to main displacements of tho Black Hills ......................

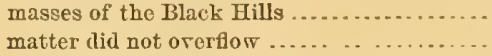
peaks..... and the Red Bed limestone .... ........133, 191 relation of, to Potsdam..................... 103, 200 rocks.............................. 190, 281 age of the...................... 219 Inclusions in sanidin.......................... 489

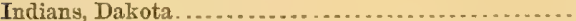

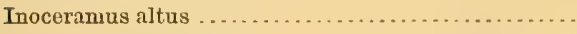
alveatus $\ldots \ldots \ldots$
balchii...$\ldots \ldots$ confertim-annulatas .................... 396

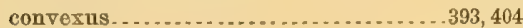
cripsii ............................... 398, 404 var. barabini ................... 398 var. suicatus .................... 404 cuneatus .......................... 398 ellioti .............................. 392 fragilis . . . . . . . . . . . . . . . . . 390

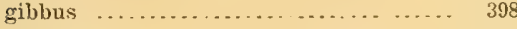
impressus .......................... 402 mortoni ............................ 390 nel rascensis . . . ...................... 393 perplexus ........................ 302 problematicus ?....................... 389 simpsoni ........................ 395

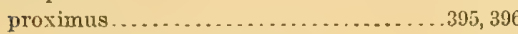
rar. subcircularis ............. 396

sagensis .......................... 393 var. nebrascensis .............. 393

sulcatus ....................... . . 403

sublevis. . . . . ... . . . . . . . . . . . . . 393

tenuilineatus ...........................

renuxemi ...................... 390

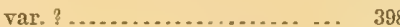

Insects, noxious. . . . . . . ...................... 32

Interlaminated veins ............................. 228

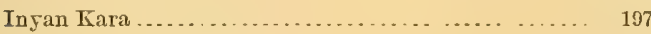

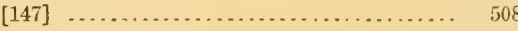

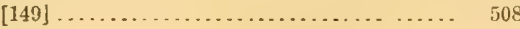

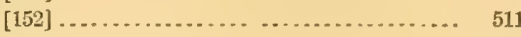

northeast of $[150] \ldots \ldots \ldots \ldots \ldots \ldots \ldots .510$

north peak of $[151] \ldots \ldots \ldots \ldots \ldots \ldots \ldots .510$

$[160] . \ldots \ldots \ldots+\ldots \ldots \ldots .514$

rrest of [157]

Iron Ledge, Box Elder Creek [85] . . . . . . . . . . . . . . . 481

Iron ore .................................. 57,60

on Beaver Creek .......................... 295

Box Elder Creek .... . . . . . . . . . . . . . . 274

Isotropic beharior of garnets . ................422, 474

mineral .............................. 517

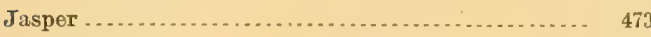

Jasper, Hill [92] .................................. 473

Jenney, Mr. Walter P ........................16], 163 cited.......................... 188 on climate mineral resources.......... 225

Joo Peak................................ 159

Jones, Prof. P. B., cited ........................... 86
Page.

Jones, Capt. W. A., exploration bj ........ .......14, 554

Jura about Bear Butte ....................... 196

and Red Beds, separation of ................ 131, 153

discovery in the Far West.................... 151

in Bello Fourcho Valley ..................... 153, 164

of' Europe . . . . . . . . . . . . . . . . . . . . . . . 151, 167

tho Bl ck Hills .............................. 43, 152

the Northwest .......................... 152

on Amphibious Creek ....................... 158

Box Elder Creek ...................... 159

Red Cañon Creek............................ 156

Rei Water Crekk ...................... 160

rariation in thickness of the ...............152, 166

Jurassic fossils. . . . . . . . . . . . . . . . . . . . 162, 165, 166, 168, 344

Kensler, Mr. Touissant.......................... 292

King, Mr. Clarence ........................... 150

cited .......................... 75

on tho Archæan ............... 48

Lands, agricultural............................... 314 grazing ................................... 317

Latitudes ....................................... 546

Laurentian formation ........................... 46

Leda bísulcata ............................... 407 evansi ........... 409

Leidy, Dr. Joseph ............................ . . 9, 13, 37, 188 Leiopistha (Cymella) meeki ................... 418 Lesquereux, Prof. Leo ............................ 112

Lewis and Clarke, exploration by ............... 6

Limestone, glauconitic ........................... 475

Limonite on Box Elder Creek ....................... 275

Lingula antiqua ......................... 335 brevirostra ........................... 340

pinnaformis .............................. 335

(?) polita .......................... 339

Lingulepis cuncolis ............................... 336

dakotensis .......................... 336 pinnaformis ........................ $329,335,336,337$ perattenuata ....................... 337 prima ................................. 460

Lioplacolus vetnrnus ............................. 461

Little Missonri Buttes ............................... 202

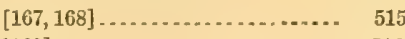

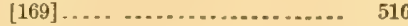

Logan, Sir William.....

Loganellus centralis. .............................. 341

Longitudes ............................... 54

Loss in acid. ........................................ 486

Lower Rapid Creek [71] ....... . . . . . . . . . . ............. 480

Ladlow, Col. William, exploration by ............... 15

Lucina occidentalis $\quad$ on climate .................... 307

var. ventricosa ................. 410

(Diplodonta?) subundata .................. 411

subundata .............................. 411

ventricosa .............................. 410

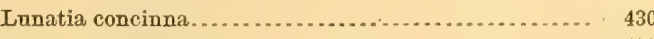
moreauensis -

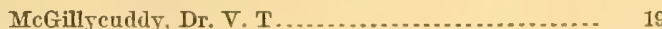

Magnetic variations .......................... 547

Magnetite border in biotite........................... 503

in biotite ......................... 502 quartzite ........................ 472

rhyolite............................. 488

submetallic luster of................ 480

Mallory, Mr. Thomas H., rited...................279, 282

Mammoth ledge................................ 562 $36 \mathrm{~B} \mathrm{H}$ 


\begin{tabular}{|c|c|c|}
\hline & Page. \\
\hline Lammoth ledge, prospecting near................... & 242 & Natica paludinæformis ................... \\
\hline 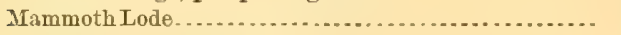 & 58 & Vatrolite . . . . . . . . . . . . \\
\hline Margarita nebrascensis. . . . . ..................... & 432 & Nautilas dekayi......... \\
\hline Margaritella flexistriata ............................ & 463 & var. montanænsis ..... . \\
\hline Marsh, Prof. 0. C ....................................... & 188 & Neæra longirostris.................. \\
\hline Marvine, Mr. A. R., cited ......................... & 150 & moreanensis? ... \\
\hline Maximilian, Prince, exploration by ................. & 6 & ventricosa $\ldots . . . \ldots \ldots \ldots . . . .$. \\
\hline Meek, Prof. F. B ................. &, 188 & Nephelite in phonolite................. \\
\hline exploration by .................... & 9 & Newberry, Dr. C. G............................. 19 \\
\hline Ieek and Hayden's Cretaceous section. .............. & 171 & Dr.J.S., .............................. \\
\hline 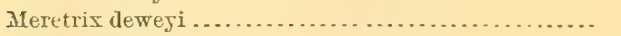 & 416 & cited. . . . . . . . . . . \\
\hline & 462 & Nicollet, J. C., exploration by.......... . \\
\hline Ieridian distances ..... . . . . . . . . . . . . . . . . . . . . . . . & 544 & Nosite in phonolite................................. 493,504 \\
\hline Ietamorphism of Potsdam sandstone . . . . . . . . . 280 & 285 & Nucula evansi . . . . . \\
\hline sedimentary rocks by contact with & & \\
\hline igneous......................... & 219 & 407 \\
\hline ( & 70 & 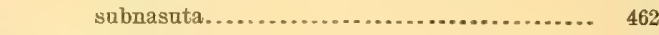 \\
\hline quartzite $\ldots \ldots \ldots \ldots \ldots \ldots \ldots .471$ & -474 & sa \\
\hline Mica-schist $\ldots \ldots \ldots \ldots \ldots \ldots .478,480$ &, 481 & cata. $.6 \ldots \ldots \ldots \ldots \ldots \ldots \ldots \ldots$ \\
\hline 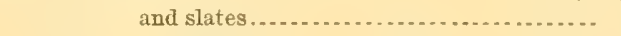 & 476 & lis . . . . . . . . . . . . . . . \\
\hline ( & 477 & ilatera . . . . . . . . . . . . . . . . . \\
\hline 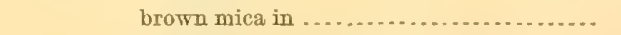 & 477 & Obella polita . . . . \\
\hline 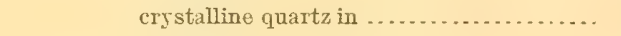 & 477 & Than \\
\hline$\ldots \ldots \ldots \ldots \ldots \ldots \ldots \ldots \ldots \ldots$ & 478 & Obolus a] \\
\hline 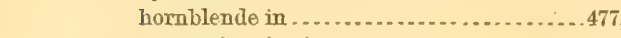 &, 478 & es......... \\
\hline ca in ......................... & 481 & 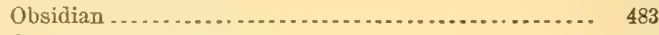 \\
\hline 然 & 477 & Odontobasis c \\
\hline (n. & 478 & osa ................ \\
\hline white mica in . . . . . . . . . . . . . . . . . &, 480 & 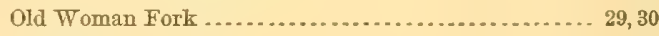 \\
\hline . & 481 & Oligoptychia concinna ....................... \\
\hline - & 477 & ite \\
\hline Imass of ..................... & 479 & 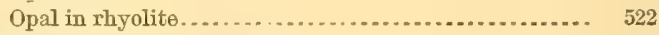 \\
\hline (n) & 473 & 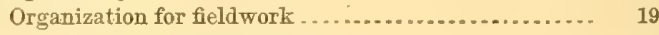 \\
\hline 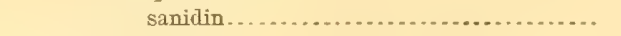 & 507 & 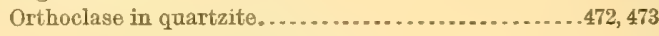 \\
\hline phy & 471 & on of banded. . . . . . \\
\hline 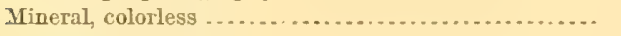 & 514 & 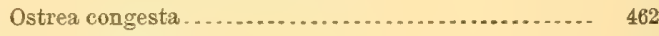 \\
\hline Minerals in quartzite . . . . . . . . . . . . . . . . . . . . . . & 472 & lemani .......................... \\
\hline Mineral Resources . . . . . . . . . . . . . . &, 225 & 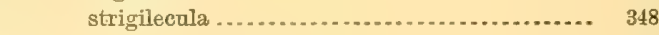 \\
\hline Report on the $\ldots \ldots \ldots \ldots \ldots \ldots$ & 4,21 & Owen, Dr. D. Dale \\
\hline Iining district, Castle Creek. ....................... & 261 & cited........................ \\
\hline French Creek........................ & 226 & Oxytoma mucronata . . . . . . . . \\
\hline Spring Creek . . . . . . . . . . . . . . . & 238 & 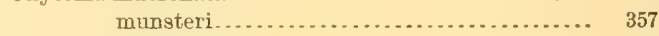 \\
\hline 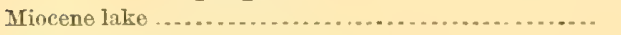 & 219 & cana \\
\hline ( & 61 & si $\ldots \ldots \ldots \ldots \ldots \ldots \ldots \ldots \ldots \ldots \ldots$ \\
\hline ploration of . . . . . . . . . . . . . . . . & 5 & Palæochorda prima . . . . . . . . . \\
\hline Modiola furmosa. . . . . . . . . . . . . & 361 & Palæophycus occidentalis ..................101, 104, 200, 332 \\
\hline Monoclinal fiexures, duplication of ............119, 139, & 142 & 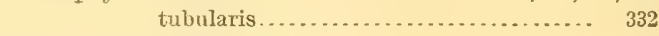 \\
\hline$\ldots \ldots \ldots \ldots \ldots \ldots \ldots \ldots \ldots \ldots \ldots \ldots \ldots, 175$ & & determined ...................... \\
\hline s & 536 & rmations . . . . . . . \\
\hline 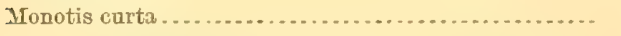 & 354 & ry of $\ldots \ldots . . .1$. \\
\hline$\ldots \ldots \ldots \ldots \ldots \ldots \ldots \ldots \ldots \ldots$ & 355 & 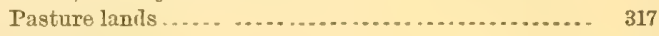 \\
\hline & 355 & Patrick, Mr. W. F. . . . . . . . \\
\hline tus............................. & 354 & cited...................... \\
\hline Morton, Dr. S. G. . . . . . . . . . . . . . . . . . . . . . . & 6,7 & Pay gravel, character of . . . . . . . . . . . . . . .237, 244, 265 \\
\hline 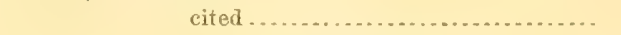 & 7 & position of . . . . . . . . . . . . . . $236,237,242,255$ \\
\hline Myacites (Pleuromya) nebrascensis................... & 461 & Peale, Dr. A. C.................. 150 \\
\hline subcompressus ................ & 368 & cited $\ldots \ldots . . . . . . . . . . . . . .$. \\
\hline subellipticus .................. & 461 & Pearlite. . . . . . . . . . . . . . . . . . . \\
\hline maticus ... ................... & 389 & Pecten bellistriata ................................. 351 \\
\hline 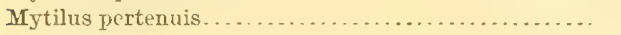 & 362 & halli $\ldots \ldots \ldots \ldots \ldots \ldots \ldots \ldots \ldots \ldots \ldots \ldots$ \\
\hline 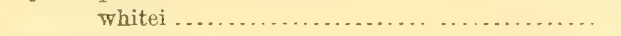 & 360 & berтуі.................................... \\
\hline Natica ambigua. . . . . . . & 430 & 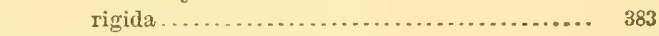 \\
\hline inua & 430 & Pentacrinites asteriscus \\
\hline moreauensis & 430 & entacrinus asteriscus... \\
\hline
\end{tabular}


INDEX.

\begin{tabular}{|c|c|}
\hline $\begin{array}{r}\text { Page. } \\
\text { Pa...112, } 150\end{array}$ & Prionocyclus wyomingensis $\ldots \ldots \ldots \ldots \ldots \ldots \ldots \ldots \ldots \quad 440$ \\
\hline Perna formosa. & Prospecting at Mammoth ledge.................. 242 \\
\hline Peronea? scitula. . . . . . & in the Bear lolge district ..............286, 287 \\
\hline Pholadomya fibrosa .......................... & Black Hills .... . . . . . . . . . . . 17, 19 \\
\hline 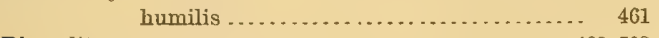 & foothills ........................ 291 \\
\hline Plonolito.......... & French Creek district ........... \\
\hline character described.... & Spring Creek district .............. . \\
\hline$\ldots \ldots \ldots \ldots \ldots \ldots . . . .$. & near Camp Terry ... .................. \\
\hline hornblende in . . . . . . . . . . . . . . . . . . . . & on Bear Butte Creek. . . . . . . . . . . . . . . . 272, 282 \\
\hline nephelite in ........................... 492, 503 & Box Elder Creek. . . . . . . . . . . . 276 \\
\hline nosite in ............................ 493,504 & Castle Creek . . ................ \\
\hline 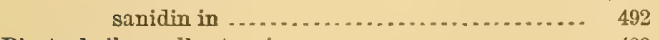 & Deadwood Creek ............................ \\
\hline Piestocheilus culbertsoni . . . . . . . . . . . & Tapid Creek ................. 207,271,291 \\
\hline 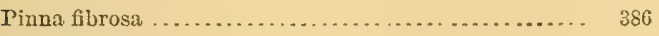 & Red Cañon Creek ................. 236 \\
\hline Ylacenticeras placenta............................... 464 & Spearfish Creek ......................... \\
\hline I'lacer deposits ...........................237, 242, 289 & Whitewood Creek.................... \\
\hline Placers of the foothills . . ......................... 289 & Protocardia shumardi................................ \\
\hline 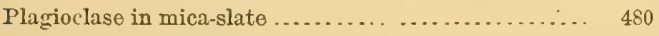 & 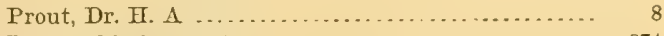 \\
\hline hornblende-gneiss .................. & Psammobia ? prematura.............................. \\
\hline rhyolite ........................... 487,507 & Pseudomonotis (Eumicrotis) curta ................ \\
\hline 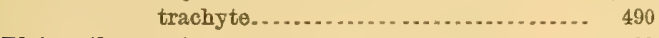 & orbiculata............. \\
\hline 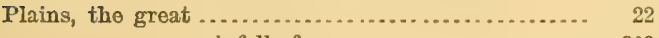 & 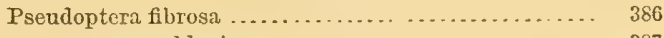 \\
\hline rainfall of . ............................ & vis ..................................... \\
\hline Tertiary of. . . . ................. & 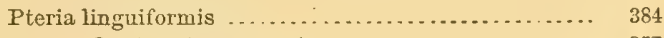 \\
\hline 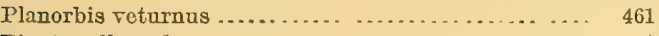 & 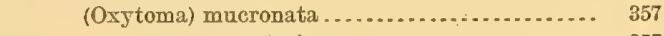 \\
\hline Plants collected...................................... 531 & 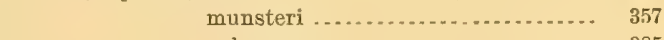 \\
\hline Plateau, Carboniferous ........................... . . & nebrascana . . . . . . . . . . . . . . \\
\hline 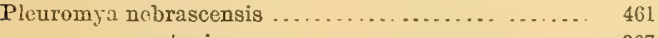 & (Pseudopteria) fibrosa ...................... 386 \\
\hline 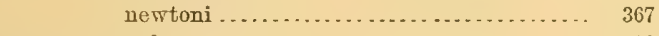 & sublacris ..........................386, 387 \\
\hline 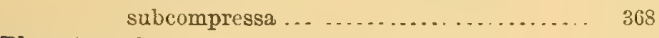 & 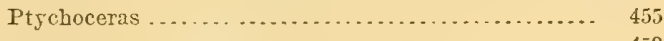 \\
\hline Pleurotomaria contorta ....... & crassum ..................................... \\
\hline 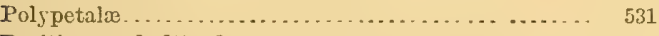 & meekanum ........................... \\
\hline 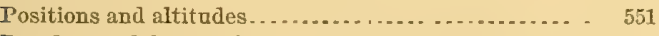 & 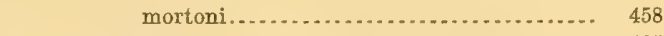 \\
\hline Potsdam and Carboniferous, separation of $\ldots . . . . .$. & 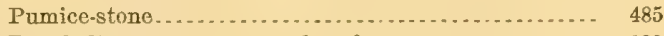 \\
\hline conglomerate a source of placer gold... ..... & 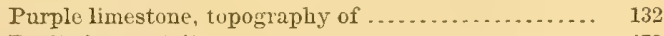 \\
\hline granite pebbles in ......... & 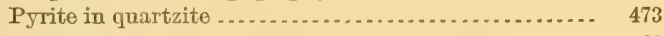 \\
\hline of $\ldots \ldots \ldots \ldots \ldots \ldots \ldots \ldots \ldots$ & Pyrites...... \\
\hline formation, character of . ............... 84,86 & Pjrrhotito in hornblende-gneiss ................... \\
\hline 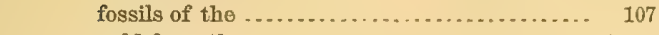 & 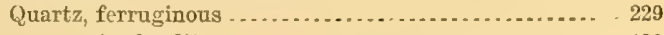 \\
\hline gold from the ............................. 104 & 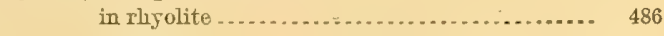 \\
\hline history, summary of . . . . . . . . . . . . . . . . 221 & ledges $\ldots \ldots \ldots \ldots \ldots$ \\
\hline metamorphism of ............ 83, $85,88,103,193,200$ & of granite.......................................... \\
\hline 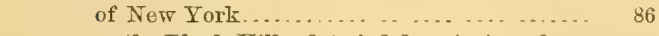 & twinned crystals of . ........................... \\
\hline Hills, detailed description of. ... & 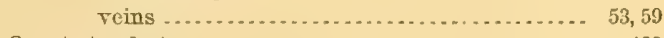 \\
\hline Countains, quartzites of... .... & 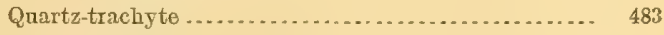 \\
\hline Wind Rirer Mountains ..... ...... & 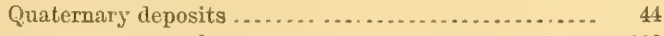 \\
\hline 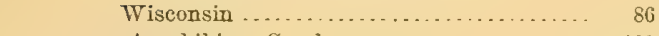 & gravels...................... \\
\hline on Amphibious Creek ................... & 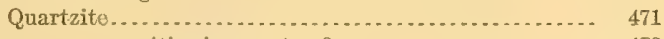 \\
\hline Creek ............................. & 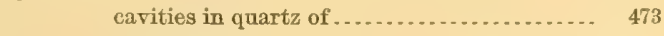 \\
\hline Burntwood Creek.......................... 101 & 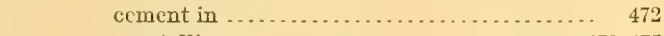 \\
\hline Castle Creek . . . . . . . . . . . . . . . . . . . 98, 262 & crystalline .............................473,475 \\
\hline French Creek . . ......................... 101 & cyanite in ............................ 472 \\
\hline Red Cañon Creck ....................... & garnet in ......................... 472,474 \\
\hline Slate Creek ....... ...................... & granular. . . . . . . . . . . . . . . . . . . . . . . . \\
\hline 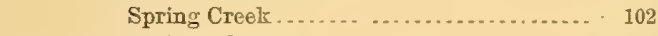 & 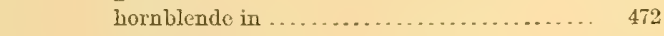 \\
\hline s of . . . . . & magnetite in ................................ \\
\hline resting on uneven surface ... ............. & 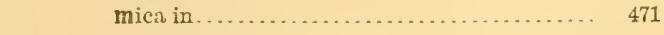 \\
\hline sandstone, manner of formation ............ 104 & microlites in .......................... 473,475 \\
\hline metamorphism of . ............280,285 & 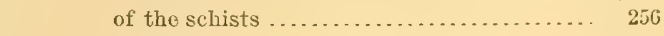 \\
\hline 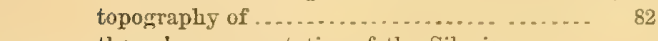 & orthoclase in .......................... 472,473 \\
\hline the onls representative of the Silurian uncon- & pyrite in \\
\hline the $A$ rchasan. ............... & grains in ........................ \\
\hline 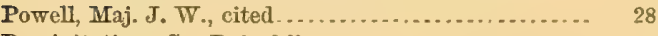 & secondary minerals in ..................... \\
\hline Precipitation : See Rain-fall. & 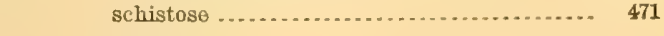 \\
\hline
\end{tabular}




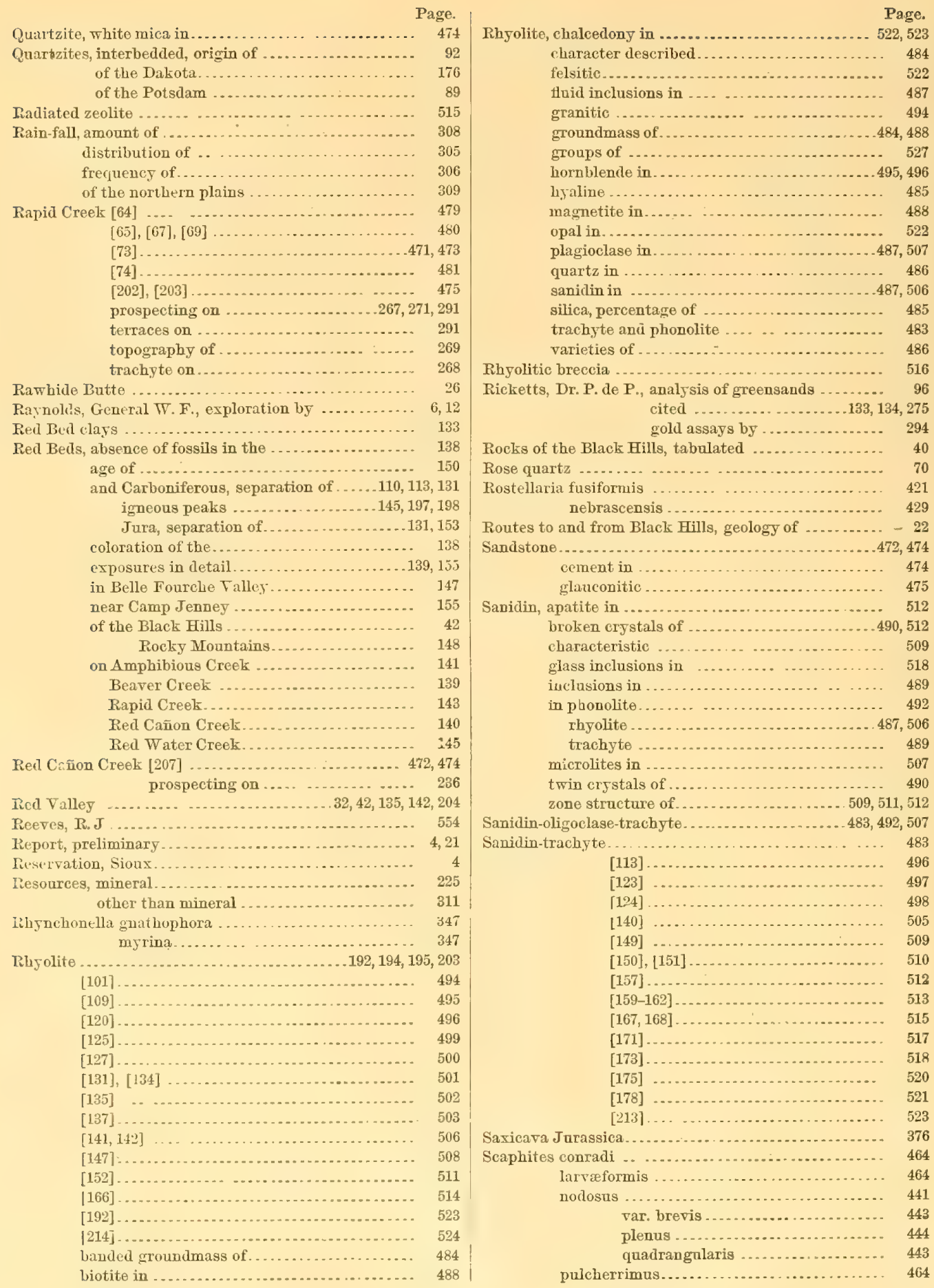




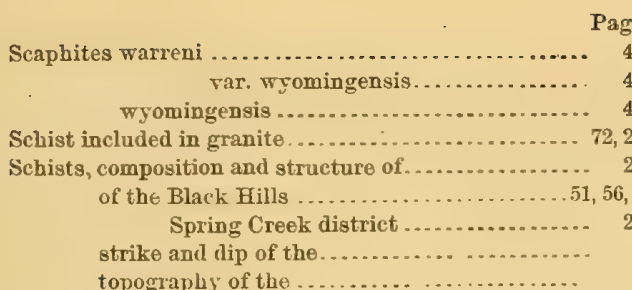

Scolithus linearis ....................... 88, 104, 200, 334 Section, descriptire, Carboniferous and Potsdam, on

Slate Crerk ............................. 99

in valley of Bearer Creek...................33, 178, 182

on Amphibious Creek........................... 122

Box Elder Creek. . ............................. 126

Castle Creek............................ 120

lower Rapid Creek............................. 125

Minne Katta Creek ........................... 121

Spearfish Creek............................ 128

Cretaceous and Tertiary at mouth of Rapid Creek .. 185 at forks of the Cherenne............. 184 near Bear Lodge .................... 180

on Freuch Creek ................... 181

north bend of Belle Fourche ... . ... 180, 183

Red Cañon Creek ................. 182

South Furk of Cheyenne. . . ...... 33

general, of Black Hills ......................... 40

Carboniferous in Black Hilis. .......... 108

Cretaceous by Meek and Hayden ........ 121

Red Beds in Black Hills .............. 131

Tertiary by Meek and Hayden ......... 187

Jura about Bear Butte...... ................. 196

and Cretaceous on Amphibious Creek ........ 158

in Redwater Valley . . . . . . . . . . . . . . . . . . 161, 162, 163

near Bear Lodge .......................... 165

Camp Jenney :...................... 155, 156

Spearfish Creek ........................160, 161

Sun Dance Hills......... . . . . . . . . . . . . . 145

on Red Cañon Creek .... . . . . . . . . . . . . . . . 157

Potsdam on Box Elder Creek.................... 91

lower French Creek.................. 90

Rapid Creek........ .......... 85, 94

Spring Creek........................ 88

Red Beds and Jura near Bear Lodge.......... .... 148 on Amphibious Creek........... 142

Red Cañon C'reek........... 140

near Rapid Creek ...................... 142

Tertiary and Cretaceous near Old Woman Butte.... 30 on Old Toman Fork .................

Serpentine .................................. 482

Serpula $\_$sp. ?........................... 461

Sheridan, General P. H., cited ..................... 17

Shumard, Dr............. . . . . . . . . . . . . .

Siderite on Beaver Creek............................

Silica determinations

percentage of rhjolite .....................

trachyte......................

Silurian formation headwaters of Niobrara...........

Silurian. See Potsdam.

Simpson, Col.J.H., exploration by ..................

Sink holes in grpsum . . . . . . . . . . . . . . . . . . . . .

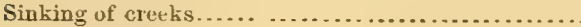

Sioux expedition

reservation.
Page.

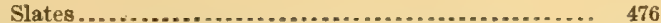

the, of the Black Hills.................... 56, 64

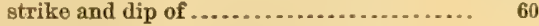

topography of........................ 58

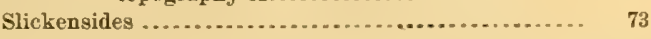

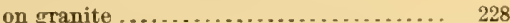

Smet, Father de .............................. 16

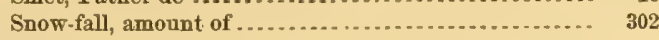

Soils .............................................. 313

Solarium flexistrialum ........................ 463

Solenoceras . .................................. 456

Solidula (Actæonina ?) subelliptica................. 463

South Fork of the Cheyenne, cañon of ........... 177

Spearfish Creek, prospecting on..................... 278

topography of ................... 277

Sphæriola moreauensis .......................... 415 obliquata ............................ 415

transversa ............................ 415

warrenana .......................... 462

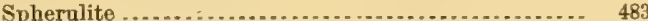

Spherulites . . ................................... 485, 499

Spring Creek, volume of ............................ 254

Spring Creek district, prospecting in ............... 240 topography of .............. 238

Spring Creek mining district ...................... 238

Springs, mineral ................................... 295

temperature of . . . . . . . . . . .

Stand-off Bar ....................................... 251

Staurotide ................................. 54,260

Stevenson, Dr. J. J., cited ........................... 149

Stockade, the ................ 17 French Creek [1] ..................... 477

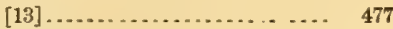

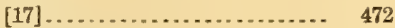

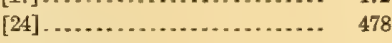

Stock-raising, futore importance of ................ 317

Storms, thunder ............................... 310

Streams, volume of . . ........................... 312

Structure and age of the Black Hills ............... 203 fluid-like ............................. 513

Sna Dance Hills . . . . . . . . . . . . . . . . . . . . . . . . . . 145, 197

Superimposed drainage ............................. 216

Surcula contorta ................................. 422

Syncyclonema rigida............................. $\quad 383$

Synopsis of the rocks of the Black Hills............ 40

Tancredia æquilateralis......................... 460 bulbosa ........................... 370

corbuliformis ........................ $\quad 370$

? inornata ........................... 368

postica........................ 371

warrenana ........................... 372

Tectura occidentalis .......................... 463

Tellina occidentalis .............................. 409

scitula .............................. 463

(Peronæa \}) scitula ....................... 463

Terebratula helena............................... 462

Terraces on Rapid Creek ........................... 291

Terry Peak ....................................... 103, 193

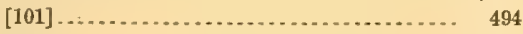

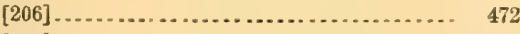

[214] ................................ 524

barometric observations on ............ $\quad 549$

beight of ............................ 540

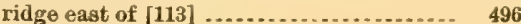




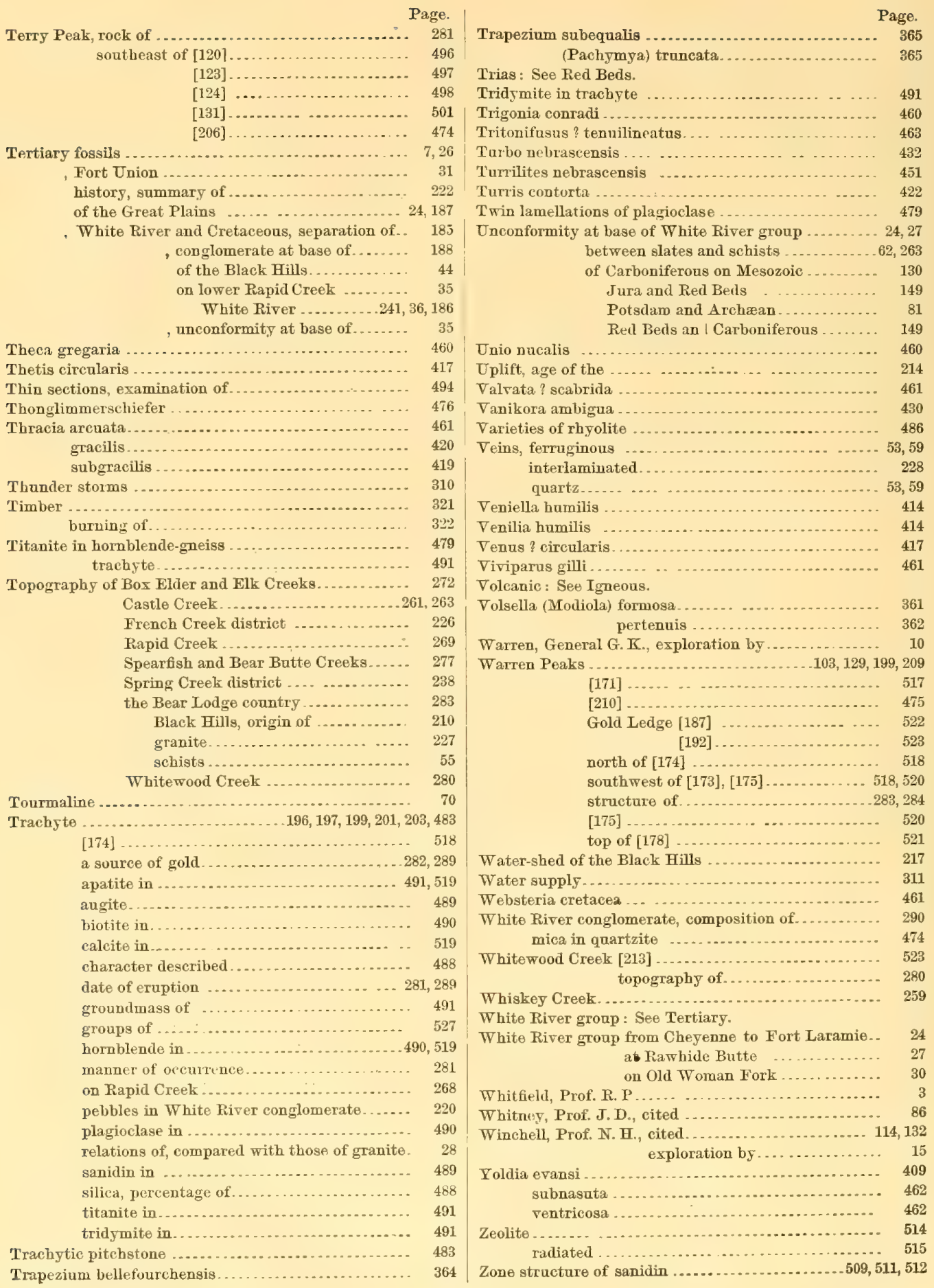




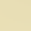





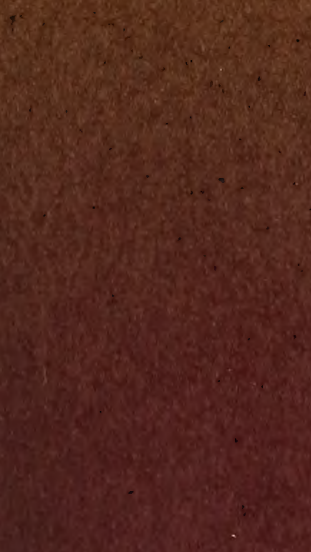

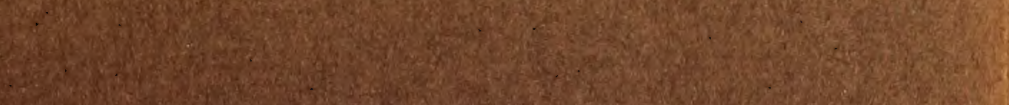

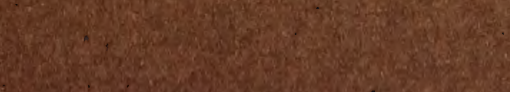



